

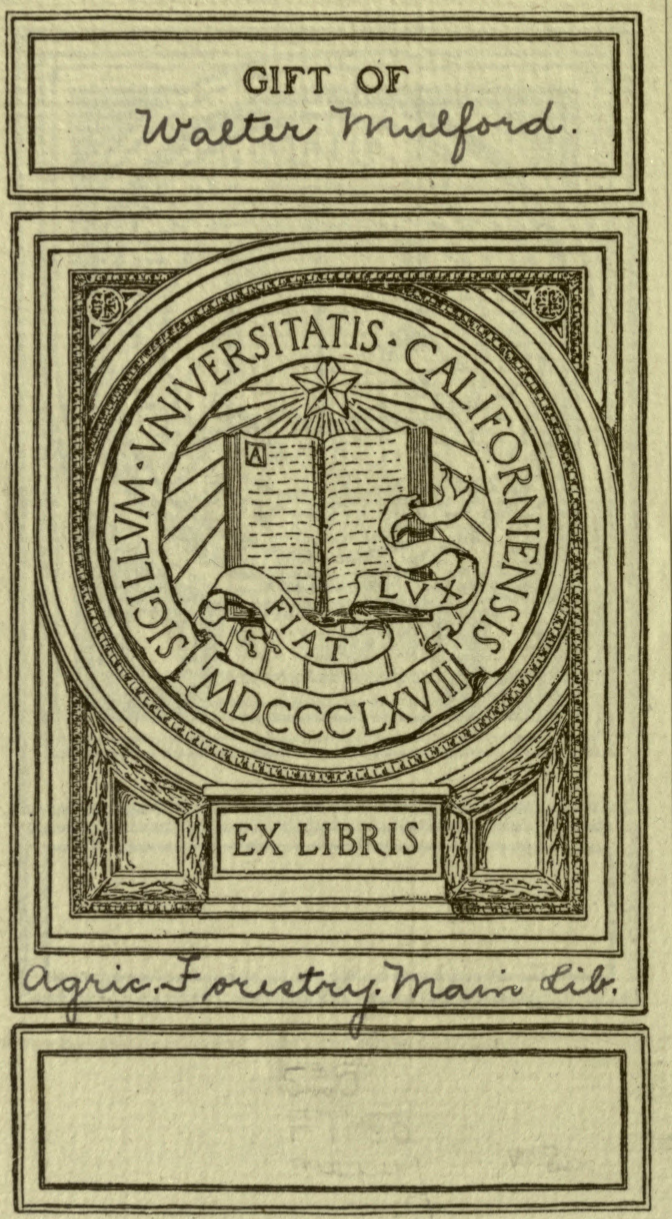



Pawgheres on foratery in Now forsap

NEW JERSEY FORESTRY PAMPHLETS

\section{VOI. II}

Seventh Annual Report of the Forest Park Reservation Commission of New Jersey. 1911.

Eight Annual Report of the Forest Park Reservation Commission of New Jersey. 1912. Trees and Forests. Ieaflet No. 9. Dept. of Public Instruction. Forest Planting in New Jersey. By Alfred Gaskill.

Ninth Annual Report of the Forest Park Reservation Commission. 1913. 
$N 5 P_{3}$ $v, 2$

난단

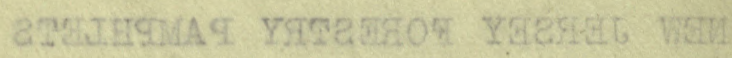

$$
\text { WI . WOV Worestry }
$$

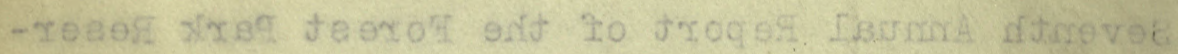

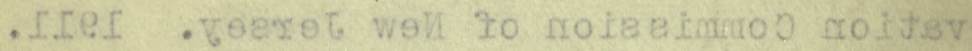

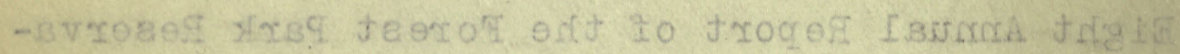

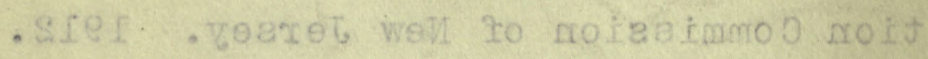

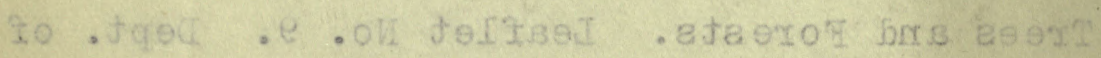

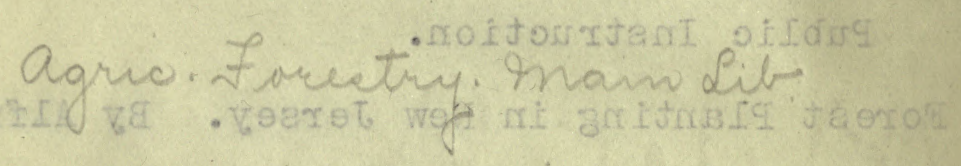
- filitis

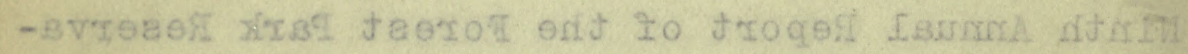
- der onojasimmos noij 
299085 


\title{
Walten Mulfond
}

\section{Seventh Annual Report}

\author{
OF THE
}

if.

POREST' PARK RRESERETATION COUMISSSION

OF

\section{NEW JERSEY}

For the Year ending October 3 Ist

\section{I9II}

TRENTON, N. J.

MacCrellish \& Quigley, State Printers, Opposite Post Office. 



\section{The Forest Park Reservation Commission.}

Hon. WOODROW WILSON, Governor, ex-officio President.

HENRY B. KÜMMEL, Trenton, Executive Officer.

ELMER H. SMITH, Salem.

CHARLES L. PACK, Lakewood.

WILLIAM W. SMALLEY, Bound Brook.

ALFRED GASKILL, Trenton, Forester and Secretary. JAMES O. HAZARD, Trenton, Assistant Forester.

CHARLES P. WILBER, Trenton, State Firewarden.

Office, State House, Trenton.

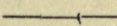

DIVISION FIREWARDENS.

Div. A-WILLIAM LINDSAY, Dover.

Div. B-FREDERIC C. TORREY, Lakehurst.

Div. C-JOSEPH E. ABBOTT, Hammonton.

Div. D-LEONIDAS COYLE, Millville. 



\section{Letter of Transmittal.}

To His Excellency Woodrow Wilson, Governor of the State of Nere Jersey and ex-officio President of the State Board of Forest Park Reservation Commissioners:

SiR-I have the honor to submit the annual report of the Forest Commission for the year ending October 3Ist, I9I I, as required by law. The control of forest fires continues to be our greatest problem, though marked progress has been made. The work of the Commission in practical forestry and on behalf of the shade trees apparently meets with public approval. The thirteen pages of illustrations accompanying the report are necessary to a proper understanding of our work.

Respectfully yours,

HENRY B. KÜMMEL,

AlFRED Gaskili, Executive Officer.

Secretary. 


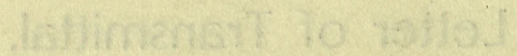

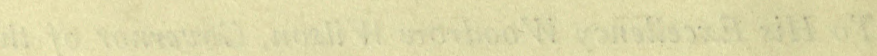

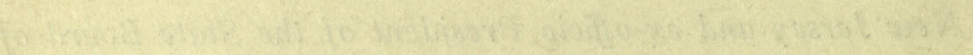

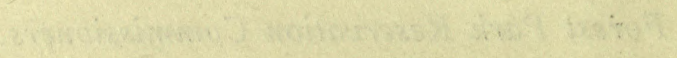

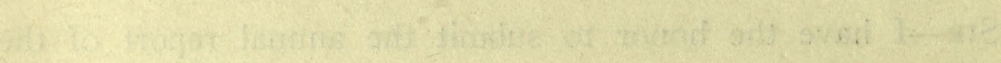

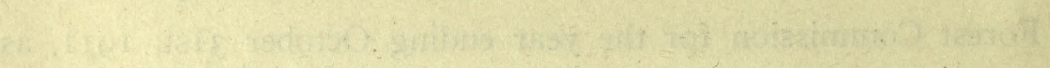

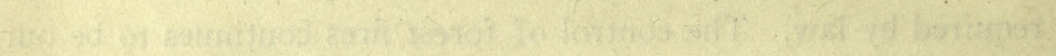

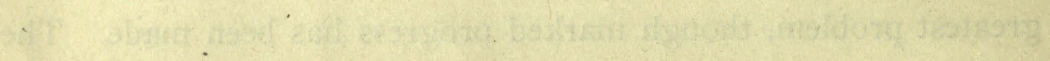

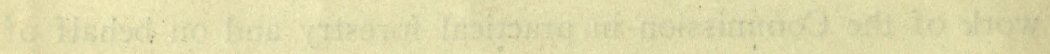

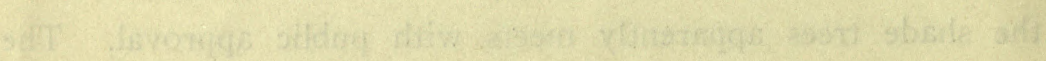

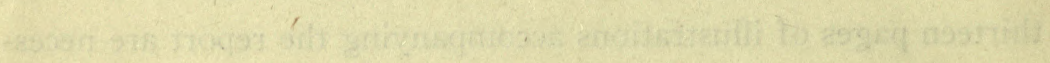

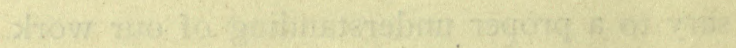

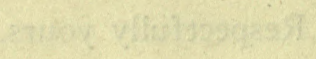

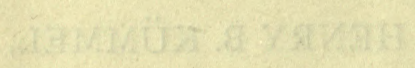

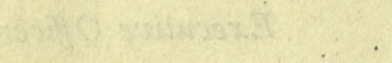

3.

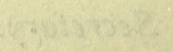




\section{Illustrations.}

PAGE.

Fig. I. A Forest Park, ............................. Frontispiece

" 2, 3, 4, 5. Four Views of Forest within I5 Miles of New York, I4

"6. A Forest Fire in "The Pines," ..................... 20

" 7. A Pine Plantation in South Jersey, .................. 20

" 8. A Typical Road in "The Pines," ..................... 59

“ 9. A Similar Road Made to Serve as a Fire Line, ........... 59

“ ı. A Railroad Fire Line, ........................ 6 I

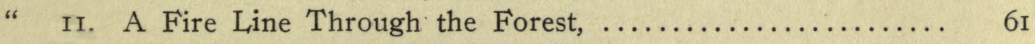

" I2. Diagram of a Railroad Fire Line, .................. 66

" I3. Map-The State Forest Fire Service, ................. 56

“ I4, I5. Forest on Mt. Laurel Reserve Before and After an Improvement Felling, ................... 70

“ I6, I7, I8. Shade Trees Accommodated to Street Conditions, .. 76

“ I9. How a Street Grade May Be Lowered Without Destroying

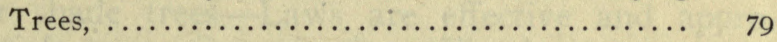

20, 21, 22. Streets and Sidewalks Can Be Adjusted to Valuable

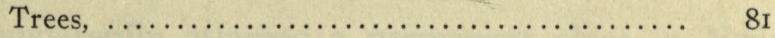

“ 23. Tree Wounds Healing Without Filling, ............. 82 



\section{Report of the Forest Commission.}

The satisfaction that the Forest Commission has with its year's work is sadly marred by the loss of Dr. Edward B. Voorhees, who died on June 7 th, I9II. Dr. Voorhees was one of the three men appointed to the Forest Commission when it was created and served ably and faithfully until continued ill health induced him to resign so that an active man might take his place. The State is fortunate in having had so wise an adviser while its forest policy was developing.

\section{SUMMARY.}

Condition of forests improving-Forest fires less destructiveMany penalties imposed for violation of law-Co-operation with Federal Government and with railroads-Private forest owners practicing forestry-State forest reserves increasing in value though not in area-Much work done and planned for shade trees-Laws are effective and appropriations satisfactory-Organization-Fiscal account.

Forestry has apparently attained a permanent place in New Jersey. Seven years ago, when the Forest Commission was created, the woodlands of the State were so degraded that few believed it possible for the remnant to be saved. Fires in South Jersey and reckless cutting in North Jersey were chiefly responsible for this condition. To-day the situation promises better things. Interested owners are taking control of the woodlands in the north, while the measure of security against fires that has been given in the south is proving that the forests there are still capable of reviving. It will be understood of course that fire alone is not responsible for the poor forests in South Jersey, nor mishandling alone responsible for the condition of those in North Jersey. Both evils, and some others, 
attach to both sections though they are radically different in most respects.

\section{GENERAL POLICY.}

No new way has been found to advance the work entrusted to the Commission, and what it is doing continues mainly along the lines laid down several years ago. The chief effort has been to meet the situation in a practical way, and to solve the problems presented rather than to say much about what should be done or how. The fact that nearly one-half ( 46 per cent.) of New Jersey's area is classed as woodland gives ample ground for a strong effort to develop this resource. That practically all of the forest long ago passed from public to private possession makes clear the course that should be followed in seeking to develop it. Thus all that the Commission does is based upon the principle of making it worth any owner's while to protect and develop his woodland. This policy does not necessarily preclude the acquisition and maintenance of State reserves, though it does subordinate that feature and has led the Commission to announce that unless the State shall decide to devote much more money than it now does to its forest interests, and specifically shall provide for the care as well as for the purchase of forest lands, it will advocate using for the protection and betterment of all forests without regard to ownership all the money that is available, and that until the whole body of woodland shall be reasonably safe from fire it will not seek to increase the State's possessions. It will be noted that this attitude is in strong contrast to that of most other bodies charged with the forest interests of a State.

\section{FOREST FIRES.}

Justification for the Commission's policy of setting fire control above all else is found in the fact that fire, or the fear of fire, heretofore has made a forest a poor investment. New Jersey is not alone in this respect, and though this Commission was the 
first to assert that the fire problem must take precedence of every other, forest interests everywhere are coming to the same conclusion. From the chief of the United States Forest Service through the ranks of the foresters it is agreed that fire is not only the greatest destroyer of forests but the greatest obstacle to reforestation. In a word, forestry is not a practical proposition so long as the fire evil continues.

In the effort to better this situation we have made material progress in spite of an unfavorable season. The fires of the year were fewer in number and less destructive than has been our experience for a long time past. Compared with last year the number of fires, large and small, was I 3 per cent. less and the total loss 32 per cent. less. And what is even better, our fire organization is much stronger as a preventive force than it has ever been, as well as more effective for fighting fires. The value of prevention is hard to measure, though a significant pointer is found in the statement that by promptly controlling 37 fires at a cost of $\$ 1,022$, property valued at $\$ 67,000$ was saved. The good work done by the local warden service is further indicated by the fact that no less than 45 per cent. of the total number of fires were extinguished before they did any appreciable damage.

It is especially gratifying to record that for the first time since the fire service was organized the Commission has closed the year's accounts with all bills paid and has returned a small balance to the State treasury. This was made possible partly by an increased appropriation and partly by the collection of the very considerable sum referred to below. Most of what had to be written a year ago about the needs of the fire service therefore no longer applies.

The four Division Firewardens who were appointed as assistants to the State Firewarden have already proved their value. Through them it is possible to exercise a better control of the local wardens and to enforce more vigorously the penal clauses of the law. 


\section{VIOLATIONS OF LAW.}

It is frequently said that laws framed to control the firing of forests can not be enforced. New Jersey does enforce hers. This is shown by the fact that during the year 254 violation cases were settled and penalties aggregating \$2,02I.24 imposed and collected. The fire law provides only money penalties except in default of fines. And this is only a beginning; if there is no other way every offender against the fire laws will be prosecuted and respect for forest property enforced.

\section{CO-OPERATION WITH THE FEDERAL GOVERNMENT.}

But perhaps the most significant feature of the new fire service is the patrol maintained in North Jersey under a co-operative agreement with the United States Forest Service. The Federal Government allotted to this State $\$ \mathrm{I}, 000$, which sum was used to pay a patrol of forty-four men who on hunting days and holidays travelled regular beats, laid out where fires might be expected, and six watchers who looked for fires from conventent observation points. Though somewhat favored by the weather this force prevented the occurrence of any serious fire where many were last year.

This National aid has been worth much more than the thousand dollars contributed, for besides preventing any serious fire it has served to demonstrate the value of a, systematic patrol at dangerous times and in exposed places; it has established an organization which with little difficulty can be kept ready tor any emergency; it has proved to the whole community the sincerity of the Forest Commission's purpose to stop forest fires. There is a good prospect that a considerably larger sum will be made available for similar use next Spring.

\section{THE RAILROADS AND FOREST FIRES.}

The record shows that in this State more forest fires are set by the railroads than by any other agency. It also shows that a 
larger proportion of these fires were put out before any appreciable damage was done than is found in any other class. This can mean only that the policy of the Commission of working with the railroad managers rather than against them is producing results.

One of the most important of these results is that most, if not all, of the roads are making more careful inspections of motive power, giving and enforcing stricter orders to trainmen and section men, clearing their rights-of-way better, and in various ways evidencing a willingness to support the local fire service. In the conviction that no mechanical device now known will entirely prevent the discharge of sparks from the stack of a coal-burning locomotive operating under the requirements of modern traffic, but that the setting of some fires is unavoidable, the Forest Commission assumes that ordinarily a fire of this kind is an accident and calls for no penalty other than the payment of the cost of extinguishing it. Without exception the railroads have accepted this and pay without question all bills contracted in extinguishing fires that are shown with reasonable certainty to have been set from their trains. During the year 183 cases, involving $\$ I, 346.23$, were settled in this way. That much of the interest shown is inspired by a desire to lessen the claims for damages made against the railroads may be admitted. It works none the less to the advantage of the forests.

\section{FIRE IINES.}

Unfortunately the "Act for the Protection of Woodlands," commonly called the fire line law, enacted in 1909, is still before the courts in such a way that the Commission has held it wise to refrain from making any attempt to compel the railroads to construct or to maintain fire lines. The statute has nevertheless been observed in an effective way through the joint voluntary action of several of the larger railraads and adjoining property owners with the Forest Commission. There have thus been made 82 miles of fire lines, which with the 153 miles constructed in IgIo gives a total of 235 miles now helping to guard the wood- 
lands of the State. The record of what these fire lines have done, and especially the action of several roads in maintaining and extending them voluntarily, justifies the assertion that fire lines are an effective and a recognized means of protecting adjacent forests against fires set along the railroads. Fig. Io.

\section{AIDING WOODLAND OWNERS.}

The second great problem to be solved is the development of private woodlands so that they shall represent actual value to their owners, not merely possible or speculative value as most of them have done heretofore. Only by thus appealing to property interest can material progress be made, since the great bulk of New Jersey's forest is, and is likely to remain, in private possession. The progress in this direction that has already been made is certified by statements of numerous owners that their forests are worth more than they were before the State forest policy gave them security. The Commission therefore seeks to interest as many owners as possible in their own property, and on merely nominal terms offers to help all who care to ask for assistance. The responses made to this offer are steadily increasing, so that in connection with the shade tree work which the Commission is also doing it has been necessary to provide an additional forester. Though it is difficult to measure the value to the State of a work of this kind, it is clear that if such assistance rendered to any property owner means the definite devotion of a given area to forest management a two-fold advantage is gained: first, that a forest from which timber may be derived is established; and second, that an example to other forest owners is furnished.

FOREST RESERVES.

The determination of the Commission to suspend all effort to increase the area of the State's forest reserves in no way lessens its interest in those that have already been acquired, now aggregating nearly I4,000 acres. Each tract is under the care of a warden who is especially active in protecting the property against fire. By improvement fellings, by experimental plantings and 


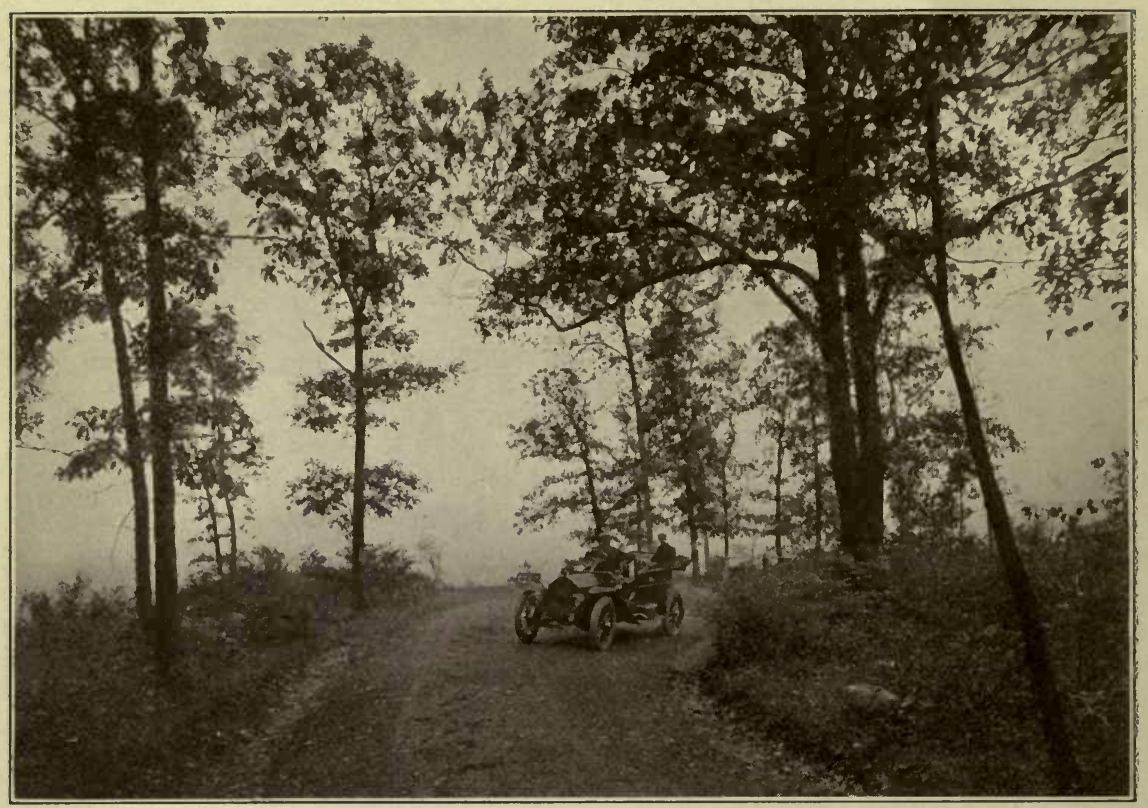

Fig. 2.-An Outlook Point; Forest too Open for Best Effect.

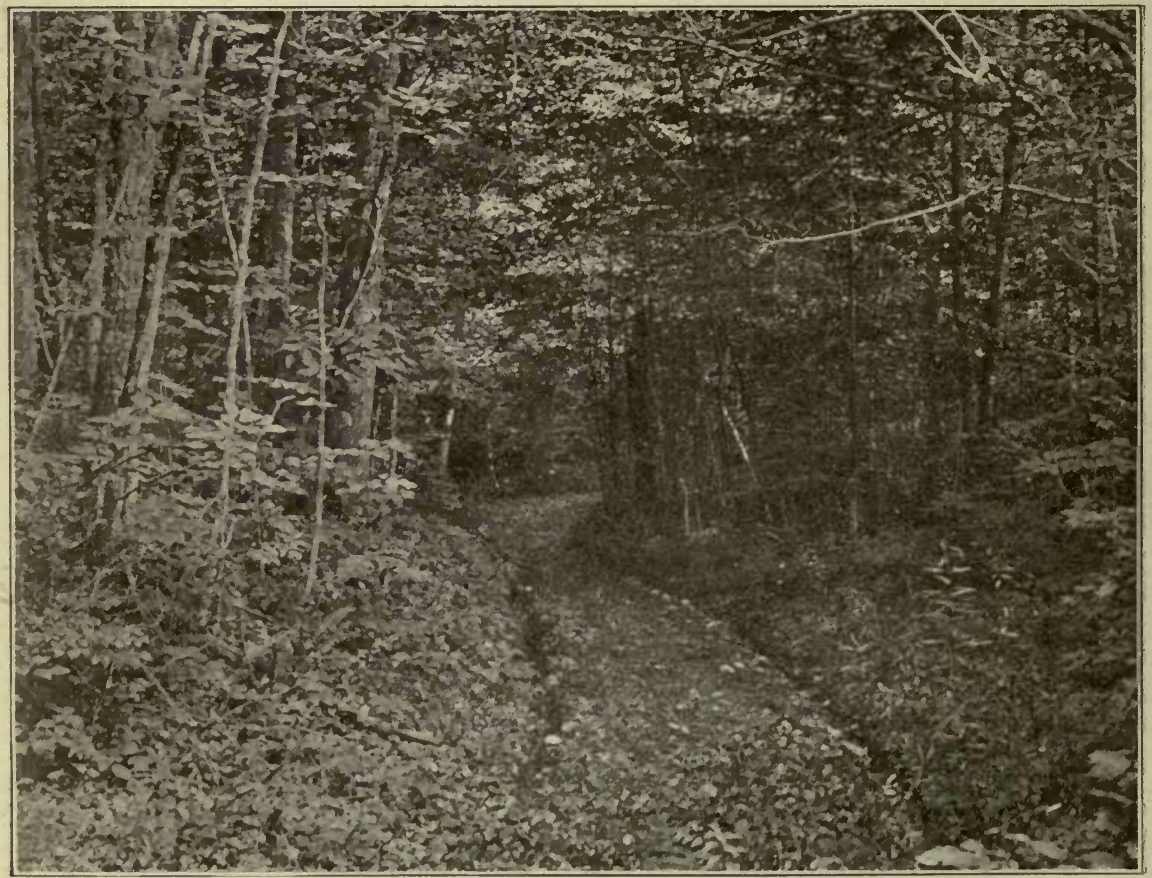

Fig. 3.-Even the Young Forest is Opened to the Public. 


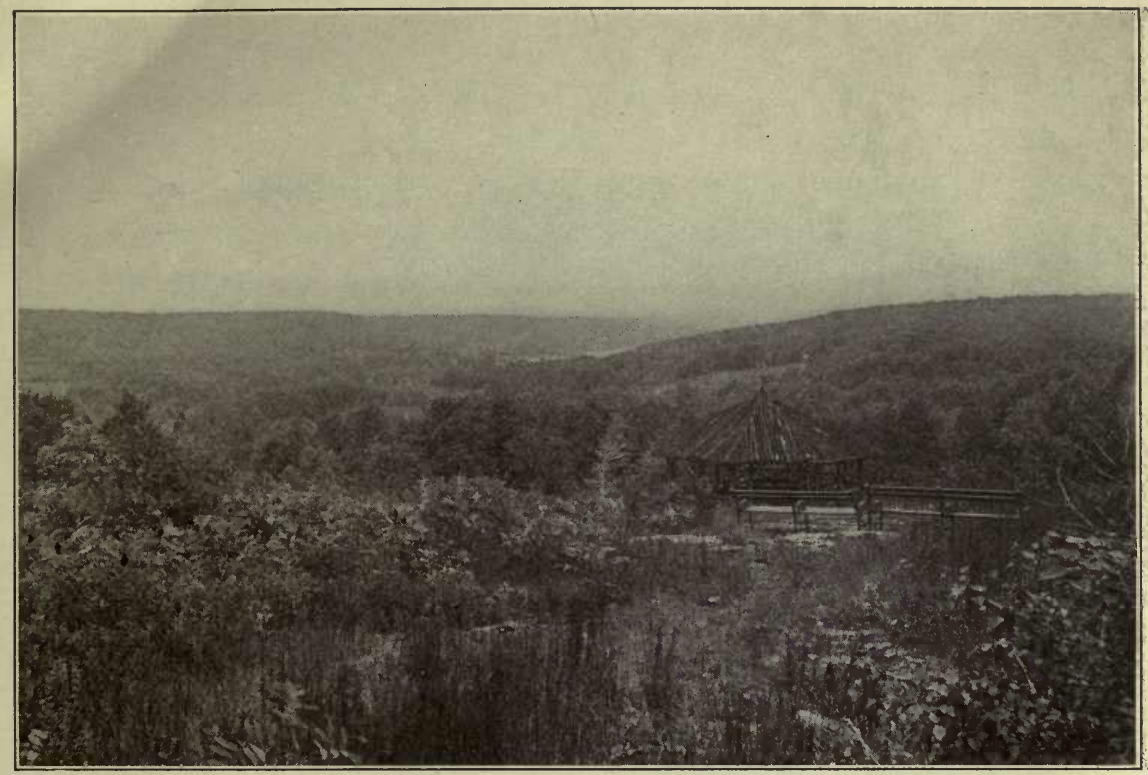

Fig. 4.-Park Forest; Extensive and Varied, yet Easily Accessible.

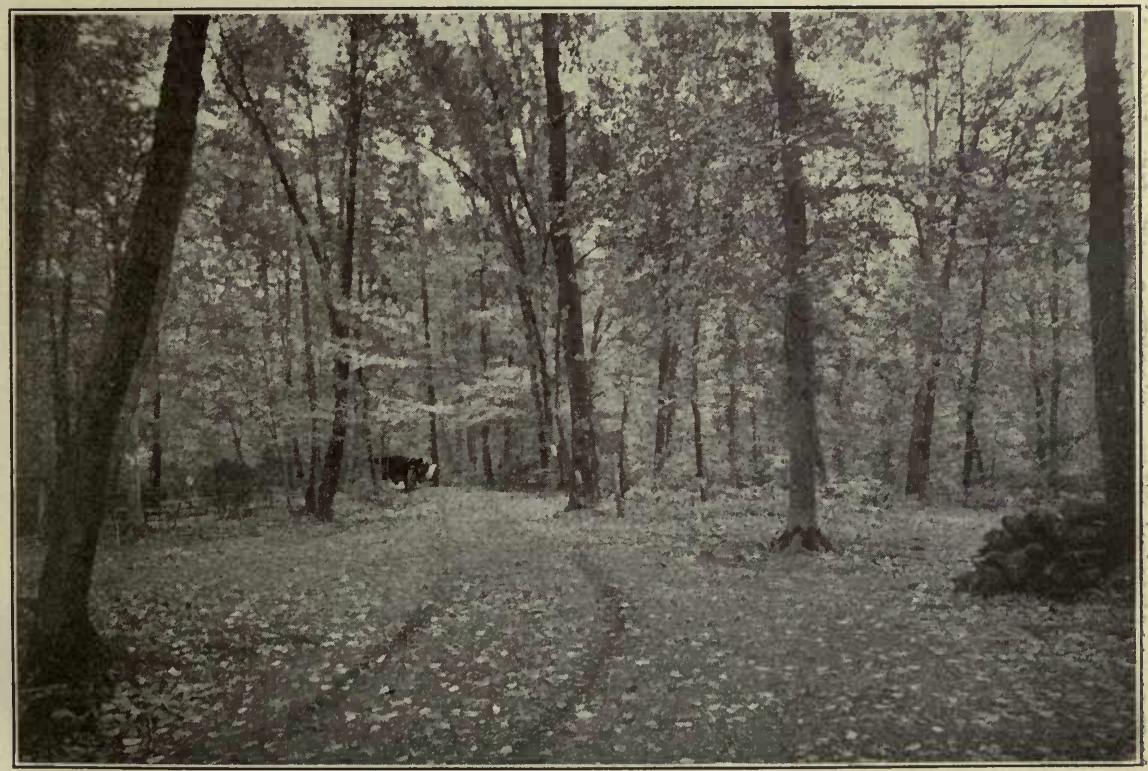

Fig. 5.-A Bit of Old Woods, Yielding Some Revenue Though Maintained for Park Uses. 
in various other ways the reserves are being made to serve as examples of what forestry will do for such properties. Generally and severally the State reserves are in better condition than when they were acquired, and are now worth considerably more than they cost.

SHADE TREES.

Interest in shade trees is increasing greatly. Under the authority given by the last Legislature the Commission is making an effort to induce communities and citizens to establish and care for these blessings of our cities and towns. While the actual direction of any work of this kind must ultimately reside in local authority, it is altogether proper for the State to help the people solve the problems that invariably come to novices, and to keep in constant touch with the situation so that dangers and ills may be avoided or guarded against, as well as opportunities to do constructive work taken advantage of. In all these ways assistance has been given as opportunity offered. The organization of a State Shade Tree Federation referred to in the report of the Forester, is indicative of the importance of this subject in the eyes of the people. The Commission believes that most country roads should be tree-bordered and stands ready to do its part in any effort to that end that may be determined upon as wise and expedient. Through co-operation with county boards and the State Road Commissioner the improved roads at least can be made much more attractive than they now are at no great cost and within a comparatively short time.

The utilization of every available woodland area as a forest park is a civic duty. It is not difficult to provide public playgrounds of this character suited to the population that may enjoy them. The Essex county parks are an example for large communities, the forest park of Bridgeton one for small places.

\section{LEGISLATION AND APPROPRIATIONS.}

The Forest Commission acknowledges with much satisfaction the public approval of its policy and acts as recorded by the Legislature in its last session. Four supplementary laws were 
passed unanimously and all the money asked for granted. With adequate laws and increased appropriations it is now felt that the State is prepared to maintain an effective fire service and a vigorous forestry branch. It is believed that the appropriation on the forest fire account is sufficient and that, for a year or two at least, no material increase is likely to be needed. On the other hand, general forestry will probably demand more and more attention, and a reasonable increase in the appropriation, from year to year. The appropriations made for the fiscal year 1912 are:

For forestry work, care of State reserves, etc., $\ldots \ldots \ldots \ldots \ldots \ldots \ldots . \$ 8,500$

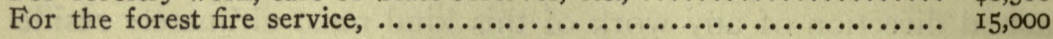

To the latter sum will be added about $\$ 5,000$, representing the townships' share of local wardens' salaries and fire fighting costs. Thus for a total expenditure of not over $\$ 20,000$ a year, an average of one cent an acre, the State is reasonably well equipped to guard its whole forest area.

On November I, I9II, the resignation of Mr. T. P. Price, as Chief Division Firewarden, formerly State Firewarden, took effect, and Mr. C. P. Wilber, Assistant Forester and Acting State Firewarden, was promoted to be State Firewarden.

On September $27 \mathrm{Mr}$. J. O. Hazard reported for duty as Assistant Forester.

The work of the Forest Commission is organized as follows:

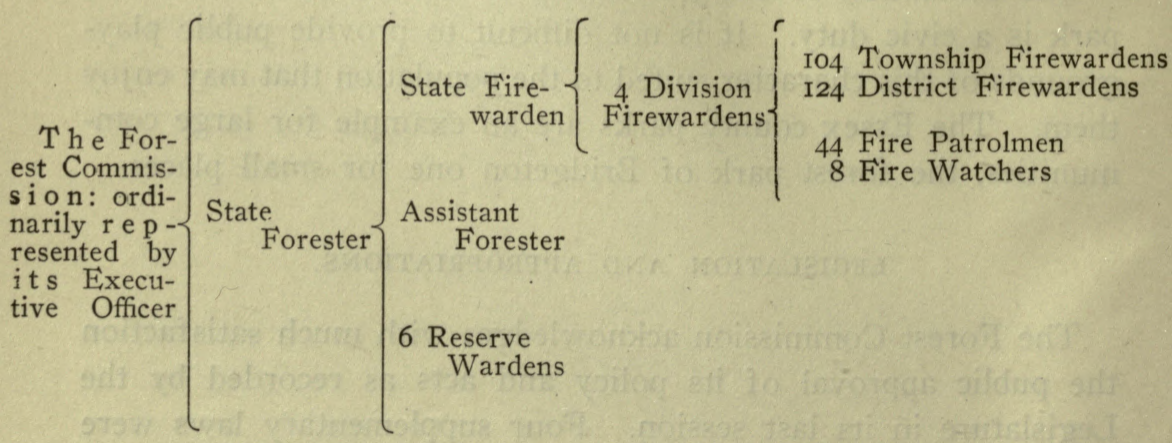




\section{Financial Statement, Forest Park Reservation Com- mission, for Fiscal Year 1911.}

\section{ADMINISTRATION ACCOUNT.}

Appropriations,

$\$ 8,000$ oo

EXPENDITURESS.

Salary and expenses, Forester and Secretary,

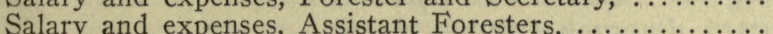

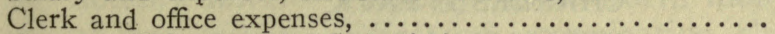

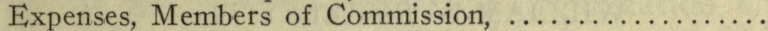

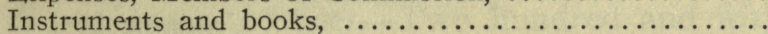

Co-operation and education, $\ldots \ldots \ldots \ldots \ldots \ldots \ldots \ldots \ldots$

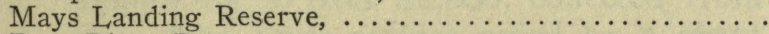

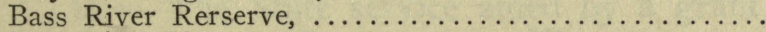

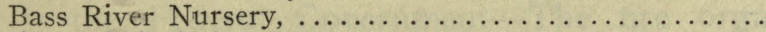

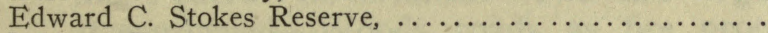

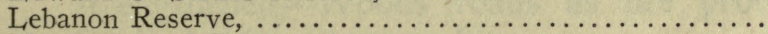

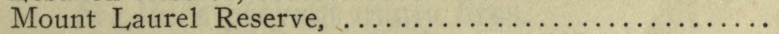

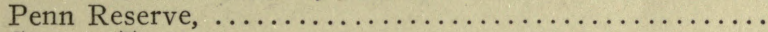

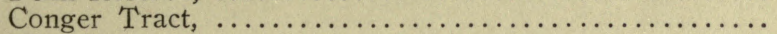

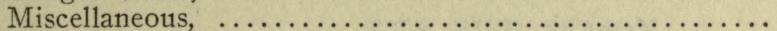

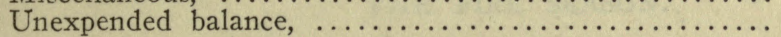

$\$ 3,15774$

I, 5 IO 23

I,473 92

III 98

20548

$748 \mathrm{I}$

3246

3I4 86

4370

I60 00

39623

7 I 27

30055

680

I22 24

I7 73

FOREST FIRE ACCOUNT.

Appropriations,

$\$ 10,400$ oo

EXPENDITURES.

Salaries and expenses State Firewardens, .......... \$4,50I 66

Clerk and office expenses,

Extinguishing forest fires:

On account of Igog fires, .............. \$137 34

On account of I9Io fires, ............... I,9II oI

On account of I9II fires, ............... I,702 5I

Local Firewardens' salaries and special expenses:

Bills carried over from I9I0, ........... \$71 66

Bills paid on account of I9II, .......... I,037 I7

Equipment,

69398

$\$ 8,000$ oo

Miscellaneous,

$\underline{1,03717} \cdot 1,10883$

Unexpended balance, 


\section{Financial Statement-Continued.}

\section{RECEIPTS.}

Balance on hand November Ist, r9Io, $\ldots \ldots \ldots \ldots \ldots \ldots \ldots \ldots \ldots \ldots \ldots \ldots \ldots$

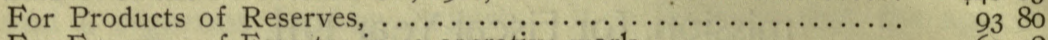

For Expenses of Forester in co-operative work, .................. $62 \quad 48$

From Settlements with Sundry Violators of Forest Fire Law, .... 2,02I 24

Total, $\$ 2,22355$

Paid to State Treasurer, ....................... $\$ 32207$

Paid to Sundry Township Treasurers, .............. I,84I 93

Paid Justice-of-peace costs, .................... I6 63

Balance in hand October 3 Ist, I9I I, ............... 4292

HENRY B. KÜMMEL, Executive Officer, ELMER H. SMITH, CHARLES L. PACK, WILLIAM W. SMALLEY,

Commissioners. 


\section{The Forest Fire Service.}

By Charles P. Wileer, State Firewarden.

SUMMARY.

An unusually dry and dangerous season-Large, destructive fires notably fewer-Property saved worth many times the cost of fire service-Effect of organization shown in analysis of causes of fires-Two hundred and fifty-three penalties, amounting to over $\$ 2,000$, collected from violators of fire law-The State service aided by a grant of $\$ \mathrm{I}, 000$ from the Federal Government-The fire organization greatly strengthened-Woods roads as fire protection-Railroad fire lines prevent many fires.

\section{THE FIRE SEASON..}

In keeping with the conditions that have prevailed for three years, the season of I9I I was unusually favorable to forest fires. This applied not only to New Jersey, but to the whole northeastern section of the country, and reports from other States in the belt show a widespread and serious forest fire problem.

A late spring aggravated the normal danger at this season, and the menace was increased by a lack of rainfall so marked in its influence upon the forest fire situation that the official weather reports for March and April make special mention of its "fostering a condition under which forest fires found particularly favorable footing"; and again that "there was a noticeable effect of this dry period on the forest fires that broke out shortly after the close of the month" (April). In May these conditions reached a climax officially designated as "the driest 
May on record" for this region. This condition, following without break the drouth of the two months preceding, places this as the worst month of the year and the worst individual month for many years. From Massachusetts comes this statement: "Not in many years has Massachusetts been subjected to so terrible a fire scourge as has fallen to her lot the past spring. By the middle of May the losses were easily twice as great as for the entire twelve months of I9ro." Pennsylvania was visited by a veritable scourge of spring forest fires. Maine was so beset that the annual forest fire appropriation of $\$ 68,000$ and a $\$ 10,000$ Federal forest fire patrol fund were exhausted by the middle of August in the effort to check the conflagration.

TABLE I.-FOREST FIRES IN IOII AND PREVIOUS YEARS.

\begin{tabular}{|c|c|c|c|c|c|}
\hline 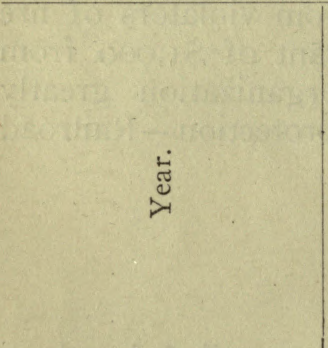 & 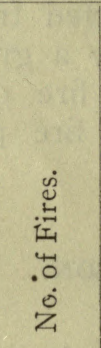 & 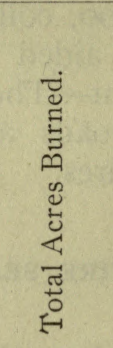 & 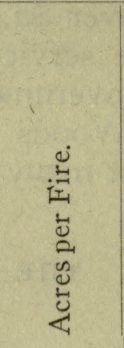 & 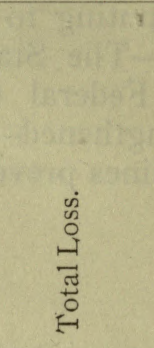 & 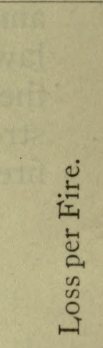 \\
\hline \multicolumn{6}{|c|}{ No organized service, incomplete reports. } \\
\hline 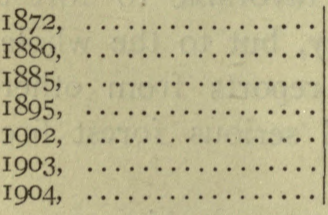 & $\begin{array}{c}\ldots \ldots \\
54 \\
49 \\
65 \\
79 \\
81\end{array}$ & $\begin{array}{r}100,000 \\
71,074 \\
128,000 \\
66,120 \\
98,850 \\
85,046 \\
41,530\end{array}$ & $\begin{array}{c}\ldots \ldots \ldots \\
1,316 \\
\ldots \ldots \ldots \\
1,349 \\
1,520 \\
1,076 \\
512\end{array}$ & $\begin{array}{r}\$ 1,000,000 \\
252,240 \\
\mathrm{I}, \mathrm{I} 28,000 \\
600,000 \\
\mathrm{I} 69,323 \\
305,744 \\
193,413\end{array}$ & $\begin{array}{r}\$ 4,671 \\
\ldots \ldots \ldots \\
\text { I2,245 } \\
2,605 \\
3,870 \\
2,388\end{array}$ \\
\hline 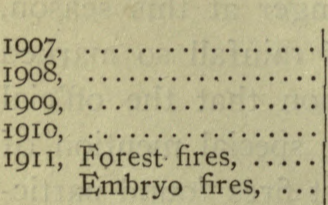 & $\left.\begin{array}{l}167 \\
533 \\
563 \\
611 \\
289 \\
239\end{array}\right\}$ & $\begin{array}{l}\text { II,525 } \\
52,978 \\
93,525 \\
81,452 \\
64,404\end{array}$ & $\begin{array}{r}69 \\
100 \\
166 \\
133 \\
122\end{array}$ & $\begin{array}{r}11,647 \\
64,536 \\
133,944 \\
127,850\end{array}$ & $\begin{array}{r}70 \\
121 \\
238 \\
209\end{array}$ \\
\hline
\end{tabular}

These general conditions are accurately reflected in the forest fire record for this State, which shows that 84 per cent. of the true forest fires, and over 75 per cent. of all fires reported, 


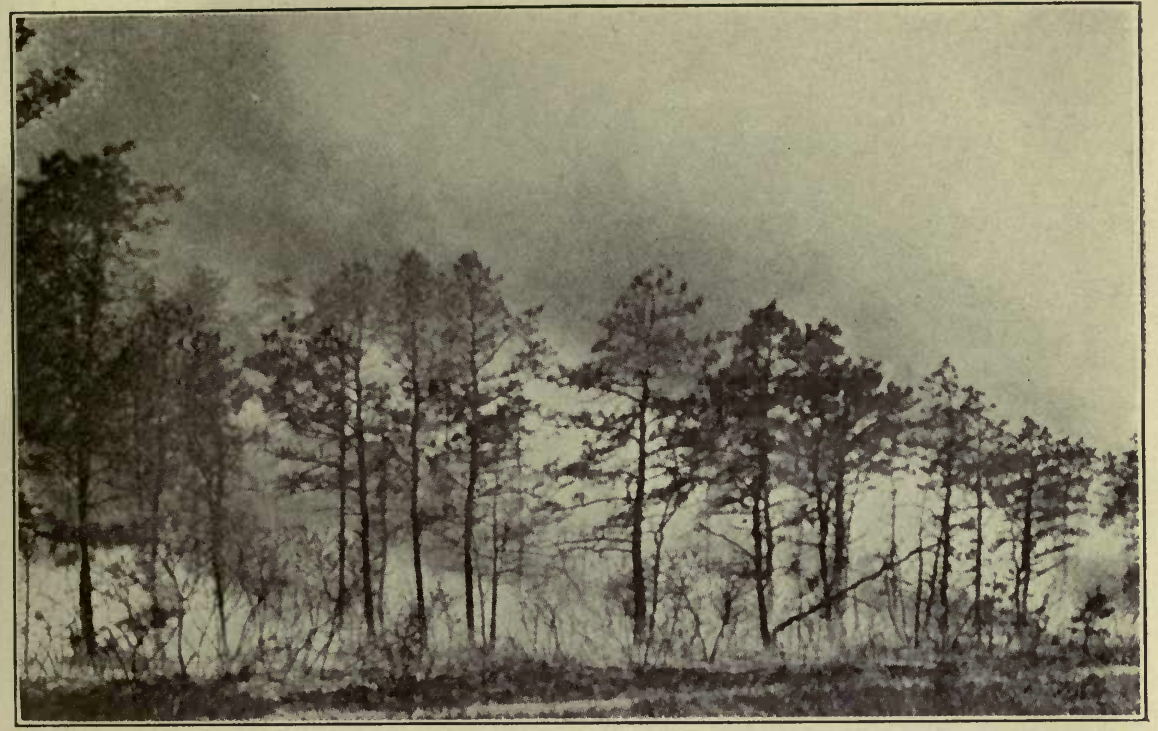

Fig. 6.-A Forest Fire in "The Pines."

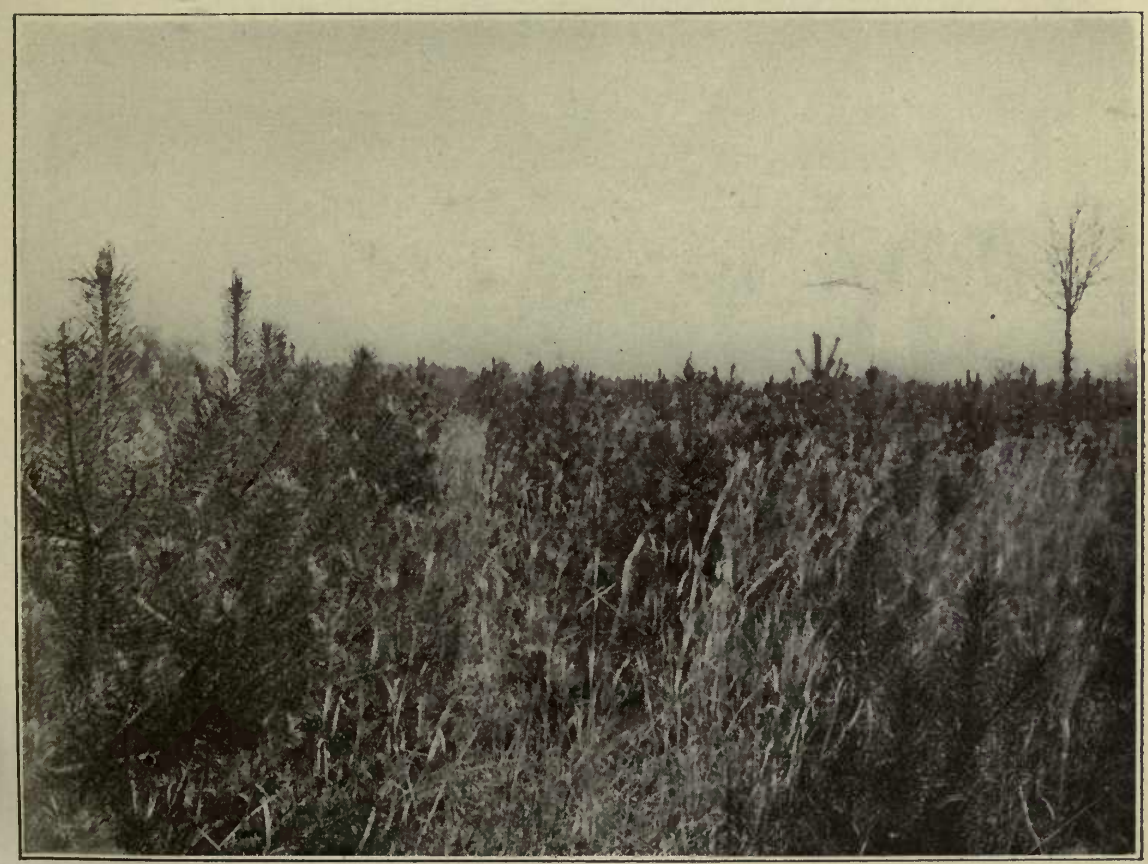

Fig. 7.-A Pine Plantation in South Jersey. Though the Trees Grow Remarkably Well the Risk of Loss by Fire is Great. Note Inflammable "Indian" Grass. 

occurred within the three spring months. It is also significant that with almost no exception every fire that burned a large area was recorded between March and the end of May, with the greater proportion in the latter month. High winds accompanying the drouth created such a situation that the setting any fire on or near forest land was foolhardy and the control of one having appreciable headway in all probability a matter of days instead of hours.

Dry weather continued well through August, when heavy rains gave a much-needed relief, and, though the September precipitation was below the normal, it tided over the hazard until the frequent and generous rainfall of October gave comparative security.

Despite the tendency of the whole season to stimulate the occurrence of fires, a comparison of the figures for this year and those of I9Io (see Table I), brings out a decided decrease for the year. The relation of each separate month to the year's total is given in Table II and points peculiarly to one acutely abnormal month in May when 189 fires burned this year instead of last year's 42. Further, the fires that now occur are more and more confined to those periods of the year when the conditions of weather and the seasonal activities may properly be expected to produce the greatest danger. Cleaning up and clearing land, with the consequent disposal of the brush and refuse, in the spring, and berrying and gunning in the late summer and fall, are properly chargeable with these conditions in the main. 


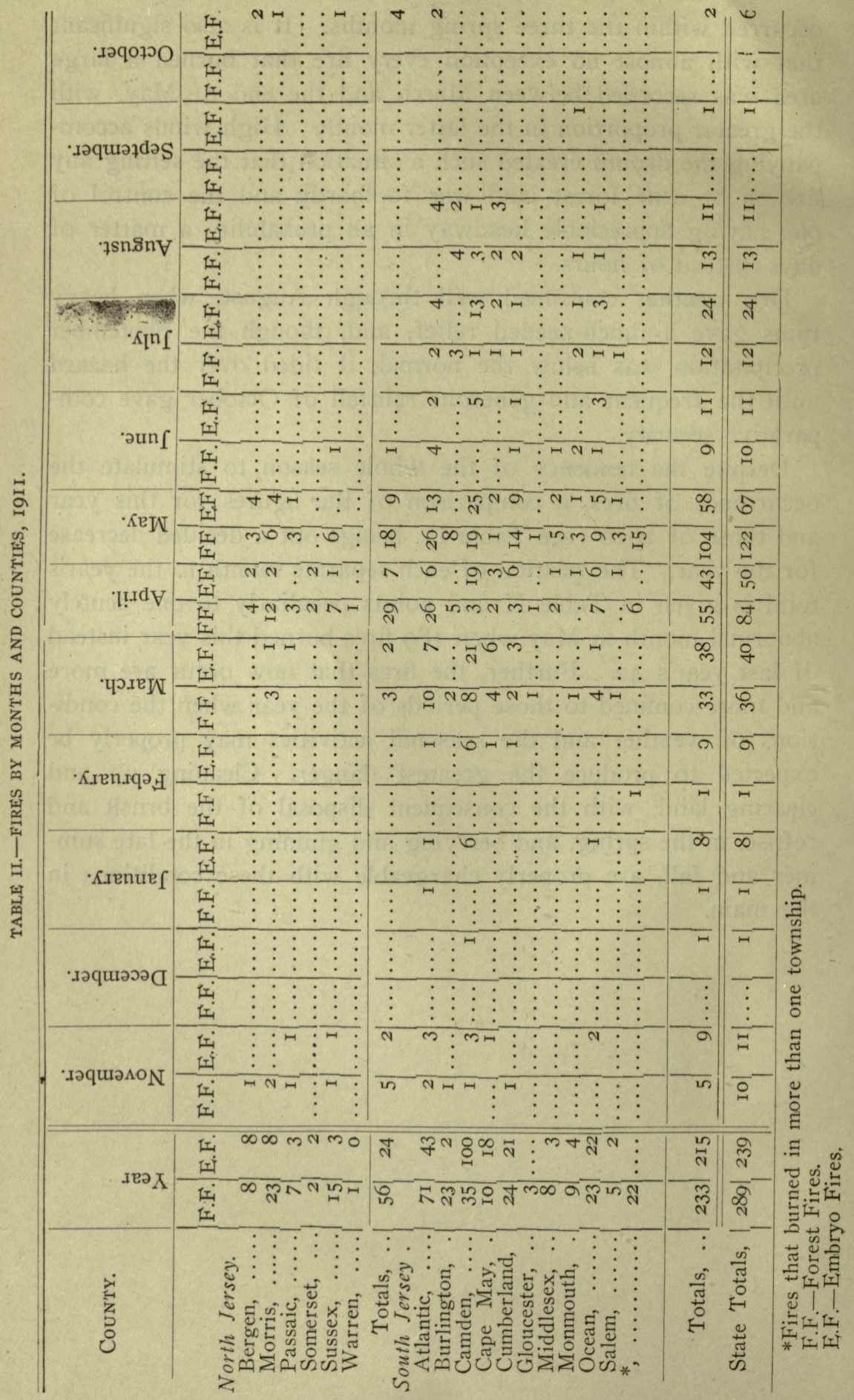




\section{INCREASING PROPORTION OF SMALI FIRES.}

There is no one feature of the work done by the Forest Fire Service more indicative of the improved forest fire conditions in the State than the fact that during the year 45 per cent. of the total number of fires reported can be properly recorded as not forest fires. Figures show that of the 528 fires reported, 239 were put out before they had burned so much as five acres. It thus appears that nearly half of the fires of which the firewardens knew were reached in time, and handled in such a way that they had no opportunity to do appreciable damage. This emphasizes the increasing activity and efficiency of the local men. It indicates further an interest on the part of the people in general through which the wardens are enabled to learn of fires promptly and to obtain assistance in the numbers necessary to check them while in the smaller stages. The significance of this feature of the record is self-evident; not alone in the reduced loss of property which it assures, but in the consequent lowered expense entailed in fighting small fires, even if numerous, as compared with the bills for extinguishing conflagrations that are allowed to gain headway. The fact that the number of embryo fires is still maintained though large fires grow steadily fewer is but a natural outcome of the restriction of the fires to smaller areas. Where heretofore a fire hás burned a large area and rendered that specific location immune from fire for the season, and perhaps for the next season as well, the same areas now present a catchment for numerous small fires, requiring greater vigilance perhaps, but of far less consequence as consumers of time and money. 
TABLE III.-FIRES BY RELATIVE AREA BURNED AND COUNTIES, IOII.

\begin{tabular}{|c|c|c|c|c|c|c|}
\hline \multirow{2}{*}{ County. } & \multicolumn{5}{|c|}{ Number of Forest Fires. } & \multirow{2}{*}{ 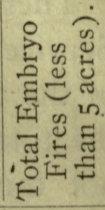 } \\
\hline & $\begin{array}{c}\text { 5-10 } \\
\text { Acres. }\end{array}$ & $\begin{array}{l}\text { II I IOO } \\
\text { Acres. }\end{array}$ & $\begin{array}{c}\text { IOI-IOOO } \\
\text { Acres. }\end{array}$ & $\begin{array}{c}\text { Over } \\
\text { IOO0 } \\
\text { Acres. }\end{array}$ & సี & \\
\hline \multirow{6}{*}{$\begin{array}{c}\text { North Jersey, } \\
\text { Bergen, } \ldots \ldots \ldots \ldots \ldots \\
\text { Passaic, } \ldots \ldots \ldots \ldots \\
\text { Morris, } \ldots \ldots \ldots \ldots \ldots \\
\text { Somerset, } \ldots \ldots \ldots \ldots \\
\text { Sussex, } \ldots \ldots \ldots \ldots \ldots \\
\text { Warren, } \ldots \ldots \ldots \ldots\end{array}$} & & & & & & \\
\hline & I & 7 & $\cdots$ & $\cdots$ & 8 & 8 \\
\hline & & 7 & $\cdots$ & & 7 & 3 \\
\hline & $\begin{array}{r}3 \\
\ldots\end{array}$ & $\begin{array}{r}16 \\
2\end{array}$ & $\begin{array}{r}4 \\
\ldots\end{array}$ & & $\begin{array}{r}23 \\
2\end{array}$ & $\begin{array}{l}8 \\
2\end{array}$ \\
\hline & 3 & 9 & 2 & I & I5 & 3 \\
\hline & $\cdots$ & I & $\cdots$ & $\cdots$ & I & \\
\hline Total, .......... & 7 & 42 & 6 & I & 56 & 24 \\
\hline \multicolumn{7}{|l|}{ South Jersey, } \\
\hline Atlantic, ....... & I5 & 35 & I7 & 4 & $7 \mathrm{I}$ & 43 \\
\hline Burlington, ........ & 4 & I4 & 5 & & 23 & 2 \\
\hline Camden,........ & 7 & 22 & 5 & I & 35 & 100 \\
\hline Cape May, ........ & I & 6 & 3 & $\cdots$ & Io & I8 \\
\hline Cumberland, ........ & 3 & I4 & 7 & $\cdots$ & 24 & $2 \mathrm{I}$ \\
\hline Gloucester, ........ & I & I & I & $\cdots$ & 3 & … \\
\hline Middlesex, ......... & $\cdots$ & 5 & 3 & … & 8 & \\
\hline Monmouth, ......... & . & 7 & 2 & $\cdots$ & 9 & 4 \\
\hline Ocean,...$\ldots \ldots \ldots$ & 2 & I2 & 8 & & 23 & 22 \\
\hline $\begin{array}{l}\text { Salem, } \\
\text { Fires that burned in }\end{array}$ & 2 & I & 2 & & 5 & 2 \\
\hline more than one twp. & 2 & 2 & I2 & 6 & 22 & $\cdots$ \\
\hline Total, . & 37 & II & 65 & 12 & 233 & $2 \mathrm{I} 5$ \\
\hline State total, . . . . . . & 44 & I6I & $7 \mathrm{I}$ & I3 & 289 & 239 \\
\hline
\end{tabular}

The relative proportion of large and small fires is given more particularly in Table III, and points, as always, to the fact that the larger area burned lies in the southern territory where forest types offer more favorable footing, and the wide reaches of level, untenanted woodland render both discovery of and access to a fire more tardy. It is therefore Atlantic, Burlington, Camden, Cumberland and Ocean counties that suffer most heavily. Moreover, these same counties, with Gloucester, are those in which the occupations of the people create the greatest danger. The berry crops, swamp work, and the development of real estate, with its consequent influx of persons ignorant of or careless in using fire, peculiarly expose these sections to burning. (See Table IV and Figs. I3 and I 3 a.) 
PROPERTY SAVED BY THE FIRE SERVICE.

Once more especial stress is laid upon the fact that the value of the fire service is properly measurable in damage prevented, and not alone by offenses punished or fires put out. Again it is possible to make an estimate of what has been accomplished in this respect, though the recital must be prefaced by the statement that the figures named can represent a fraction only of the value of the service rendered. The capacity of a forest fire for doing harm is a factor in no way fixed, on which no satisfactory estimate can be placed, and for which no systematic assembling of data is attempted. The figures given, therefore, summarize the statements on reports sent in by local wardens. They are necessarily fragmentary, but since the values are not appraised on the ground they are made amply low to insure no over-valuation. With all these reservations it is possible to show that by promptly controlling only 37 fires, at an expenditure of $\$ \mathrm{I}, 022$, property worth nearly $\$ 67,000$ was saved. This property included fifty-nine houses and thirty-two other buildings, three cranberry bogs, two of considerable area, five hundred railroad ties, three hundred cords of wood and a large cedar swamp. Among the properties from which fire was kept are named a schoolhouse, two public parks, a large bungalow settlement in North Jersey, and a South Jersey town. Besides this repeated statements occur to show that fires were cut off in time to save timberland of merchantable value. Low as these figures are in comparison with the full results obtained, they are still powerful indicants of the service's worth as a protection within the danger zone of forest fires.

CAUSES OF FOREST FIRES.

To prevent fires from starting it is as essential that the cause from which they come be known as for a diagnosis to precede a cure. Though the specific agent escapes detection the agency may more often be determined. A statement of the year's fires by causes appears in Table IV. 
TABLE IV.-FIRES BY CAUSES AND COUNTIES, IOII.

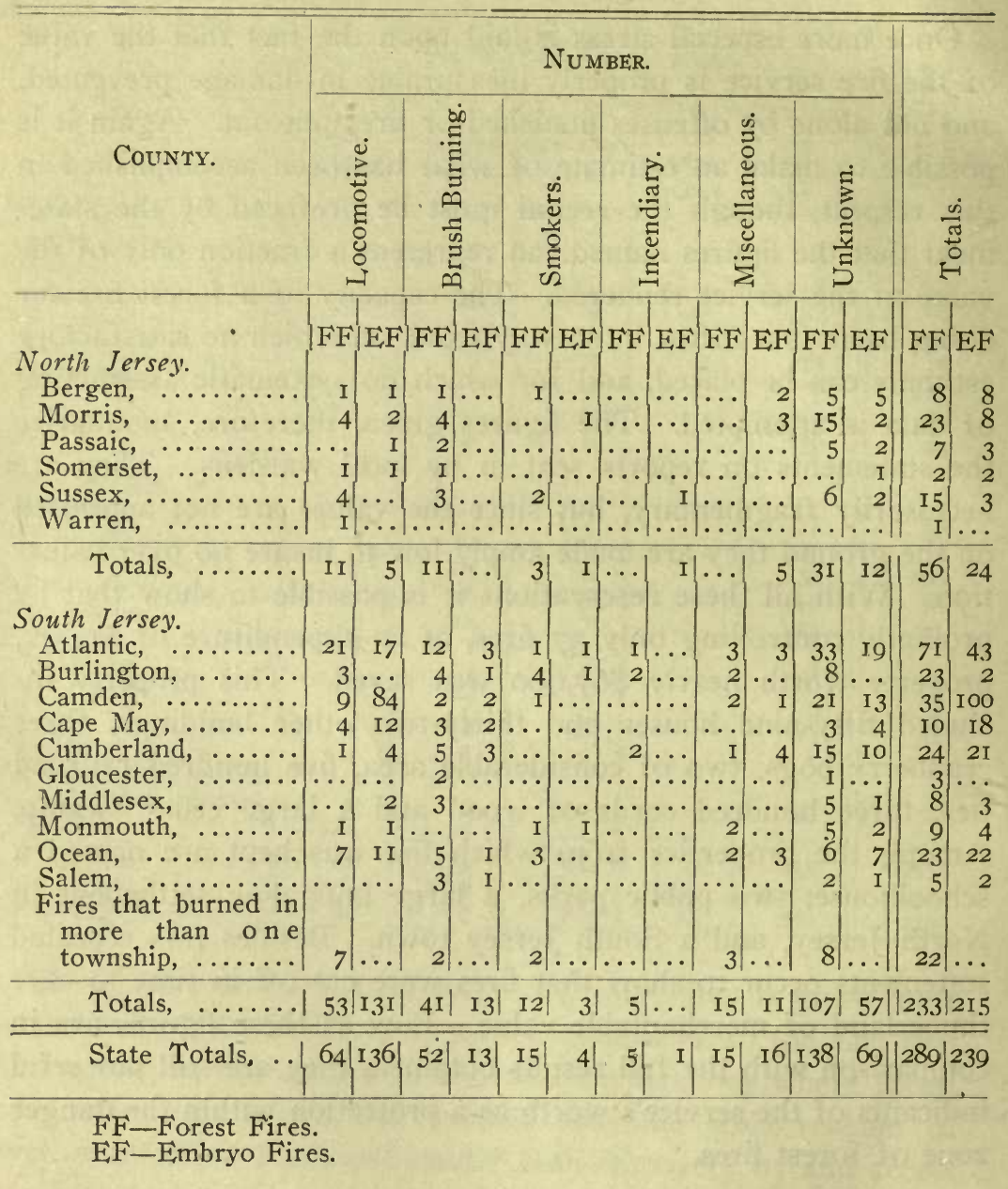

\section{Fires of Unknozon Origin.}

This year again the proportion of fires of unknown origin is higher than in any other class, though in a lower degree. Thus I 38 forest fires and 69 small burnings must be recorded in this most unsatisfactory and indefinite column. Until, however, a systematic patrol can be maintained, the number of wardens 
increased and the effectiveness of both assured this condition is likely to be maintained. But New Jersey is not the only State in which we meet this condition, for it is a general weakness felt wherever there is a State forest fire organization.

The actual ratio of this class to others is, nevertheless, on the mend, for but 39 per cent. of the reported fires are so rated, while 57 per cent. of the total came under it a year ago, 46 per cent. in 1909, and 53 per cent. in 1908. A concrete gain has, therefore, been made in eliminating uncertainty in our knowledge of fire causes.

\section{Railroad Fires.}

Of the known agencies setting fires the railroads still lead as offenders, being responsible for 38 per cent. of all the fires reported. This, as was pointed out last year, is what may be be quite properly expected, since the lack of control of locomotive fires is far less culpable than those from any other source. This does not mean that there are no means of reducing the number of railroad fires far below that now recorded, but sparks will fly from locomotives until mechanical devices, not yet known, are found to control their emission. Therefore, where proper care is taken to use and keep in repair the best spark arresters available, the remedy must be sought upon the ground.

Conditions vary greatly on the different roads and each must be treated individually For instance, it seems to be established that locomotives burning anthracite coal throw more live sparks than those of equal power using the bituminous. This may account in part for the great number of small fires set by the Atlantic City Railroad. Conditions being such, the commission sees no reason to change its attitude toward spark arresters, i. e., that it is wiser to hold the railroads responsible for results than to prescribe the use of some mechanical contrivance.

During I9I I there were 200 fires for which there is reasonable evidence that a railroad was responsible. Of these 136 were extinguished while of insignificant size, and of the 64 rated as forest fires, only i 7 burned as much as Ioo acres. Thus, though the record against the railroads is still bad, it shows unquestioned 
improvement. This may be ascribed partly to the policy pursued by the Forest Commission of holding them for the costs of putting out such fires, and partly to the action of the railroads in constructing and maintaining fire lines. (See pp. 60 to 64.)

\section{Brush Fires.}

Fires of this nature are again, next to railroad fires, the largest known class numerically, although it is noticeable that a considerable number of reports have been received this year of brush burning violations from which no forest fire resulted. While in actual numbers the fires reported equal those of last year, yet, in the promotion of a general knowledge of and respect for the brush-burning law, the prompt imposition of an increased number of penalties has been a large advance. There have been 52 forest fires reported from this cause, with I 3 additional cases in which the area burned was insignificant.

\section{Permits.}

During the year there were 2,450 permits issued. The number of these permits points to the menace created each year by this one class of fires, while the insignificant percentage of such fires which escape to become forest fires, or even come to the notice of the wardens as fires at all, testifies to the value of the permits in insuring care in the use of fire where necessary. Further, a falling off of more than $\mathrm{I}, \mathrm{OOO}$ from the number of permits issued last year, despite an equally strict enforcement of the requirement, sustains the previous argument that the permit clause in the law is curtailing needless burning with its consequent risks.

\section{Smokers' Fires.}

No proper estimate can be made of the number of fires from this cause. Although definite information indicates that but I 5 forest fires and 4 small burnings are chargeable to it, it is certain that could the fires now classed as unknown, but properly chargeable to smokers, be so listed, the number would be largely increased. Moreover, they are the most dangerous and persistent 
class of fires, in that they so often start in places where and at times when their growth to large size is assured before the fight on them can be begun. The danger is so widespread, and people so liable to neglect and carelessness in this respect, that there is practically no way in which proper supervision can be had without a patrol too extensive to be practicable.

Unlike the railroad and brush fires but few have been definitely connected with violations of the law. This fact is eloquent of the handicap in dealing with such offenders. That relief may be had in more attention to our highway rights of way is certain (See p. 59.) Final control must come, however, through aroused public interest and activity and a more general appreciation of the capacity of the most innocent spark to produce a fire of large proportions.

\section{Incendiary Fires.}

The forest fires of this sort are again few in number, there being but 5 recorded, with one other case where the fire was small. That the malicious setting of a fire in or near the woods is a risky business for the offender is certain. That the increased attention the forest fire problem now receives magnifies this risk likewise is sure. And the assured insistence on a penalty commensurate with the proven guilt makes forest firing with intent less likely each year.

\section{Miscellaneous and Automobile Fires.}

Of the burnings of miscellaneous origin reported this year, -those started by saw-mills, children at play, automobiles, etc.,there have been 15 actual forest fires and 16 small fires. Fires set by automobilists grow each year to be felt as a more serious menace. The increased mileage of good roads within the State, and the tremendous growth in the number of automobiles used, continually enlarge this source of fires. The fact that matches of the wind-fire type are used so universally, and that the tendency of automobilists to build small fires while picnicing by the roadside is so strong, makes effective control a very real concern. 
It is particularly difficult to check this firing because the movements of an offender are so uncertain and his departure from the locality so rapid that evidence of identity is rarely available. Often, too, a fire is left behind unconsciously. Despite the fact that the most severe fire of the year, and several other bad burnings also, were attributable to this source, responsibility was fixed for but one insignificant fire. This instance evidenced how troublesome it is to enforce a proper penalty. The offender was a non-resident and having returned outside our jurisdiction before the facts were known, the only penalty possible to impose was to revoke his tourist's license. That was promptly done by the State Commissioner of Motor Vehicles. Thus to the unusual difficulty of locating an offender is added in these cases a strong likelihood of his being beyond reach of punishment when located.

\section{PENALTIES COLLECTED.}

Never since the organization of the forest fire service has there been shown such progress and efficiency in the punishment of violators of the law. Alnd this is a matter for congratulation less because of the actual punishment of those concerned than because it obviously tends toward increased care and watchfulness with fire where heretofore there was negligence or wilful disregard of the law. An old trail is a dim trail, but more and more as the service becomes better organized is the former unavoidable delay in investigating reported violations on the mend. The new force of Division Firewardens recently added is telling already, because of the attendant promptness in disposing of such work. There have been 206 cases, of the total 528 reported during the year, requiring investigation in the field. In some instances the time spent was brief, though a number of fires demanded the time of a warden for periods reaching into weeks. In spite of this amount of work, to which also must be added a large share of time spent on older cases, it has been possible during the present year to fix responsibility upon and to penalize the offenders in 125 cases of the total $25^{8}$ violation cases recorded in I9I I. In Table VII these cases are item- 
ized to show each instance in which a violation of the law has been reported. Not every case can be supported by legal evidence sufficient to convict, and circumstances in some made it inadvisable to push the matter to a penalty. The latter class comprises but a small number, and few known violators have been released without being held accountable in some way. Each violation case is judged on its individual merits, and the Forest Commission finds it inexpedient to insist on equal severity. Thus, when the infliction of a penalty would have imposed a burden on the township in caring for dependents of a violator a settlement was made in another way. In some other cases the firefighters concerned withdrew their claims for pay in order to spare the offender. In another instance a man was allowed to work out his fine on a State reserve, since his condition made money payment impossible.

As will be seen from Tables VII, VIII and IX, a large proportion of the offenders are released from liability upon payment of the whole cost of the fire. While in no way retreating from its intention to prosecute every violator of the law, the commission seeks to prevent fires, rather than to impose penalties. Thus, when the fault lies not in the intention but in excusable ignorance of the law, poor judgment or pure accident, harsh measures and consequent enmities are not only impolitic but unjust. This position is strengthened by the provision of law that money so recovered shall be paid to the township by which it was originally expended.

The continued co-operation of the railroads in settling bills for fighting fire in every case where there is reasonable evidence of their responsibility gives assurance of their appreciation of the service rendered. Of 192 fires on which claims were made, 83 have already been settled and I $_{5}$ withdrawn upon evidence developed by the companies that the responsibility was misplaced. The 94 others still pending adjustment are expected to be in large part settled on the opening of the new calendar year; in accordance with an arrangement permitting periodic instead of individual settlements of these cases.*

In no case this year has a court trial been necessary, although

* Fifty-three of these 94 were settled before April I, I9I2. 
TABLE, V.-FOREST FIRES, I9II.

\begin{tabular}{|c|c|c|c|c|c|c|c|c|}
\hline \multirow[b]{2}{*}{ County and Township. } & \multicolumn{2}{|c|}{ Number } & \multirow[b]{2}{*}{ 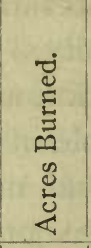 } & \multirow[b]{2}{*}{ 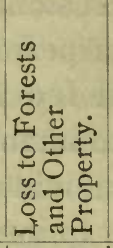 } & \multirow[b]{2}{*}{ 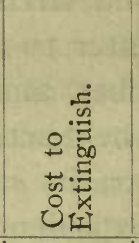 } & \multicolumn{3}{|c|}{ Paid by $\dagger$} \\
\hline & 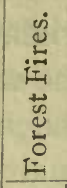 & 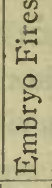 & & & & 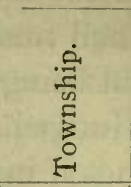 & 菎 & 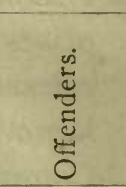 \\
\hline $\begin{array}{l}\text { Atlantic County- } \\
\text { Absecon (City), }\end{array}$ & & & & & & & & \\
\hline Buena Vista, & $1 \dot{8}$ & 9 & $2 \ddot{8} \ddot{8} \dot{8}$ & $\$ 1,880$ & $\$ 22885$ & $\$ 4477$ & $\$ 4478$ & $\$ 13930$ \\
\hline Egg Harbor, $\ldots . .$. & IO & 4 & 3,032 & $\mathrm{I}, 640$ & $227 \quad 35$ & 9092 & 9093 & 4550 \\
\hline Egg Harbor (City), & 2 & 2 & IIO & 90 & 2400 & 1200 & 1200 & $\ldots \ldots \ldots$ \\
\hline Folsom, .......... & 2 & 2 & II 8 & I30 & 2605 & 577 & 578 & I4 50 \\
\hline Galloway, ......... & 8 & I & 3,915 & 4,295 & 27875 & $\mathrm{I} 246 \mathrm{I}$ & 12464 & 3925 \\
\hline Hamilton,...$\cdots$ & I7 & 9 & 9,707 & 6,923 & 283 I0 & I27 54 & 12756 & 2800 \\
\hline Hammonton, ... & IO & I0 & 634 & 757 & 30490 & I38 45 & I38 45 & 2800 \\
\hline Mullica,,$\ldots$. & I5 & I & 2,765 & 1,605 & 41375 & $48 \quad 58$ & 4860 & 31657 \\
\hline Port Republic, ..... & I & ... & 800 & 2,500 & 2720 & I3 60 & I3 60 & $\ldots \ldots$ \\
\hline Weymouth, ....... & 9 & 5 & 447 & I59 & I45 32 & 5275 & 5277 & 3980 \\
\hline Total, .... & 92 & 43 & 23,906 & $\$ 19,979$ & $\$ 1,95927$ & $\$ 65899$ & $\$ 659$ I I & $\$ 65092$ \\
\hline Bergen County- & & & & & & & & \\
\hline $\begin{array}{l}\text { Alpine (Boro.), .. } \\
\text { Franklin, ......... }\end{array}$ & 6 & 6 & I32 & $\$ 24 \mathrm{I}$ & $\begin{array}{lll}\$ 61 & 05\end{array}$ & $\begin{array}{lll}\$ 29 & 27\end{array}$ & $\$ 2928$ & $\$ 500$ \\
\hline Hohokus, $\ldots \ldots \ldots$ & I & $\cdots$ & $\begin{array}{r}\text { I5 } \\
\ldots .\end{array}$ & & $\begin{array}{r}\cdots \\
400\end{array}$ & $\begin{array}{r}\cdots \\
200\end{array}$ & $\mid \begin{array}{r}\cdots \\
200\end{array}$ & \\
\hline Oakland (Boro.),.. & $\mathrm{I}$ & I & I5 & & 3190 & I 75 & I 75 & 2840 \\
\hline Ridgefield (Boro.),. & $\cdots$ & $\cdots$ & $\cdots \cdots$ & $\cdots \cdots$ & $\ldots \ldots \cdots$ & $\cdots \cdots \cdots$ & $\cdots \cdots \cdots$ & $\cdots \cdots \cdots$ \\
\hline Total, .......... & 8 & 8 & I62 & $\$ 316$ & $\$ 9695$ & $\$ 33$ 02 & $\$ 33$ o3 & $\$ 3340$ \\
\hline Burlington County- & & & & & & & & \\
\hline s River, ....... & I & $\ldots$ & 300 & $\$ 100$ & $\$ 450$ & $\$ 2 \quad 25$ & $\$ 2,25$ & \\
\hline Evesham, ......... & 2 & $\ldots$ & 125 & 350 & I4 00 & 600 & 600 & $\$ 500$ \\
\hline Medford, .......... & 5 & $\cdots$ & 268 & I65 & I05 70 & 49 I0 & 49 Iо & 750 \\
\hline Hanover, . & $\dot{r}$ & I & $\cdots \cdots$ & 2,600 & I5 00 & $\cdots \cdots \cdots$ & ........ & Io 00 \\
\hline Pemberton, .... & 6 & $\cdots$ & 2,245 & 1,025 & I 4740 & 3942 & 3943 & 6855 \\
\hline ong, ....... & 3 & I & IOO & 50 & 4375 & 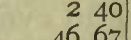 & $\begin{array}{rl}2 & 40 \\
4 & 68\end{array}$ & 3895 \\
\hline $\begin{array}{l}\text { Southampton, ..... } \\
\text { Tabernacle, ....... }\end{array}$ & $\begin{array}{l}5 \\
3\end{array}$ & $\begin{array}{l}\cdots \\
\cdots\end{array}$ & $\begin{array}{r}1,080 \\
340\end{array}$ & $\begin{array}{r}420 \\
1,810\end{array}$ & 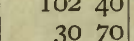 & $\begin{array}{rrr}40 & 07 \\
\ldots \ldots & \ldots\end{array}$ & $\begin{array}{r}4008 \\
\ldots \ldots \ldots\end{array}$ & $\begin{array}{l}\text { I3 } 55 \\
5000\end{array}$ \\
\hline ington,.... & & $\cdots$ & & & - & $\ldots \ldots \ldots$ & $\ldots \ldots \ldots$ & \\
\hline Woodland, §.... & 2 & ... & 550 & 800 & 2350 & $\ldots \ldots \ldots$ & I7 50 & 600 \\
\hline Total, .......... & 27 & 2 & $5, \mathrm{OI} 4$ & $\$ 7,320$ & $\$ 48695$ & $\$$ I54 59 & \$I54 6I & $\$ 19955$ \\
\hline Camden County- & & & & & & & & \\
\hline $\begin{array}{l}\text { Berlin, ........... } \\
\text { Chesilhurst (Boro.), }\end{array}$ & $\dot{2}$ & $\ddot{4}$ & $\ddot{2}, \overrightarrow{5} 40$ & $\$ 1,000$ & $\$ \begin{array}{lll}369 & 0 & 0\end{array}$ & $\$ 3827$ & $\$ 3828$ & \\
\hline Clementon, ....... & 4 & 3. & 950 & I,I I 5 & 7990 & 3995 & 3995 & $\$ 500$ \\
\hline Delaware, ........ & 2 & 2 & $\mathbf{I} 5$ & 185 & I5 00 & 750 & 750 & ........ \\
\hline Gloucester, ....... & 5 & 2 & 790 & 250 & $85 \quad 35$ & 4267 & 4268 & $\ldots \ldots \ldots$ \\
\hline Voorhees, ........ & 2 & I! & 60 & I5 & I7 00 & 850 & 850 & $\ldots \ldots \ldots$ \\
\hline Waterford, ......... & I5 & I & I,588 & 3,015 & 20965 & IOI 09 & IOI I6 & 830 \\
\hline Winslow, ......... & 6 & 87 & I36 & 255 & 35865 & 2695 & 2695 & 30600 \\
\hline Total, & 36 & IOO & 6,079 & $|\$ 5,835|$ & $\$ 83460$ & $\$ 26493$ & $\begin{array}{lll}\$ 265 & 02\end{array}$ & $\$ 31930$ \\
\hline
\end{tabular}


TABLE V.-FOREST FIRES, I9II.-Continued.

\begin{tabular}{|c|c|c|c|c|c|c|c|c|}
\hline \multirow[b]{2}{*}{ County and Township. } & \multicolumn{2}{|c|}{ Number } & \multirow[b]{2}{*}{ 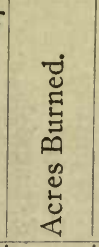 } & \multirow[b]{2}{*}{ 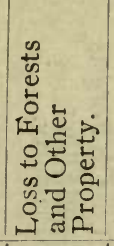 } & \multirow[b]{2}{*}{ 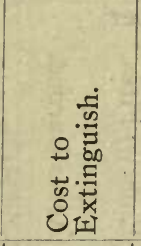 } & \multicolumn{3}{|c|}{ Paid by $\dagger$} \\
\hline & 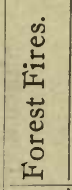 & 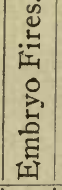 & & & & 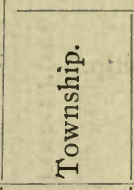 & 壱 & 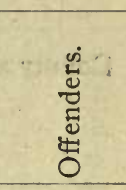 \\
\hline $\begin{array}{r}\text { Cape May County- } \\
\text { Dennis, } \S \ldots \ldots \ldots \ldots \\
\text { Lower, } \ldots \ldots \ldots \ldots \\
\text { Middle, } \ldots \ldots \ldots \ldots \ldots \\
\text { Upper, } \ldots \ldots \ldots \ldots \\
\text { Woodbine (Boro.). }\end{array}$ & \begin{tabular}{r|}
$\mathrm{I}$ \\
2 \\
3 \\
4 \\
$\cdots$
\end{tabular} & $\mid \begin{array}{r}\cdots \\
9 \\
7 \\
2 \\
\cdots\end{array}$ & $\begin{array}{r}75 \\
83 \\
220 \\
2,112 \\
\cdots\end{array}$ & $\begin{array}{r}\$ 30 \\
794 \\
125 \\
1,675 \\
\ldots \ldots\end{array}$ & 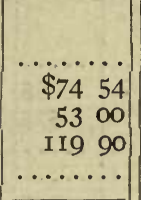 & 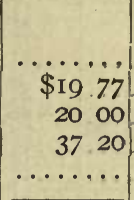 & 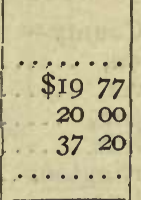 & $\begin{array}{r}\$ 3500 \\
1300 \\
3000 \\
\cdots \cdots\end{array}$ \\
\hline Total, $\ldots \ldots \ldots$ & 10 & I8 & 2,490 & $\$ 2,624$ & $\$ 24744$ & $\$ 7697$ & $\$ 7697$ & $\$ 7800$ \\
\hline 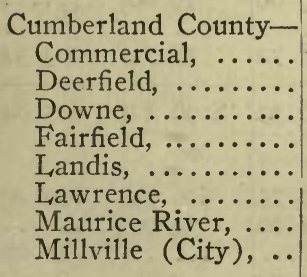 & \begin{tabular}{r|}
2 \\
3 \\
$\mathrm{I}$ \\
$\mathrm{I}$ \\
$\mathrm{II}$ \\
$\mathrm{I}$ \\
5 \\
3 \\
\end{tabular} & $\begin{array}{r}2 \\
\cdots \\
1 \\
4 \\
2 \\
4 \\
8\end{array}$ & $\begin{array}{r}100 \\
200 \\
10 \\
115 \\
3,635 \\
100 \\
2,152 \\
285\end{array}$ & $\begin{array}{r}\$ 425 \\
175 \\
55 \\
100 \\
2,170 \\
112 \\
620 \\
270\end{array}$ & $\begin{array}{rr}\$ 36 & 60 \\
10 & 00 \\
27 & 00 \\
\text { I } 1 & 00 \\
230 & 70 \\
31 & 50 \\
\text { 139 } & 60 \\
80 & 05\end{array}$ & $\begin{array}{rr}\text { \$16 } & 30 \\
5 & 00 \\
13 & 50 \\
5 & 50 \\
107 & 39 \\
5 & 75 \\
65 & 92 \\
21 & 75\end{array}$ & $\begin{array}{rr}\$ 16 & 30 \\
5 & 00 \\
13 & 50 \\
5 & 50 \\
107 & 41 \\
5 & 75 \\
65 & 93 \\
21 & 75\end{array}$ & $\begin{array}{rl} & \$ 400 \\
\cdots \ldots \ldots \\
\cdots \ldots \ldots \\
20 & 90 \\
20 & 00 \\
11 & 00 \\
72 & 00\end{array}$ \\
\hline 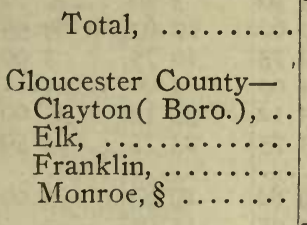 & $\begin{array}{c}\cdots \\
\cdots \\
6 \\
1\end{array}$ & $\begin{array}{l}\cdots \\
\cdots \\
\cdots \\
\cdots\end{array}$ & $\mid \begin{array}{r}6,597 \\
\cdots \\
\cdots \\
1,457 \\
200\end{array}$ & $\begin{array}{r}\cdots \\
\$ 5,725 \\
100\end{array}$ & 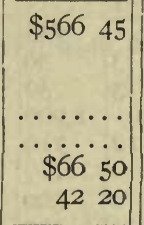 & 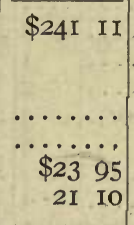 & 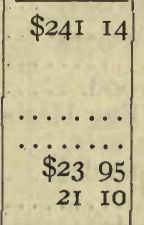 & $\begin{array}{l}\ldots \\
\$ 4360 \\
\ldots \ldots\end{array}$ \\
\hline Total, $\ldots \ldots \ldots$ & 7 & $\cdots$ & $\mathrm{I}, 657$ & $\$ 5,825$ & $\$ 10870$ & $\$ 45 \quad 05$ & $\$ 4505$ & $\$ 4360$ \\
\hline $\begin{array}{l}\text { Middlesex County- } \\
\text { East Brunswick, ... } \\
\text { Madison, ........... } \\
\text { Monroe, } \ldots \ldots \ldots \ldots \\
\text { Sayreville, ......... } \\
\text { South Brunswick,.. }\end{array}$ & $\begin{array}{r}2 \\
4 \\
I \\
1 \\
I\end{array}$ & $\begin{array}{r}\cdots \\
\cdots \\
2 \\
\cdots\end{array}$ & $\begin{array}{r}95 \\
380 \\
250 \\
\cdots \\
105\end{array}$ & $\begin{array}{r}\$ 85 \\
250 \\
25 \\
10 \\
100\end{array}$ & $\begin{array}{rr}\$ 27 & 50 \\
56 & 60 \\
14 & 00 \\
5 & 00 \\
5 & 30\end{array}$ & $\begin{array}{r}\$ 28 \\
70 \\
7 \ldots\end{array}$ & $\begin{array}{r}\$ 28 \\
70 \\
7 \ldots \\
\cdots\end{array}$ & $\begin{array}{r}\$ 2750 \\
\ldots \ldots \ldots \\
\ldots \ldots \ldots \\
5 \\
5 \quad 00 \\
530\end{array}$ \\
\hline Total, $\ldots \ldots \ldots$ & 8 & 3 & 830 & $\$ 470$ & $\$ 10840$ & $\$ 3530$ & $\$ 3530$ & $\$ 3780$ \\
\hline 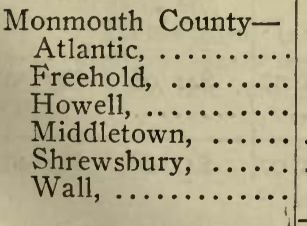 & $\begin{array}{r}2 \\
4 \\
4 \\
\cdots \cdot \\
\cdots \cdot \\
\\
\end{array}$ & $\begin{array}{r}2 \\
\cdots \\
2 \\
\cdots \\
\cdots \\
\cdots \\
\end{array}$ & $\begin{array}{r}1,850 \\
300 \\
1,200 \\
\ldots \ldots \\
\ldots . . \\
60 \\
\end{array}$ & $\begin{array}{r}\$ 8,600 \\
350 \\
4,195 \\
\ldots \ldots \\
\ldots \ldots \\
300 \\
\end{array}$ & 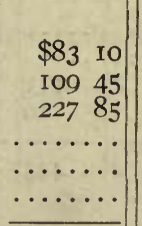 & $\begin{array}{r}\$ 300 \\
5472 \\
9679 \\
\ldots \ldots \ldots \\
\cdots \ldots \ldots \\
\cdots \cdots \\
\end{array}$ & $\begin{array}{r}\$ 300 \\
5473 \\
968 \mathrm{r} \\
\ldots \ldots \ldots \\
\cdots \ldots \ldots \\
\cdots\end{array}$ & $\begin{array}{r}\$ 7700 \\
\ldots \ldots \ldots \\
3900 \\
\ldots \ldots \ldots \ldots \\
\cdots \ldots \ldots \\
\end{array}$ \\
\hline Total, .......... & $\begin{array}{l}\text { II } \\
\text { FOR }\end{array}$ & $4 \mid$ & 3,410 & $\$ 13,445$ & $\$ 42030$ & $\overline{\$ 1545 \mathrm{I}}$ & $\$$ I54 54 & $\$ 11600$ \\
\hline
\end{tabular}


TABLE V.-FOREST FIRES, I9II.-Continued.

\begin{tabular}{|c|c|c|c|c|c|c|c|c|}
\hline \multirow[b]{2}{*}{ County and Township. } & \multicolumn{2}{|c|}{ Number } & \multirow{2}{*}{ 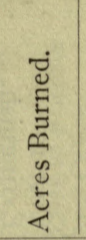 } & \multirow{2}{*}{ 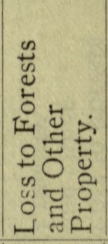 } & \multirow[b]{2}{*}{ 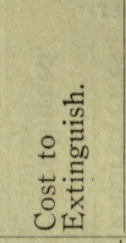 } & \multicolumn{3}{|c|}{ Paid by $\dagger$} \\
\hline & 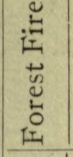 & $\begin{array}{l}i_{1} \\
0 \\
\frac{2}{E} \\
\frac{E}{I I}\end{array}$ & & & & 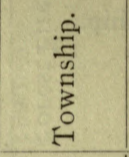 & 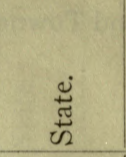 & 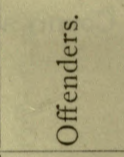 \\
\hline \multicolumn{9}{|l|}{ Morris County- } \\
\hline & & & 55 & $\$ 120$ & $\$ 5 \mathrm{I} 550$ & $\$ 1800$ & $\$ 1800$ & \$ 550 \\
\hline $\mathrm{Je}$ & 7 & & 575 & $\mathrm{I}, 400$ & I43 00 & 7150 & 7150 & $\ldots \ldots$ \\
\hline$\cdots$ & $\cdots$ & I & $\cdots \cdots$ & $\cdots \cdots$ & $\cdots \ldots \ldots$ & $\cdots \cdots \cdots$ & $\cdots \cdots \cdots$ & \\
\hline $\begin{array}{l}\cdots \\
\cdots\end{array}$ & & I & $\cdots \cdots$ & $\begin{array}{l}100 \\
522\end{array}$ & & $\begin{array}{r}750 \\
3450\end{array}$ & & \\
\hline $\mathrm{Pec}$ & & .. & $\begin{array}{l}242 \\
\mathrm{I} 75\end{array}$ & $\begin{array}{l}522 \\
310\end{array}$ & 600 & $\begin{array}{ll}34 & 50 \\
26 & 57\end{array}$ & 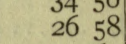 & $\begin{array}{r}\cdots \\
700\end{array}$ \\
\hline Ra1 & & $\cdots$ & 78 & 180 & 3920 & 1960 & 1960 & $\ldots \ldots$ \\
\hline $\begin{array}{l}\text { Ro } \\
\text { Ro }\end{array}$ & $\cdots$ & & $\begin{array}{r}\cdots \cdots \\
\text { Igo }\end{array}$ & $\mid \begin{array}{r}\cdots \\
1,905\end{array}$ & 6о & $\begin{array}{ll}\cdots & \cdots \\
18 & 72\end{array}$ & & $\cdots \ldots . .$. \\
\hline KOx & 3 & 0 & 190 & & & & & 2334 \\
\hline Total, .... & 23] & 8 & $\mathrm{I}, 3 \mathrm{I} 5$ & $\$ 4,537$ & $\$ 43865$ & $\$ 19639$ & $\$ 19642$ & $\$ 4584$ \\
\hline \multicolumn{9}{|l|}{$\begin{array}{c}\text { Ocean County- } \\
\text { Berkeley, ..... }\end{array}$} \\
\hline Berkeley, ..... & 5 & I & $\mathrm{I}, 70 \mathrm{I}$ & $\$ 10,370$ & $\$ 15270$ & $\$ 56.75$ & $\$ 5675$ & $\$ 3920$ \\
\hline$\cdots$ & I & $\cdots$ & $\mathrm{I}, 500$ & 2,100 & 6800 & 3400 & 3400 & $\ldots \ldots$ \\
\hline $\begin{array}{l}\text { Do } \\
\text { Ea }\end{array}$ & I & $\cdots$ & 20 & 50 & $\begin{array}{rl}12 & 00 \\
7 & 0\end{array}$ & $\cdots \cdots \cdots$ & $\cdots \cdots \cdots$ & I2 00 \\
\hline $\mathrm{Ja}$ & $\ddot{3}$ & $\ldots$ & $\cdots \cdots$ & 235 & $\begin{array}{rl}7 & 00 \\
75 & 20\end{array}$ & $\begin{array}{r}350 \\
1762\end{array}$ & $\begin{array}{r}350 \\
1763\end{array}$ & 3995 \\
\hline & $\mathrm{I}$ & $\begin{array}{r}\cdots \\
3\end{array}$ & 30 & I0 & 2540 & I0 75 & I0 75 & 390 \\
\hline & 2 & 3 & 30 & 77 & I3 00 & 400 & & ......... \\
\hline Egg Harbor,. & 3. & $\ldots$ & $\mathrm{I}, 000$ & $\mathrm{I}, 800$ & IOI 25 & $33 \mathrm{I} 2$ & 33 I3 & 3500 \\
\hline ster, $\ldots . .$. & 8 & 12 & 710 & $4 \mathrm{I} 5$ & I 1200 & 2375 & 2375 & 6450 \\
\hline $\mathrm{Oc}$ & I & $\cdots$ & $\begin{array}{l}\cdots \\
300\end{array}$ & 600 & 4265 & 1982 & I9 83 & 300 \\
\hline St & I & $\cdots$ & 500 & 1,000 & 3190 & I5 95 & I5 95 & ....... \\
\hline Union, $\quad \ldots \ldots \ldots \ldots$ & 3. & $\cdots$ & 450 & $\mathrm{I}, 505$ & II3 00 & $56 \quad 49$ & $565 \mathrm{I}$ & $\ldots \ldots \ldots$ \\
\hline Total, & 29 & 22 & 6,486 & $\$ 18,167$ & $\$ 754$ Io & $\$ 27575$ & $\$ 27580$ & $\$ 197.55$ \\
\hline $\begin{array}{l}\text { Passaic County- } \\
\text { Pompton, ...... }\end{array}$ & & & & & & & & \\
\hline West Milford, ... & 6 & 2 & 345 & $\begin{array}{l}475 \\
\mathrm{I} 55\end{array}$ & $\begin{array}{r}18720 \\
\end{array}$ & $\begin{array}{ll}4 \mathrm{I} & 55\end{array}$ & $4 \mathrm{I} 55$ & $\$ 109$ io \\
\hline Total, & 7 & 3 & 420 & $\$ 230$ & $\$ \mathrm{I} 9470$ & $\$ 4530$ & $\$ 4530$ & \$109 IO \\
\hline alem C & & & & & & & & \\
\hline $\begin{array}{l}\mathrm{A}] \\
\mathrm{L},\end{array}$ & & & & & & & & \\
\hline Pitt & 5 & 2 & 433 & $\$ 485$ & $\$ 9340$ & $\$ 4 \mathrm{I} \quad 07$ & $\$ 4 \mathrm{I}$ o8 & $\$ 2750$ \\
\hline Quinton, ........... & $\mathrm{I}$ & $\ldots$ & Io & 70 & I3 90 & $\ldots \ldots \cdots$ & $\ldots \ldots \ldots$ & I3 90 \\
\hline Total, & 6 & 2 & 443 & $\$ 555$ & $\$ 10730$ & $\begin{array}{lll}\$ 4 & 07\end{array}$ & $\begin{array}{lll}\$ 4 & 08\end{array}$ & $\$ 4 \mathrm{I} \quad 40$ \\
\hline
\end{tabular}


TABLE V.-FOREST FIRES, IgII.-Continued.

\begin{tabular}{|c|c|c|c|c|c|c|c|c|}
\hline \multirow[b]{2}{*}{ County and Township. } & \multicolumn{2}{|c|}{ Number. } & \multirow[b]{2}{*}{ 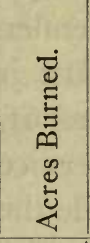 } & \multirow[b]{2}{*}{ 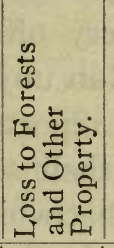 } & \multirow[b]{2}{*}{ 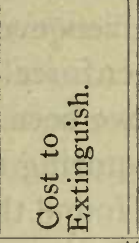 } & \multicolumn{3}{|c|}{ Paid by $\uparrow$} \\
\hline & 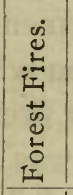 & 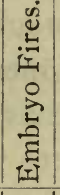 & & & & 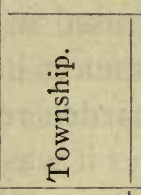 & 芯 & 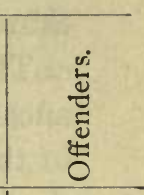 \\
\hline $\begin{array}{l}\text { Somerset County- } \\
\text { Bernard, .......... } \\
\text { Bridgewater, } 0 . \cdots \\
\text { North Plainfield, .. } \\
\text { Warren, .......... }\end{array}$ & $\mid \begin{array}{r}\cdots \\
\cdots \\
\cdots \\
\cdots\end{array}$ & $\begin{array}{r}\cdots \\
\cdots \\
2 \\
\cdots\end{array}$ & $\begin{array}{c}\cdots \cdots \\
\cdots \cdots \\
140 \\
\cdots \cdots\end{array}$ & $\mid \begin{array}{c}\cdots \\
\cdots \\
\cdots \\
\ldots \\
\ldots\end{array}$ & 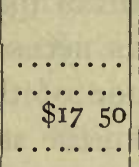 & 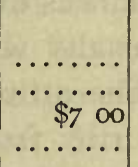 & 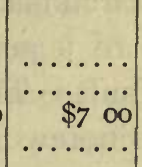 & $\begin{array}{r}\cdots \\
\cdots \\
\ldots 4 \\
\ldots\end{array}$ \\
\hline Total, . & 2 & 2 & 140 & $\$ 65$ & $\$ 1750$ & $\$ 7 \infty$ & $\$ 700$ & $\$ 450$ \\
\hline 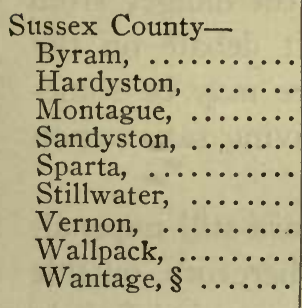 & $\begin{array}{r}\mathrm{I} \\
3 \\
\mathrm{I} \\
\mathrm{I} \\
6 \\
\mathrm{I} \\
2 \\
\cdots \\
\cdots\end{array}$ & $\begin{array}{r}\mathrm{I} \\
\mathrm{I} \\
\cdots \\
\cdots \\
\cdots \\
\cdots \\
\mathrm{I} \\
\cdots \\
\cdots\end{array}$ & $\begin{array}{r}250 \\
40 \\
4,000 \\
15 \\
240 \\
10 \\
850 \\
\ldots \\
\ldots\end{array}$ & $\begin{array}{r}\$ 135 \\
45 \\
2,000 \\
50 \\
440 \\
50 \\
885 \\
\ldots \ldots\end{array}$ & 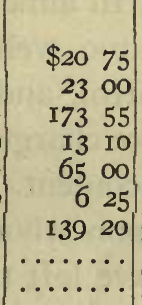 & $\mid \begin{array}{rr}\$ 2 & 00 \\
7 & 00 \\
86 & 77 \\
6 & 55 \\
24 & 00 \\
\ldots & \ldots \\
50 & 47 \\
\ldots & \ldots\end{array}$ & 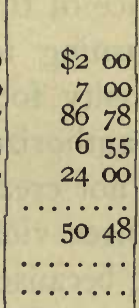 & $\begin{array}{r}\$ 1675 \\
900 \\
\ldots \ldots \\
\cdots \ldots \\
1700 \\
\ldots \ldots \\
\ldots \ldots \ldots\end{array}$ \\
\hline Total, $\ldots \ldots \ldots$ & 15 & 3) & 5,405 & $\$ 3,605$ & $\$ 44085$ & $\$ 17679$ & $\$ 1768 \mathrm{r}$ & $\$ 8475$ \\
\hline 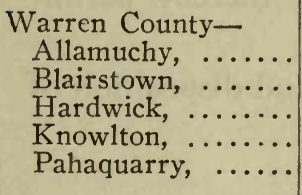 & $\begin{array}{r}\cdots \\
\cdots \\
\cdots \\
\cdots \\
\cdots \\
I\end{array}$ & $\begin{array}{l}\cdots \\
\cdots \\
\cdots \\
\cdots \\
\cdots\end{array}$ & $\begin{array}{r}\cdots \cdots \\
\cdots \cdots \\
\cdots \cdots \\
50\end{array}$ & $\mid \begin{array}{l}\cdots \\
\cdots \\
\cdots \\
\cdots \\
\cdots \\
\$_{40}\end{array}$ & 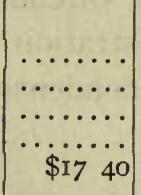 & 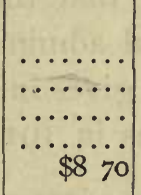 & 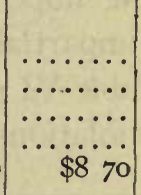 & 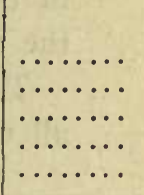 \\
\hline Total, .......... & I) & $\ldots$ & 50 & $\$ 40$ & $\$ 1740$ & $\$ 870$ & $\$ 870$ & $\ldots \ldots \ldots$ \\
\hline State Total, .. & *309 & 239 & 64,404 & $\$ 86,940$ & $\$ 6,70956$ & $\$ 2,4$ I $5 \quad 47$ & $\$ 2,4$ I5 88 & $\$ 2,08961 \%$ \\
\hline
\end{tabular}

* This total is greater than the actual number (289) because several fires burned in two or more townships at once.

t The sum of these columns often differs from the corresponding "Cost to Extinguish" item because a fine was larger than the bill, or a bill was withdrawn, etc.

$\$$ This total is greater than the year's collection $(\$ 2,021.24)$ because all violation cases are not yet settled.

$\S$ No fire service. 
three of last year's offenders resisted the imposition of penalties until court proceedings were under way. This argues well both for the commission's policy in proposing settlements and for the assurance given every offender that the power of the State is not used to enforce an unjust judgment.

Three instances have been reported of men who refused assistance to a warden requiring their service as firefighters. In two of these cases it was found that while there was an actual refusal, the circumstances did not make the offense such that the imposition of a penalty was necessary. In the third the warden was at fault. The attitude of those called to fight forest fires has been noteworthy from the start, and it is a matter for comment that in so few instances has serious objection been made to service of this sort. In almost all communities the danger from a burning forest is too well realized to permit debate on the necessity for its control, and the fact that there máy be someone authorized to take charge of such work is giving satisfaction and not creating discontent.

Three violators upon whom guilt was fixed are still unpenalized, because they have left the State and are, therefore, outside the jurisdiction of the law. Such cases are kept open indefinitely in the hope that the offender may return and thereby permit the impartial administration of the law.

Table VI gives in condensed form the status and disposition of all violations in I9I I.

TABLE VI.-VIOLATIONS OF THE FOREST FIRE, LAW, IOII.

\begin{tabular}{|c|c|c|c|c|c|c|}
\hline \multirow[b]{2}{*}{ Kind of Violation. } & \multicolumn{3}{|c|}{ Number and Statu } & \multicolumn{2}{|c|}{ I9II. } & \multirow[b]{2}{*}{ 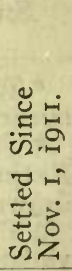 } \\
\hline & 离 & 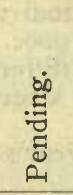 & 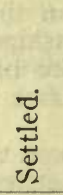 & $\begin{array}{l}\dot{0} \\
\stackrel{0}{0} \\
\text { Oे } \\
\stackrel{0}{0}\end{array}$ & 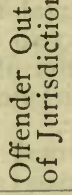 & \\
\hline Railroad, ...... & $*_{1} 83$ & 94 & 83 & 6 & & 53 \\
\hline Brush Burning, & 59 & 12 & 35 & 9 & 3 & 6 \\
\hline Smokers, ........... & 5 & $\cdots$ & 2 & 3 & .. & ... \\
\hline Misccllaneous,...$\ldots$. & 9 & 3 & 5 & I & $\ldots$ & ... \\
\hline Refusal to Fight, .... & 2 & & $\cdots$ & 2 & & $\cdots$ \\
\hline Totals, ........ & 258 & 109 & 125 & $2 \mathrm{I}$ & 3 & $\cdots$ \\
\hline
\end{tabular}

* This total does not include claims withdrawn, etc. 
There still remain two cases unsettled from I908 and I909. In both these instances, and one from I9Io, the violators had left the State before action could be taken, but like those mentioned above these are still held open pending a possible return of the offenders. The 22 other violation cases of 1909 remaining unfinished a year ago have all been settled, and of the Ioo offenses reported in I9Io as undisposed of but I I remain to be adjusted.

The penalties collected in I9I I aggregate $\$ 2,021.24$ of which the railroads paid $\$ 1,346.23$ and individuals $\$ 675.01$. A law not enforced is a stumbling block to the advancement of its purposes, but New Jersey's forest fire law has proven its efficacy by its growing power in application. 


\section{REPORT OF THE FOREST COMMISSION.}

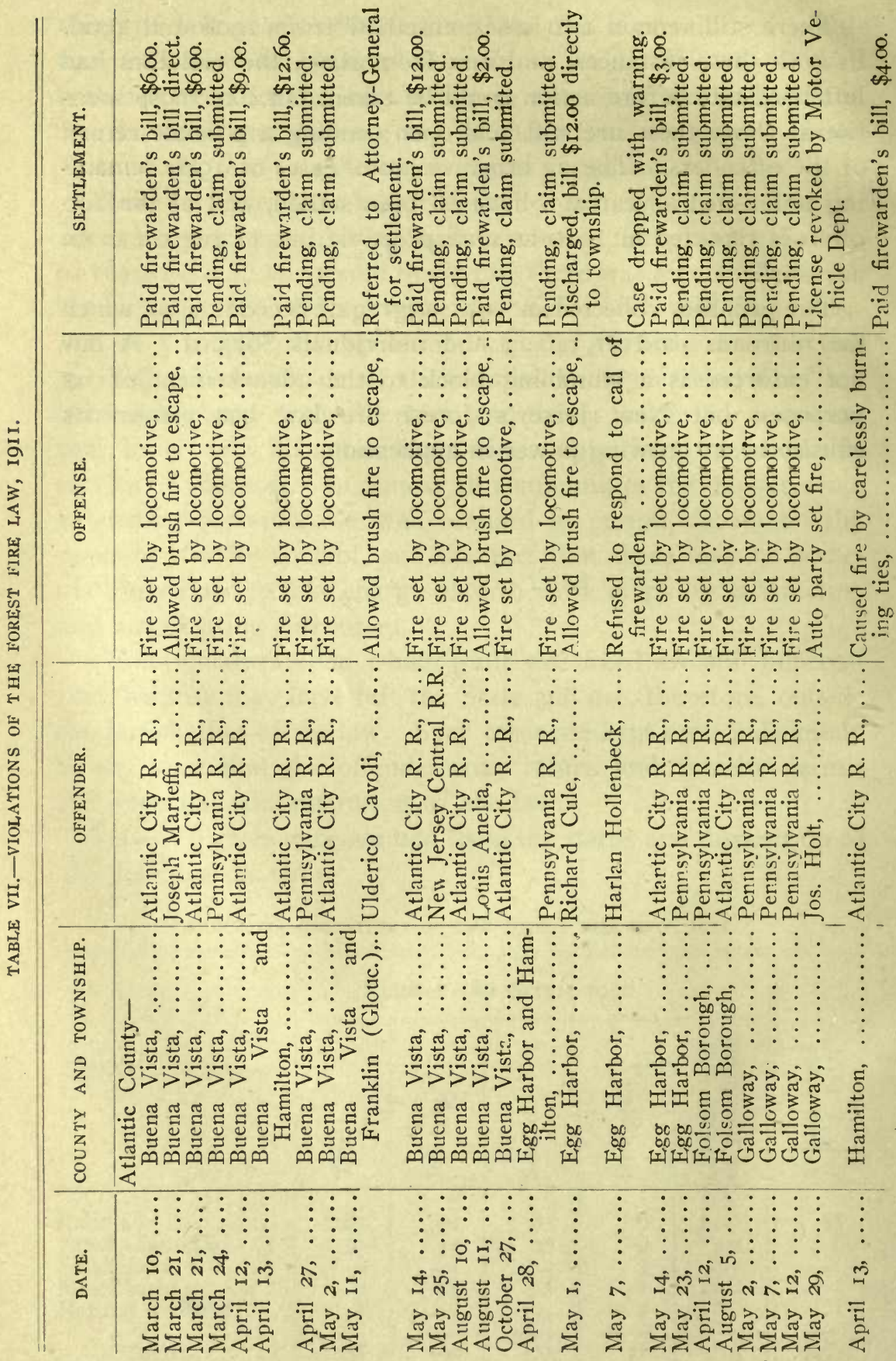




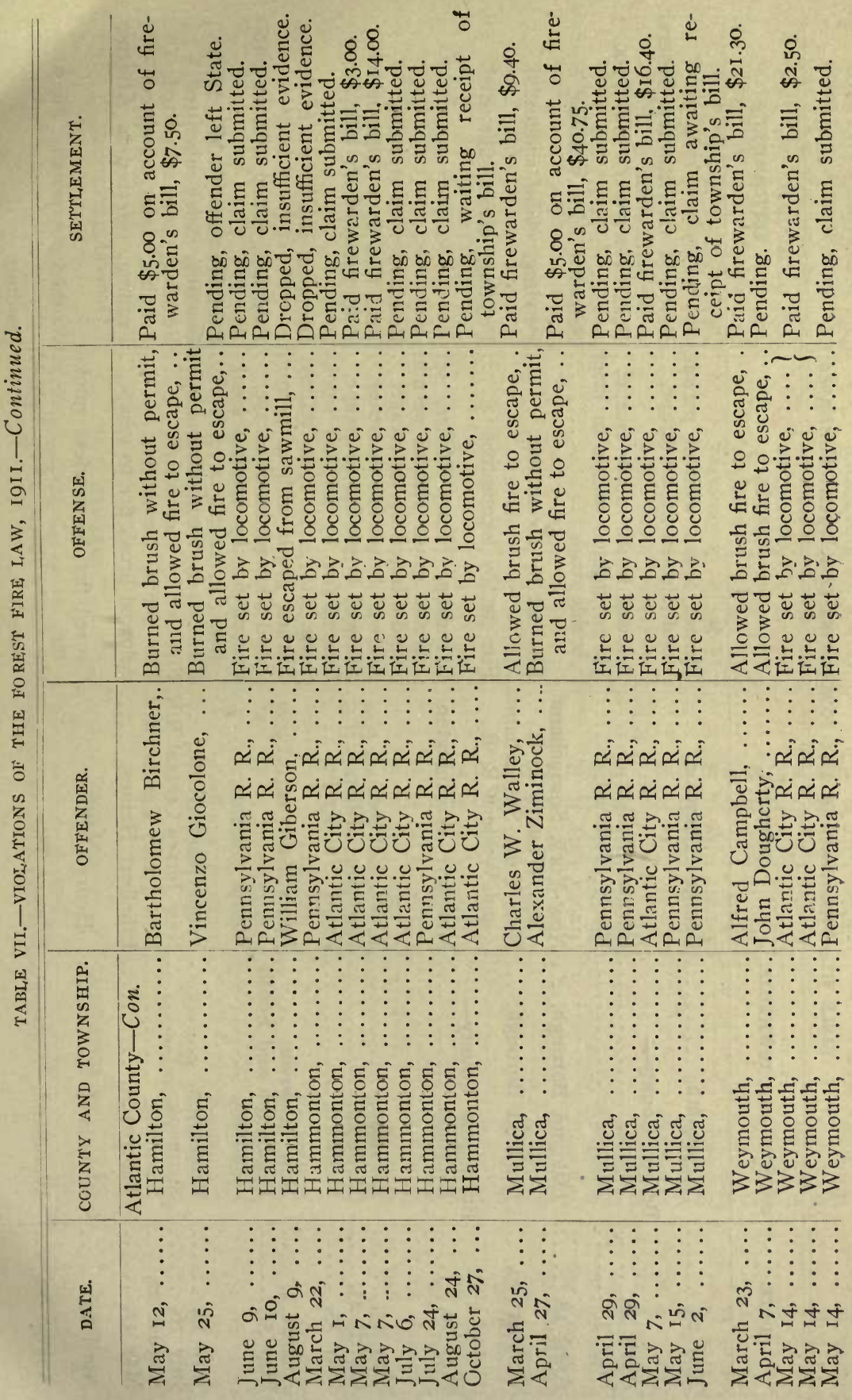




\section{REPORT OF THE FOREST COMMISSION.}

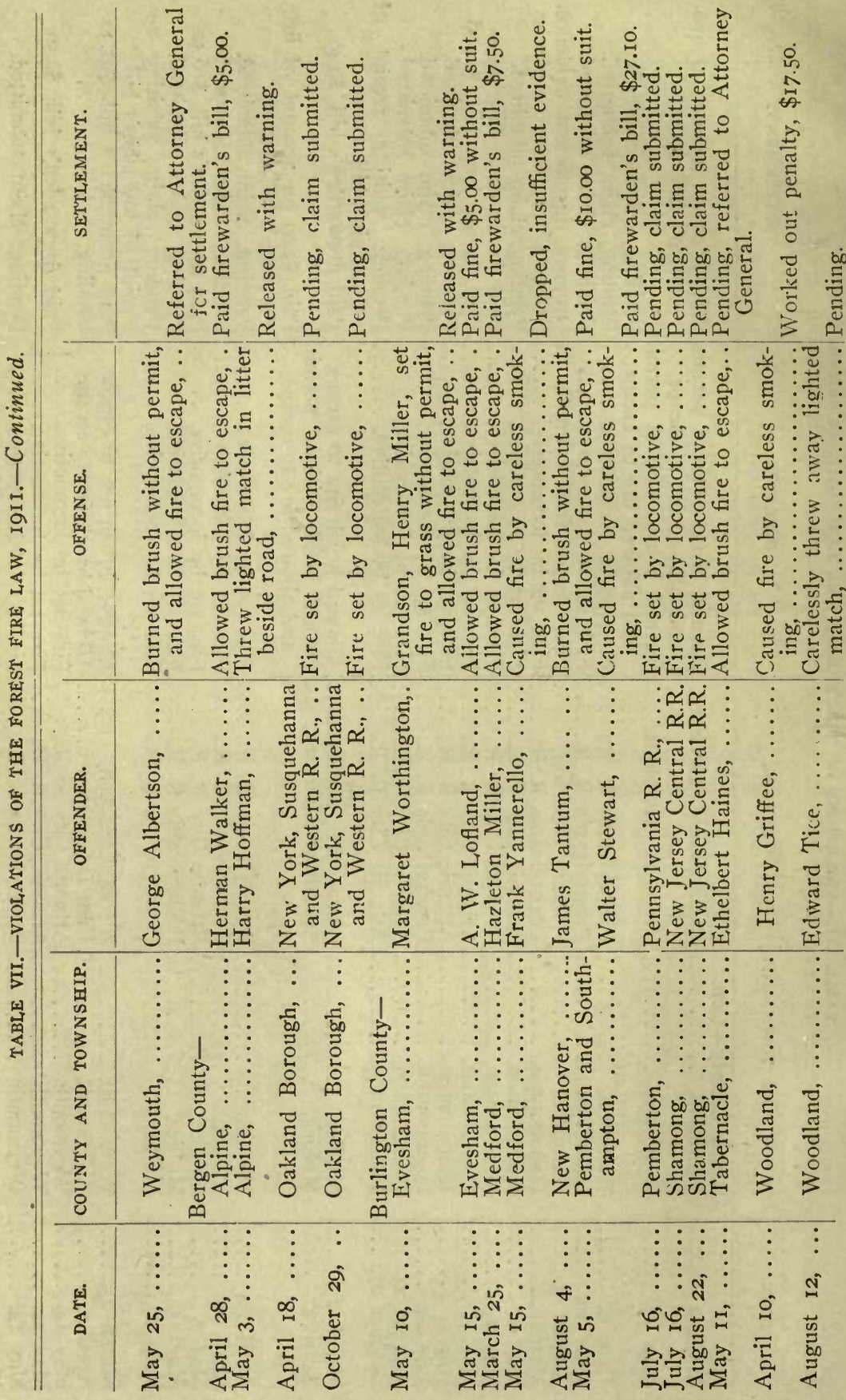




\begin{tabular}{|c|c|c|}
\hline & 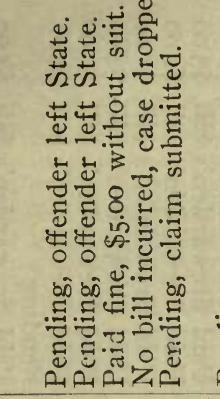 & 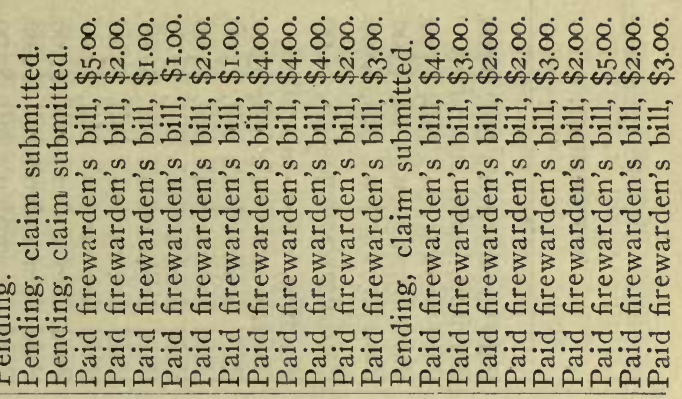 \\
\hline & 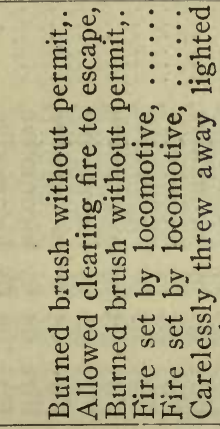 & 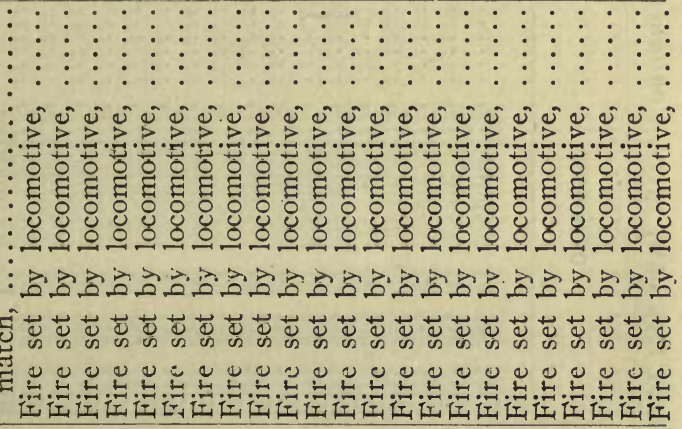 \\
\hline & 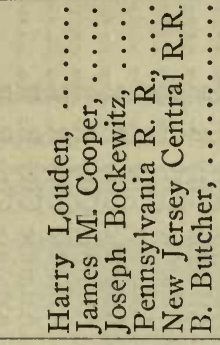 & 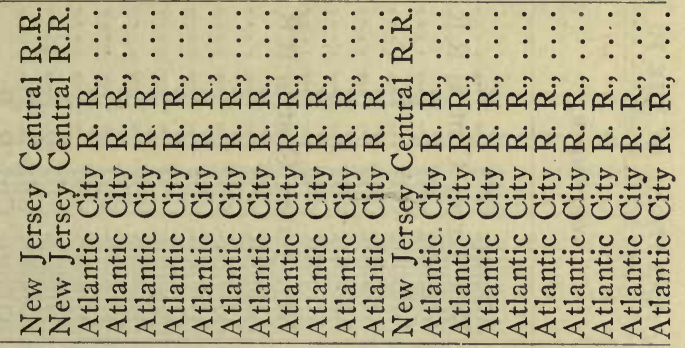 \\
\hline 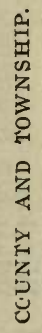 & 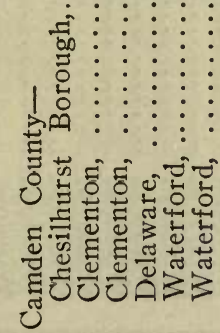 & 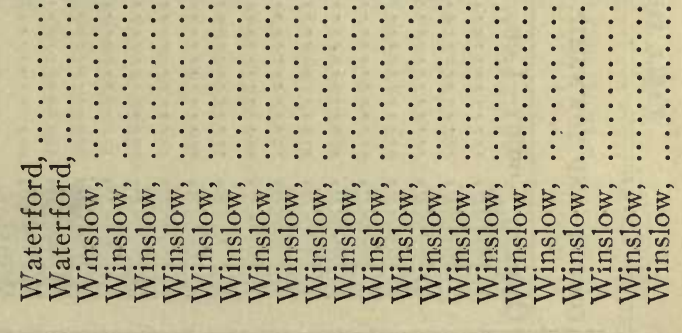 \\
\hline & 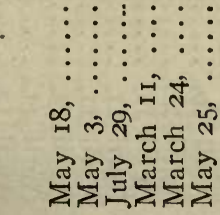 & 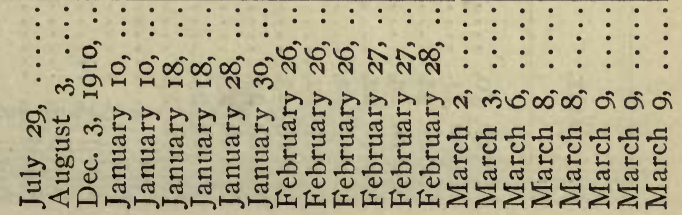 \\
\hline
\end{tabular}




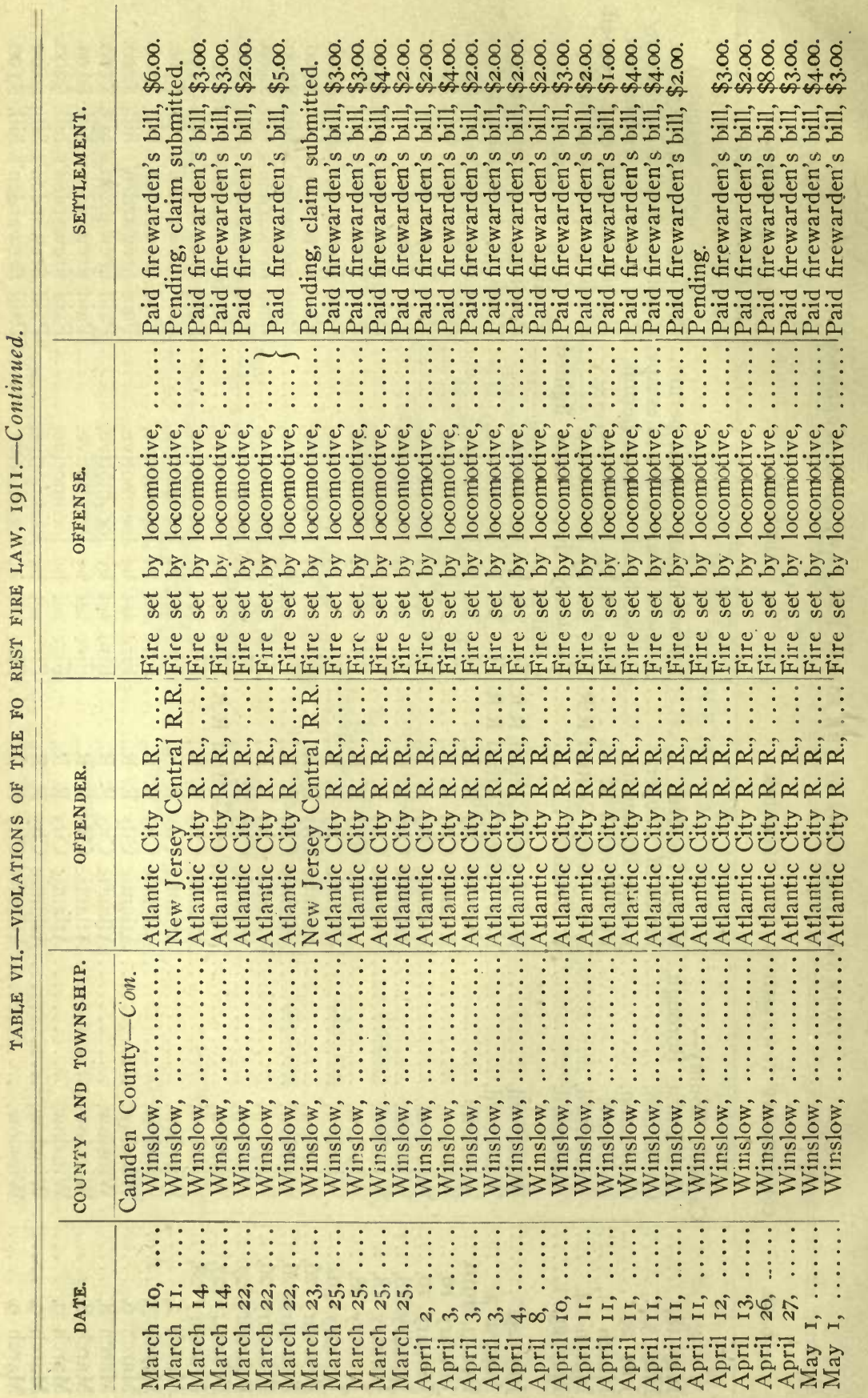




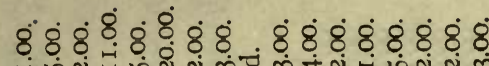

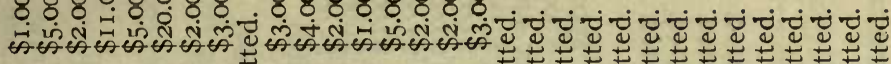

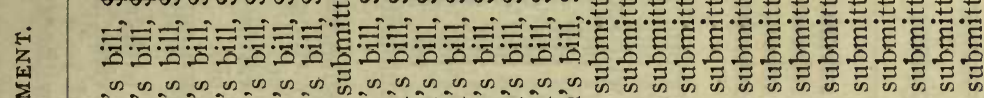

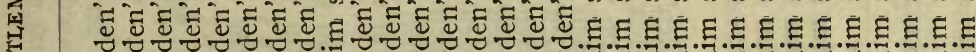

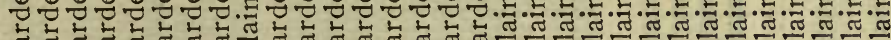

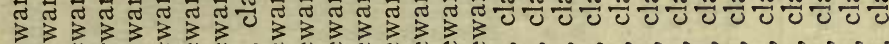
Uे

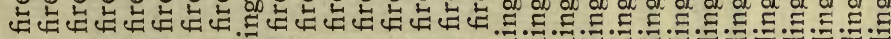

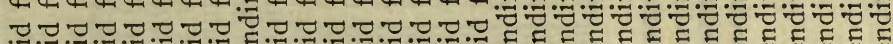

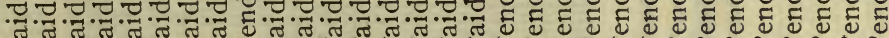

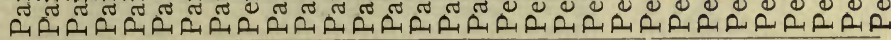

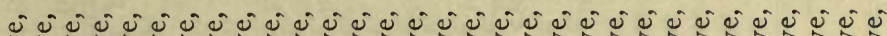

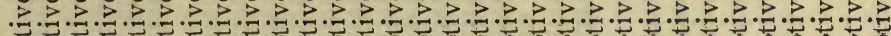

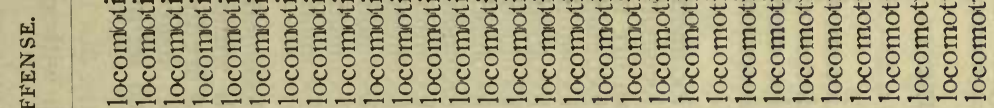

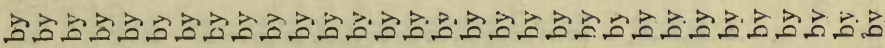

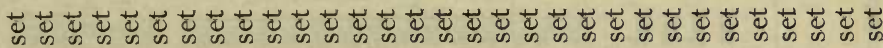

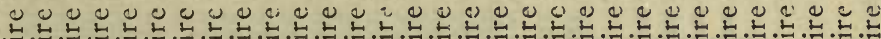

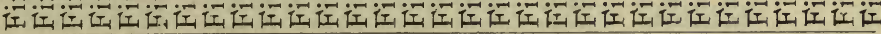

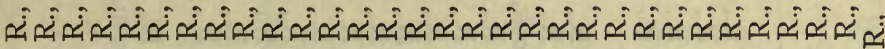

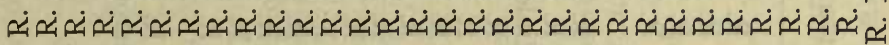

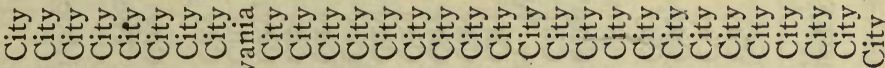

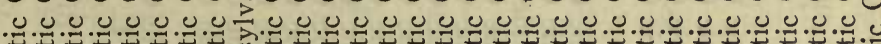

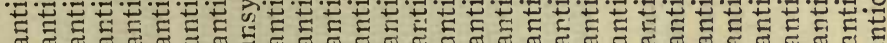

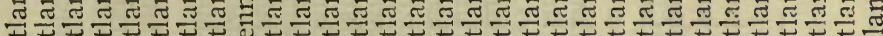

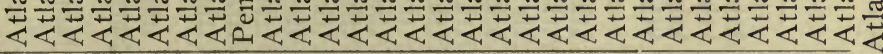

幽

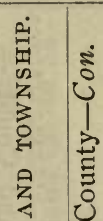

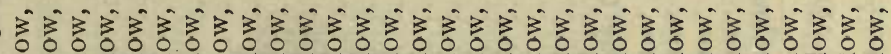

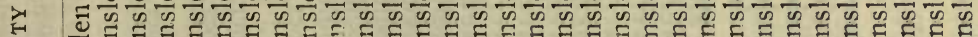

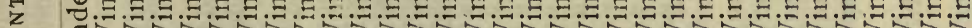

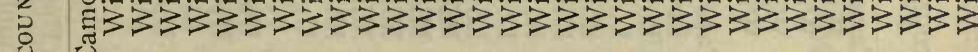

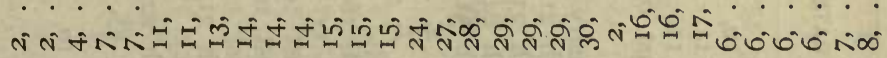

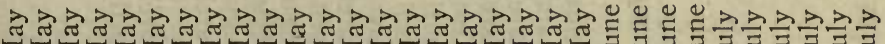

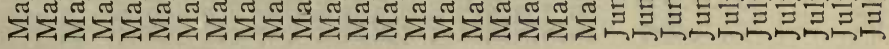




\section{REPOR'T OF THE FOREST COMMISSION.}

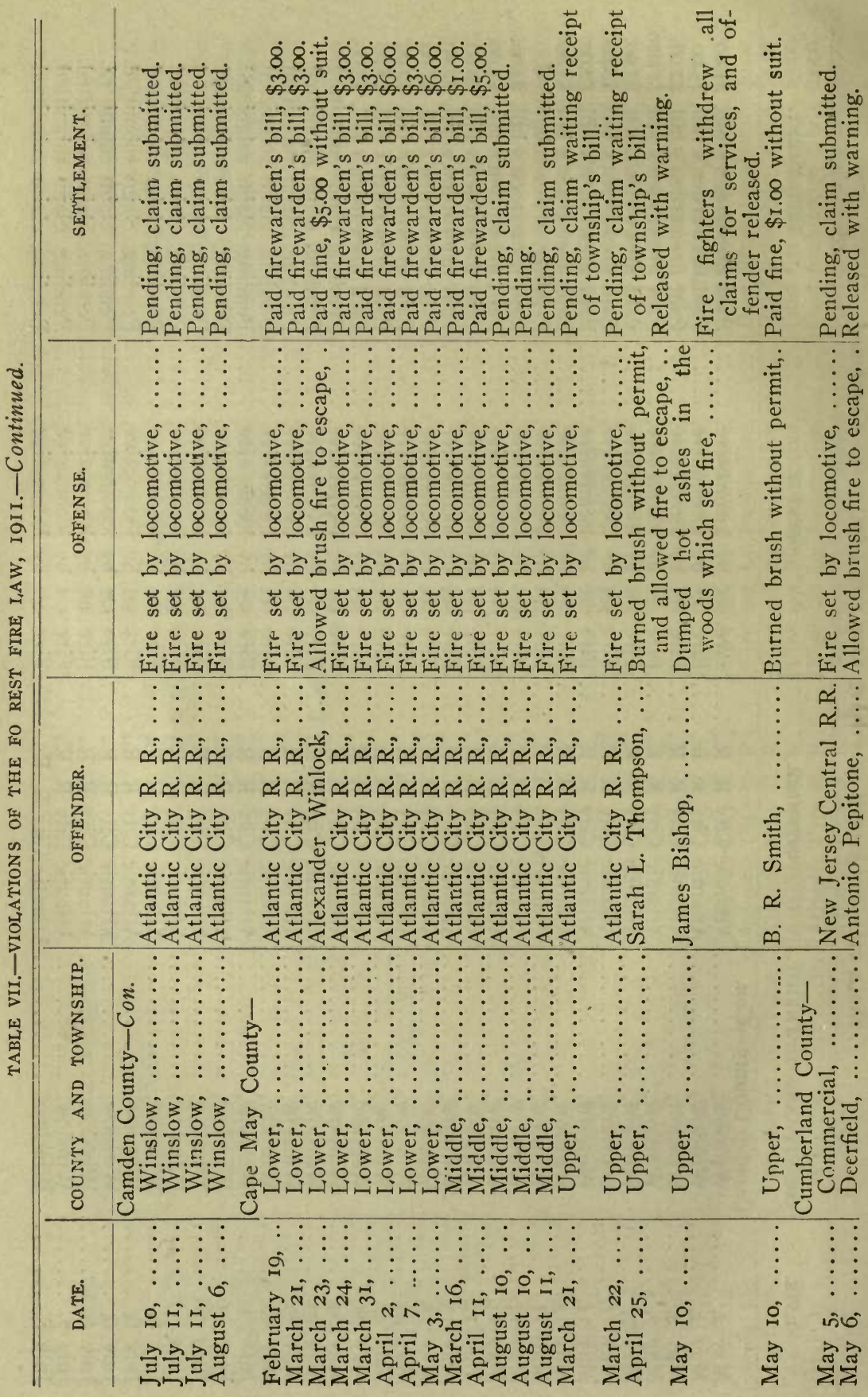




\begin{tabular}{|c|c|c|c|c|c|c|c|c|c|c|}
\hline 这 & 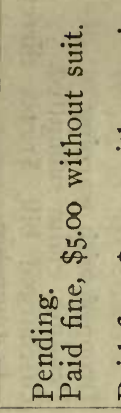 & 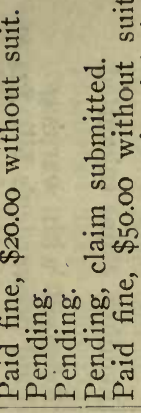 & 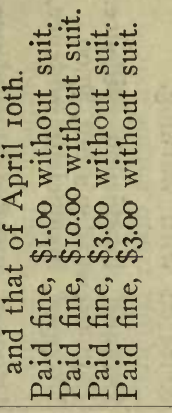 & 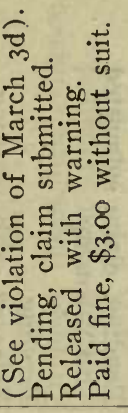 & 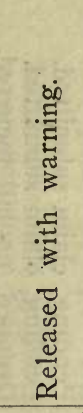 & 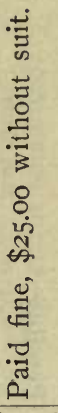 & . & & 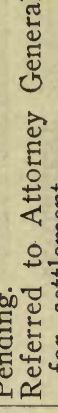 & 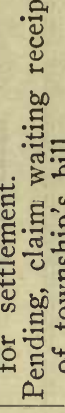 \\
\hline 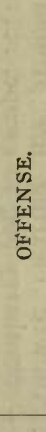 & 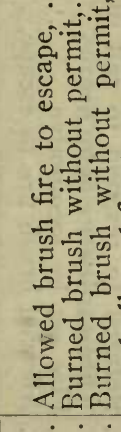 & 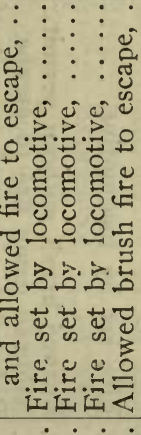 & 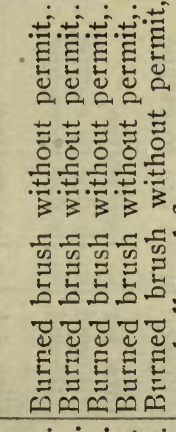 & 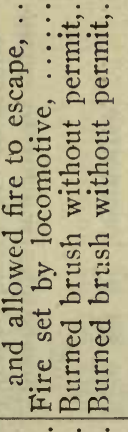 & 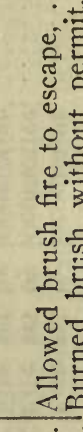 & 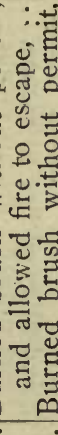 & 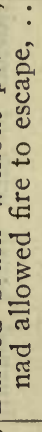 & 运 & 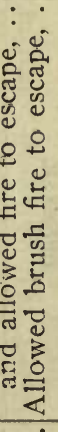 & \\
\hline 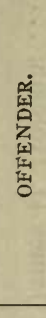 & 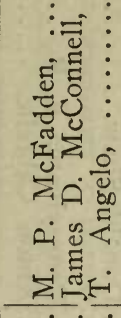 & 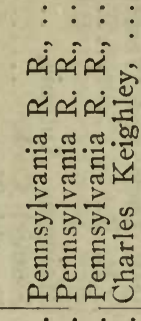 & 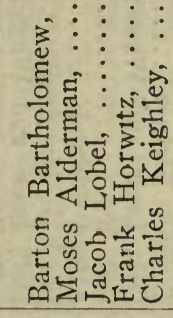 & 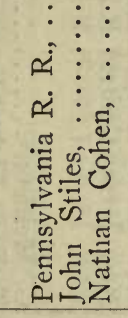 & 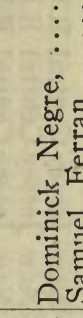 & $\frac{1}{0}$ & & 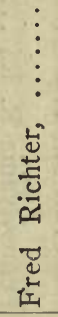 & 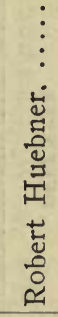 & 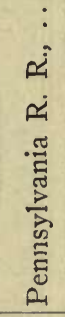 \\
\hline 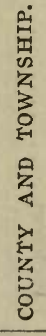 & 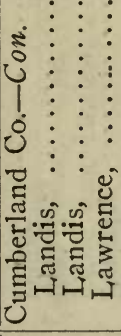 & 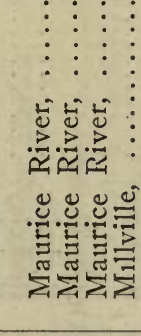 & 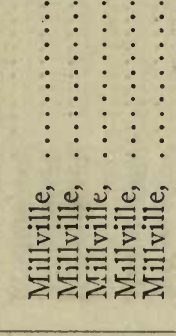 & 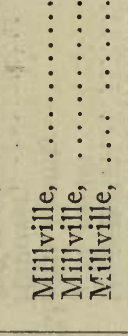 & 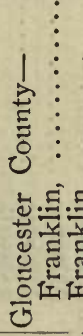 & 政 & & 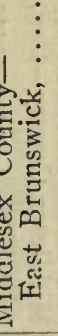 & 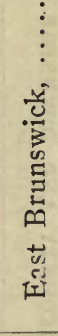 & 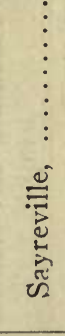 \\
\hline 必 & 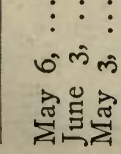 & 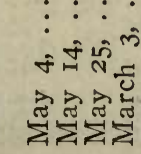 & 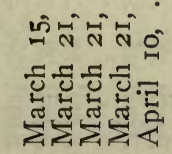 & 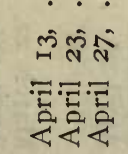 & 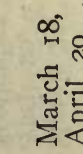 & $\sum_{\Sigma}^{\infty}$ & & $\begin{array}{l}\stackrel{\text { ñ }}{2} \\
\frac{\vec{E}}{4}\end{array}$ & $\begin{array}{l}\dot{f} \\
\stackrel{\vec{\epsilon}}{\Sigma}\end{array}$ & 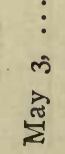 \\
\hline
\end{tabular}


46 REPORT OF THE FOREST COMMISSION.

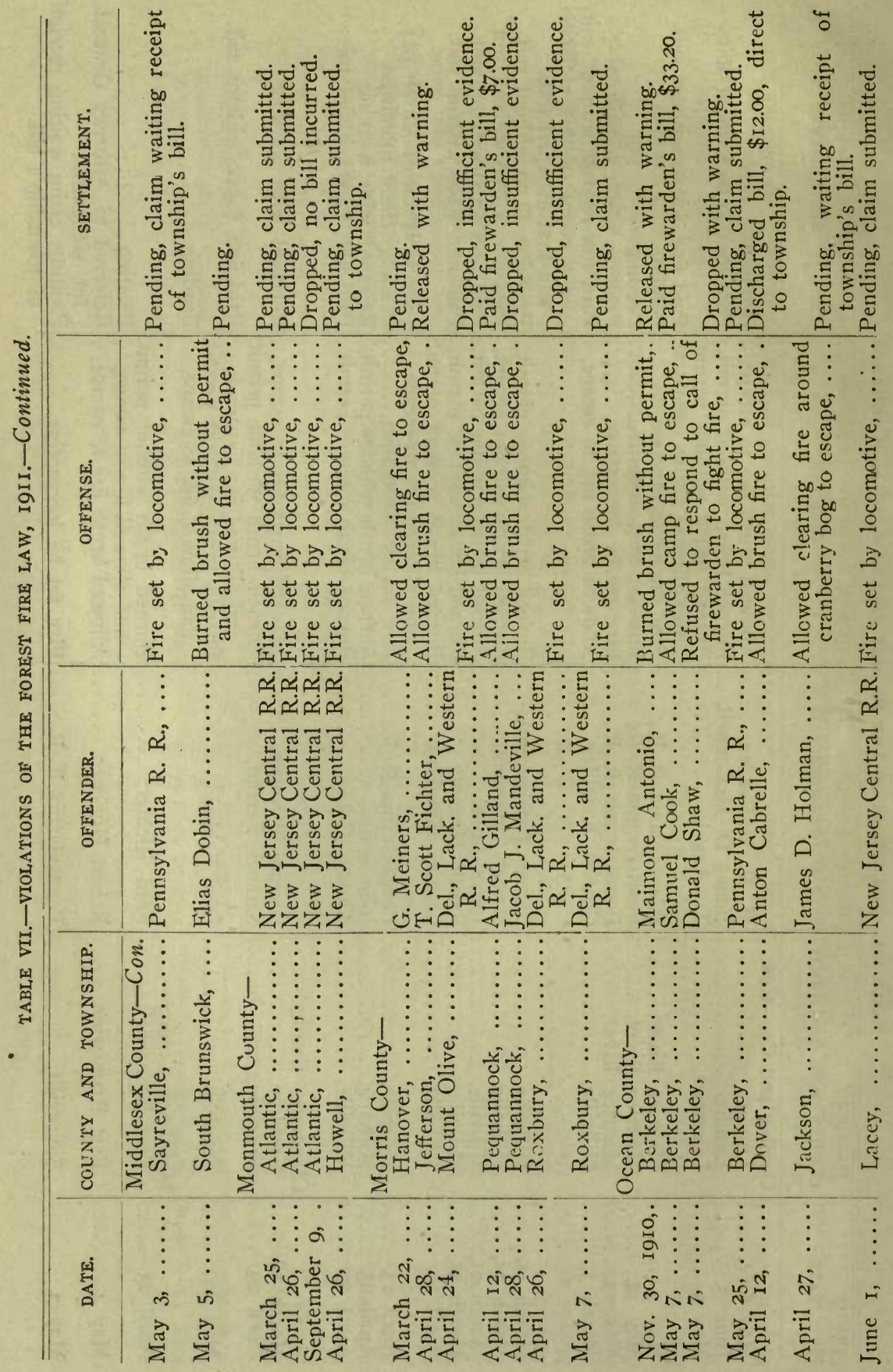




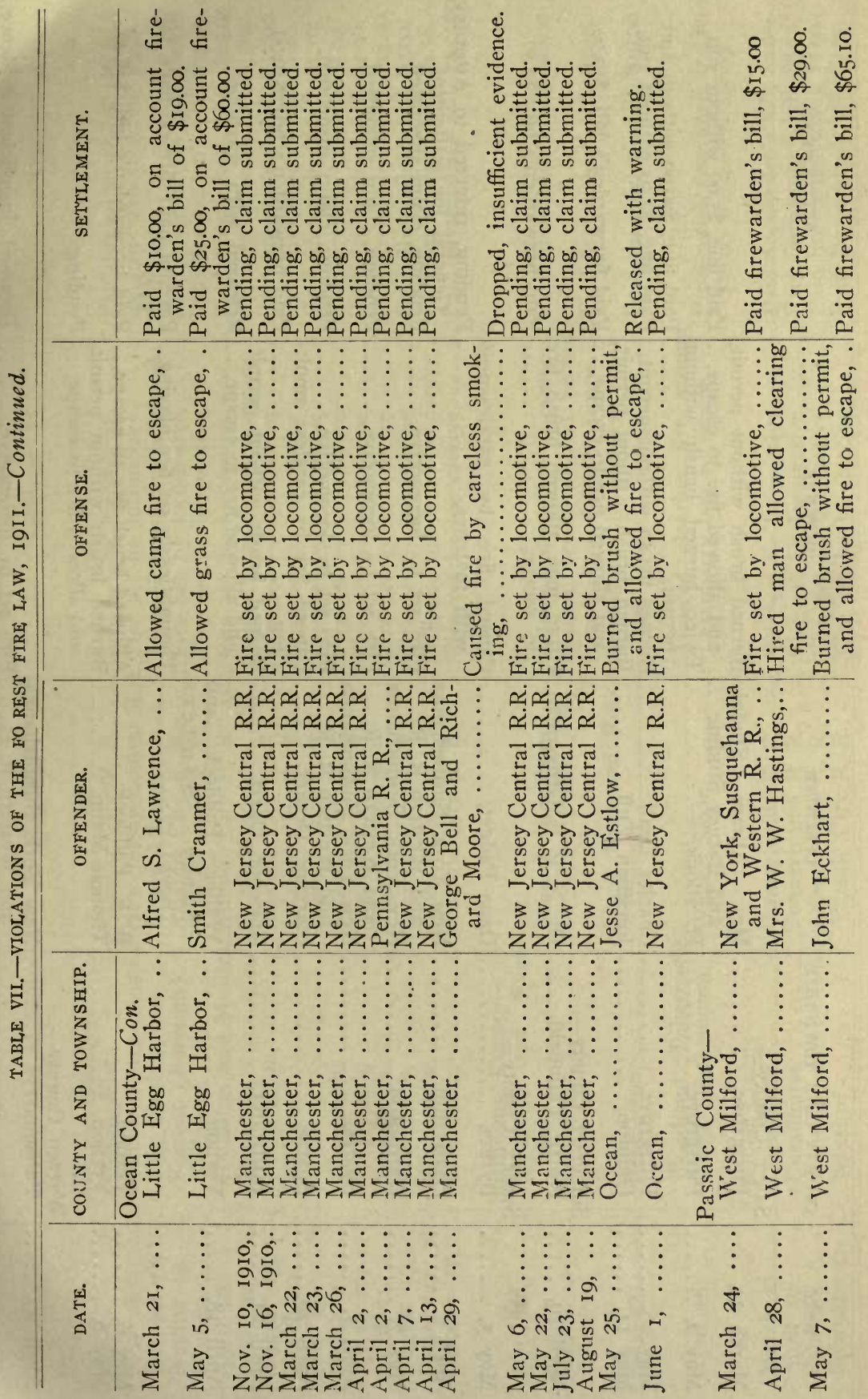


4\% REPORT OF THE FOREST COMMISSION.

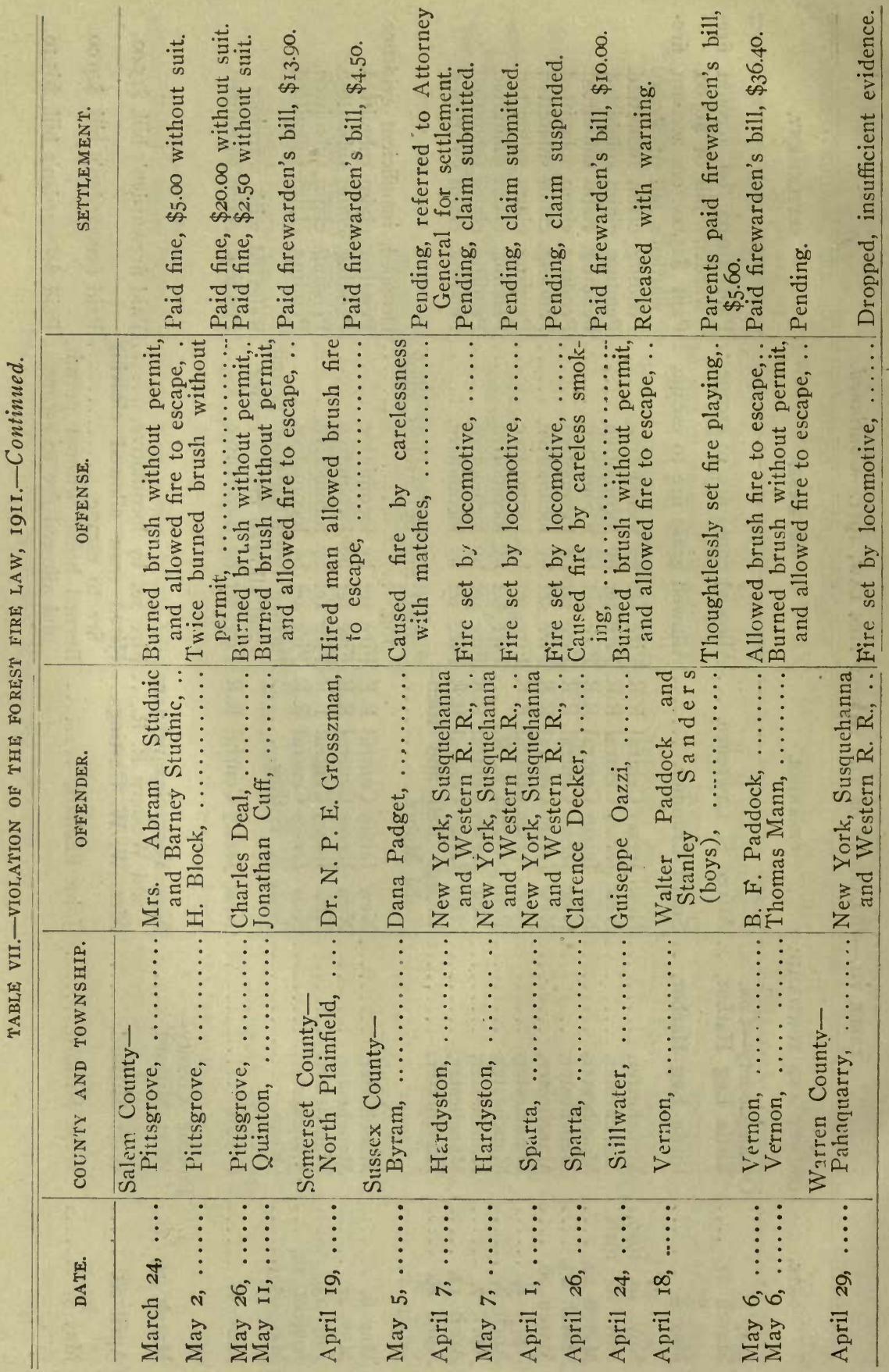




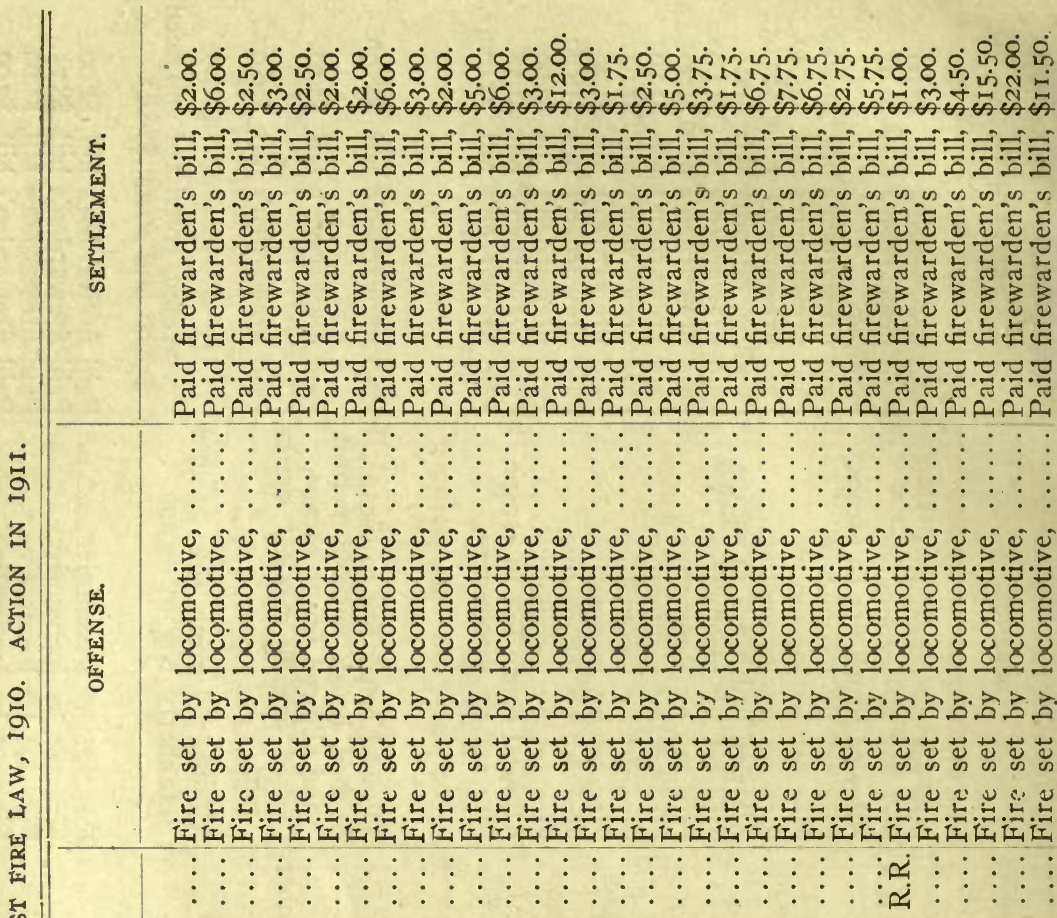

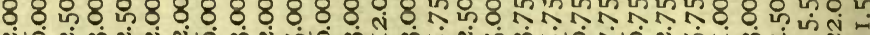

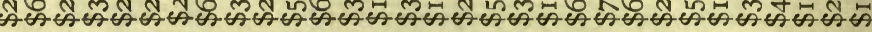

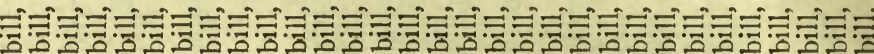

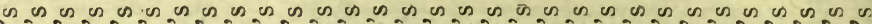

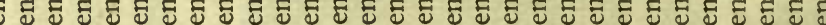
333333333333333333333333333333

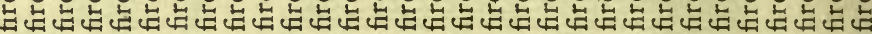

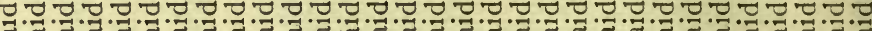

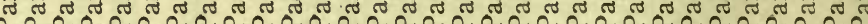

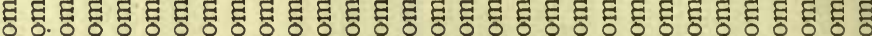
\&

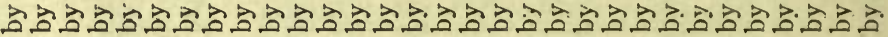

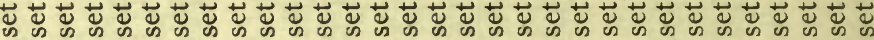

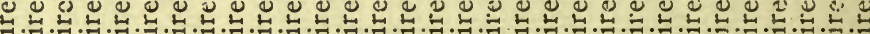

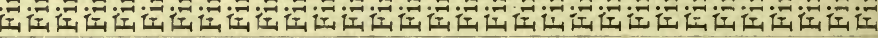

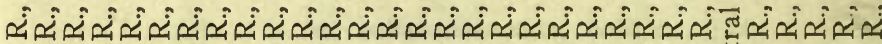

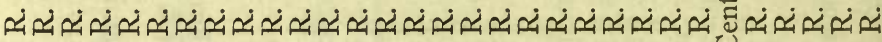

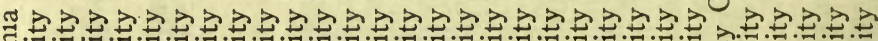

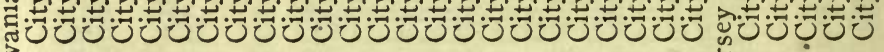
.

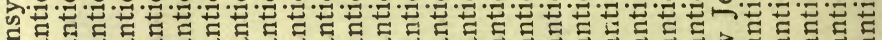
元

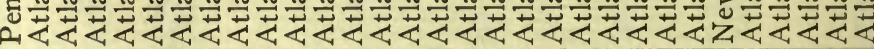

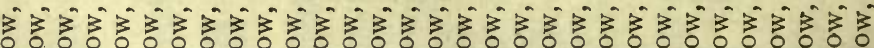

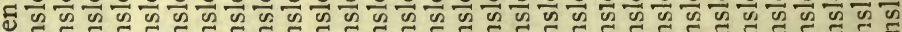

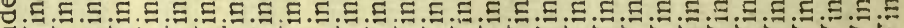

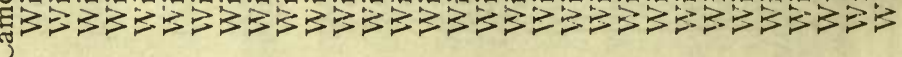

กิธูกิั

这

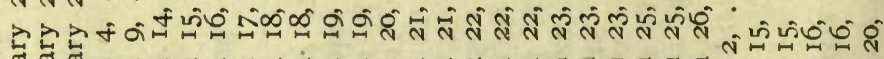

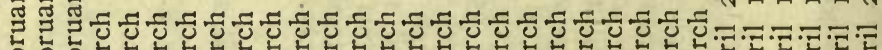

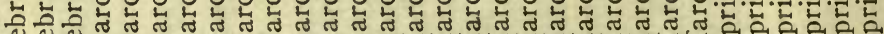

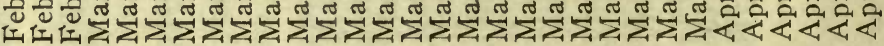




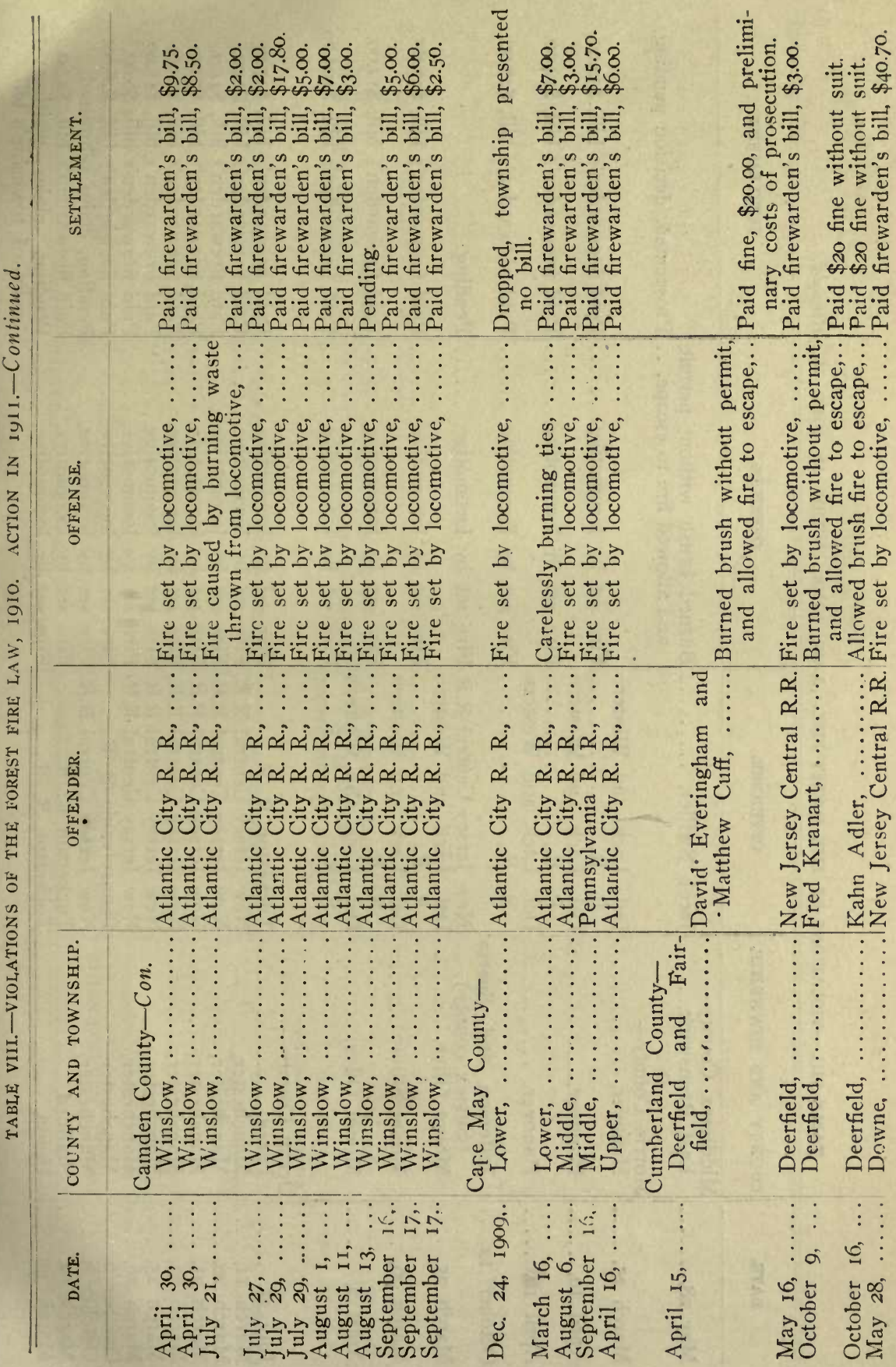




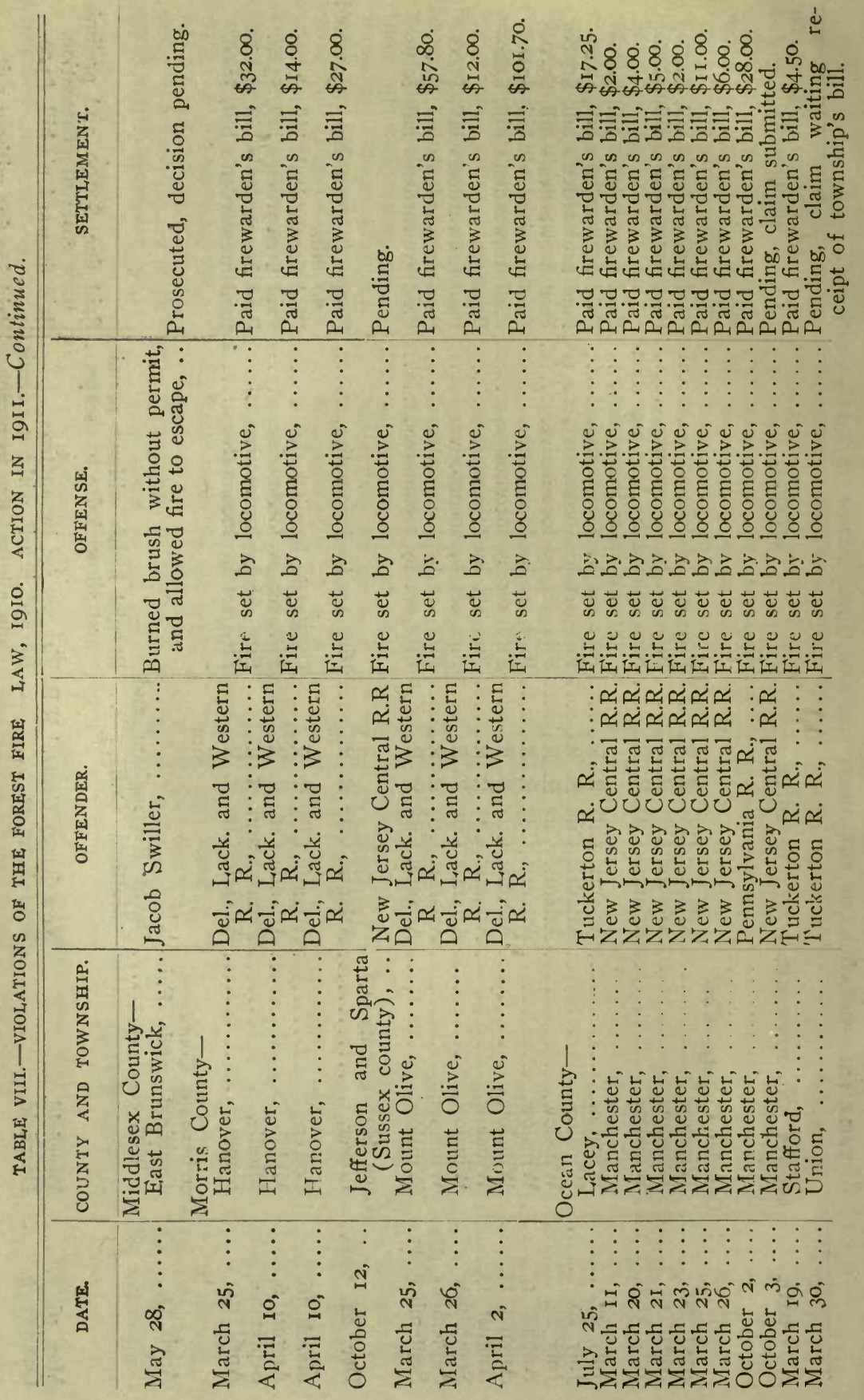


FIREWARDEN'S REPORT.

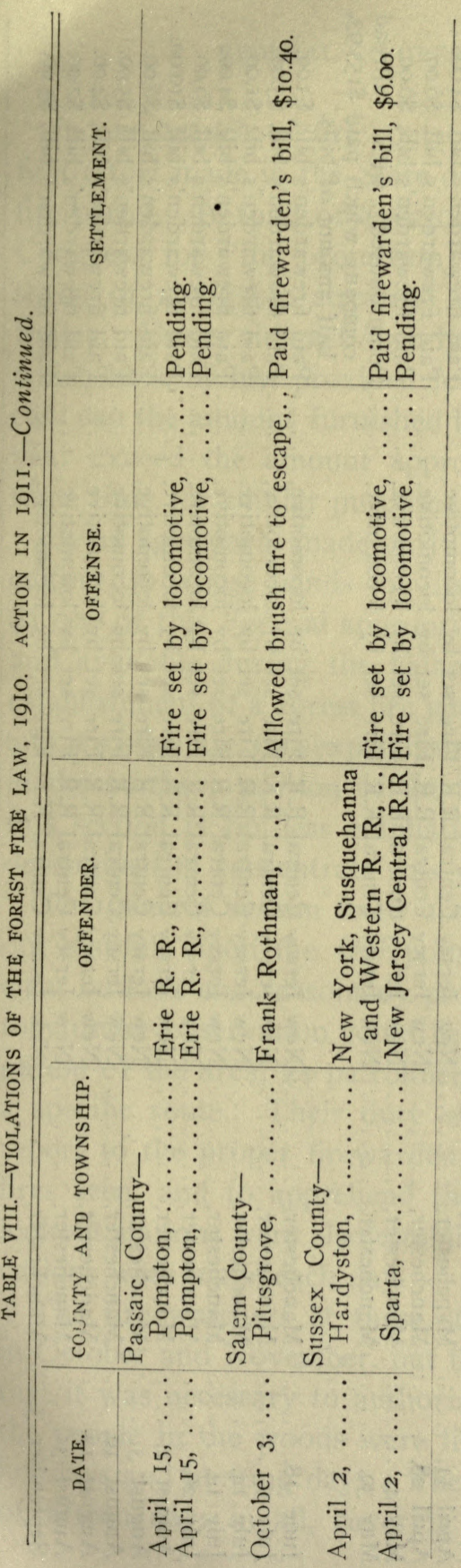




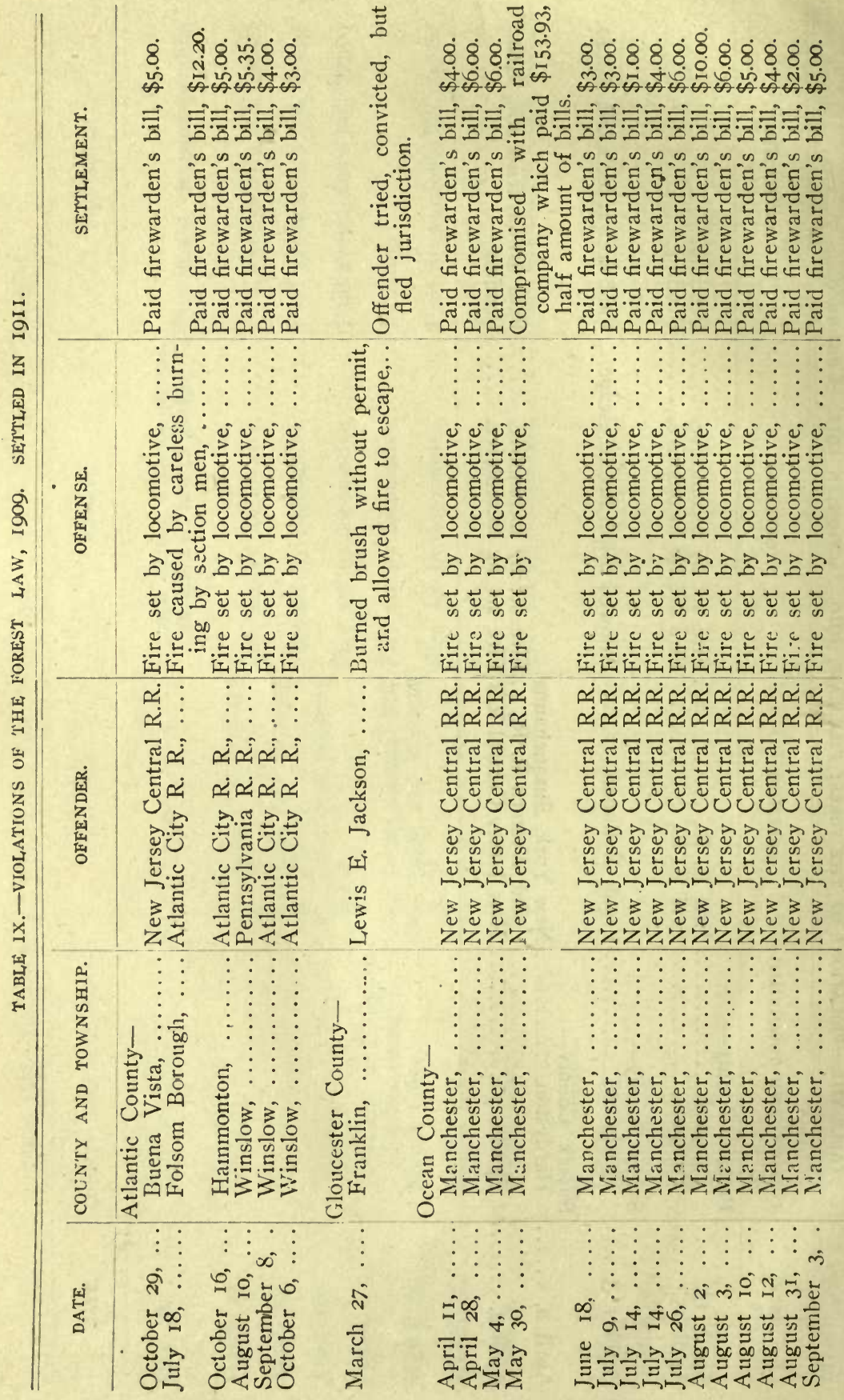


FEDERAL, CO-OPERATIVE FIRE PATROL.

In one branch of fire control the past year has developed the first effort made in the State on any general scale; this is a paid fire patrol. A fund of $\$ 200,000$ was made available by the last Congress for "the protection from fire of the forested watersheds of navigable streams" in co-operation with the various States. Under this act such help is offered only to those States which have by law provided for forest fire protection, and in no case can the amount furnished by the Federal Government in any year exceed the amount appropriated by the State within the same time for similar purposes.

By an agreement made on July Ist with the Secretary of Agriculture, in whose hands the disbursement of the fund is placed, $\$ I, 000$ of this Federal appropriation was allotted to New Jersey, and available during the balance of the calendar year for the establishment of a forest fire patrol. Under the existing interpretation of the law, this expenditure was restricted to the watersheds in the northern portion of the State, and, since the exposure of this section is far less emphatic in the summer months, it was determined to concentrate this year on the fall season.

The general system fixed upon was a road patrol, with lookout stations upon the few points available from which a sufficient outlook and reasonably prompt communication to the territory under observation could be had. After a thorough investigation of the area, 44 patrolmen were engaged, each assigned to a specific route. Their duty was to traverse these routes and report to the proper firewarden, or to extinguish themselves all fires seen, and to apprehend those responsible for them. Five lookout stations were also established from which frequent observations were made each day.

The fire watchers at these stations were on duty every day in October and November, but the fund available was so limited that it was necessary to authorize the patrol only on days when the people in the woods were likely to be most numerous, viz., holidays and hunting days. The patrol was ordered for a period of fifteen days in all, covering these dates so far as possible. 
In actual service, however, the time covered by all was less, because of the wet weather that so often prevailed, under which conditions the patrol ceased automatically. The average time served by each patrol was but nine days, and this brief service: linked with prevailing weather conditions, should properly, and does, account for a lower aggregate of tangible results than had been expected. On the other hand, the moral effect of a body of men known to be on the watch for fires and their originators is an item in the account that the future probably will appraise highly.

Despite the conditions stated, however, the patrol reported 27 fires with the significant feature that I 7 of them, found on days and in situations making it quite probable that they would have become true forest fires without this prompt attention, were put out by the patrol themselves and that a warden or competent fighting force was notified of all others in time to prevent a serious fire. It is particularly noteworthy also that so far there has been no fire repcrted from the patrolled section of which mention is not made by some patrolman.

A continued and thorough supervision of the men when on duty proved that, with few exceptions, their work was done conscientiously throughout and a canvass subsequent to the patrol season further showed that practically all are ready to serve again. The fall work has, therefore, accomplished these things: the actual control of fires in the patrolled district; the establishment of an organized force available for future use; the focussing of public interest in this section on the forest fire problem in a way never before realized; and finally, though not concretely measureable, the stimulating of respect for the fire law and of care among forest users in handling fire.

The actual expense to the Federal Government has been $\$ 984$ - for patrol service only-and the expense to the State-for patrol organization and administration only-approximately $\$ 492$, in addition to the cost of the regular fire service. It is believed that the work already done has paved the way for a continuance of this fire preventative, so vastly preferable to the most effective cure. The hope is further that the lesson in effectiveness found in the present record may encourage private enter- 


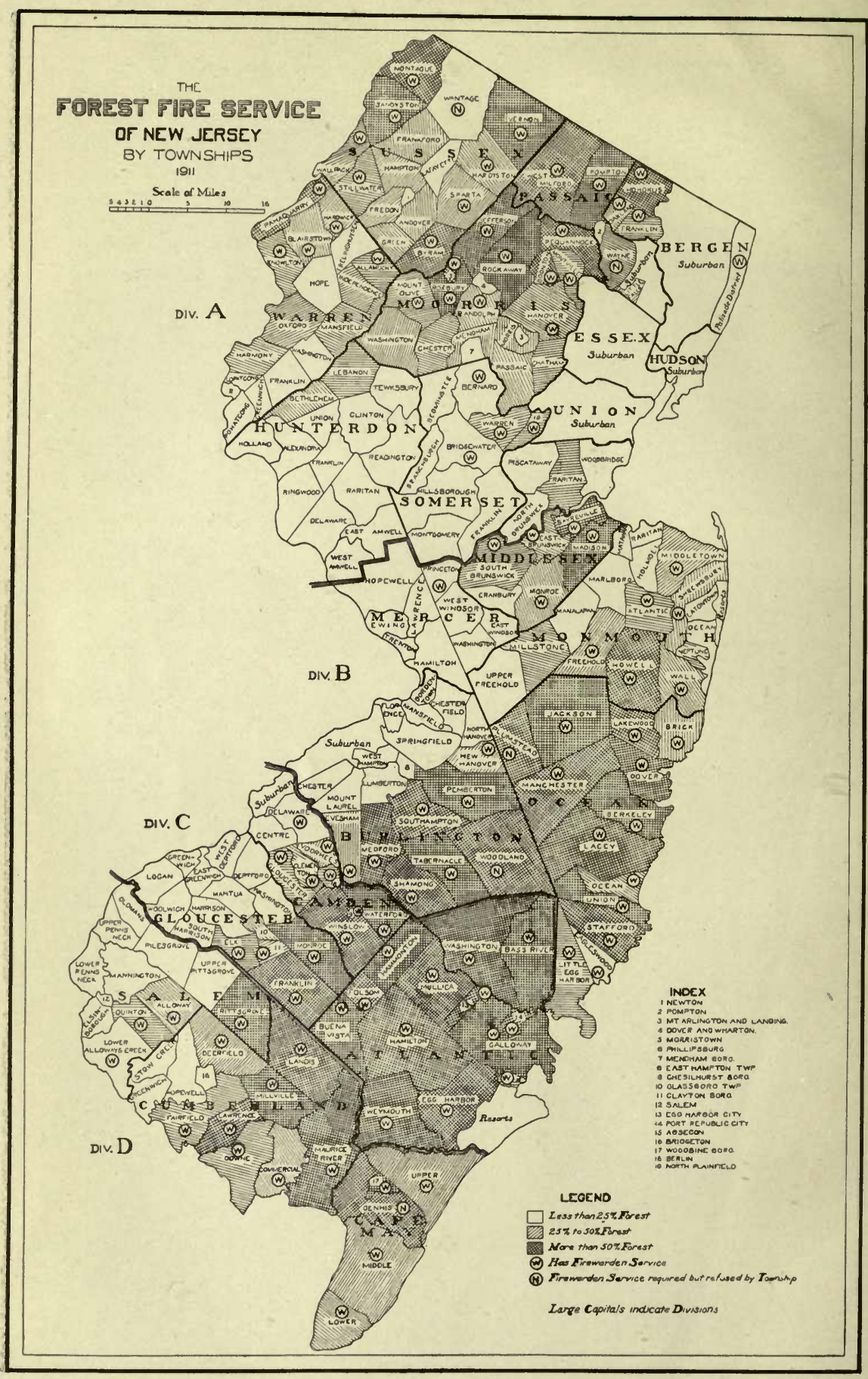

Fig. 13.-The State Forest Fire Service. 


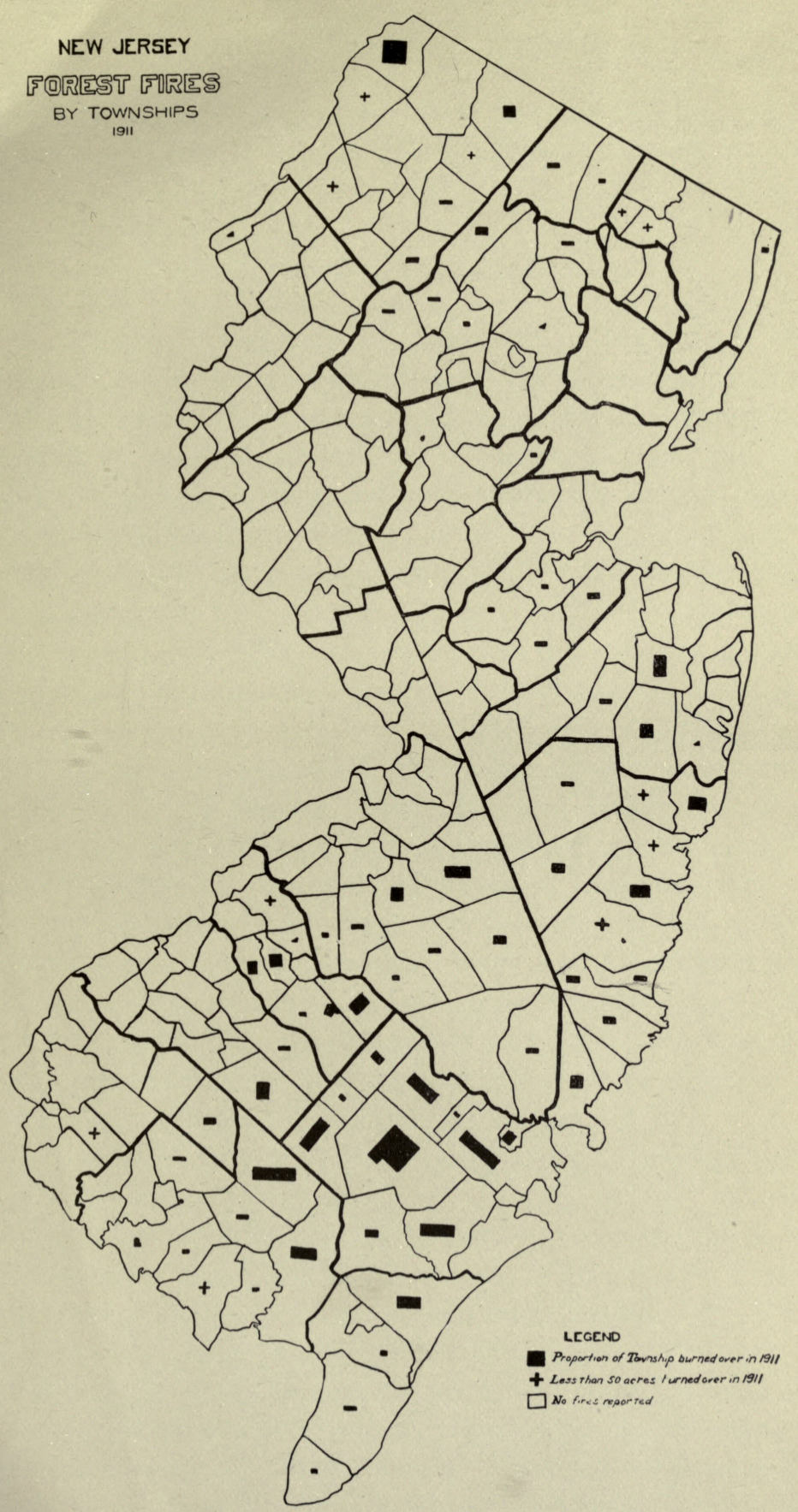

Fig. I3a.-Forest Area Burned, I9ri. The black spot in each townshipsee opposite map-represents the proportion of the township burned, but not the location of fires. 

prise of a similar type, where forest interests are large enough, or small ones closely enough allied, to make a fire patrol a practical as well as a vital feature.

\section{THE FOREST FIRE, ORGANIZATION.}

Particularly noteworthy has been the advance made during the past year in the reorganization of the whole fire service and in the increased effectiveness secured thereby on the administrative side by the addition of four State firewardens and, locally by the increased number, and the improving interest and efficiency, of the local wardens.

Made possible by an amendment to the fire law passed by the last Legislature, four division wardens have been added to the State firewarden's office, who work with that office in the administration of the forest fire business of the State. These men have headquarters in (I) Dover, (2) Lakehurst, (3) Hammonton and (4) Millville, and divide the State into divisions composed as follows: ( $\mathrm{x}$ ) Bergen, Essex, Hudson, Hunterdon, Morris, Passaic, Somerset, Sussex, Union and Warren counties and that part of Middlesex county lying north of Raritan river. Mercer, Monmouth, and Ocean counties, the portion of Middlesex lying south of the Raritan river, and Burlington county exclusive of Bass River and Washington townships. (3) Atlantic, Camden and Gloucester counties and Bass River and Washington townships in Burlington county. (4) Cape May, Cumberland and Salem counties. (See fig. I3.)

By increased activity of the local wardens, by marked promptness in handling the business of the fire service, particularly violations of the law, and by a growing co-operation between the townships and State in the control of fire, results prove the value of this extension in the short time it has been active. It is believed that these results present but surface features whose underlying utility the next year's work will amplify and prove.

The achievement of the local organization in its sphere also shows encouraging improvement. Former wardens whose service was unsatisfactory have been replaced by men whose heart is in the work. Many of those who previously neither 
appreciated the significance of the movement nor accepted the responsibilities of their position have taken a new grip. Also, where often heretofore the incumbent has been urged u a reluctant acceptance of the wardenship, vacancies may now be filled from several candidates. Alert and effective attention to fires has marked the season's record and a note that "quick work and hard fighting enabled us to put the fire out without much damage" still commands the same appreciation but less remark than in the past. Not the least satisfactory and useful feature of this year's gain, however, is the increased thoroughness in preparing and promptness in submitting reports by the firewardens, which renders it possible to take up an investigation before the matter has grown old. The items are not all on this side of the account, however, and the work of weeding out and stimulating is far from complete. In a number of cases incompetence or inactivity has caused a warden to be put on probation. For actual malfeasance removals are exceptional but were necessary in two cases.

During the year the fire service has been installed in eight new townships as follows: Absecon City, Berlin, Bernard, Bridgewater, Middletown, North Plainfield, Shrewsbury and Warren, and with the beginning of the new calendar year wardens will probably be appointed in eight more. On the other hand, wardens have been discontinued in Harrington township, Bergen county, because the forest exposure there has been so broken that they are not needed. There is no antagonism among the people.

An effort has also been made to find means of supporting wardens in the few townships that have refused to make their own appointments despite a requisition by the Commission. Although a pacific adjustment of these differences is always sought, it is apparent that strong measures will have to be resorted to.

The Commission is now prepared to make the fire service effective in every part of the State where it is needed. 
. 


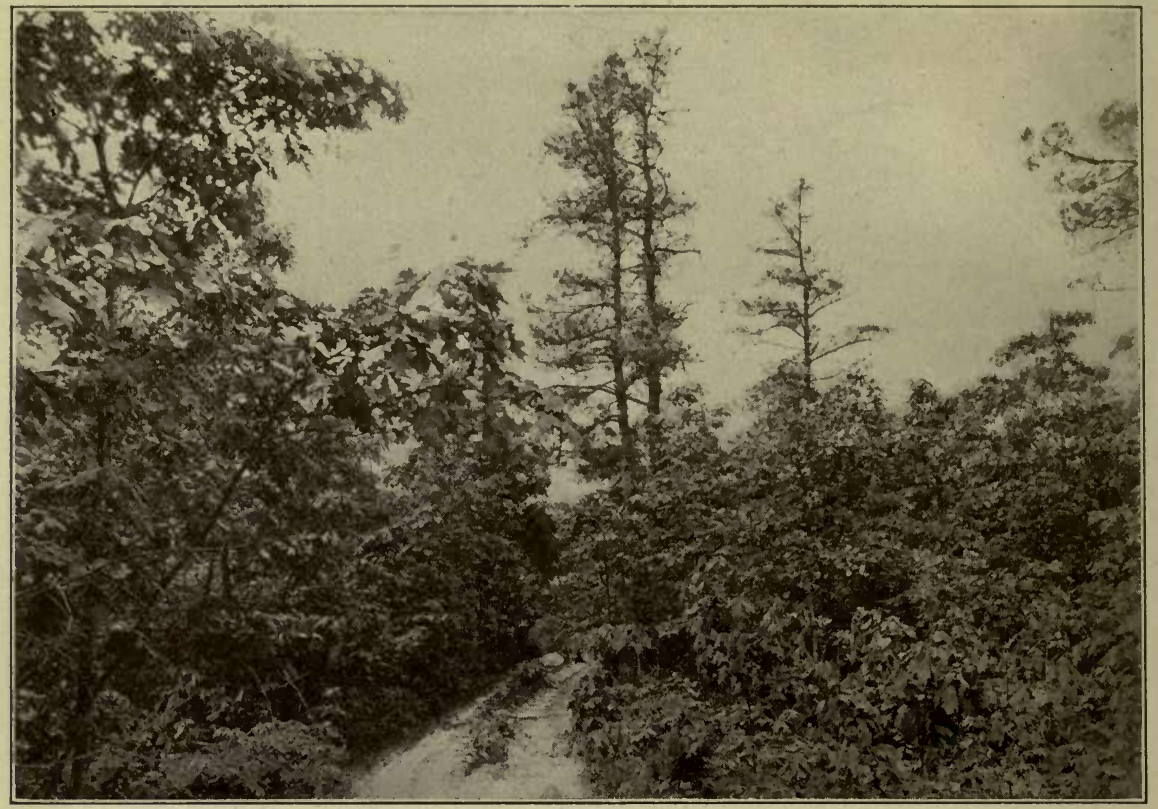

Fig. 8.-A Typical Road in "The Pines"-Overgrown and Difficult to Travel as Well as Favorable to Forest Fires.

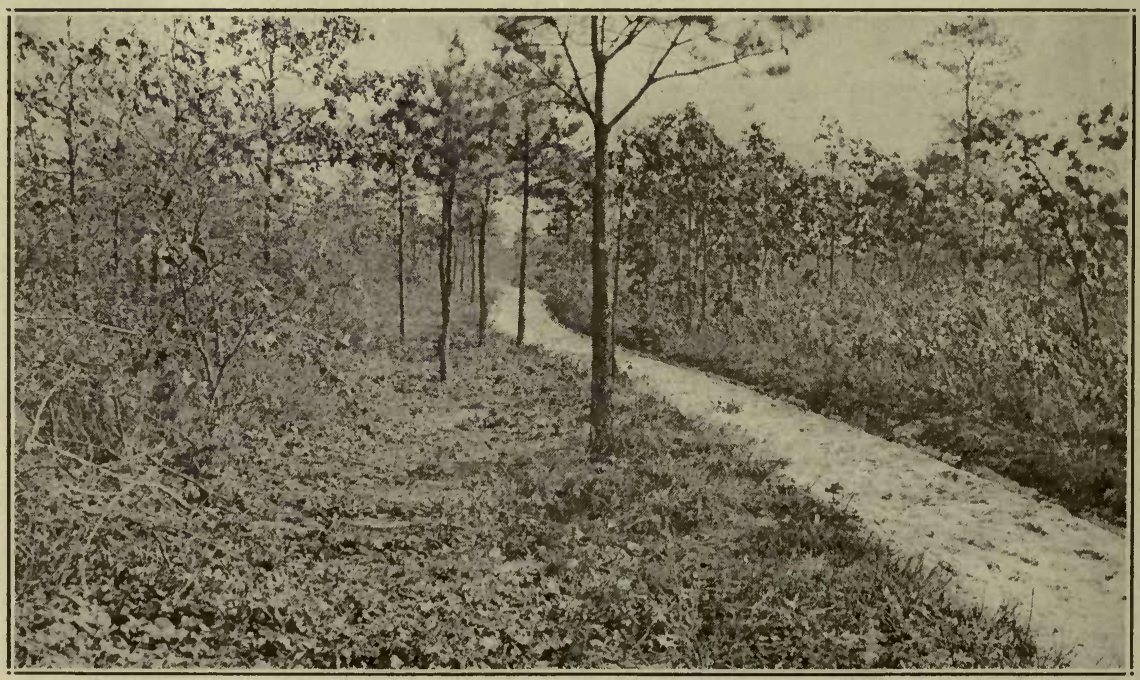

Fig. 9.-A Similar Road Made to Serve as a Fire Lane. 
ARE ROADS A WOODLAND MENACE OR PROTECTION?

As has been already indicated (see p. 29), probably a larger proportion of the fires than appears on the surface may be traced to traffic along the roads traversing the forested sections. The increasing tendency to rapid transportation and the continual extension of improved roads adds to this danger each year. Carelessness with matches and smoking materials is proverbial, and that portion of the forest affected by the road menaceis peculiarly exposed to the starting of fires by these agencies. That a road in the condition indicated in Figure 8 is a natural fire trap needs no argument, nor is the area shown there an exaggeration of conditions that are very general in all the wooded sections.

Aside from its value in curtailing the fires started, a properly or even reasonably well-cared-for roadside affords in many intances the only secure line of attack in fighting an advancing fre. That many roads are needlessly neglected, and that thereby the efficiency of the fighters' service is curtailed, if not cut off, is evidenced by constant comment from the wardens, of which the following is typical: "We could have put it out in shorter tine, but the roads were grown up and we were unable to back fire" See Figs. 8, 9.

Fres started along a road cannot be traced to those responsible excest under peculiarly fortunate circumstances. To control them therefore, we must rely entirely upon a gradual improvement in the carefulness of the public in such situations and on the prparation of the roads to obviate their tendency to spread a fire.

A lav (Chapter 98, Laws of I900) now stands upon the statutes which gives the townships ample authority to keep their roads in a safe state, but the movement must come through the governin bodies of the townships. Some few, though a deplorable minoity, are already alive to the opportunity offered by this law and ar requiring its application in their territory.

That thetax now levied upon some townships for fire fighting would in a few years be sufficiently reduced by proper care of the roads to ompensate for the expense put into this work may 
be open to question, but it is at least an open question. That such attention to road conditions is sane insurance to abutting woodland, for both fire prevention and control, does not admit of argument. The success that has attended the construction of railroad fire lines as fire deterrents (see below) leaves no doubt that time and money spent in similar improvements of our roadsides would materially reduce the area burned in our woodlands.

\section{RAILROAD FIRE LINES.}

What is commonly called the Railroad Fire Line Lâw, Chapter 74, Laws of 1909, is still in the courts, the suit by James Vreeland restraining the Erie Railroad Company and the Forest Commission from enforcing it being still undecided.

Though this state of uncertainty is deplorable, the situation has elements of encouragement, chief among them being the voluntary extension of their fire lines by the New Jersey Centra' Railroad, by the Atlantic City Railroad, and, to a limited extent, by the Pennsylvania Railroad. If the law had been enforced more or less as a compulsory measure some of the advantages of this voluntary execution would have been lost.

With respect to the effectiveness of the fire lines the frewardens' reports have but one tale to tell; namely, that wherever they have been established serious forest fires have not occured, while outside the lines some bad ones have begun. Thoush it has never been claimed that a fire line of this character vould automatically prevent any fire beyond it, it is significan that the record of the year shows only one fire which jumped the safety belt and got into the adjoining woodland. Foir fires were started beyond the fire lines by sparks thrown intirely across them, so that to this extent the lines were of $n$ value; though, as the consequent fires were all extinguishel before they became serious, it is reasonable to conclude that the lines are practically effective at their present width. A fuxher value in the measure is found in the action of practically al the railroads in the State regarding the cleaning of their rights of way. All the South Jersey roads at least are more scrupilous in this 


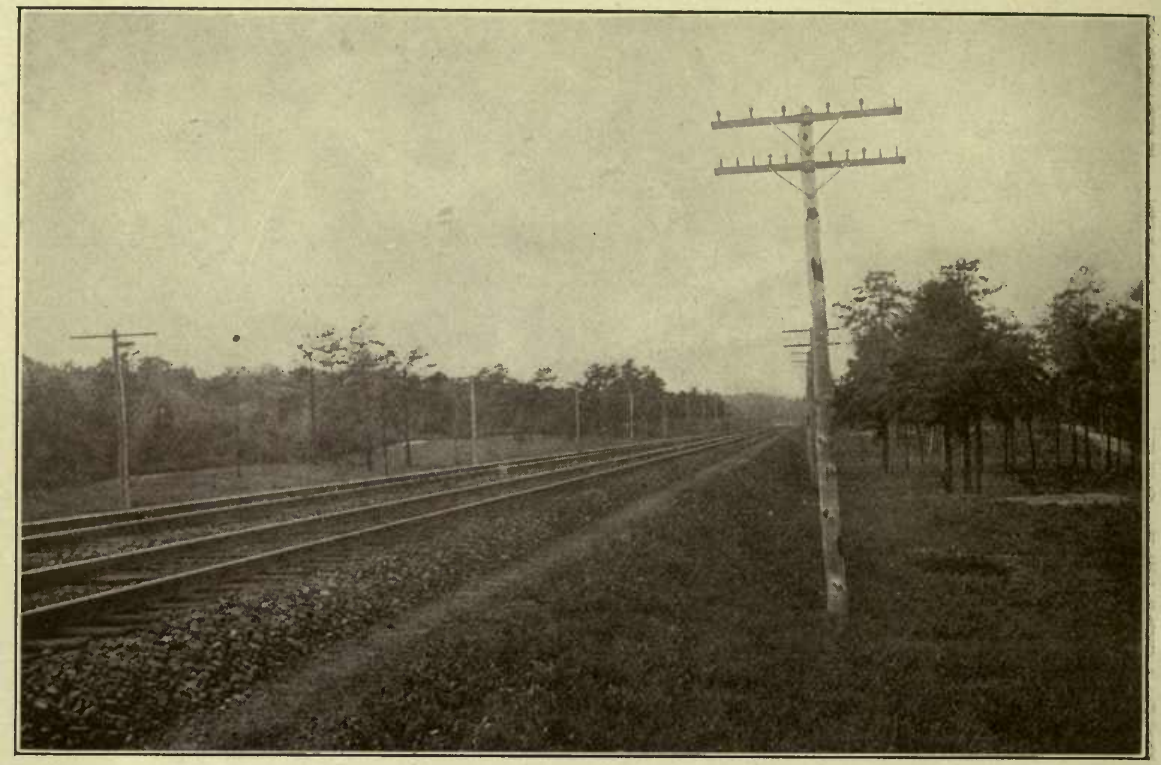

Fig. I0.-Railroad Fire Line in Good Shape. It Has Just Been Cleaned the Third Time.

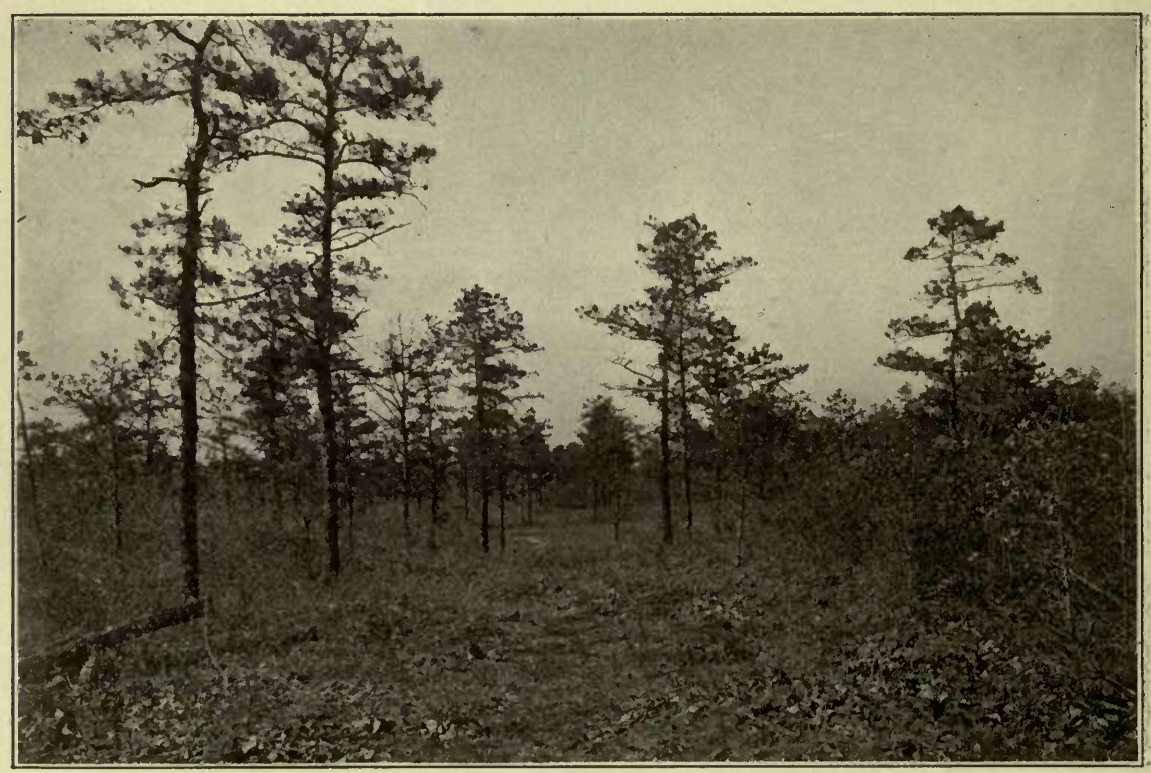

Fig. II.-A Fifteen Feet Wide Fire Line Cut Through the Forest Where there is no Road. This Cost \$15 a Mile and Should be Recleared Every Two Years. 
respect than ever, and in not a few instances their clearings have been extended considerably beyond the right of way with the consent of property owners.

This is by no means an expression of satisfaction with what has been done by all the roads, for some have failed to do anything, and even in South Jersey the quality of the work is variable. This, however, is only natural in view of the position taken by the Forest Commission, that so long as the constitutionality of the law is in question it will strive only to secure the construction and maintenance of fire lines by voluntary action, not by an attempt to enforce the provisions of the act.

The new work done by each railroad may be summarized thus:

\section{Pennsylvania Railroad.}

In the fall of I9Io it was arranged that fire lines should be extended at the following points: I. Along the Philadelphia and Long Branch Railroad, (a) between Pemberton and New Lisbon, about two and one-fourth miles; (b) east of Toms river, about four miles; (c) on the Browns Mills branch, about three miles. 2. Along the Freehold and Jamesburg Agricultural Railroad, (a) east of Fairfield, about five-eighths of a mile; (b) west of Farmingdale, about three-eighths of a mile; (c) between Farmingdale and Manasquan, about two and seven-eighths miles. 3. Along the Camden and Atlantic Railroad, (a) between Lucaston and West Berlin, one and oneeighth miles; (b) between Berlin and Atco, one and one-fourth miles. 4. On the Maurice River branch, at various points between Manumuskin and Port Norris, two and one-fourth miles. 5. On the Bridgeton branch, at various points between Aura and Finley, five and one-half miles. 6. On the Salem branch, at various points between Tomlin and Riddleton, two and onehalf miles; a total of 25.6 miles. Of this construction only 2.4 miles along the Camden and Atlantic Railroad and 10.25 miles. along the Maurice River, Salem and Bridgeton branches, a total of 12.65 miles, was carried through, although between one and two miles of standard fire lines were made at points not ordered, 
chiefly on the West Jersey and Seashore division. Wide clearings without safety belts were also made at other points.

Comparatively little reclearing of lines previously made has been done beyond the railroad right of way. As the record of the Pennsylvania Railroad with respect to the starting of forest fires grows steadily better, the necessity for maintaining fire lines decreases. Nevertheless, it is regrettable that this road has not found it expedient to protect itself by this means. No provision for new construction next year has been undertaken as only a fraction of the line authorized a year ago has been made.

\section{New Jersey Central Railroad.}

For the year I9I I this railroad agreed to extend its fire lines: I. Along the Toms River branch, (a) between Lakehurst and Toms River; (b) between Toms River and Waretown; about 26 miles in all. 2. Along the main line of the New Jersey Southern Railroad between Winslow and Landisville, about 7 miles. 3. Along the High Bridge branch between Morris County Junction and Hopatcong, about 3 miles. The work under $\mathrm{I}$ and 2 was all done in a satisfactory manner, although the total necessary clearing was found to be only 28.25 miles. On the High Bridge branch, however, many objections by property owners were made and it was deemed advisable to withdraw that section. The New Jersey Central Railroad has thus made in two years 66 miles of standard fire line, all of which is kept in good condition. This road further enjoys the distinction of being the only one in the State which has definitely agreed to extend its lines the coming winter. Thirty-two miles have been provided for through the necessary notices to property owners.

\section{Atlantic City Railroad.}

This road has made 23 miles of new fire lines under agreement with the Forest Commission and about i 8 miles more, partly effective, in co-operation with property owners. This construction with the 35 miles made last year gives a total of 76 
miles. The new work done is: I. On the Gloucester branch, between the north branch of Timber Creek and Hilltop station, five-eighths of a mile. 2. On the Cape May branch, between Tuckahoe and Woodbine, 7.6 miles. 3. On the Ocean City branch, one-half mile. 4. On the main line: (a) Between Williamstown Junction and Winslow Junction, 7 miles; (b) between Hammonton and Egg Harbor, 7.5 miles. On the Cape May branch, extra voluntary work, I 8 miles. All the line but the last has been well made according to standard and the reclearing on most sections is unusually well done. Fig. 7: For next year the Superintendent informs us that he is not authorized to agree to any new construction. There is a probability, however, that some recognized exposures will be covered.

\section{Lehigh and Hudson River Railroad.}

The exposure along this road is slight, but the requirement of 700 feet east of Allamuchy station has been covered.

New York Central and Hudson River (West Shore) Railroad.

The year's requirement for this road was 2,830 feet to be made northward from West Englewood station. The line has been made as projected, and last year's cutting worked over in a satisfactory manner. As the extension of the lines along this road are likely to encounter objections from property owners it was deemed advisable not to attempt to extend them at this time.

\section{Tuckerton Railroad.}

Last fall the Superintendent asked authority to cover the whole length of this road with fire lines. This was accordingly given after the usual notification to property owners. But the making of fire lines has gone slowly. Only a few spots along the road have been worked, and not much done outside the right of way toward keeping up the line constructed last year. In view of the many fires started along this road it is unfortunate that 
standard fire lines have not been maintained throughout its whole length.

\section{Raritan River Railroad.}

The management of this road asked for authority to construct fire lines along the whole length of its Serviss branch, considerably more than would have been required to be made in one year. Though the consent of property owners was obtained.in the manner prescribed by law no work on the fire lines has been done.

\section{Mount Hope Mineral Railroad.}

The total exposure along this road was covered by the construction of fire lines in I9IO. These have been satisfactorily maintained and the road's full obligation under the law is thereby fulfilled.

\section{Other Railroads.}

With respect to all other railroads in the State no effort has been made to enforce the law, and practically nothing has been done by way of voluntary construction outside the rights of way. The fires that have been started along these roads, notably by the Delaware Lackawanna and Western and the Errie, have been numerous and some of them serious, a condition that is in strong contrast with that found on the South Jersey railroads, where with a much greater exposure, and a greater number of fast moving trains, the damage by fires has been relatively less.

The total length of effective fire lines now in the State is approximately 235 miles.

Wharton and Northern Railroad Fire Car.

Reference was made in the last report to an order by the Forest Commission authorizing the Wharton and Northern Railroad Company to maintain a high speed motor car equipped with fire fighting apparatus as a substitute for the fire lines which under the law the road might be required to make and maintain. 
This car has been kept in service throughout the season, running close behind each train whenever the vegetation along the track was in a condition to burn. The experiment has been entirely successful. No fires have been started from the railroad, the management is satisfied alike with its freedom from damage claims and with the small cost of operation. The success of this single car may be referred to as evidence of the wisdom of authorizing a body like the Forest Commission to meet each situation in whatever promises to be the most practicable way. Such a car would be a nuisance on any of the larger roads; it is even doubtful if one could be run satisfactorily on any other railroad in the State than this where trains are few and the speed not great.

\section{Action of Property Ozeners.}

The willingness of property owners to co-operate with the Forest Commission and the railroads in the maintenance of fire lines is even more unanimous than it was a year ago, if their failure to file objections may be taken as an index. Thus of the 348 property owners who were notified of the intention to construct fire lines this year only 18 objected. Every objection has of course been upheld in accordance with the policy laid down by the Forest Commission, and in the case of the High Bridge branch of the New Jersey Central Railroad above referred to, the construction of a length of fire line was suspended on account of the objections so interrupting it that it could have had but little value. All this has had the further effect of satisfying those most interested that neither the Forest Commission nor the railroad have any sinister object in carrying through this work. The law, if it shall be finally upheld, apparently safeguards the interest of the property owners in every reasonable way. The fear that the right of entrance given a railroad company might develop into a title by possession is being allayed, and it is found practicable in cases of assumed injury to make an adjustment which satisfies all interests. 


\section{What a Fire Line Is.}

As interest in these fire lines is still active, while knowledge of their construction and specific objects is limited, the following description from last year's report is here reproduced:

Figure 12 shows in a diagramatic way the essential features of a railroad fire line constructed on level ground. Many people, including some railroad superintendents, think that the best fire line is one which is entirely clear of trees for a width of not less than Ioo feet. If the ground could be entirely bared, and kept so, that would be true, but since weeds, sprouts and a variety of growth could not be suppressed at a reasonable cost, it is much better to allow trees to stand at intervals over the greater part of the danger zone because their crowns interrupt falling sparks, and in many cases may prevent such sparks from reaching the inflammable material on the ground until they have lost their power to ignite it.

The essential features of the fire lines as required in this State are: A safety belt, or bared strip, ordinarily ro feet wide and usually 100 feet from the nearest rail of the track. This safety belt serves in a way as an automatic fire check. From its whole length and width every particle of vegetation and inflammable matter is to be removed and the mineral soil exposed, and so maintained. Between the safety belt and the roadbed lies what is called the danger zone, usually roo feet wide. Here the ground is simply cleared of grass, brush, etc., by mowing or burning, or both, and the trees where they form thickets are thinned out. There is no need to remove any tree of fairly good form unless it crowds closely upon several others, but all trees which remain are trimmed of branches to a height of 6 feet.

If a spark is thrown from a locomotive stack beside one of these fire lines the interference of the standing trees will probably so retard its fall that its igniting power is lost; but if a spark is not so killed it is practically sure to fall inside the safety belt. There it finds little to burn, and if some grass or dry leaves are ignited the fire can gain little force or headway before it 


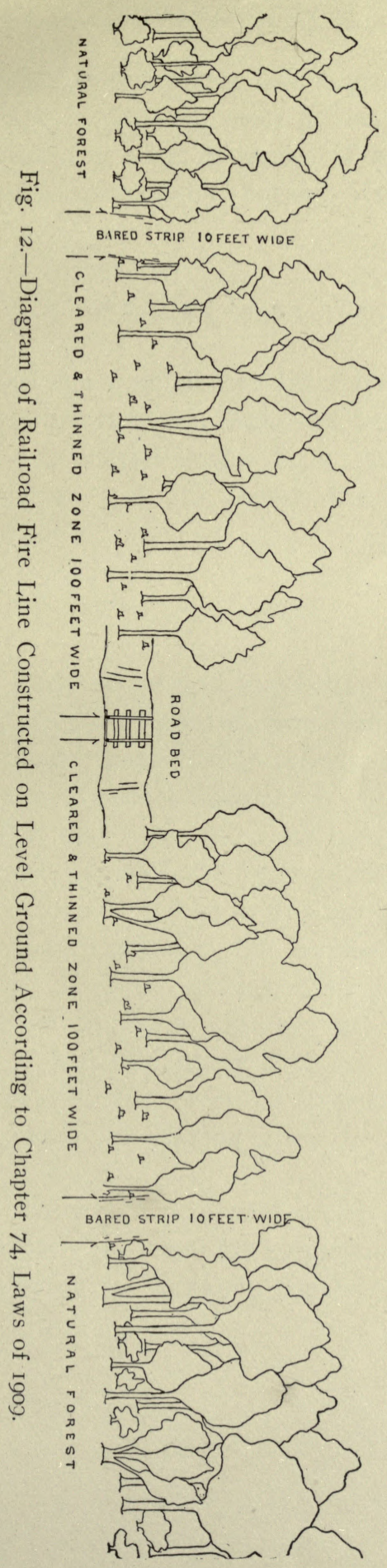



reaches the safety belt. If this safety belt is properly maintained a small fire is not apt to cross it, even if there is considerable wind, but must go out for want of fuel. If a fire starts while the wind is strong no practicable barrier will stop it. Fire fighters are needed.

\section{Cost of Fire Lines.}

No new figures of the cost of fire lines have been secured. According to our best information, therefore, the cost still ranges from $\$ 125$ to $\$ 500$ a mile; the former figure approximating the cost in the pine forests of South Jersey, the latter where the ground is rough and rocky.

\section{Value of Fire Lines.}

The Commission finds no ground to modify its belief that by means of these fire lines fires started from the railroads in our territory can be in large measure controlled. It is not in any sense implied that the fire lines themselves do this. The best that can be expected is that they will check most of the incipient fires, the rest being left to the local firewardens, who invariably look closely after territory protected in this way, and to the operatives of the railroads, especially the section men, many of whom hold it a point of honor to keep their fire lines in good condition and to allow no fire to get beyond them. There is reason to believe it a fact that many fires are set on these fire lines but never reported because they are so quickly extinguished that no one apart from the section crew is allowed to have knowledge of them.

Thus, while fire lines cannot be considered as a positive means of preventing all forest fires, they do unquestionably, either directly or indirectly, work for effective control. 


\title{
Report of the State Forester.
}

\author{
AlFRED GaskiliL.
}

STATE, FOREST RESERVES.

SUPMMARY.

State reserves not increased but improving rapidly-Area and location-Products are increasing, forest fires decreasingLittle planting necessary though some has been doneGame refuges.

In pursuance of its now established policy the Forest Commission has asked for no new appropriation to purchase land, and is making little effort to acquire more forest reserves. This is not because State reserves are undesirable, or not recognized as a means of proving the practical value of forestry, but because it is considered wisest to establish thoroughly the security of all forests throughout the State, irrespective of ownership, before seeking to increase the State's possessions. The principle that a State is better able than its citizens to control the forests and wait for returns does not apply to this State at this time. When forest fires shall have been so brought under control that any piece of woodland can be said to have positive value the increase of public forests can be considered. This argument does not apply to disconnected tracts of woodland like the Mount Laurel Reserve, which, by reason of their location, are practically safe from fires, and are of value as demonstration forests. The Forest Commission therefore hopes to acquire similar tracts in various parts of the State from time to time. It would be well to have a reserve of this kind in each county. The reserves now owned by the State are as follows: 
LOCATION AND AREA OF FOREST RESERVES.

Bass River Reserve, Burlington County, See Map in Report

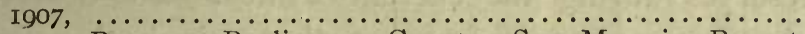

Lebanon Reserve, Burlington County, See Map in Report

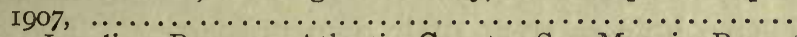

Mays Landing Reserve, Atlantic County, See Map in Report

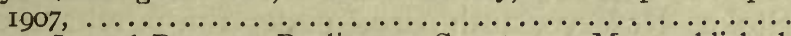

Mount Laurel Reserve, Burlington County, no Map published, Penn Reserve, Burlington County, See Map in Report IgIr, Edward C. Stokes Reserve, Sussex County, See Map in Re-

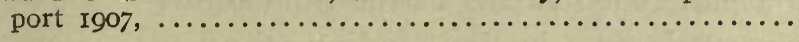

Total, I,633 acres 3,498 " 373 " 20
2,764 " $"$ $5,432 "$,

I 3,720 acres

As the average cost of these properties was but $\$ 3.30$ an acre they naturally held little timber of merchantable size. The time to make them yield a money return is therefore in the future. Nevertheless, as the growth of one kind and another responds to the security from fire which has been given, the value of the properties becomes apparent and small quantities of various products are found to be salable. Thus a beginning has been made in deriving an income from the reserves which, though insignificant in amount now, should, and under normal conditions will, increase steadily from year to year. This income for the year was $\$ 93.80$, most of it coming from the sale of cordwood, cedar poles, sphagnum moss and cranberries, chiefly the product of the Lebanon Reserve.

There is a good stand of pine timber on a portion of the Penn Reserve which will be marketed as soon as conditions are right. On the Mount Laurel Reserve, which was acquired through the interest of several people in Moorestown, an improvement felling is now under way. This is expected to return a good part of the original cost of the property, while leaving it in better condition than it was. See Figs. I4, I5. Some complaint of the foresters' work on this reserve has been heard, but only, so far as we know, from those who object to the felling of any tree. The ax and saw are the forester's plow and harrow, as well as his reaping hook; by their intelligent use he brings a forest to maturity, harvests the crop, and often starts the next generation. 
Similar cuttings for improvement, however, rather than for revenue, are planned to be made on the Mays Landing and Lebanon Reserves during the current winter. These will be located in the most exposed places, so that neighboring forest owners may learn how to treat their own properties. The cutting on the Stokes Reserve, authorized under the purchase contract, is nearly all done. A few tie choppers will work during the year and a half that remains of the time allowed, but in the main the property is now in the hands of the Forest Commission. Unfortunately, no means of disposing of the excess of cordwood has yet been found. The forest cannot have the treatment it needs until this is possible and efforts are still making to that end. See page 75 .

FOREST FIRES.

During the year a few fires occurred in the State reserves. Mays Landing, Bass River, Penn and Mount Laurel were entirely free as they have been since they were acquired, while only ten acres were burned on the Stokes and less than twenty acres on the Lebanon. This is a marked gain over I9IO, and as a result of the protection afforded, the forest, whether pine, oak or cedar swamp, is shooting upward and filling out, proving conclusively the contention that such property has a real potential value, and that the low esteem in which the woodlands of the State have been held is due almost exclusively to the recurrence of forest fires. See Figs. 6, 7, 8, 9. In particular the pine on the four South Jersey reserves is growing at a rate that promises a fair stand of timber within comparatively few years. None of this timber will be good according to present commercia! standards, for the trees have been too frequently burned and the soil too much impoverished by fires, but it will form a crop, and while growing will prepare the ground for a better forest after a while. This hopeful outlook does not extend to the Stokes Reserve, because the forest there contains a large proportion of chestnut which from present indications must be sacrificed within a few years. So far as all other species are concerned, however, the stand is as satisfactory as on the other reserves. 


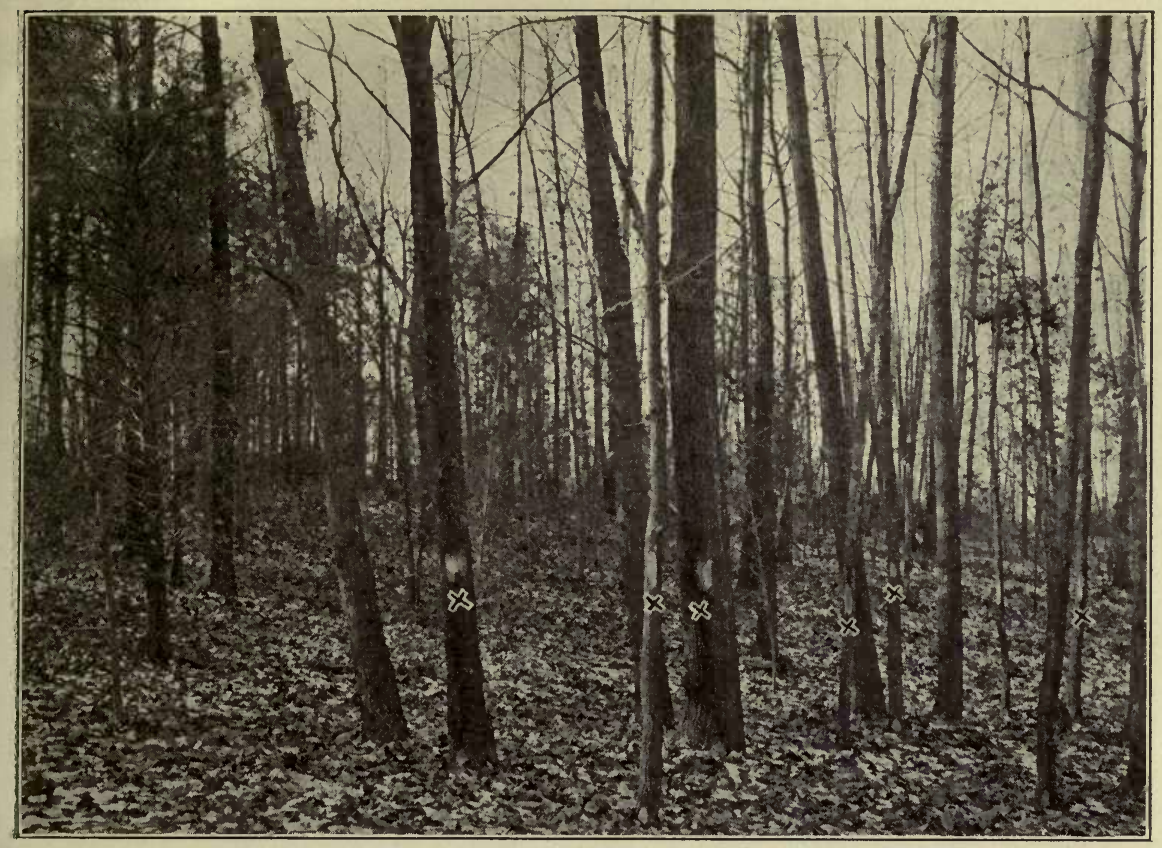

Fig. 14.-Natural Forest with Trees Marked x, x, x, x, for Removal.

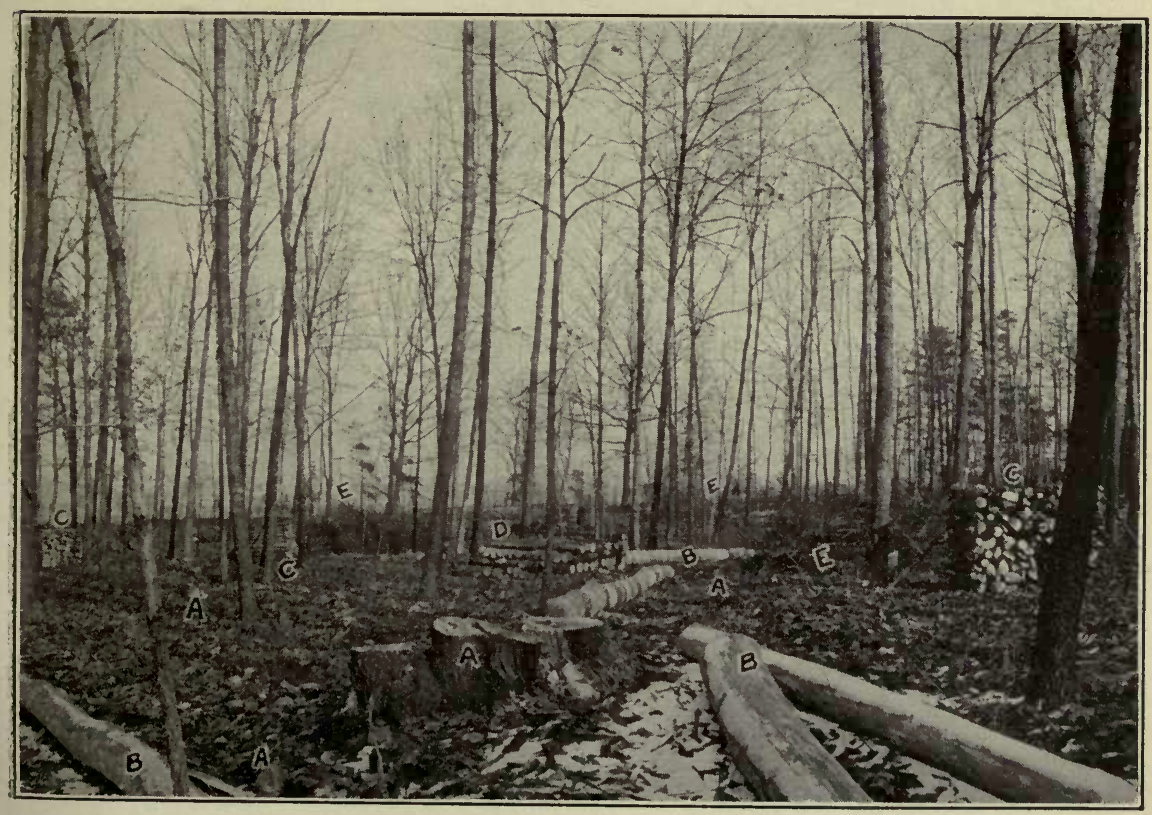

Fig. I 5.-A Place Similar to that Shown Above with Trees Felled and Material Ready to be Removed. Note: Low, Clean-cut Stumps A, A, A; Electric Poles B, B, B; Cord Wood C, C, C; Fence Posts D; Brush Piled for Burning E, E, E. The Burning Will be Done at Safe Times and Without Injuring the Standing Trees. IMPROVING A WOODLOT-MOUNT LAUREL RESERVE.

The Former Owners Proposed to Cut this Tract Clear for Firewood Only. This Felling will Yield About $\$ 40$ an Acre (40 per cent. Poles, Posts and Logs) and Leave the Forest in Better Condition to Grow than it was Before. 

The means by which this improved condition has been reached are watchfulness, the maintenance of fire lines, now aggregating about 25 miles on the South Jersey reserves, Fig. 9, and the pursuit and punishment of everyone who starts a fire.

PLANTATIONS MADE.

There is little need for forest planting on any of the reserves. Natural reproduction is active and everywhere, except on a few old fields, will take care of the future. These openings will be used for experimental plantings. Thus in the spring 14,000 young pine trees grown in the Bass River Nursery were set out in openings on the Bass River Reserve, and 18,000 from the same source were planted in openings on the Lebanon Reserve. Unfortunately a large part of these trees were killed by the drought which began shortly after the planting and for a long period deprived the roots of necessary moisture. There is a possibility, however, that some of the trees will survive, and the plantations cannot be called failures for at least two years. If any considerable portion of any of the species planted does survive they will have served their purpose, as the plantations were made as much to determine the fitness of certain trees for our soils and climate as to establish forests.

GAME, REFUGES.

For several years past there has been a strong desire in certain directions to have the forest reserves made game refuges. On the other hand, many people owning property or resident near the reserves oppose the proposition, being fearful of an increase in the fire hazard or jealous of the freedom which they have upon the reserves as public property. This opposition to any restriction on the use of wild lands is especially strong since so much private land has been posted or enclosed.

While the Forest Commission is prepared to permit any use of the reserves that will not endanger the well-being of the forests, it is obliged as trustee of the State forest 
lands to consider that well-being above all else. And it is convinced that the multiplication of game animals, especially deer and rabbits, would do a positive damage to the small trees. Furthermore, the prohibition of gunning where game was unusually plentiful would surely attract many non-resident hunters to the lands immediately adjacent, and thereby aggravate the risk of fire. It would also be extremely difficult to enforce such a law or regulation, because the reserves have no physical boundaries or fences and are traversed by public roads on which anyone may lawfully carry a gun. In view of all the circumstances -the risk of arousing antagonism in sections where it is desirable to gain support for its work, the greatly increased danger of forest fires, the probable damage to young tree growth-the Forest Commission decided that the reserves in general should not be closed; but, in order to give the proposition a fair trial, it has offered to set apart 500 acres of the Lebanon Reserve and 2,000 acres of the Stokes Reserve if the Fish and Game Commission will clearly mark the boundaries and undertake to guard the sanctuaries. It is expected that an agreement along these lines will soon be made. 
PRIVATE FORESTRY.

SUMMARY.

Owners with an interest even greater than that of the State are practicing forestry $-200,000$ trees a year being plantedWood-using industries needed-The Forest Commission will help owners develop their woodlands.

To bring about the practice of forestry by woodland owners is the ultimate object of the Forest Commission. With about $2,000,000$ acres of land classified as forest the State has only an insignificant lumber industry. That is, insignificant by comparison with the industry as it is found in many other States. Still our situation may be considered promising rather than otherwise, for while practically without the virgin forests which at present form the chief support of the lumbermen in this country, we have an opportunity to establish new forests that in time are sure to prove one of our most valuable assets. But having long passed from public to private ownership our forest land is likely to remain there. This is especially true of North Jersey, where the establishment of estates, and the development of communities in which the space devoted to each individual is unusually large, tend toward the retention of the forests in private possession against any effort that the State might make to acquire them. And from the silvicultural point of view it matters little whether a forest is publicly owned or privately owned so long as it is rightly managed.

From this standpoint the present situation is highly satisfactory for it is possible to show that properties ranging in size from 50 acres to 20,000 acres, and aggregating perhaps 200,000 acres, have been brought under forest management, while there are many indications that the actual area under development, or perhaps only under protection, is several times that total. This is because many small properties in all parts of the State, and 
some large ones with which the commission has had no concern, are taking a practical part in the new movement and practicing forestry.

This is another way of saying that the public speaking which the State Forester has done, the material furnished to the press, and the specific advice given many property owners, all supported by a fire service which gives security to the forests, is steadily bringing the woodlands of New Jersey into better condition.

\section{FOREST PLANTING.}

The number of trees planted during the year has apparently been upwards of 200,000 , although here again it has been impossible to get definite figures. But even at the rate of 200,000 trees a year it will not be long before North Jersey, where most of the planting is being done, will present an altered aspect. The recommendation of the State Forester in practically every case that planting be confined to evergreen trees is generally accepted, and patches of dark green now show through the snow or amongst the lighter green of the deciduous trees on the hillsides in many directions. Some of the most successful plantations have been made on the property of the Newark Water Board near Newfoundland in Passaic county, on the Water Reserve of the city of East Orange in Essex county, in the Essex county parks, and on two private properties near Allamuchy in Warren county. A considerable aggregate, mainly for landscape effect, however, has also been planted in the Ber. nardsville and Morristown sections. No reproach attaches to South Jersey because tree planting has been resorted to in only a few instances for the reason that there tree planting is less necessary. Property owners in any part of South Jersey can usually be assured of a new forest through natural regeneration wherever immunity from fires is secured.

FOREST MANAGEMENT.

Work in forest management can also be found on many properties in the State, although it must be admitted that thus far 
most of this has been done for esthetic effect rather than in pursuit of silviculture. The time is not far off, however, when the possibility of bringing a woodland tract under systematic management will become a practicability. The one great difficulty invariably encountered wherever this question arises is how to dispose of the rough wood that must be cut out. This problem is constantly before the Forest Commission, and though no practical solution has yet been offered, it is hoped that before long several plants adapted to using cordwood for the production of charcoal, wood alcohol, etc., or of tannic acid, may be established. As success in this direction necessarily involves the active cocperation of those who own woodland and may have wood to sell the Commission would like to have definite offers of whatever wood products are available.

In sections where the chestnut blight is active an effort is making to have mills located so that the largest possible returns may be secured for the trees that must be felled, but even there it is important that whatever industry is introduced be established on a permanent basis, since forestry is not forestry that does not consider the harvesting of all trees as they mature: and provide a profitable outlet for the anmual wood crop.

\section{ASSISTANCE TO WOODLAND OWNERS.}

The offer of the Forest Commission to aid any forest owner in the management, development or protection of his property is continued. At the request of any citizen a competent forester will be sent to examine his woodland and recommend such measures as are advisable. If necessary, arrangements can be made to have fellings, plantings or other work begin under his direction, though he can have no part in any contract or sale. The only charge for this service is the forester's actual expenses while away from Trenton. 
SHADE TREES.

SUMMARY.

Shade trees an asset of increasing value-Shade Tree Federation-How the State helps communities and individualsTrees injured by gas-Many trees damaged by droughtStreet improvements need not involve loss of trees-Country roads should be bordered with trees-A bulletin on the planting and care of shade trees.

In keeping with an ever broadening civic life grows the interest in trees and appreciation of their value. There is no need to point out that arboriculture is not forestry, for the two can easily travel together, and we have only to remember that it is important to have more shade trees and to give all, old and new, proper care. As a rule the care of old trees is the more important, for a tree established, even though it be poor, is better than one newly planted and subject to many dangers.

SHADE TREE FEDERATION.

A notable step taken in behalf of municipal tree interests was the organization of the Shade Tree Federation of New Jersey referred to in our last annual report. This association makes no effort to secure a large membership; it seeks only to represent, and afford a medium of communication between, communities in which the desire to provide for the local shade trees has crystalized in the form of a shade tree commission, or in which such crystallization is desirable. The association, therefore, with a membership of only 45 represents 26 regularly appointed shade tree commissions, or committees of council having in effect the same powers as shade tree commissions. 

These numbers are altogether too small, for there are at least a hundred communities in the State which have shade trees to be looked after. The effort of the members of the Federation, and of the Forest Commission, is to increase the membership of the former and thereby extend its usefulness. The advantages that membership offers are, an opportunity to discuss problems, needs and possibilities with others who have to deal with similar situations, and, through concerted action, to reach desired ends. One of the tasks that the Federation has set itself is to secure a revision of the State shade tree laws, by which the difficulties that have been encountered by some communities in applying the present acts may be overcome and the tried-out principles of the law of 1893 made universally applicable. The Secretary of the Federation is Mr. William Solotaroff, East Orange.

The greatest difficulty that a local Shade Tree Commission finds at the beginning of its work is to get the necessary money. No great sum is needed in any case, but it is important to recognize that very little can be done in a work of this kind without some money. To their credit and advantage many of the communities represented in the Shade Tree Federation have made provision for maintaining an effective organization by the appointment of capable men to conduct the work. In some instances these officials are named as superintendents or secretaries, in others they are called foresters, an unfortunate misnomer. I venture to use this opportunity to suggest that the title of any such city or park official be "Arborist." It is a good English word indicative of what is done.

STATE AID IN SHADE TREE WORK.

By the legislation of last winter the Forest Commission is now specifically authorized to give attention, and a part of its appropriation, to shade tree interests. It is accordingly prepared to detail a forester experienced in shade tree work to the service of any community that asks for such help. This service will ordinarily be limited as to time and free of cost, though special 
arrangements may be made in a given case. Similar assistance will be given individuals or corporations, and correspondence regarding their needs is invited, but they will be required to pay the actual expenses of the visiting forester, or arborist, while away from Trenton. Justification for this policy is found in the many appeals that now come to the Forest Commission, and in the Commission's belief that the object of its creation will be served by taking advantage of every opportunity to help conserve any body of trees in the State through co-operation with those in interest.

TREES INJURED BY GAS.

This co-operative idea has recently been applied to the adjustment of differences between owners of shade trees claimed to have been killed or injured by illuminating gas and the gas companies. In all such cases the sole aim of the Forest Commission is to establish the facts, and no case is considered except at the joint request, and in the presence of representatives, of both parties.

In four instances during the year the request for an examination has been made by, or at the instance of, a gas company. Every case, so far as we know, has been amicably settled on the basis of the opinion rendered, and both tree owners and gas superintendents have acknowledged the value of suggestions made regarding the avoidance of such difficulties.

\section{STREET IMPROVEMENTS.}

In one direction the Forest Commission has found it difficult to satisfy some shade tree interests. In a number of instances the State Forester has been called upon to prevent the destruction of trees by street improvements. With every disposition to be helpful it has been necessary to say that neither he nor the Forest Commission has the least power in such cases and can only make suggestions. Unfortunately difficulties of this kind are rarely thought of until the changes are actually under way 
$=$ 

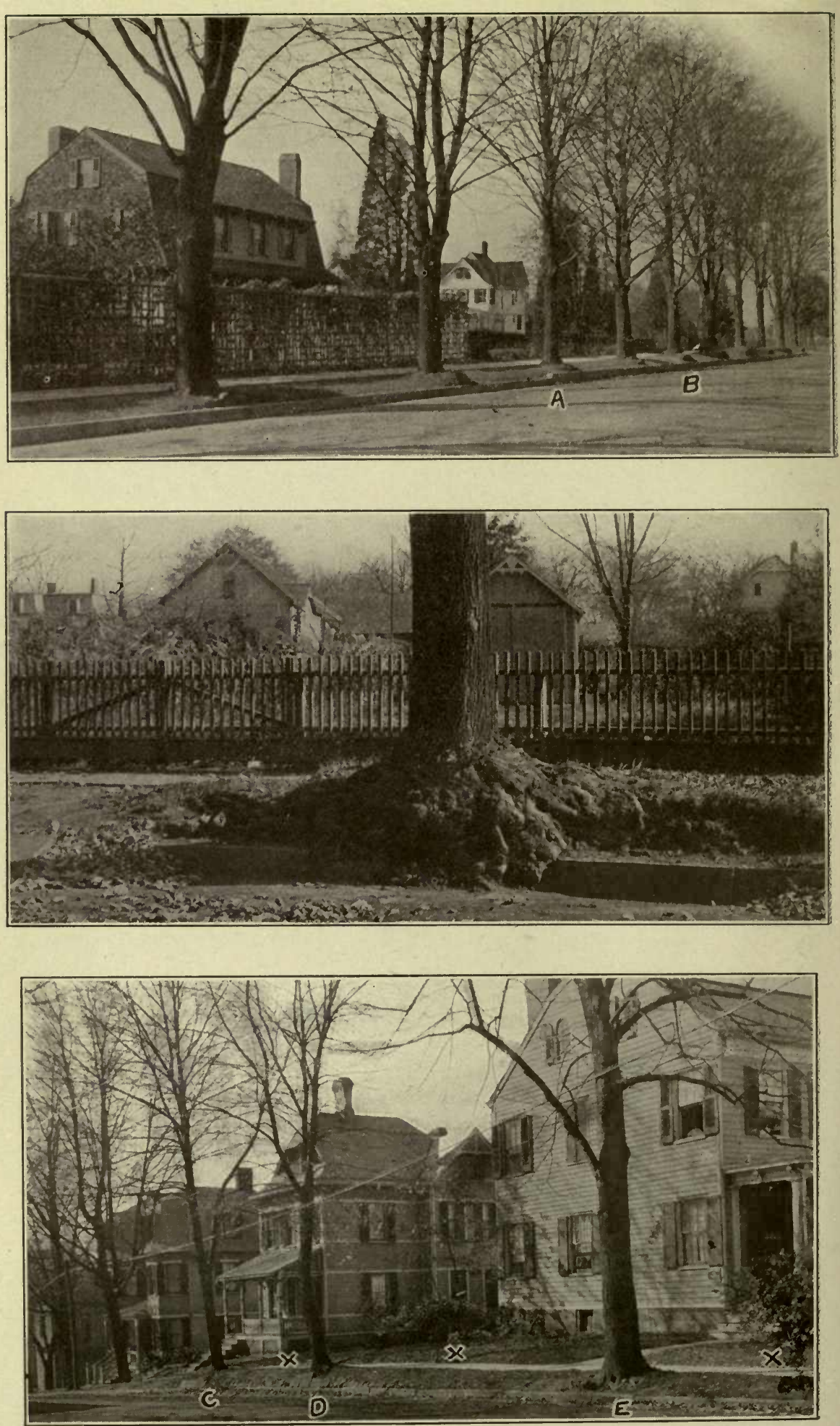

Fig. I9.-See Opposite Page. 
and everyone concerned is indisposed to alter the plans. And not infrequently the complaint is made in a way that arouses local antagonisms. The Forest Commission can have no part in such controversies, but it will gladly consider any problem that is brought to it by the authorities having jurisdiction, or by individuals when the object is not to defeat official action. It is not always possible to convert a country road to a town street, with curbing and sidewalks, and this is the commonest form of the difficulty, without injuring or destroying trees, but often a compromise can be made. If therefore unnecessary loss is to be avoided the situation must be studied before, not after, the improvement plans are adopted; most certainly before lines and levels are established, the contract let and work begun. See Figs. I6-22. Where State-aid road improvements are involved the Forest Commission is assured of the co-operation of the Commissioner of Public Roads.

Fig. 19.-How a Street Grade May Be Lowered Without Destroying Established Shade Trees.

The upper picture shows a row of fine trees where the level of the roaid and of the sidewalk has been lowered. At $A$ the curb is abruptly raised eight inches above the normal level; the base of the tree at $B$ is 30 inches above the gutter. Though the mounds about the bases of the trees are objectionable they sufficiently protect the roots.

The middle picture shows the base of a large maple tree with a barl exposure of roots and a break in the curb. Though this is objectionable it is to be preferred to the sacrifice of any reasonably well developed, healthy tree. In this case the situation can be tolerated until new trees planted on either side of the old one are grown enough to replace it.

In the lower picture are seen two devices for saving sidewalk trees: First, the provision as at $C$ and $D$ for retaining the soil about the roots of trees left above grade. This is objectionable, and cannot be permanent, but if new trees are set out at $\mathrm{x}, \mathrm{x}, \mathrm{x}$, the tree $E$ as well as $C$ and $D$ may ultimately be removed without disadvantage either to the shade tree plan, or to the adjoining properties. The second feature is that necessary electric wires are cabled and carried through the line of trees without injuring any. This is always a practical means of stringing telephone wires where trees are well grown. 


\section{ROADSIDE TREES.}

In rather striking contrast with the general activity in behalf of street trees goes a common indifference to the shadeless condition of most country roads. This should not be for a treebordered road is more comfortable and more practical than one that is exposed to sun, wind and the untidiness that is almost universal. The borders of all main highways should have some of the same care that is bestowed upon the roadbed. It is therefore recommended that the State Road Commissioner be authorized to require that all roads built or improved with State aid be provided with lines of suitable shade trees. Many country roads should have the same provision, but that may be expected to follow if the State-aid roads are used as an example. The initial cost need in no case be more than $\$ 500$ a mile, it would usually be much less through the utilization of trees already standing. Provision for the care of the trees would be an item in the upkeep of the road itself. The Forest Commission is prepared to furnish all necessary technical assistance. Any fear of excessive shading and consequent muddiness in a road may be set aside, for the duty of the arborist, as well as of the road engineer, would provide for trees, in kind and arrangement, suitable for each situation.

\section{DAMAGE BY DROUGHT.}

During the late spring and summer quite a number of owners appealed for help to avert the loss of valued trees by a blight that was evident enough, but traceable to no cause. - Street trees, lawn trees, even some beside water courses, withered and looked distressed. Beeches, pin oaks, sycamores and red cedars were most affected. It was finally established beyond all doubt that the trouble was due to an accumulated deficiency of water by which the under soil, rather than the surface, was depleted. In some cases newly planted trees failed because the water applied drained off quickly to the lower levels and left none to nourish the restricted, superficial root body. This happened in Newark 
$=$ 


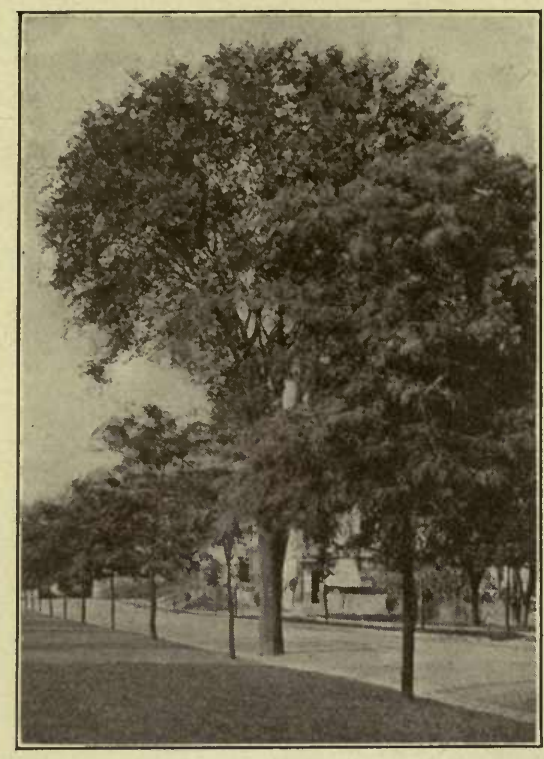

Fig. 20.-Neither New Roard nor New Trees Require the Sacrifice of a Fine Old Elm.

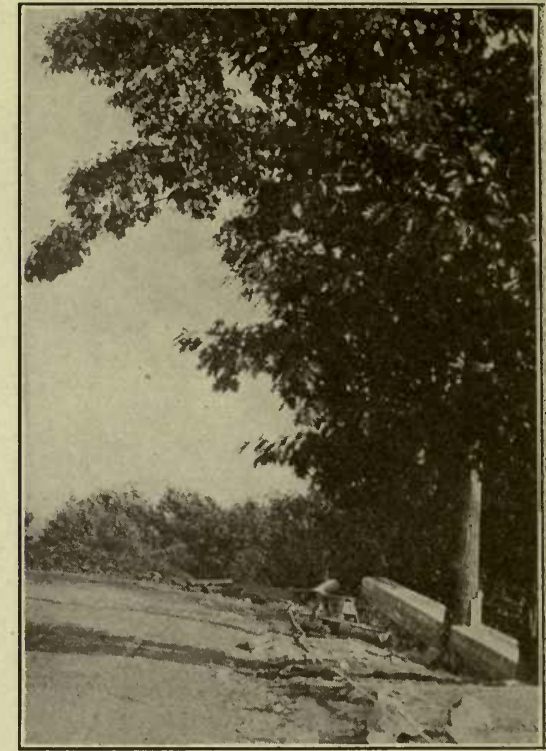

Fig. 2I.-Even a Bridge May be Built About a Big Tree.

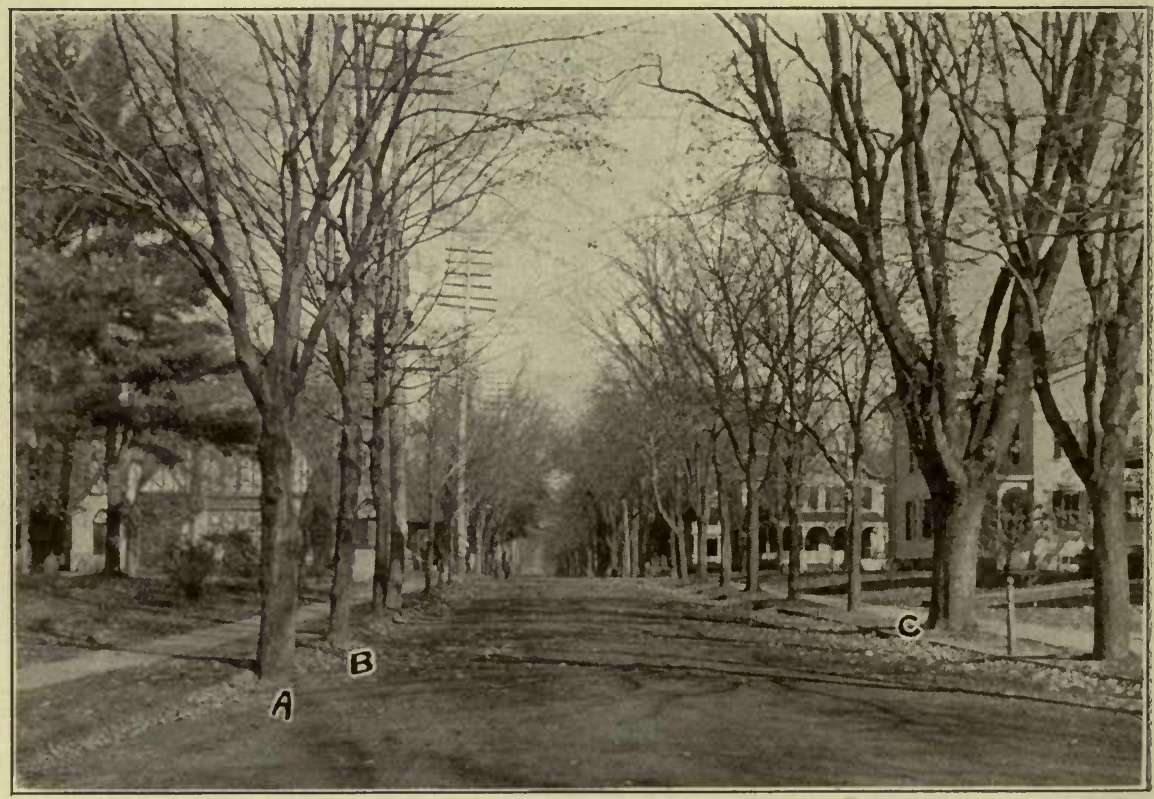

Fig. 22.—-Tree A Stands in the Gutter, Tree B in the Curb Line, Tree C is Partly on he Sidewalk.

Streets and sidewalks can be made or altered without losing valuable trees. 
and other cities. In other instances pin oaks, arborvitae, etc., that had been transplanted several years, and were thought to be established, weakened, and some died, though many revived after the rains of June and July. Many wild cedars on the hillsides failed in the spring drougth, but in several ways the most interesting, and alarming, case was that of the beeches. In dry weather one of these trees will transpire really an immense quantity of water. If that is not replaced by al sufficient supply through a considerable depth of soil, leaf wilt appears and death may follow. This situation caused much concern in the Essex county parks and a few trees died, though most of them have set normal winter buds and are apparently safe. In other places, including several private properties, valued trees were lost.

\section{TREE WOUNDS.}

So many people have been led to believe that the chief need of a tree out of condition is to fill it full of cement that a word on the subject of tree wounds and tree cavities is in place. It will be understood that this is but one feature in tree culture.

When the bark of a tree is broken, be it by accident or by design, it is necessary to guard the exposed wood against decay. The many diseased spots on our shade trees are due chiefly to neglect of this precaution. If a limb is cut off the stub should be immediately covered with tar or oil paint to prevent decay. Where a serious wound has been suffered, or where decay has set in, the best treatment in most cases is to clean the cavity and expose a smooth surface of sound wood. Coat that with coal tar, taking care not to touch the cambium-the growing tissue between the wood and bark-and leave the rest to nature. Unless the cavity be very large, or is so located that water will collect in it, there is no need for a cement filling. Fig. 23 illustrates how tree wounds are healed better with no treatment at all than when cement is used where it is not needed. 
Fig. 23.-Tree Wounds Healing Without, and in Spite of, Filling.

A: A bad scar on a fine elm healing perfectly without cement.

B: New growth on a wounded elm which has forced out a cement filling.

C: New growth closing another wound on the same tree and confining some of the cement.

D: Strong new growth closing a bad scar that would have been better left without brick or cement.

E: A fine callus closing a bad wound on a hemlock that has had no treatment. The decayed wood in center should be removed and the sound core tarred.

SHADE TREE BULLETIN.

The Commission is still distributing to all who ask for it its fourth aninual report, which contains a bulletin on The Planting and Care of Shade Trees. As the call for this bulletin promises to keep up, it is proposed thoroughly to revise it and issue a new' edition.

\section{FOREST PARKS.}

It has been repeatedly urged that New Jersey's forests, though devoted primarily to the production of timber, should be regarded and treated also as parks. This is common practice in all parts of Europe where the population needs outing grounds. It is proper and possible in this State for the same reason.

That a piece of woodland serve as a park it is not at all necessary to put it under the care of a landscapist, or to maintain flower beds and lawns. In many ways and to many people a true wildwood is more attractive than the typical park. We can, therefore, have in all parts of the State bits of woodland that will serve every need of the people at little or no tax upon local treasuries. Of course city parks have become necessities, and it is desirable for each city and town to have at least one. The example of Essex county in creating a county park of nearly 3,000 acres on the Orange mountain is also worthy of imitation in other parts of the State: See Figs. I, 2, 3, 4, 5. A community should be owner if possible, though that is not always essential. 


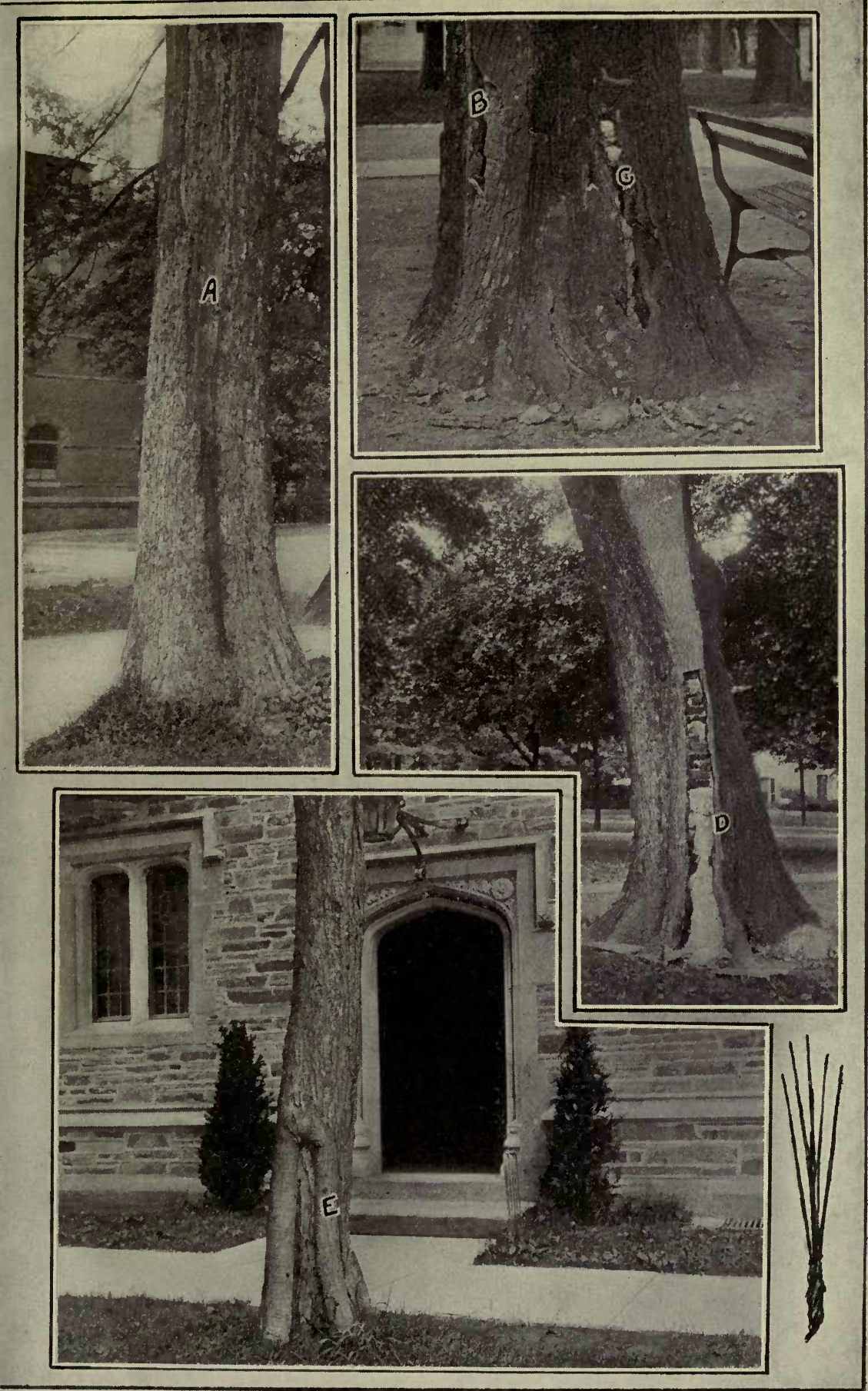

Fig. 23.-See Opposite Page. 

But the argument here is to make every tract of accessible forest a part of a State park system. The way to accomplish this is simple. Comparatively few forest owners exclude the public from their property, though many do complain, often with reason, of the depredations that are committed. If any community, therefore, will give the owner of one of these properties a reasonable assurance that his interest will not be destroyed by vandalism the public enjoyment of it need not be curtailed. If the community go a step further and definitely agree to police the property and guard it against fires and lesser injuries, the fullest privileges to the public may be secured. Or a community might acquire a right of usage in a piece of woodland by exempting the property from taxation so long as it was made available to the public. And several small tracts would be preferable to one large one, for the value of any park is in direct proportion to its accessibility.

It is the desire of the Forest Commission to have the State forest reserves used as parks as largely as possible. This can not now be done to any great extent, because the properties are too remote from population centers. Nevertheless, the reserves will be made more and more available as the improved condition of the forest on them increases their fitness as parks. Few will deny that in a community like ours every acre of woodland should form a part of the people's playgrounds. This ideal is attainable through protection and reasonable consideration of the owners. Public possession is the last, not the first, necessity. 
TREE PESTS.

SUMMARY.

Situation now better in hand under authority given State Entomologist and State Plant Pathologist, though danger still great through lack of National quarantine-Chestnut blight the most serious evil, no hope that any chestnut tree in the State will survive-Elm beetle still active, but neither Gypsy nor Brown-tail moth are yet here-Beware of fake tree doctors.

The year has again been unusually favorable for the developnent of many kinds of tree enemies. Complaints and inquiries from all parts of the State evidence at once the interest of tree owners, and the growing dependence of the people upon the Forest Commission.

Fortunately the actual situation is less serious than the average citizen imagines, for practically all the dangerous insects, and some of the diseases, are capable of control. The Legislature last year listened to the appeals of the Forest Commission, of the State Board of Agriculture, and of other interested bodies and citizens, and provided for more complete control both of insect pests and plant diseases. The insect problem is looked after necessarily and most efficiently by the State Entomologist, who now feels that with the enlarged powers and increased appropriations given him he can meet any emergency that is likely to arise. Plant diseases will be attended to by the State Plant Pathologist, an official authorized by the last Legislature, but only recently appointed because it was found most difficult to secure a competent man.

The Forest Commission is working in entire harmony with both these specialists. Ordinarily the Commission's foresters are able to satisfy inquirers from their own knowledge, though whenever there is doubt the question is referred to one or the other expert. The people of the State may, therefore, be as- 
sured that provision is made for every trouble connected with their trees and woodlands. Inquiries are invited to the end that the injury and loss which unquestionably still goes on may be avoided.

The effort to secure a National law to control the importation and distribution of diseased and insect infested plants has thus far been unsuccessful. It is perfectly clear that no State can fully protect itself against this danger on account of the operation of Federal laws regarding interstate traffic. We must, therefore, depend upon the National Government to do what is required. From its position New Jersey is constantly exposed to the danger of infection from abroad, and the best efforts of its State Entomologist and State Plant Pathologist can be only measureably successful so long as the present laws are unaltered. The need for immediate action by Congress is shown in a paper prepared by Mr. C. L. Marlatt, Assistant Entomologist in the United States Department of Agriculture, and published as a part of the report of the Committee on Agriculture to the House of Representatives.* In this paper it is said:

"Fully 50 per cent. of the important injurious insect pests in this country are of foreign origin. Many, if not all, of these pests could have been kept out, or their spread much checked, if proper quarantine legislation had been available. The gypsy moth and brown-tail moth in Massachusetts and portions of other New England States are now costing those States, in expenditures merely in efforts at control, not counting damage at all, upward of a million dollars a year. In addition to this the National Government is appropriating $\$ 300,000$ a year in controlling these pests along the highways. In spite of these efforts and this enormous expenditure, these insects are still slowly spreading and great damage is done yearly to woodlands, private grounds, and orchards. The dissemination of these two pests over the whole United States, as is extremely likely under present conditions, would entail a like cost throughout the country.

In addition to the danger of importing these insect pests is the risk of bringing in new and dangerous plant diseases. Two illustrations of this danger only will be mentioned, but there are many others equally important. First may be noted a new disease of the potato known as the 'potato wart,' which there is grave risk of establishing in this country. The other disease is the 'white pine blister rust,' which has caused enormous losses in Europe, particularly to nursery stock. Both of these diseases are examples of dangers which can be prevented only by an absolute quarantining of the infested foreign districts so far as importations therefrom to this country of these particular products are concerned. The actual value of the importations of nursery stock which are thus jeopardizing the entire fruit and forest interests of this country is comparatively small although doubtless important from the standpoint of the nurserymen."

* Report No. 1858, Sixty-first Congress, Third Session, pages 7-I2. 
The same author in Farmers' Bulletin No. 453 of the United States Department of Agriculture, says further:

"In addition to the great monetary loss, the brown-tail moth exercises a very deleterious effect on health. The hairs which cover the caterpillars of this moth are strongly nettling, and not only are they so from accidental contact with a caterpillar, but also from the myriads of hairs which are shed by these caterpillars when they transform to the chrysalis state. The latter frequently. cause very disagreeable and extensive nettling, the effects of which may last for months. Breathed into the lungs they may cause inflammation and become productive of tuberculosis. The brown-tail rash is well known throughout the regions infested in New England and thousands have suffered from it."

'Neither of these insects (see p. 88) has been establlished in New Jersey, but the danger makes the State's duty very clear, namely, to prevent absolutely the introduction into the State of all dangerous pests, and provide for the immediate extermination of any that may by accident be located here.

To satisfy the public with respect to the more common and serious tree pests the following specific references are made:

\section{CHESTNUT BLIGHT.}

No ray of hope that this disease will be checked before practically every chestnut tree in the State is dead can be held out. New Jersey is especially unfortunate in having had to take the brunt of the attack, and the whole of our territory, with the exception of Salem and Cape May counties, is infected. The disease is now progressing north and east in Niew York, Connecticut and Massachusetts, westward through New York and Pennsylvania, and southward through Maryland and Virginia. In the States where the situation is not so hopeless as with us active measures are under way to check the progress of the disease. With what success the future only can tell. For the information of those who are interested, and to offset the unwarranted and misleading statements that are frequently published, it may be said that the chestnut blight is not due to the attack of any insect but is caused by a fungus disease whose life history has been well worked out. There is no mystery about it. The disease works in the inner bark, out of sight for the 
most part, though easily recognizable by one who is instructed. There has yet been found no practicable means to control it.

Owners of chestnut trees in New Jersey, who deem them valuable enough to warrant some expense in an effort to prolong their lives, may resort to pruning. Nothing else will avail, and specific directions will be sent upon request. In all other cases, and this applies to practically every body of forest, it will be wisest to let the trees go, remove them as they die and fill their places by planting other species. There is not the slightest use anticipating the actual death of a tree, though when dead it should be promptly removed lest it provide breeding places for harmful insects or lodgment for the germs of other diseases. The possibility of a new pest following the wake of the chestnut blight is by no means remote. The disease is not known to attack any other species than chestnut.

Chestnut wood from trees killed by the blight is as sound and as good for ordinary purposes as chestnut wood from trees that have been felled while in health. It is important, however, to see that no unbarked wood of any kind is transported into territory unaffected with the blight. If logs, lumber or cordwood therefore are to be sent out of the State, or into the southern counties, they should be completely barked. This measure is advisable in the section south of the Camden and Atlantic Railroad as the disease is not yet fully established there. In this territory asso the prompt treatment of trees that may be attacked is recommended. The affected tree or branch should be promptly cut and the wound treated as indicated in the special circular above referred to. This may check the progress of the disease, though no assurance can be given that the measure will be permanently effective.

\section{ELM LEAF BEETLE.}

It is unfortunate that so many fine elm trees have been sacr1ficed to this beetle when a little care would have prevented it all. All the prophecies made a year ago with respect to the ravages of this insect have been fully justified. It has come in hordes and left behind a trail of dead elm trees which generations will not 
replace. The ravages of the beetle and its larvae may be absolutely prevented by spraying the trees soon after the leaves unfold with a solution of arsenate of lead. The effect of this treatment can be seen almost anywhere in the northern part of the State, where sprayed trees in perfect health stand side by side with dead or dying trees which have not been sprayed. The insect attacks elm trees only. Specific instructions for spraying will be given by the Forest Commission, or by the State Entomologist, though tree owners are recommended to turn first to their local shade tree commission, or if one is not organized to get it established. Through such concerted action as a shade tree commission offers the spraying of the trees, and every other thing needful for the welfare of ornamental trees, can be best and most cheaply accomplished. The cost of spraying a single large elm may be anywhere from $\$ 5$ to $\$ 20$. If the owners of fifty or more trees unite the cost may be $\$ 2$ or less.

\section{BROWN-TAIL MOTH AND GYPSY MOTH.}

The danger that threatens from these two insects is made evident on pp. 85 and 86 . Neither has yet obitained a foothold in New Jersey, and the State Entomologist believes that his inspections will serve to keep them from establishing themselves unless the influx of infested plant material from abroad shall become too great. A strict National and State quarantine is our only safeguard. A reference to the bills that New England is now paying will justify any reasonable expenditure.

WHITE PINE BLISTER RUST.

One case of this most dangerous disease (see p. 85) was discovered last spring in a plantation made in I909. Fortunately the owners recognized the danger and promptly pulled up and burned the whole I0,000 trees, those that were still apparently clean as well as those that were diseased. This source of infection is therefore removed, but constant watchfulness will be necessary, as many young white pines are being planted in this 
State. The disease is limited to pine trees with five needles, and thus far has been discovered only on stock grown in German or French nurseries. Home-grown planting material may therefore be depended upon. Nothing need be feared from this disease on any pine bearing two or three needles in a sheath.

\section{HICKORY BARK BEETLE.}

Only a few instances of serious damage by this insect have been reported of late. It will undoubtedly be found here and there where hickory trees have been weakened by fire, changes in grade, sudden exposures, etc. If a tree is badly infested, that is, if the borers are actively at work in the body, it should be cut down and the wood burned. If the attack is in the twigs alone, and the tree is valuable, the insects may be killed in their burrows by being followed up with wires or destroyed by cutting off and burning the twigs. It is not likely that the beetle will do much harm except where the trees have been previously weakened.

\section{OTHER INSECTS.}

In consequence of the long dry summer many insects, such as the maple louse, the tussock moth and the locust leaf miner, which ordinarily do not appear in great numbers, have become apparent. None of these is apt to do serious or permanent harm, yet where the infestation is noticeable practicable remedies may be applied. These will be recommended in each case upon request.

In various parts of the State the so-called seventeen-year locust has done some damage. As a rule, however, the loss of a few twigs through the scarifying of the bark by the female in ovipositing does no particular harm. No serious permanent injury has been observed.

\section{A WARNING.}

Ignorant or unscrupulous men who advertise themselves as tree doctors, or who are interested in getting material for saw- 
mills, are still preying upon tree owners. The fact that many trees need spraying, pruning or filling, that many chestnuts are dead of the blight and must be removed, induces property owners to listen to these men. There are, however, entirely reputable parties to be found to do any necessary work of this kind. Tree owners are warned against men who promise to cure a tree of any ill, and who come without recognized credentials. No chestnut tree can be cured of the blight; a wound badly filled or unnecessarily filled would be better left open (Fig. 23), and a tree that is sprayed carelessly or with wrong material will not be benefited any more than a tree that is butchered under a pretence of being pruned. In short, it is a waste of money to pay unknown men for any work of this kind. And if dead trees are to be sold it is well to remember that the wood is not useless, but that in most cases it has a value much greater than is represented by the cost of removing it. Those who have work of this kind to do are advised to seek assistance from the local shade tree commission, or if help cannot be secured in that way to apply to the Forest Commission, to the State Entomologist or to the State Plant Pathologist. 


\section{INDEX.}

A.

PAGE.

Appropriations, $\ldots \ldots \ldots \ldots \ldots \ldots \ldots$ 16-18

Arborists, City, ............. 77

Automobile Fires, .............29-30

B.

Brown-tail Moth, .......... 85, 86-88

Brush Fires, ............... 28

\section{c.}

Chestnut Blight, ........... 86,87 Co-operation-。

With rederal Government, ... I2, 55-57

With Private Owners, ....... $44,65,75$

With Railroads, ...... 3, I4, 28,31, 60-64

With State Road Com mis sioner, ............. $5,79,80$

\section{D.}

Diseases of Trees, ............ 86-89

Drouth, .................. I9-2I

\section{E.}

Elm Leaf Beetle, ............ 87,88

\section{F.}

Financial Statement, ......... I , 7 , I8 Fire Car, Railroad, ................ $6_{4}$ Fire Lines, Railroad, ........13, 14, 60-67 Cost of $\ldots \ldots \ldots \ldots \ldots \ldots \ldots \ldots 6_{7}$

Description of $\ldots \ldots \ldots \ldots \ldots \ldots .66$

Effectiveness of $\ldots \ldots \ldots \ldots \ldots$ I4, 60

Extension of, ........... $3, \mathrm{r}_{4}, 6 \mathrm{I}-6_{4}$

Summary of by Railroads, .... $3,61-64$

Value of, .............. 14,67

Firewarden, Report of State, ....... $19-67$

Firewardens, ........... $11,30,57,58$

Forest Area, ................ 73

Forest Commission-

Organization of, $\ldots \ldots \ldots \ldots \ldots$ in 6

Policy of, ........ 10, 13, 14, 31, 36, 68

Report of, .............. $9-18$

Forest Conditions, ............ 9, 70

Forester, Report of State, .......68-90 Forester-

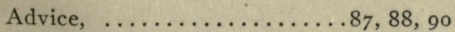

Services of $\ldots \ldots \ldots \ldots \ldots \ldots 75,78,80$
Forest Fires-

PAGE.

Causes of, $\ldots \ldots \ldots \ldots \ldots \ldots 12,25,26$

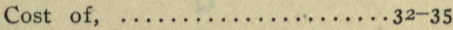

Decrease in Number of, ....... II, 2I

In New Jersey, ............ I0, II, 20

In Other States, ........... 20

In Previous Years, ......... 20

Responsibility for, .........12, 30

Size of, ............ I , 23, 24

Summary of by Months, ...... 22

Summary of by Townships, $\cdots \cdot 32-35$

Forest Fire Service-

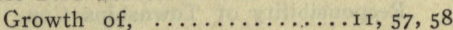

New Townships, $\ldots \ldots \ldots \ldots \ldots \ldots \quad{ }_{58}$

Organization of $\ldots \ldots \ldots \ldots \ldots \ldots$ I6

Value of, ..............

Forest Parks, ............. ${ }_{5}, 82,8_{3}$

Forest Planting-

On Reserves, ............ $7 \mathrm{I}$

Private, ................. 74

Forest Reserves, ...........14, 68-72

As Game Refuges, ......... 7 I

Forest Fires on, ........... 70

Improving Condition of, .... I5, 70, 7 I

Location and Area of, ........14, 69

Planting on $\ldots \ldots \ldots \ldots \ldots \ldots \ldots$ 7I

Products of,$\ldots \ldots \ldots \ldots \ldots \ldots \ldots .69$

G.

Gypsy Moth, $\ldots \ldots \ldots \ldots \ldots \ldots \ldots 8_{5}, 88$

\section{H}

Hickory Bark Beetle, .......... 89

I.

Incendiary Fires, ............ 29

Insect Tree Enemies, $\ldots \ldots \ldots \ldots \ldots 87-89$

\section{L.}

Land Purchase, ............... 64

Legislation needed, $\ldots \ldots \ldots \ldots \ldots 77,85,86$

Passed, ................ 5 , 16

M.

Maine, Forest Fires in, ........ 20

Massachusetts, Forest Fires in, .... 20

P.

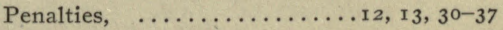

Permits, Fire, ............. 28 


\section{INDEX.}

PAGE.

PAGE.

Private Forestry, .......... 14, 73-75

Forest Management, ........ $44,74,75$

Forest Planting, .......... 74

Increased Application of, .... I4, 73, 74

Increased Interest in, $\ldots \ldots \ldots \ldots 14,73$

Increased Value of Private

Woodland, .............. I4

State Assistance in, ......... 44, 75

\section{Q}

Quarantine, National, ...........85, 86

R.

Railroad Fires, ..........12, 13, 27, 3I Reserves, $\ldots \ldots \ldots \ldots \ldots \ldots$ 1 $4,15_{4}, 68-72$ Roads-
A Fire Menace, ........... 29
Forest Fires Along, ........ 59
Responsibility of Townships Con-
cerning, . . . . $5 \ldots \ldots \ldots \ldots$ 5
Shade Trees Along, ......... ${ }_{5}, 80$

S.

Shade Trees, $\ldots \ldots \ldots \ldots \ldots \ldots \ldots$ 1 $_{5}, 76-82$

Along Country Roads, ......... I $_{5}, 80$

And Street Improvements; ....78, 79

Bulletin on, .............. 82

Co-operation with Road Commis-

sioner,

I $5,79,80$
Shade Trees-Continued.

Enemies of, $\ldots \ldots \ldots \ldots \ldots \ldots$ 86-89

Federation of New Jersey, .. 15, 76, 77

Injury to by Drouth, ........... 8 ,

Injury to by Gas, .......... 78

Injury to by Wounds, ....... 8 I

State Aid, ............ I $_{4}, 77,78$

Smokers Fires, .............. 28

Spark Arresters, ............. 3,27

State Entomologist, $\ldots \ldots \ldots .8_{4}, 85,88,90$

State Plant Pathologist, .......84, 85, 90

T.

Tree Doctors, ................ 89

Tree Enemies, ............... $8_{4-90}$

Advice Concerning, ......... 84

Control of, ............. 84

Insects and Diseases, ........86-89

National Quarantine of, ......85, 86

V.

Violations of Forest Fire Law, . . 12, 30, 37 Fines Collected, .......... 12, 1 3,37

Old, Still Open, ............ 36

Settlement of, .......... 12, 30-37

Tabulated in Detail, ........36, 38-54

\section{W.}

Weather,.$\ldots \ldots \ldots \ldots \ldots \ldots \ldots \ldots \ldots \ldots \ldots \ldots \ldots$ I9 2 I

White Pine Blister Rust, . . . . 85, 88-89 


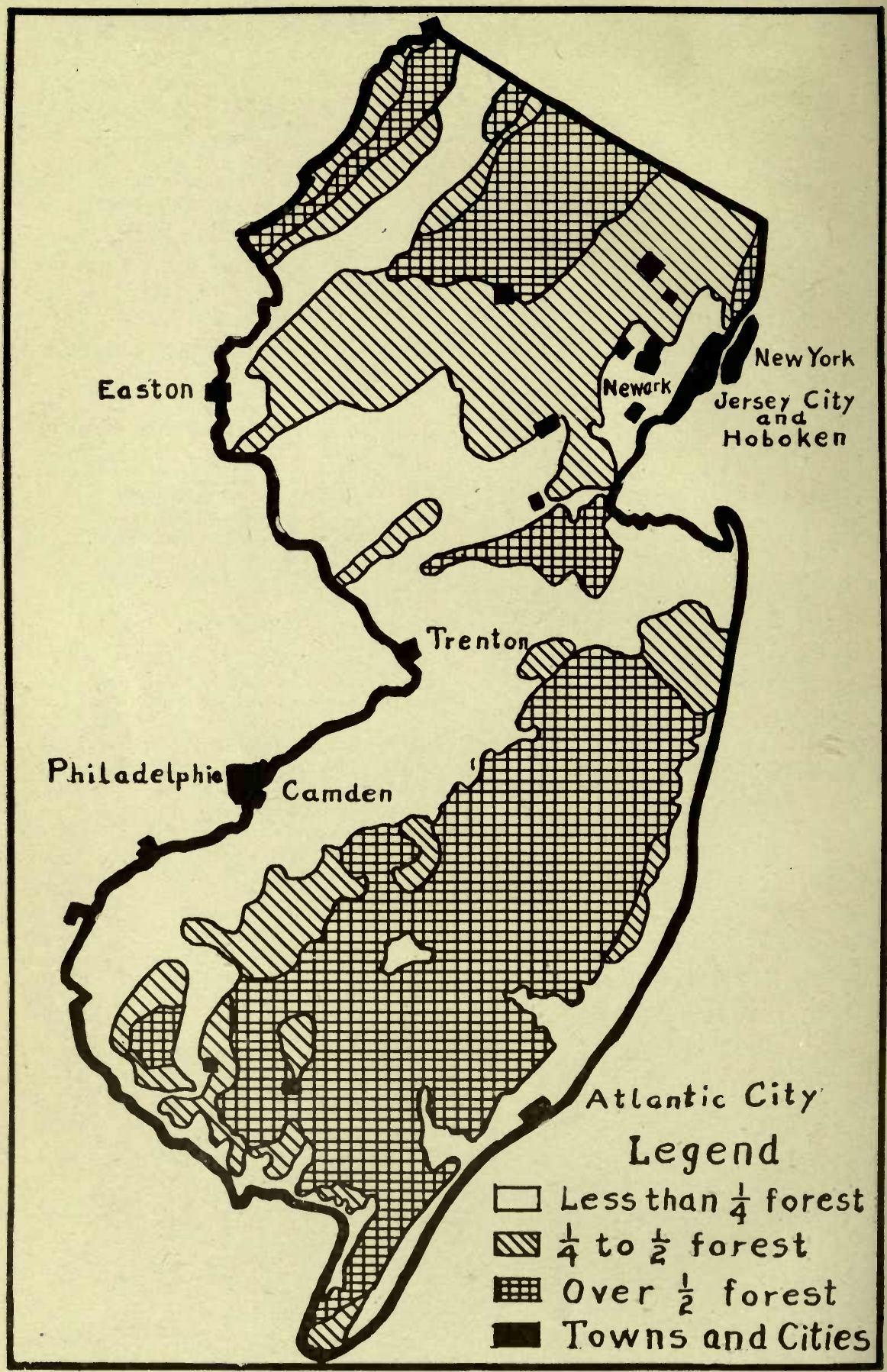

Fig. I. New Jersey's Forest Work Shop. 2 Million Acres, 42 per cent. of the State's Land Area. 


\section{Waltex Mulpond}

\section{REPORTS OF}

THE FOREST PARK RESERVATION COMMISSION OF NEW JERSEY

\section{EIGHTH ANNUAL REPORT}

For the Year ending October 31st
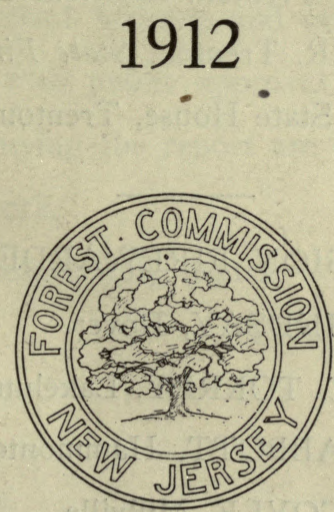

UNION HILL, N. J.

Dispatch Printing Company 


\section{The Forest Park Reservation Commission.}

Hon. WOODROW WILSON, GOVERNOR, ex-officio President. HENRY B. KÜMMEL, State Geologist, Trenton, Executive Officer.

ELMER H. SMITH, Salem.

CHARLES L. PACK, Lakewood.

WILLIAM W. SMALLEY, Bound Brook.

ALFRED GASKILL, Trenton, Forester and Secretary. JAMES O. HAZARD, Trenton, Assistant Forester. CHARLES P. WILBER, Trenton, State Firewarden. OfFice, State House, Trenton.

DIVISION FIREWARDENS.

Div. A-WILLIAM LINDSAY, Dover.

Div. B-FREDERIC C. TORREY, Lakehurst.

Div. C-JOSEPH E. ABBOTT, Hammonton.

Div. D-LEONIDAS COYLE, Millville. 


\section{Letter of Transmittal.}

To His Excellency, Woodrow Wilson, Governor of the State of New Jersey and ex-officio President of the State Board of Forest Park Reservation Commissioners:

SIR-I have the honor to submit the annual report of the Forest Commission for the year ending October 3 Ist, I9I2, as required by law. The control of forest fires continues to be our greatest problem, though marked progress has been made. The work of the Commission in practical forestry and on behalf of the shade trees apparently meets with public approval. The thirteen pages of illustrations accompanying the report are necessary to a proper understanding of our work.

Respectfully yours,

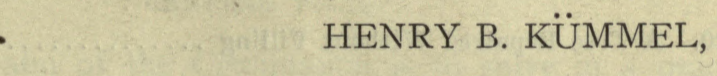

Executive Officer.

Alfred Gaskill,

Secretary. 


\section{Illustrations.}

PAGE.

Fig. 1. Outline Map-New Jersey's Forest Workshop ........Frontispiece

" 2. Fire Resistent Pitch Pine with a Reserve Poster ........... 10

" 3. A Reserve Boundary Cleared to Serve also as a Fireline ..... 10

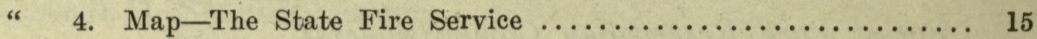

" 5. Forest Made Worthless by Repeated Fires .............. 22

“ 6. A Similar Forest Not Burned and Well Grown ........... 22

“ 7, 8. How a Pine Forest Grows Under Protection Alone ........ 50

“ 9. A Railroad Fireline $\ldots \ldots \ldots \ldots \ldots \ldots \ldots \ldots \ldots \ldots \ldots \ldots \ldots$

“ 10. A Clear Cutting Near a Summer Resort .............. 58

" 11. A Heavy Felling in Blighted Chestnut .............. 58

" 12, 13. Successful Forest Planting $\ldots \ldots \ldots \ldots \ldots \ldots \ldots \ldots \ldots \ldots, 60$

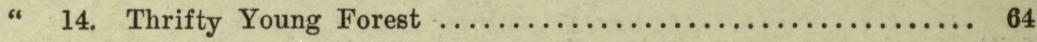

“ 15. Sprout Oak Forest Newly Thinned $\ldots \ldots \ldots \ldots \ldots \ldots \ldots \ldots \ldots .64$

“ 16, 17, 18. Views on Mount Laurel Before and After Treatment... 66

“ 19. A Street Tree Filled to Repair Injury $\ldots \ldots \ldots \ldots \ldots \ldots \ldots \ldots \quad 70$

a 20. A Tree Repaired Without Filling $\ldots \ldots \ldots \ldots \ldots \ldots \ldots \ldots \ldots \ldots$

“ 21. Street and Sidewalks Newly made Without Destroying Old Trees 70

“ 22. Diagram-How to Doctor a Tree $\ldots \ldots \ldots \ldots \ldots \ldots \ldots \ldots \ldots \ldots$ 


\section{Report of the Forest Commission.}

\section{SUMMARY.}

Forestry applied in practical ways-The people approve-Forest fires much less serious-Forestry must be practiced by forest owners if by anyone-State reserves beginning to yield some revenue-Much activity on behalf of shade trees-Legislation and appropriations adequate-Financial Statement-Organization.

In publishing its eighth annual report the Forest Commission records with much satisfaction a very material improvement in the condition of the forests of the State and an increasing interest in forestry and arboriculture. Much of the interest is undoubtedly a part of the nation-wide extension of the conservation idea: it apparently is true, however, that the Commission's efforts have made forest property more secure and more valuable than it was, that the shade trees in cities and towns are better cared for. The matters that have engaged the Commission's attention are presented in some detail in the reports of the State Forester and State Firewarden which are printed herewith. A summary of them follows :

\section{GENERAL POLICY.}

The constant aim of the Commission is to solve in a practical way the problems presented. Conditions in this State are unilke those in most others. We have two million acres of woodland, yet little of it is either good forest yielding lumber or devastatec barrens. Good soil, good climate and a sufficient remainder of the old stand make it possible to establish fairly good commercial forests anywhere without planting-provided fires are stopped. See Figs. 6, 7, 8, I4. The first concern, therefore, has been, and is, to organize an effective fire service. The second is to get forest owners to practice forestry. There are plenty of arguments in support of 
State forestry, the difficulty is to get the forests. Therefore, since the State owns but a small portion of the woodland within its borders, private owners, not the State, must do most of the forestry. The third line of effort is to make the State forest reserves as valuable, in themselves and as demonstrations, as is possible; and the fourth to get more and better shade trees.

\section{PUBLIF; APPROVAL.}

The Commission feels justified in calling attention to the generous measure of approval that is accorded its efforts, by those who watch from a distance as well as by those who are immediately concerned.

At home the last remnant of opposition to the Commission's policy with respect to forest fires has given place to constant demands for a strict enforcement of the laws. The effort to interest forest owners in the practice of forestry by giving security and value to their properties is steadily gaining support. The work that is done for shade trees satisfies a large number of urban citizens and makes the Commission and its activities widely known. In other States, New Jersey's laws and policy are frequently endorsed by imitation.

But in many ways the Commission's work is little more than begun. The fire habit is cliecked, not broken. Now comes the task of enriching the State by establishing good forests where poor forests, or none, have been, and providing for their highest utilization. The effort is educational and will proceed slowly, for in this direction the Commission can compel no one.

\section{TRAFFIC IN WILD LAND.}

A subject that has engaged the Commission's attention, though not strictly within its province, is the exploitation of land in forested sections by unscrupulous promoters. On account of its proximity to New York and Philadelphia, New Jersey has always been a fertile field for this sort of thing. The worst offenders are those who seek to sell building lots in "towns" whose existence is evidenced solely by a plot map and by "streets" cut through the brush. The statement that the "streets are opened" seems to satisfy those who think to inquire about improvements, and a railroad within 
a mile or two gives an impression of conveniences that is apt to be illusory. Less objectional are the schemes for exploiting small farms. Some valuable pioneering has unquestionably been done, and is being done, in this way, though in numerous instances the facts are greatly distorted and innocent people misled.

Many of these projects are hard to deal with because no law is violated. The land is shown-often free excursions are run to it, and a valid deed is given; but improvements are promised, not made, and the ignorant foreigners who are the majority of victims know nothing of the conditions which attach to such situations, whether "town" or "farm." The worst feature, of course, is that the prices demanded are usually at least ten times as much as the land is worth. To one accustomed to city values a town lot is cheap at twenty dollars, and a farm at only fifty dollars an acre looks easy to one who in the old country has had to pay that much each year as rent. Discontent and discouragement are apt to enter when it is realized that land as good can be bought nearby at its market value and that the payments made, and many yet to be made, are money thrown away.

The town lot schemes have another bad side, for when they fail, as most do, the property is actually of less value than it was before, because the divided ownership and clouded titles that result make it unavailable for legitimate development.

In respect to agriculture New Jersey offers opportunities that need only to be known. The State has plenty of good farm land unoccupied that can be bought at low prices. In co-operation with the Board of Agriculture plans are making to inform prospective buyers of its location and value. The Forest Commission is impelled to refer to these schemes because the abuses deal largely with land that is now forested.

\section{THE FOREST FIRE SERVICE.}

Forest fires, that for years ravaged the State, are steadily becoming less serious. This statement is not born of hope, nor is it based upon the record of a single favorable season. The year for which this report is made gave almost as great opportunity for disastrous fires as any of the three years preceding. As the State Firewarden's report amply shows forest fires in this State are now affairs of minutes, or at most hours, whereas they often 
used to burn for days. And the serious fires are concentrated in dry periods when everything goes so quickly that even vigilant wardens cannot always be in time. How efficient the present forest fire service is may be gathered from the following statements:

Loss-The number of fires which burned five acres or more was reduced from 289 in $19 \mathrm{II}$ to $2 \mathrm{I}_{4}$ in $\mathrm{IgI} 2$, while of the last only fifty-one covered over 100 acres and only three over I,000 acres. The total area burned in 1912 was 26,29 I acres against 64,404 acres in I9II, The total loss in 1912 was $\$ 21,501$. The loss in I9I I was $\$ 86,940$. Comparisons with earlier years are made in Table I, p. I6.

Causes - In respect to origin, the proportion of fires for which no definite cause can be assigned has been reduced from about fifty per cent. to twenty-six per cent. This means efficient wardens, for an invariable sign of a weak organization is a large proportion of "cause unknown" fires. Fires from brush burning were reduced to thirty-eight, only seven per cent. of the total, though 4, IOO permits were issued. Last year there were sixtyfive fires from burning brush. It is significant that as the consequences of many brush burnings are made apparent and emphasized by penalties enforced, people find that brush fires need not be made at all. The railroads continue to be the chief source of forest fires. Yet this statement can be made as information rather than complaint since all the more important roads are working earnestly to lessen the hazard that their trains inevitably create. Though 295 fires were started, the firewardens and railroad men were so vigilant that only 25 of them burned as much as fifty acres.

Railroad Fire Line LAw-The Commission deeply regrets that this law, 2 Comp. Stat. p. 2,339, under which so much has been done to guard the forests against fire from the railroads, has been declared unconstitutional by the Court of Chancery. An appeal has been taken to the Court of Errors and it is hoped that the decision may be reversed. The value of these fire lines to the railroads, as well as to property owners, is indicated by the instructions issued by superintendents in the Pennsylvania Railroad System. See p. 53 . 
Violations of LAw-The Commission stands firmly by its policy of enforcing the law vigorously and impartially. In all 252 violations were established, these being forty-two per cent. of all fires reported, little and big. Though most of these violations were unintentional, penalties have been imposed in I05 cases; 33 of them being against individuals and 72 against railroads. One hundred and twenty cases against railroads and nine cases against individuals are still pending. Eighteen cases have been dropped for lack of conclusive evidence. The sum lof $\$ 1,312.19^{*}$ was recovered as penalties, of which $\$$ I, I I 5.49 was paid to the treasurers of the townships concerned, the balance going to the State.

Federal Co-Operation-Not the least important and valuable aid that the fire service enjoys is that furnished by the United States Government. The $\$ 2,000$ allotted to this State from the appropriation made by Congress to execute the "Weeks Law" made it possible to maintain a patrol in North Jersey which extinguished an average of eighteen fires a month during the spring and summe:In July thirty-five fires were put out. The order of the Postmaster General by which 55,000 rural mail carriers are made auxiliary firewardens in States having an organized fire service was originally proposed by the Stata Firewarden of New Jersey. The rural carriers now serving as patrolmen in this State under that order number about $3 \mathrm{co}$.

\section{PRIVATE FORESTRY.}

New Jersey is fortunate in having a large number of property owners who want to improve their woodlands. Many are concerned chiefly, or solely, with landscape effects, yet an increasing number are considering the profit in timber growing. These the Commission tries to help, upon the ground that a properly managed forest is a public benefit no matter who pays the taxes on it. Thirteen such properties, having an area of 1,600 acres, have been added this year to the total of those upon which forestry looking to the utilization of one timber crop and the production of another is practiced.

On some of these properties as many as 40,000 young trees were planted. The Commission is always ready to encourage and aid such work, though so little land in the State needs to be planted that it requires no emphasis.

*See Foot Note, p. 27. 
WOOD UTILIZATION.

Along with the production of wood goes its proper utilization. As a means of knowing what the State uses and what it needs a special study of its wood-using industries is being made in cooperation with the United States Forest Service. A report on this will be published next year.

\section{FOREST RESERVES.}

The State reserves aggregate 13,720 acres and the effort to increase them has been suspended in order that all the money available may be devoted to protecting the whole body of woodland without reference to ownership. The properties all are increasing in value as the forests develop in response to immunity from fire. See Fig. 6. They prove beyond question that fire is the chief bane of New Jersey's forests and that reasonably good timber lands can be obtained solely through protection. See Figs. 7,8 .

None of the larger reserves is yet in condition to yield any considerable revenue. That they can and will do so is clearly indicated by the growth of the trees and by what was done on Mount Laurel last winter. In briet, the twenty acres there produced timber which when sold netted nearly $\$ 300$, yet left a better forest than was found. (See Figs. I6, I7, I8). A special bulletin describing what was done has been published as "A Practical Example of Woodlot Foresty." The Commission hopes to acquire other woodlots upon which to make similar demonstrations.

The total income from all the reserves was $\$ 508.57$-an insignificant sum except that it indicates the Commission's purpose to make the State lands vield all they can.

The recent action of the State Water Supply Commission in contracting to purchase the Wharton tract in Burlington and Atlantic counties for the water found on it will bring under State control an area of forest aggregating close to I00,000 acres. Though no active work can be done on this property until title shall have passed, the Forest Commission stands ready to co-operate with the Water Supply Commission for its fullest development. 


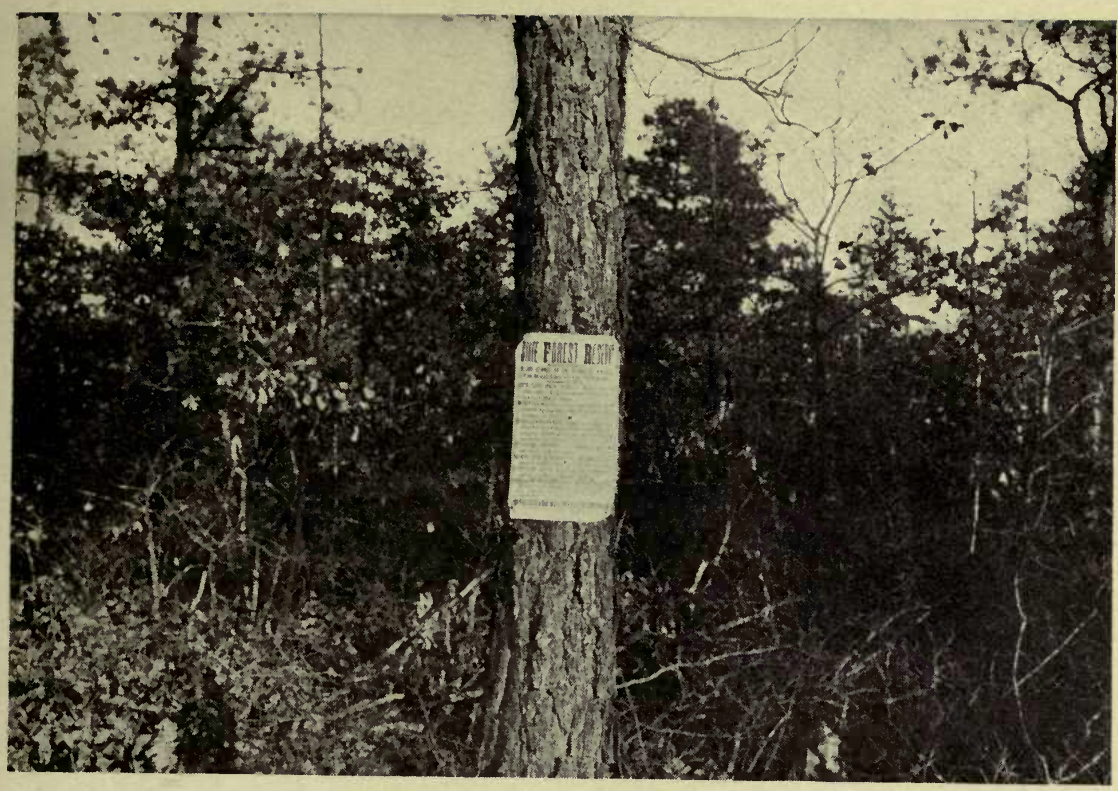

Fig. 2. Fire-Resistent Pitch Pine with a Reserve Poster.

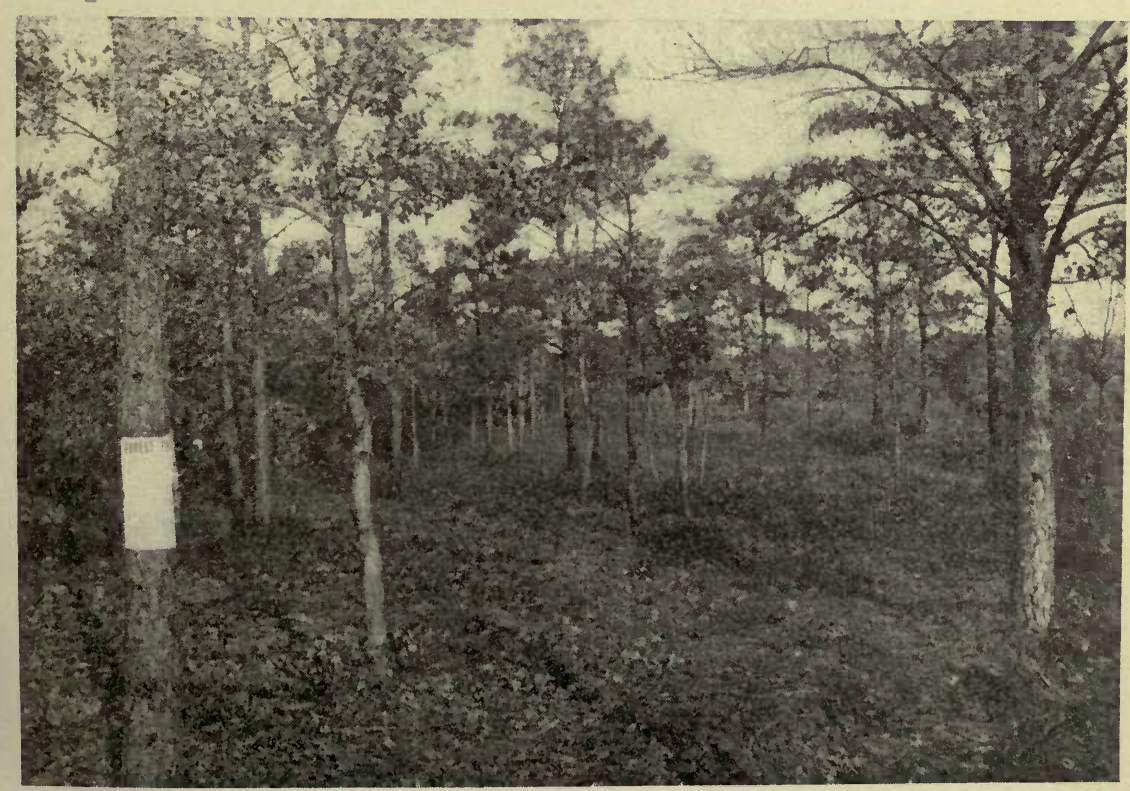

Fig. 3. A Reserve Boundary Cleared to Serve Also as a Fire Line. 

SHADE TREES.

There are now $4 \mathrm{I}$ active Shade Tree Commissions in the State having combined appropriations of $\$ 85,000$. Nine of these were appointed during the current year. Thus is indicated the importance and wide extension of the shade tree propaganda. It clearly demonstrates that a Shade Tree Commission combines the interest, enthusiasm and authority necessary to accomplish results in any community. Certain defects in the laws have developed as one of the results of all this activity. The legislation necessary to remedy them can doubtless be secured without difficulty. The Shade Tree Book published by the Commission has been of value alike to Shade Tree Commissicns and to individual tree owners.

A leginning has been made also towards providing shade treas for country roads. By the law passed last spring the State Commissioner of Public Roads is authorized to require that State-aid roads shall be tree bordered. Specifications covering the choice, planting and care of trees in such cases have been prepared by the State Forester, who will co-operate with the Road Commissioner. It is expected that a beginning in this important work will be made next spring.

The Forest Commission aims to keep in touch with all shade tree interests and is always ready to lend a hand to those who need help, See p. 7 I.

\section{LEGISLATION AND APPROPRIATIONS.}

The forestry laws are proving in most respects entirely adequate. As the fire record shows it is possible to enforce the observance of reasonable regulations. No new legislation in this line was sought this year and there is, apparently, no need to ask any of the next legislature. In general forestry the situation is the same except that a law was enacted at the instance of many users of the northern lakes by which an exemption of taxes on water bodies can be secured when they are made free to the public. The practical value of this statute is yet to be proven.

In respect to shade trees it is apparent that the laws need to be simplifie: 1 and so modified that a community can better control its own shade tree work, and shall not be limited, as it now is, in the amount that may be appropriated for such purposes. The Forest 
Commission will co-operate actively with the shade tree interests that have this matter in charge.

The appropriations made for the year 1912,- $\$ 9,200$, for salaries, traveling expenses, care of the reserves, shade tree work, etc., and \$15,000 for forest fires, have also been sufficient. In fact, it was possible to return to the Treasury an unexpended balance of $\$ 1,700$ on the fire account and to pay in nearly $\$ 600$ received for products sold and for recovered fire expenses. The exact total of all expenditures cannot be given because the accounts with many townships are never fully settled, while numerous pending cases are subject to a varied disposition. Approximately the net expenditure for the year, by State and townships, is:

BY THE STATE.

For Administration, Care of Reserves, Education, Etc.

Appropriation ........................ $\$ 9,200$

Less expenses and income refunded ............... 580

For the Forest Fire Service.

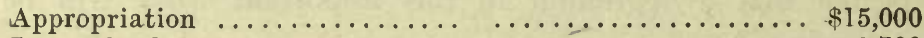

Less refund $\ldots \ldots \ldots \ldots \ldots \ldots \ldots \ldots \ldots \ldots \ldots \ldots \ldots \ldots \ldots \ldots \ldots, 1,700$

$\$ 13,300$

BY THE TOWNSHIPS.

For Firewardens' salaries and expenses ...........\$ 3,176

Less penalties refunded $\ldots \ldots \ldots \ldots \ldots \ldots \ldots \ldots \ldots \ldots \ldots \ldots, 1,421$

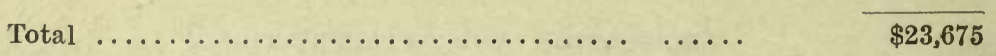

For the year I9I3 the appropriations already made are $\$ 15,000$ for forest fires and $\$ 10,500$ for forestry. It is the aim of the Commission to keep the State's share of the cost of the forest fire service within $\$ 15,000$ a year, for while certain expenses will increase as the organization is made more effective those charges should be offset by a reduction in fire-fighting bills. In any case the State now pays its full share, and if the cost does increase the townships and the property owners that are benefited should bear the excess. On the other hand, the Commission must ask for a reasonable increase from year to year in its appropriation for forestry. As the reserves increase in value they require more labor on them, yet under the law every. expenditure for making timber or other product available, as well as cost of maintenance, is charged to the forestry account, while all income must be covered directly 
into the State Treasury. Moreover, woodlot assistance, shade-tree direction, publications and propaganda are demanding more attention and more money. The Forest Commission conceives that it is charged with an educational work which cannot be carried on without money but which promises to repay. many fold any reasonable outlay. A summary of expenditures and receipts is annexed.

\section{Financial Statement, Forest Park Reservation Com- mission for Fiscal Year, 1912.}

\section{ADMINISTRATION ACCOUNT.}

Appropriations

EXPENDITURES.

Salary and expenses, Foresters and Secretary ..... \$5,086 85

Clerk and office expenses ................ 1,330 13

Expenses, Members of Commission ............ 10270

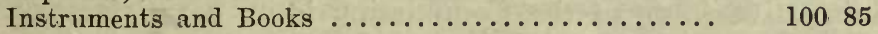

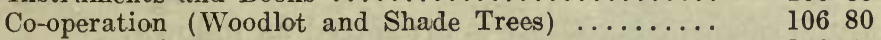

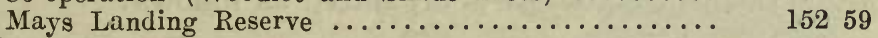

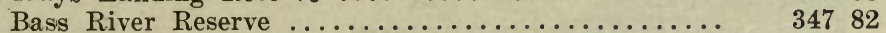

Edward C. Stokes Reserve ................. 25317

Lebanon Reserve ...................... 43511

Mount Laurel Reserve ................... 84194

Penn Reserve ....................... 32883

Conger Tract ........................ 1878

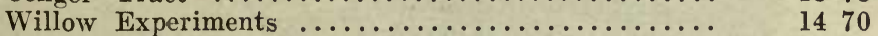

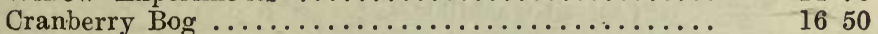

Miscellaneous ........................ $\quad 5900$

Unexpended Balance ................... 423

FOREST FIRE ACCOUNT.

Appropriation

EXPENDITURES.

Salaries and Expenses State Firewardens ......... Clerk and office expenses.

$\$ 7,883 \quad 43$

Extinguishing forest fires:

On account of 1909 fires

1,13644

On account of 1910 fires

On account of 1911 fires

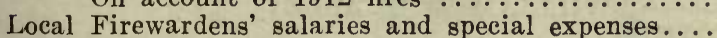

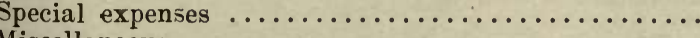




\section{FINANCIAL STATEMENT.-Continued.}

LAND PURCHASE ACCOUNT.

Appropriation carried forward by contract ....... \$ 52240

.
$\$ \quad 82240$

Refunded to Treasury, contracts cancelled ......... $\quad \begin{array}{lll}\$ & 82240 \\ \$ & 82240\end{array}$

RECEIPTS BY EXECUTIVE OFFICER.

Balance on hand November $1,1911 \ldots \ldots \ldots \ldots \ldots \ldots . \$ 4292$

For Products of Reserves ................. 50857

For Expenses of Forester in co-operative work ...... 6909

From Settlements with Sundry Violators of Forest

Fire Law .......................... 1,19784

Paid to State Treasurer .................. \$ 58512

Paid to Sundry Township Treasurers .......... 1,11549

Paid Justice-of-Peace costs ............... 450

Balance in hand October 31, 1912:

Due State Treasurer ................ 2811

Due Township Treasurers .............. 8520

ORGANIZATION.

The administrative force of the Commission is on a satisfactory and apparently permanent basis. It is organized as follows:

THE FOREST COMMISSION.

Ordinarily represented by its executive officer, (H. B. Kümmel.)

STATE FORESTER
(Alfred Gaskill)

STATE FIREWARDEN ASSISTANT FORESTER 6 Forest Reserve Wardens

(C. P. Wilber)

(J. O. Hazard)

4 Division Firewardens

110 Township Firewardens

151 District Firewardens

3 Fire Watchers

THE FOREST PARK RESERVATION COMMISSION

HENRY B. KÜMMEL, Executive Officer

ELMER H. ȘMITH

CHARLES L. PACK

WILLIAM W. SMALLEY 


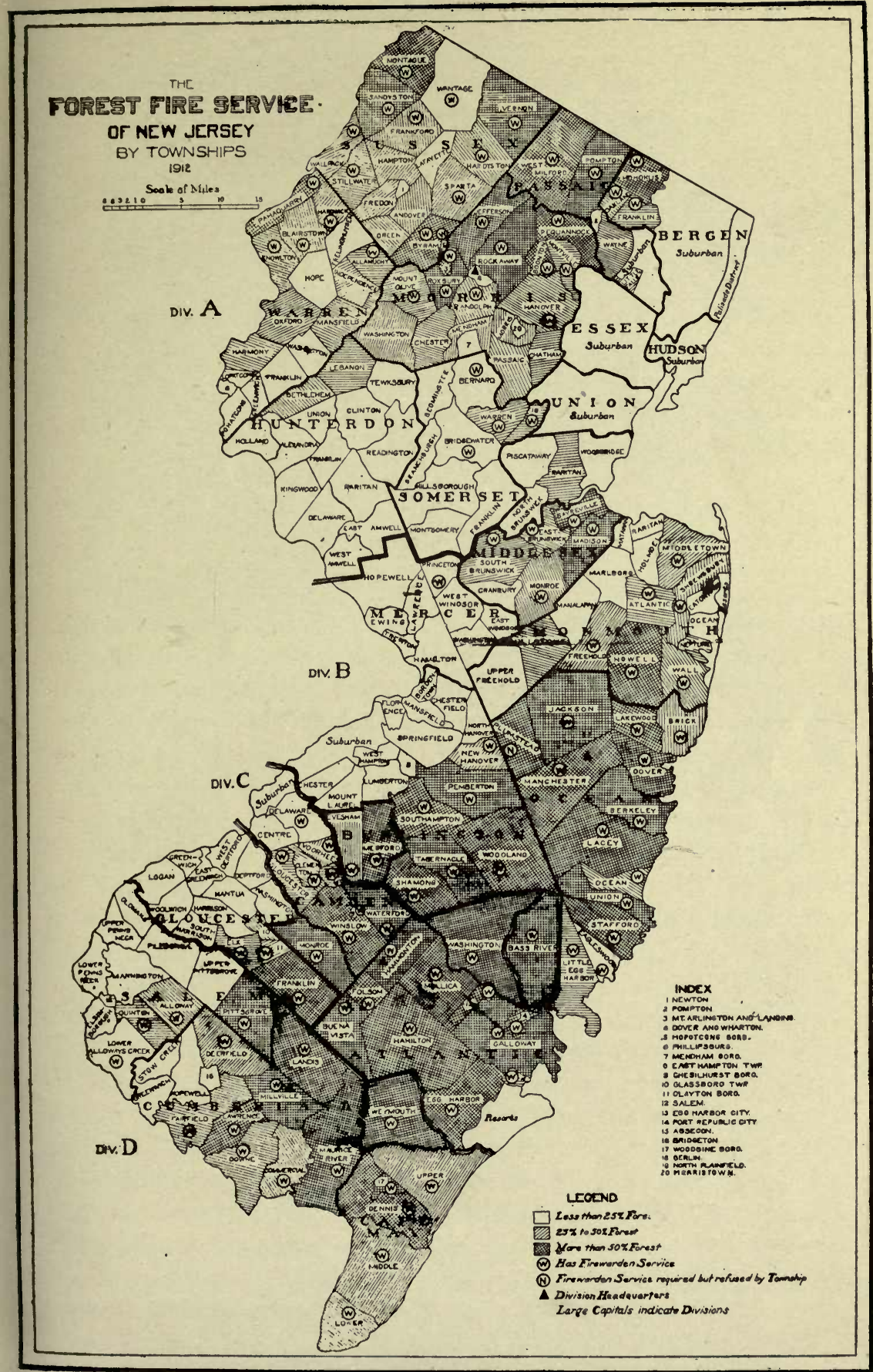

Fig. 4. The State, Showing Forests and Where Forest Fire Service is Maintained. 



\section{The Forest Fire Service.}

By Charles P. Wilber, State Firewarden.

SUMMARY.

Weather again favorable to forest fires-Damage by fires much reduced-Railroads cause most fires, fewer than ever from brush burning-Fire service more efficient-Many violations of law established-Co-operation with Federal Government-Lookout and telephone construction-Railroad fire-lines extended.

\section{THE FIRE SEASON.}

Unlike the last three years, I9I2 was normally moist. An unusually late spring with its tendency towards fire was to a large degree offset by prevailing wet weather. Until the middle of May no prolonged dry spell threatened the woodland with the fires usually connected with such conditions, and after that time the rising sap and rapid growth of retarded vegetation tended to reduce the danger well below what is usual. When June was reached dry weather had become fixed, however, so that during this month and in July precipitation fell far enough under the normal to create drouth conditions. Although the rest of the central weather district shows a rainfall above the average in August, New Jersey did not share the moisture, and the usual late summer drouth was as pronounced as any of recent years. With September normal conditions returned and, though October was drier than ordinarily, heavy rainfall in the middle of the month and later prevented serious trouble with fall fires. Thus, while the rainfall for the year stands well above that for the last few years, drouth did occur to such a degree that forest fire conditions were on the - whole as bad as heretofore. While there were 99 less spring fires this year than last, the summer record was reversed, with 89 more from June to September than a year ago, explaining why fires for the year show no marked numerical decrease despite a higher annual moisture average. 
TABLE I.-FOREST FIRES IN 1912 AND PREVIOUS YEARS.

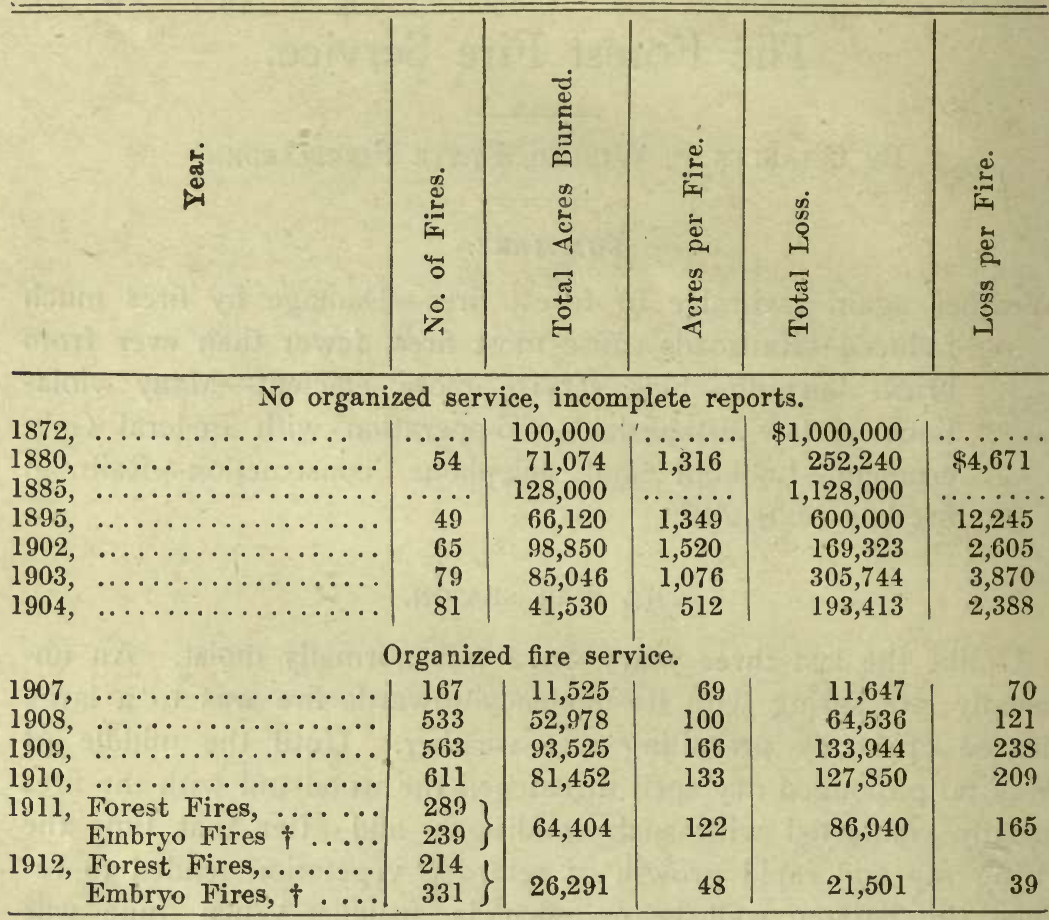

tBurned less than 5 acres.

NUMBER AND AREAS OF FIRES.

To one unfamiliar with the problem it may seem strange that with more and better wardens, continued enforcement of the law and increased co-operation both public and private, fires reported still multiply. It is by this feature, however, that the Fire Service measures its advance, when linked to the results shown in Table II. Highwater mark has probably not yet been reached in numbers, for as both the wardens and the public take more active interest in the work, in just the same proportion do hitherto unnoticed fires assume importance enough to demand attention and report. The increasing number of fires reported is, therefore, a sign of health, not of decline.

That the flood tide seems passed in area burned, however, is brought out strongly from this year's record. .A year ago increased efficiency of the fire service was argued from the diminished number of large fires and the increased number of small ones caught. 
promptly by the wardens. The total number of fires burning over five acres is reduced from 289 in I9I I to 2 I 4 in I9I2 Serious fires during the past year were so few that there have been but $5^{I}$ reported to have burned more than Ioo acres and of these but 3 reached the 1,000 acre mark. The sole increase even in numbers is found in fires that burned insignificant areas and did negligible damage. The total area burned has dropped from 64,404 acres a year ago to $26,29 I$ acres, with an average area per fire of 48 acres contrasted with I22 acres in I9II. It is noteworthy also that practically every county shows a reduction; an indication that the improvement is not local, but universal.

TABLE II.-FIRES BY RELATIVE AREA BURNFD AND COUNTIES, 1912.

\begin{tabular}{|c|c|c|c|c|c|c|}
\hline \multirow{2}{*}{ County. } & \multicolumn{5}{|c|}{ Number of Forest Fires. } & \multirow{2}{*}{ 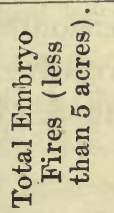 } \\
\hline & $\begin{array}{r}5-10 \\
\text { Acres. }\end{array}$ & $\begin{array}{l}11-100 \\
\text { Acres. }\end{array}$ & $\begin{array}{c}\text { 101-1000 } \\
\text { Acres. }\end{array}$ & $\begin{array}{l}\text { Over } \\
1000 \\
\text { Acres. }\end{array}$ & Total. & \\
\hline 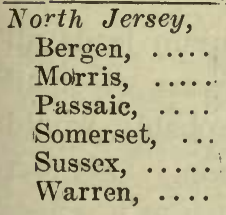 & $\begin{array}{c}\ldots \\
2 \\
2 \\
2 \\
1 \\
\cdots \cdots\end{array}$ & $\begin{array}{c}\cdots \\
9 \\
6 \\
3 \\
4 \\
2 \\
\end{array}$ & $\begin{array}{c}\cdots \cdots \cdots \\
\cdots \cdots \\
\cdots \\
\cdots \\
\cdots\end{array}$ & 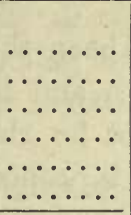 & $\begin{array}{r}11 \\
8 \\
6 \\
5 \\
3 \\
\end{array}$ & $\begin{array}{r}25 \\
11 \\
17 \\
7 \\
14 \\
4\end{array}$ \\
\hline Total, .... & 7 & 24 & 2 & $\ldots \ldots \ldots$ & 33 & 78 \\
\hline $\begin{array}{l}\text { South Jersey. } \\
\text { Atlantic, .... } \\
\text { Burlington, . } \\
\text { Camden, .... } \\
\text { Cape May, .. } \\
\text { Cumberland, } \\
\text { Gloucester, . } \\
\text { Mercer ..... } \\
\text { Middlesex, .. } \\
\text { Monmouth, . } \\
\text { Ocean, ..... } \\
\text { Salem, .... } \\
\text { Fires that } \\
\text { burned in } \\
\text { more than } \\
\text { one twp... }\end{array}$ & $\begin{array}{c}14 \\
\ldots \ldots \\
3 \\
3 \\
6 \\
2 \\
\ldots \ldots \ldots \\
\ldots \ldots \\
2 \\
5 \\
\ldots \ldots\end{array}$ & $\begin{array}{r}26 \\
7 \\
10 \\
9 \\
18 \\
4 \\
\ldots \ldots \\
2 \\
13 \\
6 \\
2\end{array}$ & $\begin{array}{c}19 \\
1 \\
2 \\
4 \\
7 \\
1 \\
\ldots \ldots \\
3 \\
1 \\
4 \\
\ldots \ldots\end{array}$ & 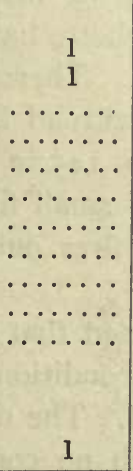 & $\begin{array}{r}60 \\
9 \\
15 \\
16 \\
31 \\
7 \\
\ldots \ldots \\
5 \\
16 \\
15 \\
2\end{array}$ & $\begin{array}{r}114 \\
11 \\
68 \\
16 \\
19 \\
4 \\
4 \ldots \\
2 \\
6 \\
13 \\
\ldots \ldots\end{array}$ \\
\hline Total, .... & 35 & 97 & 46 & 3 & 181 & 253 \\
\hline State total, . & 42 & 121 & 48 & 3 & 214 & 331 \\
\hline
\end{tabular}




\section{CAUSES OF FIRES.}

Forest fire control depends finally upon the education of the public to watchfulness both in themselves and in others. However, to point out the danger to them and to prevent fires from starting, it must be known upon whom, or what, to concentrate, as well as where trouble is most prevalent. The year's fires in relation to their causes are considered below and summarized in Table III.

\section{Unknown Causes.}

Only I40 of this year's fires started from causes not ascertained, and of these 63 were merely beginnings caught promptly. This is a marked reduction in this class, despite the fact that the total number of fires reported has increased, and is one of the most encouraging features of the year's work. The following shows the relative proportions of this class to the total fires for each year: I908, $53 \%$; 1909, 46\% ; I910, $57 \%$; I9II, $39 \%$; I912, $26 \%$.

\section{Railroad Fires.}

As has always been the case, this class of fires again leads all others in numbers, and indeed shows a marked increase of small fires that may not be classed as forest fires, yet probably would have grown to such proportions but for prompt attention. This fact is not ground for condemnation of the railroads so much as a reflection of the improving attitude of the local service in reporting the small fires that hitherto have been extinguished but deemed too small for official notice. There is encouragement in the fact that while there were 295 railroad fires reported this year, as against 200 in I9II, 146 in I910, 145 in 1909, 148 in 1908, the increase is entirely in the number of small fires. Of the 67 fires that may rightly be classed as forest fires only 25 burned to become large fires of 50 acres or more.

It is not expected that railroad fires can be appreciably reduced in number while conditions remain as they are, though their spread may be prevented. The menace of its locomotives to forest growth is one over which no company has more than limited mechanical control. Much improvement can still be made in maintaining spark arresters and screens in good repair, but these devices yet remain inadequate where high speed or heavy haul must be maintained. 
Fire line construction has already helped to lessen the area burned per fire and presents the best apparent mechanical control generally available for coal-burning roads. (See pp. 52-56), Special patrol in many places will be found a cheap insurance for both railroad and land owner. (See pp. 48-50). Insistance by a company on a strict observance by its employees of every precaution in control of fire such as the Pennsylvania Railroad outlined this year cannot fail to help materially. (See p. 53). In dealing with this class the major emphasis, however, must lie on preparedness to put out fires promptly rather than on control of their cause.

\section{Brush Fires.}

The effect of rigid enforcement of the brush-burning permit law stands out clearly in the continually decreasing number of fires connected with this work. There were 65 fires definitely allied with brush burning last year, and but 38 recorded from this cause during the current year. This reduction is definitely traced to the increased care used by those burning brush, and to the fact that a continually decreasing number find it necessary to burn brush at all. It is to carelessness or ignorance that all so-called brush fires owe their origin. As the danger of handling fires becomes better recognized, because of active warning or penalties imposed, these causes are removed.

There were 4, I00 permits issued for burning brush during the year, and fewer violations of this requirement. 
TABLE III.-FIRES BY CAUSES AND COUNTIES, 1912.

\begin{tabular}{|c|c|c|c|c|c|c|c|c|c|c|c|c|c|c|}
\hline \multirow[b]{2}{*}{ Countr. } & \multicolumn{12}{|c|}{ NUMBER. } & \multirow{2}{*}{\multicolumn{2}{|c|}{ 这 }} \\
\hline & \multicolumn{2}{|c|}{ 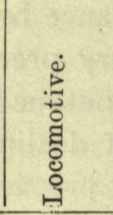 } & \multicolumn{2}{|c|}{ } & \multicolumn{2}{|c|}{ 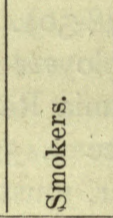 } & \multicolumn{2}{|c|}{ 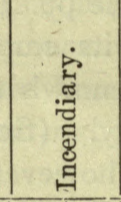 } & \multicolumn{2}{|c|}{ 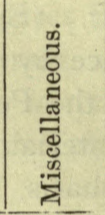 } & \multicolumn{2}{|c|}{ 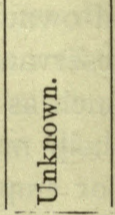 } & & \\
\hline North Jersey. & $\mathrm{FF}$ & $\mathrm{eF}$ & $\mathrm{FF}$ & $\mathrm{eF}$ & FF & $\mathrm{eF}$ & $\mathrm{FF}$ & $\overline{\mathrm{eF}}$ & $\overline{\mathrm{FF}}$ & $\sqrt{\mathrm{eF}}$ & FF & $\overline{\mathrm{eF}}$ & $\mathrm{FF}$ & $\mathrm{eF}$ \\
\hline Bergen,...$\ldots \ldots$ & $\ldots$ & 17 & $\ldots$ & 2 & $\ldots$ & $\ldots$ & $\ldots$ & $\ldots$ & $\ldots$ & 1 & $\ldots$ & 5 & & 25 \\
\hline Morris, $\ldots \ldots \ldots$ & 1 & 5 & 1 & 1 & 2 & 1 & $\cdots$ & $\cdots$ & 3 & 2 & 4 & 2 & 11 & 11 \\
\hline Passaic, ........ & 3 & 15 & . & $\ldots$ & $\ldots$ & $\ldots$ & $\ldots$ & $\ldots$ & $\ldots$ & $\ldots$ & 5 & 2 & 8 & 17 \\
\hline Somerset, ......... & $\cdots$ & $\ldots$ & 1 & $\cdots$ & 1 & 1 & $\ldots$ & $\ldots$ & $\ldots$ & 2 & 4 & 4 & 6 & 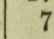 \\
\hline Sussex, ......... & 1 & 8 & $\ldots$ & $\ldots$ & $\ldots$ & $\ldots$ & $\ldots$ & $\ldots$ & 1 & 4 & 3 & 2 & 5 & 14 \\
\hline Walrren, ......... & 2 & 3 & $\ldots$ & $\ldots$ & $\ldots$ & $\ldots$ & $\ldots$ & $\ldots$ & 1 & ... & $1 \ldots \mid$ & 1 & 3 & \\
\hline Totals, $\ldots \ldots \ldots$ & 7 & 48 & 2 & $|3|$ & $|3|$ & 2 & $\ldots$ & $\mid \cdots$ & 5 & 9 & $\mid 16$ & 16 & 33 & 78 \\
\hline \multicolumn{15}{|l|}{ South Jersey. } \\
\hline Atlantic, .... & 24 & 84 & 8 & 1) & 5 & 3 & $\cdots$ & 2 & 7 & $|5|$ & 16 & 19 & & |114 \\
\hline Burlington, ...... & 2 & 5 & 3 & 1 & 2 & $\cdots$ & $\cdots$ & $\cdots$ & 1 & $\cdots$ & 1 & 5 & 9 & 11 \\
\hline Camden, ......... & 9 & 58 & $\cdots$ & $\because$ & 1 & 1 & $\cdots$ & $\cdots$ & $\cdots$ & 2 & 5 & 7 & 15 & 69 \\
\hline Cape May, ...... & 12 & 10 & 1 & 1 & $\cdots$ & $\cdots$ & $\cdots$ & $\cdots$ & $\cdots$ & 1 & 3 & 4 & 16 & 16 \\
\hline Cumberland, ..... & 3 & 9 & 5 & $\cdots$ & 1 & $\cdots$ & $\cdots$ & $\cdots$ & 6 & 2 & 16 & 8 & 31 & 19 \\
\hline Gloucester, ...... & 2 & 2 & 2 & $\cdots$ & $\cdots$ & $\cdots$ & $\cdots$ & $\cdots$ & $\cdots$ & 2 & 3 & $\cdots$ & 7 & 2 \\
\hline $\begin{array}{l}\text { Mercer, } \ldots \ldots \ldots \ldots \\
\text { Middlesex, . . . . . }\end{array}$ & $\cdots$ & $\cdots$ & $\cdots$ & $i$ & $\ddot{2}$ & & $\cdots$ & & $\cdots$ & i & $\because$ & $\cdots$ & $\cdots$ & 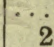 \\
\hline $\begin{array}{l}\text { Middlesex, } \ldots \ldots \ldots \\
\text { Monmouth, ....... }\end{array}$ & $\cdots$ & $\ddot{3}$ & $\ddot{2}$ & 1 & 3 & & & ... & 1 & 1 & $\begin{array}{l}3 \\
5\end{array}$ & i & $\begin{array}{r}b \\
16\end{array}$ & \\
\hline Ocean ............ & 3 & & 3 & 1 & 1) & $\ldots$ & & ... & $\ldots$ & $\ldots$ & 8 & 3 & 15 & 13 \\
\hline $\begin{array}{l}\text { Salem, . . . . . . . } \\
\text { Fires that burned }\end{array}$ & & & & & & $\ldots$ & $\cdots$ & $\cdots$ & $\cdots$ & $\cdots$ & 2 & $\cdots$ & 2 & \\
\hline $\begin{array}{l}\text { Fires that burned } \\
\text { in more than one }\end{array}$ & & & & & & & & & & & & & & \\
\hline township, $\ldots \ldots$. & $\ldots$ & & 3 & $\cdots$ & & $|\ldots|$ & $\ldots$ & $\ldots$ & 2 & $\ldots$ & $\ldots$ & $\ldots$ & 5 & \\
\hline Totals, ........ & 60 & 180 & 27 & 6 & $\mid 15$ & 4 & $\ldots$ & $|2|$ & 17 & 14 & $62 \mid$ & 47 & $|181|$ & 253 \\
\hline State Totals, ... & 67 & 228 & 29 & 9 & $|18|$ & 61 & $|\ldots|$ & 2 & 22 & $|23|$ & 78 & 63 & |214| & 331 \\
\hline
\end{tabular}




\section{Smokers' Fires.}

The number of fires attributed to smokers shows an increase of from 19 in I9II to 24 in I9I2, despite the fact that fires of this nature are the hardest for which to fix responsibility. It must be repeated that undoubtedly the major proportion of the fires attributed to unknown and miscellaneous causes would fall into this column if their origin could be determined. As was also emphasized last year, the elimination of such fires must be effected by the smokers themselves. The conditions governing their origin are such that adequate measures to reduce their number are entirely disproportional to the cost involved. However, it is hopeful to note that with the means now available more such fires are located than heretofore.

\section{Incendiary Fires.}

So few have fires of this class become that but two are known to have originated during the last year from malicious intent. One of the offenders has already been brought to trial and the other case points to the same outcome.

\section{Miscéllaneous Fires.}

Into this class fall fires started by hunters, automobilists, campers, etc., and the number so fixed shows an increase over last year of from $3 \mathrm{I}$ to 45 . Of these the sportsmen set II and huckleberry pickers 9, whether by careless smoking, with intent, or in some other way is not known. It does grow more plain each year, however, that these two classes of forest users must be watched and warned. Another variety of this class of fires is demanding especial attention, viz., those started by certain types of fireworks in which the fire persists. These exhibitions endanger more than the woods, for relics from'which forest fires have started show that the fire carriers are capable of doing damage to crops or to any material not fire proof.

\section{THE FOREST FIRE SERVICE.}

At the end of the first full year of service under the re-organization described a year ago, the Fire Service has plainly proven its increased efficiency. Of the $2,000,000$ acres of forest in the State, 
the existing organization covers $1,700,000$ acres. A large portion of the remainder lies in small scattered woodlands, supervision over which properly rests on the owner (See p. 50). Some increase in the area protected is planned for next year and it is hoped that when it closes, the entire area that should properly be the State's responsibility will be under firewarden service.

During the past year wardens have been withdrawn from Alpine Borough, Bergen County, by mutual agreement between the local government and the Forest Commission, because the exposure did not seem to justify the expense of maintaining wardens. The forest area is small and tends more to park conditions than to true forest. On the other hand wardens have been added in seven new townships, as follows: Dennis, Frankford, Hopatcong; Monroe, (Glo. Co.), Princeton, Wantage and Woodland. It is also hoped that Plumstead Township, the last of those heretofore refusing to install the system, will do so with the opening of a new calendar year and thereby make it unnecessary to continue a division warden as its township warden.

One particular advance made is in the use of motor vehicles by the division wardens. A motor cycle used by one and more recently an automobile by another at fixed rates of mileage have so reduced distances and lost time and so increased their scope of influence that results formerly impossible have been obtained in both administrative and investigative work.

The local service now inclucies IIo township wardens, and $\mathbf{I}^{\mathrm{I}} \mathrm{I}$ district and deputy wardens, who with the 3 fire watchers that the State employs, make a total of 264 men actively engaged in fire control covering I I townships. The effect of a closer touch with the local wardens stands out especially plainly in the fact that 73 fewer State investigations of fires were necessary this year than last, yet responsibility has been fixed for 15 more cases. This is a real tribute not only to the wardens' activity, but to their thoroughness in handling details that heretofore have placed an unnecessary and hampering burden on the State's wardens. It also gives the latter opportunity to take up the more obscure cases that could be given no attention under the old organization. There is also a growing disposition among the wardens to disregard the natural claim of friend or neighbor to special consideration and to deal with all infringements of the law alike, a long stride toward effective service. These facts with increasing promptness 


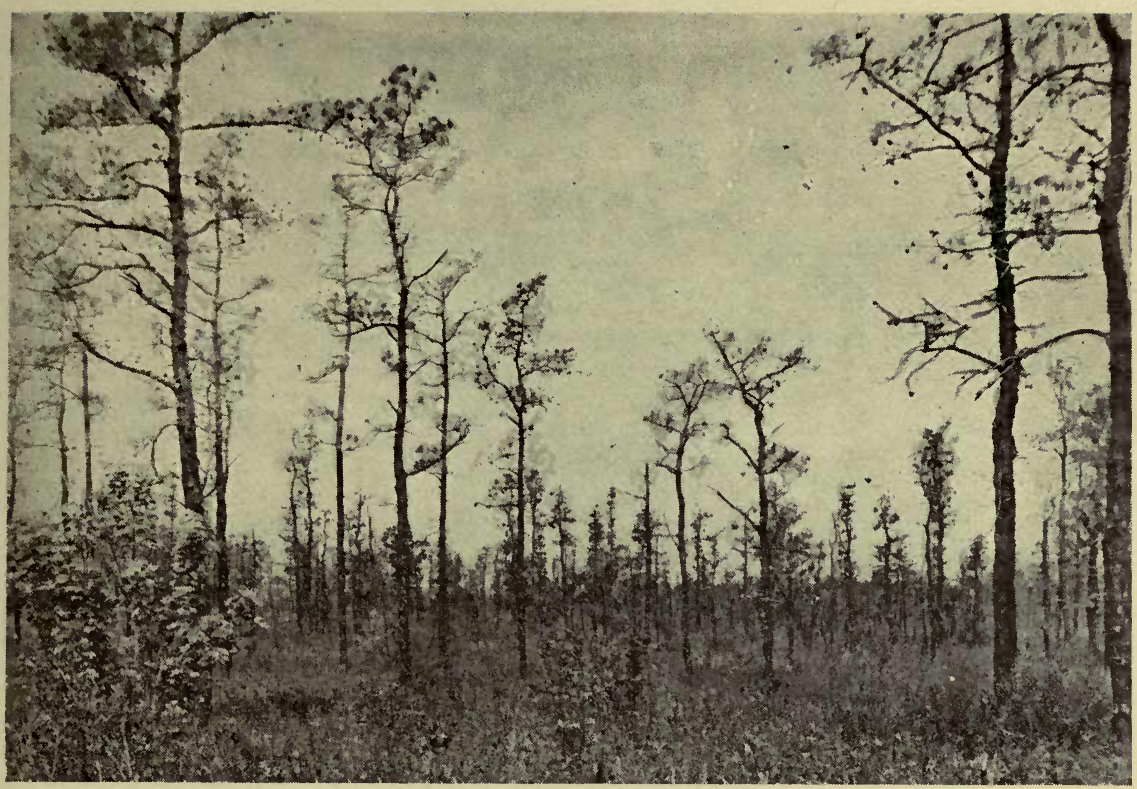

Fig. 5. Pine Forest, With Oak, Made Worthless by Repeated Fires.

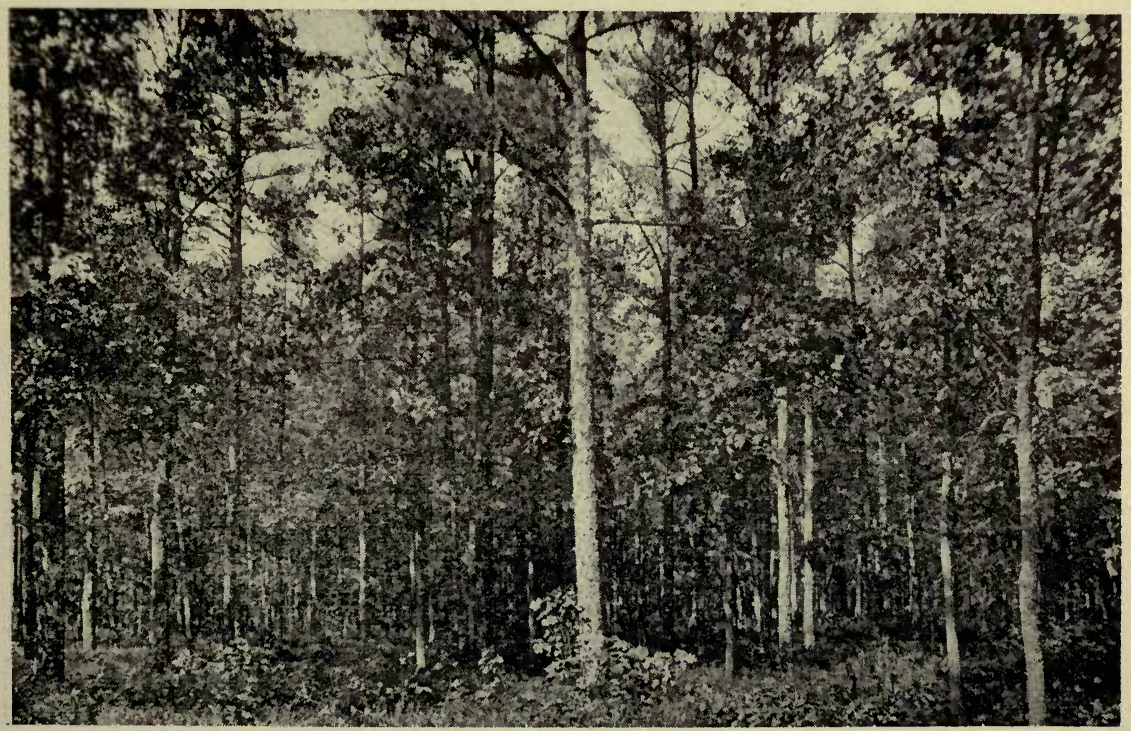

Fig. 6. A Similar Forest Not Burned and Well Grown. 

and efficiency in actual fire fighting, ( $\mathrm{s}$ e pp. $\mathrm{I} 5^{-1} \mathrm{7}$ ), evidence a continuing advance in every line. There is still much dead wood to be replaced by sound timber, and many local situations are yet in a

TABLE IV.-SUMMARY OF FOREST FIRE BUSINESS 1912 WITH SOME COMPARATIVE FIGURES FROM TWO YEARS PRECEDING.

\begin{tabular}{|c|c|c|c|c|c|c|c|c|c|c|c|c|c|}
\hline \multirow{4}{*}{$\begin{array}{l}\text { Date of } \\
\text { Fires. }\end{array}$} & \multirow{2}{*}{\multicolumn{2}{|c|}{$\begin{array}{c}\text { Total } \\
\text { Reports } \\
\text { Received }\end{array}$}} & \multirow{4}{*}{ 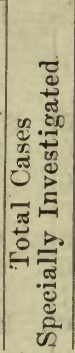 } & \multirow{4}{*}{ 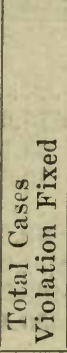 } & \multicolumn{2}{|c|}{$\begin{array}{l}\text { Tocal Fire } \\
\text { Service. }\end{array}$} & \multicolumn{7}{|c|}{$\begin{array}{l}\text { Action on Supposed } \\
\text { Violations During } 1912 .\end{array}$} \\
\hline & & & & & \multirow{3}{*}{ 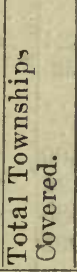 } & \multirow{3}{*}{ 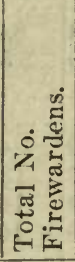 } & \multicolumn{4}{|c|}{ Individual } & \multirow{2}{*}{\multicolumn{2}{|c|}{$\begin{array}{l}\text { Railroad } \\
\text { Claims. }\end{array}$}} & \multirow[b]{3}{*}{ 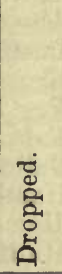 } \\
\hline & \multirow{2}{*}{ 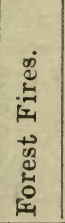 } & \multirow{2}{*}{ 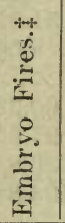 } & & & & & \multicolumn{2}{|c|}{$\begin{array}{l}\text { Court } \\
\text { Trial }\end{array}$} & \multicolumn{2}{|c|}{$\begin{array}{l}\text { No } \\
\text { Trial }\end{array}$} & & & \\
\hline & & & & & & & 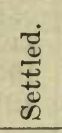 & 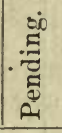 & 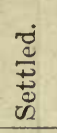 & 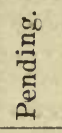 & 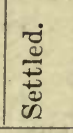 & 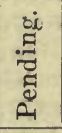 & \\
\hline 1910, & \multicolumn{2}{|c|}{611} & No & No & 98 & 229 & 1 & 1 & 1 & $\ldots$ & 5 & 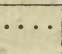 & 2 \\
\hline \multirow{3}{*}{$\begin{array}{l}1911, \\
1912,\end{array}$} & 309 & 239 & 206 & 237 & 100 & 228 & 4 & 3 & 9 & & 73 & 12 & 8 \\
\hline & 214 & 331 & 133 & 252 & $110 \dagger$ & 261 & & 4 & 33 & 6 & 72 & 120 & 17 \\
\hline & $\ldots$ & $\ldots$ & $\ldots \ldots$ & $\ldots$ & \multicolumn{2}{|c|}{ Totals } & 5 & $8^{*}$ & 43 & 6 & $\mid 150$ & 132 & 27 \\
\hline
\end{tabular}

\$Burned less than five acres.

*Two of these have been tried and are awaiting appeal. In all the others except one 1912 case, the offenders have left the State.

t In one additional township a division warden acts as township warden.

condition far from satisfactory, but the year has been one of improvements so pronounced that there is nothing but encouragement felt for the ensuing season.

During the year the Forest Fire Manual, published in I9Io, was thoroughly revised and enlargec and has been found of great value in informing both local wardens and the township officers of the way in which Fire Service business should be handled. 
TARLE V.-FOREST FIRES, 1912.

\begin{tabular}{|c|c|c|c|c|c|c|c|c|}
\hline \multirow[b]{2}{*}{ County and Township. } & \multicolumn{2}{|c|}{ Number } & \multirow[b]{2}{*}{ 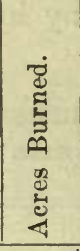 } & \multirow[b]{2}{*}{ 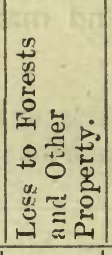 } & \multirow[b]{2}{*}{ 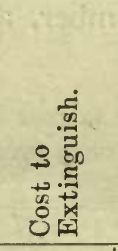 } & \multicolumn{3}{|c|}{ Paid by $\uparrow$} \\
\hline & 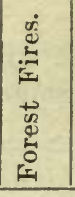 & 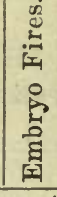 & & & & 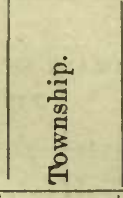 & 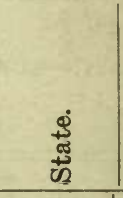 & 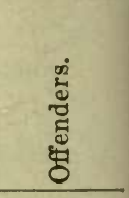 \\
\hline \multicolumn{9}{|l|}{$\begin{array}{l}\text { Atlantic County- } \\
\text { Absecon (City) }\end{array}$} \\
\hline Buena Vista, ... & 6 & & 968 & $\$ 424$ & $\$ 75.65$ & $\$ 16.42$ & $\$ 16.43$ & $\$ 42.80$ \\
\hline Egg Harbor, $\ldots \ldots \ldots$ & 5 & & 1075 & 595 & 63.10 & 31.55 & 31.55 & \\
\hline Egg Harbor (City), . & & 3 & $\cdots \cdots$ & $\cdots \cdots$ & 19.00 & 8.00 & 8.00 & 3.00 \\
\hline $\begin{array}{l}\text { Folsom, } \ldots \ldots \ldots \ldots \\
\text { Galloway, } \ldots \ldots \ldots \ldots\end{array}$ & ${ }_{i i}$ & $\ddot{30}$ & $\cdots 339$ & $\because 400$ & ${ }^{\cdots} \ddot{258.05}$ & 60.92 & 60.93 & 136.20 \\
\hline Hamilton,...... & 13 & 4 & 2427 & 1325 & 211.90 & 97.95 & 97.95 & 16.00 \\
\hline Hammonton,.... & 8 & 18 & 1950 & 1685 & 483.21 & 230.85 & 230.86 & 21.50 \\
\hline Mulliea, $\ldots \ldots \ldots \ldots$ & 16 & 50 & 1219 & 1005 & 550.46 & 194.89 & 194.90 & 160.67 \\
\hline $\begin{array}{l}\text { Port Republic, ....... } \\
\text { Weymouth, ........ }\end{array}$ & $\ddot{5}$ & $\cdots$ & $\ddot{5} \dot{800}$ & $\dddot{75} \dot{5}$ & 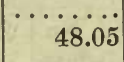 & 14.82 & 14.83 & $\ddot{18.40}$ \\
\hline Total, .. & 64 & 114 & 9258 & $\$ 6989$ & $\$ 1709.42$ & $\$ 655.40$ & $\$ 655.45$ & $\$ 398.57$ \\
\hline \multicolumn{9}{|l|}{$\begin{array}{l}\text { Bergen County- } \\
\text { Franklin, ..... }\end{array}$} \\
\hline Hohokus, .... & & 3 & $\ldots \ldots$ & $\ldots$ & $\$ 5.80$ & $\$ 2.90$ & $\$ 2.90$ & \\
\hline Oakland (Boro.), ... & & 22 & $\ldots \ldots$ & $\cdots$ & 32.25 & 8.37 & 8.38 & $\$ 15.50$ \\
\hline Ridgefield (Boro.), .. & & $\cdots$ & $\cdots \cdots$ & & $\ldots \ldots \ldots$ & $\ldots \ldots$ & $\cdots \cdots$ & $\ldots \ldots \ldots$ \\
\hline Total, .. & $\cdots \cdots$ & 25 & $\ldots$ & & $\$ 38.05$ & $\$ 11.27$ & $\$ 11.28$ & $\$ 15.50$ \\
\hline \multicolumn{9}{|l|}{ Burlington County- . } \\
\hline Bass River, ........ & & 1 & $\cdots$ & $\$ 5$ & $\$ 34.85$ & $\$ 14.42$ & $\$ 14.43$ & $\$ 6.00$ \\
\hline Evesham, $\ldots \ldots \ldots \ldots$ & & 1 & $\cdots$ & 5 & 6.00 & 3.00 & 3.00 & . \\
\hline Medford, ............ & & 2 & $\cdots \cdots$ & 15 & 11.85 & 5.92 & 5.93 & • \\
\hline $\begin{array}{l}\text { New Hanover, } \ldots \ldots \\
\text { Pemberton, ......... }\end{array}$ & $\begin{array}{l}\cdots \\
\cdots \\
\cdots\end{array}$ & $\cdots$ & $\cdots \cdots$ & & $\ldots \ldots \ldots$ & $\cdots \cdots$ & $\cdots \cdots \cdots$ & $\cdots \cdots$ \\
\hline Shamong, .......... & 3 & 5 & 160 & 25 & 46.95 & 14.00 . & 14.00 & 18.95 \\
\hline Southampton, ....... & 2 & 1 & 115 & 50 & 39.50 & 3.00 & 3.00 & 33.50 \\
\hline Tabernacle, $. . . \ldots .$. & 3 & . & 400 & 500 & 64.85 & 7.15 & 7.15 & 19.00 \\
\hline Washington, ........ & 2 & & 4000 & 3000 & 376.00 & 188.00 & 188.00 & \\
\hline Woodland, $\ldots . . . .$. & 3 & 1 & 1015 & 1050 & 74.80 & 28.10 & 28.10 & 18.60 \\
\hline Total, & 13 & 11 & 5690 & $\$ 4650$ & $\$ 654.80$ & $\$ 263.59$ & $\$ 263.61$ & $\$ 96.05$ \\
\hline \multicolumn{9}{|l|}{$\begin{array}{l}\text { Camden County- } \\
\text { Berlin, .......... }\end{array}$} \\
\hline Chesilhurst (Boro.), & 2 & 3 & 24 & $\$ 10$ & $\$ 19.15$ & $\$ 9.57$ & $\$ 9.58$ & \\
\hline Clementon,...$\ldots \ldots$ & 1 & $\cdots$ & 30 & 15 & 7.00 & 3.50 & 3.50 & \\
\hline $\begin{array}{l}\text { Delaware, } \ldots \ldots \ldots \ldots \\
\text { Gloucester, } \ldots \ldots \ldots\end{array}$ & $\ddot{2}$ & $\ddot{2}$ & 108 & 110 & 26.13 & 13.06 & 13.07 & 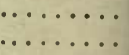 \\
\hline Voorhees .......... & & & & & & & $\cdots \cdots$ & \\
\hline Waterford, ......... & 2 & 3 & 200 & 185 & 20.60 & 5.10 & 5.10 & $\$ 10.40$ \\
\hline Winslow, $\ldots \ldots \ldots \ldots$ & 8. & 60 & 460 & 415 & 289.00 & 29.27 & 29.28 & 230.45 \\
\hline Total, & 15 & 68 & 822 & $\$ 735$ & $\$ 361.88$ & $\$ 60.50$ & $\$ 60.53$ & $\$ 240.85$ \\
\hline
\end{tabular}


TABLE V.-FOREST FIRES, 1912.-Contimued.

\begin{tabular}{|c|c|c|c|c|c|c|c|c|}
\hline \multirow[b]{2}{*}{ County and Township. } & \multicolumn{2}{|c|}{ Number } & \multirow[b]{2}{*}{ 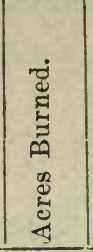 } & \multirow[b]{2}{*}{ 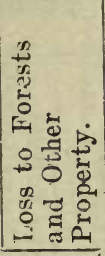 } & \multirow[b]{2}{*}{ 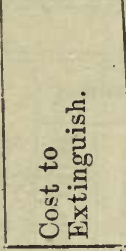 } & \multicolumn{3}{|c|}{ Paid by $\dagger$} \\
\hline & 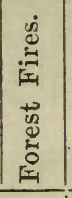 & 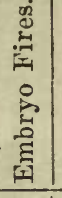 & & & & 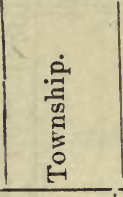 & 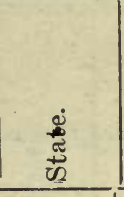 & 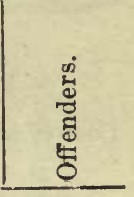 \\
\hline \multicolumn{9}{|l|}{ Cape May County- } \\
\hline Dennis, ............ & 2 & 3 & 25 & $\$ 55$ & $\$ 21.25$ & $\$ 3.00$ & $\$ 3.00$ & $\$ 15.25$ \\
\hline Lower, .... & 1 & 5 & 15 & 100 & 35.50 & 15.75 & 15.75 & 4.00 \\
\hline Middle, ... & 10 & 8 & 564 & 1100 & 138.85 & 22.37 & 22.38 & 94.10 \\
\hline Upper, $\ldots \ldots \ldots$ & 3 & $\ldots$ & 731 & 730 & 74.85 & 31.92 & 31.93 & 11.00 \\
\hline Woodbine (Boro.), & $\cdots$ & $\cdots$ & $\cdots \cdots$ & $\ldots \ldots$ & $\ldots \ldots \ldots$ & $\ldots \ldots$ & $\ldots \ldots \ldots$ & $\ldots \ldots \ldots$ \\
\hline Total, ... & 16 & 76 & $\overline{1335}$ & $\$ 1985$ & $\$ 270.45$ & $\$ 73.04$ & $\$ 73.06$ & $\$ 124.35$ \\
\hline \multicolumn{9}{|l|}{ Cumberland County- } \\
\hline Commercial, .......... & 2 & & 150 & $\$ 175$ & $\$ 6.25$ & $\$ 3.12$ & $\$ 3.13$ & \\
\hline Deerfield, ..... & 2 & $\cdots$ & 85 & 75 & 18.00 & 3.00 & 3.00 & $\$ 12.00$ \\
\hline Downe, .... & 1 & 3 & 6 & 15 & 37.50 & 18.75 & 18.75 & $\cdots \ldots$ \\
\hline Fairfield, $\ldots \ldots \ldots \ldots$ & 4 & & 112 & 125 & 51.25 & 18.12 & 18.13 & 15.00 \\
\hline I andis, ...... & 8 & 2 & 1485 & 885 & 125.40 & 49.45 & 49.45 & 26.50 \\
\hline Lawrence, .... & 2 & & 145 & 275 & 76.20 & 38.10 & 38.10 & $\ldots \ldots$ \\
\hline Maurice River, ... & 4 & 6 & 150 & 150 & 141.37 & 47.93 & 47.94 & 45.50 \\
\hline Millville (City), ... & 10 & 8 & 782 & 902 & 167.00 & 61.00 & 61.00 & 45.00 \\
\hline Total, & 33 & 19 & 3170 & $\$ 2902$ & $\$ 622.97$ & $\$ 239.47$ & $\$ 239.50$ & $\$ 144.00$ \\
\hline \multicolumn{9}{|l|}{ Gloucester County- } \\
\hline Elk, $\ldots \ldots \ldots \ldots$ & 1 & $\cdots$ & 10 & $\$ 40$ & $\$ 6.00$ & $\$ 3.00$ & $\$ 3.00$ & \\
\hline Franklin, ........ & 4 & 3 & 112 & 120 & 67.30 & 27.17 & 27.18 & $\$ 12.95$ \\
\hline Monroe. .......... & 2 & 1 & 400 & 500 & 38.40 & 14.20 & 14.20 & 10.00 \\
\hline Total, .......... & 7 & 4 & 522 & $\$ 640$ & $\$ 111.70$ & $\$ 44.37$ & $\$ 44.38$ & $\$ 22.95$ \\
\hline \multicolumn{9}{|l|}{ Mercer County- } \\
\hline Totol & & & & & & & & $\cdots$ \\
\hline Total, & & & $\cdots \cdots$ & & & & $\ldots \ldots \ldots$ & $\ldots \ldots \ldots$ \\
\hline \multicolumn{9}{|l|}{ Middlesex County- } \\
\hline East Brunswick, & & 1 & & & $\$ 2.00$ & $\$ 1.00$ & $\$ 1.00$ & $\ldots \ldots \ldots$ \\
\hline Madison, ......... & & $\cdots$ & & & $\cdots$ & ...... & …... & \\
\hline Monroe, .... & 1 & & 400 & $\$ 150$ & 54.10 & 27.05 & 27.05 & ...... \\
\hline Savreville. .......... & 3 & 1 & 1230 & 480 & 19.30 & 9.65 & 9.65 & $\ldots \ldots \ldots$ \\
\hline South Brunswick, ... & 1 & $\ldots$ & 20 & 20 & 366.22 & 183.11 & 183.11 & $\ldots \ldots \ldots$ \\
\hline Total. & 5 & 2 & 1650 & $\$ 650$ & $\$ 441.62$ & $\$ 220.81$ & $\$ 220.81$ & \\
\hline \multicolumn{9}{|l|}{ Monmouth County- } \\
\hline Atlantie, ........ & 2 & 1 & 62 & $\$ 25$ & $\$ 14.00$ & $\$ 3.00$ & $\$ 3.00$ & $\$ 8.00$ \\
\hline Freehold, .... & 4 & & 510 & 800 & 95.00 & 47.50 & 47.50 & $\ldots \ldots$ \\
\hline Howell, . . . . . & 8 & 5 & 285 & 215 & 157.95 & 19.32 & 19.33 & 119.30 \\
\hline $\begin{array}{l}\text { Middletown, } \\
\text { Shrewsburv, }\end{array}$ & 1 & & 43 & $\cdots$ & ii 70 & 585 & $\cdots \cdots \cdots$ & $\cdots \cdots \cdots$ \\
\hline $\begin{array}{l}\text { Shrewsbury, } \\
\text { Wall, ...... }\end{array}$ & 1 & & $\begin{array}{l}43 \\
50\end{array}$ & $\begin{array}{l}20 \\
75\end{array}$ & ....... & $\begin{array}{r}5.80 \\
\ldots \ldots\end{array}$ & $\begin{array}{r}5.80 \\
\ldots \ldots\end{array}$ & $\begin{array}{l}\cdots \cdots \cdots \\
\cdots \cdots \cdots\end{array}$ \\
\hline Total, & 16 & 6 & 950 & $\$ 1135$ & $\$ 278.65$ & $\$ 75.67$ & $\$ 75.68$ & $\$ 127.30$ \\
\hline
\end{tabular}


TABLE V.-FOREST FIRES, 1912.-Continued.

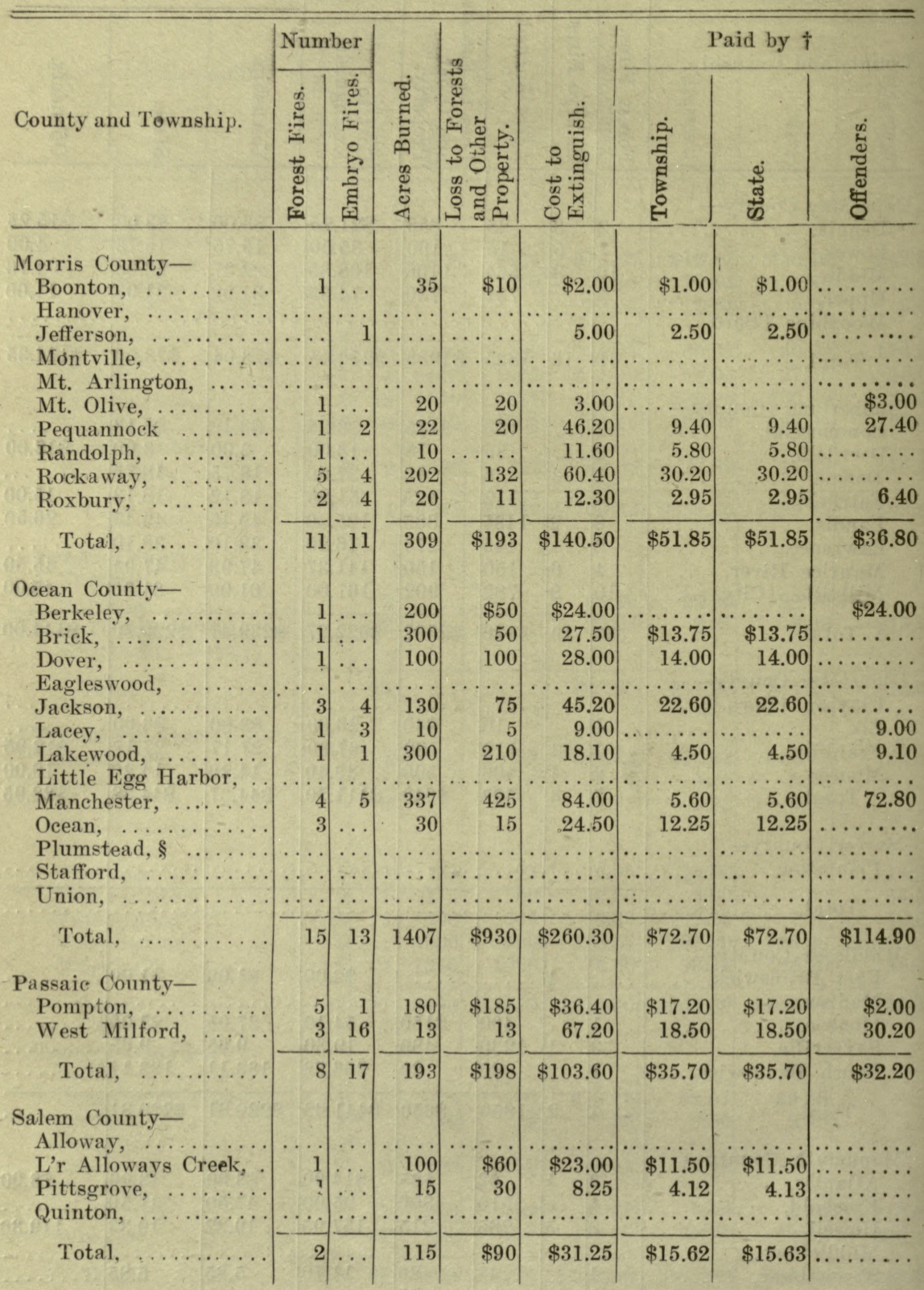


FIREWARDEN'S REPORT.

TABLE v.-FOREST FIRES, 1912.-Continued.

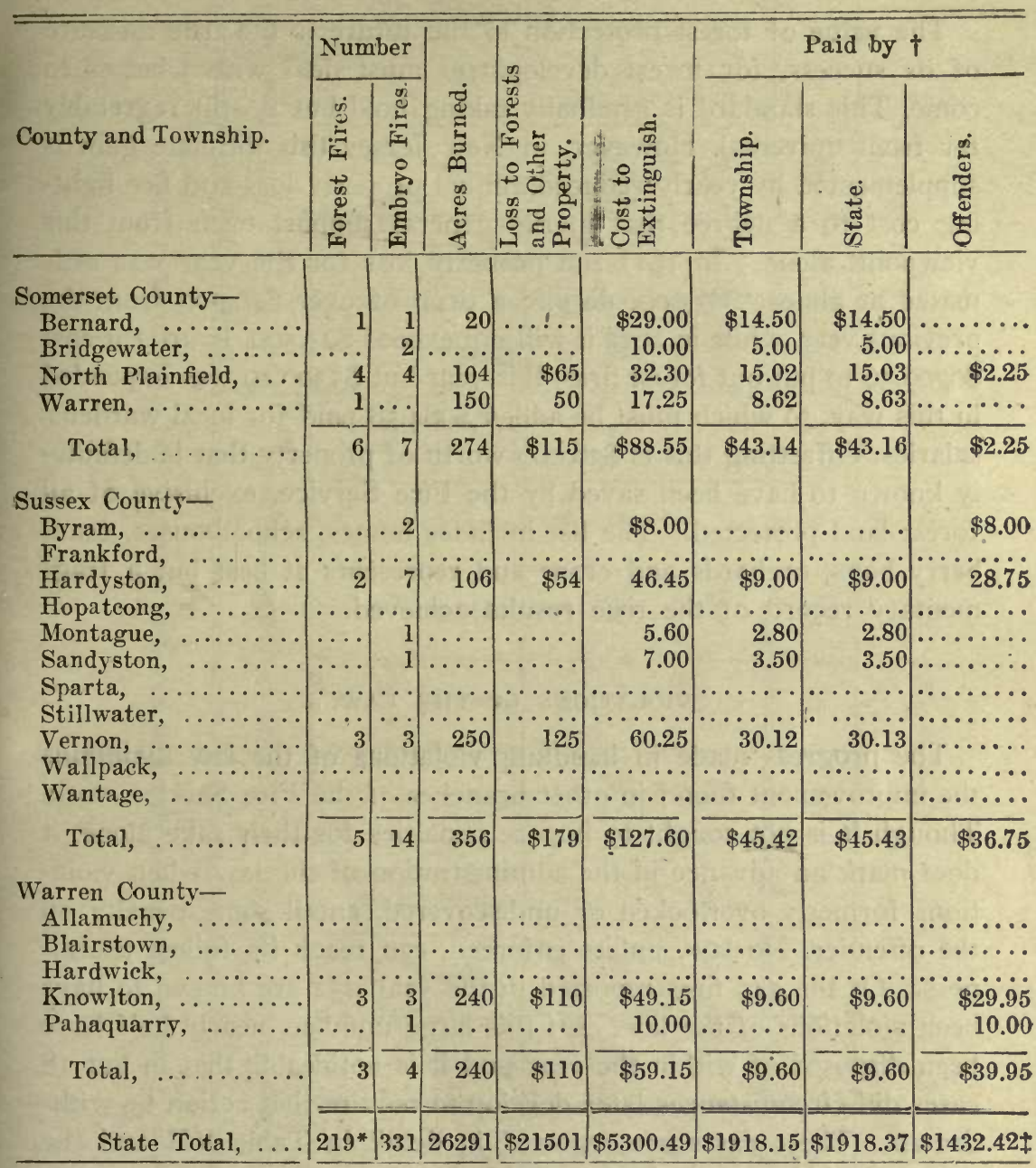

* This total is greater than the actual number $(214)^{\circ}$ because 5 fires burned in two or more townships at once.

$\dagger$ The sum of these columns often differs from the corresponding "Cost to Extinguish" item because a fine was larger than the bill, or a bill was withdrawn, etc.

\$ This total is greater than the year's collection $(\$ 1312.19)$ because all violation cases are not yet settled.

$\S$ No fire service. 


\section{THE FIRE SERVICE'S VALUE.}

The value of forest protection to the future is the true measure of its success, for forest development must deal with what is to come. This standard is gradually taking hold but is still regretably far from universal. However, in New Jersey this ultimate gain is supplemented by yearly reduced annual property loss and fire fighting cost to a degree that merits general support even from this viewpoint alone. In I9I I the property loss for the year was estimated at almost $\$ 87,000$, despite a drop of over $\$ 40,000$ from the previous year, while in I9I 2 it will not exceed $\$ 21,500$. In I9I I it cost $\$ 6709.56$ to put out forest fires, this year but $\$ 5300.49$ was expended in this way, to which must be added $\$ 984.58$ paid for local wardens' salaries. Offsetting this is $\$ 36$,oon worth of property that is definitely known to have been saved by the Fire Service, exclusive of all forest land protected. The list includes homes, schoolhouses, cranberry bogs, orchards and crops and represents at best but a fragmentary record of the true results achieved.

\section{VIOLATIONS OF THE LAW.}

The progress made in handling violations of the law maintains the improvement found in other branches of the Fire Service work. Though it is not sought to impose penalties for their sake alone, it does mark an advance in the administration of the law when violations formerly overlooked or undiscovered, entail some penalty on the offender. No law, unless enforced, can reach its fullest usefulness. Of the 545 fires reported in the year 252 are known to have been violations of the law. Of this large number, nearly half have been disposed of within the year and it is noticeable that in but 18 cases did circumstances later develop to require that action be withdrawn. These cases are reported in detail in Table VII and the year's work is summarized in Table VI.

For the most part, the violations are unintentional, and for this reason the penalties imposed are mostly light. When there are specially extenuating circumstances they have been remitted entirely. 
FIREWARDEN'S REPORT.

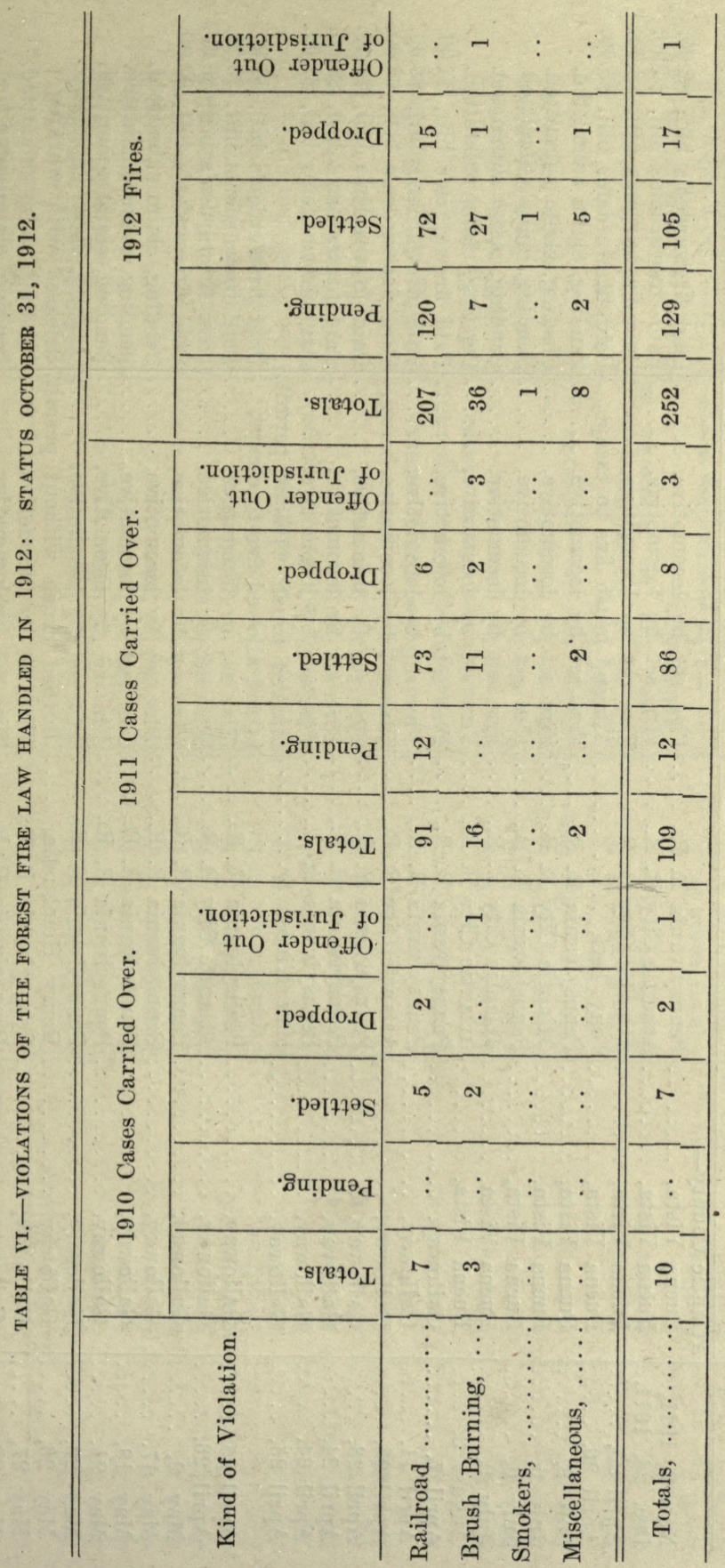




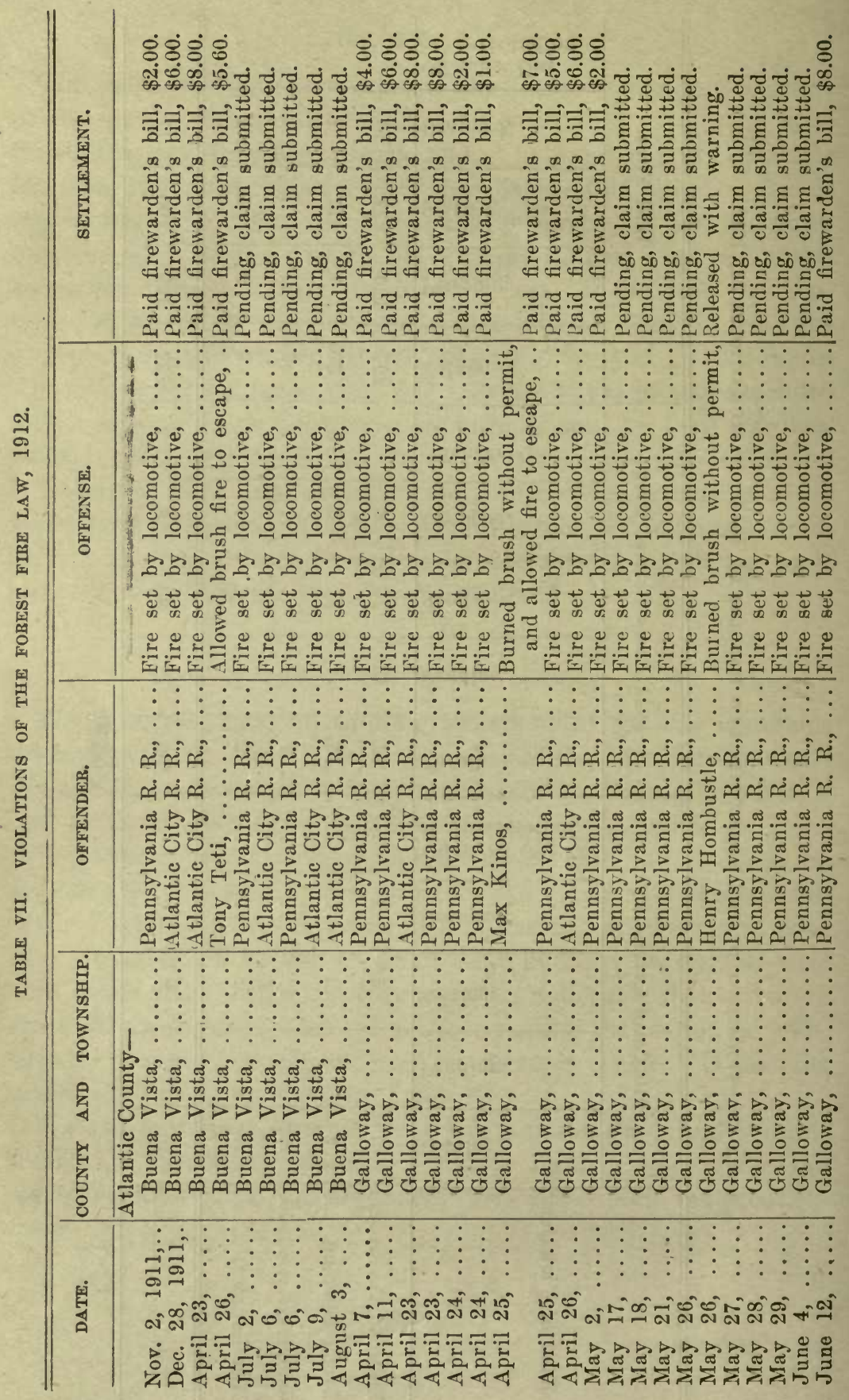




\begin{tabular}{|c|c|c|c|c|c|}
\hline & 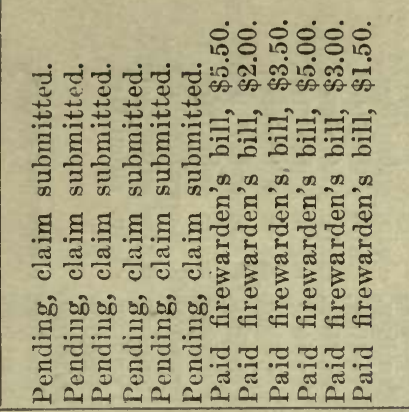 & 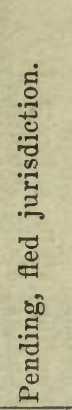 & 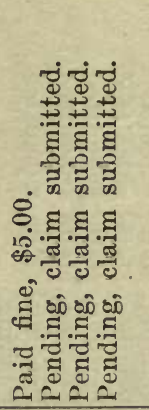 & 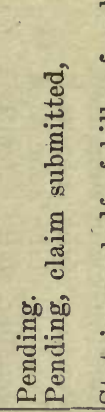 & 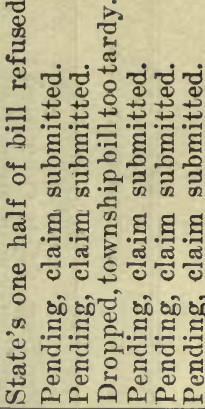 \\
\hline & 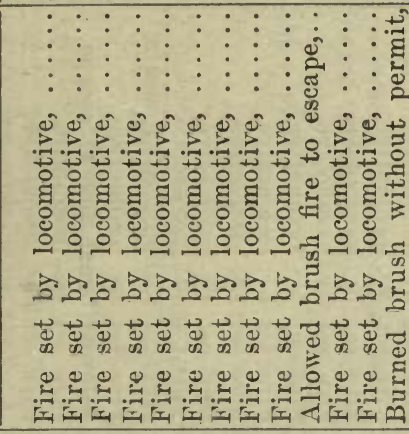 & 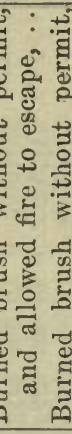 & 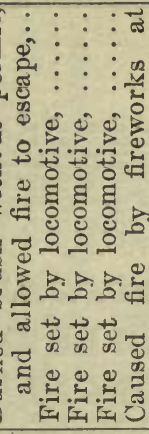 & 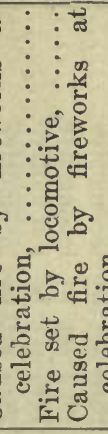 & 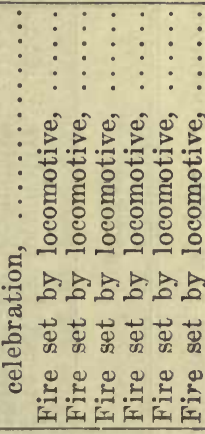 \\
\hline & 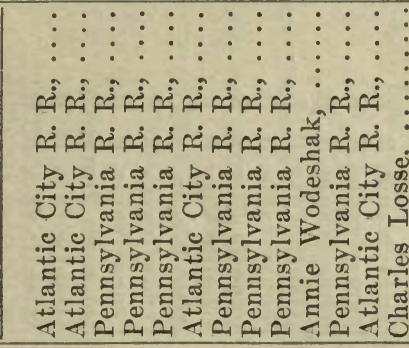 & 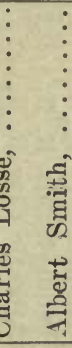 & 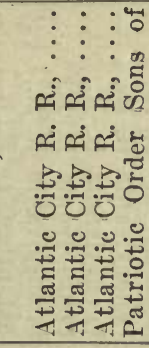 & 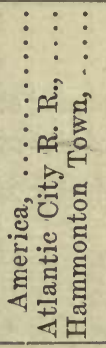 & 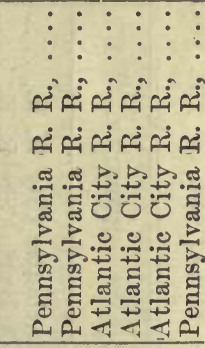 \\
\hline 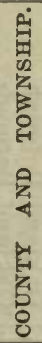 & 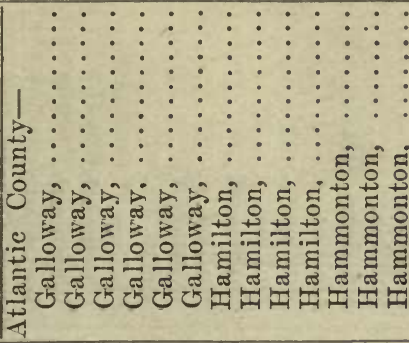 & 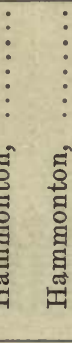 & 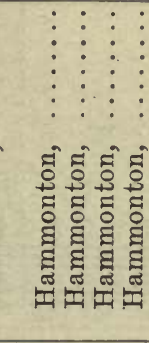 & 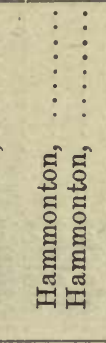 & 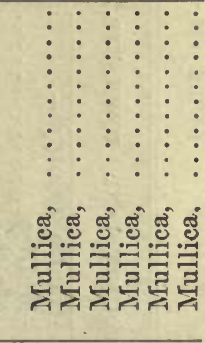 \\
\hline
\end{tabular}

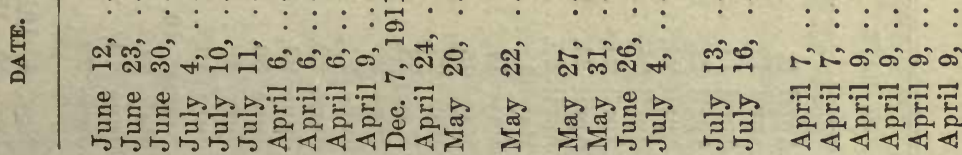




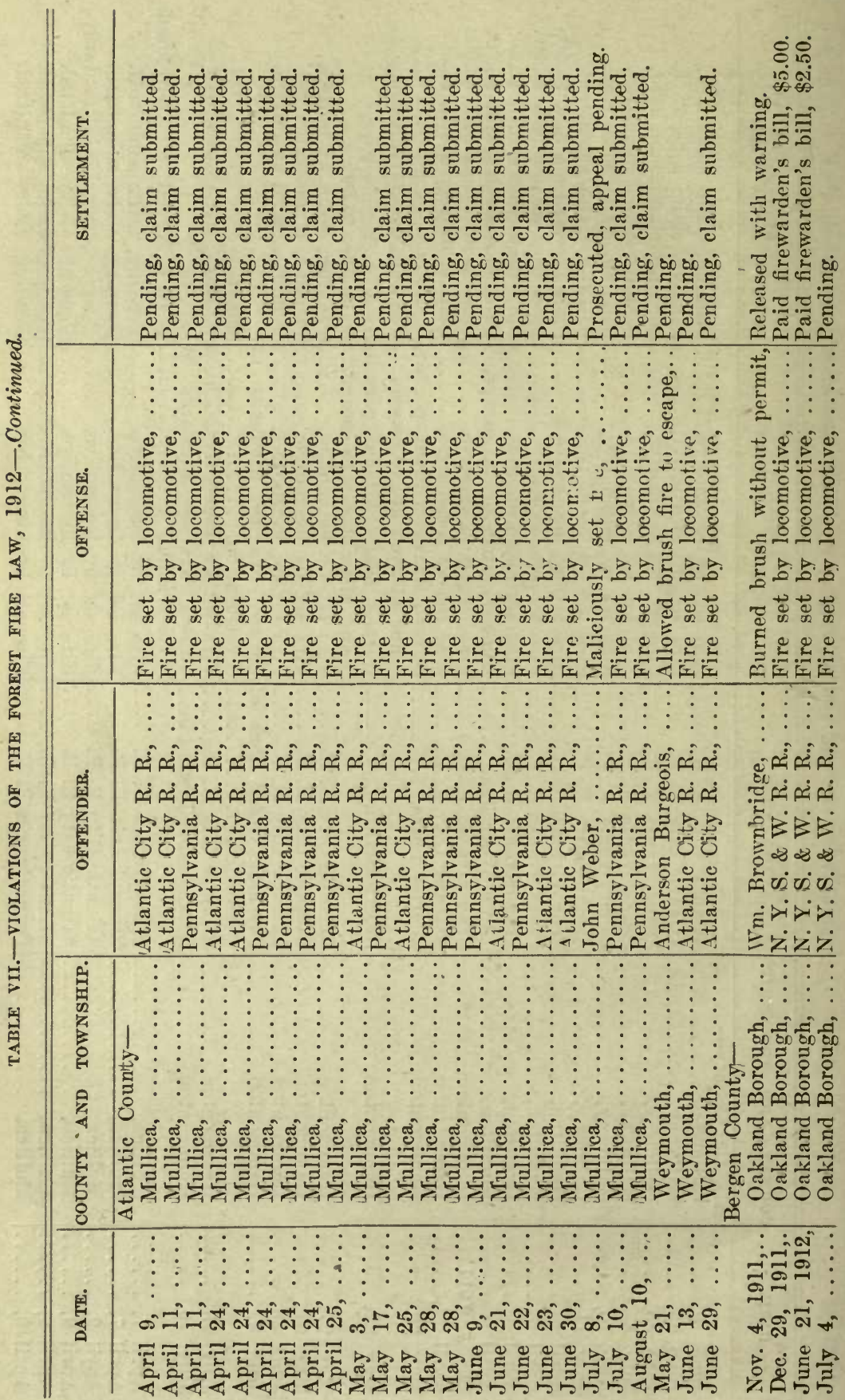




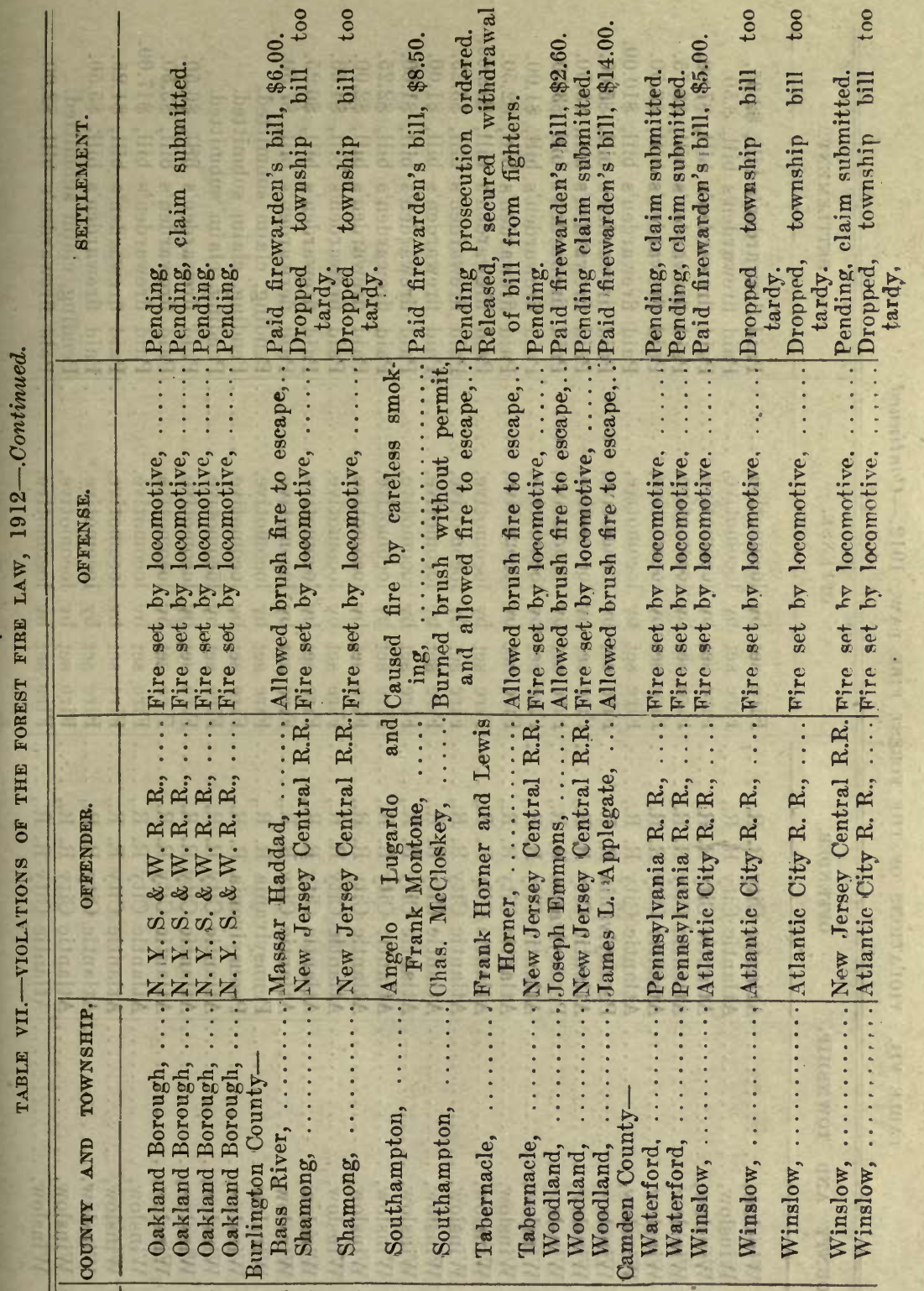

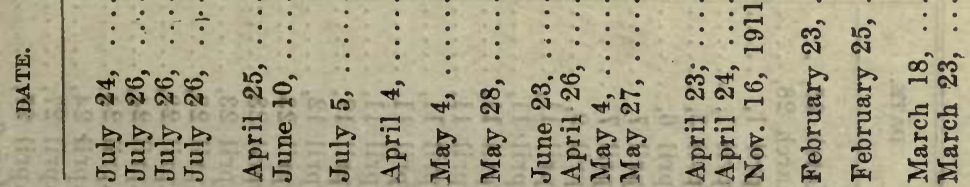




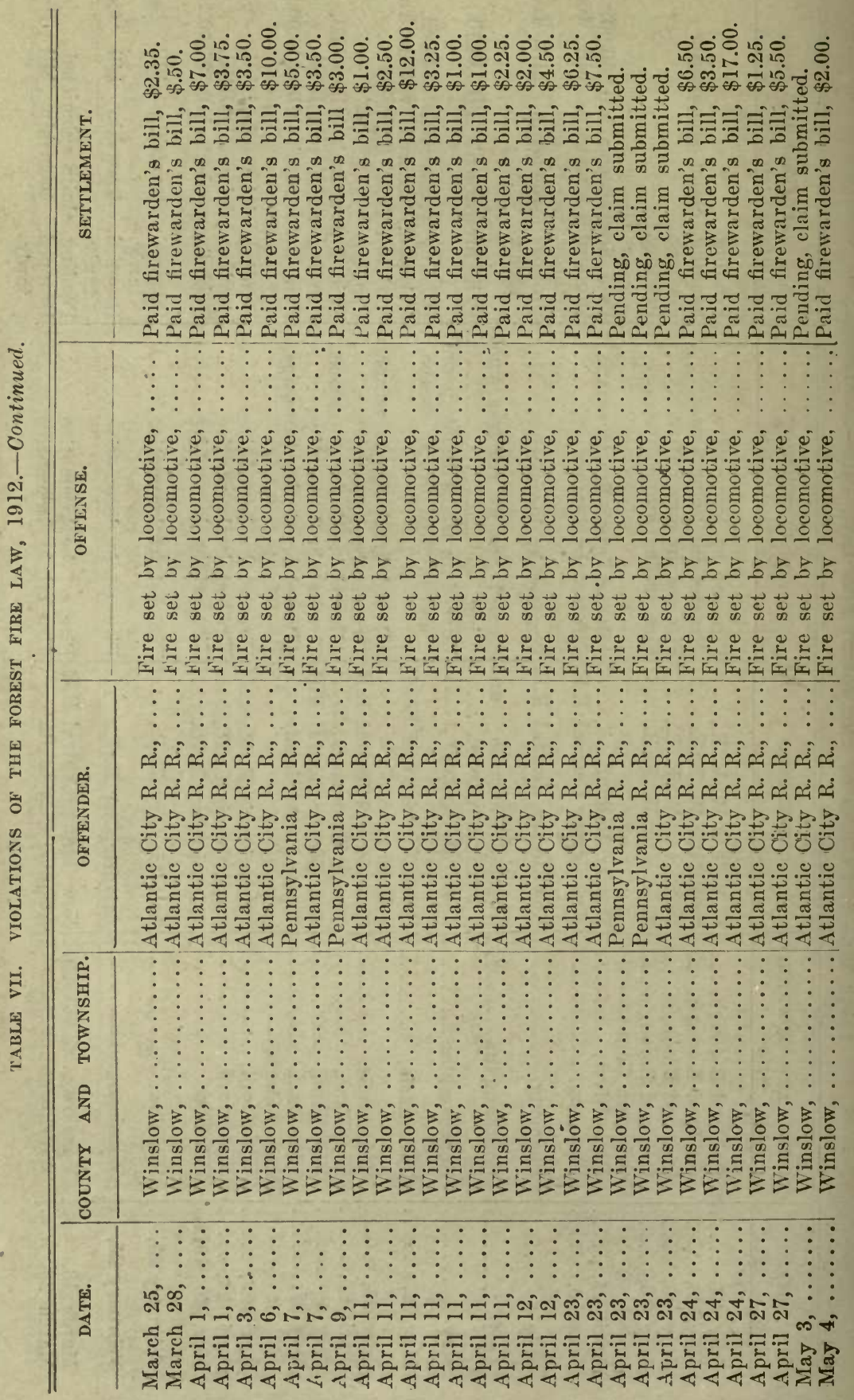




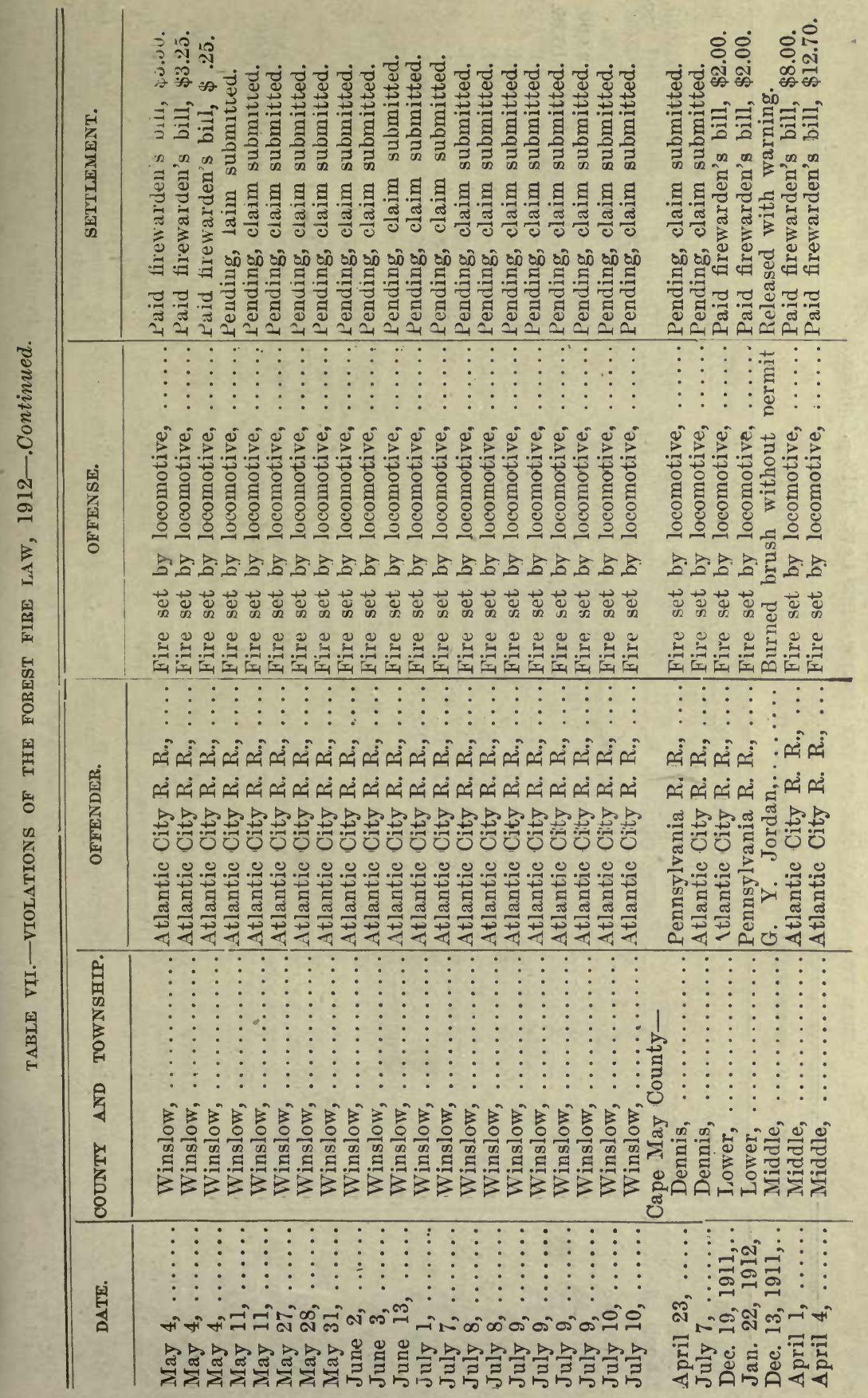




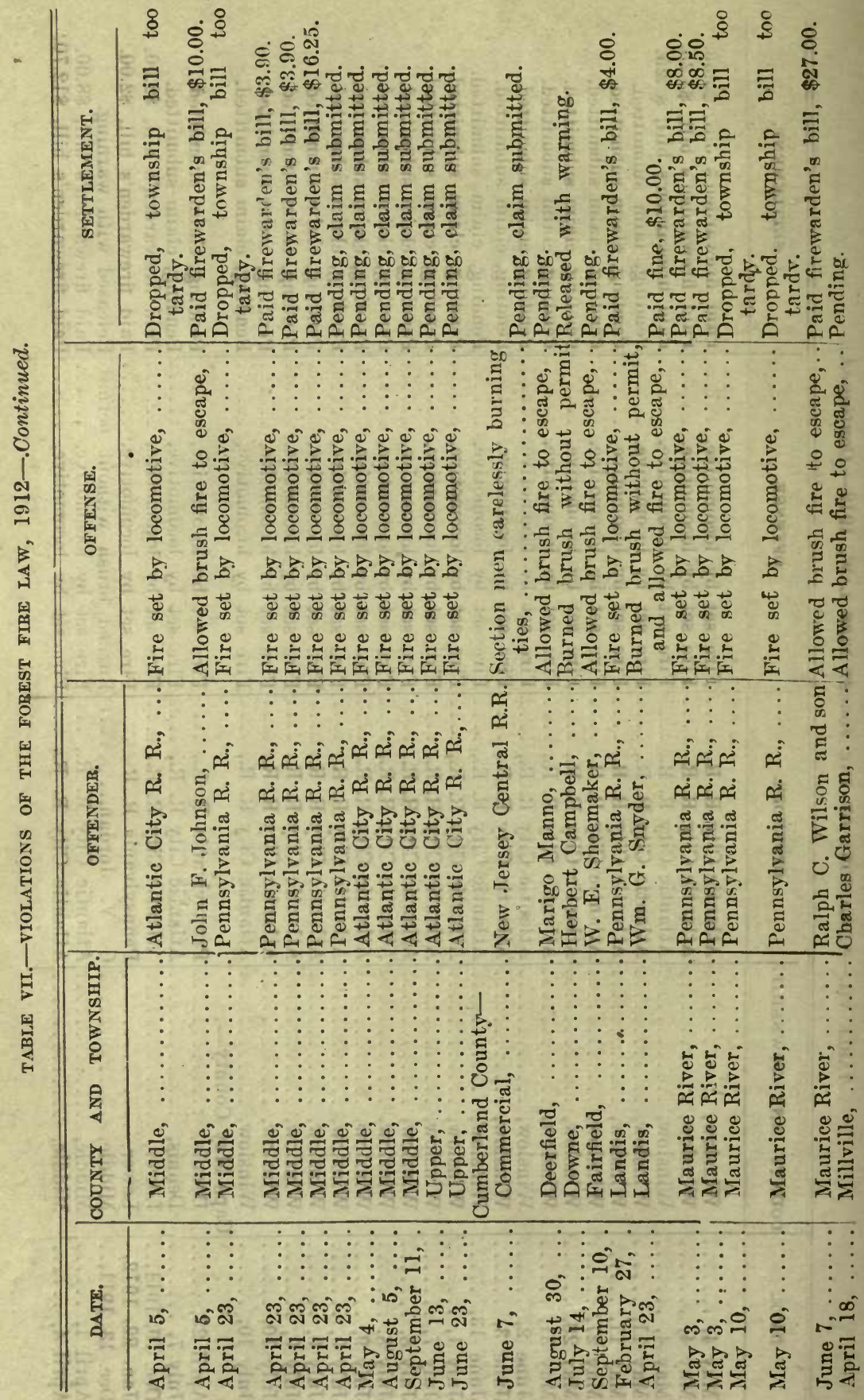




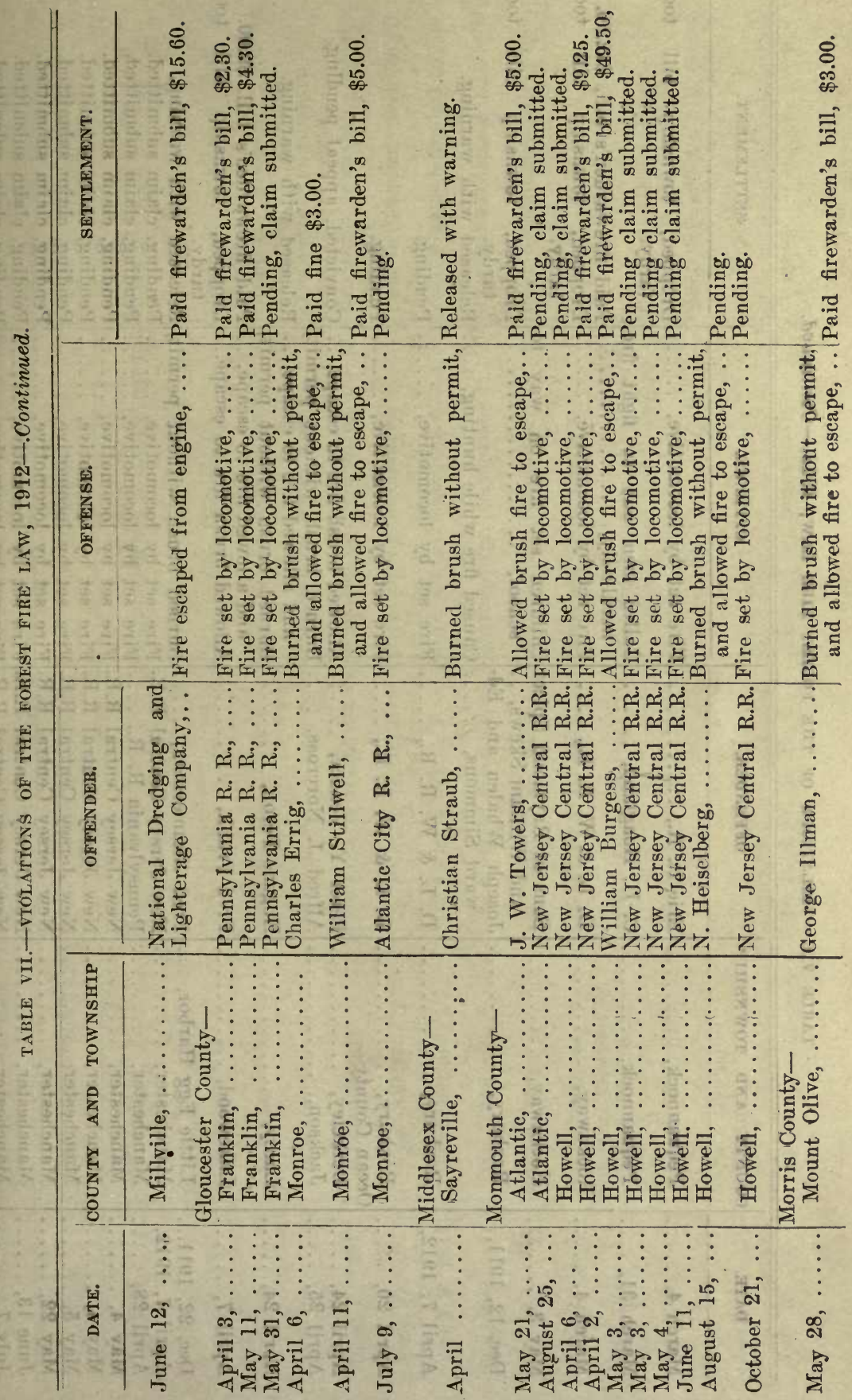




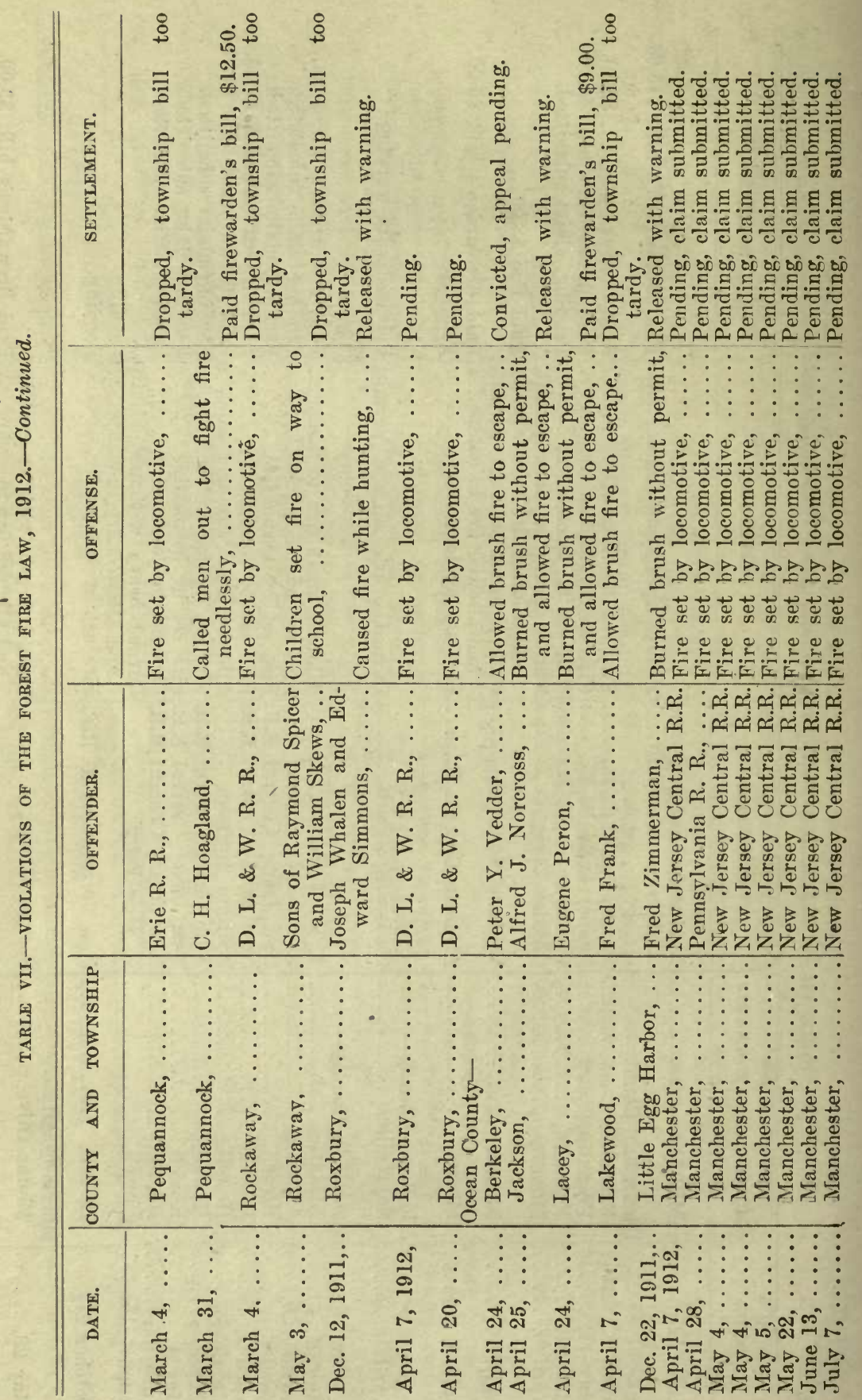




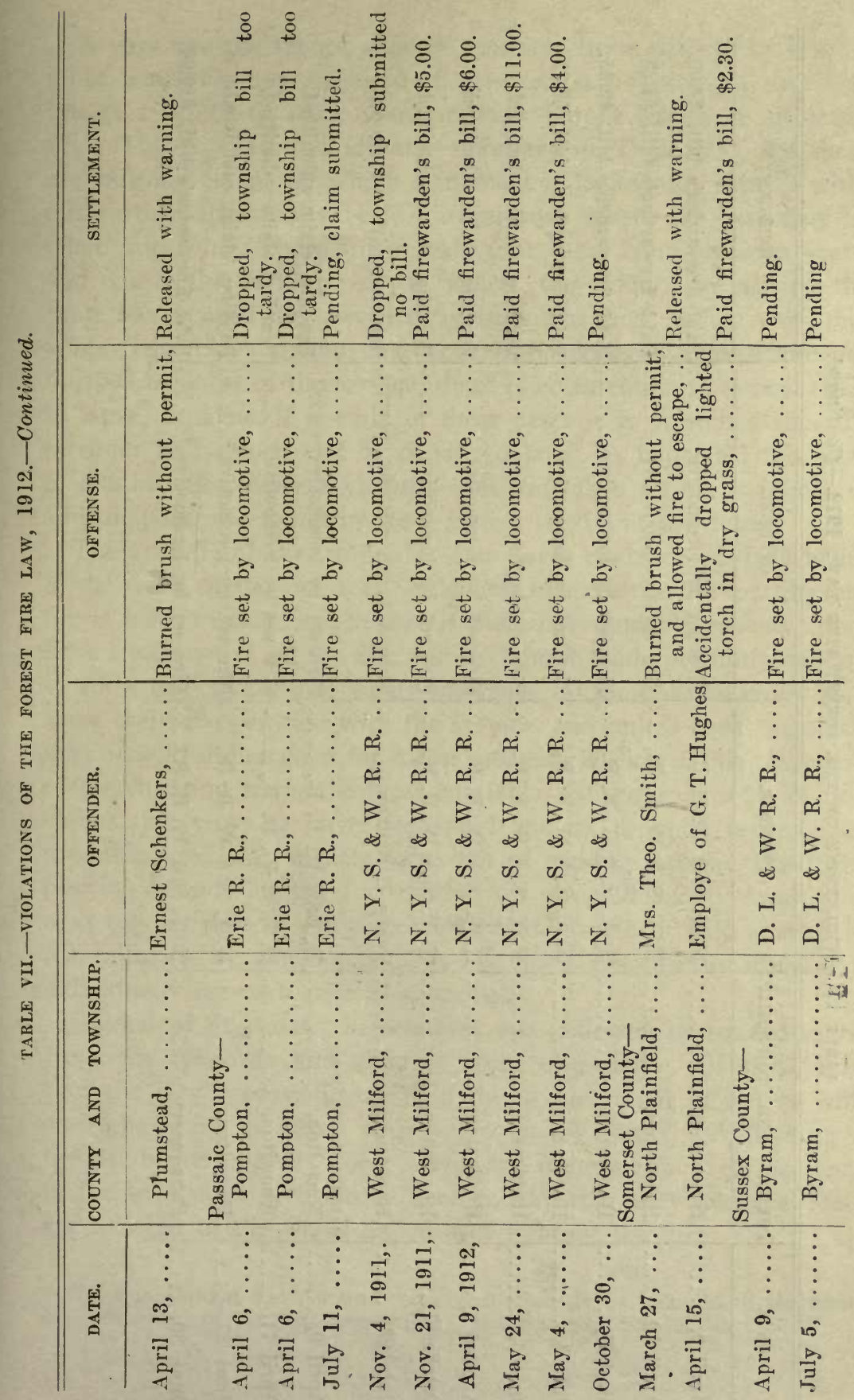




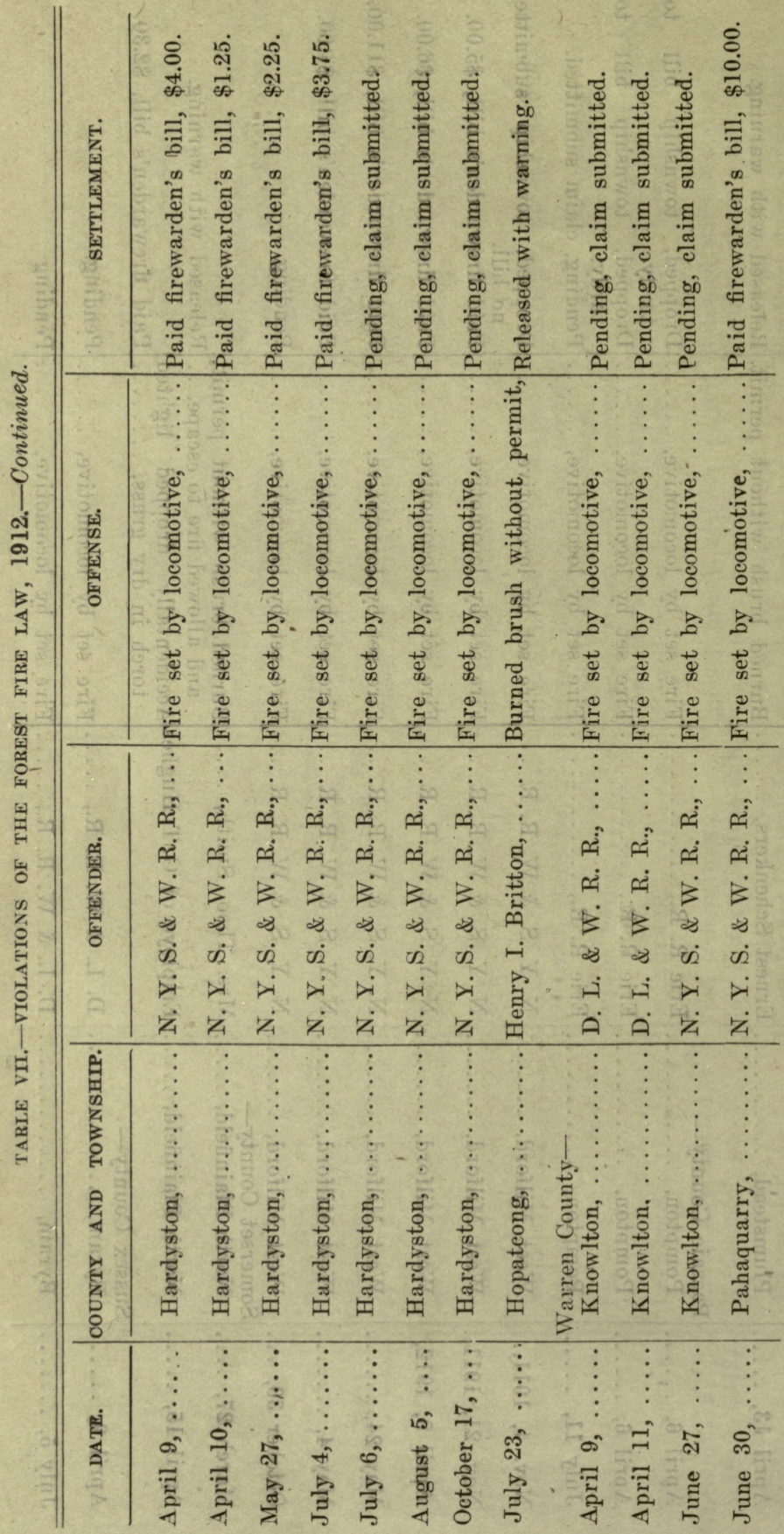


A year ago the record showed Io cases from I9Io to be settled, all of which are now disposed of. Of the 109 violations in I9I I that fell as a le acy to 1912 , there are now but 12 left to be adjusted. (See Tables VIII and IX and summary in Table VI) All these are railroad claims on which scttlement is looked for shortly without further attention, save in one instance where the case may be taken into court. There still remain four cases from previous years, and one in the current year, in which the violator by leaving the State has escaped the law. It is again emphasized, as last year, that

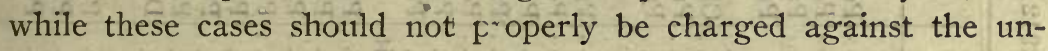
finished business of the service, there is no intention to permit them to lapse. In some, if not all, of these cases it is presumed that the offender will return and be penalized later, as happened this year ir one instance, when a violator who had taken up his residence in Philadelphia was found in New Jersey, tried and convicted.

The attitude of the railroads again gives evidence of their belief in the work of the Service. Settlement of expenses for putting out fire is readily made in each case if there is reasonable ground to believe a locomotive set the fire, and if claim is made promptly enough to allow the company to verify the facts. So long as the roads continue their co-operation with the service, and unless gross carelessness or willful disregard for forest interests is shown, this treatment of the situation seems the most equitable. Of 207 railroad violation claims this year, 72 have been paid and 15 dropped because the township's bill was too late to permit of making a claim. Final disposition of most of the 120 claims still unsatisfied only awaits the next regular date of settlement under an agreement with several of the railroads by which payments are made periodically instead of individually for each case as submitted.

A total of $\$ 1,312.19^{*}$ in penalites was collected in 1912, $\$ 944.85$ from the railroads and $\$ 367.34$ from elsewhere. Of this latter sum the larger portion was paid by ig individual offenders with one other case in which a gravel company scttled for fighting a fire set by its engine. These sums are returned in every instance to the townships involved in such a way that they and the State are relieved of the whole expense of fighting the fires.

* Of this anount $\$ 144.35$ was received too late to be included in the financial statement of the year (See p. 14), but was paid on October 31 . 


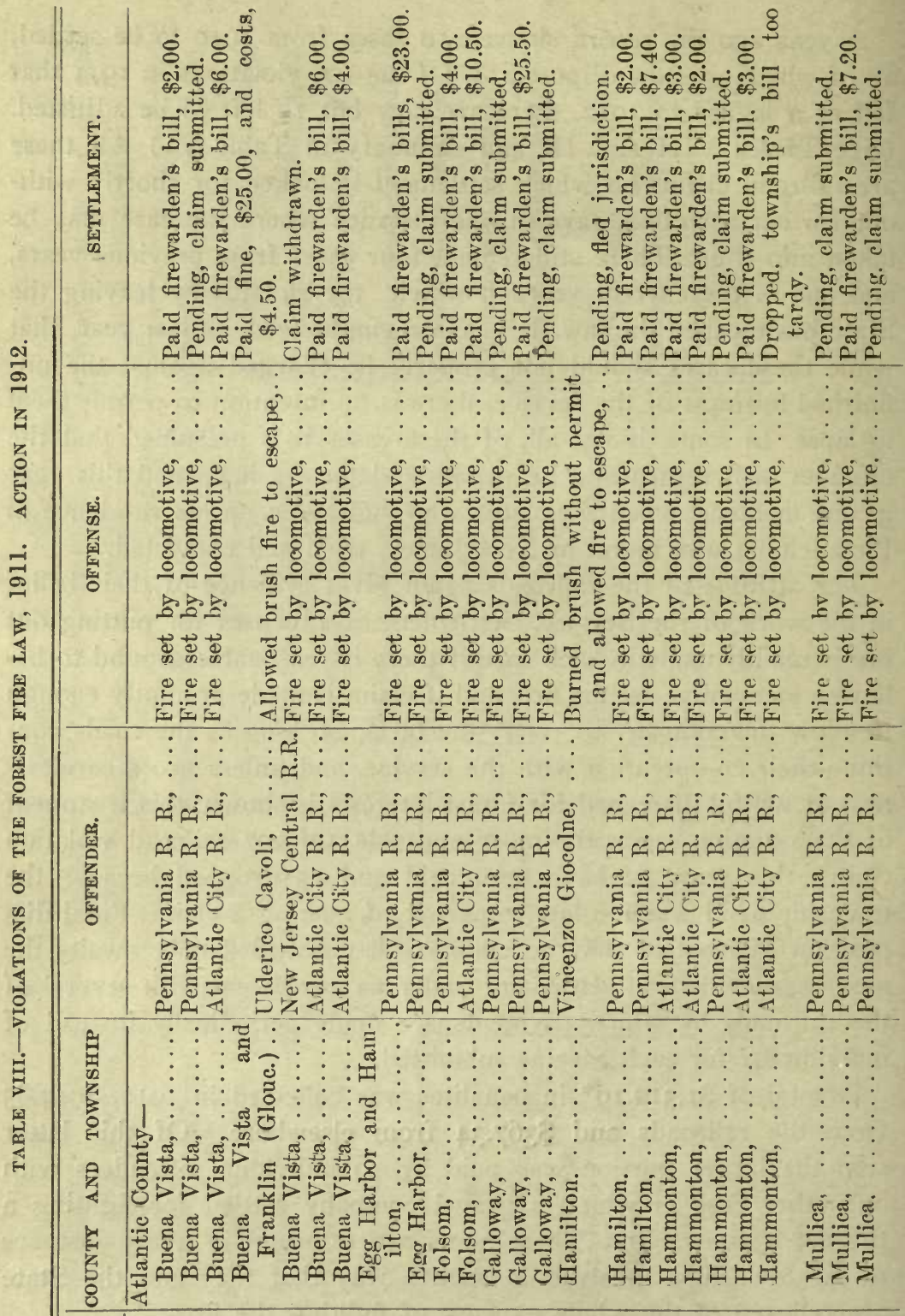

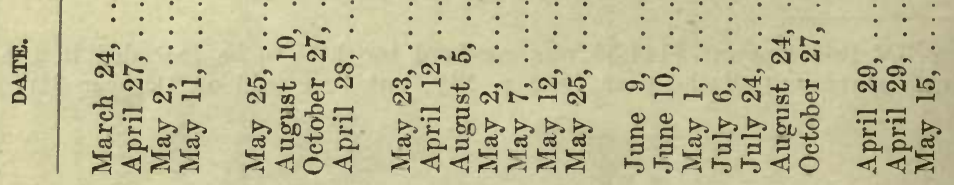




\begin{tabular}{|c|c|c|c|c|c|c|}
\hline & 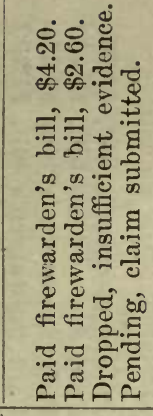 & 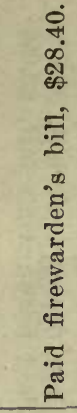 & 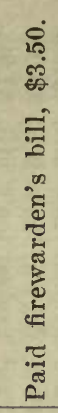 & 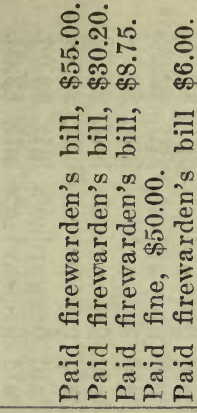 & 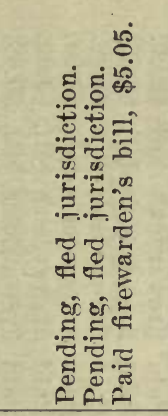 & 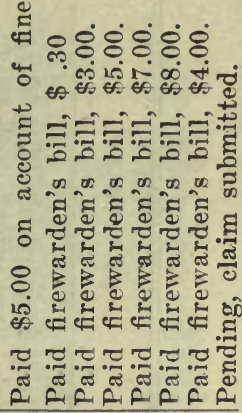 \\
\hline & 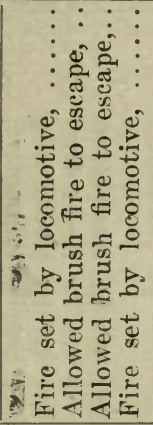 & 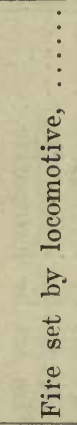 & 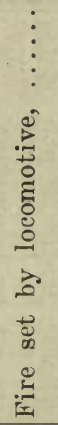 & 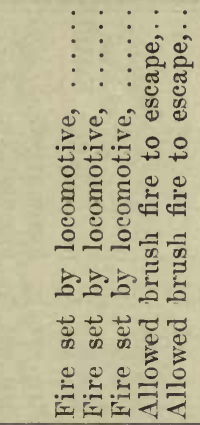 & 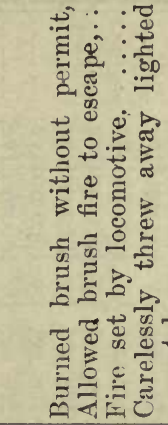 & 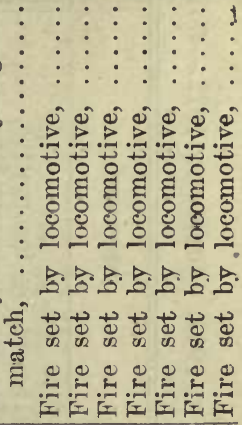 \\
\hline & 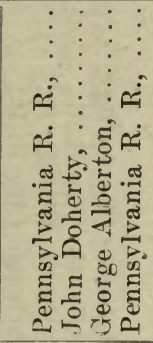 & $\begin{array}{l}\hat{\varepsilon} \\
\dot{4} \\
\dot{3} \\
\dot{8} \\
\dot{2} \\
\dot{x} \\
\dot{z}\end{array}$ & 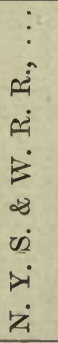 & 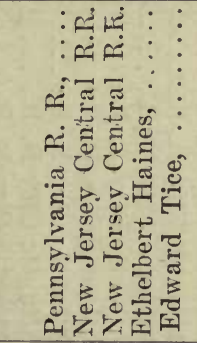 & 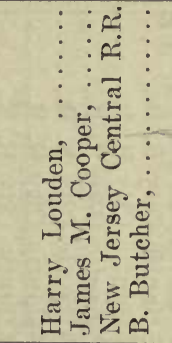 & 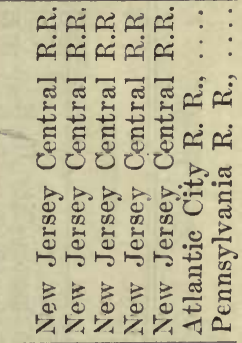 \\
\hline 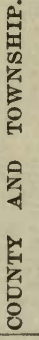 & 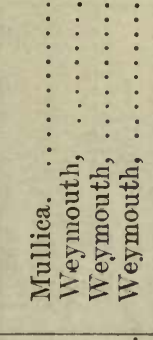 & 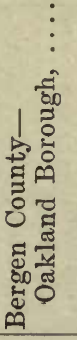 & 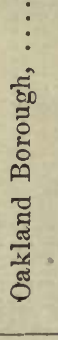 & 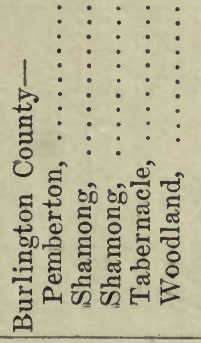 & 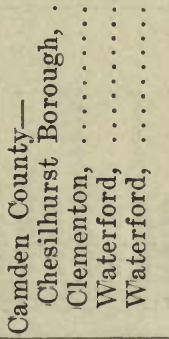 & 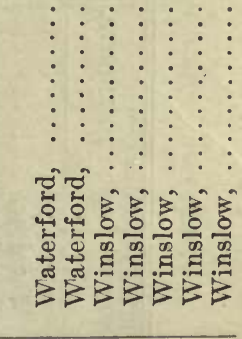 \\
\hline 逶 & 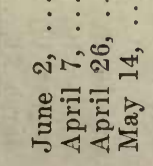 & $\begin{array}{l}\infty \\
\stackrel{\infty}{\square} \\
\stackrel{\square}{4}\end{array}$ & 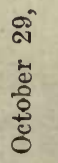 & 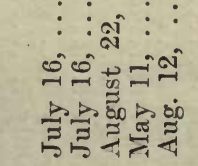 & 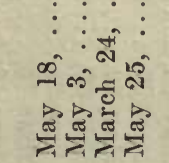 & \\
\hline
\end{tabular}




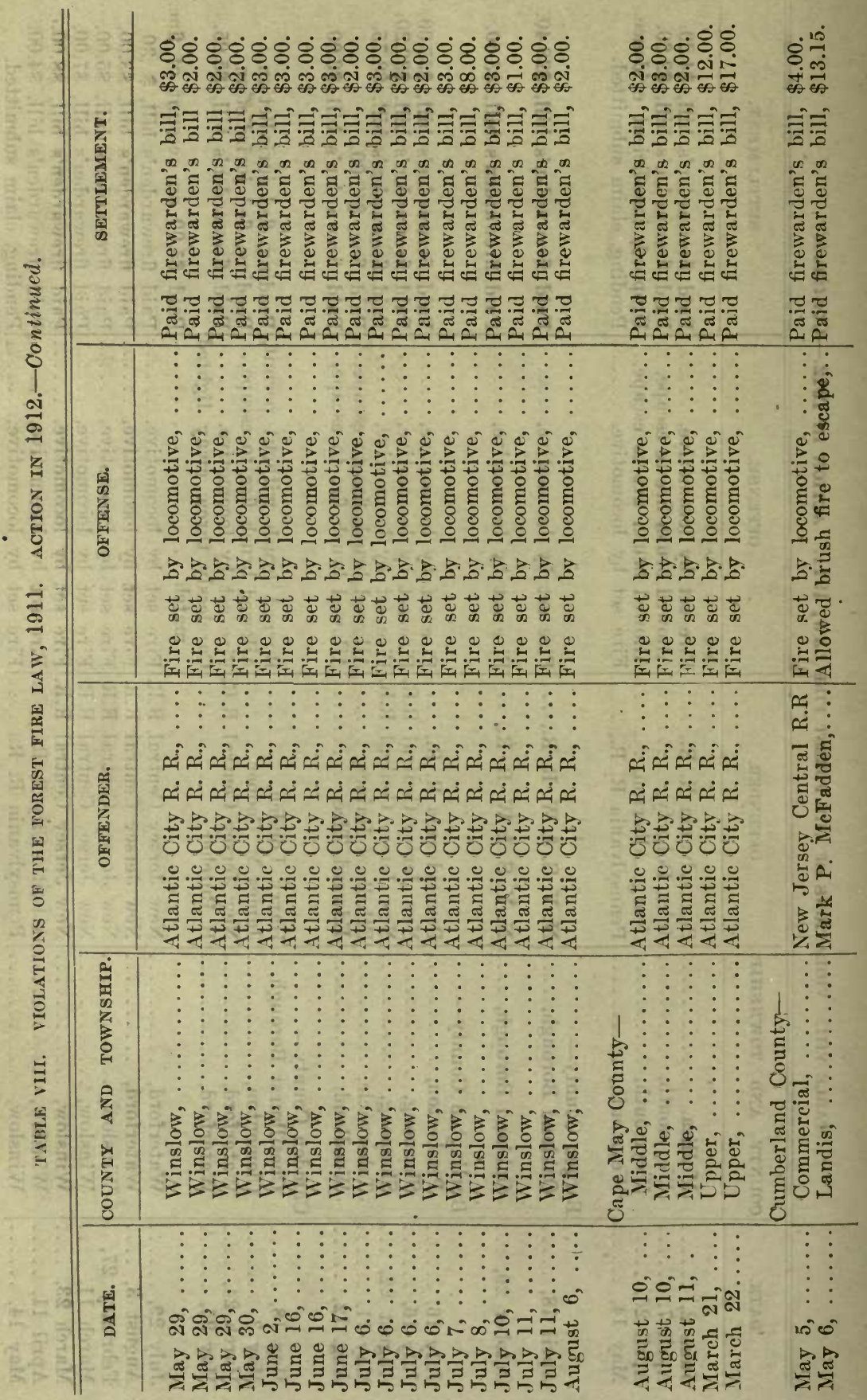




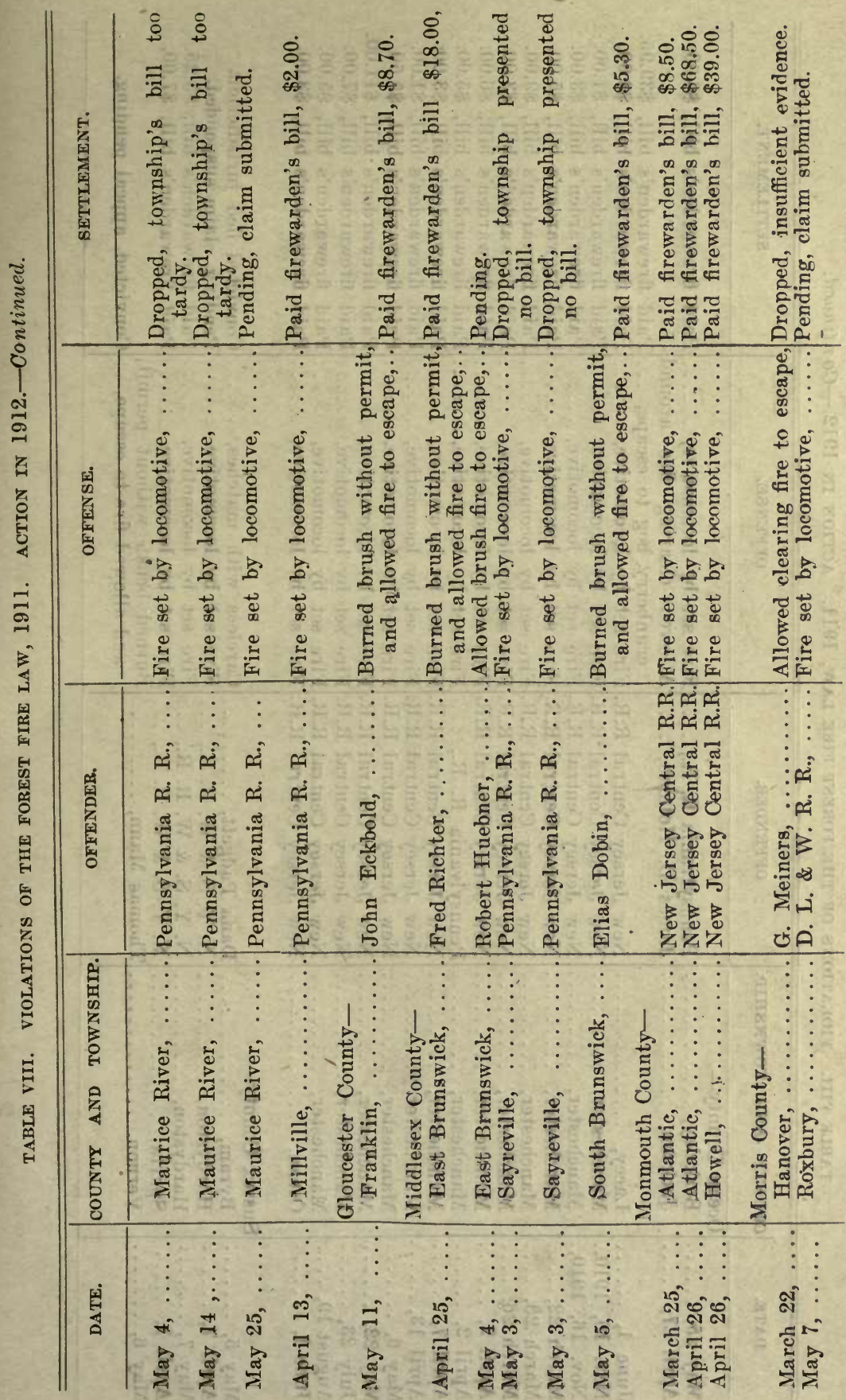




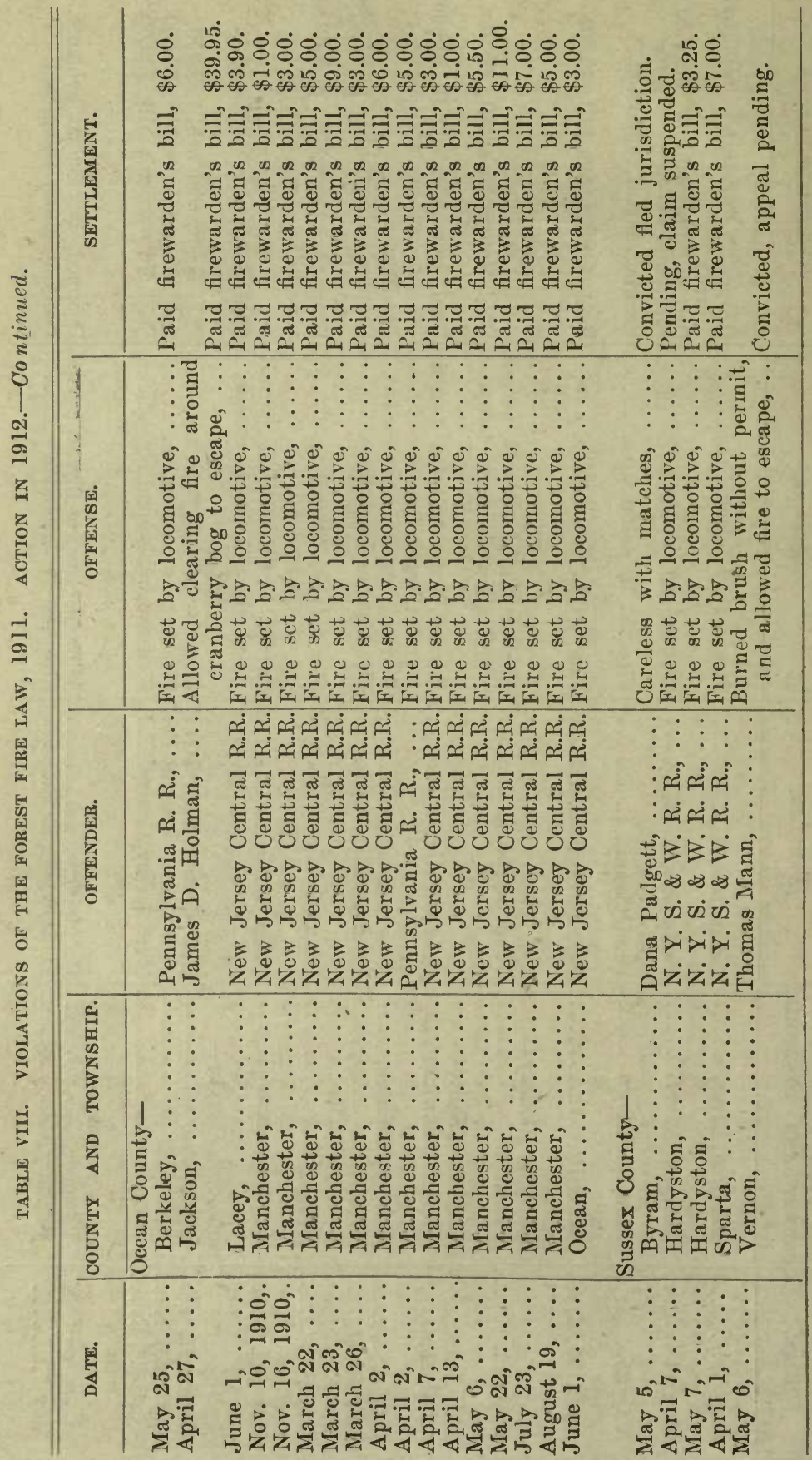


FIREWARDEN'S REPORT.

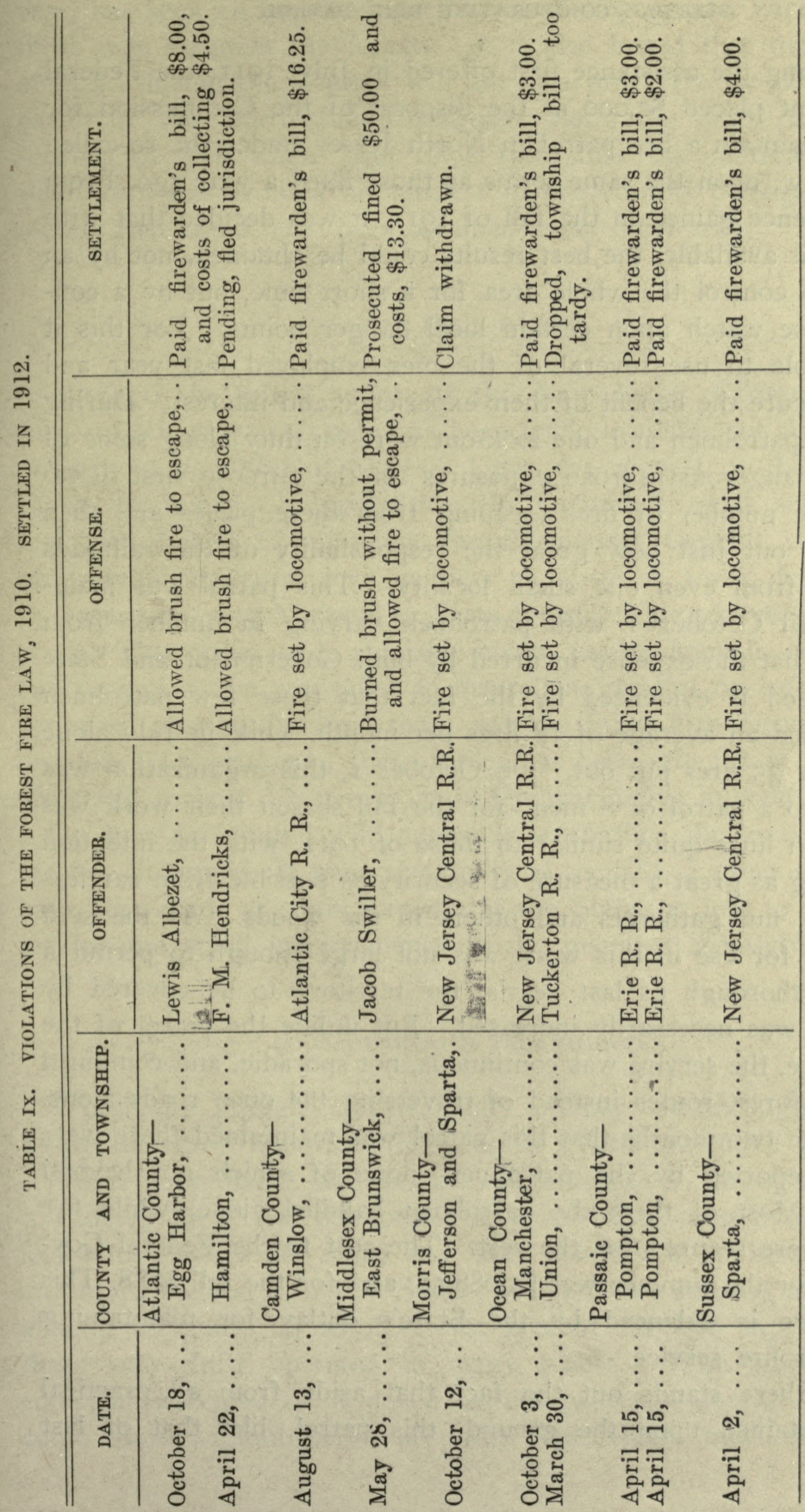


FEDERAL CO-OPERATIVE FIRE PATROL.

Continuing the assistance first offered in July, I9I I, the Federal Government placed $\$ 2,000$ at the disposal of the Commission fo: I9I 2 to maintain a fire patrol in North Jersey under the so-called Weeks Law, upon the same terms as those fixed a year ago. From the experience gained in the fall of I9II, it was decided that with the amount available, the best results could be obtained, not by an attempt to control the whole area for a short time, but br a continued close watch upon certain local danger points. For this it was possible to use several of the men employed last year and thereby secure the benefit of their experience and interest. During May four patrolmen and one look-out were on duty along some of the most dangerous railroad exposures for the purpose, first of re. ducing the number of fires escaping from these places and then of finding out just how great the responsibility of the railroads might be from even one small locality. This patrol was maintained until October $I$ with patrolmen varying in number from 4 to 6 . That the expense incurred by both Government and State was justified is evidenced by the fact that these few patrolmen extinguished an average of 18 fires per month, while in July alone there were 35 fires put out. On October I, this organization was enlarged to a patrol of 8 men; for the fall season their work was laid out on lines quite similar to those of $191 \mathrm{I}$, with the intention of assuring as great a measure of security as possible from careless sportsmen, nut gatherers and others in the woods. As the sum remaining for use in this work was not large enough to permit a patrol as thorough as last year's, the territory to be covered by each man was necessarily increased. But unlike the patrol of the year before, the service was continuous, not sporadic, and combined road ind forest routes instead of traversing the open roads alone. During the two months that this patrol was maintained there were 20 fires reporteci by the patrolmen, none of which got beyond control. Most of them the patrolmen handled alone, while fire fighters were secured for the rest. The cost to the Federal Government for the summer was $\$ 1,088.50$, and for the fall $\$ 888$. This expenditure is balanced by the State's outlay for maintaining its regular fire service.

Again there stands out the fact that aside from all practical results obtained upon the ground, this patrol, like that of last 
year, has been an important factor in inducing greater care among those who frequent the forests. It is also hoped that the results obtained during the summer will aid in a provision for permanent fatrol by the North Jersey railroads along the most dangerous sections of their lines. But aside from this the continuation of such work has aroused an interest in fire control throughout the section that could have been obtained in no other way.

\section{RURAL MAIL PATROL.}

Through the initial action of the New Jersey Commission, a force of almost 55,000 men has been made available for fire patrol throughout 20 different States. Upon the request of the United States Secretary of Agriculture, in pursuance of a suggestion from the Forest Commission, the Postmaster General issued an order requiring rural mail carriers to serve as forest fire patroi in territory having National or State forest fire protective organizations. This order made available about 300 mailmen in this State and prompt action was taken to insure the greatest measure of cooperation possible between them and the State Fire Service. No organized correlation of these forces has been effected in a movement still so new. However, it is felt that active interest by even a few men so situated will materially strengthen the local grip on the fire situation. If general activity is secured, a great gain will have been made at slight expense to the State, no loss to the mail service and small inconvenience to the mailmen themselves.

\section{LOOK-OUTS AND TELEPHONES.}

Where fire fighters are available, as they are throughout this State, the most important features in a fire protective plan are constant surveillance and ready communication throughout the territory. To secure the former at a reasonable cost a system of look-outs gives wider scope and more continuous application than any other method. In tlis State good look-out stations are available to commancl its whole forest area at far less expense than those sucessfully operated in many places. With trained and equipped watchers on a dozen towers properly placed, few fires could start withotit bein! jormptly discovered and accurately 
located. But the jetection and location of a fire is of no value unless fire fighters can be speedily summoned. To do this effectively over an area of any extent the telephone, is essential, yet, in sections where look-outs are most necessary telephones are rare. For this reason the Commission is unable to establish stations at most of the points where they should be.

The number of wardens within reach of a telephone is, however, increasing yearly and one handicap to lookout installation is thereby growing less. The Commision is endeavoring further to remedy the lack by actual telephone construction (see p. 64) and by a constant effort to induce private interests to build lines. Such improvements come slowly, but it is hoped that in the ensuing year the first step may be made towardl providing permanent fire control of this nature.

PRIVATE AND LOCAL CO-OPERATION.

Though the Forest Commission has always sought to enlist the co-operation of property owners in the protection of their own holdings, this effort has necessarily been subordinated to the demand for an efficient public service. However, the fire service has now reached a stage where this side demands and can be given more attention. There are within the State many large forest holdings in private or corporate hands, whose owners' dependence on fire control is great. It is felt that the equipment of their employees for fire fighting and patrol, or the installation of look-outs and telephones, properly rests on the owner. Nevertheless, where such service can be made of wider use and its permanence be assured, the State will gladly share the cost with the owner.

In many localities where regular fire warden service is not justified, co-operation between the Commision and local fire or police officials would make the fire law applicable.to isolated and suburban areas. Requests for such joint action always receive careful attention.

The appreciation of the Fire Service is expresed to the Fish and Game Commission for placing the following effective forest fire warning notice on this year's game chart: "Every Forest Fire Destroys a Game Cover. Be Careful Not to Cause Any." 


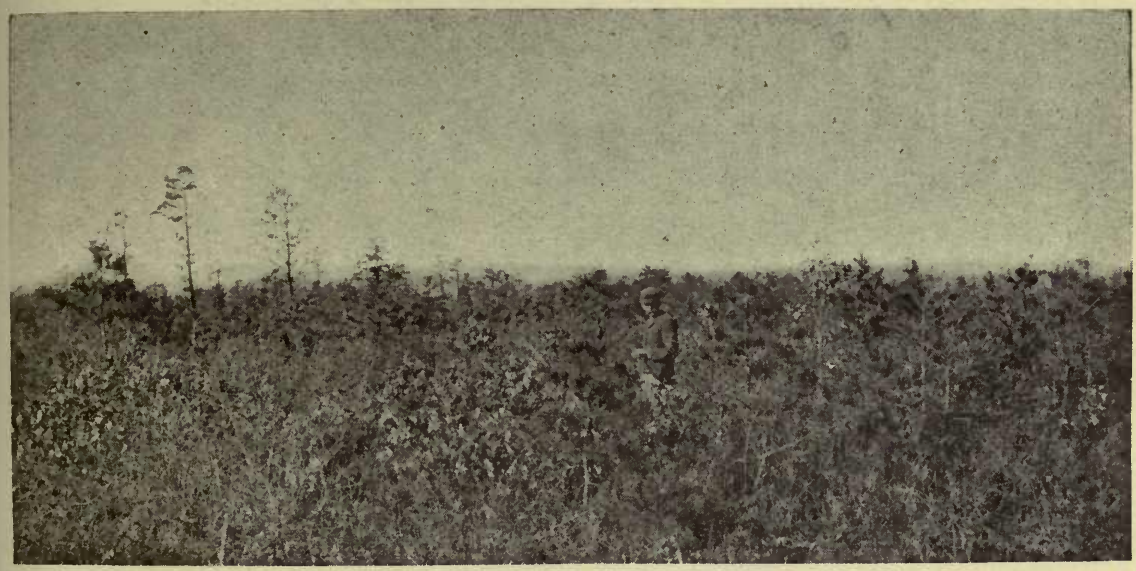

Fig. 7. Pine Re-establishing Itself After Logging and Fire.

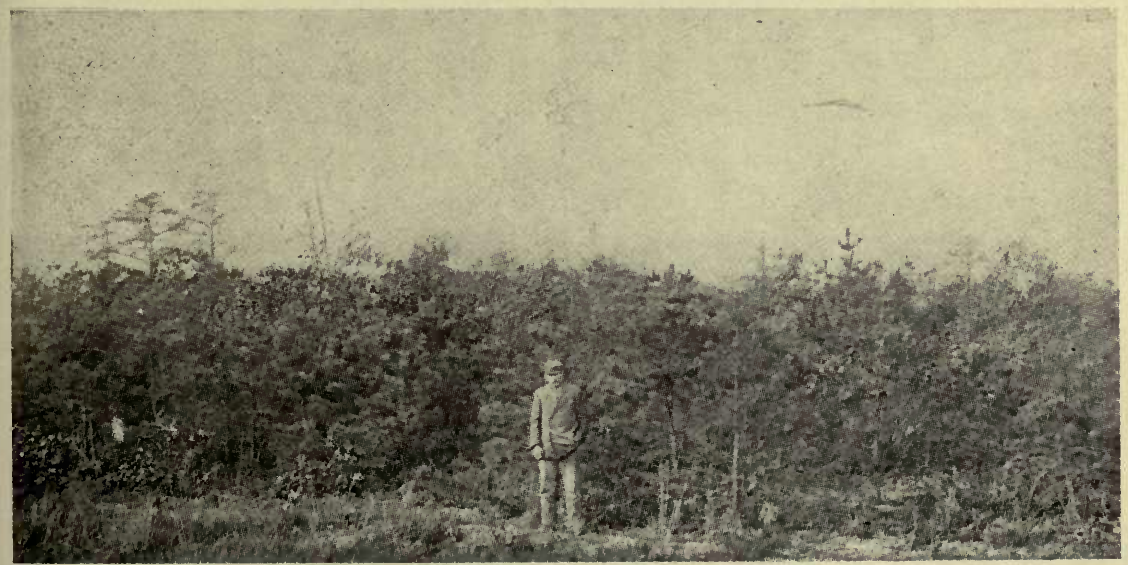

Fig. 8. The Same Area Five Years Later. Note How Trees Have Grown Under Protection Alone. Bass River Reserve. 

THE CARE OF ROADSIDES.

A year ago emphasis was laid on the unnecessary menace to New Jersey's forest land created by the prevalent condition of many public roadsides. Although without authority to insist on any remedy for this condition, the Forest Commission has endeavored to bring the matter to wider attention among those who have control. To this end a letter was sent to each township having enough woodland to justify it pointing out that an unkempt condition of the road borders creates a danger to the woodland and indicating the particular legislation (P. L. I885, p. 36 and P. L. I900, p. 284) under the authority of which it lies within a township committee's power to find a remedy. In a number of townships this appeal found ready support, although it is regretable that so large a proportion of the local governing bodies still permit the former laxity in this respect.

In addition, new legislation has made it possible to use State-aid highways in the protection of the forests. A clause (Secs. 4 \& 29, Chap. 395, P. L. 1912) gives to the State Road Commissioner authority to require that all roads hereafter constructed through the wooded sections shall be effective fire breaks. With the cooperation of the Forest Commission, specifications have been prepared for such construction as will render the roads more effective for protection to the woodlands. 


\section{PENNSYLVANIA RAILROAD'S ENIORSEMENT.}

Probably the most significant single effort to secure forest protection is the action of the Pennsylvania Railroad embodied in instructions issued to its employees on Feiruary I, 1912. So complete and so emphatic are these instructions that a copy, much reduced in size, is reproduced. In the last paragraph the railroad's breadth of attitude is particularly emphasized. See opposite

\section{RAILROAD FIRELINES.}

The status of the law commonly known as the Railroad Fireline Law, 2 Comp. Stat. p. 2239, has not been altered, so far as its operation is concerned.

Although the temporary nullification of the law, (See p. 8) is hampering the construction and maintenance of the firelines to a large degree, it is again cheering to note that the railroads, more particularly the New Jersey Central, continue their policy of voluntary fireline construction. An unfortunate feature in connection with the situation is, however, that along some railroads, and some sections of others, existing lines have been neglected. This failure to maintain construction already done is most unfortunate, both because it is a direct loss of expensive work and also because on those lines that have been allowed to grow unkempt at least five fires have started and burned from them to adjoining woodland. There is no case recorded in which a fire has crossed a well made and properly maintained fireline.

There have been again one or two instances in which a fire has started from a spark thrown clear beyond the fireline, but as heretofore these cases are so rare and occur under conditions so unusual, as to wind and atmosphere, that they in no way arguce against the value of the fireline in controlling railroad fires.

The outlook for next year's work is highly encouraging in that three roads, the Atlantic City, New Jersey Central and Pennsylvania, have already indicated their desire to make appreciable additions to their mileage of firelines and the latter its intention to put into first class shape the total mileage that is now completed along its lines.

Although these features do encourage, the situation is still one upon which the Fire Service looks with concern. That firelines 


\section{THE PENNSYLVAMIA RALLROAD COMPANY \\ NORTHEAN CENTRAL RAILWAY COMPANY
WEST JERSEY A SEASHORE RAILAOAD COMPANY}

\section{THE PREVENTION AND EXTINGUISHMENT OF FOREST AND GRASS FIRES}

In order to prevent as far as possible the occurrence of Forest and Grass Fires and eliminate the damage which they cause, stringent measures for their prevention and suppression must be taken during the season of fire danger before vegetation starts in the spring and after it dies in the fall, and during periods of dry weather at any time. Beginning about March 1st and October 1st of each year, special vigilance must be exercised until the season of fire danger is passed, and Supervisors, track foremen, and others must be governed by the following regulations:

1. Trackmen shall burn old ties and other debris at such time and in such places as will not result in any spread of the fire.

4 2. Enginemen shall use every precaution against fire and not permit burning waste, hot cinders, or any other inflammable material to be thrown or dropped from the engine; clean the ash pan or front end only at points specially designated; and report promptly any defects in the devices on locomotives designed to prevent the throwing of sparks or dropping of hot coals.

3. Trainmen shall place fusees only where there is no likelihood of fire spreading from them

4. Tracknoen shall promptly extinguish all fires which start on or near the rightof-way, and render all possible assistance in fighting fires whether on private land or on property owned by the Company.

5. Trainmen shall notify the first section gang passed.and report to the Superintendent from the nearest telephone or telegraph, the existence of fires which evidently have not previously been discovered or had no steps taken toward their extinguishment. Freight trainmen shall, wherever practicable, stop and extinguish small fires, since waiting to report them might give them time to get beyond control. Other employes will take the necessary steps to notify the Superintendent and trackmen of such fires as come to their notice.

6. Supervisors shall have all grass, brush, and debris within the right-of-way line opposite the forest plantations, and, when feasible, as far back as the plowed fire line (which will be 100 feet from the track wherever possible), burned in the fall of each year as soon as the grass has died down enough to make this possible. Wherever practicable, the same plan of burning shall be followed on the right-of-way where there are no forest plantations. This burning shall be done with extreme care, and only when there is a calm or when the wind is blowing toward the track; and sufficient men shall be kept on the work to prevent the fire spreading to adjoining property.

7. If a large fire occurs on land not owned by the Company, the Supervisor shall notify the nearest State Fire Warden. In case he cannot be located and the fire is in Penn. sylvania, notify the Commissioner of Forestry at Harrisburg; if it is in Maryland, notify the State Forester at Baltimore; if it is in New Jersey, notify the State Forester at Trenton. The names and addresses of the Fire Wardens for the various districts will be furnished prior to each season of fire danger.

8. Operators shall transmit without charge, as Company business over Company lines, all messages relating to forest, woodland, or grass fires which are on or near Company property or are likely to affect Company property.

\section{CENERAL INSTRUCTIONS}

Remember that the most effective means of controlling forest flres is to prevent them. Use great care in the use of fire in forests or grass lands. Do not throw burning matches or tobacco where they can set fire, and impress others with the necessity for following these precautions.

If a fire starts, take prompt and energetic action to prevent its getting beyond control, and make use of the telephone, telegraph, or other means of getting help when it is needed. Plan definitely what action to take and how much help will be needed; a few men properly directed will accomplish much more in extinguishing a fire than a large force working at random.

After a fire is controlled, guard it until it is entirely extinguished. Not even a spark should be left where fire might start. Fires which have been thought to be under control have broken out afresh with a change in the wind. It is safe to watch a woods fire twentyfour hours after it is seemingly out.

Fight light grass fires and ground fires in the woods with green boughs, brooms, wet burlap, or by throwing on fresh dirt. If the line of flame is too hot for this, try scraping or digging a trench around the fire. Take advantage of natural vantage points, such as rock outcrops, streams, roads, etc., and connect them with lines or trenches along which the mineral soil is exposed. In severe fires start back-firing toward the approaching main fire from a break or line of some kind. For the ordinary ground fire the tools most readily available - the axe, hoe. shovel, water bucket, and burlap bag-are usually sufflient.

The fundamental object in'suppressing forest fires is to protect property, particularly buildings, fences, timber, forest plantations, etc. It should also be remembered that the suppression of fires is an essential step in the conservation of our forest and water resources. The various States have fire laws and organizations to fight them. The States alone, however, cannot at present suppress all fires, and it is obviously the duty of all land-owning individuals and corporations to help create a public sentiment adverse to fires and to take all possible action in their power to curb the fire evil 
are efficient is assured both by results and by the desire of the railroads most concerned to continue their construction, though under no obligation to do so. The lines thus made are not satisfactory in all respects, however, because the objection of a single sinall holder of woodland causes a break which greatly lessens the value of a line by leaving a spot from which fire can be communicated to adjoining properties. The situation on the individual railroads is as follows:

\section{Atlantic City Railroad.}

This road has now completed 76 miles of fireline, all of which has been recleared within the last year, though no new construction has been added. This leaves approximately 84 miles still to be constructed to complete the protection of the entire system as at first planned. Of this, it is intended to make about 6 miles during the coming year.

Lehigh and Hudson River Railroad.

No new construction has been added along this line, but the exposure is slight and is partially covered now by three-eighths of a mile of fireline, leaving not more than half a mile still to be constructed.

\section{Mount Hope Mineral Railroad.}

The entire distance required to be constructed along this road, one and one-half miles, having been completed in I9IO, no new work was done during this year, although the old fireline has been maintained.

\section{New Jersey Central Railroad.}

During 1912 this railroad has increased its firelines by 8 miles, making the total distance now protected 74 miles and leaving 202 miles of the originally estimated construction still to do. Of this remainder 28 miles more were partially finished in I9I2. The old lines have been kept up throughout their whole length. Next year this road intends to complete a fireline from Lakehurst to Landisville on the west side of the track, approximately 50 miles. This will furnish firelines along this entire strip of road on both sides, 


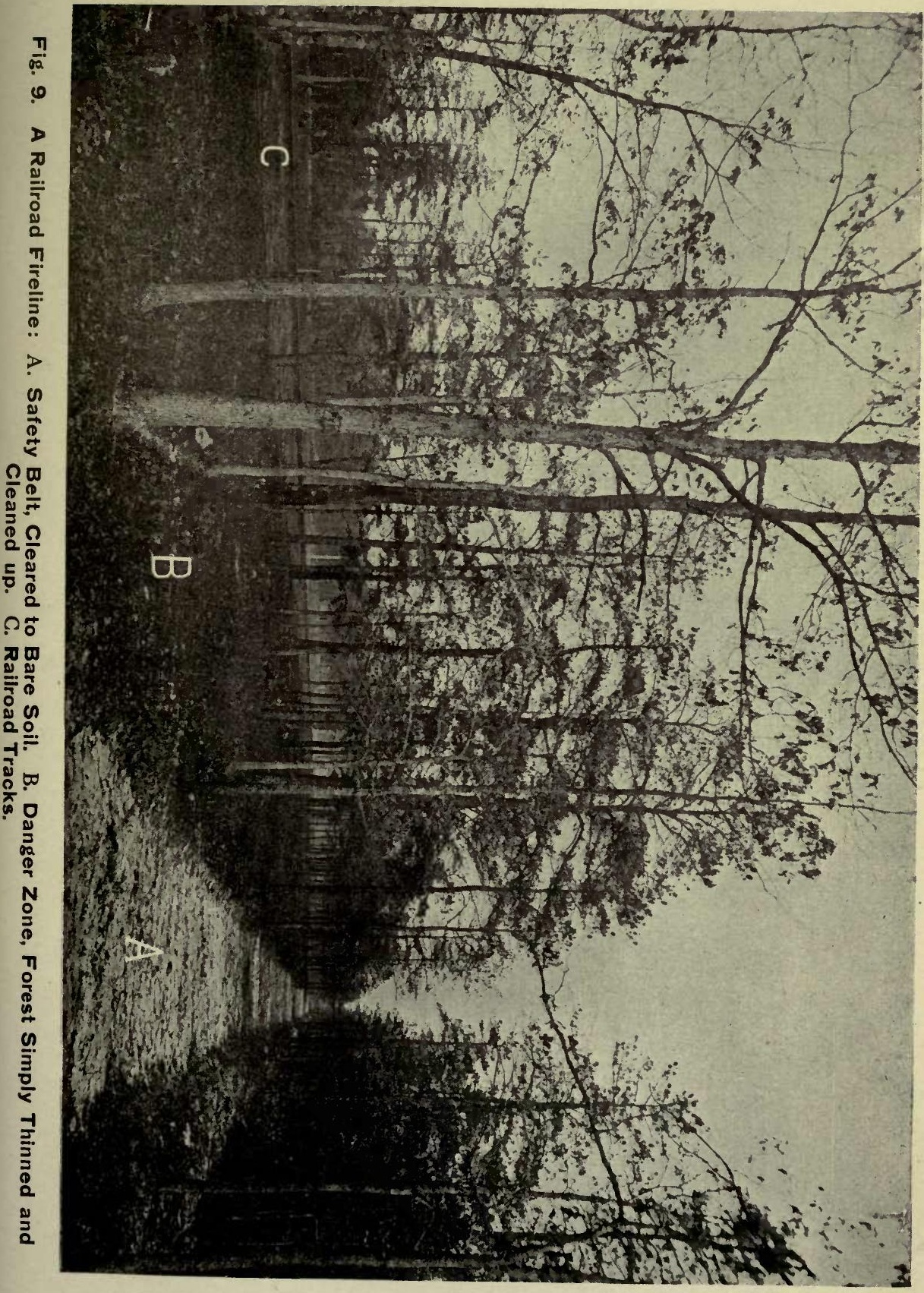



since the east side has already been covered, with the exception of a few short reaches where private interests object.

\section{Pennsylvania Railroad.}

No new fireline construction is reported from these lines this year and much of that $\mathrm{o}$ merly installed, about 75 miles, has been permitted to lapse. Next year a new fireline is planned to cover about 34 miles, with a thorough renewal of all previous construction.

\section{Raritan River Railroad.}

No new construction of firelines along this road has been done and save on a very small portion probably none will be installed, because conditions have so changed since the first enforcement of the fireline law that the original exposure is now materially reduced, if not wiped out.

\section{Tuckerton Railroad.}

No new firelines along this road are reported for 1912 and none are planned for the coming season.

\section{New York Central and Hudson River (West Shore) Railroad.}

No new construction along these lines was asked for and no new -work has been done. The exposure is, however, continually growing less as the small amount of woodland that required protection at the outset is rapidly reduced.

\section{Wharton and Northern Railroad.}

As was described in last year's report, this road maintains a fire car following the few trains that run over the road, in place of constructing and maintaining tirelines at a high cost. This year again the wisdom of the arrangement is evidenced by the fact that no fires have been reported from along the railroad. - If some have started they have been controlled immediatly by this railroad patrol without calling on the Fire Service. 


\section{Other Railroads.}

The Delaware, Lackawanna and Western, the New York, Susquehanna and Western, the Erie and the Lehigh Valley Railroads have made practically no contributions to fireline construction, though the latter did make three miles in I9I0. It is especially unfortunate that the two former companies have made no effort to follow the example of the roads that operate in South Jersey.

The total length of effective fire lines now in the State is approximately 250 miles. 


\title{
Report of the State Forester.
}

\author{
Alfred Gaskill.
}

SUM MARY.

New Jersey must induce forest owners to practice forestryCurtail cordwood and increase lumber production.-Enough forest is being planted.-Shade trees of increasing importance.-Many new Shade Tree Commissions.-County roads may now be treebordered.-Shade Tree Book for all who want one.-State aid.State forest reserves growing in value.-Fires on reserves few, products increasing, tree planting unnecessary.-Tree pests.

The Forest Commission's policy of giving fire control precedence over all other lines of effort is proving its own advocate. As the fires cease forest property becomes more secure and owners see some reason in undertaking forest management. Our effort is, and must be, directed chiefly towards inducing private owners to practice forestry because the State cannot expect to own or control more than a small fraction of the two million acres that comprise our total woodland. The map, Fig. I, indicates the magnitude of our interest, yet if we have forestry at all it must be forestry supported by the people who own the forests.

The strongest inducement held out to forest owners who would look for good returns from their investment is found in the fact that in this country no lumber has yet been sold at the cost of production, except perhaps small quantities in strictly local markets. This means that lumber prices must advance until timber crops replace the virgin store upon which the country is now drawing. That an owner who gets a forest started while land values and forest values are low has an advantage reeds no demonstration.

New Jersey's forestry work concerns itself largely with the future, with such effort as shall convert our burned and battered forest remnants to highly productive forests. And this aim is helped, not hindered, by the interest of many owners in forest 
esthetics. It is as easy to make a woodland attractive, while developing it commercially, as it is to neglect either its utility or its inherent beauty. In a settled community a forest park is more normal than a wild woodland. Thus is it explained why estate owners are the first to take up forestry and why so much of the effort of the Forest Commission is devoted to them. Forestry that deals solely with debit and credit is still subject to uncertainties: it will gain a place with increased security and such demonstrations as the estates and the forest reserves afford.

As means to bring about the practice of forestry the following, apart from fire control which always has first consideration, are engaging attention:

Forest management, on private lands and on the State reservessee pp. 59, 6r.

Forest planting-See pp. 60, 65. In this connection a series of experiments is being carried on, partly in co-operation with the United State Forest Service and with private owners, to determine the best species and the best methods for our territory. Some interesting results have already been obtained.

Investigations in wood utilization and wood values. These include a complete study of the wood-using industries of the State, their needs, sources of supply, etc., now being made in co-operation with the United States Forest Service. The report, to be published during the coming year, will show how much and what kinds of wood the State uses, where the shortages and wastes are, and how to correct them.

Lumber Directory. Co-ordinately with this an effort is making to bring wood users into communication with wood producers. Much loss is occasioned by the inability of one who has timber to sell to find a market for it. A classified list of buyers now enables us to put the would-be seller of almost any kind of wood into communication with those who use it. Correspondence with either buyers or sellers is invited-upon the distinct understanding, however, that all arrangements are made by and between the parties concerned. The only interest of the Forest Commission is to promote utilization.

Other lines of investigation, planned to acquire the knowledge that is sure to be needed as forestry progresses, irclude the planting 


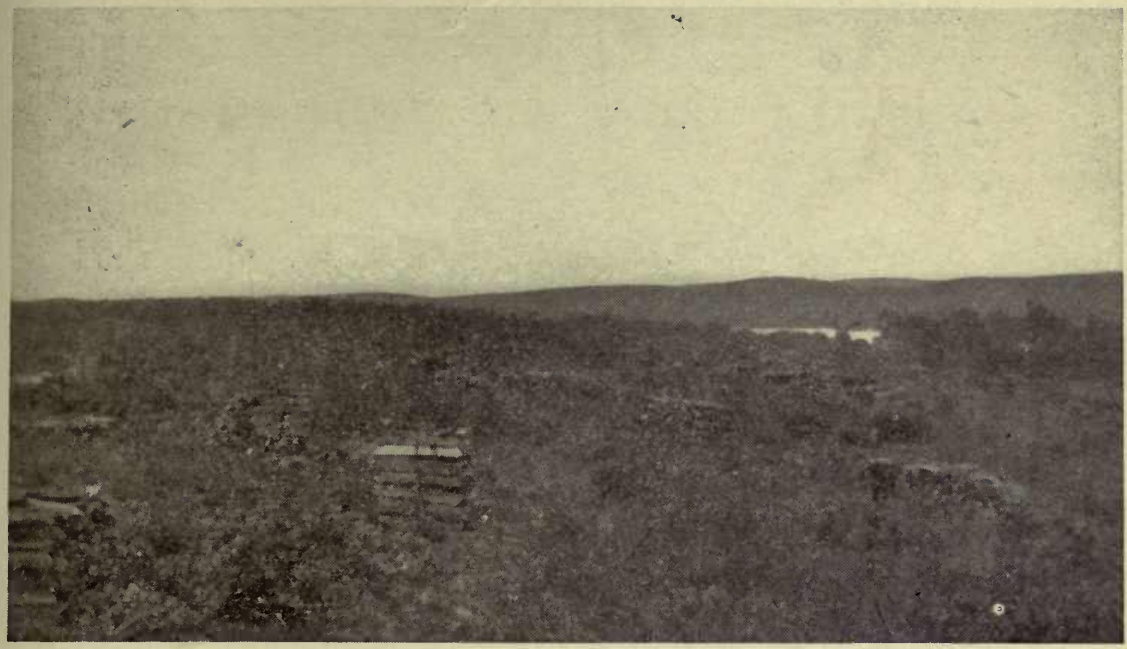

Fig. 10. A Clear-Cutting Near a Summer Resort. This is wrong from every stand. point. It Sacrifices Growing Trees, Produces Low Value Material (Firewood) Instead of Lumber, and Lessens the Attractiveness of the Locality.

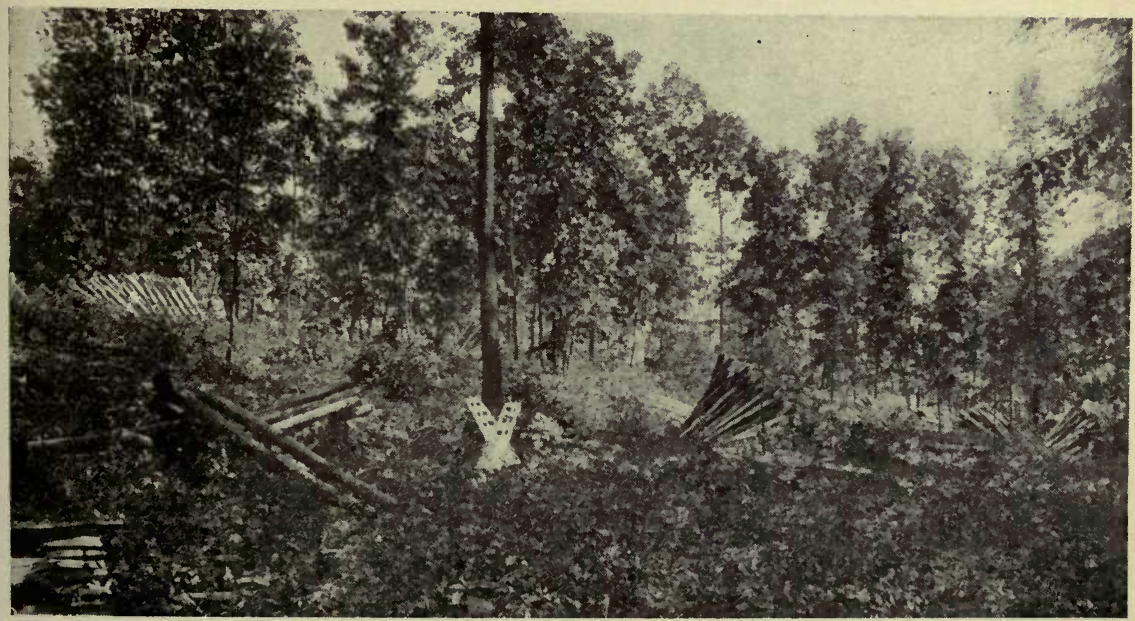

Fig. II. A Heavy Felling in Blighted Chestnut. The Chief Product is Fence Posts and Rails. 

of cottonwoods and other quick growing trees that have value for paper pulp and excelsior, and of willows for making baskets. Several years must pass before anything of value can be said about these efforts.

\section{PROGRESS.}

The year has seen a notable increase in the number of citizens who want to practice forestry or are looking after the shade trees in their neighborhoods. Though shade tree work, or arboriculture, is not forestry the Forest Commission is charged by law to promote it.

The means by which forest owners are interested and induced to look after their properties are first, protection against fire, and second, showing them how. As reasonable safety is assured to a locality interest in forestry awakens and the opportunity to practice it is given. The day of enthusiasm for a vague abstraction is passing; it must be demonstrated that forestry will pay better than letting the woodlands alone. And, fortunately, an extra dividend can be taken in the form of pleasure. This the public can share with the owner.

An indication of the activity in this direction is found in the statement that during the year improvement fellings and plantations have been made under the direction of the State foresters on 13 properties embracing 1,600 acres. This is in addition to about 25,000 acres that have been under their direction for several years.

\section{FOREST MANAGEMEN'T.}

In New Jersey this means finding ways to develop the "second growth" forest, which is practically all we have, and make it continuously productive. In North Jersey the necessity of removing trees affected with the chestnut blight, (see p. 75) undoubtedly has induced many owners to think of forestry and to appeal to the Forest Commission. In several cases it was possible to direct necessary fellings so that the growing trees of other species than chestnut were saved. By then planting evergreens in the gaps new forests were established which, in time, may easily be more attractive and valuable than the old.

Markets. The chief difficulty encountered when a forest is to 
are always salable, as are oak railroad ties; chestnut poles and posts are in demand but ties are often slow. In the neighborhood of Morristown the most profitable use of chestnut is for post and rail fences; Fig. II. But every cutting, South or North, yields much cordwood-often a greater volume than of anything else. Efforts have been made and are still making, to find a use for this but thus far with no great success. Chestnut is not always marketable as fuel and there is more than enough oak for all needs within the economic delivery range. As a rule pine will bear a higher freight charge than any hardwood but hickory. The solution of this problem apparently lies in the establishment of some new industry, like a wood-alcohol still, in the heart of our northern forests. In South Jersey it will come of itself when the fires cease and the pine trees are allowed to grow to timber size. In any case, no reason can be found for making cordwood the main crop. Tops and thinnings always furnish enough where forests are well managed.

\section{FOREST PLANTING.}

Our policy witl respect to forest planting also differs from that of most States. We find it unnecessary to plant trees except in a small way. Bad as the fires have been, reckless the chopping, deserts like those of the Adirondacks, the Lake States, and the West are unknown with us. There are hillsides in North Jersey that liever should have been cleared, they will yield more in timber than in farm crops or in pasture. These the owners are recommended to plant, usually with evergreens, which are preferred chiefly because they produce more and better lumber (softwood) in a given time, but partly also because the landscape needs them. About Ioo,ooo young trees have been planted this year under the direction of the State foresters. Not less than 300,000 have been planted within five years. Notable instances of this are found on the water reserves belonging to the cities of Newark and East Orange. The former has set out upwards of 100,000; the latter, working with larger plants, has set out 10,000 and has in nursery 75,000 young trees to be planted within the next three years.

In South Jersey there is even less opportunity to make commercial plantations. The clearings are practically all on the better 


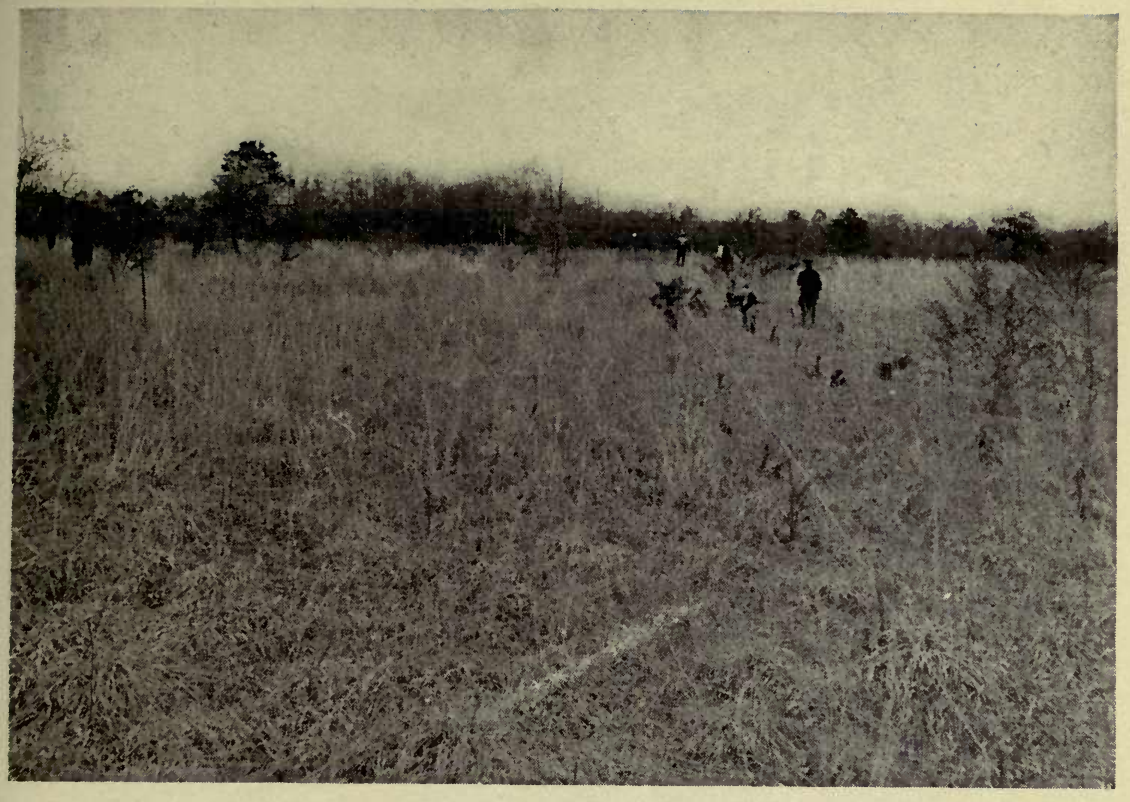

Fig. 12. Planting a Forest. Bass River Reserve.

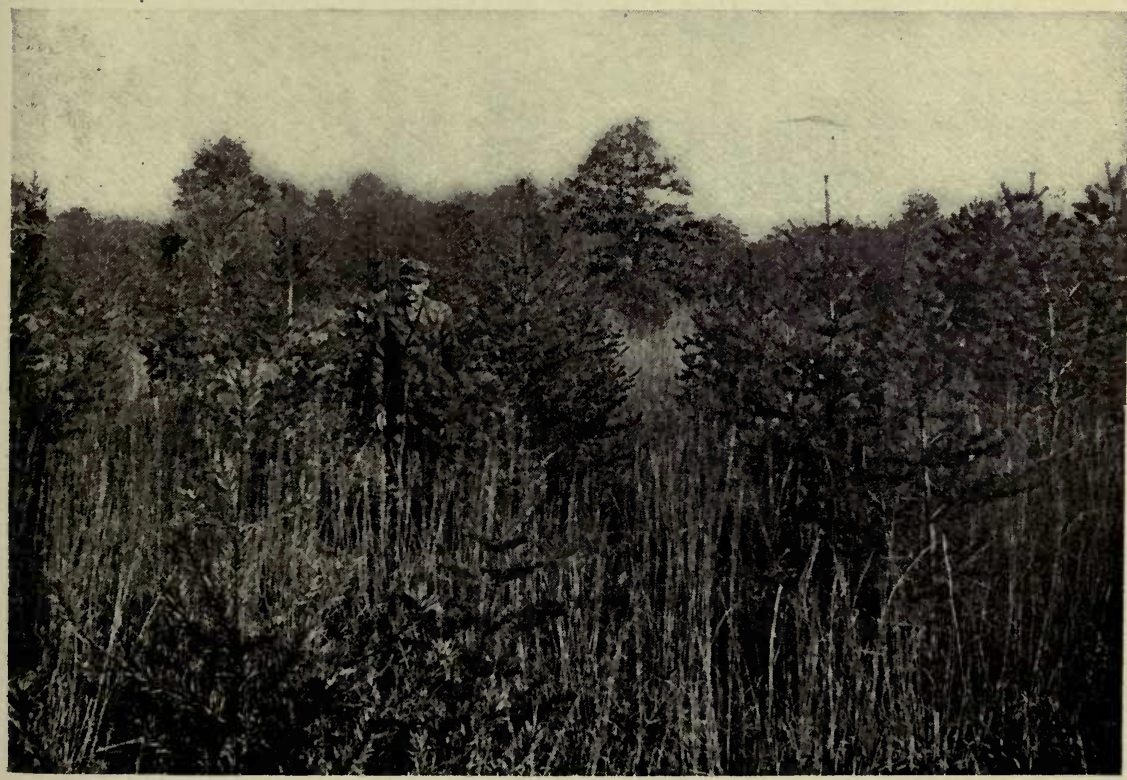

Fig. 13. The Same Spot Six Years Later. SUCCESSFUL FOREST PLANTING. 

soils and though the land is often given over to neglect, that condition is temporary only. Every acre of agricultural land will be needed before any planted trees could reach maturity. Moreover it would be foolish to plant a forest on cleared land when other land with a forest already started can be bought nearby for less than the cōst of planting.

Forestry in New Jersey does not exclude tree planting but subordinates it to fire control, to the development of existing forests, to agricultural needs.

The Forest Commission would like to be informed of the location and character of all forest plantations in the State in order that they may be recorded and become available for silvicultural studies.

\section{STATE FOREST RESERVES.}

The State reserves havc not been increased in area but are steadily growing in value--a proof that even the most degraded of our woodlands can and will revive under simple protection and reasonable care. It sounds well to announce that a State is acquiring a great area of public forest, yet, unless the property is actually improved by passing from private to public ownership, the advantage to the people is nothing. Indeed the only justification for assuming control is that the State will do what the individual does not and will develop the forest for public advantage. New Jersey's Forest Commission is therefore wise in holding to its decision to create forest reserves only when they can be used to advance the understanding and practice of forestry by private owners. In general this end will be gained by numerous small reserves, so located that their good condition and careful management will inspire woodlot owners and forest owners to do the right thing with their own. Mount Laurel reserve is the ideal-see page 64 , and an effort is now making to secure othe suitable tracts.

PURCHASE OF RESERVES.

This argument in no sense precludes the acquisition of other lands having especial value. Thus this year the legislature was asked for, and made, an appropriation to buy 70 acres lying in an angle of Bass River Reserve. The land was offered at a low price and its purchase would round out the State lines. Unfortunately the 
title was found so defective that nothing could be done. It was necessary to cancel also a contract made in 1909 for the purchase of another tract of II 2 acres, again because a clear title could not be given.

\section{LAND TITLES.}

It is apparent that our law is too stringent in respect to the title of wild lands. Lax methods and defective records have created such a general clouding of titles in some sections that it is almost impossible to find a property that is entirely free of some technical defect. That most of these defects can be ignored is evidenced by the fact that properties rejected by the Forest Commission are afterwards bought by individuals and that ordinary transfers are constantly made. The State would run little real risk if the law were so changed that the Attorney General could approve a title of ordinary commercial integrity.

\section{WHARTON TRACT.}

A project that promises to bring a great tract of forest into the control of the State is that now being considered by the Water Supply Commission to create a water reserve in South Jersey. Though this scheme has for its prime object the utilization of the potable waters of the region it necessarily involves the protection and utilization of the forests. These forests, though of comparatively little present value, are easily capable of being so developed that they will yield after thirty or forty years more than enough to pay the interest on the cost of the property. If New Jersey shall reserve to her people this dual resource, water and forest, she will have gone further in true conservation than any other State.

The forest lands now held by the State are as follows:

\section{LOCATION AND AREA OF FOREST RESERVES.}

Mays Landing Reserve, Atlantic County, see Map in Report, 1907. 373 acres Bass River Reserve, Burlington County, see Map in Report, 1907. . 1,633 acres Lebanon Reserve, Burlington County, see Map in Report, 1907... 3,498 acres Mount Laurel Reserve, Burlington County no Map published.... 20 acres Penn Reserve, Burlington County. See Map in Report 1911... 2,764 acres Edward C. Stokes Reserve, Sussex County. See Map in Report

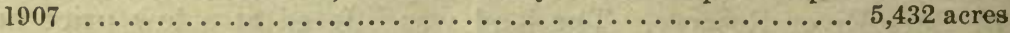



These properties cost but $\$ 45,277$, or an average of $\$ 3.30$ per acre. In a State like New Jersey therefore they are almost sure to be a good investment, cven when the charge for administration and protection is added.

\section{COMPENSATION TO TOWNSHIPS.}

The communities in which the reserves are located are taken care of by the law (Comp. Stat. p. 2609) providing for the annual payment to the local treasury of two cents for each acre of land held by the State and therefore exempt from tax. The amount is fair in all cases except that of the smallest reserve.

\section{TRESPASS.}

Trespass in the State forests is practically unknown. In two instances small amounts of wood were cut on Bass River Reserve but it was easily shown that the crossing of a partly obscured line was unintentional. Settlement was made by requiring payment of the market price of the wood. Neither case warranted the imposition of a penalty. The respect that is universally accorded the State's property may be ascribed to the vigorous prosecution of every offender, combined with a liberal policy regarding every reasonable use of the land. That is, the people have perfect freedom on the reserves to hunt, fish or do what they will but they must do no damage nor remove anything of value except wild berries. See Fig. 2.

\section{MARKING BOUNDARIES.}

Considerable time has been given to making resurveys of some of the reserve boundaries, and to setting permanent corners. This work is slow, but it is important to establish definitely and to mark permanently the boundaries of the land belonging to the State. This work will be continued and in some cases boundaries will be marked by thinning the forest in a belt two rods wide, or by planting belts of exotic trees, instead of by the usual blazes. The purpose of this is to make the lines permanent. A blazed or cleared line is soon obscured by new growth while a "thinned" line becomes more and more distinguishable through the stimulated growth of the favored trees, the suppression of undergrowth and the consequent contrast with the surrounding forest. See p. 66 , also Fig. 3 . 
FIRE,

The year's record is again good. Only Ioo acres burned on the Penn Reserve-the first fire that has touched it since the State came into posession, and a fraction of an acre on the Stokes Reserve. Lebanon escaped entirely for the first time in its history - as a reserve at least. Bass River, Mays Landing and Mount Laurel likewise have not suffered. This satisfactory situation is due only in part to favorable weather conditions. If either of the two fires started had not been discovered quickly and handled energetically it probably would have become serious.

The properties are more secure than they ever have been because more and better fire lines are maintained (Fig. 3) because township wardens as well as reserve wardens are vigilant, and, above all, because the strict enforcement of the forest fire law (see p. 28) is making everybody mo:e careful about fire. A few more years of immunity will carry many of the young pine stands beyond all ordinary danger, for it is the great virtue of our common yitch pine that after early youth it is highly fire-resistant. Fig. 2.

TELEPHONES.

A measure of protection which the reserves enjoy in common with the forests that surround them is found in the Federal fire patrol-see p. 48 , in the postal service patrol, and in the constantly extending telephone service. So important and so valuable is the latter that the Forest Commission felt justified in securing the erection of a line from Chatsworth, Burlington County, to a private cranberry bog on the East Branch of Wading River and contributing \$300 toward the cost. This line, nine miles long, traverses Penn Reserve and brings into communication a section of the State having few inhabitants but much subject to forest fires. To this construction all property owners except one gladly consented and gave free right-of-way. It is worth observing that this objector demanded $\$ 250$ for the right to set poles on his land. Of course he did not get it, one sufficient reason, though not the only one, being that a strip of similar land roo feet wide and as long as the line across his property can be bought in fee simple for $\$ 50$. The telephone line was carried around the objector at an additional cost of less than $\$ 40$. 

SHELTER CABINS.

Another means of helping to control fires is provided by the erection of cabins where tools can be stored and, at need, men find shelter. One is located on Lébanon Reserve and one on Penn Reserve near points from which a good outlook can be had and convenient to the telephone. As no stream is near each is also provided with a pump to furnish water for fighting fire as well as for drinking. Other similar cabins probably will be built from time to time. They cost with equipment about \$I 50 each.

\section{FOREST PLANTATIONS.}

No new plantations lave been made within the year. Those established last year and earlier have been so handicapped by successive droughts that it has been thought advisable to hold up this work for a time and meanwhile to plan for a series of experimental plantings that may be expected to indicate quite definitely what species of trees are best adapted to our conditions. Fortunately we have no reserve land that lacks forest and must be planted to redeem it. The fifty or sixty acres that are cleared give no more ground than is needed for experiments.

\section{PRODUCT OF THE RESERVES.}

Forestry is justifiable when it produces tangible results. Forest reserves must yield an income to the State, in money that represents current interest on the investment, in material that its citizens need, or in improved living conditions-fresh air, pure water, convenient play grounds. The aim of the reserve management is to do all these things. But as often happens the last is apt to be first. No forest as degraded as those on all the reserves but one can be expected to yield much timber for many years; it can, however, soon yield many benefits, as the reserves now do.

On the material side each reserve produces a little: some firewood, a little moss, a few cranberries. The total receipts for the year were $\$ 508.57$ though the greater part, $\$ 410.95$, came from an improvement cutting of 20 acres on Mount Laurel. 
Unfortunately this demonstration cannot be repeated for some time. There is a body of mature pine ori Penn Reserve but it must await better transportation facilities before it can be marketed. On the other southern reserves the timber is too young to be cut, or is needed to furnish seed for reproduction. Stokes Reserve carries a great quantity of scrap wood, at least 30,000 cords, which should be got rid of, but thus far it has been impossible to interest any user in the situation. As the timber cutting contract which formed part of the purchase price will expire next spring and the property come under the absolute control of the Forest Commission it may be possible to do something then. This reserve probably is the most valuable that the State possesses, for while it is remote and the forest has been heavily cut there is a great number of vigorous half-grown trees. (Fig. I4). Ten years more of protection, with such improvement fellings as may be found practicable, will develop a considerable volume of merchantable timber.

\section{MOUNT LAUREL IMPROVEMENT.}

This little reserve of 20 acres carried a forest of hardwoods and pine, 40 years old, that needed attention. long before it came into the possession of the State. By an improvement thinning made last winter 45 per cent of the stand was removed at a net profit of not quite $\$ 300$. The remainder forest is better than that which was found. The fellings, and the studies that folowed them, afforded so good an example of what forestry really does that they were used as the basis of a special bulletin entitled "An Example of Woodlot Forestry." This has been widely distributed and will be furnished anyone upon request. 


\section{SHADE TREES.}

"Greater activity and interest than have ever been shown" sums up the shade tree situation. This is evidenced in newly appointed Shade Tree Commissions, in increased appropriations for old commissions and in much individual effort.

The Forest Commission is in close touch with all the more active Shade Tree Commissions and by conferences and periodical inspections aims to help each solve its peculiar problems. The Commission's foresters are always ready to aid as they can the officials of any community.

SHADE TREE COMMISSIONS.

As a means of measuring the strength of local interest in shade tree work, letters of inquiry were sent to officials in the 180 cities. towns and boroughs, which, by reason of having a population of I,000 or more, were assumed to be interested. The replies show that no less than 4I communities have established and are maintaining more or less efficiently, a Shade Tree Commission or equivalent agency, and that their combined annual resources are $\$ 85,000$. The extent of the activities of these bodies is summarized on pp. 68 and 69. 


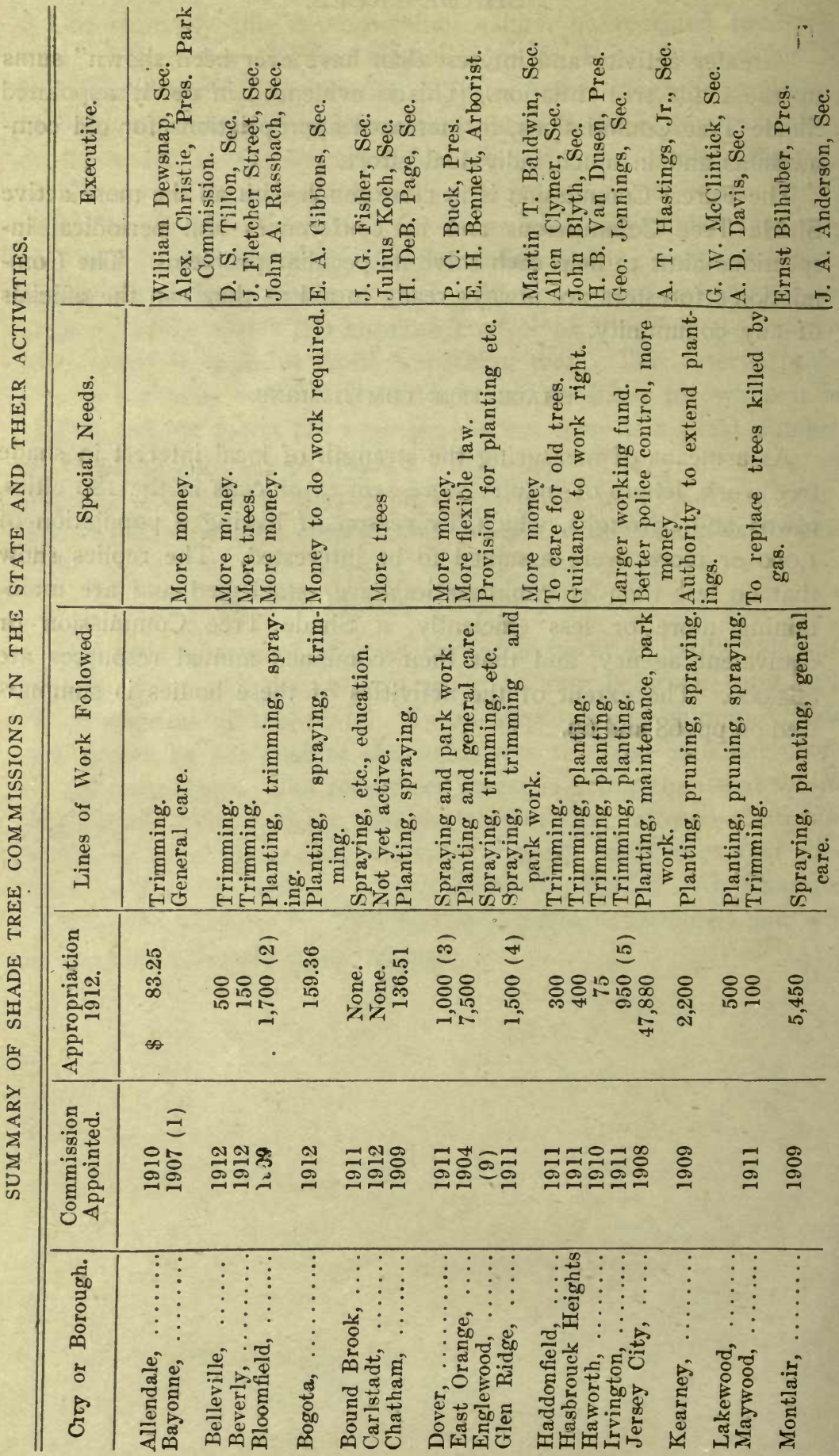




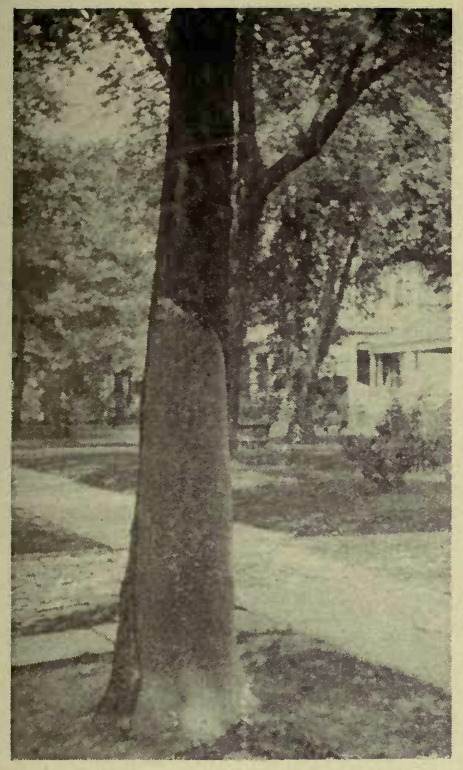

Fig. 19. A Street Tree Half Killed by Abuse and Neglect. Doctored, It has a chance to Live Many Years. In This Case Filling Was Necessary. [Photo by E. H. Bennett, East Orange].

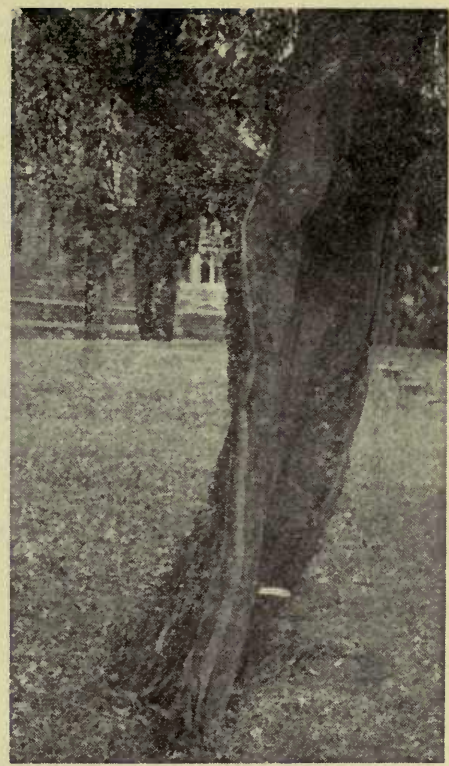

Fig. 20. Fragment of Tree Cleaned and Painted. It Often is Better to Treat a Tree Like This Than to Fill It With Cement. Note Healthy New Growth at Edges.

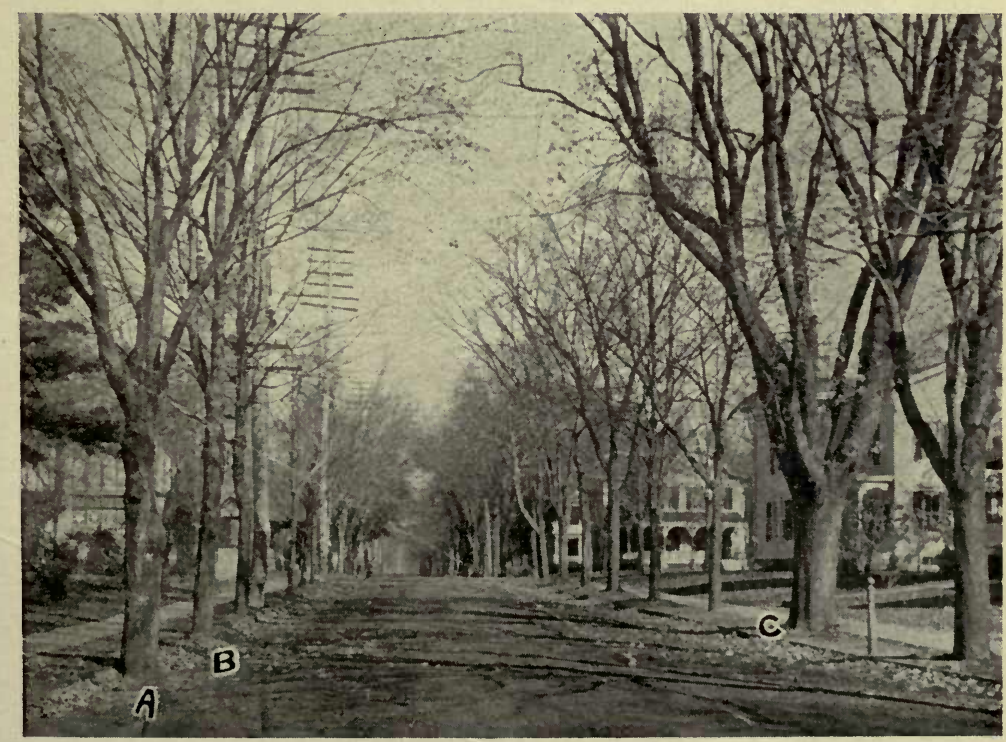

Fig. 2I. Street and Sidewalks Newly Made Without Destroying Old Trees. Tree A Stands in the Gutter, Tree B in the Curb Line, Tree C Cuts Into the Sidewalk. 



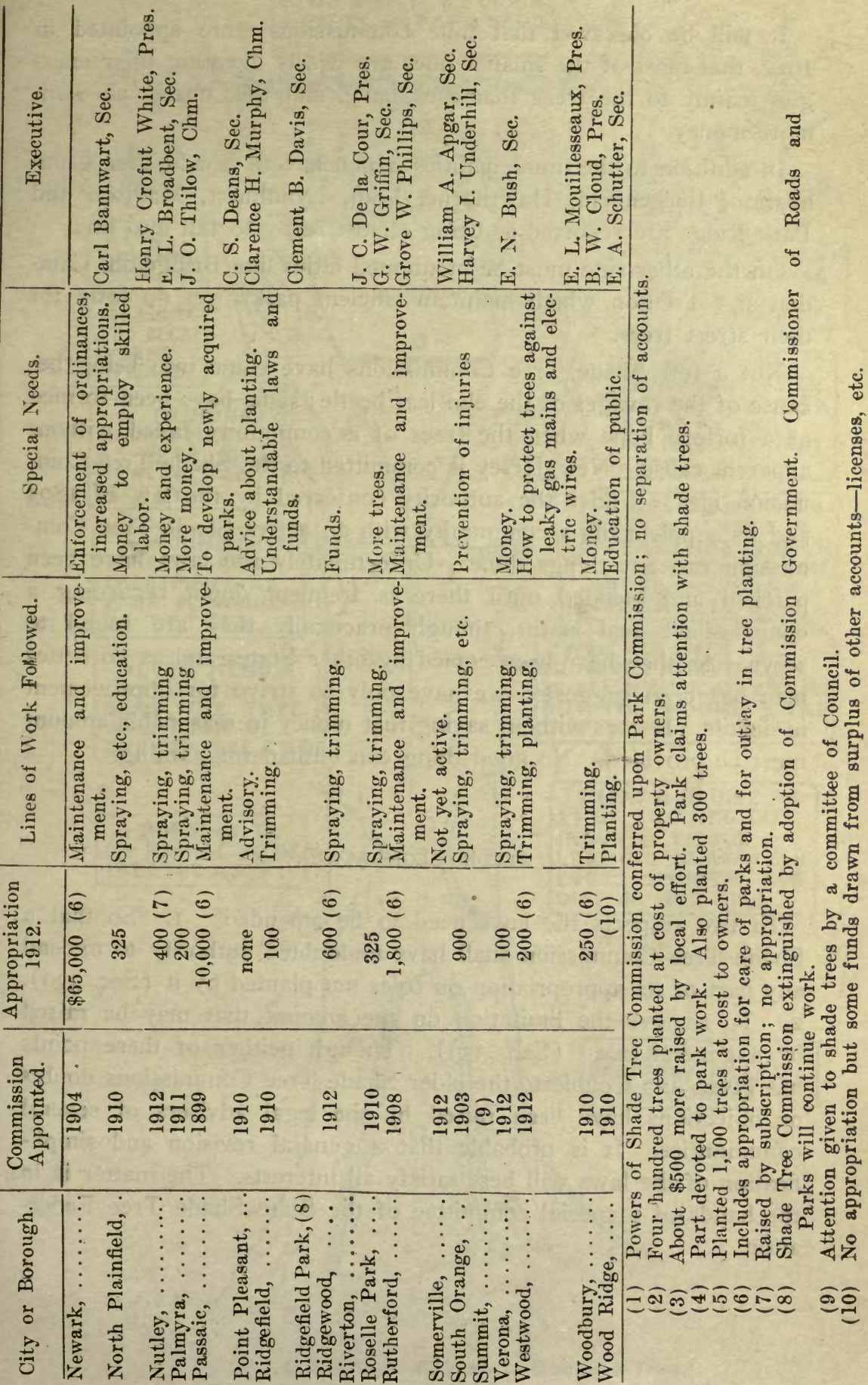


It will be observed that nine commissions were appointed in 1912, that most of the smaller ones are wisely devoting their energies mainly to the trees that they have, and that nearly all want more money.

In addition to the municipalities which have a Shade Tree Commission, Bergenfield, Hawthorne, Lodi, Lyndhurst, Madison and Park Ridge are reported as being almost ready to fall into line.

On the other side must be mentioned cities like Bridgeton, Camden and Trenton which maintain efficient parks, yet do little for their street trees.

Not a few Shade Tree Commissions have come into being because of the ravages of the elm leaf beetle; some have been formed as a forlorn hope when the trees of a community failed without apparent cause. New Jersey is committed to the Shade Tree Commision idea. Under the authority conferred by the law of 1893 and its supplements a community with an active Shade Tree Commission can get things done. Unfortunately the laws have been patched and mended until there is frequent doubt regarding a commission's real status, though practically they are found to serve. As they have been copied by other States and as no better plan has been suggested we have only to strive for improvement in details. It goes without saying that money in reasonable amount must be provided. No good thing can be had for nothing.

\section{NEEDED LEGISLATION.}

In two respects the laws need to be amended: I. So that a Shade Tree Commission shall have undoubted authority to expend any part of its appropriation on trees not planted by it ( $\mathrm{Sec}$. 339). 2. To remove the limitation on the amount that may be raised by a general tax. (Sec. 339). Though neither of these points has given any trouble to the older Shade Tree Commissions doubts or objections have been raised by the legal advisers of several communities. It is probable that a general revision and simplification of the laws will best satisfy all interests. The matter is in the hands of a special committee of the State Shade Tree Federation. 


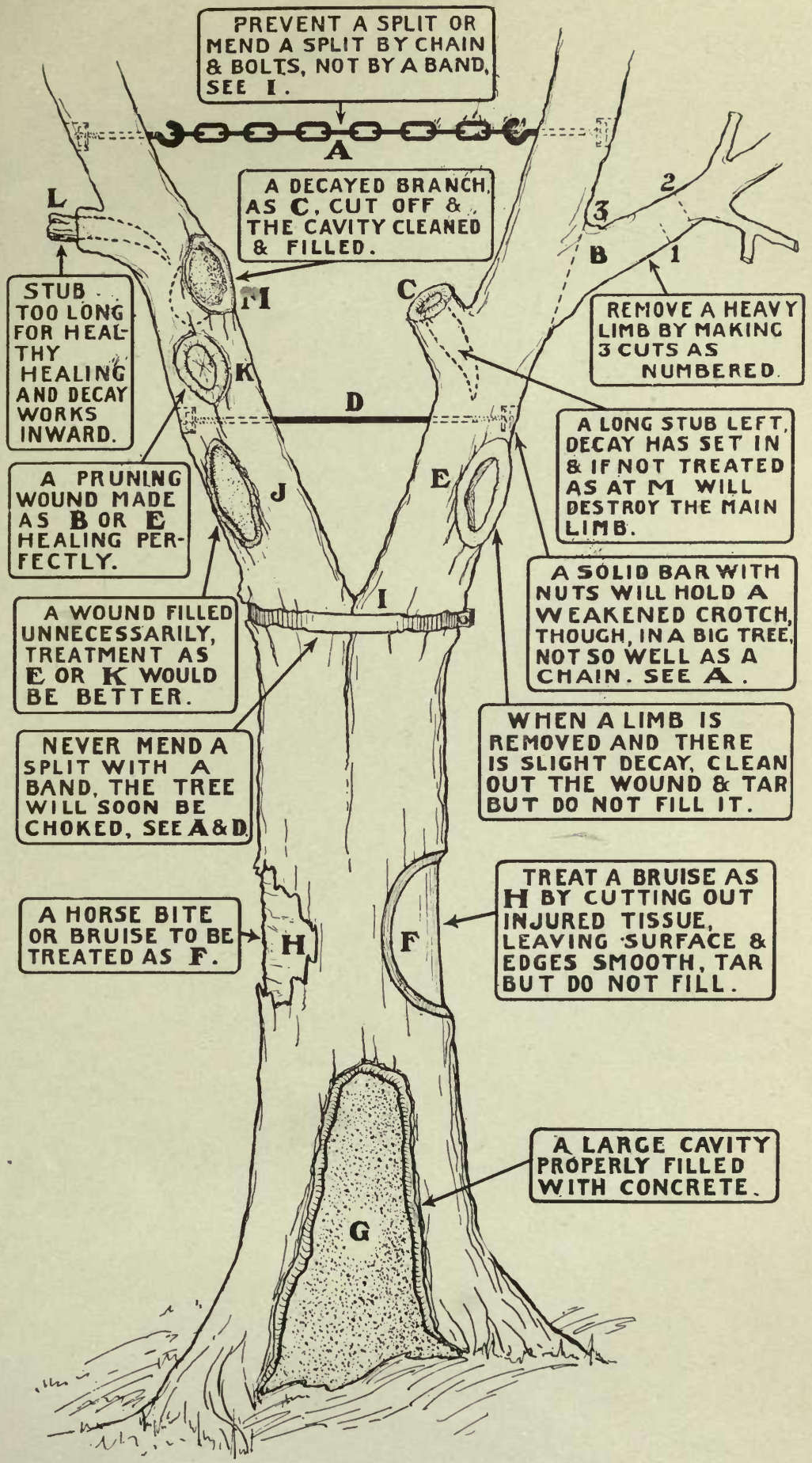

Fig. 22. Diagram-How to Doctor a Tree.

From "The Planting and Care of Shade Trees", 1912. 

CO-OPERATIÓN.

The maintenance of shade trees involves active co-operation between the State, the municipality and the property owners. The State's interest is to make its territory good to live in and good to visit, to stimulate activity and to harmonize differences: the municipality stirs civic pride and through the exercise of its police power, enforces what is needful. Individuals by yielding the control over their trees give the work unity and coherence. Evidence of the accomplishment of the Shade Tree Commissions is easy to find in any community where one has been at work. In one town the elms will have been saved by spraying, in another the chief effort will have been directed to planting, in a third settlements have been made with the gas company, in a fourth some other trouble has been overcome. What can be done is indicated in the following report made by the President of the Maywood Shade Tree Commission.

"We have induced the Public Service Electric Light and Telegraph Company to take off from our streets the large unsightly poles which brought the wires right in the crowns of our trees, doing much damage to tree and wire. These poles were replaced by shorter painted poles, each with a horizontal arm under the trees carrying the wires at a height (20 feet above the walk) where the heavy limbs would not sway in the wind and the end of the horizontal bars is used for the street light. We have these poles in our main street under our large silver maple shade trees and experience no trouble in any way, and while there was some kicking at first, everybody is well pleased now and the avenue looks fine and orderly."

\section{ROADSIDE TREES.}

In the revised State highway law passed by the last Legislature the State Commissioner of Public Roads is authorized to require that any road made with State aid shall be tree bordered and that the Forest Commission shall provide the necessary plans. The same law also provides that the Forest Commision shall decide when differences arise involving roadside trees. It was deemed advisable to make object lessons on State-aid roads rather than seek the enactment and attempt the enforcement of a more general law. Desirable as roadside trees are more will be accomplished by arousing local sentiment in their favor than by striving to establish them against the wish of the communities most concerned. The specifications under which this work will be done are as follows: 
APECIFICATIONS FOR SHADE TREES ALONG STATE-AID ROADS.

Rows of shade trees consisting of one or more of the following species, to be detarmined by the State Forester, shall be planted on either side of the said highway: White Elm, Red Oak, White Oak, Scarlet Oak, Pin Oak, Tulip Poplar, Sycamore, Basswood, Sugar Maple, Norway Maple, Red Gum, Ginkgo, Lombardy Poplar. Each tree shall be obtained from a reputable nursery, not less than 2 inches in diameter at $4 \frac{1}{2}$ feet above the ground, well grown, healthy, and with fully developed roots and symmetrical crown.

If native trees of acceptable species shall be found on or near the planting line they may be designated by the State Forester to stand permanently. Such designated trees will take the place of those required to be planted in approximately the same situations.

Holes shall be prepared in advance of the delivery of the trees on lines to be established by the State Road Commissioner and spaced 50 feet apart. Each hole shall be 3 feet in diameter and 2 feet deep. Rich loam, humus, or stable manure shall be provided for a proper bedding of the new trees as may be required by the State Forester.

Each tree shall be set carefully under the direction of the State Forester, and shall be securely fastened to a chestnut or oak stake $21 / 2$ inches in diameter and 8 feet long driven 2 feet into the ground. The fastening by which the tree is secured to the stake shall consist of a length of number $10 \mathrm{gal}$ vanized iron wire eovered with half-inch rubber tubing.

If in the judgment of the State Forester the safety of any tree requires it, a strong guard made of 3 inch by 1 inch by 6 feet wooden slats according to a design to be furnished shall be placed about it.

All trees planted or designated as a part of the road construction shall be subject to inspection by the State Forester and as required by him shall be pruned, doctored, fertilized or replaced by the township supervisor to the end that the established rows may be maintained in their integrity.

\section{-SHADE TREE TROUBLES.}

More and more citizens, more and more communities turn to the Forest Commission for advice when their trees are in trouble. An effort is made to consider every case; frequently the inquirer can be given all necessary information in a letter: often a visit to the locality is made. The difficulties encountered are due most often to neglect, sometimes to insects, occasionally to leaky gas mains or to fungi. Rarely is the trouble so serious that more than a few trees need be lost. Often prompt treatment will save those that are in worst condition.

To the Shade Tree interests of the State the Forest Commission offers a helping hand and the recommendation that ills and dangers be avoided by anticipation. Street trees have a hard life at best; whether they thrive or struggle through a brief existence, depends upon the wisdom exercised in their choice, and the extent to which they are guarded, watered and fed. It is especially important to consider the effect upon standing trees of contemplated street improvements. In many old towns it is impossible to make uniform 
street grades and straight curb lines without injurying trees. A solution of such difficulties must be sought in compromise, before: not after, the street work is begun. And those whose trees have been injured or killed by illuminating gas are recommended to make sure of the facts, and upon them, not upon assumption, to enter reasonable claims upon the responsible company. Exorbitant demands will be contested, naturally, but in our experience a loser can always get fair compensation, or a new tree of good size, without resorting to legal action.

\section{DROUTH.}

The dry weather that last year caused the loss of so many valued trees was less universal this year. Deficiency of rainfall again made some trouble but only where the trees were newly planted or where reasonable care had been long denied. The occurrence of periodical droughts emphasizes the need of systematic care for all valued trees.

\section{SHADE TREE BOOK.}

Through the generosity of Mr. Charles Lathrop Pack, a member of the Forest Commission, it was made possible to publish in attractive form a revised edition of the series of papers on the Planting and Care of Shade Trees first issued in the Commission's report for 1908. This publication apparently meets an actual need in that it tells what to do when trees are to be planted, when they are injured, when they suffer in any way. The book is still available and will be sent to any citizen who asks for it.

\section{ASSISTANCE TO FOREST OWNERS AND OTHERS.}

The organization now maintained by the Forest Commission makes it possible to give proper attention to private interests as well as to look after the State forest reserves. Assistance may be asked for by any citizen who wants to develop a forest, to plant a forest, to provide for the proper care of shade trees, or to remedy some ill or danger to shade trees or forests. Advice by mail will be given freely. When the situation warrants or requires an examination a competent forester will be sent to study it and give advice on the ground. For such service individuals are required 
to pay only the forester's actual expenses while away from Trenton. His salary is paid by the State. Municipalities and institutions will pay nothing. No young trees or seeds are furnished by the State. Special advice and assistance will be given any organized Shade Tree Commission without charge unless extended service is desired. In that case a definite arrangement will be made.

\section{TREE PESTS.}

The number of tree enemies in no wise lessens. Chestnut blight, elm leaf beetle, fake tree-doctors and their kind are still with us. Nevertheless, our tree interests are better off in this respect than they ever have been. The State Plant pathologist appointed last year, Dr. Mel. T. Cook, has his office organized and already has four assistants studying plant diseases and enforcing the laws regarding them. On October I a new State Entomologist, Dr. T. J. Headlee, took up his duties as successor to the lamented Dr. John B. Smith. Thus with active officials and adequate laws the State is well provided to hold in check all diseases and insects dangerous to plant life. With these officials the Forest Commission and its foresters are working in complete harmony.

Another factor of great importance is the passage by Congress of a law, as recommended in our report for I9I, authorizing the Secretary of Agriculture to restrict, or to prohibit, the importation into the United States of diseased or insect-infested plants; to prohibit the importation of any or all plants from a country or district known to harbor diseases or insects dangerous to plants, and to control the movement of diseased or infested plants from one State to another. New Jersey needed this law more than most States because so many foreign plants are landed here. Under it the importation of White Pine from certain districts in Germany, where the Blister Rust (See p. 77) is prevalent, is prohibited. An embargo has been placed also on the shipment of Christmas trees from sections of New England infested with brown-tail and gypsy moths.

The present situation with respect to the more serions tree pests is as follows: 


\section{CHESTNUT BLIGHT.}

This disease has become so wide-spread and so serious that the whole country is aroused. All efforts to check it have proved un. availing and those who know most about it, the plant pathologists, are agreed that much systematic study is necessary before an effective remedy is likely to be discovered. Meantime the blight may run its course or gradually become innocuous.

The State Plant Pathologist has been appointed a member of the Federal Board authorized by Congress to study the disease in all its phases. Of the $\$ 80,000$ appropriated for this purpose, a considerable portion has been allotted to this State. A more detailed account of this work will be found in the report of the State Plant Pathologist.

In so far as New Jersey is concerned we are still bearing the brunt of the attack. No infections have been reported from Salem or Cape May counties, but elsewhere the progress of the pest is steadily westward and southward. Whether this progress is more or less rapid than it has been can not be determined; there are some indications that it is slightly more sluggish in its progress and in its virulence. But there is no reason to modify the recommendations heretofore made, namely:

Where trees valuable enough to warrant some expense are concerned it may be worth while to try to prolong their lives by prun. ing. No assurance can be given that such treatment will prove of more than temporary value, yet as nothing else will avail at all it may be resorted to. Prompt treatment of this kind is recommended in Salem and Cape May counties where the disease has not yet cbtained a foothold. Specific directions for such pruning will be sent upon request.

In all other cases, and this applies to practically every body of forest, it will be wisest to convert the trees into timber as soon as the disease appears and allow the young oaks, etc., that may have started under them to fill their places. Where there are large gaps evergreens should be planted. There is not the slightest use anticipating the actual death of any tree for our whole territory is so full of spores that to fell it would have no effect. On the other hand every dead tree should be promptly removed lest it provide breeding places for harmful insects or lodgment for the germs of other diseases. The blight is not known to attack any other species 
than chestnut, notwithstanding many published statements to the contrary.

Chestnut wood from trees killed by the blight is as sound and good for ordinary purposes as the wood of trees felled while in health. It is important to see that all lumber or cordwood shipped out of the State, or into the southern counties, is completely barked since it has been learned that the disease may live in unbarked logs or wood for six months or more. Markets for chestnut lumber are still good, though it must be borne in mind that the wood from one or two isolated trees is less valuable than where a large quantity is offered.

\section{ELM LEAF BEETLE.}

The ravages of this pest have been notably less than for several years past. This is accounted for in part by a much more general resort to spraying and in part by the establishment of a parasitic eneny. True, many trees have died; they were invariably those that have been neglected. We may be so fortunate as to find this pest retreating as it did a dozen years ago, but the time to relax vigilance has not come. No elm tree need die of the leaf beetle; timely and careful spraying with arsenate of lead is an infallible remedy. The effect of this treatment can be seen almost anywhere in North Jersey where sprayed trees in perfect health stand beside those dead and dying which have not been sprayed. Specific directions for spraying will be given by the Forest Commission, or by the State Entomologist, though tree owners are recommended to turn first to their local Shade Tree Commision. Apart from other advantages a Shade Tree Commission can have such work done much cheaper than individuals. It may cost anywhere from $\$ 5$ to $\$ 20$ to spray a single tree; if the owners of 50 or more trees unite the cost may be $\$ 2$ or less.

\section{BROWN-TAIL MOTH AND GYPSY MOTH.}

Neither of these most dangerous insects has been established in the State, and the likelihood that either will be is greatly lessened by the passage of the National quarantine law referred to above. Under it the Secretary of Agriculture has prohibited the shipment from the infested territory of plants, lumber and anything that may carry the pests to new territory. New Jersey is fortunate in having 
this Federal law to supplement her own efforts to prevent these pests from getting a foothold in our territory. The New England States are still spending upwards of $\$ 2,000,000$ a year in the effort to save some portion of their woodland from ravage.

WHITE PINE RLISTER RUST.

No new case of this disease has been discovered in the State, and though we are still going slowly in planting white pine there is now a reasonable assurance that the disease will not become established. Nevertheless, there is a danger and on that account it is advisable always to use only a small proportion of white pine in any forest planting. Owners of pine plantations may be assured that the disease attacks only pine trees with five needles, never those with two or three needles, in a sheath. As the disease is of foreign origin, planters are especially warned against buying imported material. A guarantee amounts to nothing, and State or National inspection may fail, as in its earlier stages the disease is very obscure.

\section{HICKORY BARK BEETLE.}

Numerous instances of damage done by this insect have been reported, though in practically every case an examination has shown that the affected trees were weakened by fire, lack of food, or in some other way made unable to offer a normal resistance to the atack of the insects. There is no evidence that the hickory trees in our territory are likely to be exterminated or even to be greatly damaged.

For the benefit of those who have been alarmed, or may be otherwise interested, it can be stated that the pest manifests itself by small openings in the bark of the stem, from which refuse like sawdust is often extruded. If a tree has many of these "shot holes" cut it down and burn the wood at once as it cannot recover and its preservation simply gives the insects a chance to multiply and spread to other trees. If the atack is on the twigs only, causing them to wilt or break off, let all affected twigs be cut off with a tree pruner and burned. After such treatment a tree will ordinarily revive. On small trees it is sometimes possible to follow up the insects in their burrows with a wire or to kill them by injecting carbon di-sulphide. Ordinarily, however, neither of these means is practicable. In all 
instances where the beginning of an attack is observed, or before one is observed, let the trees be well nourished and watered.

\section{OTHER INSECTS.}

The list of insects that do serious harm to trees in this State is short. During the late summer patches of oaks in South Jersey, sometimes of considerable size, were completely defoliated by the striped oak worm. Insofar as the attack was confined to scrub oak, and that seems to be the creatures' preference, it was decidedly beneficial. Some tree oaks of many species were also injured, yet no great harm was done. The worm is one that is constantly with us but is held in check by its natural enemies.

In the same section, and in some plantations in the North, two and three needle pines were defoliated by the larvae of a saw-fly. In piantations a permanent injury is sometimes done, in the natural forest there is little to be feared.

Any type of insect like the two described can be easily controlled where trees are valuable enough to justify spraying. Arsenate of lead as for the elm leaf beetle is best for any deciduous tree. Evergreens may be treated in the same way, though the mixture should be not more than one-third as strong. A better remedy for the latter is a spray composed of one pound of whale-oil soap and one half pound of arsenate of lead in six gallons of water.

Locally the cottony maple scale, the maple pseudococcus, and the tussock moth have injured shade trees, usually in consequence of previous weakening. Remedies for any of these will be found in our Shade Tree book. (See p. 73.)

\section{TREE DOCTORS-WARNING.}

Once more a warning against fake tree doctors must be published. One or two of these men have been driven from the State, but several are still preying upon tree owners. The fact that many trees need spraying or filling, that many chestnuts are dead of the blight and must be removed, that it is becoming the fashion to do something to one's shade trees, induces property owners to listen to these men. Do not trust your tree work to the first man that comes along, but seek a reputable workman. No chestnut tree can be cured of the blight. A wound badly filled, or unnecessarily filled, would 
be better left open, and a tree that is sprayed carelessly or with wrong material will be benefited as much as, and no more than, one that is butchered under the pretense of being pruned. It is a sheer waste of money to pay unknown men for work of this kind. And if dead trees are to be sold it is well to remember that the wood is not useless but usually has a value greater than is represented by the cost of removing it. Tree owners and forest owners are warned against men without credentials. Those who have work of this kind to do are advised to seek assistance of the local Shade Tree Commission, of the Forest Commission, of the State Entomologist or of the State Plant Pathologist. All have knowledge of reputable parties. 


\section{INDEX.}

A.

Agriculture,

Aid, State,

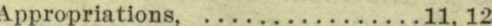

Area of Woodland, ......... 5

Assistance to Forest Owners, .... 73

Automobilists Fires, ......... 21

B.

Brown-tail Moth, ......... 76

Brush Burning, . . . . . . 18, 19, 20

Fires, $\ldots \ldots \ldots \ldots \ldots \ldots$ 18, 19, 20

Boundaries, Marking Reserve, .... 63

c.

Cabins, Shelter, $\ldots \ldots \ldots \ldots \ldots \ldots .65$

Campers' Fires, ........... 21

Clestnut Blight, $\ldots \ldots \ldots \ldots \ldots .59,75$

Co-operation

With Federal Government, .9, 48, 64

With Fish and Game

Commission, ......... 50

With Private Owners, ..... 50

With Railroads, . . . . . 41, 52,-56

Re. Shade Trees, ........ 71

With State Road Commissioner, $\ldots \ldots \ldots \ldots \ldots \ldots 1,71,72$

With Water Supply Commis.

sion, $\ldots \ldots \ldots \ldots \ldots \ldots \ldots \ldots$ 10, 62

Cordwood, .............60, 66

Cost of Forest Fire Service, 12-14, 24-28

Cost of Forestry, ..........12-14

D.

Diseases, Tree, ......... 74-77

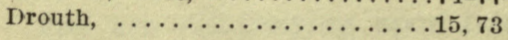

E.

Elm-leaf Beetle, .......... 70,76

Entomologist, State, ........ 74

Evergreen Trees, ........... 60
F.

PAGE.

Farm Land, ............. 7

Federal Co-operation, .......9, 48, 64

Financial Statement, ........13, 14

Fire Car, ............. 56

Fire Lines, . . . . . . . . 8, 19, 52-56

Fire Patrol, .......9, 19, 48, 49, 64

Firewardens, $\ldots \ldots \ldots \ldots \ldots \ldots 14,22$

Fireworks, ............ 21

Fish and Game Commission, Co-op-

eration with, ........... 50

Forest Area, ........... $5,20,21$

Forest Fires, .........24-27, 57,64

Area of, . . . . . . 8, 16, 17, 24-27

Causes of, $\ldots \ldots \ldots \ldots \ldots, 18,20$

Control of, .......... 18

Cost of, . ......12, 14, 24-27, 28

Loss by, . . . . . . . 16, 24-27, 28

Number of, $\ldots \ldots \ldots \ldots 8,16,24-27$

S'eason of, ........... 15

Forest Fire Service, ...66-9, 21, 23, 28

Cost of, $\ldots \ldots \ldots \ldots \ldots \ldots$ 12-14

Forest and Land Values, ....... 57

Forest Management, ........58, 59

Forest Owners, ......... $50,57,58$

Forest Planting, ....5, 9, 58, 59, 60, 65

Forest Reserves, .........10,61-66

Area and Location of, ...... 62

Cost of, . . . . . . . . 63

Fire on $\ldots \ldots \ldots \ldots \ldots \ldots .64$

Value of, $\ldots \ldots \ldots \ldots \ldots \ldots 61$

Forestry, Private, ...6, 9, 50, 57, 58, 61

G.

Gypsy Moth, .......... 76

H.

Hickory Bark Beetle, ........ 77

Highways, State, ........51, 71, 72

Huckleberry Pickers, ......... 21

Hunters' Fires, . ........... 21

I.

Incendiary Fires, $\ldots \ldots \ldots \ldots \ldots 20,21$

Income of Forest Commission, ... 14 
PAGE.

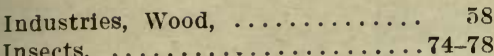

Insects,

\section{L.}

Lakes, $\ldots \ldots \ldots \ldots \ldots \ldots \ldots \ldots \ldots, 11$

Land and Forest Values, ...... 57

Land Titles, ....................... 62

Land, Traffic in, ........... 6

Law, Enforcement of, . . . . . 9, 28, 41

Legislation, .............. 11, 70

Lookouts, Fire, ..........49, 50

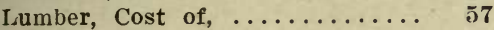

Directory, ........... 58

M.

Manual, Forest Fire, ......... 23

Markets, Wood, ............

Mount Laurel Reserve, ........10, 66

o.

Oak Worm, Striped, ........ 78

Organization of Forest Service, .. 14

\section{P.}

Pathologist, State Plant, .....74, 75 Patrol, Fire, ........9, 19, 48, 49, 64 Federal, ............. 64

Railroad, ............. 19

Rural Mail, ........... 9, 64

Penalties, $\ldots \ldots \ldots \ldots \ldots \ldots \ldots 9,28,41$

Permits, Brush Burning, ....... 19

Planting Forest, .... 5, 9, 58, 59, 60, 65

Policy of Forest Commission, .... J Private Forestry ....6, 9, 50, 57, 58, 61

Promotion Schemes, ......... 6 Publications, $\ldots \ldots \ldots \ldots$ 10, 11, 23, 66, 73

\section{R.}

Railroads, Co-operation with, .41, 52-56 Railroad Fires, .........8, 18, 20 Railroad Fire Lines, .......8, 52-56 Iieserves, Forest, ........10, 61-66

Income from, ........... 10

Product of, $\ldots \ldots \ldots \ldots \ldots \ldots$ 65
PAfE.

Road Commissioner, State, ...51, 71, 72

Road-Sides, Care of, ......... $\mathbf{5} 1$

Danger in, ............ 51

Road-Side Trees, ........11, 71, 72

Rural Mail Carriers (see Patrol)

S.

Saw Fly, .............. 78

Shade Trees, ..........11, 59, 67-73

Shade Tree Book, ...........11, 73

Commissions, ........11, 67-71

Federation, ........... 70

Troubles, ............. 72

Smokers' Fires, ............20, 21

Spark Arresters, ........... 15

Spraying, ............76, 78

State Aid, ............. 73

T.

Tax Lieu, ............... 63

T'elephones, ............ 49, 50, 64

"Town Lots," .............. 7

Tree Doctors, .............. 78

Tree Pests, .............. 74

Trespass on Reserves, ....... 63

\section{V.}

Values, Land and Forest, ...... 57

Violations of Law, ........9, 28-47

\section{W.}

Wardens, Fire, (sée Firewardens)

Watchers, Fire, .........22, 49, 50

Water Supply Commission, .....10, 62

Weeks Law, ............... 48

Wharton Tract, .............10, 62

White Pine Blister Rust, ...... 77

Wild Land, Traffic in, ........ 6

Wood Industries, ............ 58

Wood Utilization, ..........10, 58

Wood Values, ............57, ธ8

Woodland, Area of, ......... 5

Woodlot Forestry, .........10,66 



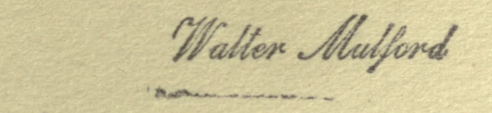

STATE OF NEW JERSEY

DEPARTMENT OF PUBLIC INSTRUCTION

TRENTON

\section{Elementary Agriculture \\ Leaflet No. 9 \\ Trees and Forests \\ April, 1913}

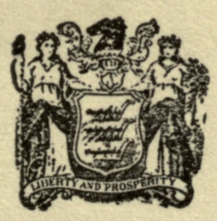




\section{2:

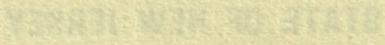

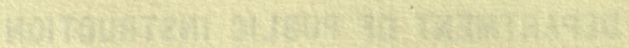

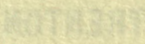

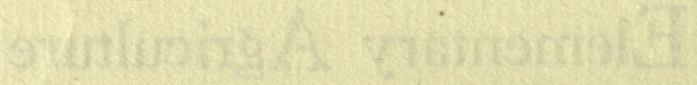

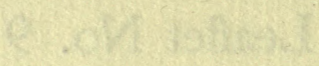

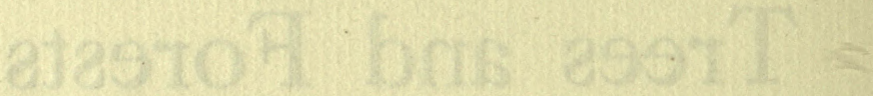

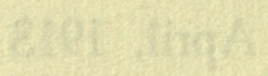

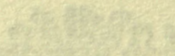

(x)

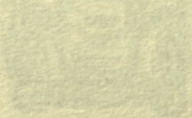


This is Leaflet No. 9 of the series to be issued by the Department of Public Instruction to promote the Study of Agriculture in the Schools of the State. Other leaflets are in preparation.

Respectfully,

CALVIN N. KENDALL,

Commissioner of Education.

April, 1913. 

E.
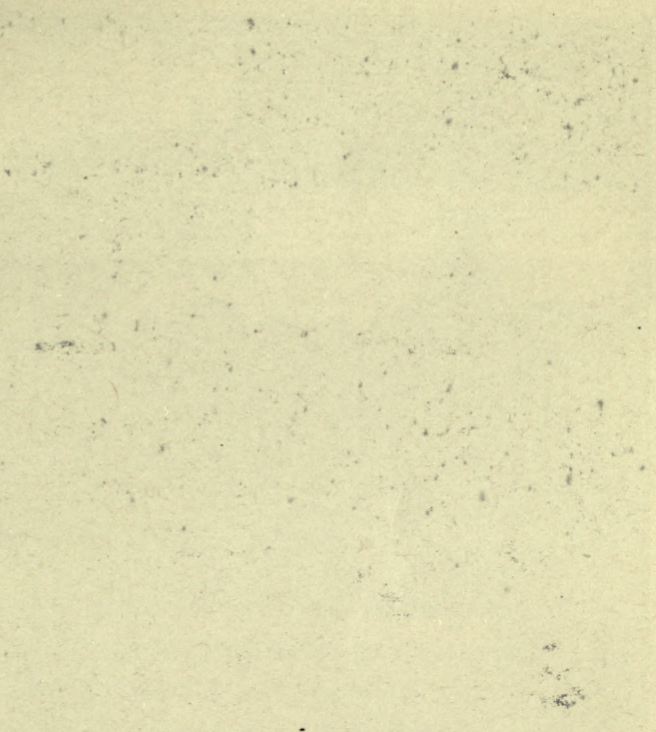
4 sit.

$+8+i^{2}=$ $\frac{1}{4}+\frac{1}{2}+x^{2}$ 


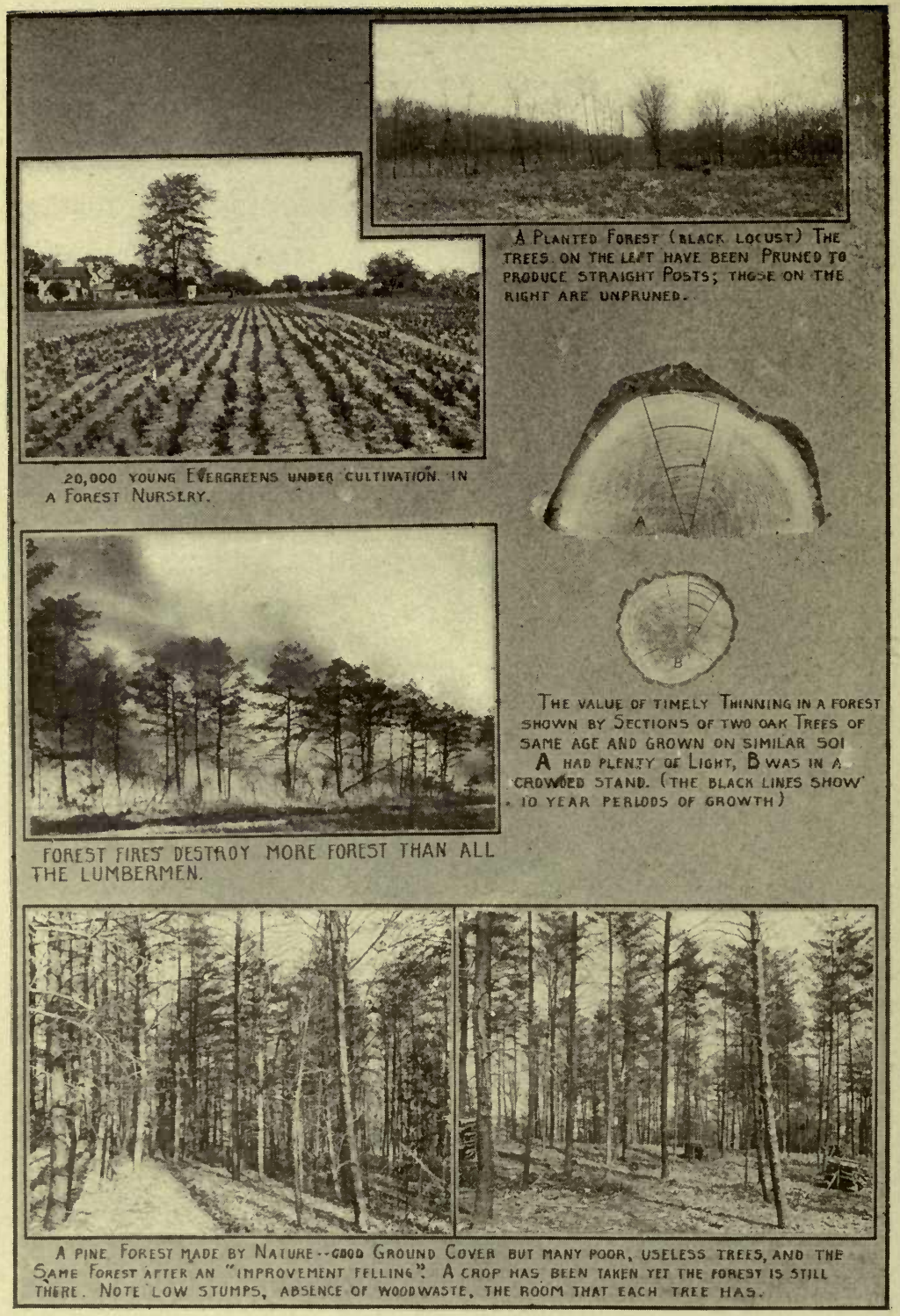

Forestry from Several Viewpoints. 


\section{ELEMENTARY AGRICULTURE.}

\section{Trees and Forests.}

\section{Introduction.}

The topic of Trees and Forests was not included in the list of subjects given in the pamphlet issued by the Department of Public Instruction on the Introduction to the Teaching of Elementary Agriculture, but it is deemed of enough importance, and is thought to have enough content to warrant its introduction into some of the schools of the State as a special topic for study in the higher elementary grades. Its publication would be justified alone in its bringing to the attention of the future citizens of the State some of the work which is being done by the New Jersey Forest Commission for the preservation and propagation of our forest lands.

The Secretary of this Commission, Mr. Alfredl Gaskill, has prepared a monograph which is presented herewith. It is so full of suggestions for teachers and pupils that no extended introduction need be written to guide teachers who wish to introduce this topic of study.

Unlike such subjects as Vegetable Growing, Corn Growing and other purely agricultural projects, the study of Trees and Forests does not permit of very much individual initiative on the part of the child.

The life of a tree extends over so many years that the school can usually superintend only the planting and the first year or two of its growth, but it is hoped that some children who study about trees in school may be inspired to continue their interest in forestry.

Many educators now believe that the public schools in the higher elementary grades should present to the pupils some view of the different human activities. The profession of forestry is still in its infancy and the economic needs of our State alone will provide 
positions of importance for many young men of the next generation. For this reason, again, it is thought worth while to publish this pamphlet.

\section{RELATIONS WITH OTHER SCHOOL SUBJECTS.}

Mr. Gaskill has pointed out clearly the connection which can be made with reading and with composition in his references and questions. One of the principal pieces of work which a child will have to do while studying this subject under the direction of a teacher will be to make a comprehensive note book in which he answers the questions asked after they have been discussed by the class and in which he may write his individual observations as to the forest lands nearby and of the shade trees on the school ground and in the neighborhood. Each school should secure as many as possible of the books and pamphlets suggested in the bibliography. Many of them can be secured free of charge from the government and State bureaus.

\section{Arithmetic.}

The child may compute the area of forest land in the school district, the part of the land of the county devoted to forests, the part of the county which is set off as county parks; he may compute the value of these lands; he may be taught to estimate roughly the amount of lumber in a tree, the amount of fire wood which a tree can produce in addition to the lumber; he may compute roughly the amount of fire wood which is taken from the wood plot on his farm or from some neighboring wood plot, etc.

\section{Geography.}

The subject of trees and forestry is closely corThe child may learn some of the principal forest areas of the State; he may learn how they affect drainage; he may study their economic value; he may study the trees as raw material and the methods by which they are converted into the manufactured products of lumber in its various forms, and fuel; he may learn something about the method of distribution of lumber, its transportation and final use in buildings. 


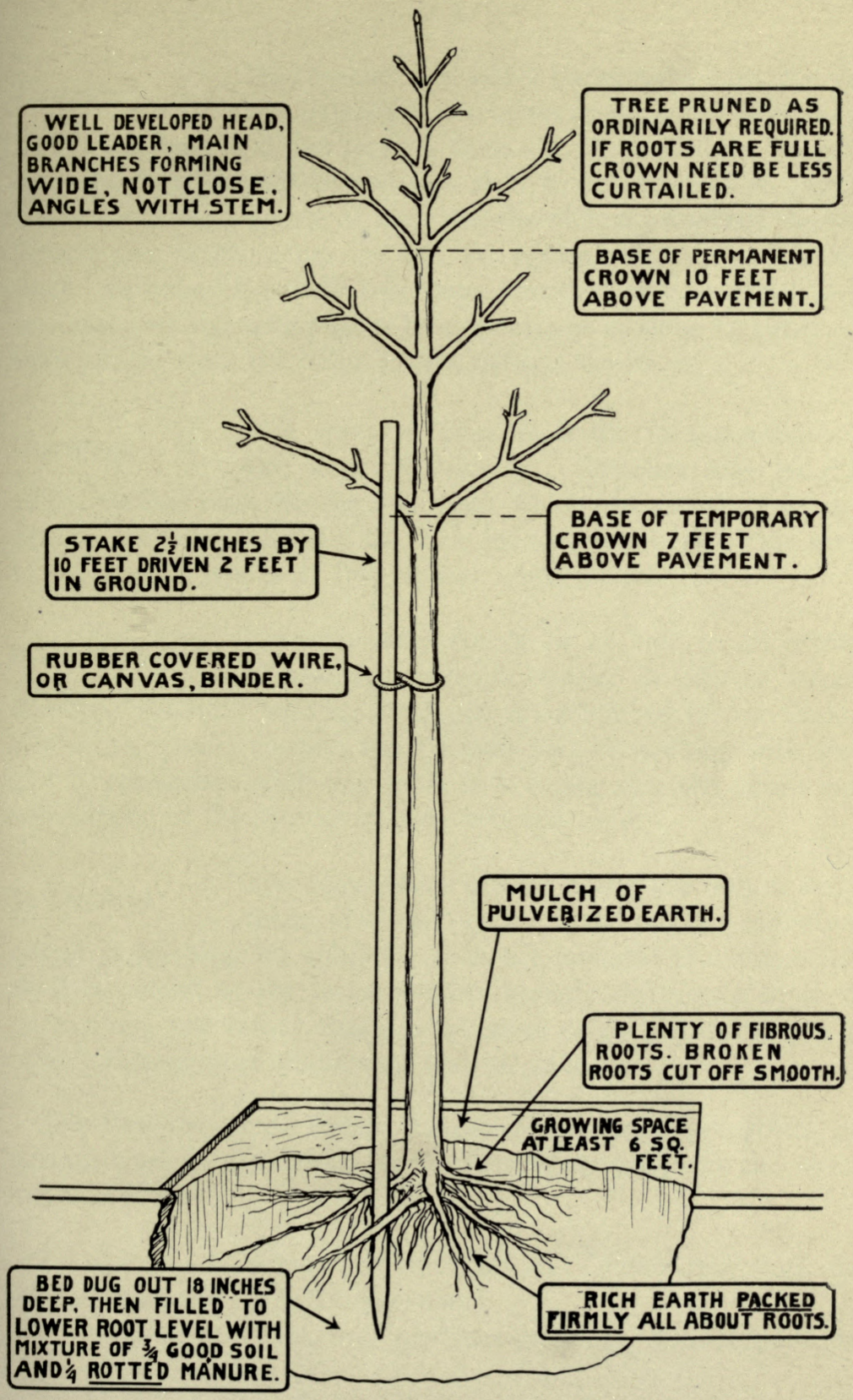

How to Plant a Shade Tree.

It is important to observe every point indicated. 



\section{History.}

The teacher can select paragraphs from the various pamphlets and books given in the bibliography which will have a direct bearing upon the history work. A study may also be made of the methods used by the Indians in clearing tracts for the cultivation of corn and the difficulties which the early settlers met in preparing the soil for agriculture by clearing it of trees. In connection with this some attention may be given to the wasteful methods which have been employed in some localities, and their effects upon the value of our natural resources.

Drawing. The study of trees is fertile in suggestions for the work of drawing. Sketches may be made of the various trees for the note book which has already been mentioned. Sketches may also be made for this note book of the grains of the various woods as they appear when polished.

Manual Training This pamphlet should be of help to all teachers of manual training whether in city or country districts. Manual training as at present practiced in our State in elementary grades consists for the most part of working with wood, and in connection with this work it is fitting that the pupils make some study of the sources of raw material used.

In General.

The suggestions offered above are only a few of those which will occur to the teacher actively engaged in teaching the subject. It is not intended that this subject shall be added to the large number already differentiated in our curriculum, but rather that it may serve as an aid in making the other subjects more interesting and valuable.

The Department of Public Instruction furnishes pamphlets suggesting work in agriculture in the elementary grades in the following subjects:

I. Course in General Experimental and Observation work of a simple character. (In Preparation.)

2. Alfalfa, cow-peas, and soy-bean growing. (In Preparation.)

3. Corn Growing.

4. Vegetable Growing.

5. White Potato Growing. 
6. Sweet Potato Growing.

7. Tomato Growing. (In Preparation.)

8. Poultry Raising. (In Preparation.)

9. Trees and Forests.

A copy of any of these will be sent to any teacher applying to the Department of Public Instruction, Trenton.

LEWIS H. CARRIS, Assistant Commissioner of Education. 


\section{TREES AND FORESTS.}

By ALFRed Gaskmi, state Forester of New Jersey.

Object.

The object of this study is to show the relation between tree life and human life, how the one acts and reacts upon the other, how and why society gains by association with the trees, and somewhat of the methods of forestry and of arboriculture. As both forestry and tree culture are subjects concerning which few people have any definite knowledge it is necessary to treat them quite elementarily. Teachers, therefore, as well as pupils will look for guidance and instruction. It is suggested that essays and debates, with classroom exercises and reading lessons be based upon the statements, references and questions. Pupils should be given to understand that these lessons and exercises are intended in no sense to lead up to professional forestry. Properly directed they will lead to an intelligent understanding of a live economic and social interest.

In the first place it is important to distinguish clearly between forestry and arboriculture.

Forestry. Forestry, "the art of producing wood crops," is essentially an economic subject since it deals with masses of trees and in large measure ignores, or subordinates, the features that make a forest attractive. It deals also with the economic relations between forests and climate, stream flow, etc. A forester is supposed to know about all these things and to be a practical woods manager. Of course, he can have knowledge of shade trees as well, but the term "city forester" is a misnomer.

References: Nos. 1, 2, 3, 4, 5, 6, 7, 9 .

Arborculture. On the contrary trees as individuals represent social and aesthetic interests. Their beauty, friendliness and vitality give them value far beyond their wood. One who deals with trees, their culture, injuries and diseases is an arborist.

References $5,13,14,15,16$. 
Questions. I. Where you live is there need of foresters or of arborists? Why?

2. What is the relation between forests and rainfall? Between forests and stream flow? Between forests and the atmosphere?

3. Is the influence of forests upon stream flow the same in a flat country with porous soil like South Jersey that it is in a mountainous country, or in a hilly region like North Jersey?

4. In what ways are city people interested in or dependent upon forests?

5. Why are shade trees important to country people? To city people?

6. In cities and towns is public control or private control of shade trees to be preferred? Why?

7. How does the lack of forests affect the people of a community?

\section{FORESTRY IN NEW JERSEY.}

As a whole, the State needs no more forest: with 46 per cent. of its surface wooded the task is to establish valuable, productive forest, where little more than wreckage now is. Exceptions to this rule will be found on many farms where sandy land, rocky land or wet land can be profitably planted. An axiom in forestry reads, "Use all the poor land, clear the good for farming."

I. How much forest has your county? (See report
Questions. State Geologist, 1899.)

2. Is there any land that is lying idle? Where?

3. What kinds of trees are in the forests near by? Note: If the trees are all, or nearly all, of one kind it is a "pure" forest, in South Jersey are many pure pine forests : if of several kinds it is a "mixed" forest; all the forests of North Jersey are mixed.

Woodlots. Much of the forestry in this State deals with small always worth more than one without, because it produces, or may produce, the farm lumber and fuel which otherwise must be bought. A farmer who cares for his woodlot, cuts the wood he needs carefully and in the winter when work is slack, can save many dollars. 


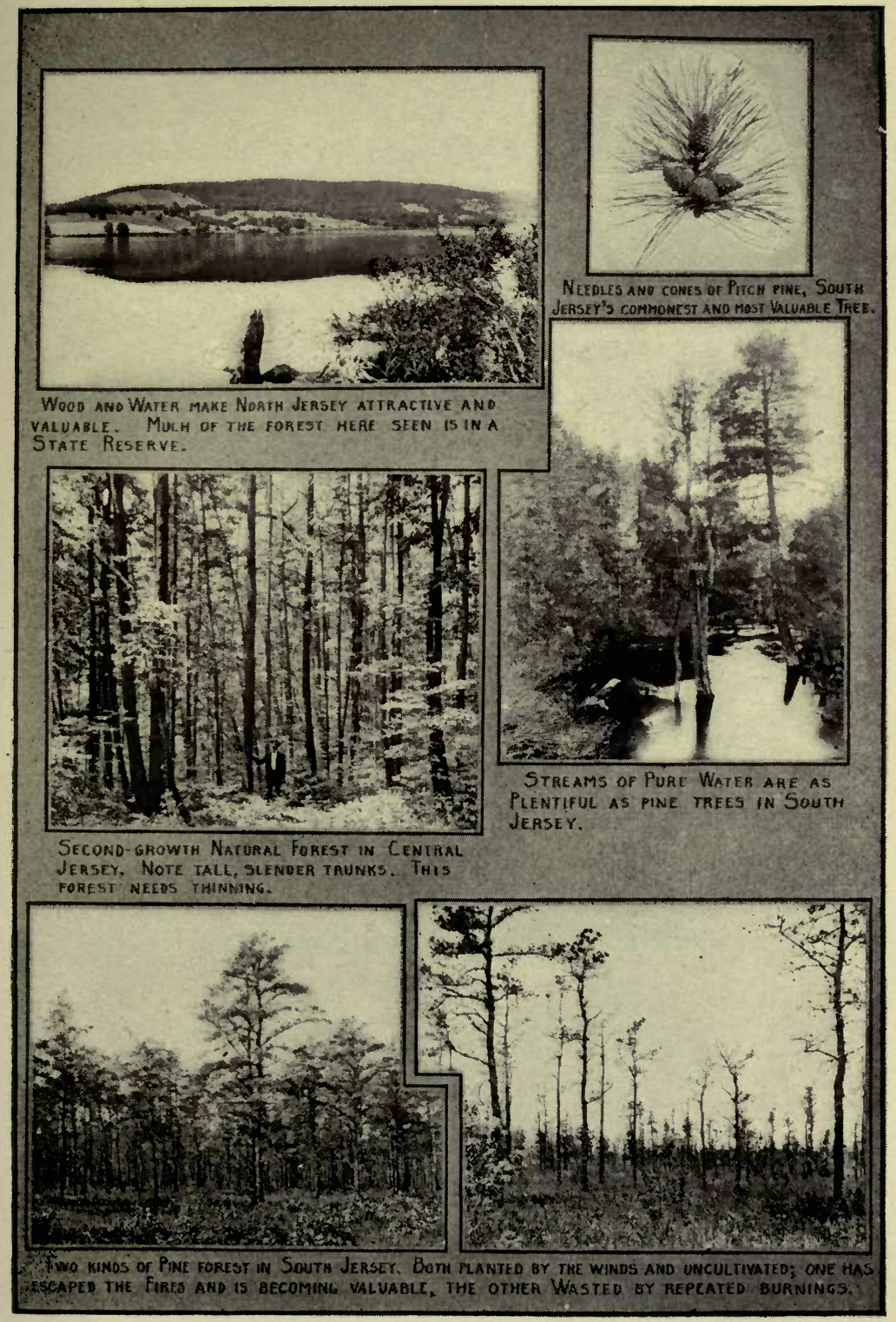

TYPes of New .Jersey Forests. 

One need not be a forester to get good results from a woodlot, yet the yield will be in direct proportion to the skill and intelligence bestowed upon it.

Many a woodlot is a farmer's savings bank; into it he puts thought and knowledge, and a little labor in the winter, and draws out at need, or periodically, material that has as assured a value as wheat. Something definite on this will be found in reference No. 7 .

References Nos. I, 2, 5, 6, 7, 8, 9 .

Questions. I. Why is a woodlot of especial value on a farm?

2. To what kind of land should woodlots be restricted? Why?

3. Why is a woodlot like a savings bank?

4. What is the character and condition of your woodlot?

\section{SILVICULTURE.}

Success in growing trees for lumber depends upon some knowledge of what helps and what retards their growth; how the species differ from one another with respect to soil, light, moisture? what species are best suited to given conditions. To know these things, and to apply the knowledge is silviculture, as agriculture is to know and to do what is needful to make a field fruitful, or, to cultivate apple trees, or to produce potatoes.

The silviculturist or forester has an advantage over the agriculturist in that nature is always a guide. Observe and follow her. An infallible rule deduced from sucin observation is that only a few kinds of trees are found naturally on poor soils, while many kinds are found on rich soils. This explains the presence of pines alone, or with a few oaks, on the sandy areas of South Soil. Jersey, while the strong soils of Central and North Jersey bear (or bore) a great variety of oaks, maples, ashes, elm, tulip, etc. It also indicates the kind of trees that should be propagated in any locality. Conversely the soils that produce the finest forests are the best for farming. 
Tolerance. Next to soil fertility and moisture the factor that most determines tree growth is the amount of sunlight afforded. All trees grow most rapidly in the full sunlight; yet each species has its peculiar requirements. A species that thrives with little sun is tolerant of shade, or commonly simply "tolerant"-sugar maple, spruce:-one that requires full sunlight is intolerant-pitch pine, gray birch. There are all degrees between the extremes, though young trees of any species are more tolerant than old ones. It is this quality of tolerance, or light requirement, that determines whether trees make the tall clear shafts that produce the most valuable lumber, or whether they grow short and branchy as a shade tree should. It is also one of the forester's chief aids, since by taking it into account nature will help produce the desired results.

Know

Of course, one must know the trees-what are the the Trees. characteristics of oaks, of maples, of pines, etc. Whether or not one gets any knowledge of silviculture, it is a pleasure to be able to identify any tree at sight. This can be done in a comparatively short time by carrying a tree book and studying each tree on the spot. The best for this purpose are references II, I2, I3.

References I, 2, 5, 6, 7, I1, 12, 13 .

Questions 1. In a mixed forest what kinds of trees have the best chance to grow?

2. On sandy land of low fertility what kinds of trees will be apt to thrive best?

3. How does sunlight affect the relative vigor of forest trees?

4. How can any one tree in a forest be given an advantage over its neighbors?

5. How can the age of a tree be told?

6. Are trees of the same kind and same size always of the same age? Why?

\section{FOREST PLANTING.}

Forest planting must not be confused with tree planting, for like forestry in general it deals with masses, not with individuals. More trees always are planted than are expected to mature. 


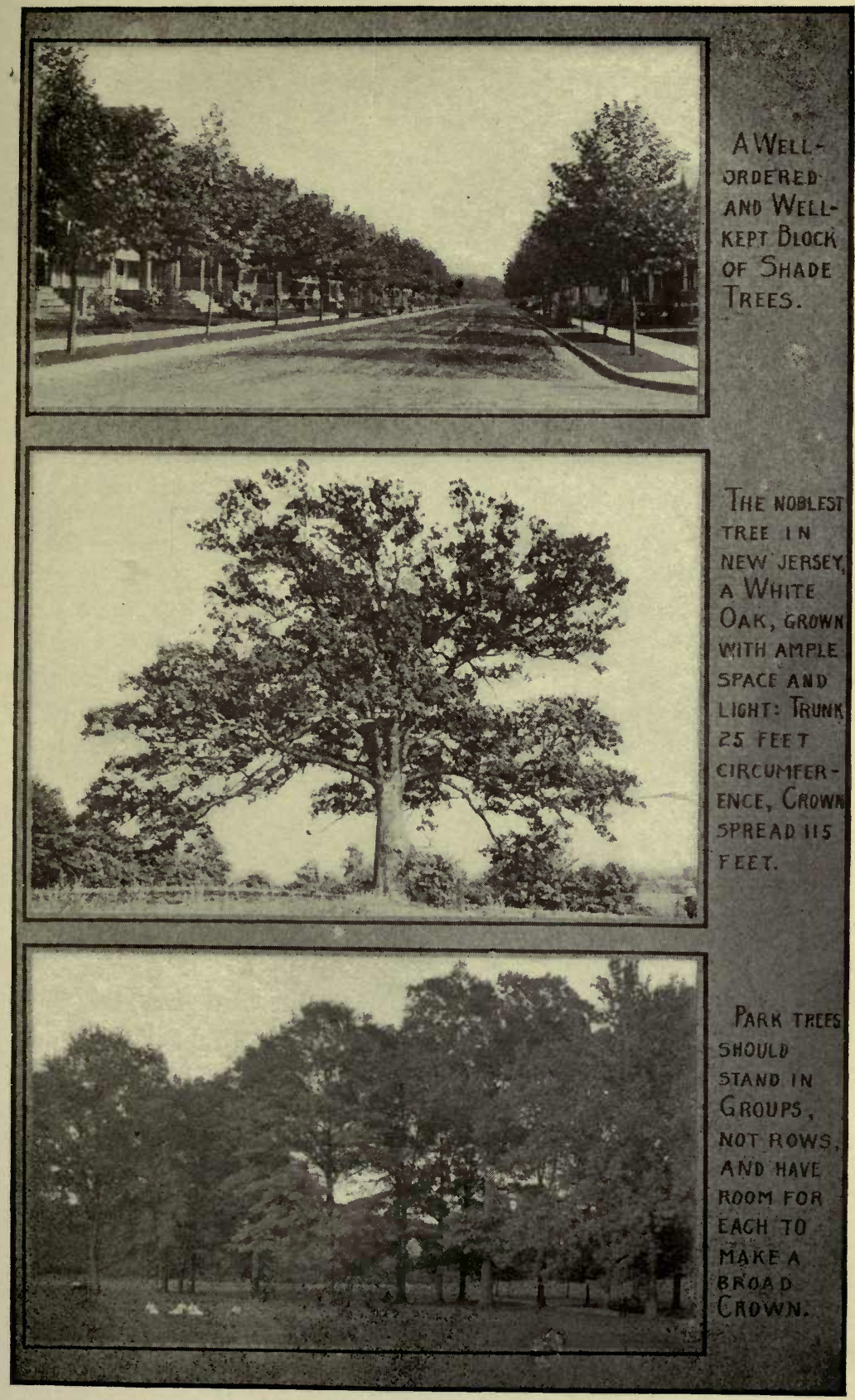

Shade Tbees. They abe UnLIKe forest trees in Form, in pUrpose, iN EXPOSURE TO DANGERS. 

Object.

The objects of forest planting are to produce timber of a special kind, to form windbreaks, to fasten the soil on steep hillsides, or merely to cover bare spots. Wherever there are remnants of natural forest it is better, because cheaper, to develop them than to plant. In this State there is so much forest that windbreaks are not often needed-on the prairies it is quite otherwise. Our reason for planting then is usually found in a desire to have trees where none are, or to produce special kinds.

Choice of When planting is proposed let three rules govern; Species. I. Choose the kind that has highest local value: 2. Choose that which is best adapted to soil and climate: $3 . \mathrm{Be}$ shy of experiments. In general an evergreen-most often one of the pines, will be best, for though the wood is low priced there is an unlimited demand, and the trees grow rapidly in poor soil. Black walnut is valuable only because it is now scarce; when there was plenty it was used for fence rails. Avoid novelties and the things that are much praised. Catalpa, for instance, is fit for only a few localities in this State and when grown is worth no more than cedar.

Plantations should be made of quite small trees-evergreens not over a foot high, deciduous trees not over three feet high: they cost less than larger ones, are more easily handled and are more apt to thrive.

References I, 5, 6, 9, 10, 14, 21.

Questions. I. Why is forest planting less necessary in New Jersey than in some other States?

2. In New Jersey what should govern the planting of forests?

3. What kind of trees are best for forest planting? What are 1!ot good?

4. What distinguishes the two great classes of trees, evergreen and deciduous?

\section{FIRE}

There can be no forestry where fires are allowed. The first principle of forestry then is to stop the fires. They can be stopped, and New Jersey is doing it by having in all parts of the State 
fire wardens whose business it is to prerent and to fight fires, and by punishing everyone who violates the law.

References I, 3, 5, 6, I5.

Questions.

I. Who is fire warden in your neighborhood?

2. What is the law about burning brush?

3. Who can be paid for putting out a forest fire?

\section{SHADE TREES-A RBORICULTURE.}

In every settled community shade trees should be planted and cared for. School grounds above all need trees as shade givers, as material for study, as objects of beauty and as refining influences.

Too often is the interest in trees, in Arbor Day observance, limited to planting a tree, or several trees-and then forgetting all about it. Far more important is it to preserve and develop, a tree that is in place than to plant a new one. Let the trees in front of the school house, in the school house yard, about the home and in the next block be looked after, guarded from injury, freed from injurious insects, kept watered and fed. Then, at proper times and in proper places let other trees be planted and likewise cared for. Where there is room about the school house let a planting plan be prepared for the gradual introduction of representatives of the most important tree species and a variety of shrubs. Thought should be given also to the birds, and houses be provided for them.

It is time, too, to consider our country roadsides. A bare sunny road is hot in summer, cold in winter and not pleasant at any time. A shaded road is more agreeable and adds value to adjacent properties. Unfortunately, no one is charged with the care of the trees in such places. Here is a good opportunity to do some work.

References 5, 9, II, I2, I3, I4, I5, 16, I7, I8, I9, 20, 21 .

\section{REFERENCES.}

The following publications are especially recommended for study ir: connection with this outline. Numerous others will be found in most public libraries. 
Where no price is affixed the volume can ordinarily be obtained free. Requests for Farmers' Bulletins should be addressed to the Secretary of Agriculture, Washington, D. C.

\section{FORESTRY.}

I. A Primer of Forestry-Pinchot. Part I. Farmers' Bulletin, No. I73.

2. A Primer of Forestry-Pinchot. Part II. Farmers' Bulletin, No. $35^{8}$.

3. Economics of Forestry-Fernow. Crowell, N. Y. \$I.50.

4. The Influence of Forests on Climate and on Floods, Moore, Supt. of Documents, Washington, D. C.

6. Forestry in New England-Hawley and Hawes. Wiley, N. Y. $\$ 3$.

7. An Example of Woodlot Forestry-New Jersey Forest Commission.

8. The Woodman's Handbook. Bulletin No. 36 U. S. Forest Service.

9. Forestry in Nature Study-Farmers' Bulletin No. 468.

10. Forest Nurseries for Schools-Farmers' Bulletin No. 423.

II. Key to Trees-Collins and Preston. Holt, N. Y. \$I.35.

12. Trees of the Northern United States-Apgar, American Book Co. \$I.

I3. Trees in Winter-Blakeslee and Jarvis. Macmillan. \$2.

15. Arbor Day, 1913. New Jersey Dept. of Public Instruction.

I6. The Planting and Care of Shade Trees-New Jersey Forest Commission.

18. Beautifying the Home Grounds-Farmers' Bulletin No. I85.

19. Tree Planting on Rural School Grounds-Farmers Bulletin No. I34.

20. Insect Enemies of Shade Trees-Farmers' Bulletin No. 99.

\section{SHADE TREES.}

5. Reports of the New Jersey Forest Commission.

14. Arbor Day. Schauffler, Moffatt, N. Y., 90 cents.

I7. Reports of Newark (New Jersey) Shade Tree Commission.

2I. Various Nurserymen's Catalogs. 


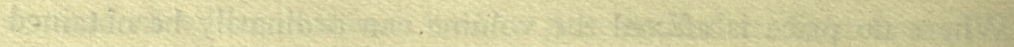

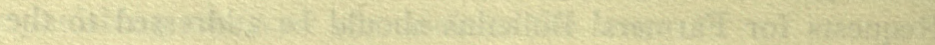

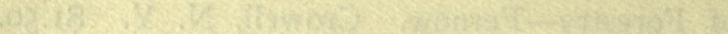

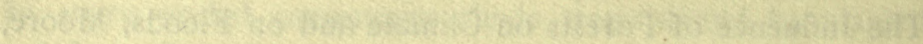
-

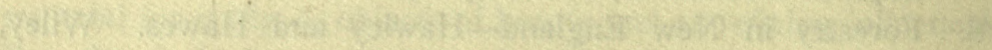

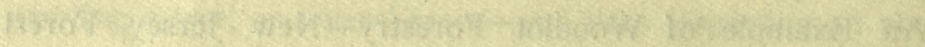

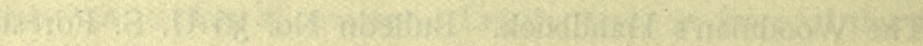
$\tan 2$

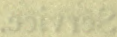

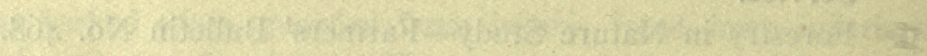

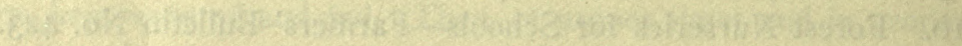

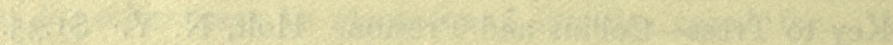

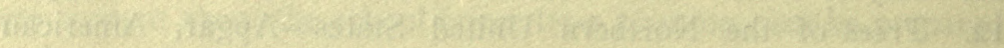

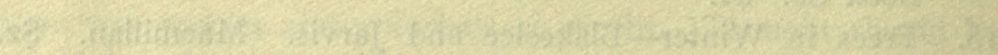

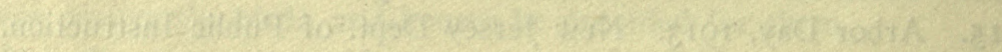

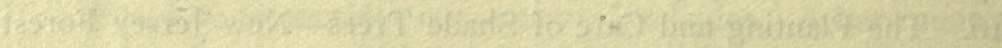

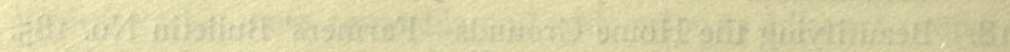
Hito:

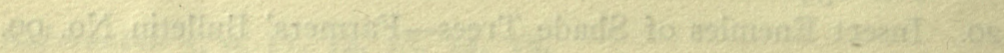

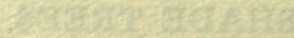

Tis

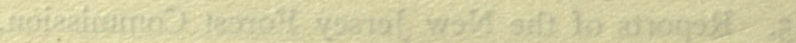

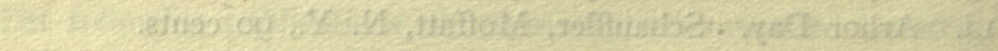

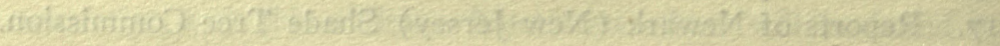

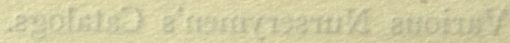




\title{
Wratter Mulfow
}

\section{REPORTS OF}

THE FOREST PARK RESERVATION COMMISSION OF NEW JERSEY

\section{FOREST PLANTING IN NEW JERSEY}

\author{
BY \\ ALFRED GASKILL \\ State Forester
}

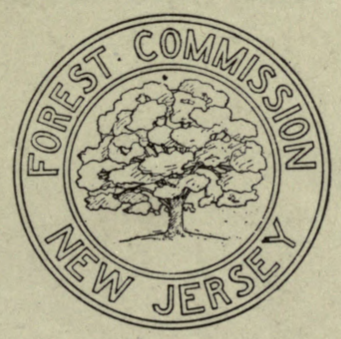

UNION HILL, N. J.

DISPATCH PRINTING COMPANY.

$19 \overline{13}$. 


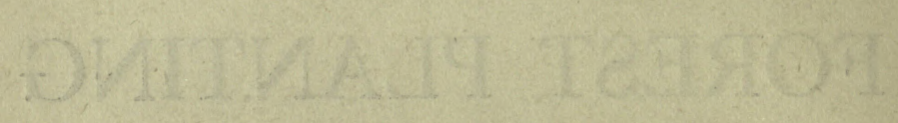




\section{The Forest Park Reservation Commission.}

Hon. JAMES F. FIELDER, ACtING Governor, ex-officio President.

HENRY B. KÜMMEL, Trenton, Executive Officer.

ELMER H. SMITH, Salem.

CHARLES L. PACK, Lakewood.

WILLIAM W. SMALLEY, Bound Brook.

ALFRED GASKILL, Trenton, State Forester and Secretary.

JAMES O. HAZARD, Trenton, Assistant Forester.

CHARLES P. WILBER, Trenton, State Firewarden.

Office, State House, Trenton. 



\section{CONTENTS.}

The Need of Planting,

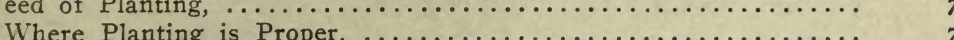

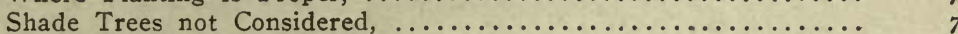

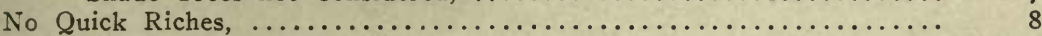

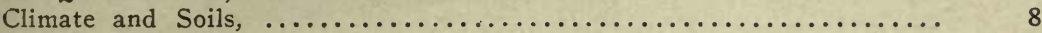

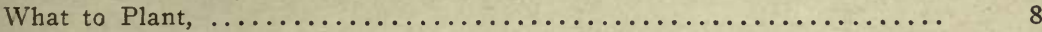

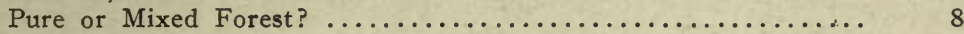

Evergreens or Deciduous Trees? ...................... 9

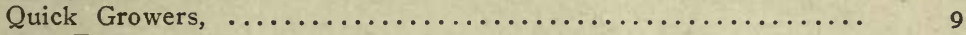

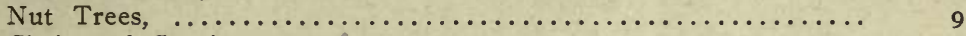

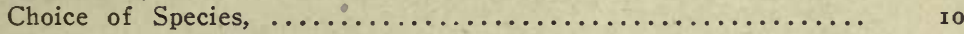

Specific Descriptions, ........................ I0-1 3

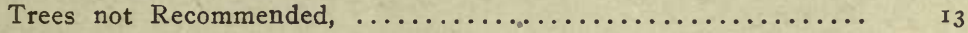

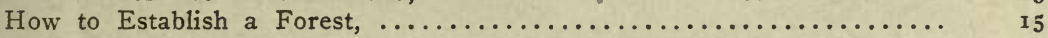

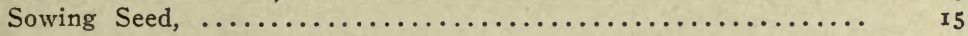

Best to Plant Small Trees, ............................ I5

Preparing the Ground, ......................... I5

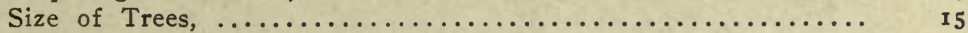

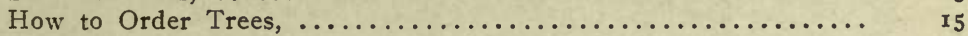

How to Handle Trees Before They Are Planted, ............. I5

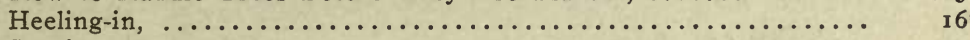

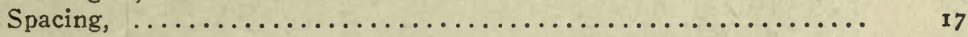

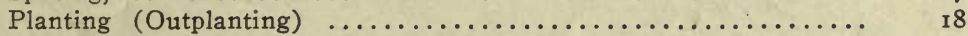

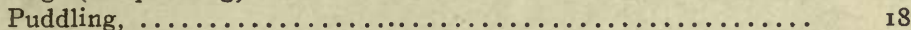

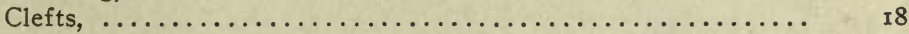

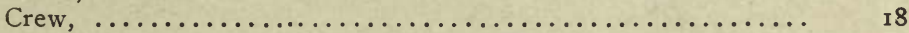

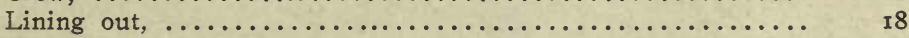

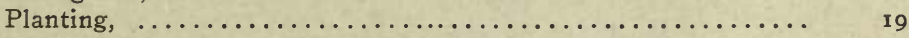

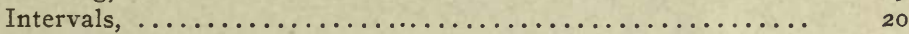

Speed in Planting, ................................ 20

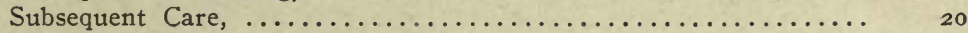

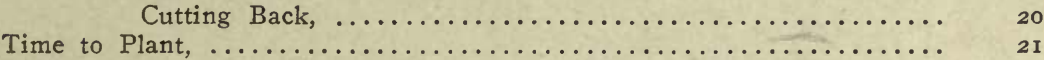

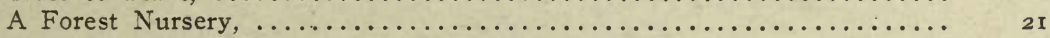

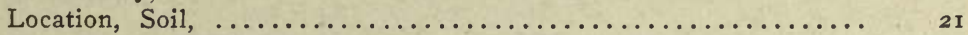

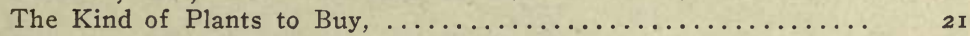

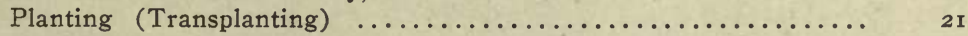

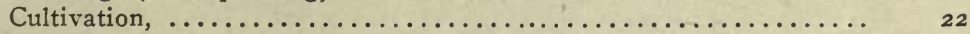

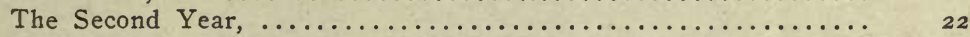

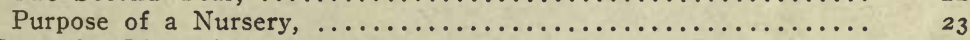

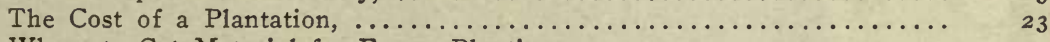

Where to Get Material for Forest Planting, ................... 24

The Profit in Planted Forests, ............................ 26-28

\section{ILLUSTRATIONS.}

Fig. I. - The Kind of Land that Should Be Restored to Forest, ...... 7 7

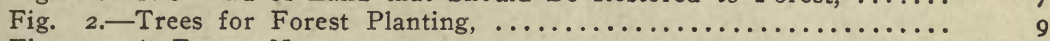

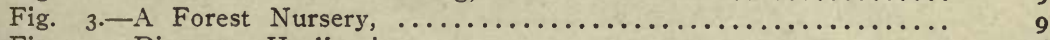

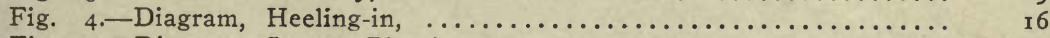

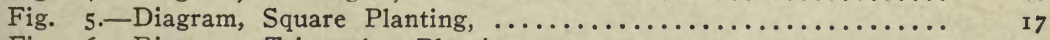

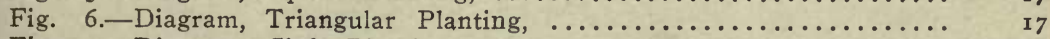

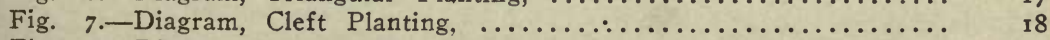

Fig. 8.-Diagram, Area to be Planted, ............................ I9

Fig. 9.-Diagram, Furrow Planting, and Slit Planting, .......... 22

Fig. 10.-Eight Examples of Planted Forests, ................... 23 



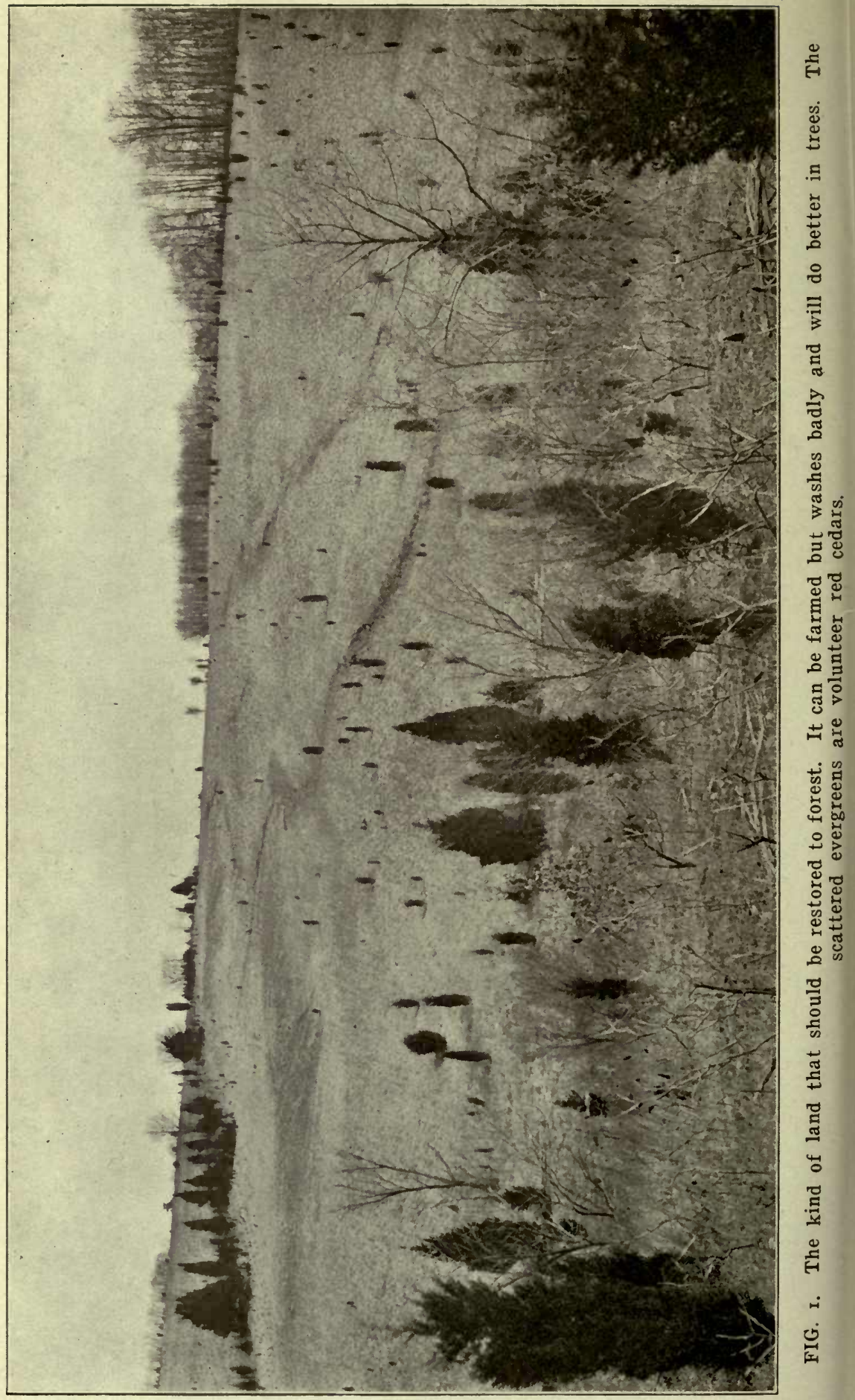




\section{STATE AID IN FORESTRY.}

The Forest Commission wants to assist farmers, and all woodland owners, to practice forestry. See offer on page 28 .

\section{Forest Planting in New Jersey.}

THE NEED OF PLANTING.

The Forest Commission lays little stress upon forest planting because the State's woodland area is now as great as it should be, and because it is easier, cheaper, and, for the present, better to make good forests out of the abused and neglected natural forests. To do this requires, in most cases, no outlay; simply protection against fire and proper thinnings at the proper time are enough. The result will rarely be as good, silviculturally, as from a planted forest, but the crop will come quicker and it will cost less.

Where planting is proper. There are places and conditions, however, that justify planting; they are where land cleared for cultivation or pasture is found unfit, or is no longer wanted, and where forest is desired for pleasure or to simplify the administration of an estate (Fig. I). In the first case the land, being fit for nothing but forest-true forest soil, would naturally have a low value; a plantation therefore should be expected to yield a profit. In the latter cases satisfaction rather than profit would be the object.

Underplanting, or filling gaps, in woodlots is often advisable. The procedure is the same as in open plantations but greater care in the choice of species is required on account of the deficient light afforded-see tolerance, p. 9.

Shade trees not considered. The present discussion deals solely with the production of timber. Beauty and shade are entirely apart. 


\section{NO QUICK RICHES.}

Intending forest planters are reminded that an investment in forestry will yield returns in proportion to the skill and wisdom that underlie it; that the income from a plantation may equal from four to eight per cent., compound interest, yet can rarely be more because there is a limit to the rate at which trees grow. Sure, steady, moderate returns, rather than quick riches are always the foresters aim. See p. 25.

\section{CLIMATE AND SOILS.}

The climate of New Jersey is everywhere suitable for many kinds of trees, and highly favorable to some. No part is too hot, too cold, or too dry to produce vigorous trees.

Its soils, on the contrary, are very diverse, and make necessary a careful adaptation of species to local conditions. No part of the upland, except the beaches and about 25,000 acres on "The Plains," is incapable of supporting a forest of some kind. Even the sandy soils of the pine section are less sterile than is commonly supposed. Solely for the guidance of tree planters the soils of the State may be divided into six classes. See p. I4.

\section{WHAT TO PLANT.}

When a forest is founded by Nature one wisely uses what he finds; when a forest is to be planted the aim should be to choose the best for given conditions.

Pure or mixed forests? Many foresters advocate mixed plantings (two or more species) upon the ground that that is $\mathrm{Na}$ ture's way, that one species helps another, that insects and disease do less harm than in pure (one species) forests. All these arguments have weight, yet most authorities now favor comparatively small groups of a single species, each group representing the fittest tree when climate, soil, markets and all other factors are considered. Under this rule pure forests of several hundred acres may be established. For these reasons, and because it is hard to determine the character and proportions of a mixed forest without a careful study of local conditions, only pure forest plantations are here considered. 

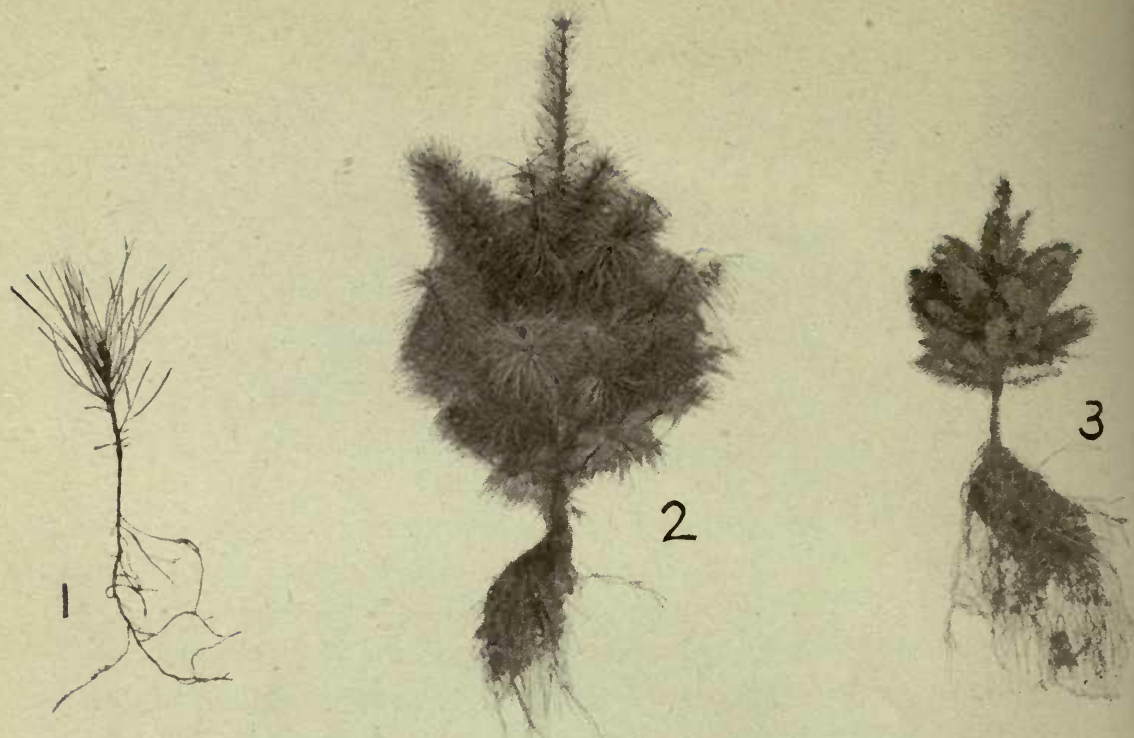

Fig. 2. TREES FOR FOREST PLANTING.

r.-Two-year-old Pine Seedling: It is healthy but not sturdy and has long slender roots. 2.-Four-year-old Pine Transplant: Vigorous, sturdy, well-compacted roots. 3.-Four-year-old Spruce Transplant: Not so large as the pine but capable of making a good growth.

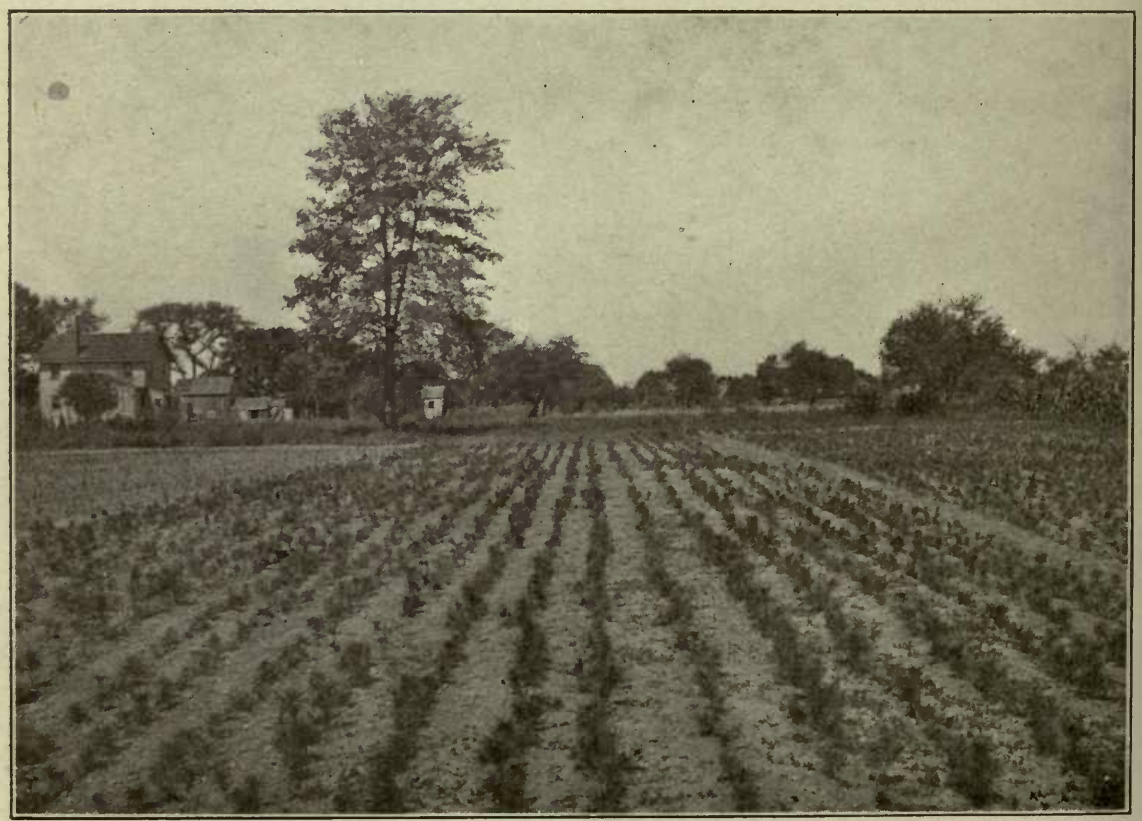

Fig. 3. A FOREST NURSERY.

Scotch Pine at right, Norway Spruce, left. All two years old. 
Evergreens or deciduous trees? An impression prevails that black walnut, white oak, black cherry, hickory, etc., are the most profitable trees to grow because their woods bring high prices. If the available land is suited to these trees it may be so used, yet such trees grow well only on strong agricultural soil of which there is, or soon will be in this State, none to spare. If we deal with true forest soils the conifers or evergreens will yield more per acre and year than any others. Pine of some sort is the world's most valuable wood, and always will be, bebecause it satisfies most needs. Pine is best for planting in South Jersey because it is suited to the sandy soils, and it is best for planting in North Jersey because it produces more wood in less time than any deciduous tree. Spruce and fir are almost as valuable, and may be used as variants.

Tolerance. In forest planting, as in every branch of silviculture, the innate qualities of each tree species with respect to sunlight must be considered. Some; pines, ash, cottonwood, will endure little shade from other trees; they are called lightrequiring or intolerant: others; spruce, fir, beech, are less particular and are called shade-enduring or tolerant (of shade). Tolerant trees when well grown always have more branches than intolerant trees, but more of them can thrive on a given area. An intolerant species must never be planted where it will lack light.

Quick growers. By all means use the species that will give quickest returns, but bear in mind that rapid growth is usually a response to stimulation through fertile soil, abundant moisture, excess of warmth, etc. Cottonwood grows rapidly in moist soil; it will fail where it is dry. Catalpa requires warmth, fertility and moisture for its full development. White pine thrives on a medium soil, yet on poor soil may fall behind pitch pine.

Nut Trees. Nut culture is not forestry, but a branch of horticulture. A tree developed for fruit has too much crown to produce good lumber; one grown tall and straight for lumber has too little crown to yield much fruit. Dismiss, therefore, all thought of combining the two crops. Let fruit (including nuts) be grown where that is likely to be profitable and the trees can be given the care that they need. Trees for lumber are satisfied with poorer soil and much less care. Of course, fair crops 
of nuts may be, and often are, produced by forest trees.

Choice of Species. For most situations in New Jersey let the choice be limited to the following species. Their qualities and values are known; others may be as good, but are less sure.

White Pine. (Pinus strobus.) This is unquestionably the most promising tree for forest planting. Its silvical qualities adapt it to any but the poorest soils, its growth rate is high and tolerance considerable. All this results in a large timber production at a comparatively early age. A yield of $30 \mathrm{M}$ board feet per acre at 50 years is not excessive. The one drawback is that a dangerous disease threatens the species. For the present it is recommended that white pine be planted in moderate quantity only.

Red Pine or Norway Pine. (Pinus resinosa.) A tree that in many ways promises to be quite as valuable as white pine. Its wood is a little heavier, but is also stronger. The tree is not so rapid a grower, and in maturity the forest is less dense, but the individual trees are apt to be taller and their stems clearer. A yield of $30 \mathrm{M}$ board feet per acre at 60 years may be expected. The tree has no dangerous enemies.

Scotch Pine. (Pinus sylvestris.) This is the common pine of Europe. It thrives on good soil, and makes a fair growth on the poorest. It is especially vigorous when young. The wood is practically like that of red pine, consequently sure of a market in any form. A yield of $25 \mathrm{M}$ board feet per acre at 50 years should be obtained from a plantation established under fair conditions.

Austrian Pine. (Pinus laricio.) A much heavier-set tree than any of the others, and generally appreciated for its good looks. The species is adaptable to poor soils, especially limestone rocks. The stem cleans about as well as white pine. The yield is somewhat less.

Pitch Pine. (Pinus rigida.) The common pine of South Jersey and of the mountain ridges in North Jersey. It is by no means the valueless tree that many imagine. The wood is resinous, but strong and fairly durable, and is in demand always for construction lumber and box boards. The rate of growth depends largely upon the soil. On poor sand it is naturally relatively slow, but its great value is that it is highly fire resist- 
ant. The tree should be fostered wherever found and may be planted on land too poor for other species, or where the fire risk continues.

Loblolly Pine. (Pinus taeda.) A tree native of the Southern states, where it grows with marvelous rapidity. Recent experiments indicate that it can be grown successfully in South Jersey and in sheltered situations, but for the present it is recommended only for experimental planting.

Shortleaf Pine. (Pinus echinata.) The species found in Central and South Jersey, usually mixed with oaks, on the better soils. It is comparable in most respects with red pine, and in South Jersey may be planted as an alternative.

Norway Spruce. (Picea excelsa.) The common spruce of Europe. A tree of great economic value because its wood is sought for paper pulp as well as for lumber, and because, by reason of its tolerance, it is able to grow in close stands. It requires fairly strong soil, and thrives on ground much moister than is acceptable to any of the pines. (It will not grow where the ground is constantly wet.) This species is preferable to any of the native spruces. The average yield on suitable soil is about 30 $\mathrm{M}$ board feet at 60 years.

Douglas.Fir. (Pseudotsuga taxifolia.) Stock from Rocky Mountain seed only should be used. That from Pacific Coast seed is apt to be frosted. The tree grows at about the same rate as the Norway spruce, though the stands are not quite so dense. The wood is tough and strong, comparing favorably with red pine or shortleaf pine. From the best information available, a yield of $25 \mathrm{M}$ board feet at 60 years should be obtained on fair soil.

European Larch. (Larix europaea.) A tree especially valuable on account of the durability of its wood. Unlike the Eastern American species, it requires well drained as well as fairly strong soil. It is advised for planting where the extinction of chestnut is likely to create a demand for posts, poles, etc. A yield of $20 \mathrm{M}$ board feet at 60 years may be expected.

Balsam, Fir. (Abies balsamea or Abies pectinata.) The first is the native species; the second the European. They are valuable on account of their adaptability to moist land, high degree of tolerance, and production of a wood that is about as usefwl 
as spruce. In many situations the plantations may be made with a view to marketing Christmas trees, for which either species is preferred. A mixture of balsam and spruce with a view to removing the former at Io or 15 years, leaving the latter to grow to timber size, would often prove advisable.

Cottonwood. (Populus deltoides.) The so-called Carolina poplar, a tree of very rapid growth on moist soil-of little value where it is dry. It should be planted not less than to feet apart, either pure or mixed with a more tolerant species suited to the same conditions. A yield of $25 \mathrm{M}$ board feet in 30 years may be expected.

Red Oak. (Quercus rubra.) Probably the most promising deciduous tree for soils of moderate fertility. Its wood has a recognized value for many purposes, and apparently is the most available for railroad ties. A yield of $20 \mathrm{M}$ board feet, or 700 railroad ties, per acre in 40 years is possible.

Tulip Poplar. (Liriodendron tulipifera.) The most valuable soft wood deciduous tree. It requires strong, well-drained soils, but when planted in such situations grows vigorously. As the wood is used generally for cabinet work and fine box boards, trees less than I6" diameter, breast-high, have comparatively little value. Properly made plantations should yield $30 \mathrm{M}$ board feet per acre at 50 years.

White Ash. (Fraxinus Americana.) This tree grows vigorously on ground too wet for cultivation. Its wood is in constant demand on account of its toughness and elasticity. As sapwood is even more valuable than heartwood, the trees can be marketed when comparatively young. Ten $M$ board feet, or 20 cords, at 25 years are easily possible.

Hickory. (Hicoria laciniosa, [shellbark,] H. alba, [bullnut,] $\mathrm{H}$. glabra, [pig nut.]) The first grows on moist land, the two latter on drier ground, but all require considerable fertility for a satisfactory development. The wood is highly valuable for vehicles and tool handles, and is preferred when young rather than when old. Where conditions are favorable, no crop is likely to be more valuable than one of hickory. It will usually be marketed in the form of billets and measured by the cord. A yield of 15 cords in 25 years may be expected.

Basswood. (Tilia americana.) A tree in many respects sim- 
ilar to tulip poplar, though rather less rapid in growth. It may be planted as an alternative or variant.

Locust (Robinia pseudacacia) is in demand everywhere for posts and railroad ties. The trees grow with marvelous rapidity for a few years on any but the poorest soils, but soon slack up. They are, moreover, almost invariably attacked by a boring insect. Plantations should be made with a view to harvesting the crop at about 15 years of age. Two thousand posts per acre is a fair yield.

Trees not recommended. A few trees entirely unfit for economic planting in New Jersey are so persistently boomed that their real qualities should be known.

Catalpa. Grows very rapidly on rich, moist soil and in a mild climate. In North Jersey its late growth is apt to be frozen; in South Jersey only the best soils are fit. Its wood is valuable only for posts and poles, being very durable, but weak.

Black Walnut. The wood is valuable only when cut from the heart of large, old trees. A tree 40 years old might be 12 inches in diameter yet contain only a 4-inch cylinder of brown wood. The sapwood of young black walnut is very wide, light in color and unmarketable.

Silver (White) Maple. The tree requires good soil, while its wood is weak, perishable and of little value. In fact, no maple is worth planting for lumber in New Jersey.

Eucalyptus. No species is adapted to conditions in this State. The quick growing kinds are as sensitive to frost as orange trees. 
SPECIES RECOMMENDED FOR VARIOUS LOCATIONS.

\section{Poor Soil}

Dry sand with little humus. ( Natural Pitch Pine land.)

Very stony ground with little soil of any kind.

Pitch Pine

Austrian Pine

Scotch Pine

\begin{tabular}{|c|c|}
\hline Mediu & Soil \\
\hline $\begin{array}{l}\text { Sandy or gravelly } \\
\text { loam, dry with little } \\
\text { hum us. (Natural } \\
\text { Chestnut Oak land in } \\
\text { South Jersey.) }\end{array}$ & $\begin{array}{l}\text { Ground of any } \\
\text { kind naturally fresh, } \\
\text { but exhausted by } \\
\text { cropping or by fire. } \\
\text { (Stones need not be } \\
\text { considered.) }\end{array}$ \\
\hline
\end{tabular}

White Pine

Red Pine

Shortleaf Pine

Austrian Pine

Scotch Pine

Pitch Pine

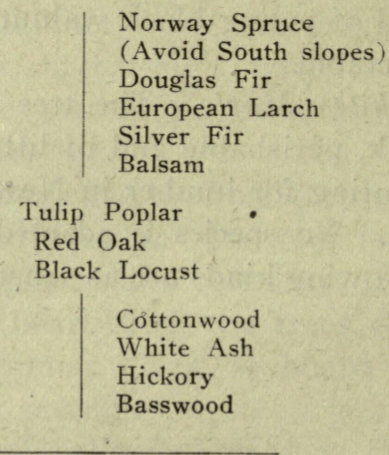

\section{Good Soil}

Loam with some / Rich ground with humus. (Good arable standing water at land.) times.

Stones need not be considered.

Any tree on the list.

Norway Spruce

Balsam

Cottonwood

White Ash

Shellbark Hickory

Basswood 
HOW TO ESTABLISH A FOREST.

As every item of cost in growing a forest must be carried as an investment at compound interest until the timber is mature, it is important to save every possible expense.

Sowing Seed. The lowest initial cost is found when seeds are sown on the ground, yet neither that method nor planting the seeds in prepared spots gives good results. Birds, mice, dry weather and many adverse influences make it advisable to start with sturdy young trees.

Best to Plant Small Trees. These may be grown in a home nursery or bought. Unless the quantity wanted is great, the latter is the better plan and as cheap in the long run. Evergreens, in particular, require much skill to grow successfully.

Preparing the Ground. Though trees undoubtedly grow better when planted in worked and fertilized soil, the practice is to omit everything of the kind on account of its cost. If the ground is very weedy or covered with brush, it may be mowed and burned over; that is all.

Size of trees. There is no economy in large trees; the only advantage they possess is that the plantation shows sooner. On the other hand, very small trees are handicapped by the weeds. A safe rule is to use plants about a foot high. Deciduous species may be larger, evergreens smaller. Of the latter those that have been transplanted are stronger and better rooted than seedlings and are to be preferred unless the cost is too great. See Fig. 2.

How to Order Trees. If the number needed is not over five thousand, buy trees of the size required for planting and have them delivered at the time they are to be set. If the quantity is large, it may pay to get small seedlings and cultivate them for a year or two in a nursery (see p. 2I). The latter plan has the further advantages that it produces strong, sturdy trees, and insures their being on the ground exactly when they are wanted.

How to Handle Trees Before They Are Planted. When a tree is out of the ground its roots must never become dry. It is especially important to guard evergreens since the foliage is active at all times and the draft upon the root moisture therefore con- 
stant. Deciduous trees without leaves are less sensitive. In foliage they should never be moved. Nurserymen now make it a rule to leave a quantity of earth about the roots of all evergreens over 18 inches high and keep it in place by a piece of sacking (ball plants), but this is not necessary with smaller plants if the roots are kept moist. When the box or package arrives, open it at once and thoroughly wet the contents. If planting is to be delayed more than forty-eight hours, take out the plants and heel them in in a convenient place to stay until wanted.

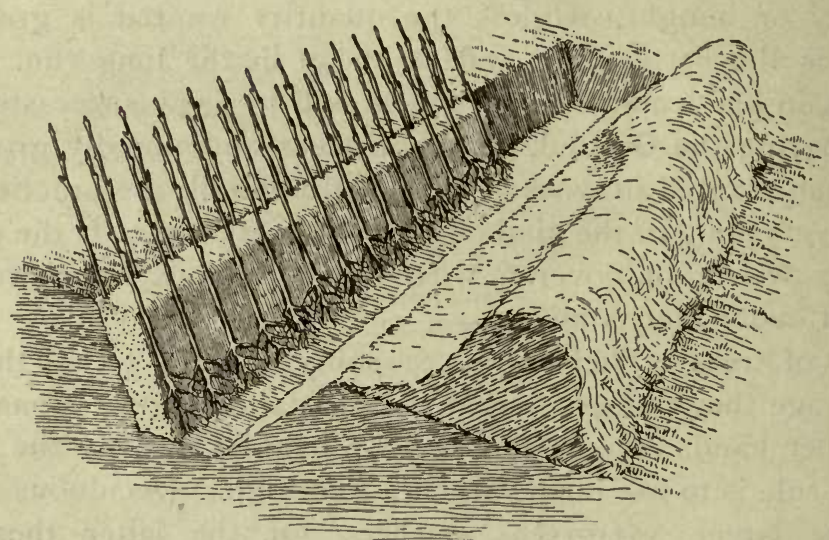

Fig. 4. Heeling in Young Trees. A trench properly made and two layers of deciduous trees in place; the first is covered in; the second ready to be covered. Evergreen trees should have none of the foliage covered.

Heeling In. This simply means putting a tree in the ground temporarily so that its roots shall not become dry before it can be regularly planted. With a number of trees to heel in, dig a trench in moist soil. Let the front of the trench be on a $45^{\circ}$ slope and somewhat deeper than the length of the tree roots. Then loosen the tree bundles and spread the trees along the sloping wall in a single row and an inch or two apart. Cover the roots and lower stems with earth taken from the trench and tamp it down firmly so that every root is embedded. Successive layers of trees may be put one on another, with two or three inches of earth between, if the quantity is too great for a single row. If dry weather comes, wet the earth freely. Trees of any kind can be kept in this way several weeks without injury. 
Spacing. The proper interval between planted trees depends upon the habit of the species, the strengtli of the soil, the expected life of the plantation, etc. In this part of the country it is most usual to space $6 \mathrm{ft}$. by $6 \mathrm{ft}$. in squares. Cottonwood should have a little more room, locust a little less. The aim is to give each tree room to develop a good-sized crown, yet not so much that it will have big lower branches, or the plantation need thinning before the stems are large enough to be salable. Straight rows equally spaced, thus,

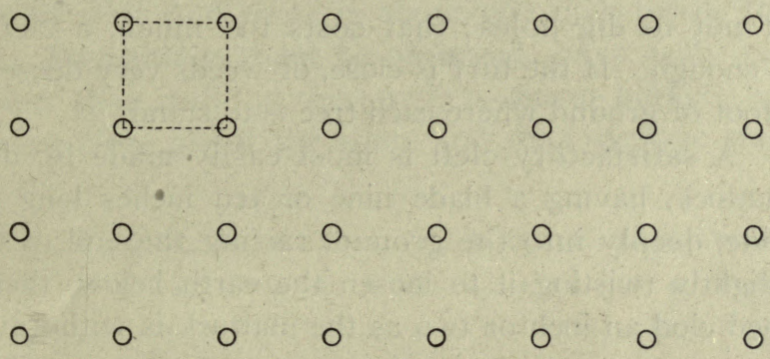

Fig. 5. Diagram Illustrating Tree Planting in Squares.

are better than "staggered" rows or triangular spacing, thus,

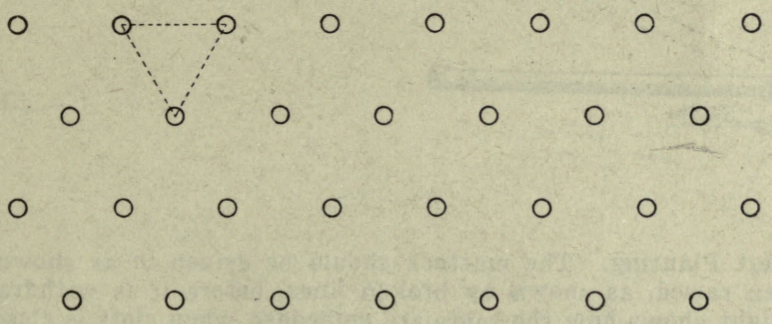

Fig. 6. Diagram Illustrating Tree Planting on Triangular Plan.

because removals can be made more uniformly when the time for thinning comes. Wider intervals between the rows than within the rows are justified only when one element in a mixed plantation is intended to be removed early.

TREES PER ACRE AT VARIOUS SPACINGS.

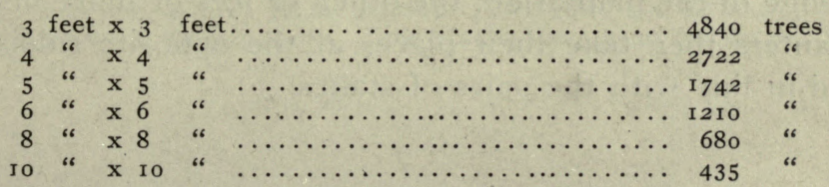


Planting (Outplanting). It is well to work systematically though no more than a couple of thousand trees are to be set.' As soon as the trees are brought on the ground mix a "puddle" and put the roots in it, leaving the tops in the air. "Puddle" is simply thin mud, preferably made of clay and water. It can be mixed in a tub or in a shallow pit. Provide baskets lined with wet moss or burlap, or pails, to carry the trees, and a heavy mattock or grub hoe for each planter-that is all. Baskets are lighter. If mattocks are not available, spades may be used, but not to dig holes; that costs too much, a cleft in the ground is enough. If the turf is close, or weeds very dense, "scalp" a square foot of ground where each tree is to stand.

Clefts. A satisfactory cleft is most easily made by driving a hoe or mattock, having a blade nine or ten inehes long and five inches wide, deeply into the ground, raising the end of the handle and slightly twisting it to loosen the earth below, then lifting the loosened clod an inch or two as the mattock is. withdrawn.
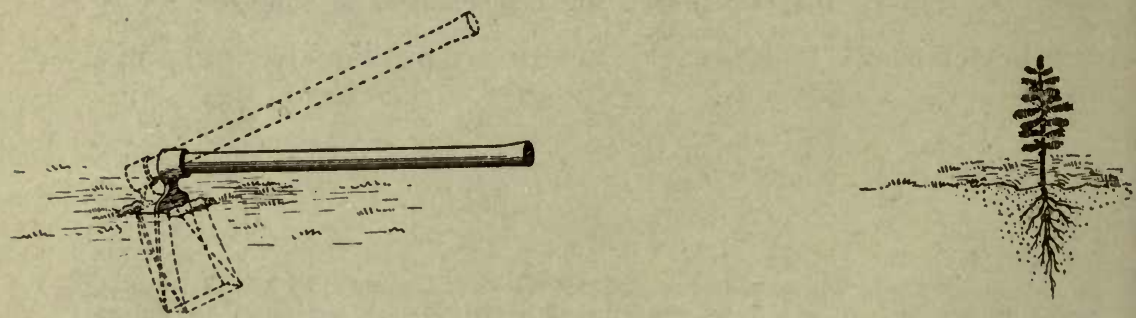

Fig. 7. Clert Planting. The mattock should be driven in as shown by solid lines, then raised, as shown by broken lines, before it is withdrawn. The tree at right shows how the roots are embedded when cleft is closed.

A spade driven straight down and then worked back and forth from the handle serves the same purpose, though less speedily.

Crew. Crews of two planters and one boy to hand trees to them, with a man to set the line stakes for several such crews and to puddle the trees, are most effective.

Lining-out. Let the line man set two stakes in each line, one at the edge of the plantation, the other 50 feet or more inside it. The planters then take their places at the opposite side of the plot and in line with the pairs of stakes. 
Planting. Each planter sights over his two line stakes and drives his mattock into the ground at the proper point. After raising the handle, he slips one hand along to the head and with the other receives a tree from the basket boy. Then as the mattock is lifted with one hand the tree is put into the cleft with the other, the mattock is removed and the cleft closed with a stamp of the planter's heel. To spread the roots as much as possible, and not bunch them, it is well to put the tree deep into the cleft and before stamping withdraw it until the collar (the junction of stem and root) is about one inch below the ground surface. Two things must be observed: have each tree stand a little lower than it did in the nursery-never higher; be sure the earth is set close about the roots and that the tree stands fairly upright.

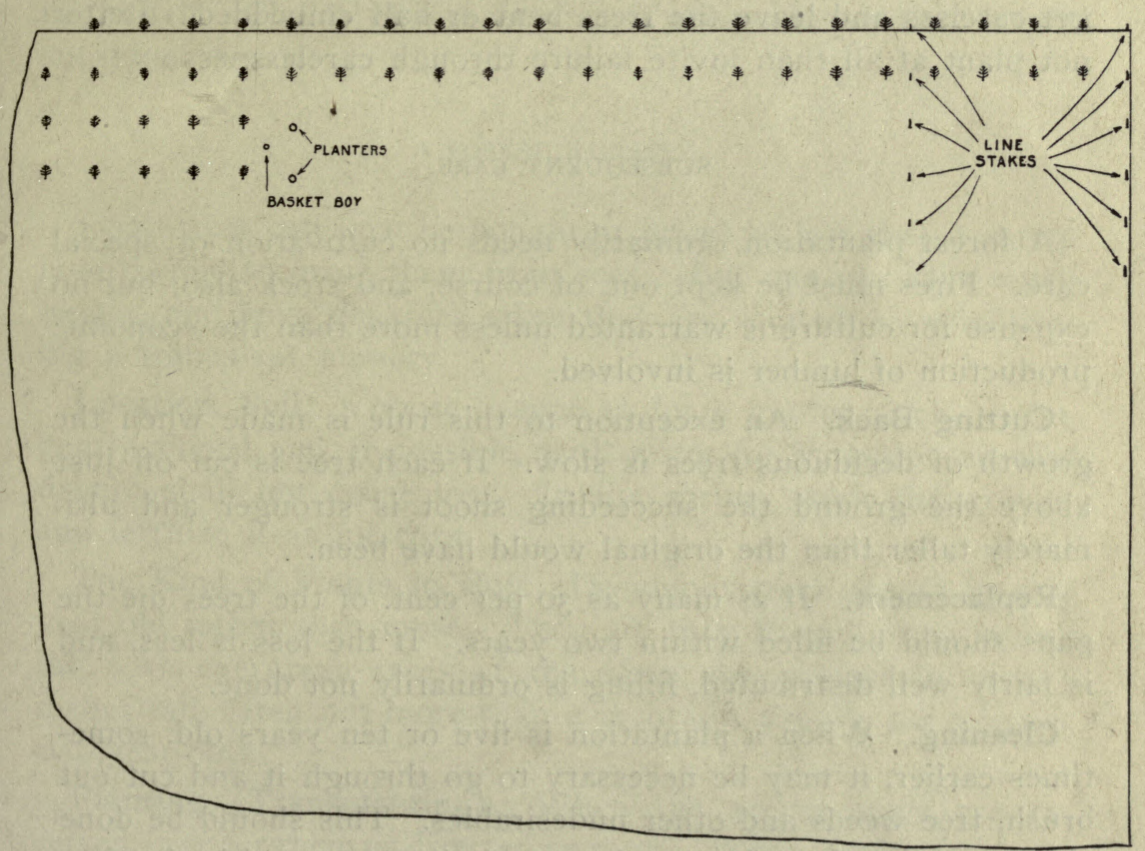

Fig. 8. Diagram of area to be planted. Two rows are finished, the planters are at work on two more. Line stakes have been set for six rows. 
Intervals. After the first tree is set let the planter move forward the required distance and again sighting for his line, make his second cleft, and so on. It is always possible to approximate the required distance by pacing, by adding the length of the tool or of the tool and arm, to one, two or three steps. A six-foot interval can be fixed by taking one step forward and, with both feet set, making a mattock stroke at arm's length. It is not necessary to attain precision in line or interval; slight irregularities will be lost as the trees grow.

Speed in Planting. With the help of a line man and basket boy, two planters should set 200 trees per hour unless the ground is very stony or heavily turfed. One man doing all the work himself should average 600 trees a day. But do not acquire speed at the expense of good work. Watch the planters that they do not get carelsss and leave the trees bent or half embedded. Better not plant at all than invite failure through carelessness.

\section{SUBSEQUENT CARE.}

A forest plantation ordinarily needs no cultivation or special care. Fires must be kept out, of course, and stock also, but no expense for culture is warranted unless more than the economic production of lumber is involved.

Cutting Back. An exception to this rule is made when the growth of deciduous trees is slow. If each tree is cut off just above the ground the succeeding shoot is stronger and ultimately taller than the original would have been.

Replacement. If as many as 30 per cent. of the trees die the gaps should be filled within two years. If the loss is less, and is fairly well distributed, filling is ordinarily not done.

Cleaning. When a plantation is five or ten years old, sometimes earlier, it may be necessary to go through it and cut out brush, tree weeds and other undesirables. This should be done always, and only, when such growth interferes with the free development upwards of the planted trees. Keep the crowns of the young trees free to the sunlight; let low-growing brush and weeds alone. They stimulate height growth and shade the ground. 
Thinning. No plantation made as here directed will need thinning before it is twenty years old. When the time for that comes further advice should be sought.

TIME TO PLANT.

In this climate early spring, as soon as the frost is out of the ground, is best. Be ready so that no time need be lost. Deciduous trees should never be taken from the ground while their leaves are on. Evergreens can be, and often are, planted successfully in late summer and early fall, but there is always danger that the winds of winter, often very dry, will put too great a strain upon the weakened root system of any tree that is moved in the fall. Cloudy or wet weather is always better than bright sunshine.

\section{A FOREST NURSERY.}

Small trees can now be bought at prices so low that it rarely is advisable to grow them from seed. But one can save much money, and have the trees when they are wanted, by establishing a transplant nursery.

Location, Soil. Choose a spot as for a garden; rich, warm, gently sloped and, if possible, with water for irrigation so that drouth shall not cause loss. In the spring, work the ground and fertilize it as for corn.

The Kind of Plants to Buy. Deciduous trees should be one year old rather than more. They are then from 4 to 16 inches tall. As evergreen trees of the same age are rarely over 5 inches tall, often not more than 2 inches, it usually pays to get two-year-olds.

Planting (Transplanting). When the young trees are received, care for them as directed on p. I6. When ready to plant, make furrows 18 inches apart with a hand-plow, going over each line twice if necessary to get the required depth. Or, if the soil is moist and compact, make a long cleft with a spade along each line. This method is often better than furrowing because the opening is deeper and the roots are more easily covered. 

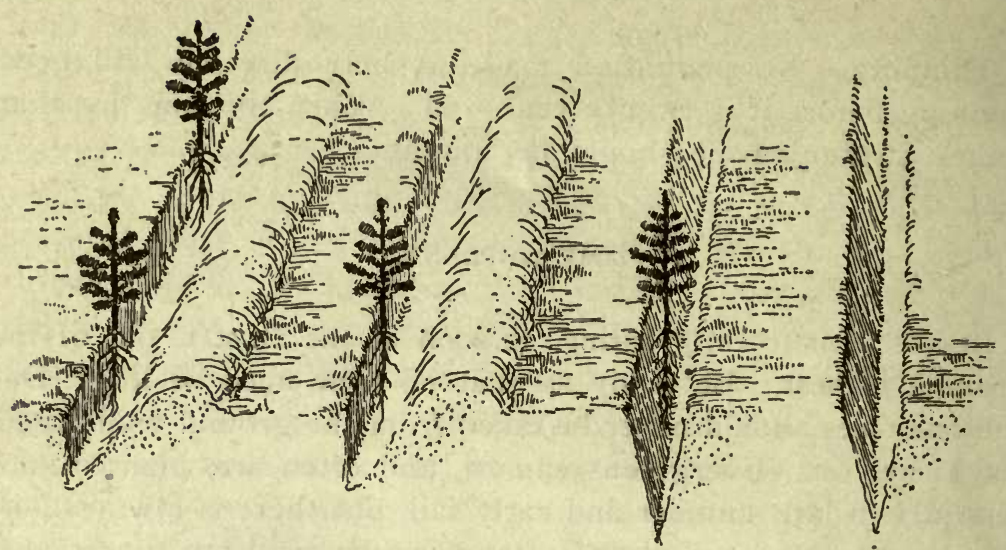

Fig. 9. Furrow Planting and Slit Planting. At left the earth is shown as opened by a plow with trees set against the vertical sides but not covered in. At right slits have been made with spades to receive the trees.

Let each planter then take a pail partly filled with trees whose roofs have been puddled as directed on p. 18 . Beginning at one end of a row, he then sets the trees by hand about 6 inches apart. If furrows have been made, each tree is set against the vertical side and the earth scraped over and packed about its roots. If clefts, the tree is pushed down as far as it will go, then withdrawn until the collar is level with the ground surface and the cleft closed. As always, it is important to spread the roots as much as possible, not buch them, and to embed them firmly. See p. 19. After the planting is done, run a wheel hoe over the rows to close all gaps and level the ground.

Cultivation. Treat a tree nursery exactly like a garden. The planting method indicated implies the use of a wheel hoe. Keep the surface soil pulverized and destroy all weeds. Cease cultivating about August 20 so that growth may be checked and the shoots have a chance to lignify before frost comes. The weeds that grow after that time will help to shield the little trees over winter. If some of the trees are lifted by frost, as often happens when they are very small, they must be set back at once.

The Second Year. After the trees have been in the nursery a year one of three things is to be done. I. Leave all to grow another season. In this case remove all weeds and trees that have died and continue the cultivation. This will be the rule where small evergreens are concerned. It is good practice if the 


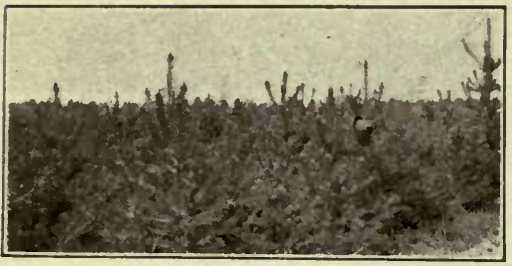

Scotch pine 7 years old, 5 feet high.

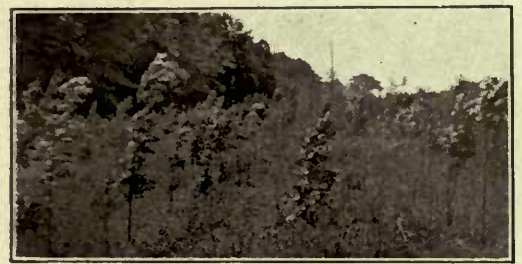

White Ash and Red Oak 7 years old, 4 feet high.

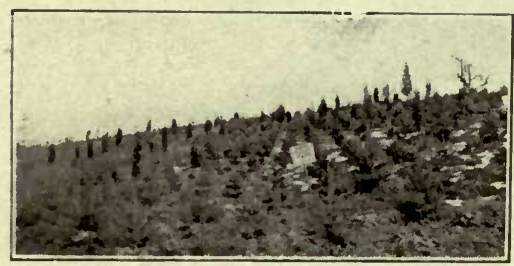

Scotch pine 6 years old on a water shed.

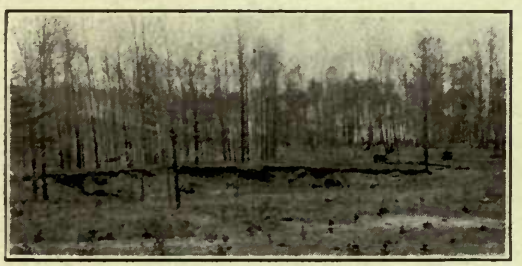

Jack pine filling a gap in a forest.

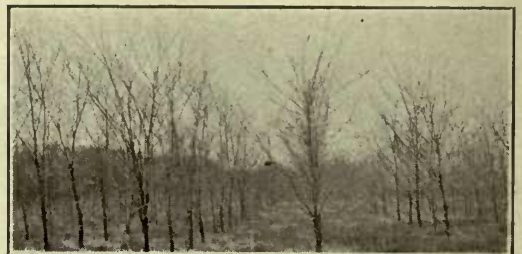

Locust 6 years old, I4 feet high.

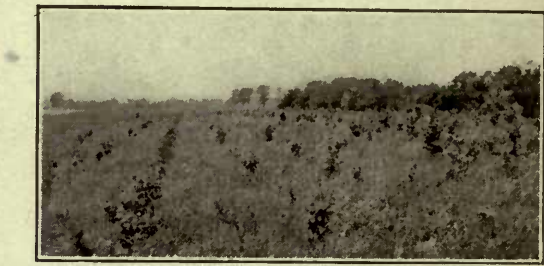

Beech 7 years old, 2 feet high.

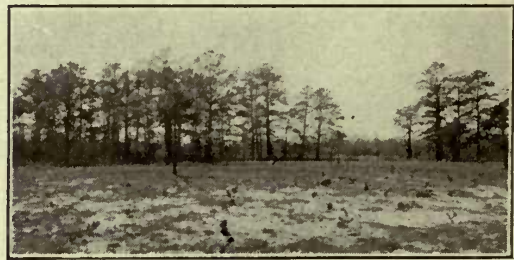

Pitch pine 2 years old newly planted.

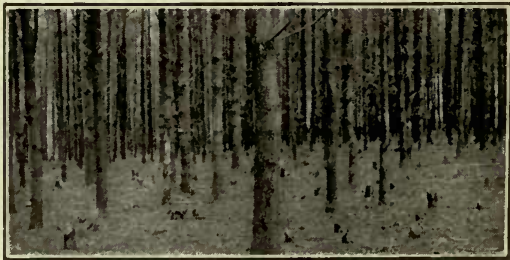

White pine 30 years old recently thinned. 
land to be planted is weedy and strong plants are needed. Deciduous trees can often be induced to grow more vigorously by cutting off the main stem just above the ground. A sturdy sprout soon replaces the first growth. 2. Take everything for out-panting. This will be the rule with most deciduous trees as they should be large enough. Evergreens may have to stay. 3. Remove the well grown trees for out-planting and leave the smaller ones. This is always good practice if growth has not been uniform, as the weaklings then have a better chance.

Purpose of a Nursery. It is well to remember that the object of nursery treatment is to produce trees that are healthy and vigorous, that can be transplanted safely and that will give quick results in their permanent places. This is attained in commercial nurseries by constant care and thorough cultivation. Trees in a private nursery require no less.

\section{THE COST OF A PLANTATION.}

It is self-evident that a plantation can be made to cost more than it is worth-by using big trees, by spending more time than is necessary. It is quite as easy to do the work so hastily that there will be no permanent result. The necessary outlay includes only the cost of trees, delivery, labor in planting, and sometimes a charge for removing brush and putting the land in shape. Fair average costs may be estimated as follows:

COST OF PLANTED FOREST-PER ACRE.

\begin{tabular}{|c|c|c|c|}
\hline \multirow{2}{*}{$\begin{array}{l}\text { Trees set } 6 \mathrm{ft} . \times 6 \\
\mathrm{ft}=\mathrm{I} 2 \text { I0 per acre. }\end{array}$} & \multicolumn{2}{|c|}{ Ordinary Conifers. } & \multirow{2}{*}{$\begin{array}{l}\text { Deciduous } \\
\text { Trees. } \\
\text { I-year } \\
\text { seedlings } \\
4^{\prime \prime}-8^{\prime \prime} \text { tall }\end{array}$} \\
\hline & $\begin{array}{l}\text { 4-year } \\
\text { transplants } \\
8 "-12^{\prime \prime} \text { tall }\end{array}$ & $\begin{array}{c}\text { 3-year } \\
\text { seedlings } \\
5^{\prime \prime}-8^{\prime \prime} \text { tall }\end{array}$ & \\
\hline $\begin{array}{l}\text { Trees ........... } \\
\text { Freight \& hauling } \\
\text { Planting time at } \\
\text { 2oc per hr. ..... }\end{array}$ & $\begin{array}{c}\text { (at } \$ 10 \text { per } \\
\$ 12.10 \\
1.00 \\
4.00 \\
4\end{array}$ & $\begin{array}{c}(\text { at } \$ 4 \text { per } M .) \\
\$ 4.84 \\
.75 \\
3.50\end{array}$ & $\begin{array}{c}\text { (at } \$ 3 \text { per M.) } \\
\$ 3.63 \\
.75\end{array}$ \\
\hline Total $\ldots \ldots \ldots$ & $\$ 17.10$ & $\$ 9.09$ & $\$ 7.38$ \\
\hline
\end{tabular}

These costs can be materially reduced if the plants are bought small-2-year seedling conifers can be had for $\$ 3.00$ per $M$ and cultivated one or two years in a nursery.

See p. 21. Some 
saving may also be made in planting cost, though too great speed always means poor work and ultimate loss. Of course, if home labor is employed, the entire planting cost may be ignored. On the other hand the cost may be considerably increased if many trees die and replacements become necessary. German forest plantations rarely cost less than $\$ 10$ an acre even with the low wages that prevail.

WHERE TO GET MATERIAL FOR FOREST PIANTING.

\section{The State of New Jersey Furnishes No Trees to Forest Planters.}

Young trees can be obtained from many nurserymen, although as a rule those who handle ornamental stock do not have the large quantities of small trees that often are wanted, or are not prepared to make the price low enough.

Buyers are recommended to satisfy their needs from nurseries within the State, and, other things being equal, from that which is nearest the planting site, or which will deliver the stock with least delay. In all cases it is advisable to stipulate that stock shall be taken from the ground of the vendor-not assembled from other nurseries.

The following carry a good variety in moderate quantities:

Bound Brook Nurseries,

The Shrewsbury Nurseries,

The Elizabeth Nursery Co.,

Hiram T. Jones,

Joseph H. Black, Son \& Co.,

North Jersey Nurseries,

Arthur J. Collins,

Bobbink and Atkins,

Steele's Pomona Nurseries,

F. and F. Nurseries.
Bound Brook.

Eatontown.

Elizabeth.

Elizabeth.

Hightstown.

Millburn.

Moorestown

Rutherford

Palmyra

Springfield

As there are no nurseries in the State especially devoted to forestry stock, it is sometimes advantageous to buy large quantities outside-specifying always that the trees shall be grown by the seller, and that prices shall be based upon size, not upon age alone.

The following are trustworthy:

North-Eastern Forestry Co.,

D. Hill Nursery Co.,

Isaac Hicks and Son,

Biltmore Nurseries,

American Forestry Co.
New Haven, Conn.

Dundee, Ill.

Westbury, L. I.

Biltmore, N. C.

South Framingham, Mass. 
THE PROFIT IN PLANTED FORESTS.

No planted forest can be a bonanza. Tree growth rarely averages more than six per cent. a year (wood volume), consequently the profit is determined by what the land will produce plus the increase in land and lumber values, minus the cost of care, taxes and compound interest on the investment. As land values and lumber values are steadily increasing, while planting costs are as low as they ever will be, almost any plantation made now on land of low value is practically sure to yield a fair profit. As forestry has no place on land that is valuable for something else, moderate returns are many times better than nothing at all. The following will show what may reasonably be expected, though it is emphasized that no one really knows what lumber will be worth forty or fifty years hence or what expense in the way of taxes, etc., may be involved. We can only make estimates, using the best knowledge that we have of rates of growth and the tendencies of lumber and land values, and of $\operatorname{tax}$ levies. The latter in particular are so uncertain that each owner must make his own estimate of the probable burden. For the sake of simplicity only initial costs and final yield are considered. In fact, there will be some intermediate costs and some income from thinnings. The latter, however, should more than balance the former. Immunity from fire and other dangers is assumed. Forestry is utterly impracticable where there are forest fires! 
EXAMPLE 1.

EXPECTED PROFIT FROM A PLANTATION OF WHITE PINE OR AUSTRIAN PINE ON ROCKY GROUND IN NORTH JERSEY - PER ACRE.

\author{
INVESTMENT.
}

Land $\ldots \ldots \ldots \ldots \ldots \ldots \ldots \ldots \ldots, \ldots \ldots \ldots$

Planting Cost $\ldots \ldots \ldots \ldots \ldots \ldots+9.00$

$\$ 15.00$ with compound interest at 5

per cent. for 40 years.... $=\$ 105.60$

Taxes-I per cent. on land value $=6$ cents paid annually for 20 years ; then I per cent. on $\$ 30$ (average value land and forest) $=30$ cents for 20 years; all with compound interest at 5 per cent......... Protection= $=10$ cents paid annually for 40 years with 5 per cent. com-

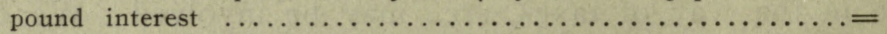

Total investment YIELD.

Sale Value after 40 years:

$20 \mathrm{M}$ ft. lumber at \$io per $\mathrm{M}$ stumpage

$\$ 200.00$

Land at original price

Total ................ \$206.00

Less cost ............ $\quad{ }^{1} 32.84$

Or, figured another way:

Net profit $\ldots \ldots \ldots \ldots \ldots \ldots+\$ 73.16$

INVESTMENT.

Land $\$ 6.00$

Planting Cost $\ldots \ldots \ldots \ldots \ldots \ldots \ldots \ldots \ldots$

Capital at 5 per cent. required to produce cost of Taxes and Protection as above

Total

$\$ 20.00$ YIELD.

Sale Value after 40 years:

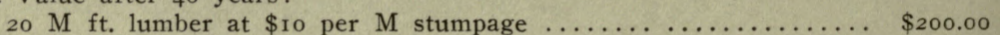

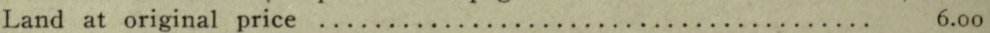

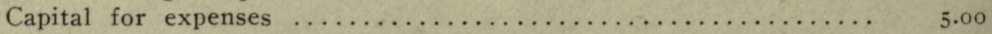

Total

$\$ 211.00$

This $\$ 2 \mathrm{I}$. equals 6 per cent. compound interest on the original investment of $\$ 20$. 


\section{EXAMPLE 2.}

EXPECTED PROFIT FROM A PLANTATION OF RED PINE ON SANDY SOIL IN SOUTH JERSEY-PER ACRE.

\section{INVESTMENT.}

Land $\ldots \ldots \ldots \ldots \ldots \ldots \ldots \ldots \ldots \ldots+\ldots .00$

Planting Cost $\ldots \ldots \ldots \ldots \ldots \ldots \ldots+8.00$

\$1 3.00 with compound interest at 5 per cent, for 60 years.... $=\$ 242.84$

Taxes-I per cent. on land value $=5$ cents paid annually for 20 years; then I per cent. on $\$ 20$ (average value land and forest) $=20$ cents for o years; all with compound interest at 5 per cent......... $=$ Protection- Io cents paid annually for 60 years with compound interest

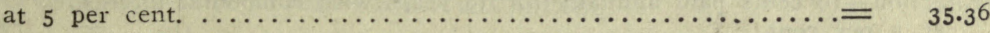

Total investment $\ldots \ldots \ldots . \$ 314.00$ YIELD.

Sale value after 60 years:

$30 \mathrm{M}$ ft. lumber at $\$ 12$ per $\mathrm{M}$ stumpage................. $\$ 360.00$

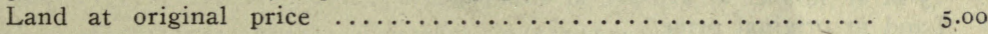

Total $\ldots \ldots \ldots \ldots \ldots \ldots \ldots \ldots+\$ 365.00$

Less cost $\ldots \ldots \ldots \ldots \ldots \ldots \ldots \ldots \ldots+314.00$

Net profit $\ldots \ldots \ldots \ldots \ldots \ldots+\$ 51.00$

Or figured to show the rate of profit as in the first example:

\section{INVESTMENT.}

Land

Planting Cost $\ldots \ldots \ldots \ldots \ldots \ldots \ldots \ldots \ldots \ldots \ldots \ldots \ldots \ldots \ldots \ldots \ldots \ldots . \ldots \ldots . \ldots \ldots$

Capital at 5 per cent. required to produce cost of Taxes and Protection

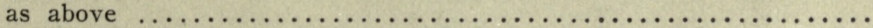

YIELD.

Sale Value after 60 years:

- $30 \mathrm{M}$ ft. lumber at $\$ \mathrm{I}_{2}$ per $\mathrm{M}$ stumpage.................. $\$ 360.00$

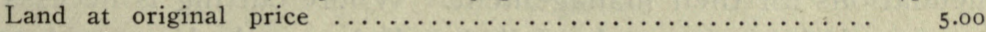

Capital at 5 per cent. required to produce cost of Taxes and Pro-

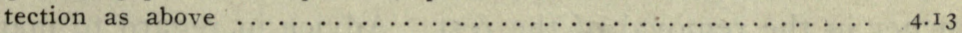

Total $\ldots \ldots \ldots \ldots \ldots \ldots \ldots \ldots$ \$369.13

This $\$ 369 . \mathrm{I}_{3}$ equals 5.25 per cent. compound interest on the original investment of \$17.r3. 
EXAMPLE 3.

EXPECTED PROFIT FROM A PLANTATION OF COTTONWOOD ON DISUSED BUT SUFFICIENTLY STRONG LAND IN NORTH OR SOUTH JERSEY

-PER ACRE.

INVESTMENT.

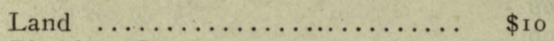

Planting Cost $\ldots \ldots \ldots \ldots \ldots \ldots \ldots$ ro

\$20 with compound interest at 5 per cent. for 30 years....=

Taxes - 1 per cent. on land value $=$ io cents paid annually for - 10 years; then I per cent. on $\$ 25$ (average value land and forest) $=25$ cents for 20 years; all with compound interest at 5 per cent. $\ldots \ldots \ldots=$ Protection-ro cents paid annually for 30 years with compound interest at 5 per cent. YIELD,

Sale Value after 30 years:

$25 \mathrm{M}$ ft. lumber at $\$$ Io per $\mathrm{M}$ stumpage............... \$250.00

Land at original price 10.00

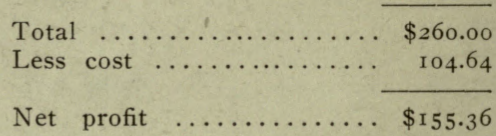

This may be calculated, in the same way as the two former illustrations, as equivalent to 8 per cent. compound interest on the original investment.

STATE AID IN FORESTRY.

To encourage the practice of forestry on private lands, the Forest Commission offers the services of its foresters, so far as their time will permit, to all who ask for them. The assistance given includes the examination of woodlands and making recommendations for their management. Where cutting is necessary, a part of the trees to be felled will be marked to guide the owner in the removal of the rest. Advice in regard to markets will be given, but in no case will the forester have part or interest in a sale. Those who wish to undertake forest planting will 
be advised regarding the most suitable species for their situations, how to obtain the trees and how to plant them. The State supplies no planting material. Fire protective plans will also be formulated.

In all cases the assistance given is advisory. There is no obligation to follow the recommendations made, though where they are acted upon the Forest Commission claims the right to inspect the property from time to time and to publish facts concerning the work for the benefit of the public. The cost to the owner is the forester's actual expenses while away from Trenton. His salary is paid by the State. Public institutions, Shade Tree Commissions, etc., will be aided without charge. Inquiries by mail on any forest or shade tree matter will be carefully answered.

Write to the State Forester, Trenton, about anything relating to forests or shade trees-not fruit trees.

FOREST FIRES MUST NOT BE TOLERATED. 


\section{INDEX}

PAGE

\section{A}

Ash $\ldots \ldots \ldots \ldots \ldots \ldots$. 12,14

Assistance to forest planters 7,28

B

Ball plants

Basswood $\ldots \ldots \ldots \ldots \ldots$

Box boards

\section{c}

Care of plantations

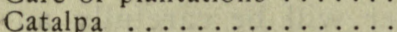

Cherry, black .........

Choice of species .......

Christmas trees

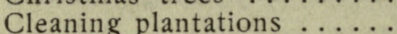

Cleft planting .........

Climate ..............

Cost of plantations .......

Cost of trees ...........

Cottonwood $\ldots \ldots \ldots 9,12,14,17$

Cultivation

Cutting back

11,14

12,14

10,12

20

9,13

9

8,10

12

20

18,21

8

23

23

17
22

D

Deciduous trees ...... 9, 15

E

Eucalyptus ...........

Evergreen trees ......9, 15, 16

F

Fall planting ..........

Fir ............. 11, 14

Fir, douglas ........11, 14

Fir, silver ........... 14

Forest fires ......... 25, 29

Forest planting, need of .... 7

Forest planting, places for . . 7

Forest planting, profit in ...

Forest soil ............

Frost ..............

Fruit trees $\ldots \ldots \ldots \ldots \ldots$

$\mathrm{H}$

Handling trees .........

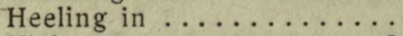

Hickory $\ldots \ldots \ldots \ldots \ldots \ldots, 12,14$

I

Intervals
4

Kind of plants to

K

PAGE

15,21

L.

Larch, European ....... 11, 14

Lining out ............ 18

Locust .......... 13, 14, 17

$\mathbf{M}$

Maple, silver ......... 13

Mattocks ............ 18

Mixed forest ......... 8

$\mathbf{N}$

Number of trees per acre .. 17

Nursery, forest ........ 21

Nurserymen .......... 24

Nursery, purpose of ..... 23

Nut trees .............. 9

O

Oak, red .......... 12, 14

Oak, white ......... 9

Ordering trees ........ 15

Outplanting $\ldots \ldots \ldots \ldots \ldots \quad 18$

\section{$\mathbf{P}$}

Paper pulp .......... 11

Pine ..........9, 10,11, 14

Pine, Austrian .......... 10, 14

Pine, loblolly, ......... 11

Pine, Norway (See Pine, red)

Pine, pitch .........9, 10,14

Pine, red .......... 10, 14

Pine, Scotch ......... 10,14

Pine, shortleaf ......... 11, 14

Pine, white .......... 10, 14

Plantation, cost of ...... 23

Planting .......... 18, 19

Planting crew ......... 18

Planting, forest (See Forest planting)

7, 9 Planting in triangles ....... 17

22 Planting, rate per day ..... 20

Planting speed .......... 20

Planting in squares ...... 17

15 Poplar (See Tulip and Cottonwood)

Posts ..........11, 12, 13

Profit in planted forests... 25-28

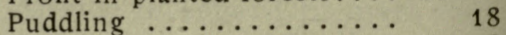

Pure forest .......... 8 


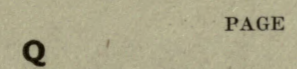

Quick growing species ....

$\mathbf{R}$

Railroad ties

Replacement

$\mathbf{S}$

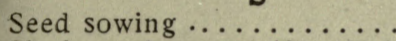
Shade endurance (See Tolerance)

Shade trees

Size of trees .............

Soil

spacing

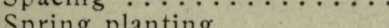

Spring planting

Spruce

Spruce, Norway

State aid
$\mathbf{T}$

9 Thinning $\ldots \ldots \ldots \ldots \ldots 17,21$

Time to plant ........ 21

Tolerance ............ 9

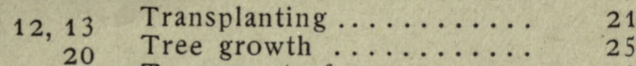

Trees, cost of ......... 23

Trees not recommended ... 13

15 Trees, where to get ...... 24

Tulip poplar ......... 12, 14

$\mathbf{U}$

7

$8,14 \quad \mathbf{W}$

17 Walnut, black ........ 9, 13

21 Where to get trees ........ 24

Y

Yield from plantations ..10, 11, 12 



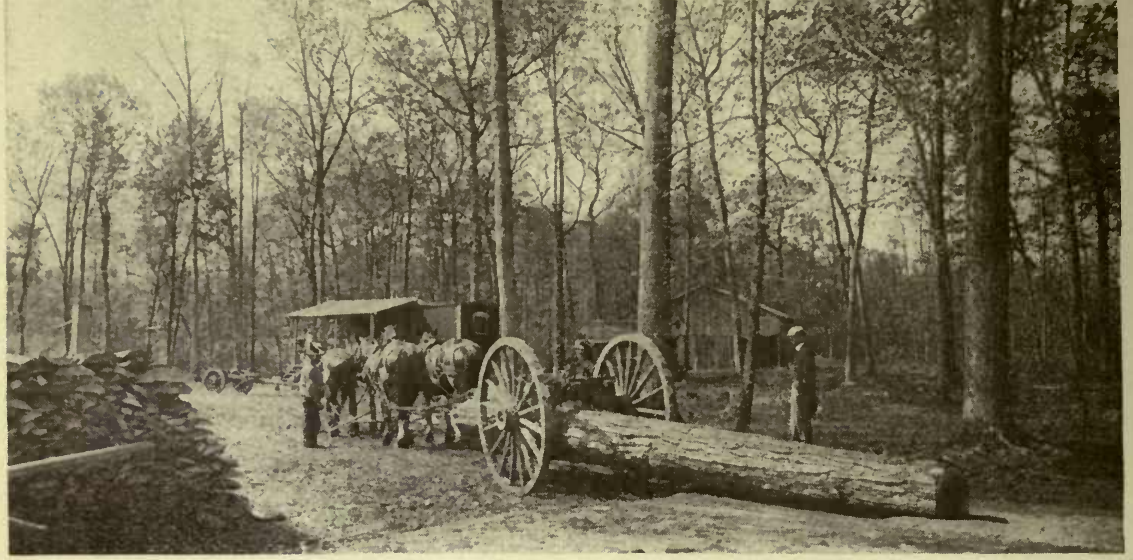

Fig. i: White Oak Log On Its Way to Mill: Burlington County.

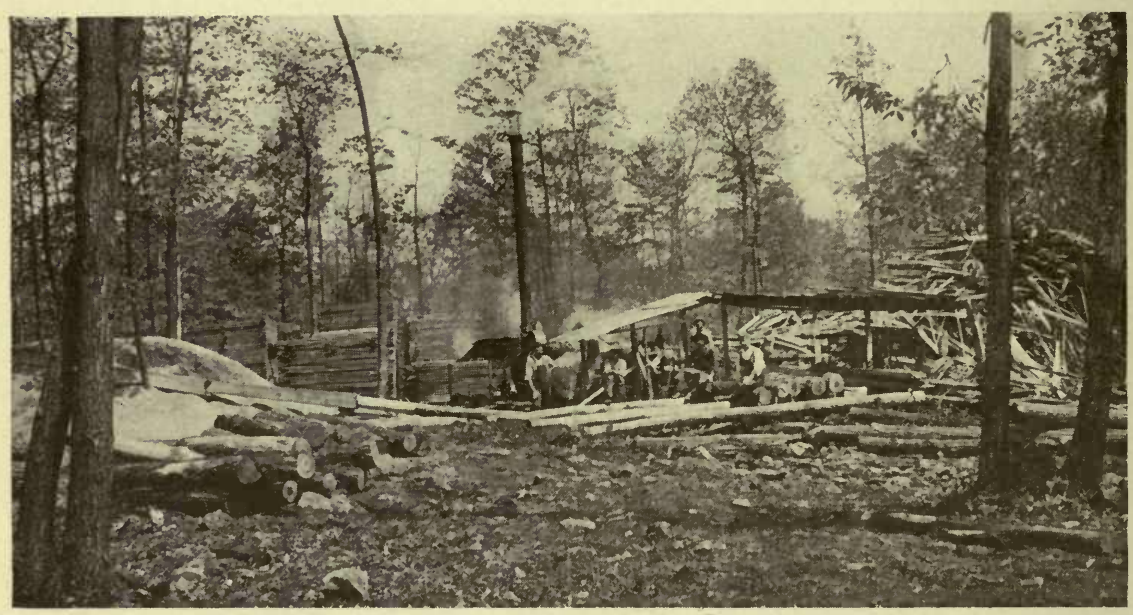

Fig. 2: A Portable Saw Mill: Somerset County.

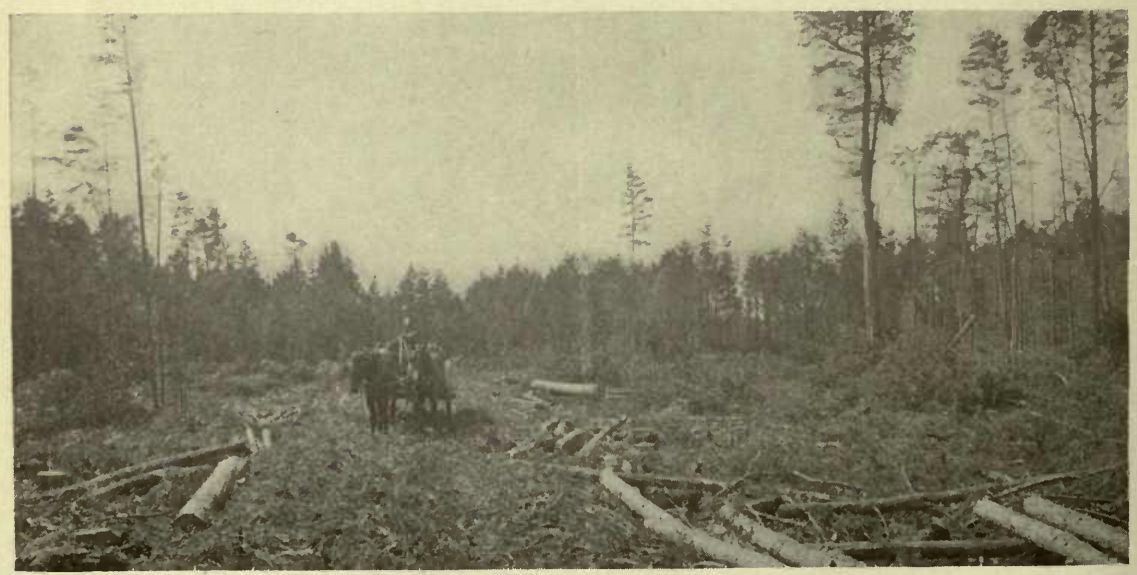

Fig. 3: Logging White Cedar: A Clean Cut is Necessary: Ocean County. 


\section{REPORTS OF}

THE FOREST PARK RESERVATION COMMISSION

$$
\text { OF NEW JERSEY }
$$

\section{Walter Mulfond}

\section{NinTH}

\section{ANNUAL REPORT}

For the Year Ending October 31st 1913

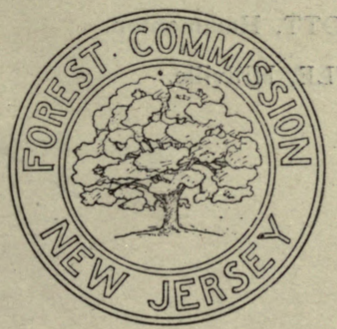

UNION HILL, N. J.

Dispatch Printing Company, 


\section{The Forest Park Reservation Commission}

Hon. LEON R. TAYLOR, Acting Governor, ex-officio President. HENRY B. KÜMMEL, State Geologist, Trenton, Executive Officer. ELMER H. SMITH, Salem.

CHARLES L. PACK, Lakewood.

WILLIAM W. SMALLEY, Bound Brook.

ALFRED GASKILL, Trenton, State Forester and Secretary. JAMES O. HAZARD, Trenton, Assistant Forester. CHARLES P. WILBER, Trenton, State Firewarden. Office, State House, Trenton.

DIVISION FIREWARDENS.

Div. A-WILLIAM LINDSAY, Dover.

Div. B-FREDERIC C. TORREY, Lakehurst. Div. C-JOSEPH E. ABBOTT, Hammonton. Div. D-LEONIDAS COYLE, Millville. 


\section{Letter of Transmittal}

To His Excellency, Leon R. Taylor, Acting Governor of the State of New Jersey and ex-officio President of the State Board of Forest Park Reservation Commissioners:

SIR-I have the honor to submit the annual report of the Forest Commission for the year ending October 3 Ist, 19I3, as required by law. The control of forest fires continues to be our greatest problem, though marked progress has been made. The work of the Commission in practical forestry and on behalf of the shade trees apparently meets with public approval. The eighteen pages of illustrations exhibit more effectively than words the scope and importance of our work.

Respectfully yours,

Alfred Gaskill,

Henry B. Kümmel, Executive Officer.

Secretary.

State House, December 18, 1913. 


\section{Illustrations.}

PAGE.

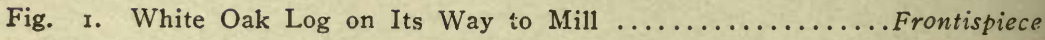

" 2. A portable Sawmill ........................ "

" 3. Logging White Cedar ........................ "

"4, and 5. Fire Hazard and No Fire Hazard After Logging ..... 5

" 6, 7, 8 and 9. Four Views of New Jersey Forests Proving That

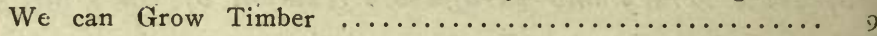

" Io and II. Practical Forestry-Stand of Young Pine Before and

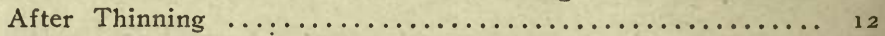

" I 2 and I3. Forester's Work and Ordinary Loggings Contrasted .... If

"..14 and 15. Two Forestry Exhibits .................. 19

"16 and 17. Restoring Forest to Land That Yields Nothing ....... 22

“ I8. Fire Resistant Pitch Pine With Reserve Poster ............. 24

“ I9. How Surface Fires Cause Lumber Loss ................ 24

“ 20, 21 and 22. A Seven-Year-Old Plantation in Which Forest Con-

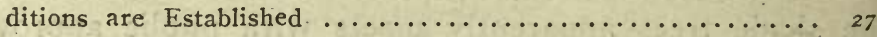

" 23. A Successful Shade Tree Circular ................... $3^{2}$

" 24, 25 and 26. Straight Lines in Shade Trees and in Roads May Often be Departed From ...................... 35

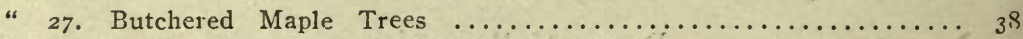

“ 28. Shade Trees Abused by Builders .................... ${ }_{3}^{8}$

" 29 and 30. Tree Wounds Improperly and Properly Treated ...... 40

“ 31. Shade Trees Planted and Maintained at Cost of a Public Service

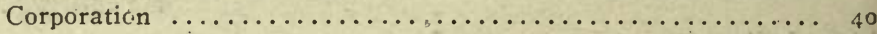

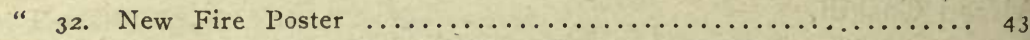

" 33 and 34. Fighting a Forest Fire with Dynamite ........... 46

" 35. Map of the State Showing Forests and Where Forest Fire Service

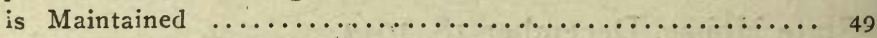

" 36 and 37. Woodland Roads as Fire Hazards ............... 5 I

" 38 and 39. Two Kinds of Fire Lookouts $\ldots \ldots \ldots \ldots \ldots \ldots \ldots \ldots \ldots$

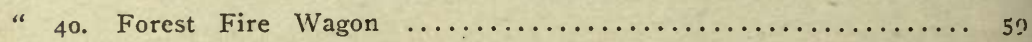

“ 4r. A Railroad Fire Line $\ldots \ldots \ldots \ldots \ldots \ldots \ldots \ldots \ldots \ldots \ldots \ldots \ldots \ldots \ldots$ 


\section{Report of the Forest Commission}

The ninth annual report of the Forest Commission is made with strong assurance that a work of positive value is being accomplished. There is no need to prove that New Jersey needs lumber, nor that forest fires are wasteful, nor that conservation of forests is desirable. The Commission has taken all this for granted and has set itself the task of educating the whole citizenship in respect to the aims of forestry and demonstrating its applications.

The Commission feels that its efforts are appreciated, that the economy of forestry is apparent, that the reform of long standing abuses is proven a possibility, that the people are with it, and that there can be no backward step.

It is worth bearing in mind that the powers of the Commission are chiefly constructive and advisory; that its duty is, not to execute an established policy and a fixed routine, but to popularize a new subject and make practical application of its principles. The sole compensation of its members consists in the satisfaction that comes of worth-while service. The policy that it formulates, the measures that it devises, the interest and enthusiasm that it awakens are made effective by the State Forester and State Firewarden whose reports, published herewith, show specifically what is being done. The cardinal points of the Commission's effort are these:

Forest fire control is an absolute condition precedent to the practice of any kind of forestry. The chief effort is, therefore, in this direction.

The practice of forestry by those who own the forests is preferable to state purchase and control.

Development of the forests we have through protection and care is wiser than planting more forests.

State forest reserves should be limited to tracts held for demonstration, for water control and other specific purposes.

Shade trees are vital to every community.

This entire program, except in respect to shade trees, seeks to 
develop forests of positive value. Our possibilities are suggested by a comparison with Württemberg. That German state and ours have practically the same area, the same population, similar territory and similar interests. The annual net income from New Jersey's forests is about 50 cents per acre, the annual net income from Württemberg's forests is upwards of $\$ 6$ an acre. We can do as well if we will.

\section{FOREST FIRES.}

The State Firewarden's report-see p. 43-makes it clear that prevention is the only effective way to control this evil. So long as fire setting agencies persist the best organized fire service that is possible can do no more than put out fires before they become serious. Whenever dry weather and high winds coincide, as they did last spring, a big crop of fires is inevitable. The year's record thus suffers by comparison with that of last year which enjoyed a comparatively wet spring, but it is better than that of any previous year since the service was fully organized. The measure of the season's success, however, is to be found, not in the number of fires reported, but in the list of potential fires that did not get away, and in the ability of the fire service steadily to increase their proportion. In this respect the fact that 54 per cent of all fires known to have started were put out before they had burned as much as five acres affords strong ground for satisfaction.

Loss: See Table II, p. 44. The estimated value of all kinds of property destroyed by forest fires during the year was $\$ 67,205$ against a similar loss of $\$ 2$ I,5OI in I9I2. More than the whole of this increase, however, is due to twenty-seven fires which under extreme conditions of drouth and high wind escaped control and caused a loss of $\$ 47,370$. Neighboring states suffered relatively much more.

Causes: See p. 46 and Table IV. A study of causes necessarily precedes any application of remedies. A steady reduction in the proportion of "cause unknown" fires indicates efficiency in a fire service; this year only 30 per cent of all fires were so reported. The average in most states is upwards of fifty per cent, 


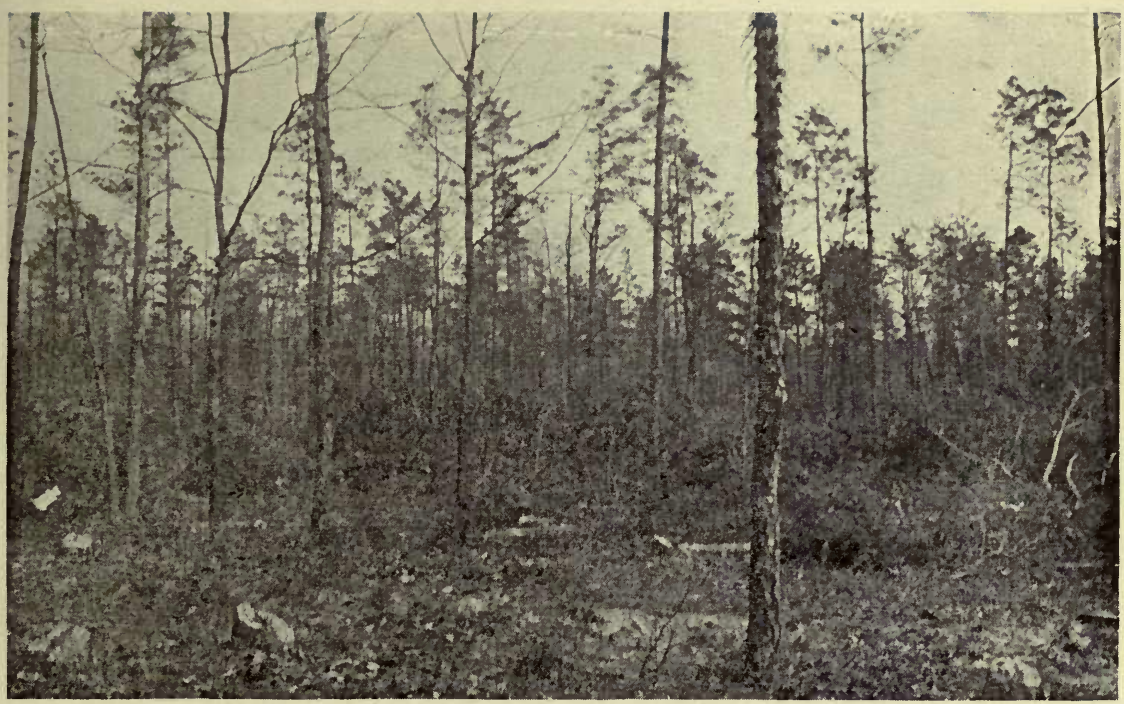

Fig. 4: A Bad Fire Hazard Created by Unregulated Logging. The Forest Commission Should Have Power to Control This.

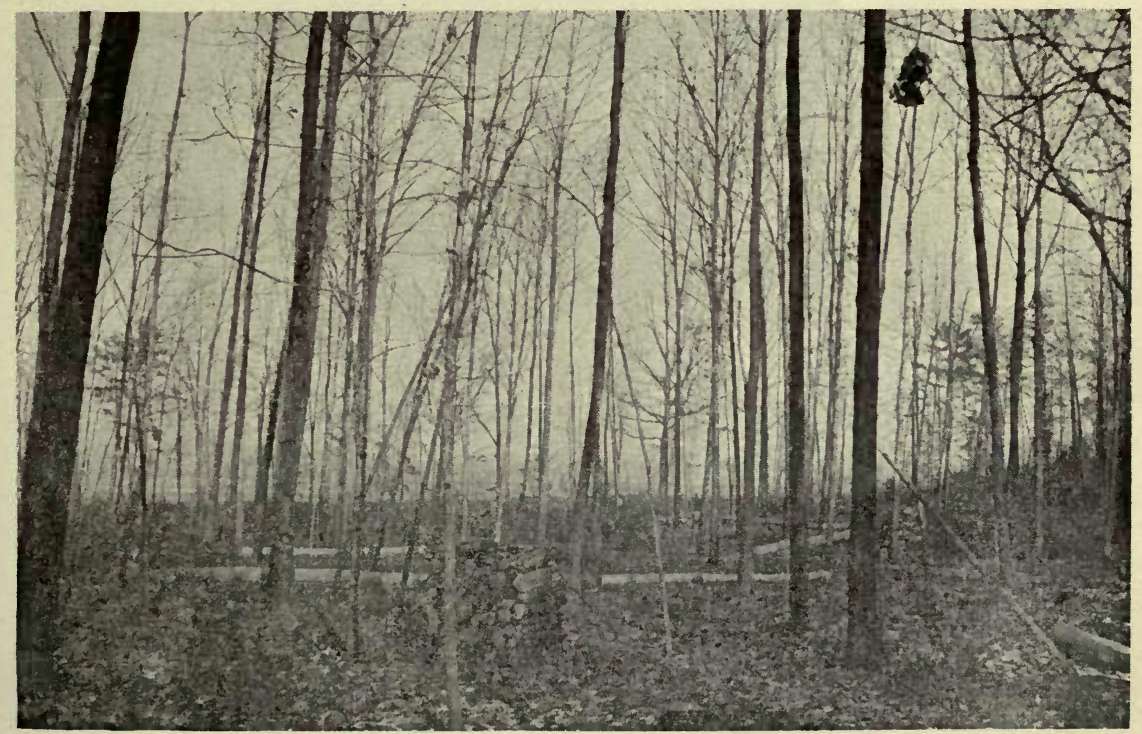

Fig. 5: Ideal Logging. Everything of Value Utilized and Brush Piled FOR BURNING.

FIRE HAZARD AND NO FIRE HAZARD AFTER LOGGING. BOTH BURLINGTON COUNTY. 

and we had as many in earlier years. Fires due to brush burning have been reduced to 7 per cent of the total, largely through vigorous enforcement of the permit law. (There were 5,240 permits issued.) This is the same ratio as obtained in I9I 2 and is a distinct gain in view of this year's increased hazard. The Commission shares the State Firewarden's belief that this very common source of forest fires is rapidly being reduced to a point which presents little serious difficulty. Smokers, hunters and similar careless people are known to be responsible for 18 per cent of the fires for which any cause is assignable, and probably for most of those of unknown origin. Little can be done to lessen these except through expensive patrol and education. Beyond all question, the railroads are our principal cause of forest fires. The offending is not wilful, and all roads are not equally culpable, but in the face of the facts that railroads caused 45 per cent of all fires this year, that property owners are complaining bitterly, and that neither fire lines nor the efforts at co-operation which have been made have produced any improvement at all comparable with that shown in connection with other hazards, it is clearly the duty of the Commission to provide some relief. See pp. 12, 46.

Railroad Fire-Line Law: The act of 1909,2 Comp. Stat. p. 2339, which gave the railroads power to reduce the fire danger along their lines by providing for the construction of wide fire breaks on private property adjacent to the right-of-way, and which has been contested in the courts since April, I9Io, was on June 18, r9r3, declared unconstitutional by the Court of Errors upon the ground that it appropriated private property without compensation. Thus this effort to bring about co-operation between the railroads and neighboring forest owners for the prevention of forest fires finally fails, insofar as its compulsory application is concerned. Indirectly it has succeeded in that upwards of three hundred miles of fire lines have been built, mostly through the voluntary action of the railroads and with consent of the owners concerned. These have proven beyond all doubt the value of such lines as an aid to fire control. From several railroads the Commission has assurances that fire lines will be maintained and extended wherever owners will give consent. 
Violations of Law: The vigorous pursuit of every individual and corporate violator of the forest fire law is doing more to secure forest property than any other element of the Commission's policy. The oft-heard assertion that no law against firing the forest can be enforced does not apply in New Jersey. The total violations established were $35^{\circ}$, of which 39 were technical offenses, chiefly illegal back-firing and burning without permit. Deducting these, though they are among the most important, it is found that over forty-five per cent of the 678 fires reported were traced to their authors and fixed as violations of law! Of the 350 established violations the railroads were responsible for 255 , or 72 per cent; brush burners for 72 , smokers for 8 and miscellaneous agents for I $_{5}$. The detailed distribution and disposition of this responsibility is shown in Tables V, VI, VIII, IX, X, XI, XII and p. 56. The points that demand emphasis here are, that the authors of forest fires can be and are discovered; that an active fire service is a strong deterrent force in that through the constant watchfulness of its members there is less disposition to take chances with fire, to risk burning without a permit, to do anything that may result in a forest fire; that the greatest responsibility is upon the railroads; and that while enforced penalties are making individuals more careful the same policy has had little effect upon the railroad managers.

The money penalties recovered amounted to $\$ 1,538.67$, if which \$I,3 I 4.62 was paid to township treasurers and the balance to the State Treasurer.*

Federal Co-operation: See p. 59. The co-operative agreement with the U. S. Forest Service by which $\$ 2,000$ a year is allotted to this State from the appropriation made by Congress to execute the "Weeks Law" is still in force. This sum has made possible the maintenance of lookouts and patrolmen in North Jersey at dangerous times, particularly during the hunting season. The organization and its influence have become so effective that for two years no serious fire has burned in the patrolled area.

Fire Patrol: See p. 59. The results gained by the Federal -patrol in North Jersey naturally suggest an extension of the plan to other sections, and that is being provided for. As the

* Between the writing of this report and March I, I9I4, additional penalties amounting to $\$ 1,072.51$ were recovered from railroads, and $\$ 136.95$ from individuals. 
$=$

0

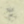

15. 

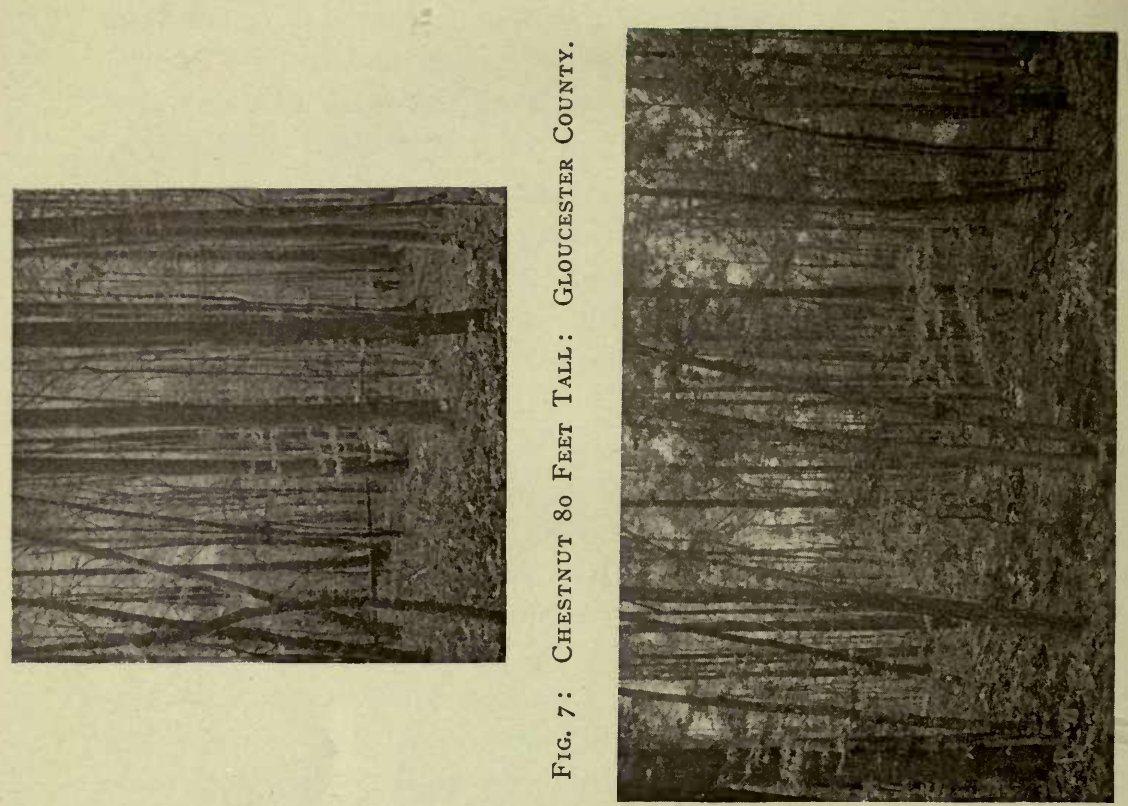

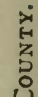
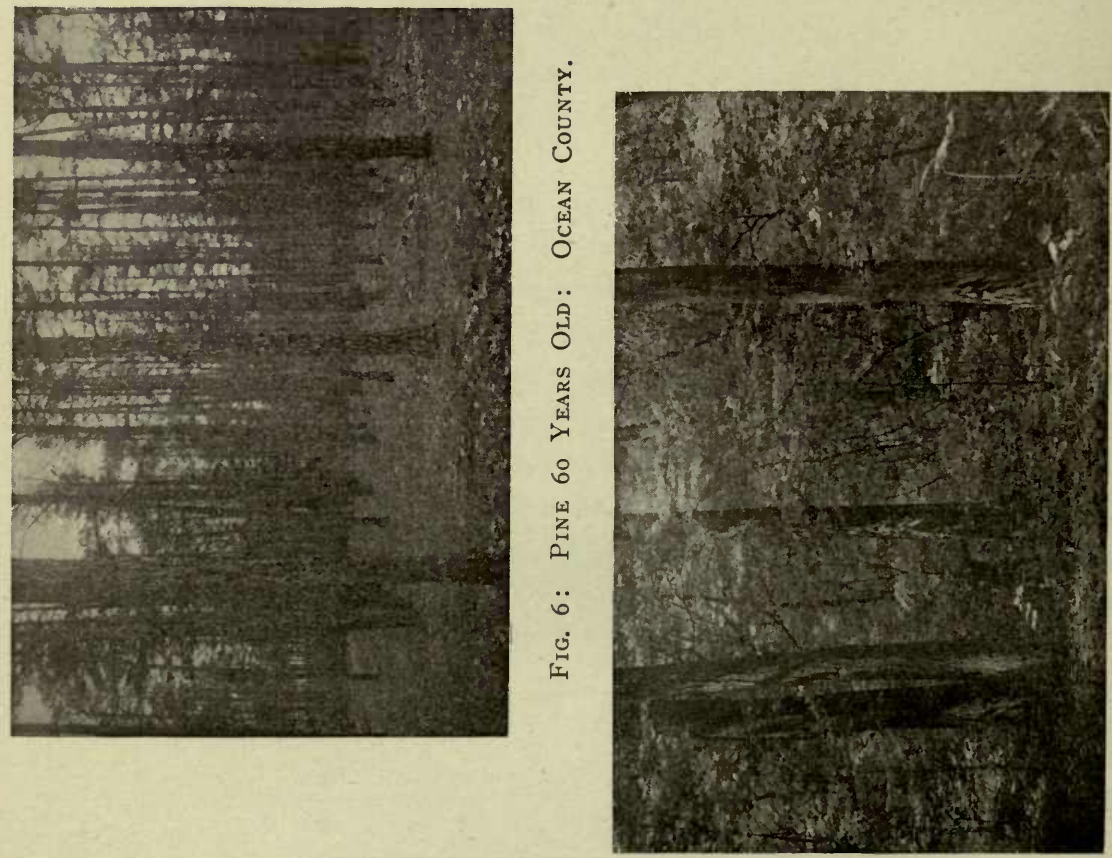

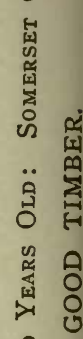

足

๕ั

되

3

包

占

aे

II

ह

究

咍 I

ن

z

经

a

总

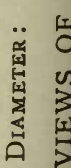

显 됙

II II

N 密

ठั

$\ddot{\infty}$

它 
cost is considerable it is intended to establish the service only where the chief beneficiaries will bear a part of the expense. The same principle will extend to the maintenance of lookouts.

\section{PRIVATE FORESTRY.}

Unless those who own the forests can be induced to practice forestry there will be little forestry in New Jersey, because the purchase by the State of any considerable area is out of the question. The Commission, therefore, is striving to interest individuals, corporations and municipalities. As a basis for this it can be shown that there is no great need to plant forests, sce p. 22; that though our original timber forests were cut long ago we still have abundant "second-growth"-in reality often fourth or fifth growth, to start with-there are two million acres of it. Forestry is now practiced in a more or less intensive way on not far from two hundred thousand.acres-ten per cent of the total, and the State foresters are advising a goodly proportion of the owners. Though what is done often includes no more than protection from fire and abuse, that as a beginning will lead naturally to growing timber crops-which is forestry. In direct response to the efforts of the Commission, its practical assistance, and its published advice are private woodlands being brought under management. New Jersey stands third amongst the States in density of population; our forests must serve as play grounds as well as producers of lumber. See p. 27.

\section{FOREST RESERVES.}

The value of the state reserves as demonstration areas is amply shown wherever they have been established. Every piece of practical forestry carried out on one of them has been imitated by nearby owners. It is desirable that small reserves, capable of immediate effective treatment be located in every part of the State. Except in this way the Commission does not now advocate increasing the State's holdings.

The aggregate area of all State reserves is 13,720 acres. They have escaped fire entirely this year and are improving in condition and value. See p. 22. 


\section{EDUCATION.}

In addition to what is done in the forest reserves and through forest owners a constant effort is made to reach the people at large. By means of lectures, publications, exhibitions and demonstrations the meaning of forestry and the State's interest in it are taught to the children and their elders. Valuable aid in this work is given by the Department of Public Instruction. See p. 4I.

\section{SHADE TREES.}

Though this subject can be dismissed with a few words it touches and interests more people intimately than does forestry itself. Shade Tree Commissions are organized in $\mathbf{5 2}$ communities, with aggregate resources of $\$ 175,000$, and the trees are having more care than ever before. The State foresters are actively aiding this work, giving advice about troubles of all kinds and furnishing the technical knowledge that the local authorities usually lack. There is a growing demand that the shade tree idea be extended to country roads and the Forest Commission is trying to satisfy it through co-operation with the State Road Commissioner. See pp. 27-34.

\section{FARMS AND FARMING-TOWN SITES.}

Agricultural opportunities may be looked for in the forested sections. Forestry makes no claim on land fit for farming but welcomes the farmer as a helper. But beware of Land Schemers who offer "town lots in the pines" at bargain prices. The land may be there, the deed all right yet the buyer gets little of value for his money. See p. I8.

\section{CO-OPERATION WITH STATE INSTITUTIONS.}

The movement to employ state dependents out of doors is strongly supported. Portions of the forest reserves have been offered as colony sites and a proposition made to use convicts to construct fire lines. See p. 25. 


\section{WOOD USERS.}

The Study of Wood Industries, announced last year, has been delayed but is now in shape to be published during the coming winter. See p. 40.

\section{COST OF FORESTRY.}

The net cost of all the work done by, and under the direction of, the Forest Commission was as follows: See also financial statement, pp. I4, I5.

BY THE STATE.

For Administration, Care of Reserves, Education, Etc. Appropriation ................................. 1000

Less income and balance refunded............... 595.45

For the Forest Fire Service.

Less penalties and unexpended balance............. 364.49

BY THE TOWNSHIPS.

For Firewardens' salaries and expenses........... \$ 4,371.77

Less penalties refunded...................... 1,314.62

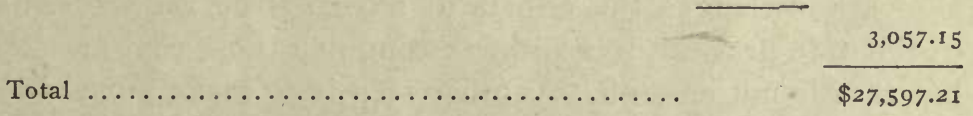

\section{LEGISLATION AND APPROPRIATIONS.}

All the legislation desired was enacted and almost the full sum of money asked for was appropriated. One new law gives the Commission authority to lease, sell or exchange reserve landsa power formerly denied; another specifically provides for a State Forester. This simply rectifies a defect in the old law as the chief forester to the Commission has been State Forester by courtesy and usage.

The appropriations already made for I9I4 are \$I5,000 for forest fires, \$I I,500 for forestry, and \$30,000 to purchase lakes. The last is a special provision to enable the Commission to make effective a law of 1907 which authorizes the acquisition and maintenance of fresh water bodies as parts of the forest reserve. 
Apart from one appropriation of $\$ 10,000$, which lapsed because it was insufficient to pay for any desirable lake, no money has ever before been provided to execute this law. The need of forest patrolmen and of increasing the number of lookouts involves an expenditure that will make it necessary to ask for a small increase in the appropriation for the fire service. An effort will be made to meet all demands for advice and assistance and to care for the state forest reserves without seeking an increase in the appropriation for forestry.

\section{THE FUTURE.}

The work of the Commission is thoroughly organized and the way to attained results is open. But the time has come to take several forward steps. The first and most important is to reduce the fire hazard along the railroads. Fires started by individuals are becoming rarer, the permit law and the warden service are effective, but railroad locomotives are driven under ever increasing pressure, they discharge sparks in spite of spark arresters, and fires are set in great numbers whenever vegetation on and adjoining the right-of-way is inflammable. The Commission acknowledges the efforts of most of the railroads, not all of them, to prevent fires and to extinguish those that are started; but that is not enough. Another step is to make our shade tree laws more effective. A third is to get more and better public roads in the woodland sections. They will facilitate fire control and make communication easier, but above all, they will open up parts of the State that are now unknown and undeveloped. Another assistant forester to give special attention to shade trees and to woodlots is urgently needed. For his salary and expenses, and for additional help in caring for the forest reserves$\$ 3,000$ a year will be required.

\section{OFFICE ROOM.}

The work of the Commission is conducted with difficulty in the limited office space provided. The State Forester, Assistant Forester and State Firewarden, with their library and records, occupy one moderate sized room, each has frequent conferences 


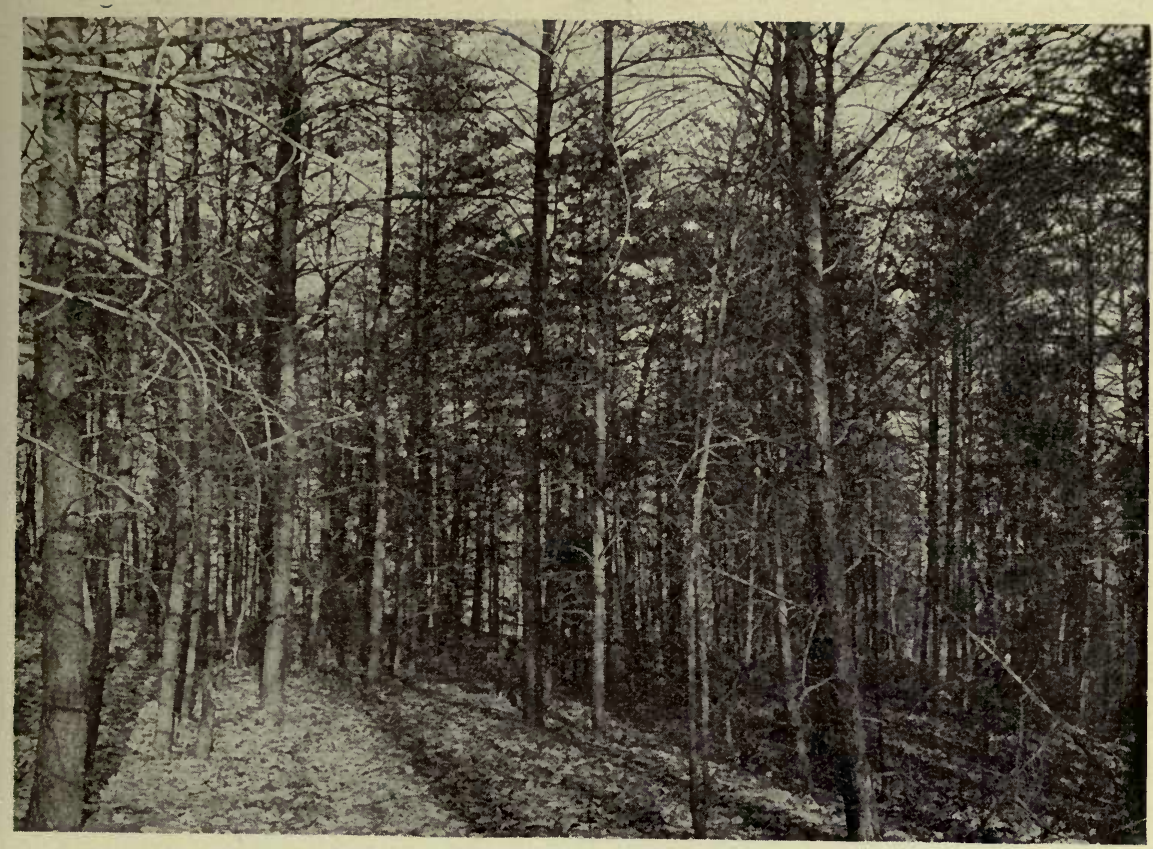

Fig. io: The Naturai. Forest. Note the great number of small, weak trees.

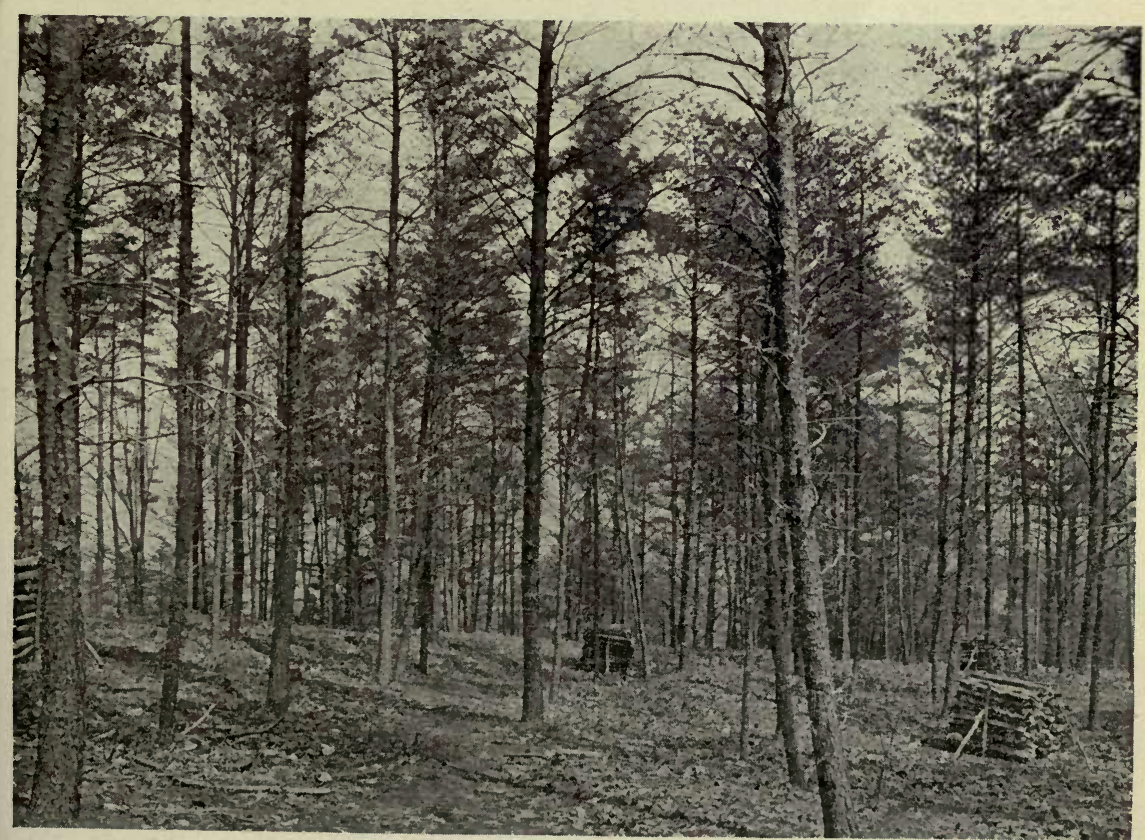

Fig. il : The Same location After Thinning. The wood removed yielded $\$ 10$ per acre more than the work cost. The remaining trees will now grow better.

PRACTICAL FORESTRY. STAND OF YOUNG PINE BEFORE AND AFTER TREATMENT. BURLINGTON COUNTY. 

with outsiders for which it is not possible to have even ordinary quiet; each dictates many letters and prepares reports subject to great annoyance and difficulty. In this same room the Commission must hold its meetings; as many as eight people are sometimes gathered in a space eighteen feet square-no privacy, no opportunity for deliberate discussion! The two stenographers with their files share one room with the clerks of the Geological Survey and the office assistant has a desk in a dark room in the basement.

\section{ORGANIZATION.}

The administrative force of the Commission is on a satisfactory and apparently permanent basis. It is organized as follows:

\section{THE FOREST COMMISSION.}

Ordinarily represented by its executive officer, (H. B. Kümmel.)

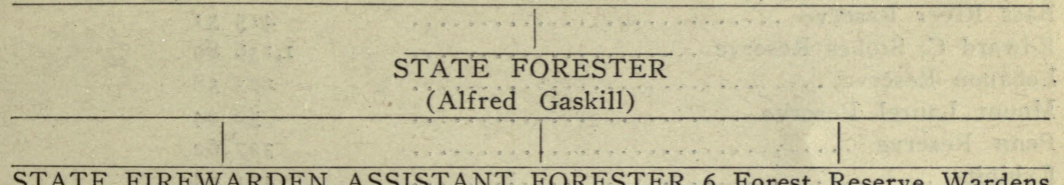

STATE FIREWARDEN ASSISTANT FORESTER 6 Forest Reserve Wardens (C. P. Wilber)

(J. O. Hazard)

4 Division. Firewardens

I 2 Township Firewardens

I 57 District Firewardens

3 Fire Watchers 


\section{Financial Statement, Forest Park Reservation Com- mission for Fiscal Year, 1913}

\section{ADMINISTRATION ACCOUNT.}

Appropriatior.

EXPENDITURES.

Salary and expenses, Foresters and Secretary ....

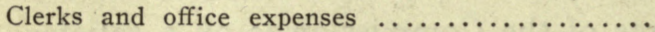

Expenses, Members of Commission .............

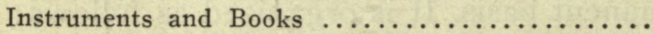

Co-operation (Woodlot and Shade Trees) ........

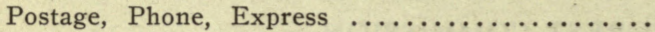

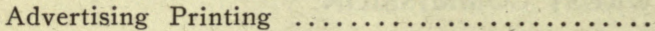

Mays Landing Reserve.$\ldots \ldots \ldots \ldots \ldots \ldots \ldots$

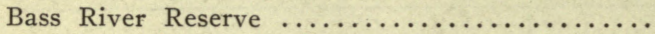

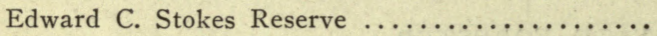

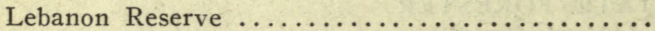

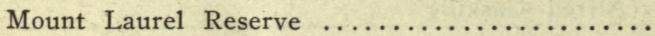

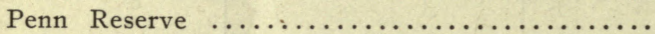

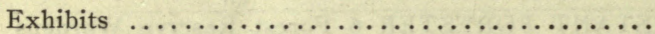

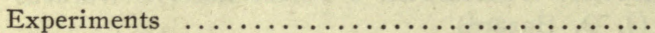

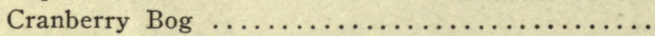

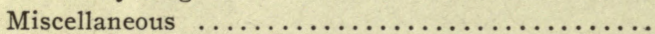

Unexpended Balance...$\ldots \ldots \ldots \ldots \ldots \ldots$

$\$ 4,97631$

I, 58492

I I I OI

I 3479

I 3135

34043

21350

12057

41531

I, 13689

27358

$\begin{array}{ll}52 & 24\end{array}$

32762

47185

17539

$\begin{array}{lll}25 & 03\end{array}$

725

I 96

FOREST FIRE ACCOUNT.

Appropriation

EXPENDITURES.

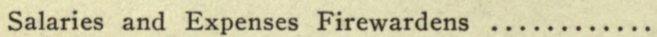

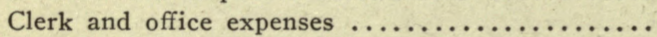

Postage, Phone, Express ..................

$\$ 8,82357$

1,29634

$156 \quad 31$

Extinguishing forest fires:

On account of 1911 fires $\ldots \ldots \ldots \ldots$ I72 82

2,89264

On account of 1912 fires ....... 87523

On account of $19 \mathrm{I}_{3}$ fires ........ 1,84459

Local Firewardens' salaries and special expenses..

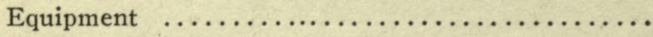

Special expenses $\ldots \ldots \ldots \ldots \ldots \ldots \ldots \ldots \ldots \ldots \ldots \ldots \ldots$

Unexpended balance $\ldots \ldots \ldots \ldots \ldots \ldots \ldots \ldots \ldots . .20463$ 


\section{Financial Statement-Continued}

\section{RECEIPTS BY EXECUTIVE OFFICER.}

Balance on hand November I, rgir $\ldots \ldots \ldots \ldots$.

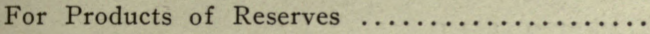

For Expenses of Foresters in co-operative work ..

From Settlements with Sundry Violators of

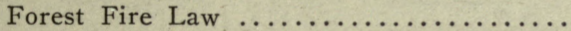

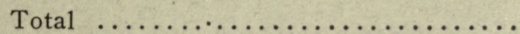

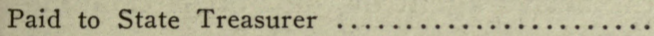

Paid to Sundry Township Treasurers ...........

Balance in hand October 31 , $1913 \ldots \ldots \ldots \ldots$

Due State Treasurer ............ 905

Due Township Treasurers ......... 6845

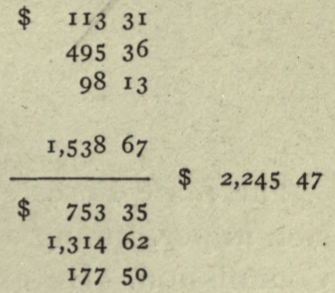

$\$ \quad 2,24547$

THE FOREST PARK RESERVATION COMMISSION,

Henry B. KüMMEL, Executive Officer

Elmer H. SMith

Charles L. Pack

William W. SMalley 


\title{
Report of the State Forester
}

\author{
Alfred Gaskill.
}

The State Forester is the active agent of the Forest Commission in performing all the duties which by law devolve upon the Commission. He exercises a general supervision of the Forest Fire Service, through the State Firewarden, but gives most of his time to aiding and advising forest owners and shade tree interests, to developing the State forest reserves, and to keeping up an active educational campaign on behalf of the trees and forests. Forestry demands a long look ahead and much patience. Full recognition of the importance of the subject, and of the State's interest in it, are apparently still far off.

\section{WHAT WE ARE WORKING FOR.}

It has been said that "in this country forestry succeeds everywhere but in the woods." The remark suggests the presence of mature forests and a desire to reform logging practices without due reference to economic conditions.

In New Jersey approximately 2,000,000 acres, or 45 per cent of the total upland, is still wooded. But the forests, especially those in South Jersey, are so degraded that they must be valued in the past and in the future rather than in the present. We have to create through forestry the forests in which more and other forestry may be practiced by and by. It goes without saying that a community having 337 people to the square mile needs to develop its forests to the utmost that there may be shaded playgrounds, pure water and lumber, and that there shall be no waste places.

The means by which this end is to be attained appear perfectly plain. A favorable soil and climate produced forests which were partly harvested long ago and have since been kept in subjection by fire. We still have all that is necessary to make trees grow, manifestly the control of forest fires must be our first 


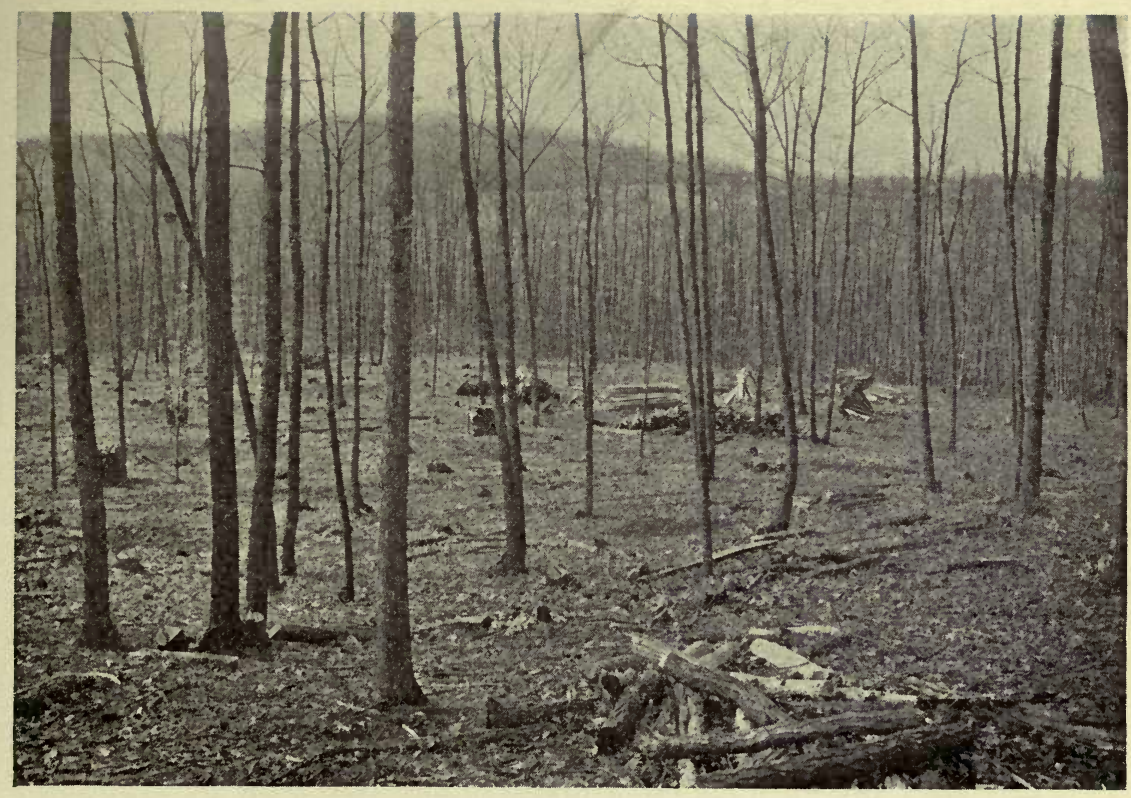

Fig. i2: Chestnut Blight Enforced a Heavy Felling: Oak Was Thinned at Same Time and Everything Used: A Clean Job Directed by a State Forester: MORris COUnTy.

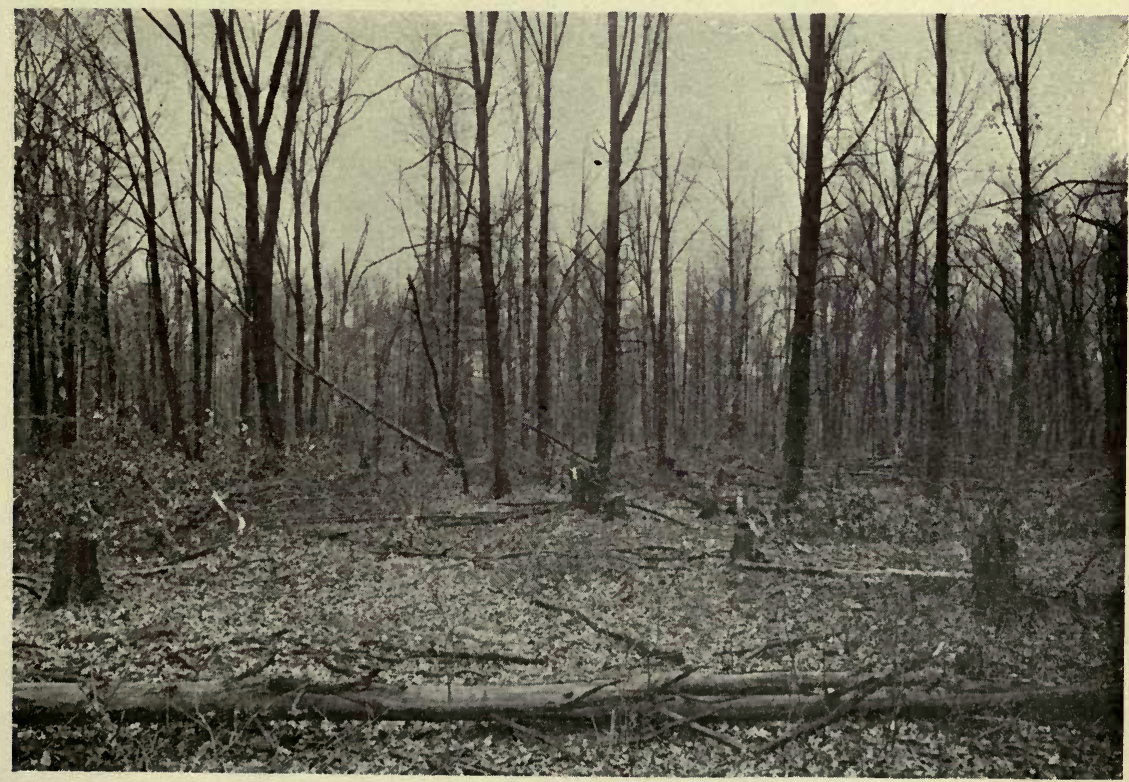

Fig. I3: The Way Logging Usually is Done: Mucin Waste in Stumps ANd Tops: Middlesex County.

FORESTERS' WORK AND ORDINARY LOGGING CONTRASTED. 

concern. And it is. We distinctly affirm that in New Jersey, or anywhere else, there can be no forestry where serious fires are feared. Forestry, after all, involves an investment in growing trees. If that investment is jeopardized beyond what is normal and reasonable, a practical man will have none of it.

Our chief and constant effort is, therefore, directed towards fire control. The very. considerable measure of success attained is set forth in the State Firewarden's report. There are portions of the State in which the fire risk is now inconsiderable; there management and planting are going on successfully. In others the fire problem still controls.

Next comes the effort to induce forest owners to practice forestry. The State owns, and can own, but a small fraction of the total woodland, yet it is possible to make it worth an owner's while to do the right thing. The means to this are, first, assured security from fire and then showing him how and getting him started. This may include improvement thinnings, or logging, planting or the control of pests. See pp. 19, 22, 32, 35 .

The third effort is educational. The people at large do not yet know what forestry is, how it touches their interests or that the State is prepared to help those who want help. This work is carried on through the schools by means of lectures, exhibits and special publications. A popular lecture can be provided at any time or printed matter supplied.

A fourth line of work is with the Shade Trees. More people are immediately interested in them than in forestry: for this reason and because trees are so vitally important in city and town life every effort is made to help solve local problems and to encourage the support of Shade Tree Commissions. See p. 27.

The fifth activity is with the State forest reserves. In many states the acquisition of state forests is held of prime importance; in some the interest looms so large that there is little room for anything else. New Jersey believes it wiser to own a small area of State forest which can be fully protected and managed to demonstrate what forestry will do for any owner than to withdraw great tracts from private control. Moreover, the cost is prohibitive. Demonstration forests in some parts of the state not now provided are desirable and the effort to acquire such that is still being made is not inconsistent with the general 
policy of restricting rather than enlarging the state's possessions. See p. 22.

All these activities are carried on simultaneously and as much time devoted to each branch as circumstances justify.

\section{AGRICULTURE.}

And with the work in forestry goes hand in hand an effort to open up portions of the present forest to agriculture. It is a mistake to assume that great unbroken forest areas are desirable, as it is to entertain the belief, unfortunately too common, that most of South Jersey is valueless. Large portions, indeed, will yield more from forestry than from farming, yet scattered everywhere through the woodland are soils that should be put to the higher use. In a state with such hunger needs as this it is quite as important to locate agriculturists upon every parcel of arable land as it is to advance timber interests; to consider the well-being of those who live adjacent to the forests as well as the advantage of the forests themselves. Field and forest is not a mere phrase, they go together by nature.

\section{LAND SCHEMES.}

This interest in farm extension by no means includes approval of the many development projects that afflict our territory. "A town lot in the pines" is more apt to be a delusion than a bargain. Legitimate efforts to open up any wild section are commendable, and there are such, but a majority of the new towns have little more than a paper existence and no future.

Most of these schemes violate no law, the victims are voluntary. All that can be done is to sound a warning and urge every intending purchaser to be sure that besides a deed to his lot, usually at from four to twenty times its value, he gets society, water, schools, stores and other necessities.

\section{PROGRESS.}

It can be said in a word that forestry has found a permanent place in this state. The citizens believe in it. No small part of the Commission's task has been to correct misapprehension, an- 


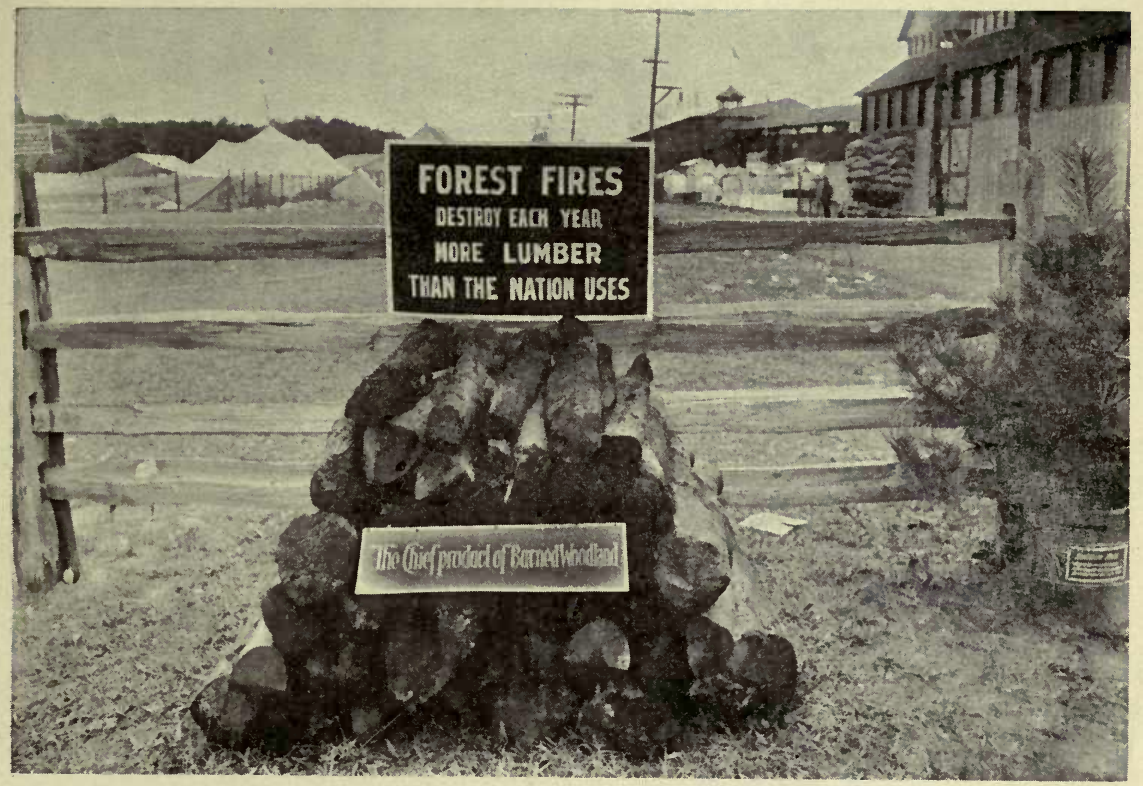

Fig. I4: Part of Exhibit at Interstate Fair, October, igiz.

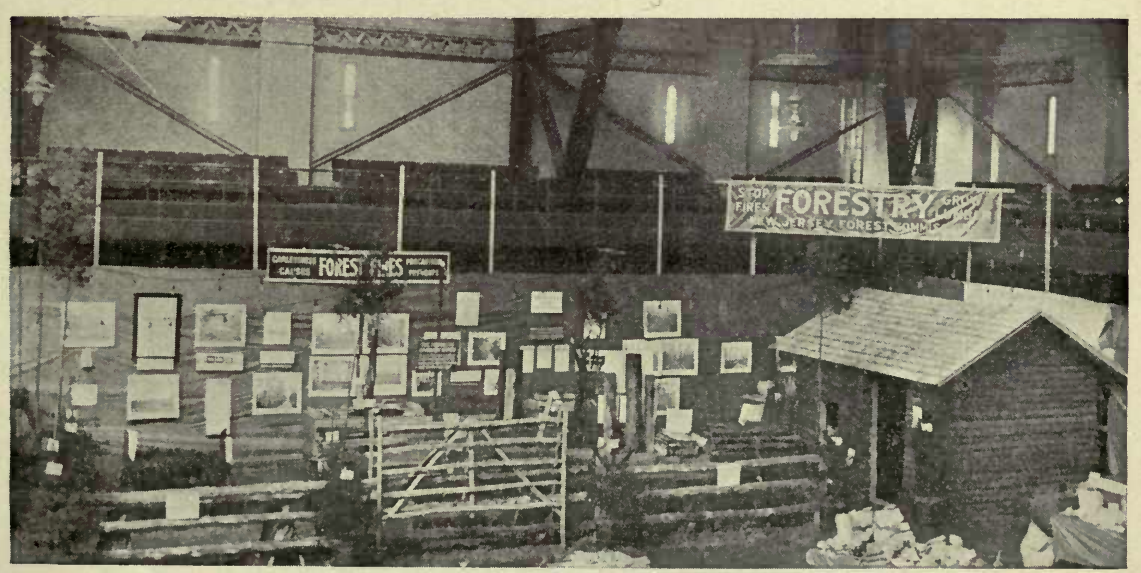

Fig. I5: Forestiky Exhibit at Trenton, January, igi3. 

other to set the people's own interest affirmatively before them. Though little more than a beginning has been made the demands upon the foresters for advice and assistance are so many that it is difficult to satisfy all.

\section{EXHIBITS.}

This year for the first time the Commission undertook to advertise its activities, emphasize the importance of fire control and inform the public of what forestry would do for them, by arranging attractive exhibits. The first was made in the Trenton Armory in connection with the January meeting of the Agricultural and Horticultural Societies. The second was an outdoor exhibit at the Trenton Interstate Fair in October. Both accomplished much in the direction intended, especially as opportunity was given for all who were interested to discuss their own problems with the attending foresters and to get information of a definite kind. See Figs. I4, I5.

\section{PRIVATE FORESTRY.}

It is impossible to go about anywhere in New Jersey without finding evidences of an active, practical application of forestry to private lands. Owners in all sections are studying the subject and working out their problems in their own ways, sometimes under the advice of the Forest Commission, sometimes entirely alone. Though results in the latter case are not always the best the effort is in the right direction. Naturally, this interest is most strongly expressed in North Jersey where many private estates are maintained. A significant example is that of the Mine Mount Forestry Association composed of a group of property owners in Somerset and Morris counties whose desire is to handle their woodlands in a practical way. Under the advice of the State Forester the Association has employed a forester who is actively directing fellings, thinnings, planting, and various other phases of forest work. In South Jersey can be seen numerous examples of applied forestry-thinnings inspired by similar work done on the State reserves, or more directly under the advice of State foresters, logging that aims at 
a future crop, and commercial plantations. Here, however, the continuance of the fire hazard is a serious handicap and owners cannot be expected to invest largely where the risk is great. All parts of the State still afford ample room for improvement in this line. See Figs. IO, II, I2, I6, I7.

\section{CHRISTMAS TREES.}

The embargo laid and maintained by the U. S. Department of Agriculture upon the shipment of Christmas greens from the territory infested by the gypsy moth and the brown tail moth (portions of New England) has created an unusual demand for the home product. In itself this is good, although it must be admitted that our pines and cedars are not very satisfactory substitutes for the balsams and spruces of the north. But the situation has its evil side in that our forests near the large cities are being raided. In portions of Camden, Gloucester and Burlington counties this became such an abuse that the Forest Commission was besought to support restrictive legislation. It was easy to show that there is no need for legislation, that existing statutes are ample to meet the situation, provided the forest owners themselves do their part. It was thus arranged through an agreement with the Senator from Gloucester County, $\mathrm{J}_{2}$ is also Master of the State Grange, to distribute through the granges a circular letter informing farmers of their rights, their privileges and their opportunities. See opposite page. 


\section{Forest Park Reservation Commission of New Jersey}

\section{CUTTING TREES ON LAND NOT ONE'S OWN IS UNLAẄFUL.}

Numerous complaints have been made to the State Forester that much destruction is wrought in New Jer. sey woodlands by outsiders who seek Christmas trees and Christmas greens.

\section{FARMERS CAN MARKET EVERGREENS.}

The use of evergreen trees and shrubs at Christmas time is commendable; the practice of stealing the material is wrong. The best that can be said for it $1^{*}$ that most property owners have considered young trees of so littic valuc that anyone who chose might cut them. There is not the slightest reason why the farmers of New Jersey should not themselves supply the demand for this material, either by growing suitable trees on theit poorest lands, or by utilizing in this way some of the smaller wild trees whose timely removal from their woodlands would benefit those that remain. This is practical forestry.

\section{DON'T EXPECT STRANGERS TO VALUE YOUR WOODLAND IF YOU DON'T SHOW THAT YOU VALUE IT YOURSELF}

The best way to stop the trespass complained of is to keep each piece of woodland as though it were valued; that is, keep out fires, encourage the young growth and fell intelligently when need arises. No one need suffer from trespassers who will take the trouble to assert his rights. The law of the State, emphatic and long standing, is as follows

\section{"AN ACT TO PREVENT WILLFUL TRESPASS UPON LANDS}

That if any person or persons shall unlawfully enter upon any lands not his own, after having been forbidden so to do by the owner of legal possessor of such lands, he shall forfeit and pay for exch offense to the owner of said lands or his or her tenant in possession, the sum of three dollars, to be sued for and recovered, with costs, in an action of debt; before any justice-of-the-peace in this State. (P L. 1857 p. I6-4 Comp. Stat. p. 5653.)"

\section{"AN ACT TO PREVENT TIE UNLAWFUL WASTE AND DESTRUCTION OF TIMBER IN THIS STATE.}

That if any person or persons whatsoever, shall, at any time hereafter, eut, fell, work up, carry away, box, bore, or destroy any tree, sapling or pole, standing or lying on any land within this State, to which such person or persons hath not er have not any right and title, without leave first had and obtained of the owner or owners of the said land for that purpose, every such person or persons so offending, shall forf cit and pay for each tree, sapling, or pole so cut, felled, worked up earried away, boxed, bored, or destroyed as aforesaid, the sum of eight dollars; one-half to the owner or owners of the land, and the other. half to the person or persons who shall sue for and prosecute the same to effect, at any time within tighteen months from the cutting, felling, working up, carrying away, boxing, boring, or destroying of any such tree, sap. ling or pole; and that whenever any person or persons, within this State, shall be sued or prosecuted before any justice-ofthe-peace within the same, it shall and niay be lawful for such justice-of-the-peace to proceed, whenever the penal,ty demanded shall not exceed one hundred dollars, notwithstanding any claim the defendent or defendants may offer to make to the land whereon and from which the said tree, sapling, or pole may be cut, feiled, worked up, boxed, bored, destroyed, or earried away, and to issue execution for the same, with costs of suit, unless the defendant or defendants shall immediately (nter into bond to the plaintiff or plaintiffs, with one or more sufficient sureties or surety, being freeholders, in double the sum so demanded, with a sufficicncy for costs of suit, conditioned for his or their appearance at the next court where the same may be cognizable, in an action of trespass, and to pay damages found against him, her or them, with eoste of suit, any law, usage, or custom to the contrary notwithstanding. (Rev 1877, p. 1187-4 Comp. Stat. p. 5397)"

\section{POST YOUR LAND}

The easiest and best course for property owners who liave suffered, or may suffer, on this account, is to post their land with. notices somewhat as follows and then vigorously pursue every offender

\section{IT IS FORBIDDEN}

To cut, destroy, or remove, any trees, poles, or shrubs from this property undar penalty of the law.

JOHN DOE,

Owner

\section{STATE AID TO FOREST OWNERS.}

The State Forest Commission is maintained to help woodland owners develop their properties and make them profitable. It cannot prosecute violators of the law, or assume a burden for anyone, but the State Forester ane his assistants will gladly advise and instruct. anyone regarding the management of his forest

\section{(Approved)}

\section{HenRY B. KuMMEL,} Executive Officer
ALFRED GASKILL, Forester

TRENTON, February I, I9I3 


\section{FOREST PLANTING.}

The conception that forestry begins and ends with tree planting is wide of the mark. Nine-tenths of the world's forests under management were started and are maintained with little or no planting. This is no argument against planting where that is the only means to get forests, as on the prairies, in the Northern States where fire has wiped out the old forest, in our own territory where forest is desirable on land that has once been cleared. Figs. I6, I7. But we are so fortunate as still to be able to have forest in almost any place where forest is desirable by simply protecting the remnant of the old forest and fostering the volunteer growth. Planted forest is better, of course, but it costs so much more than natural forest that under present conditions it usually is wiser to depend upon the latter. Nevertheless, forest trees are planted in North Jersey in considerable number, many of the plantings being made under the direction of the state foresters. With only partial figures of what has been done it is apparent that close to half a million young trees, mostly conifers as they should be, have been set out within a few years. This looks pretty large though in reality it embraces only about 500 acres.

For the guidance of those who have opportunities to plant, or wish to go into the subject more fully, a bulletin Forest Planting in New Jersey has been published and will be mailed free upon request. See also p. 26.

\section{STATE FOREST RESERVES.}

The area of the forest reserves remains as follows:

Mays Landing Reserve, Atlantic Co. Map in Report 1907 ....... 373 acres Bass River Reserve, Burlington Co. Map in Report $1907 \ldots \ldots \ldots$. I,633 acres Lebanon Reserve. Burlington Co. Map in Report 1907 ........ 3,498 acres Mount Laurel Reserve, Burlington Co. No map published ....... 20 acres Penn Reserve, Burlington Co. Map in Report Igr .......... 2,764 acres Edward C. Stokes Reserve, Sussex Co. Map in Report 1907 .... 5,432 acres 


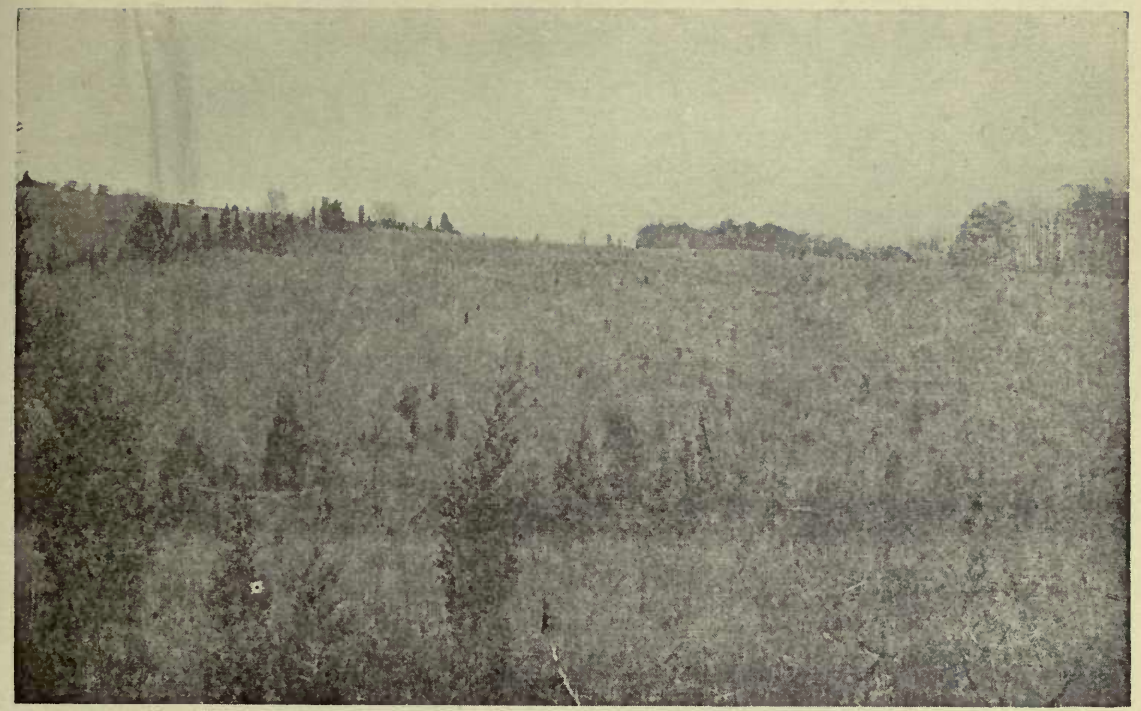

Fig. i6: Plantation of Pine Made May, rgi2: Morris County. The Littez Trees Are Seen Best on Top of Hill and at Left.

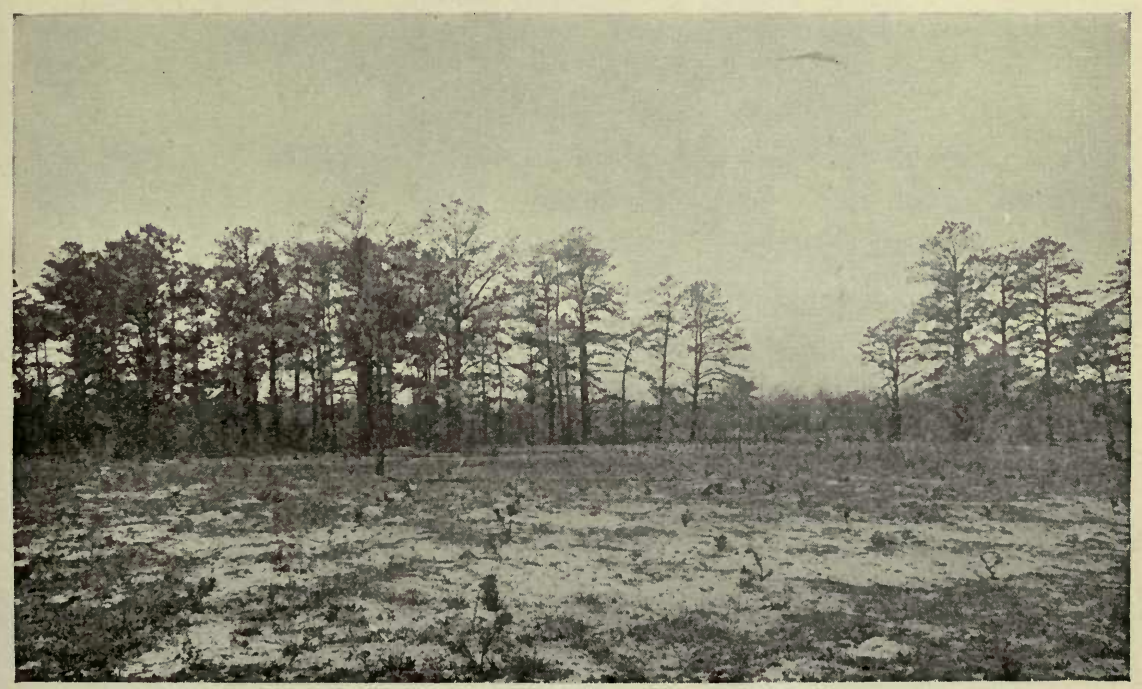

Fig. 17: Plantation of Pitch Pine Made April, igi 3: Atlantic Countr. RESTORING FOREST TO LAND THAT YIELDS NOTHING. 

As these properties cost but $\$ 45,277$, or an average of $\$ 3.30$ per acre, they can scarcely fail to increase in value. The aim of the Commission is to redeem them from their low estate, first by keeping out fire, and second by such thinnings, fellings and plantings as are practicable. They are already valuable as examples of what fire protection will do; in time each will yield a revenue that should represent an annual interest on the investment.

\section{NO EFFORT TO OWN LARGE AREAS.}

As is indicated at page 9, the Forest Commission deems it wiser to devote its efforts to uplifting the woodlands of the state without regard to ownership than to strive to increase the state's possessions. This is not at all in harmony with the policies or the desires of most states, but since little land can be acquired except by purchase, and since the removal of any large area from the tax list is of at least questionable wisdom, New Jersey is satisfied to provide demonstration forests and forego larger possessions. We do need more demonstration forests-small tracts in the agricultural sections which can be so managed as to afford object lessons to individual owners. Mount Laurel (see p. 24) is of this class. Nor does the argument against the acquisition of reserves in general preclude the purchase of property from time to time which may have a peculiar value. The Commission now has under consideration the acquisition of a piece of land which will simplify the boundaries of Stokes Reserve and of another adjoining Bass River Reserve.

\section{WHARTON TRACT.}

The project of the state Water Supply Commission to acquire what is known as the Wharton Tract is moving forward. If this great area shall finally come into the control of the state we shall have a large forest reserve as well as a unique source of potable water. The Forest Commission is interested in the plan and is p'edged to do its part in the development of the woodlands. The tract includes about I00,000 acres, of which not less than 80,000 acres are forested. 


\section{FIRE.}

This year for the first time no fire has touched any of the state reserves. Mays Landing, Bass River and Mount Laurel have been kept free ever since they came into the possession of the state. Penn also has escaped except for a burn of about Ioo acres in I9I2. Stokes has suffered two or three small fires, but in the main has also been immune. That Lebanon, which heretofore has borne the brunt of the burnings, has escaped for two successive years is a source of great relief. This general immunity is due in some measure to good fortune, as the spring was very dry, but chiefly to the changed public attitude, to the constant watchfulness of the wardens and to the system of fire-lines which is maintained. See Fig. 37. Telephone connection has now been established with all the reserves except Stokes - a provision that adds much to their security. Fires in the future are not impossible; they are unquestionably less probable than on lands similarly situated which are not cared for.

\section{IMPROVEMENT.}

On all the reserves the improvement in the forest due to immunity from fire is noticeable. Pine trees which a few years ago were little more than knee high now stand above the head of a man. The vigorous growth, and in many cases the density of the stand, indicate the value of these low grade soils for timber production. Those portions of the reserves which have been thinned or otherwise treated are responding to the work of the ax in the way expected.

\section{MOUNT LAUREL.}

This little reserve deserves especial notice because it is serving so well the purpose of its acquisition, namely, the maintenance of the forest and the coincident utilization of a large proportion of the trees. See Figs. 5, IO, II. The people of the neighborhood who secured the transfer of the property to the Forest Commission because they feared that the Mount was to be denuded are pleased with the improvemnet in the condition of 



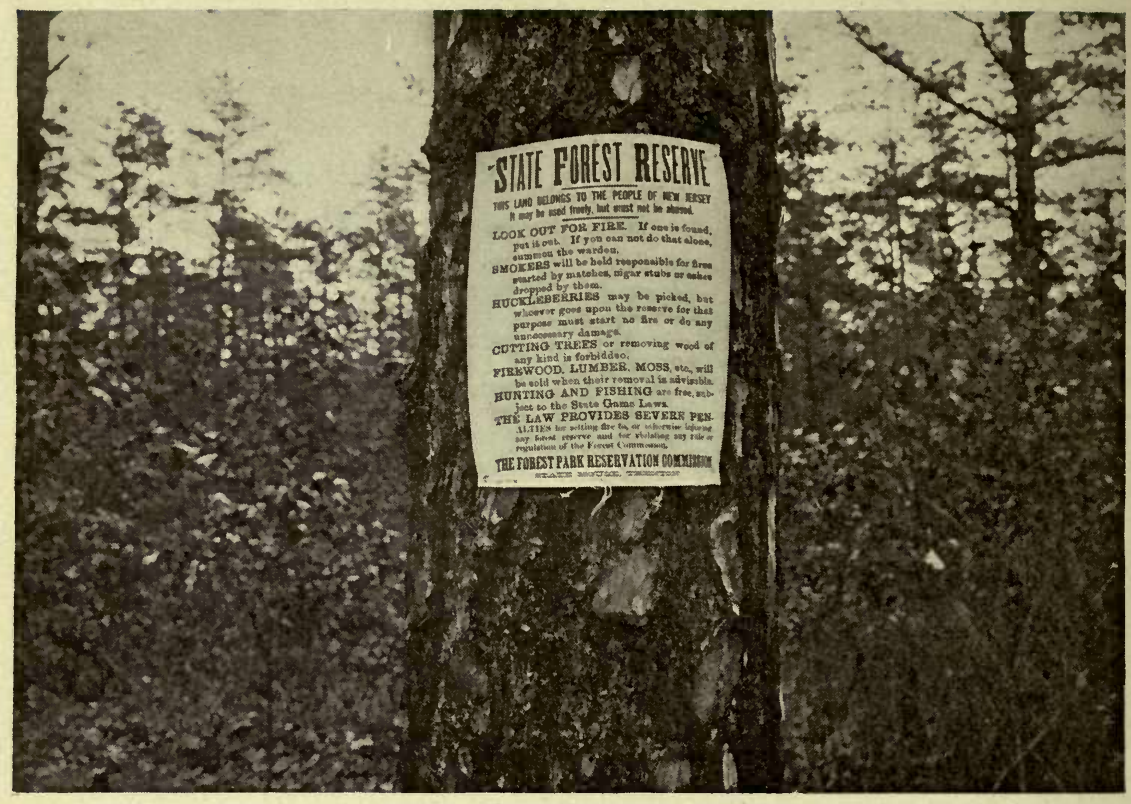

Fig. i8: Fire-Resistant Pitch Pine With Reserve Poster.

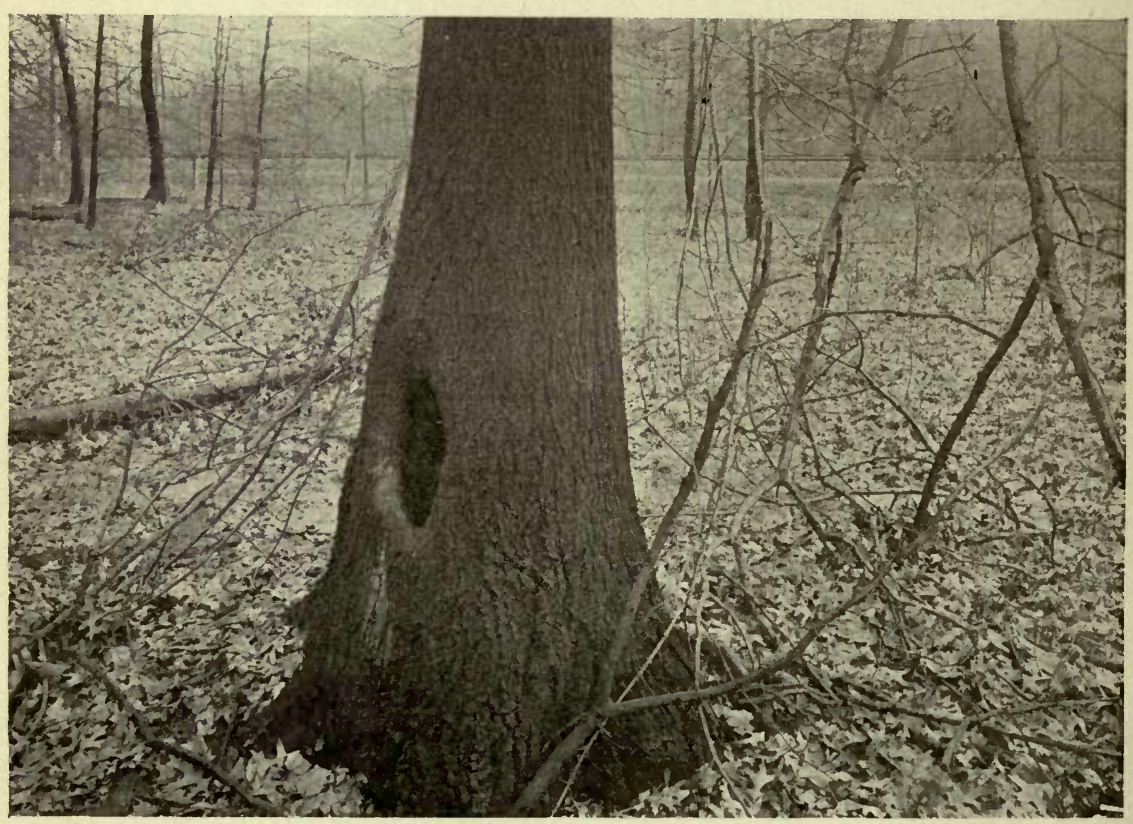

Fig. I9: Surface Fires Cause Much Lumber loss by Injuring Trees LIKE THIS. 
the property, while as before reported, the lumber and wood taken out yielded a net profit of \$I 5 an acre. The bulletin "An Example of Woodlot Forestry," which describes this piece of work in detail, is still available.

\section{PRODUCTS.}

It would not be difficult to derive a considerable income from any of the reserves if all the timber on them were to be cut. It is deemed expedient, however, to reserve everything that is now there, except such as can be removed in thinnings, until the trees shall be more mature and until a sufficient reproductions is assured. Nothing, of course, can be expected for a number of years from the greater part of the areas as all have been repeatedly cut and burned. On the other hand, there are less than Ioo acres of open ground in the whole I3,720 acres and every assurance that natural forests will come with time. The receipts for the year were $\$ 495.36$, a sum quite insignificant except that it indicates the Commission's purpose to put the properties on a paying basis as soon as possible.

\section{TRESPASS.}

All unlawful use of the reserves has practically ceased. Absolute freedom in respect to berry picking and hunting (subject to law) is allowed and sometimes dead wood is given away. Timber, moss and cranberries are, however, considered as property to which the state has an owner's right. One insignificant infraction of this right on Stokes reserve was the only instance discovered during the year.

\section{USE OF RESERVES BY STATE DEPENDENTS.}

The State Forester has taken part in several conferences looking to the establishment of colonies or camps from the state charitable and correctional institutions. Contrary to a rather wide-spread belief there is no great opportunity for the employment of labor in forest planting (see p. 22) and comparatively little in other lines of forestry. There are, however, 
areas within the reserves where colonies can be advantageously located, where farming can be carried on and where some winter work in forestry can be provided. Furthermore, there is great need, off the reserves as well as on them, for the cleaning of forest roads so that they shall be effective fire lines. This in particular offers an opportunity for the employment of a limited number of convicts. It is expected that some of these projects will crystallize during the coming year.

\section{SURVEYS.}

A survey of Stokes reserve has been practically completed and provision made for marking each corner permanently. In so rough a territory, and with many doubtful points in the old survey, this has been a task of some difficulty. Considerable work of this kind remains to be done on other reserves, several points in the original surveys having been found faulty.

\section{SHELTER CABINS.}

To the cabins erected last year on Lebanon and Penn reserves a larger one, built of logs, has been added this year on Stokes reserve. This will serve as headquarters for the warden and shelter to any who may be working on or visiting the reserve. Its cost, including furniture, was about $\$ 400$.

\section{FOREST PLANTATIONS.}

In the spring a number of experimental plantations were made on Mays Landing, Bass River and Lebanon reserves. These were located on old fields and designed to give some exact information about the availability of various conifers, chiefly pines, for planting on the poorer soils of South Jersey. No results can be expected for several years.

It is possible to record, however, and with some satisfaction, that the plantations made in 1907 on the Conger tract at New Brunswick are in several instances developing true forest forms. The evergreens there planted have not succeeded well, proving, as was expected, that the heavy soil of that section is not 
$4+$

$3+4=$ 


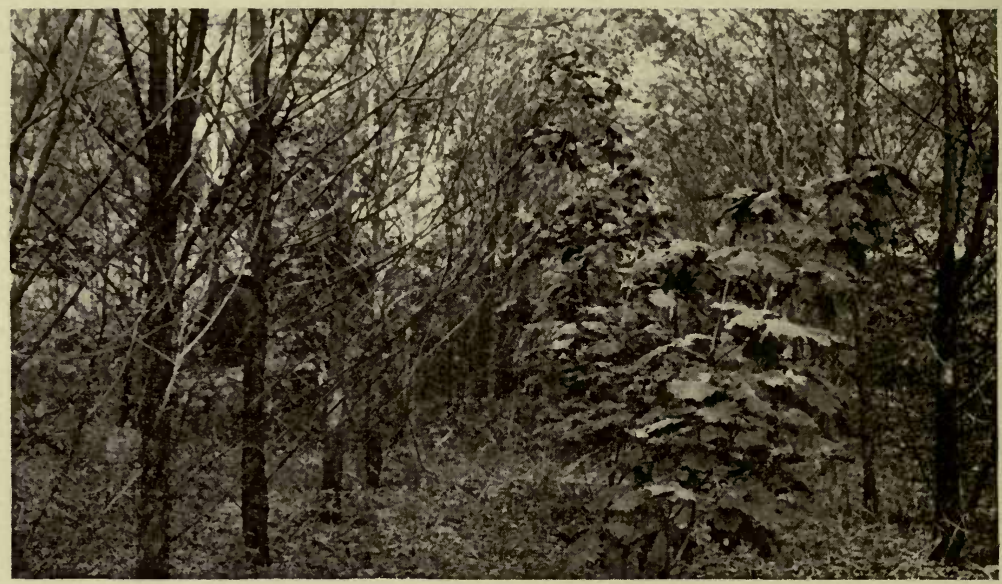

Fig. 20: Black Locust and Red Oak 6 ft. $x 6$ Ft. in Alternate Rows. Locust 25 FT. High: OAK I 3 FT. High.

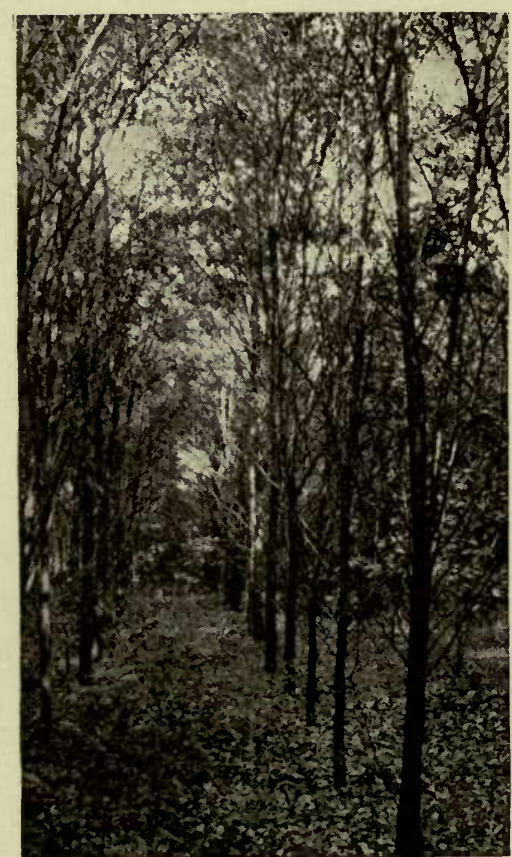

Fig. 2i: Straight Stemmed Locust : In Two Years Some Will Be Fit FOR POSTS.

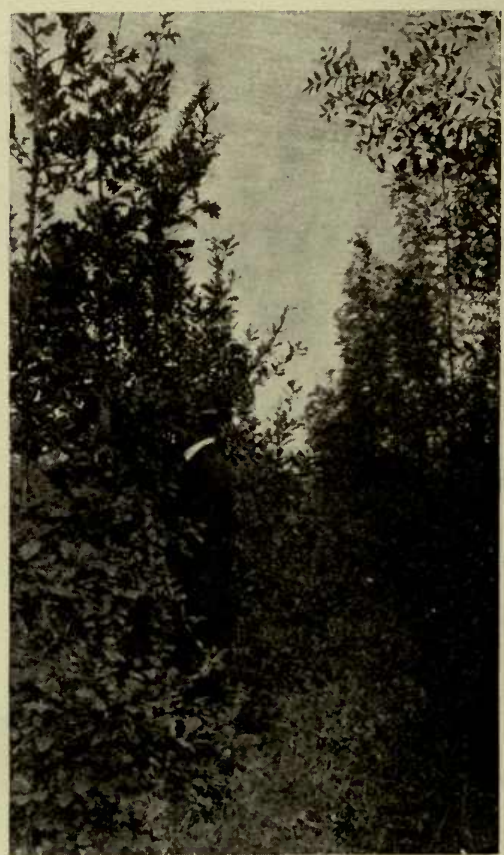

Fig. 22: OAK and Ash, Planted 6 ft. $x \quad 6$ Ft., Now Average I 2 FT. HIGH.

A Seven-Year-Old Plantation (Seedlings zYears Old) In Which Forest Conditions Are Established: Middlesex County. 
adapted to coniferous trees. Here we have learned through failure what not to do. In contrast with this is the success of the deciduous plantations. Red oak, European white oak, ash and beech, all set out when less than a foot high, now range up to 12 feet and are in good form. Beech naturally is more backward than any of the others. Locust of the same age, planted 6 feet by 6 feet, has an average height of about 20 feet. A limited number of fence posts can in all probability be cut after two years. It is notable that comparatively little damage has been done by the locust borer and that mixed plantations of red oak and locust are in better form than the pure plantations of either species. See Figs. 20, 21, 22. These stands are now in a condition to afford object lessons of several kinds. The pure locust stands are fully closed and a characteristic forest litter, with almost a complete absence of undergrowth, is observed. In mixed stands the development of this typical condition is in progress.

\section{SHADE TREES.}

It has been necessary to give more attention than ever before to shade tree interests. Appreciation of shade tree values is growing everywhere and the Forest Commission is called upon to help individuals and communities. There is no question that the shade trees all over the state are in better condition than they ever have been, nor that there are more of them by many thousands.

\section{PARKS.}

The foresters of the Forest Commission have also been called into consultation in a number of instances by those having charge of local parks. Assistance of this kind is given as readily as in the case of shade trees. Necessarily, landscape questions are not considered, at least in an authoritative way, but advice is offered regarding tree diseases, insect enemies, planting, fertilizing, etc.

In this connection it may be reaffirmed that most private woodlands are in effect public parks. Few owners object to a 
reasonable use of their property; barriers are rarely raised until fires, hackings and other abuses become intolerable. The most highly organized forests of Europe are great playgrounds as well as producers of lumber. Ours should be, and can be, the same.

\section{SHADE TREE COMMISSIONS.}

The number of these organizations is increasing as the people learn of the effective work that such bodies can do. According to the best information obtainable there are now $5^{2}$ shade tree commissions, or equivalent organizations, in as many communities, organized under the law of 1893 and its supplements. These are enumerated in the accompanying summary: Table I. It will be observed that five have been created within the year. The appropriations, though aggregating $\$ 175,000$, are in most cases deemed insufficient for local needs; indeed, the sums allotted in all but two or three of the larger cities seem almost insignificant. Effective work cannot be expected where money in reasonable amount is withheld.

The value of a commission organized under our State laws is, however, fully established. Apart from the tree planting, doctoring, etc., that is provided for it can, and often does, represent the community interest in some controversy. Thus the Secretary of one commission writes:

\footnotetext{
"We have utilized our authority to save three large elms. The trees in question were about eighteen inches within the curb line as established by the engineers preparatory to paving as a County Road. We induced our local engineer to extend the curb out the necessary distance, which preserves the trees for the present.

"As a growing town we are having a considerable amount of paving and curbing laid at present and we are continually called upon to determine whether trees are to come down or whether street lines are to be deflected to accommodate the trees. So far we have had no trouble with either contractors or engineer, both accept our position as arbitrators."
}

Fig. 31 shows an improvement made by a Shade Tree Commission at the expense of a local gas company. All this is as it should be.

Unfortunately, the recognized defects in the laws have not yet been remedied. One enactment contradicts or involves another until some communities have actually declined to organize commissions because they could not be sure what one's 
FORESTER'S REPORT.

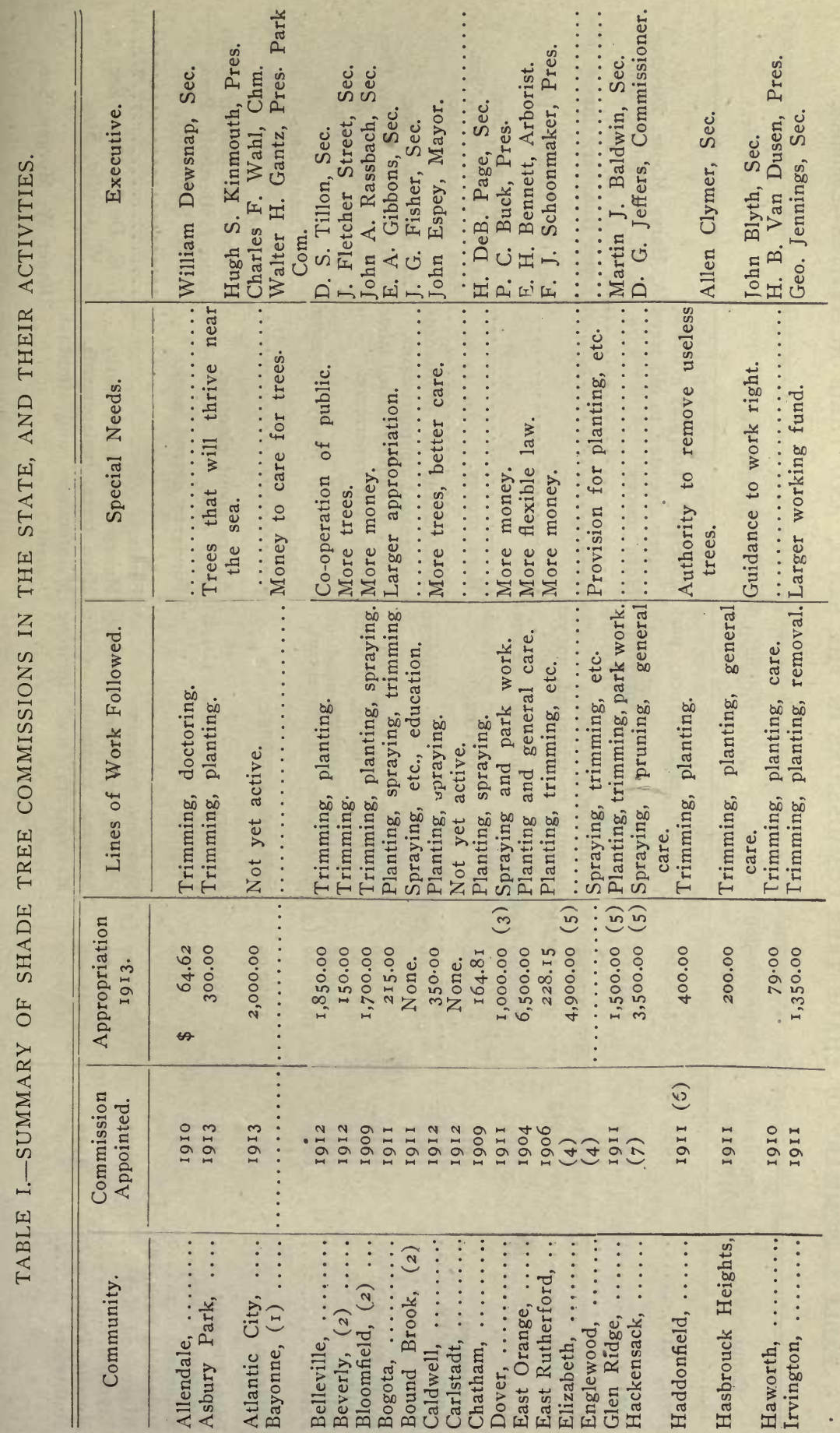




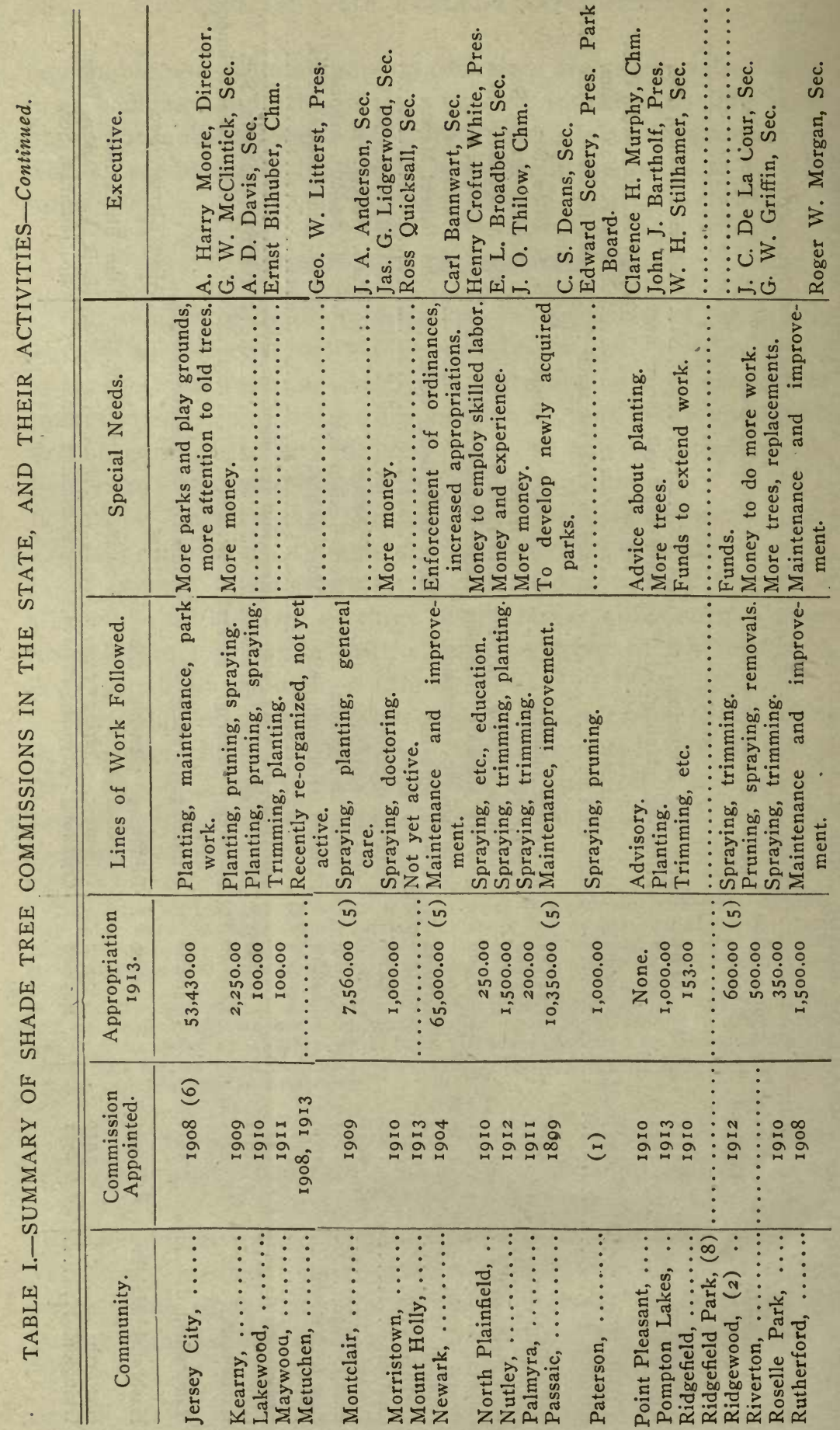




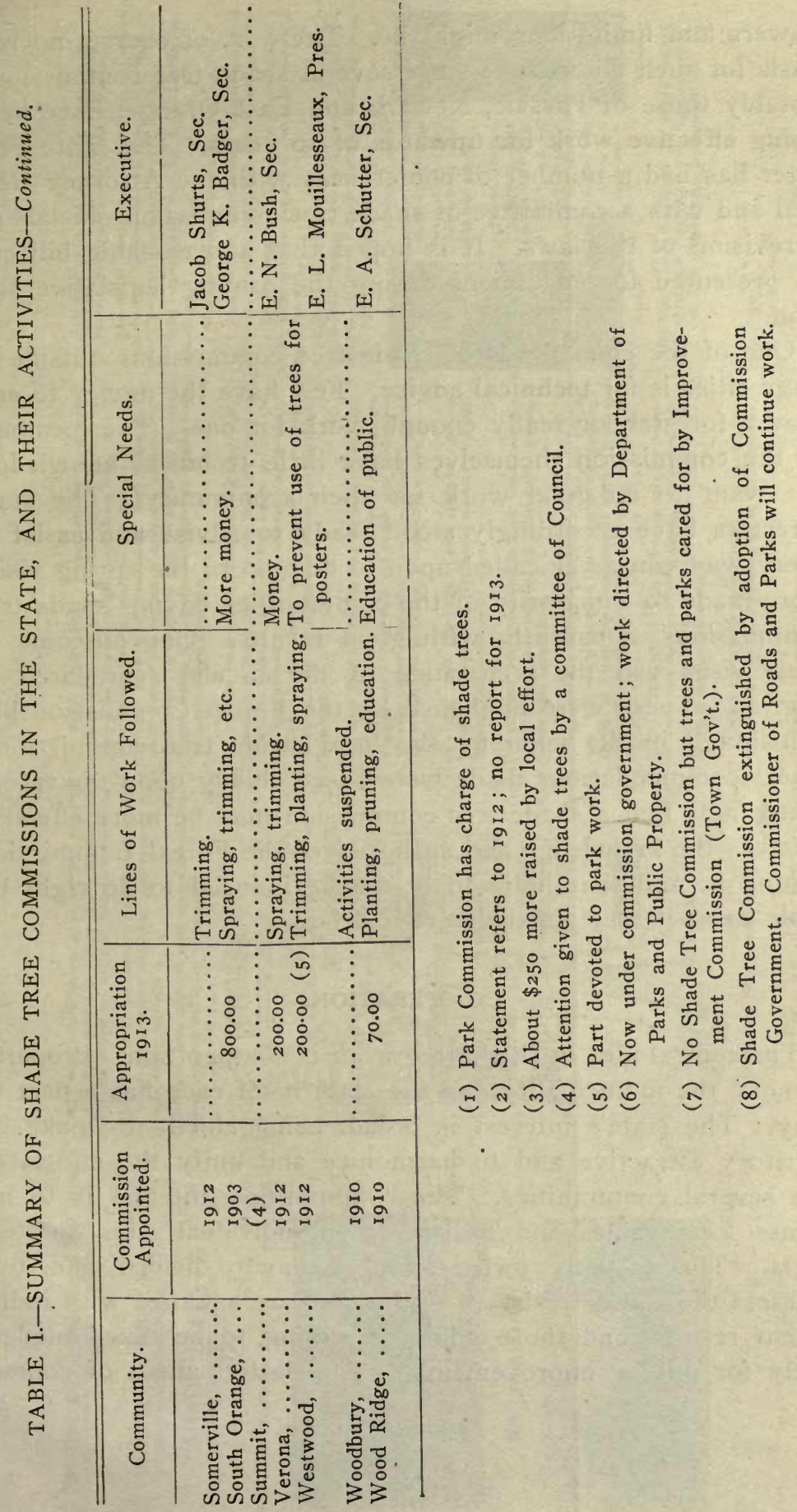


powers and limitations might be. There is, of course, no real basis for such an attitude since several shade tree commissions, notably those of Passaic, Newark and East Orange, have been doing effective work for upwards of ro years. The State Forester has had a number of conferences with the Attorney General and with a committee of shade tree commission officials on a revision of the laws. It is hoped that a reasonable bill can be presented for enactment during the coming legislative session.

One of the chief needs of shade tree commissions outside of large cities is for technical advice. Few have the money to employ a forester, or really enough work for one. The members of the commission themselves have little technical knowledge, yet want to do good work for their community. The state foresters have accordingly stood ready to advise and assist in every way whenever called upon to do so. In the spring visits were made to a majority of the communities having shade tree commissions, apparently with good results. One outcome of these visits was the preparation of the circular reproduced as Fig. 23. These were published by the Forest Commission but distributed in the main by the local shade tree commissions. The recommendations made were based chiefly upon the recognized facts that a shade tree commission may be more effective if it has the knowledge and authority of the Forest Commission behind it, and that individuals can be induced to do right by their trees if they definitely are told how.

\section{CO-OPERATION.}

The central idea in shade tree work is co-operation. Property owners, the municipality and the state itself each has a part to play. The state's interest is broad, being chiefly to make its territory attractive and to harmonize and unify the efforts of the several communities. The communities' interest is to increase local values and to strengthen individual aims and efforts. The property owners are commonly divided into two classes: those who resist all outlay and are satisfied with indifferent results, and those who are willing to be taxed moderately for public improvements. The latter must, of course, 


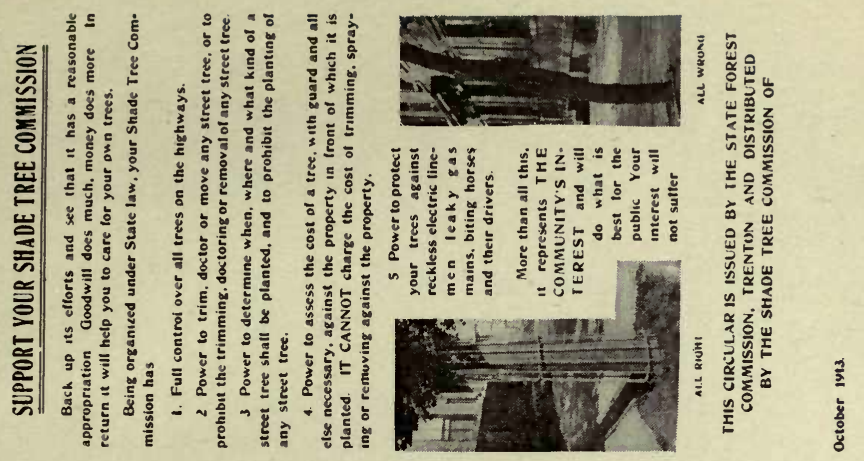

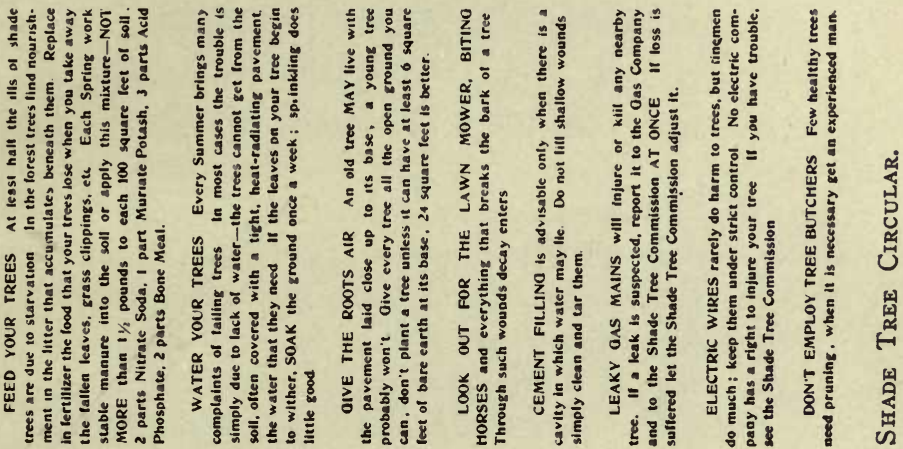
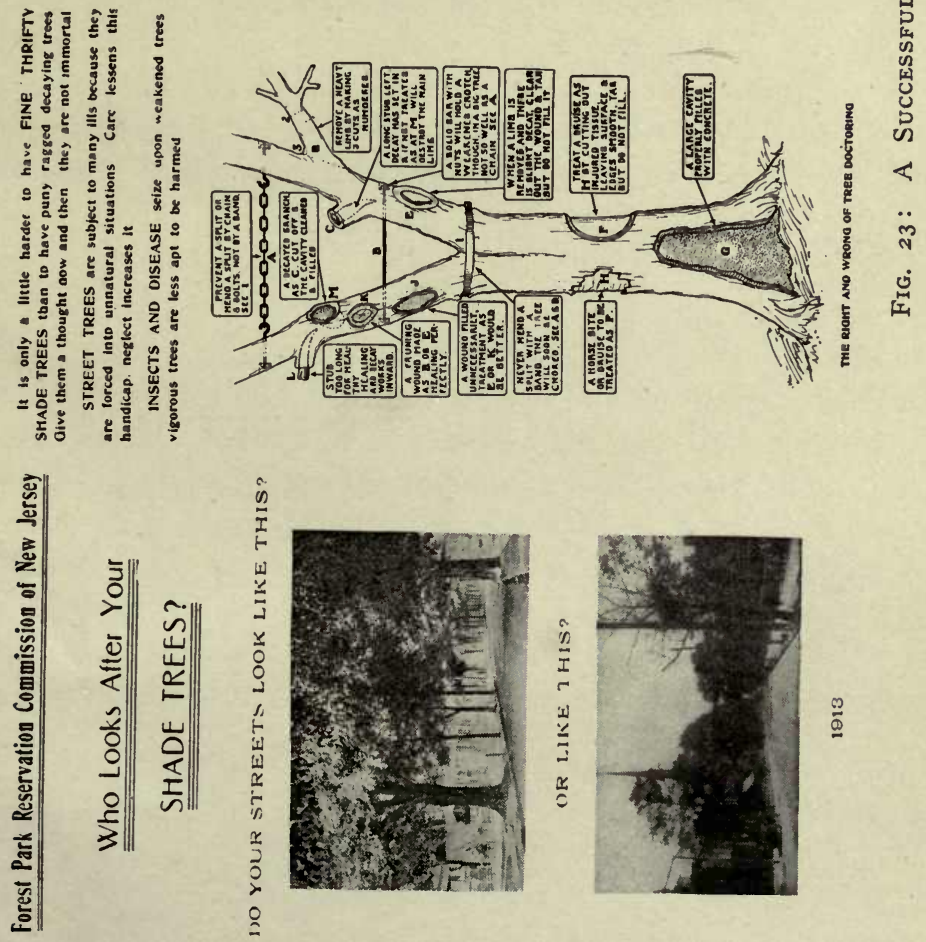

govern, and individuals must yield their preferences, and sometimes their personal interests, for the general advantage. Here is where the value of a shade tree commission comes in. Such a body presumably does everything for the public welfare. If it restricts an individual it does so because it is necessary. Shade tree work cannot be carried on satisfactorily where every property owner is allowed to follow his own will. A measure of public control by which symmetry, effectiveness and balance are achieved is absolutely necessary.

\section{ADJUSTING CLAIMS FOR DAMAGES.}

One of the most satisfactory lines undertaken by a shade tree commission is the adjustment of claims for damages arising from public improvements, such as road construction, gas or electric installations. In several instances, some of them at the request of service companies, the State Forester has aided in effecting settlements out of court for injuries suffered by individuals. Numerous local shade tree commissions have done even more. In Passaic, East Orange and Newark very considerable payments have been made by the public service corporations to cover the cost of replacing and maintaining shade trees that were lost.

Another important line of effort is to avoid claims for damages by adjustments before injury is suffered. The Forest Commission and several Shade Tree Commissions have been helpful in this way. See p. 28.

\section{ENEMIES.}

The dangers that beset shade trees are considered somewhat fully under the subject of tree pests, see p. 35. It is emphasized here, however, that shade trees are unavoidably and necessarily always under strain, that consequently they should. have care and attention at all times if they would be kept in good condition. It is almost literally true that most of our shade trees suffer from one ill only, neglect. The remedy is obvious, the means to be employed in any specific case are given in this report or in other publications of the Forest Commission. 


\section{DROUTH.}

In parts of the state many shade trees have suffered through lack of rain. See p. 43. Taken altogether the losses by the unusual drouths of the past five summers have been serious. Tree owners are reminded that when Nature fails they must lend a hand. Cultivation of the surface soil in a dry time often does as much good as water.

\section{NORWAY MAPLES.}

There is danger that the planting of Norway maples in towns and villages, and to some extent in cities, will be carried to excess. The tree is unquestionably a good one; it is especially adapted to narrow streets and unfavorable locations, but too often is planted where a larger, more dignified and more valuable tree is indicated. Red oak, scarlet oak, tulip poplar, white elm, sycamore, linden and sugar maple are all worthy of place on the wider, better cared-for streets. - Let norways serve where the others cannot be.

\section{TOO ClOSE PLANTING.}

And it is advised that street trees be not planted too close together. A spacing of 25 feet seems ample when the trees are set out, yet it is too little even for norway maples when well grown. In some towns large-growing species like sycamore have been set on twenty feet intervals. In all planting it is highly important to consider the mature size and form of a tree. It rarely is advisable to set trees less than forty feet apart.

\section{ROADSIDE TREES.}

- The proposal to apply the shade tree laws to country roads has not yet been brought to a practical demonstration. The State Road Commissioner has found no opportunity to carry into effect the plans published a year ago by which new road construction might be required to include tree planting. It is agreed that such improvements should not be forced upon any community, but should come rather in response to a demand 


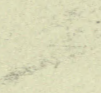




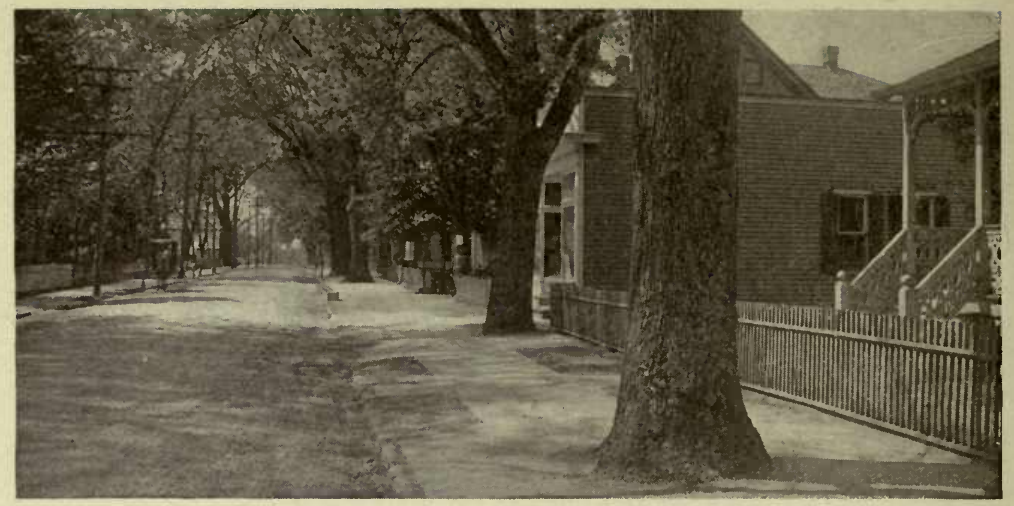

Fig. 24: New Sidewalk laid Without Disturbing fine Old Trees.

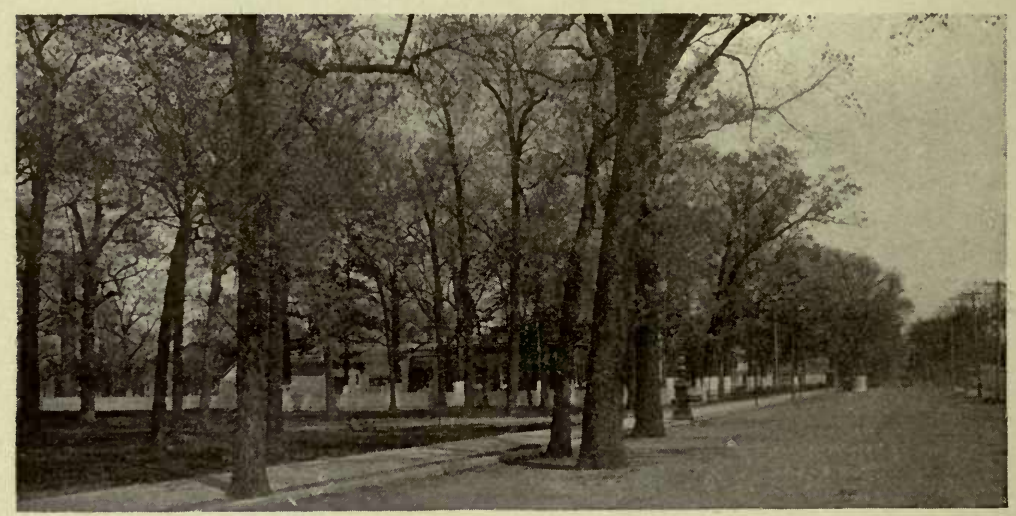

Fig. 25: Old Oaks Left Standing in Improved Road.

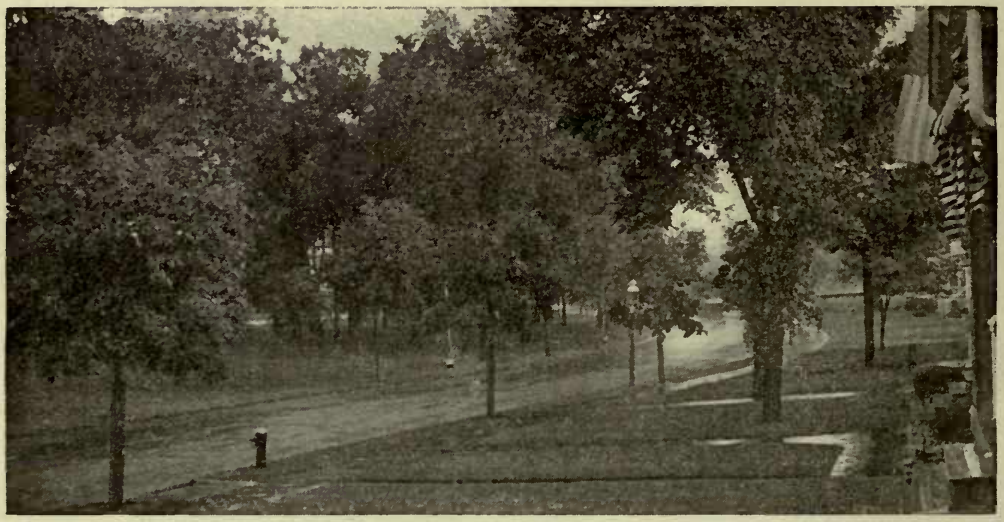

Fig. 26: Broad Lawns and Park Areas Give Opportunity for Irregular Planting.

STRAIGHT LINES IN SHADE TREES AND IN ROADS MAY OFTEN BE DEPARTED FROM. 
for such betterments as shade trees give in conjunction with improved highways.

\section{OILED ROADS.}

Some apprehension is abroad that the use of dust-reducing preparations on stone roads will injure nearby trees. Ground for this fear is given in reports from France that some loss has been suffered where a roadbed had been treated with tar. The evidence is not conclusive, however, and insofar as our territory is concerned there is no immediate danger. Nevertheless, to forestall any possible trouble from the continued use of these surfacings a series of experiments and tests is to be undertaken with a view to determining the actual effect upon vegetation of road-building methods and road materials.

\section{SHADE TREE BOOK.}

The Commission's publication, "The Planting and Care of Shade Trees." See p. 42. apparently meets a real need. It is in constant demand and though still available, it has been found necessary to limit its distribution to citizens of the State.

\section{TREE PESTS.}

The open winter and wet early spring favored the development of an unusual number of insect pests. Cottony maple scale, tulip soft scale, and clm scale were prevalent on trees of those species. Some damage was done, and in numerous cases it was necessary to resort to treatment, but there is no reason to believe that natural enemies will not soon restore the normal balance. The State Entomologist and the State Plant Pathologist, either of whom may be addressed at New Brunswick, are active in looking after troubles in their particular lines and the State Forester is working in complete harmony with them. There is no indication of any dangerous new pest attacking our trees and forests.

The Federal law under which the Secretary of Agriculture is controlling the importation of, and the interstate traffic in, diseased or insect infested plants is in full operation and is effec- 
tive. With the watchfulness maintained by the state officials, and a general co-operation of the nurserymen, it is expected that our territory will be kept free from serious dangers. The situation with respect to the more common tree pests is this:

\section{CHESTNUT BLIGHT.}

The disease has been found in Salem County so that the only part of the state now unaffected is Cape May County. Trees in the northern and central sections are dying rapidly and falling under the ax. There are some indications that the blight is slightly less virulent than it was. and is progressing less rapidly. There is, however, no proof of this.

It is now thought that the disease came from China where it has been found on native chestnuts which are virtually immune to its attack. The practical bearing of this discovery is that we may look forward to a time when the chestnuts in this country will become resistant. It is not likely that this will happen before all of New Jersey's chestnut trees are gone. Tree and forest owners are advised, as heretofore, to realize on their chestnut timber as soon as the trees are dead or seriously affected, but not to fell any tree in advance of its death except in situations where economy dictates a clear cutting. In this case the sacrifice of affected individuals will not help those that are still apparently sound. On the other hand, dead trees should not be allowed to stand long lest they furnish breeding places for harmful insects or foster other diseases.

The market for chestnut poles, posts and railroad ties is still good and prices well maintained, but there is a glut of cordwood and it appears inevitable that much must be allowed to decay. All efforts to utilize this material in excess quantity have thus far failed, though the forest authorities of New York, Pennsylvania, Connecticut and the $U$. S. Department of Agriculture have joined with those of New Jersey in attempts to find an outlet.

Valuable shade trees may sometimes be given an increased length of life by careful pruning if their owners feel warranted in incurring the expense. Specific directions for such work will be sent upon request. Owners of blighted chestnut are espe- 
cially warned not to spend money on so-called cures. No practicable remedy has been discovered. If one shall be found the State authorities will make the fact known promptly. Recently published statements that children have been poisoned by eating nuts from diseased trees are not substantiated, though investigations to determine the fact are under way.

Assurance can be given that the disease attacks no other species than chestnut, and that it has no injurious effect upon the wood. A blight similar to that of the chestnut has been observed on chestnut oaks. Chestnut oak is not a chestnut but an oak of the white oak group. The disease proves to be comparatively well known to plant pathologists and is not dangerous. Its occurrence, however, should be promptly reported so that it may be kept under observation. A somewhat similar disease has also been-found on norway maples. All reported cases. are under observation. Serious trouble may come but need not be anticipated.

\section{ELM LEAF BEETLE.}

The damage done by this pest was much less serious than it has been for several years. Most communities continued their sprayings, but in a few, it was omitted with no serious results. The indications are that the insect is coming under control and that before long the expense. of spraying may be saved, but for the present shade tree commissions, city authorities and private owners are advised to hold themselves and their spraying equipment in readiness. If the pests shall have been so reduced that there is no serious danger next spring the State Entomologist will advise that spraying is not necessary. In the absence of such advice the usual precautions should be taken, since proper spraying at the proper time is an infallible remedy. Where trees are weakened in other ways, as they often are, other measures are indicated. Specific advice will be given upon request.

\section{HICKORY BARK BEETLE.}

This insect is doing more and more damage. In some sections most of the hickory trees are gone. Nevertheless, all fear 
that the hickories are doomed like the chestnuts may be set at rest. In this case we have to deal with an insect instead of a fungous disease, a less serious matter. Moreover, the larvæ of the beetle, which do most of the damage, work chiefly in weakened trees, generally avoiding those that are well nourished and healthy. Attacks on the twigs by which the foliage is made to wilt and fall off can be controlled in a measure by pruning, and moderate infestations reduced somewhat by coating the trunk with white-wash in which arsenate of lead has been mixed, or with strong whale-oil soap suds. In any case, burn at once all trimmings that may harbor the insects or their eggs. But the best and most practicable remedy is to work the ground beneath the trees, fertilize and water it. See p. 39. If the insects are very active, cut the tree down and burn the wood at once; it can be expected to live only a short time anyhow; to delay its removal simply gives the beetles a chance to multiply and attack neighboring trees.

\section{BROWN TAIL MOTH AND GYPSY MOTH.}

The State is still free of these dangerous insects. Specimens of both have been discovered but thus far the State Entomologist has succeeded in exterminating them. There is, therefore, no necessity for assuming the great expense that New England now bears in its effort to control these pests.

\section{TUSSOCK MOTH.}

In several cities this insect does much damage besides being a general nuisance. It can be controlled, however, by picking off and destroying the cocoons in winter and banding the trees with cotton batting in May. If this is omitted, or is not effective, the caterpillars can be poisoned when on the foliage by spraying as for elm leaf beetles.

\section{LEOPARD MOTH.}

The larvæ of this insect do much damage in several of the northeastern cities, but the trouble is not general. Control is 


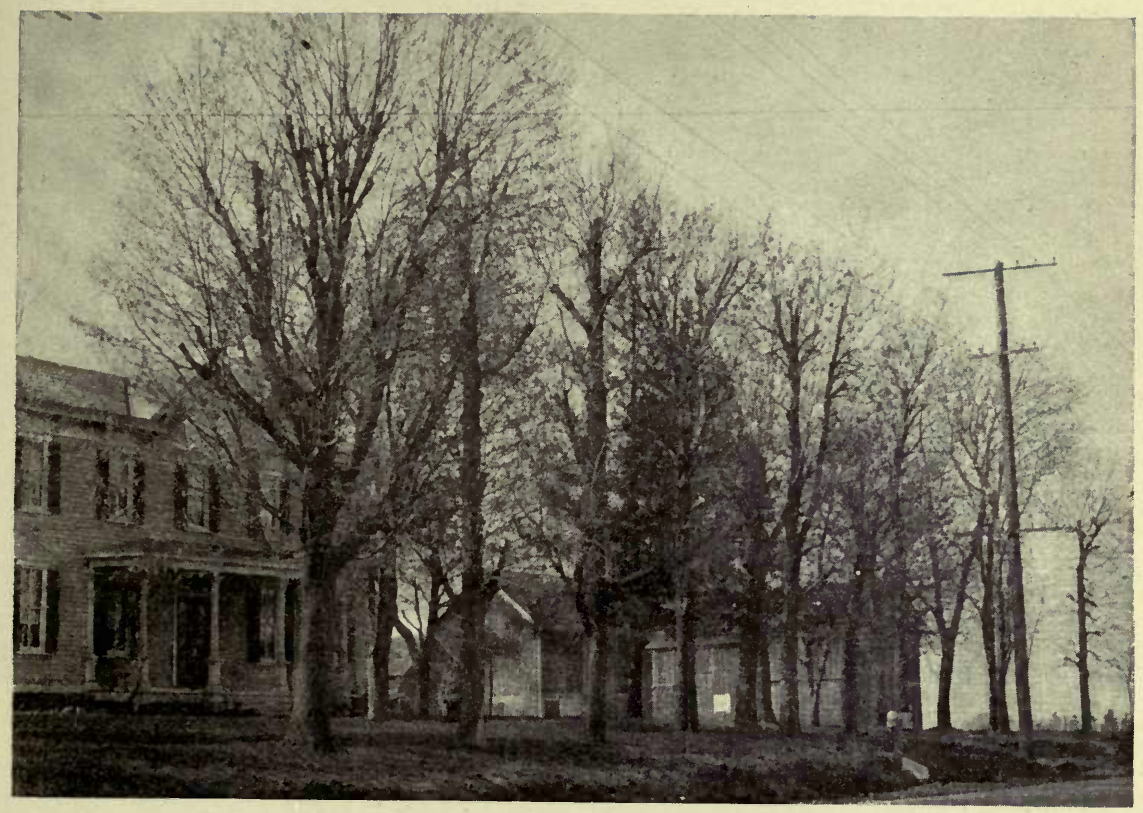

Fig. 27: Butchered Maples: Such Pruning is Never Justified. Wires Do Not Interfere.

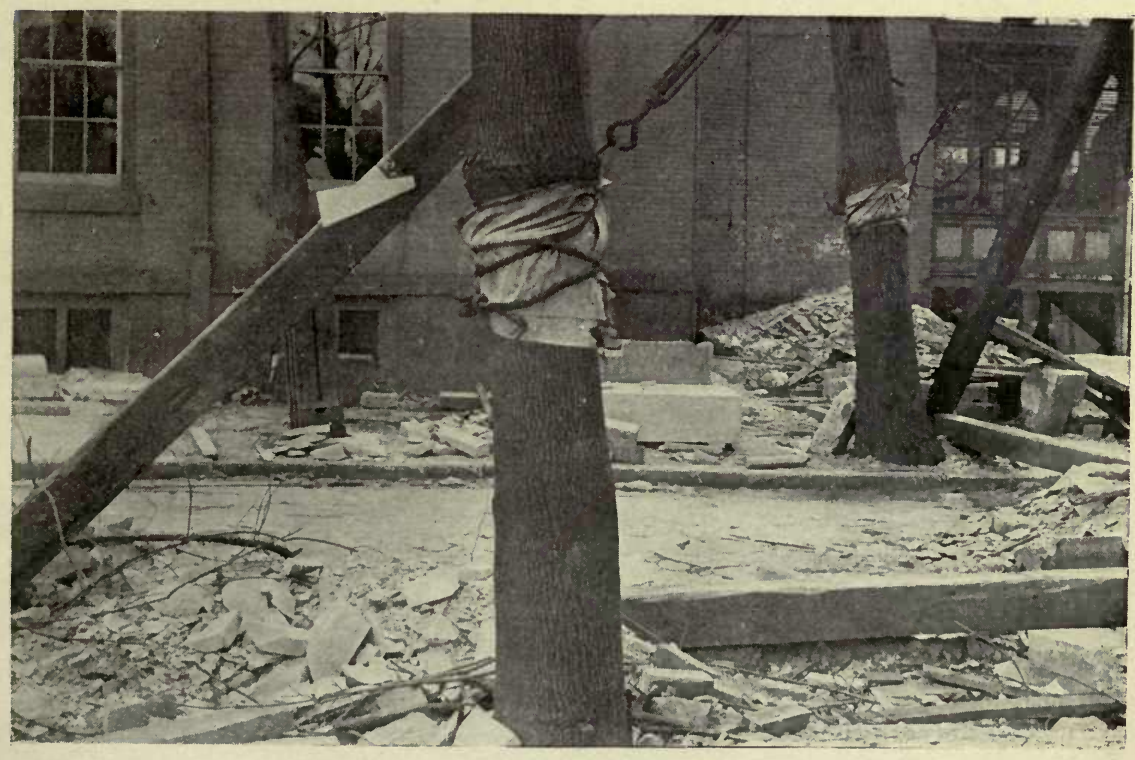

F1G. 28: Trees Abused by Builders: Always Put Strong Guard About Trees While Building is Going ON. 
difficult as the borers live in the trees two full years. It is advised that the borers be pursued in their burrows with wires or with carbon disulphid and especially that insectivorous birds, which eat the moths, be encouraged.

\section{WHITE PINE BLISTER RUST.}

This dreaded disease, which in 1909 threatened to become established with us, is apparently under complete.control so far as New Jersey is concerned. A few affected trees were found in two small.nurseries but the owner of each readily consented to the destruction of the entire stock. Notwithstanding this it is still advised that white pine be not.planted in large quantities, but rather mixed with other species which are not susceptible.

\section{MAPLE BLIGHT.}

Many reports have been made of failing maple trees, chiefly sugar maples and norway maples. In most cases, the trouble was traced to a deficiency of water or tó a lack of nutriment. The remedy is to supply, these deficiencies, and in some cases to reduce the draft on the roots by thinning the crown. This should be done by inside pruning, rarely by outside pruning, never by topping.

\section{STARVATION.}

Forest trees, rarely suffer in this way, or from lack of water, because Nature has provided for a supply of both in the unremoved litter on the ground and in the unrestricted root system. It is a fact, however, that more shade trees are lost through starvation or thirst than in any other way. Owners are advised, first, to see that their trees do not lack water; if rain fails apply the hose. A drenching once a week is better than a sprinkling every day. Second, to be sure that the roots of the trees are not cut off from air by a close pavement, or even by a thick sod. The best condition is afforded by a free earth space about the base of each tree which is kept well cultivated. Third, to apply fertilizer , every spring. If a tree has lacked for a number of 
years apply in fall as well until a normal condition is reached. Well-rotted stable manure forked into the soil is best. If that is not available, or is objectionable, use a mixture of commercial fertilizer in the following proportions: For loamy or sandy soils equal weights of nitrate of soda, acid phosphate, muriate of potash and ground bone. For heavy soils use 2 parts nitrate of soda, 3 parts acid phosphate, I part muriate of potash, 2 parts bone meal. In either case use not over I I-2 pounds of the mixture to Ioo sq. $\mathrm{ft}$. of exposed soil. If the footing (open space at the base) of a tree is small, apply one ounce of fertilizer for each four square feet once a month between April and September.

\section{TREE DOCTORS-WARNING.}

The warning against fake tree doctors that has been issued for several years past is repeated. Notwithstanding several exposures and numerous complaints these men still ply their trade. Plenty of trees need doctoring and there are reputable tree doctors. The Forest Commission urges owners of trees to give them proper attention. It also urges them not to employ irresponsible men, and particularly not to allow an unknown man to prune a tree upon his own assertion that the tree needs it. Owners of shade trees are always advised to consult their local shade tree commissions when work is apparently necessary. If there is no, such organization the State Forester, the State Entomologist, or the State Plant Pathologist will recommend competent men.

\section{WOOD INDUSTRIES.}

The study of wood utilization and wood values announced a year ago is nearly ready for publication. The field work, done by the U. S. Forest Service under a co-operative agreement, is finished and the revision of the tables, etc., is under way. It is expected that this report will be of considerable value to all buyers, sellers and users of wood.

The Lumber Directory of wood buyers is constantly gaining accessions and usefulness. It is not to be published but to serve simply as a record of parties with whom any citizen having 


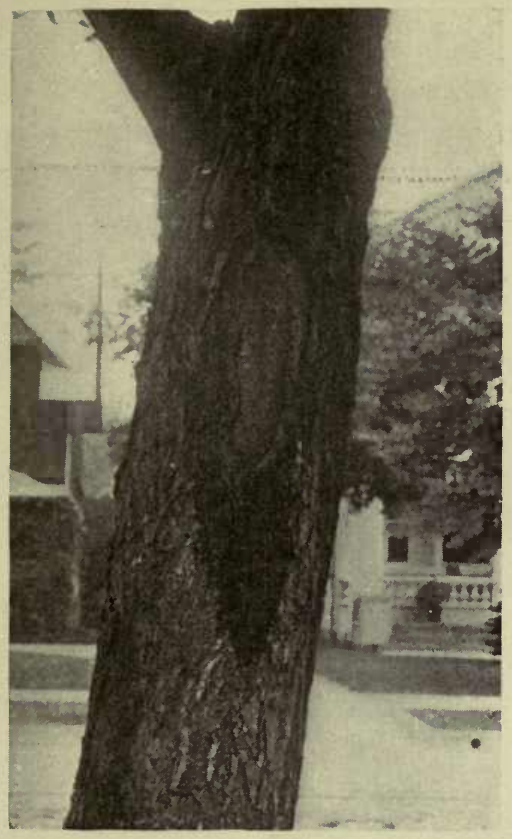

Fig. 29: A Wound With a Harmful Filling. Normal Healing is Checked ANd THE Tree is "BleEding." (Note dark spot below wound).

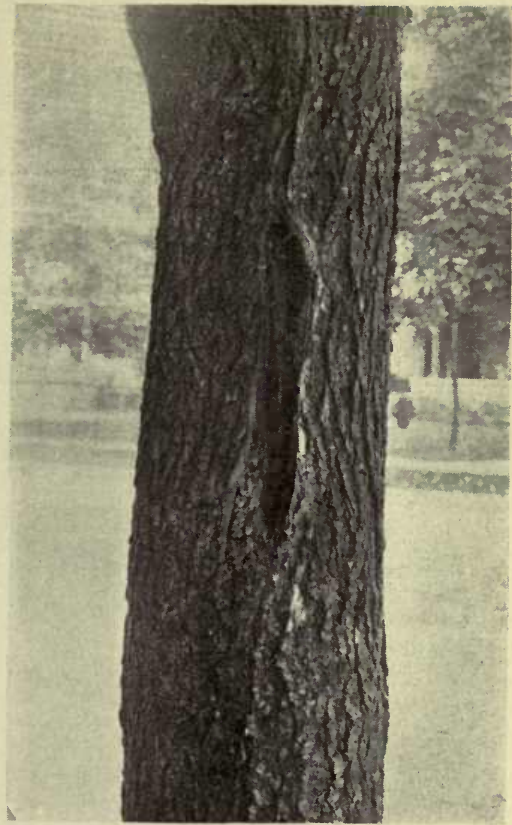

Fig. 30: A Wound Cleaned and TARred, But Not Filled. Healing Perfectly.

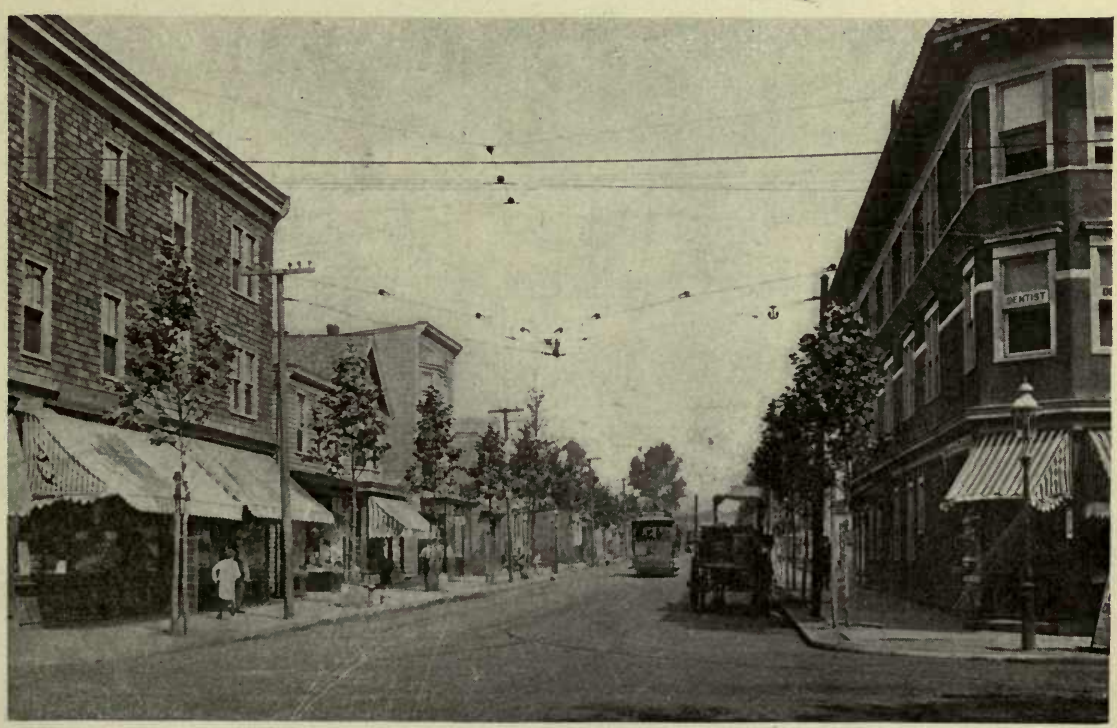

Photo by E. H. Bennett. Fig. 31: Doubie Row of Plang. Trees Planted and Maintained by the Shade Tree Commission at Cost of Public Service Corporation. East Orange. 

wood to sell may deal. In numerous instances owners of chestnut timber have been helped to find buyers for a material that they themselves knew not how to dispose of. The Commission invites correspondence on this subject. Manifestly, its only object is to facilitate the utilization of forest products.

\section{PUBLICATIONS.}

In this direction the Commission has been more active this year than ever before. Grateful acknowledgment is made to the Commissioner of Public Instruction and his staff for their hearty co-operation in the effort to bring forestry and its aims before the public school pupils. Besides the Annual Report, of which 2,500 copies were distributed, the following have been issued:

\section{Cutting Trees on Land Not One's Own is Unlawful. Edition 2,500.}

A circular, distributed through the Granges, to answer many complaints of vandalism and show that no forest or tree owner need suffer if he will take the trouble to invoke the law. See p. 21.

2. Trees and Forests. I5 pp. with illustrations. Published by the Department of Public Instruction as Elementary Agriculture Leaflet No. 9. It is intended chiefly to show teachers how to connect forestry with geography, history, arithmetic, ete.

3. Arbor Day. 31 p. A reprint, published by the Department of Public Instruction, of the series of papers first printed in I912. Its aim is to fit arbor day exercises to New Jersey conditions.

4. Forest Planting in New Jersey. 31 pp. with illustrations. Edition $3,000$. Gives full instructions for planting forest trees and some figures of cost and yield.

5. Forest Fire Manual. 44 pp. Edition 2,500. A handbook for firewardens and others who have to do with the control of forest fires.

6. List of Firewardens. $15 \mathrm{pp}$. Edition r,ooo. A directory of all connected with the State Forest Fire Service.

7. The Automobile. Edition 50,000. A card of warning and advice to automobile drivers about forest fires. Distributed in co-operation with the State Motor Vehicle Department and the Associated Automobile clubs.

8. Nezu Jersey's Forest Fire Lazv. Edition 5,000. A card showing what inay and what may not be done with fire. Distributed through boy scouts, by mail, etc.

9. Did You Ever Stop to Think? Edition 50,00o. A leaflet to emphasize the evil in forest fires and the dependence of all forestry upon forest fire control. Distributed chiefly through the rural schools.

10. Forest Fires. Edition 1,000 . A card $9 \mathrm{X}_{1} \mathrm{I}$ inches printed in black on red and posted in rural railroad stations and other prominent places.

11. Forest Fire Puzzle Cup. Edition 100,000. A paper drinking cup (devised by the Western Forestry and Conservation Association) intended to emphasize 
the forest fire evil as it is folded into usable shape. It was distributed in large quantities at several fairs and through the rural schools.

12. Who Looks After Your Shade Trees? Edition 20,000. A 4-page leaflet, illustrated, giving practical instructions about shade trees. Distributed chiefly through local Shade Tree Commissions. See Fig. 23.

All the above except Nos. I, 6 and Io are still available and will be sent free upon request.

"An Example of Woodlot Forestry" and "The Planting and Care of Shade Trees," both published in I912, are also available though the demand for the latter is so great that some restrictions are imposed.

\section{STATE AID IN FORESTRY.}

To encourage the practice of forestry on private lands, the Forest Commission offers the services of its foresters, so far as their time will permit, to all who ask for them. When it is necessary or advisable a competent forester will study the situation on the ground. If cutting is to be done a part of the trees to be felled will be marked to guide the owner in the removal of the rest. Advice in regard to markets will be given, but in no case will the forester have part or interest in a sale. Those who wish to undertake forest planting will be advised regarding the most suitable species for their situations, how to obtain the trees and how to plant them. No young trees or seeds are furnished by the State. Fire protective plans will also be formulated.

In all cases the assistance given is advisory. There is no obligation to follow the recommendations made, though where they are acted upon the Forest Commission claims the right to inspect the property from time to time and to publish facts concerning the work for the benefit of the public.

Similar aid will be given regarding Shade Trees except that inspections can ordinarily be made only upon the request of a Shade Tree Commission or similar public agency-not of an individual.

The cost to any owner is the forester's actual expenses while away from Trenton. His salary is paid by the State. Public institutions, Shade Tree Commissions, etc., will be aided without charge.

Write to the State Forester, Trenton, about anything relating to forests or shade trees-not fruit trees. 


\section{FOR}
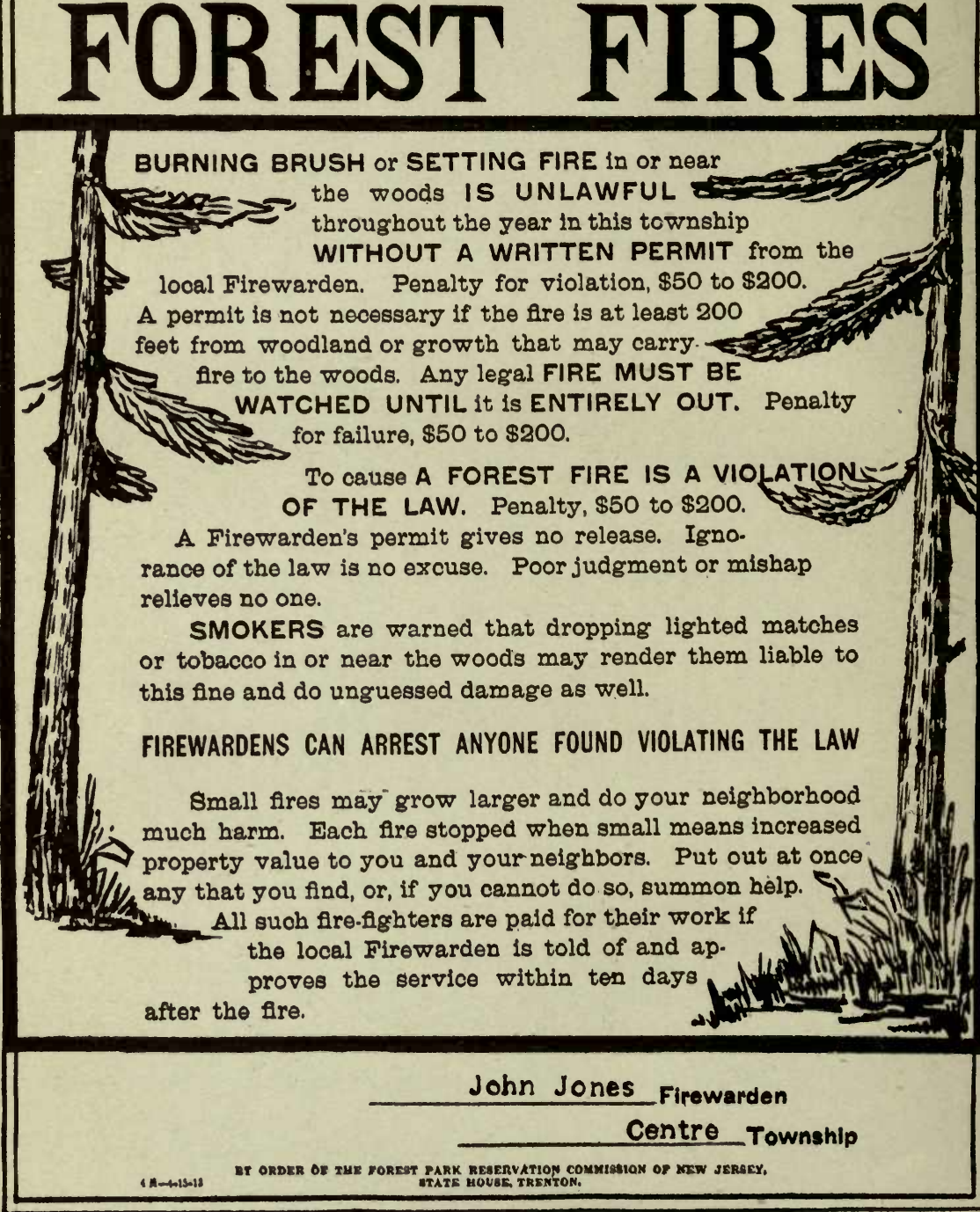

Fig. 22: New Fire Postrir. Wherever Tuese Applear the Forest Fire Law is iN EFFECT. 


\section{The Forest Fire Service}

By Charles P. Wilber, State Firewarden.

\section{THE FIRE SEASON.}

The year I9I3 presents an unfortunate break in the record of diminishing forest fires. See Table II. New Jersey was hard hit, but the setback discloses no weakening in the efficiency of the Fire Service, for it is directly attributable to the weather, always the controlling and uncontrollable factor in forest fire prevention, as in crop production. The weather throughout the season combined in a curious way excessive moisture and abnormal drought; no one period of great duration, but in several instances unusually intense. In March and April brief but excessively dry periods combined with abnormally high winds. As all vegetation is undeveloped at that season and the sandy soils in the pine region dry out rapidly, this condition brought two periods of unusually disastrous fires in South Jersey. Out of a State total of 678 fires reported, Ic9 burned in March and 203 in April; and of the 27 large fires-those burning 500 acres or more, one occurred in early March and eight in the two dry periods of April. In May there was a drouth almost unprecedented in the history of South Jersey for that time of year. The local press of May 13 mentions the fact that not since I880 had conditions of this sort been recorded. During this period I4I more fires were added. The result of these conditions is that we find charged to the spring nearly all of the bad fires and two-thirds of the total number for the year.

In June there was another lack of rainfall, which is to some extent reflected in the 88 fires that burned, though as vegetation was then advanced and the high winds of the spring were lacking, the fires were far smaller in size. At the end of June and throughout July, there was, according to the Atlantic City weather data, "less precipitation than during any year since the 
establishment of the U. S. weather service here twenty-four years ago." These conditions grew more severe in August, the whole rainfall being limited to locally distributed and brief thunder showers. Large fires, however, were not encountered save on a few specific dates when the wind again made any spark a potential fire of large area. The total number of summer fires, 156 , is less than those of the same three months last year, although conditions were more dangerous. The rainfall in the two fall months was normal and there were almost no fires.

TABLE II.-FOREST FIRES IN 1913 , AND IN PREVIOUS YEARS.

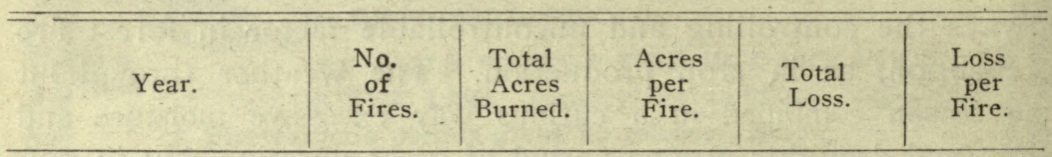

No organized service, incomplete reports.

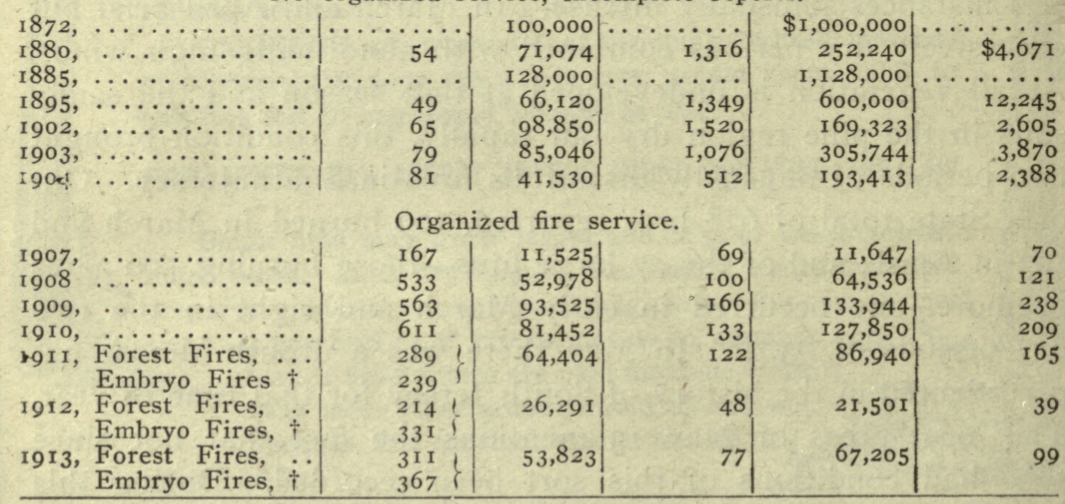

$\dagger$ Burned less than five acres. 


\section{NUMBER AND AREA OF FIRES.}

In numbers, the record of fires of 1913 , as shown in Table III below, bears out the expected increase in the embryo class due to more conscientious reporting of every fire. The marked increase in the number of true forest fires mirrors the acute climatic conditions of the Spring. The striking feature is that, with so many more fires started under adverse conditions, the proportion of them that reached five acres in size shows so slight an increase over that of a year ago. See Table III. It is encouraging to find that 54 per cent of all fires recorded were but embryos and that but I3 per cent burned more than Ioo acres. The total area burned marks a still greater increase over a year ago, though analysis shows that 80 per cent of the

TABLE III.-FOREST FIRES BY RELATIVE AREA BURNED, AND BY COUNTIES, I9I3.

\begin{tabular}{|c|c|c|c|c|c|c|}
\hline \multirow{2}{*}{ COUNTY. } & \multicolumn{5}{|c|}{ Number of Forest Fires. } & \multirow{2}{*}{$\begin{array}{c}\text { Total } \\
\text { Embryo } \\
\text { Fires (less } \\
\text { than } 5 \\
\text { acres) }\end{array}$} \\
\hline & $\begin{array}{l}\text { 5-10 } \\
\text { Âcres. }\end{array}$ & $\begin{array}{l}\text { II-I } 00 \\
\text { Acres. }\end{array}$ & $\begin{array}{c}101-1000 \\
\text { Acres. }\end{array}$ & $\begin{array}{l}\text { Over } \\
\text { Iooo } \\
\text { Acres. }\end{array}$ & Total. & \\
\hline 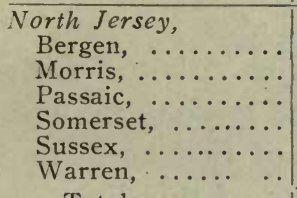 & $\begin{array}{l}2 \\
3 \\
1 \\
3 \\
3 \\
1 \\
\end{array}$ & $\begin{array}{r}23 \\
5 \\
3 \\
17 \\
1 \\
\end{array}$ & 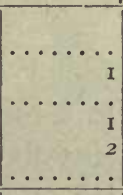 & 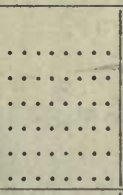 & $\begin{array}{r}2 \\
27 \\
6 \\
7 \\
22 \\
2\end{array}$ & $\begin{array}{l}18 \\
31 \\
20 \\
12 \\
25 \\
12\end{array}$ \\
\hline 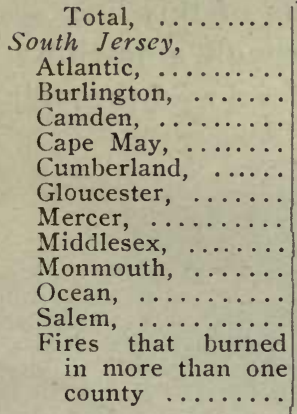 & $\begin{array}{l}8 \\
4 \\
3 \\
7 \\
4 \\
2\end{array}$ & $\begin{array}{r}34 \\
17 \\
17 \\
10 \\
13 \\
4 \\
4 . \\
\cdots \\
10 \\
8 \\
14 \\
1\end{array}$ & 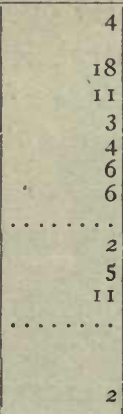 & 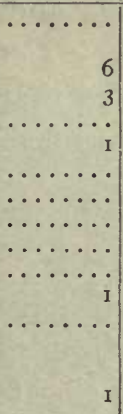 & $\begin{array}{r}66 \\
35 \\
23 \\
22 \\
23 \\
12 \\
12 \\
15 \\
13 \\
32 \\
1\end{array}$ & $\begin{array}{r}49 \\
17 \\
46 \\
48 \\
12 \\
\cdots \\
\cdots \\
15 \\
9 \\
51 \\
2\end{array}$ \\
\hline Total, ......... & 37 & 128 & 68 & 12 & 245 & 249 \\
\hline State totals $\ldots \ldots$ & 50 & 177 & 72 & 12 & 311 & 367 \\
\hline Per cent of total.. & 7 & 26 & II & 2 & 46 & \\
\hline
\end{tabular}


total is chargeable to 27 fires which burned on dates that stand out as notably hazardous. Thirteen of these, driven by high winds, burned 500 acres or more, with an aggregate of almost 20,000 acres out of the year's total of 53,823 acres.

\section{CAUSES OF FIRES.}

\section{(See Table IV.)}

\section{RAILROAD FIRES.}

Of the known agents, the railroads are as they have always been, the worst offenders. This year they started 3 I per cent of the true forest fires and 57 per cent of those described as embryo fires, any of which but for prompt attention might have ranked as a forest fire. This preponderance of railroad fires need not be, as is strikingly indicated in the experience of the Pennsylvania Railroad system (see Table V). By exercising care in the operation of its locomotives, and by emphasizing the importance of fire control, this company almost nullified the dangers of the season, and reduced the number of fires on account of which claims for expenses were made from 63 a year ago to 18 this year.

The marked difference between this and the Atlantic City Railroad's record suggests a failure to solve the mechanical and administrative problems involved in the kind of fuel used, the type of locomotive and its operation. Portions of this line, as of the New Jersey Central Railroad, run through a territory so sparsely peopled that large fires are easily developed through lack of help to control them in the early stages.

\section{BRUSH FIRES.}

Fires from brush burning were 9 more than occurred last year. True forest fires from this cause were fewer than in any previous year's record, the slight increase being all in embryo fires. This record reflects directly the decreased number of unnecessary fires now started under the permit requirement, and the increased caution that strict enforcement of the permit law has secured. 


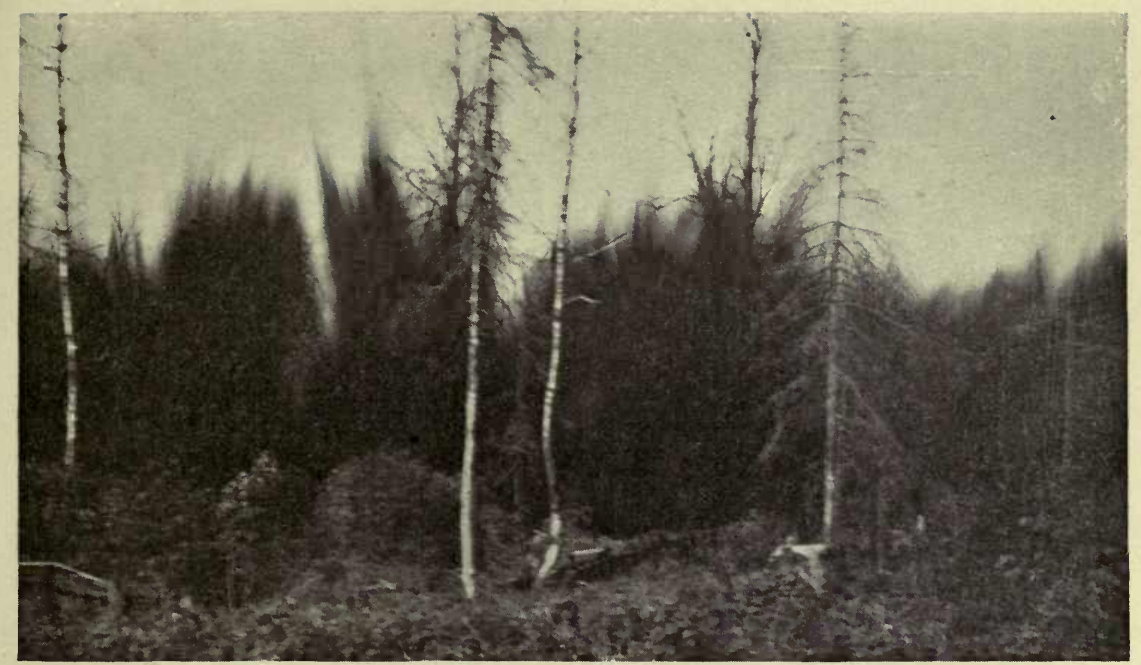

Photo. by Hugh P. Baker. Fig. 33: The Explosion Tiiat Stopped the Fire.

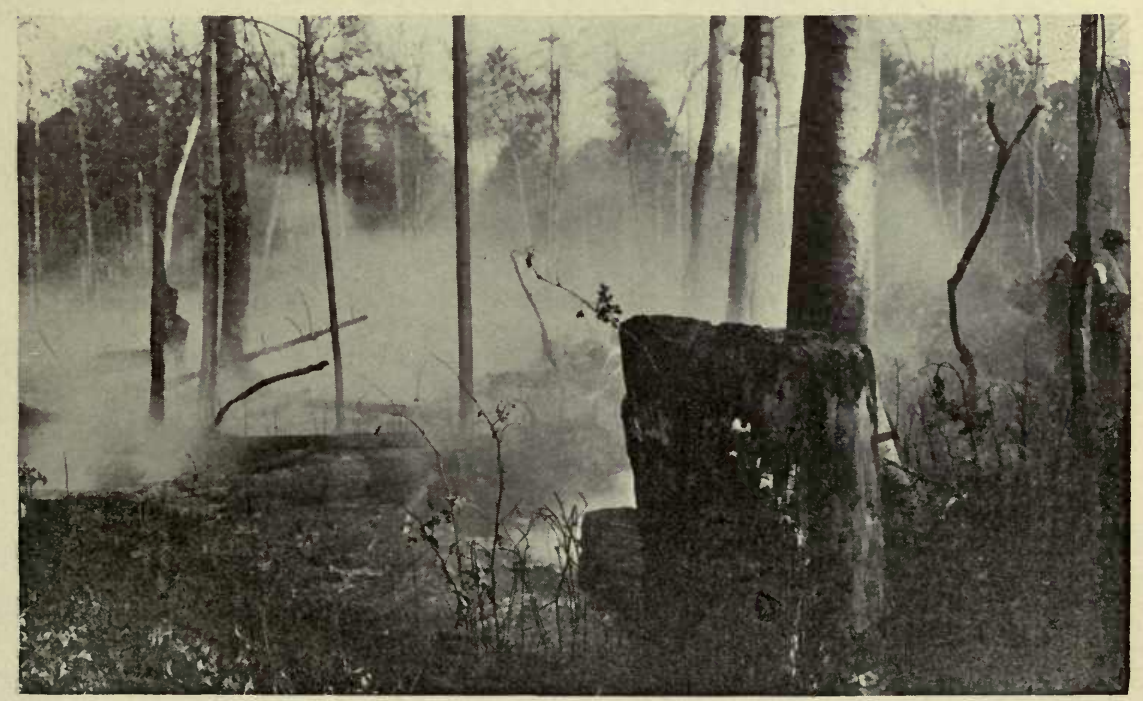

Photo by Hugh P. Baker.

Fig. 34: A Part of the Ground After the Explosion. The fire Can Be Easily Controlled Now.

FIGHTING A FOREST FIRE WITH DYNAMITE. 

TABLE IV.-FOREST FIRES BY CAUSES AND COUNTIES, I9I3.

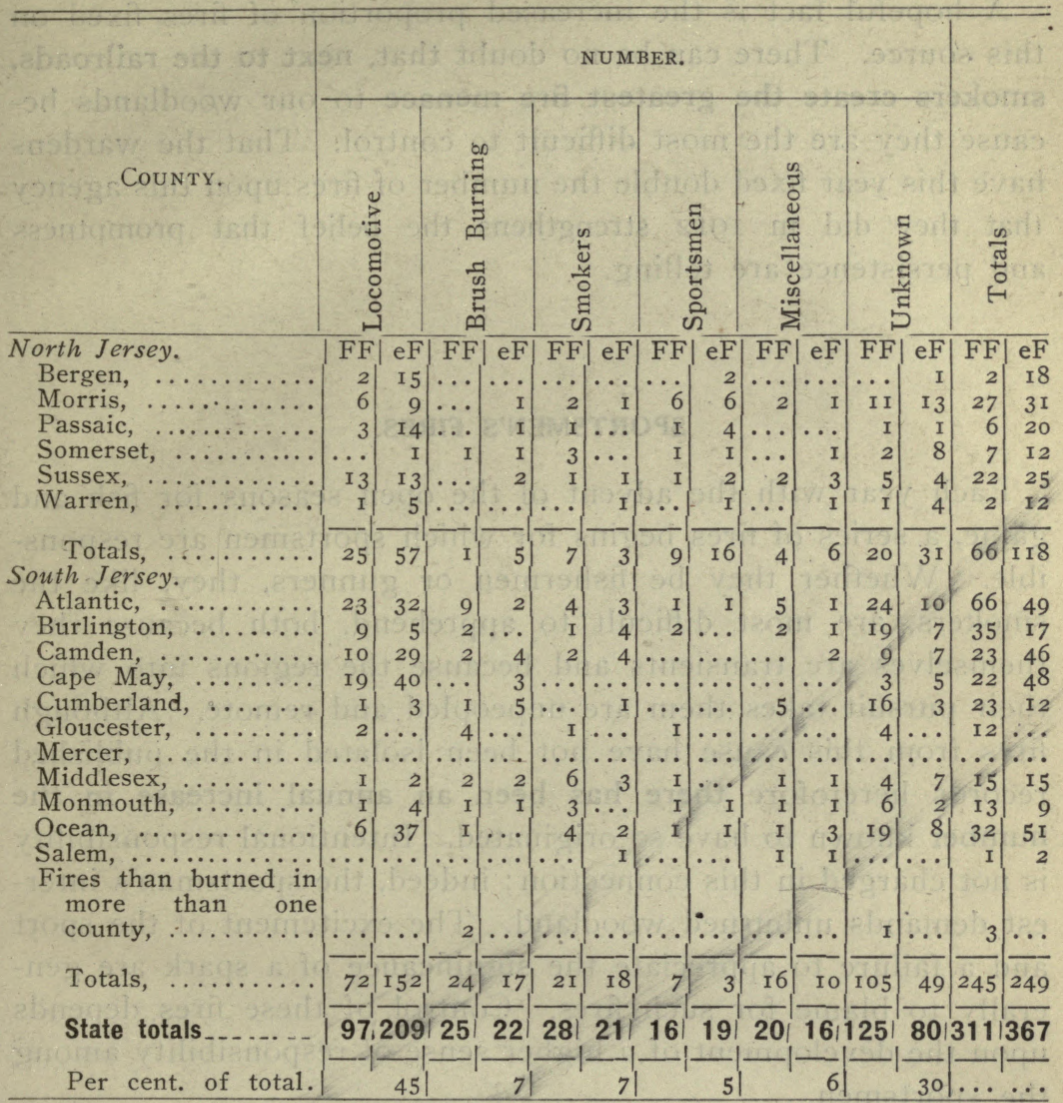

FF-Forest Fires.

eF-Embryo Fires; (less than 5 acres). 


\section{SMOKERS' FIRES.}

A hopeful fact is the increased proportion of fires fixed on this source. There can be no doubt that, next to the railroads, smokers create the greatest fire menace to our woodlands because they are the most difficult to control. That the wardens have this year fixed double the number of fires upon this agency that they did in 1912 strengthens the belief that promptness and persistence are telling.

\section{SPORTSMEN'S FIRES.}

Each year with the advent of the open seasons for fish and game, a series of fires begins for which sportsmen are responsible. Whether they be fishermen or gunners, they, like the smokers, are most difficult to apprehend, both because they themselves are transients and because the regions into which their pursuit takes them are unpeopled and remote. Although fires from this cause have not been isolated in the published records heretofore there has been an annual increase in the number known to have so originated. Intentional responsibility is not charged in this connection; indeed, the sportsman's interest demands unburned woodland. The excitement of the sport and a failure to appreciate the significance of a spark are generally to blame for such fires. Control of these fires depends upon the development of a higher sense of responsibility among the sportsmen.

\section{MISCELLANEOUS FIRES.}

Year by year a small proportion of the fires, smaller this year than last, arises from causes too varied to deserve special consideration. Of these the huckleberry pickers cause most and are most difficult to control. Children at play also cause a number of fires. Especial effort is being made to reduce this danger through the schools, the Boy Scout Movement and other channels. 


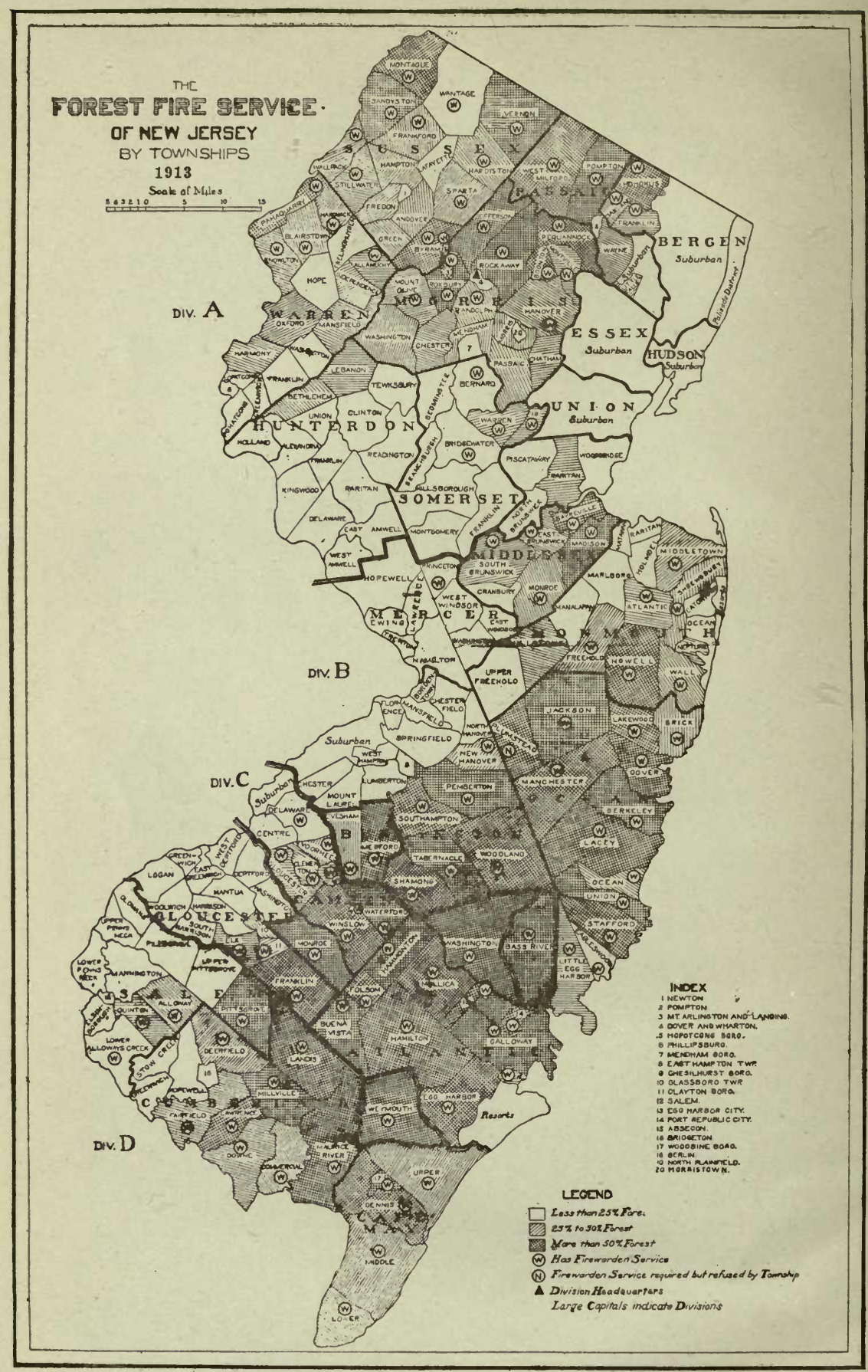

Fig. 35: The State, Showing Forests and Where Forest Fire Service is Maintained. 
TABLE V.-THE RELATION OF THE PRINCIPAL RAILROADS OF THE STATE TO FOREST FIRES, I9I3.

\begin{tabular}{|c|c|c|c|c|c|c|c|}
\hline \multirow[b]{2}{*}{ RAILROAD. } & \multirow[b]{2}{*}{ 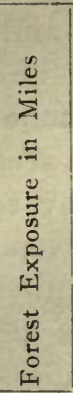 } & \multicolumn{2}{|c|}{$\begin{array}{l}\text { Number ot } \\
\text { Fires Chargeable } \\
\text { in } 1913\end{array}$} & \multicolumn{2}{|c|}{$\begin{array}{c}\text { Claims rresented } \\
\text { on Account 19I3 } \\
\text { Fires }\end{array}$} & \multicolumn{2}{|c|}{$\begin{array}{l}\text { Proportion } \\
\quad \text { of } \\
\text { Responsibility }\end{array}$} \\
\hline & & 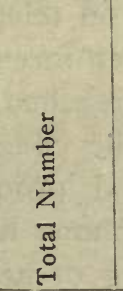 & 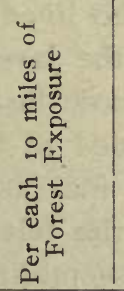 & हूّ & $\begin{array}{l}\stackrel{\Xi}{\Xi} \\
\stackrel{\Xi}{\Xi} \\
\end{array}$ & 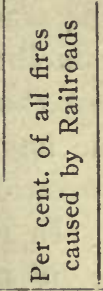 & 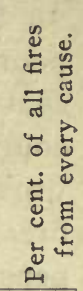 \\
\hline A tlantic City, ... & 157 & I 35 & 8.5 & 102 & $\$ 711.01$ & 44 & 19.9 \\
\hline D. L. \& W., ... & 52 & 10 & 1.9 & 7 & 46.50 & 3 & 1.5 \\
\hline $\begin{array}{l}\text { Erie, } \ldots \ldots \ldots \ldots \text {. } \\
\text { Lehigh } \& \text { Hudson }\end{array}$ & $\begin{array}{r}32 \\
4\end{array}$ & $\begin{array}{l}2 \\
s \\
\text { I }\end{array}$ & & $\cdots \cdots{ }_{i}$ & $\cdots \cdots \cdots$ & & \\
\hline Lehigh \& New E. & 4 & $\$ 6$ & $\ldots$ & 2 & 4.00 & I & .9 \\
\hline N. J. Central ... & 202 & 56 & 2.8 & 44 & 526.80 & 18 & 8.3 \\
\hline N. Y. S. \& W... & 29 & 58 & & 40 & 260.00 & 19 & 8.6 \\
\hline Pennsylvania .... & 310 & 26 & .8 & 15 & $93 \cdot 30$ & 8 & 3.8 \\
\hline $\begin{array}{l}\text { Raritan River } \ldots \\
\text { Tuckerton } \ldots . . .\end{array}$ & $\begin{array}{l}13 \\
38\end{array}$ & $\begin{array}{r}1 \\
10\end{array}$ & $\begin{array}{r}.8 \\
2.7\end{array}$ & $\begin{array}{l}1 \\
7\end{array}$ & $\begin{array}{r}7.00 \\
85.25\end{array}$ & 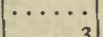 & $\therefore \frac{1}{5}$ \\
\hline Tuckerton $\ldots . .$. & & & 2.71 & & 85.25 & 3 & - 1.5 \\
\hline Totals ....... & $\dagger 84 \mathrm{I}$ & *305 & $\ldots \ldots \ldots$ & 219 & $\$ 1739.86$ & $\mid \ldots \ldots$ & 45 . \\
\hline
\end{tabular}

† Does not represent the entire R. R. forest exposure of the State.

* One additional fire charged to the Wharton and Northern R. R., but with no basis for claim.

$\S$ Not on own right-of-way, but while running over track of another railroad.

\section{THE FOREST FIRE SERVICE.}

In consequence of the considerable increase in the number of firewardens, and in the territory covered, which took place when the service was reorganized in I9II and I9I2, the growth in I9I3 has been largely through internal development. Only one township has been added to the list of those covered by. the Fire Service, that of Pleasantville, Atlantic County. In numbers the enlisted force has been slightly increased, there being now II 2 township wardens and I 57 district and deputy wardens, with the same three fire watchers that have served for several years past.

The distinct improvement in the organization is due largely to the increased stability of the personnel and to the readier accessibility of the wardens, both in times of fire and for the issuance of brush burning permits. In the force this season 
there were but 45 new appointees, a great gain in this respect over past years. This means on the one hand that many of the men find the work worth while and are willing to continue in it; and on the other that they have been tried and found capable. The larger number of changes made were effected to secure for the wardenship men who lived on telephone lines. Despite poor facilities in most of the larger forest areas, over 50 per cent of those serving can now be reached by telephone. This course has still further added to the effectiveness of the local organization by inducing increased promptness in reaching fires. In many instances, the telephone has also curtailed expense by preventing the assembling of needlessly large forces at small fires, or the attendance of several wardens at one fire.

TABLE VI.-SUMMARY OF FOREST FIRE BUSINESS I9I3 WITH SOME COMPARATIVE FIGURES FROM TWO YEARS PRECEDING.

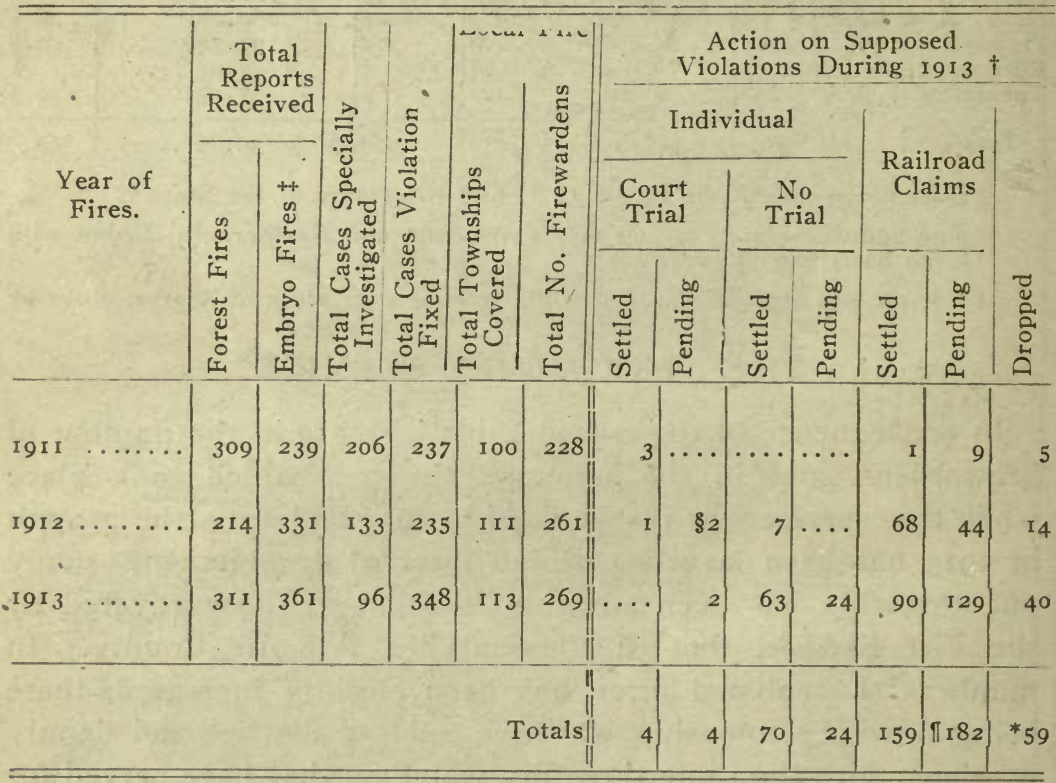

$\$$ Both of these cases are awaiting appeal.

* 5 cases dropped for lack of evidence; 8 cases in which offenders left the State and have not returned; 46 cases in which R. R. claims were not made because the township bills of costs were too tardy to permit their presentation.

II All but 37 of these were settled before March I, 1914.

$\uparrow$ See also Tables VIII and IX.

$\ddagger$ Burned less than 5 acres. 


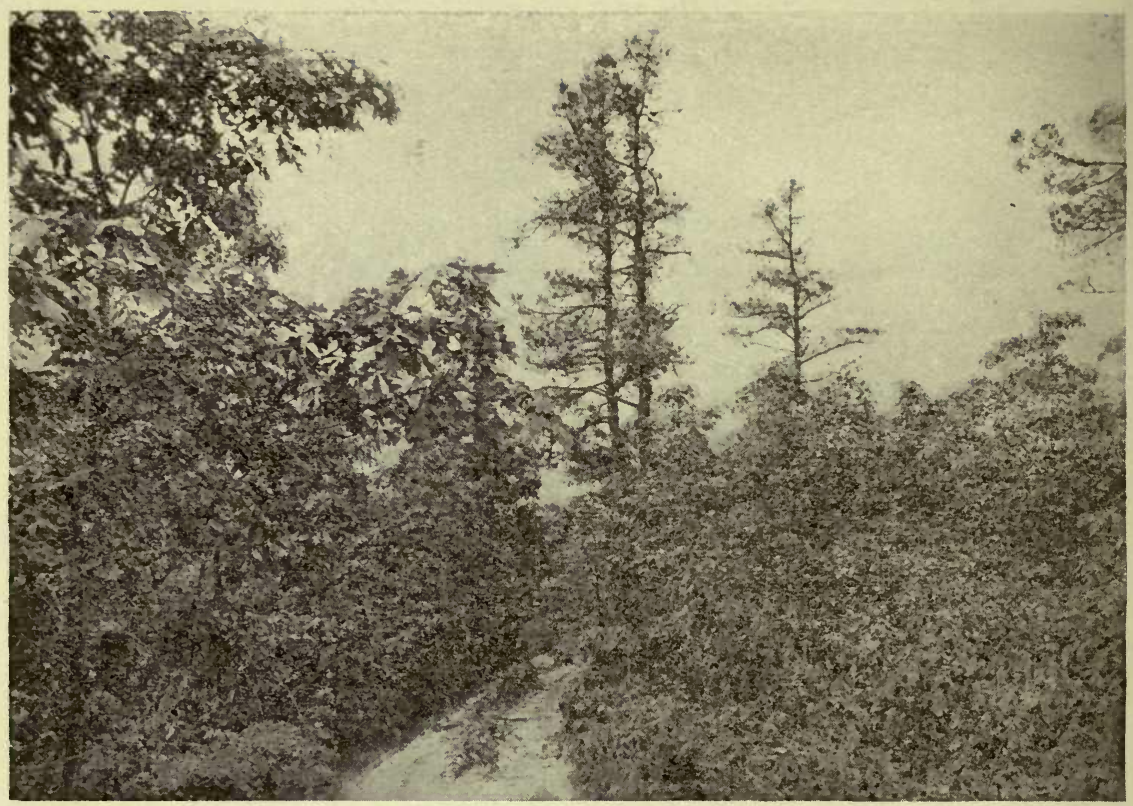

Fig. 36: A Match Dropped Beside This Road At a Dry Time Would Almost Surely Cause a Fire.

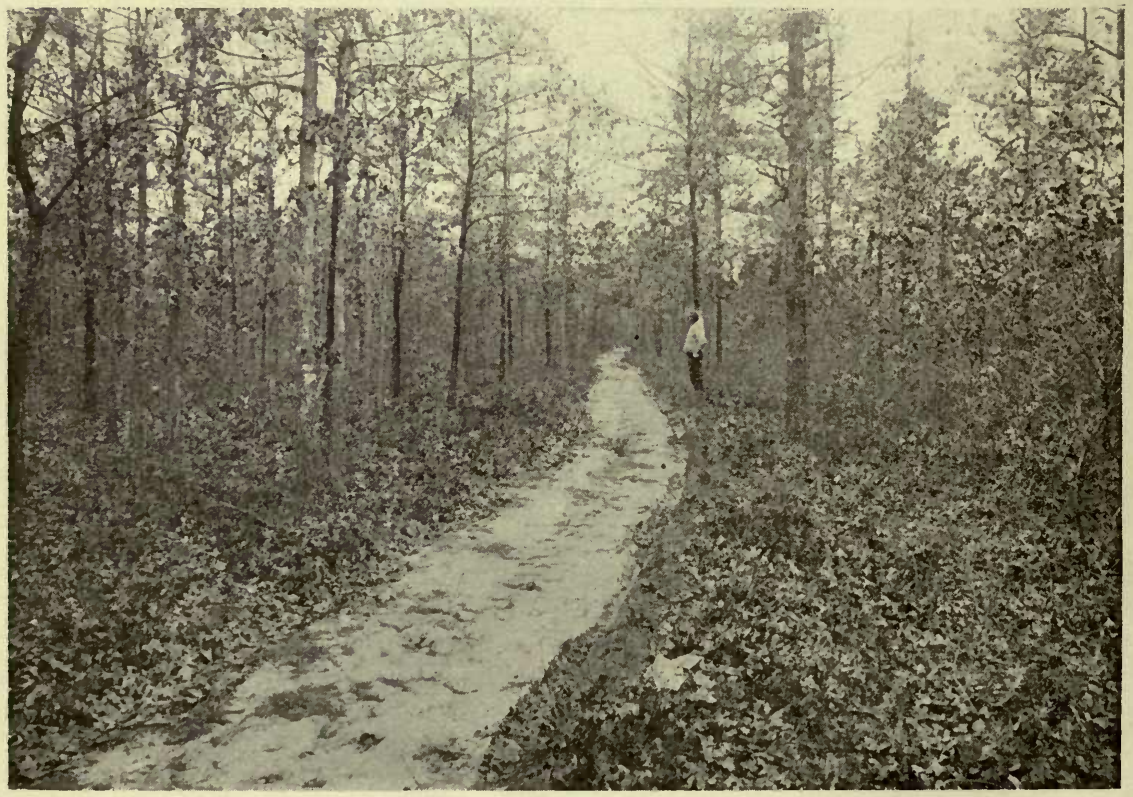

Fig. 37: The Danger is Greatly Lessened by Roadside Clearing, As Here.

OUR FORESTS ARE FIRED AND BURN FIERCELY BECAUSE THEY ARE SO LARGELY IN THE BRUSH STAGE. CLEARING THE ROADS WILL DO MUCH TO PREVENT FIRES AND TO CONTROL THEM. 
With a far larger volume of responsibility fixed, the cases have been much fewer in which unsatisfactory preliminary preparation of the matter by the local wardens has demanded further investigation. This and the use of motor vehicles have enabled the division wardens to give personal attention to most of the more dangerous fires and to assist more effectively in enforcing a strict observance of the fire law. A summary of the year's activities is given in Table VI, which shows improvement in every respect over the records of previous years.

\section{WARDENS' CONFERENCES.}

In the late winter and early spring a new step in developing the local fire service was taken by calling a conference of local firewardens in each of the divisions. Despite uniformally bad weather, these four meetings brought out a large attendance and awakened an interest among the firewardens far beyond that anticipated. The value of these gatherings is measured by increased personal activity among the wardens, by firmer and more widespread co-operation between neighboring wardens, by closer attention to detail in investigating and reporting fires, and by a more thorough appreciation of the larger problems in the solution of which each local service plays its part. The result has been a more effective, independent and publicly recognized organization than we have ever had. 
TABLE VII.-FOREST FIRES BY COUNTIES AND TOWNSHIPS, 1913.

\begin{tabular}{|c|c|c|c|c|c|c|c|c|}
\hline \multirow[b]{2}{*}{$\begin{array}{l}\text { County and } \\
\text { Township. }\end{array}$} & \multicolumn{2}{|c|}{ Number } & \multirow[b]{2}{*}{ 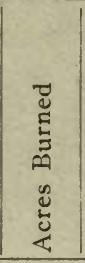 } & \multirow[b]{2}{*}{ 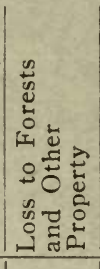 } & \multirow[b]{2}{*}{ 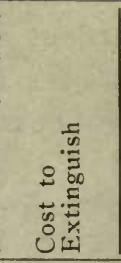 } & \multicolumn{3}{|c|}{ Paid by $\dagger$} \\
\hline & 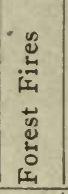 & 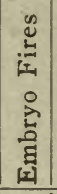 & & & & 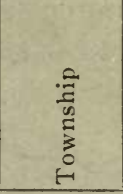 & 苋 & 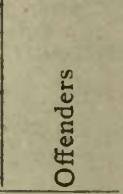 \\
\hline \multicolumn{9}{|l|}{ Atlantic County- } \\
\hline Absecon (City), .. & I] & & Io & $\$$ & $\$ \quad 4.00$ & & & $\$ \quad 4.00$ \\
\hline Buena Vista, .... & 19 & 12 & 879 & 572 & 183.40 & 32.87 & 32.88 & II 9.65 \\
\hline Egg Harbor, .... & 12 & 2 & 880 & 805 & 152.18 & $64 \cdot 60$ & $64 \cdot 58$ & 5.00 \\
\hline Egg Harbor (City) & $\cdots$ & 2 & $\ldots \ldots$ & $\ldots \ldots$ & 18.00 & $3 \cdot 50$ & 3.50 & 16.00 \\
\hline $\begin{array}{l}\text { Folsom, } . . . \cdots \cdots \\
\text { Galloway }\end{array}$ & $\cdots \cdots$ & $\cdots$ & $\ldots \ldots$ & $\cdots \ldots$ & ......... & $\cdots \cdots$ & $\ldots \ldots \cdots$ & $\cdots \cdots$ \\
\hline $\begin{array}{l}\text { Galloway, } \ldots \ldots \ldots \\
\text { Hamilton, } . . . \cdots\end{array}$ & I I & II & $\begin{array}{r}1660 \\
\mid\end{array}$ & I I 95 & 239.85 & 102.80 & 102.80 & 44.25 \\
\hline $\begin{array}{l}\text { Hamilton, } \\
\text { Hammonton, ....... }\end{array}$ & I0 & I) & $\begin{array}{lllllllllllll} & 1 & 1 & 78\end{array}$ & 9300 & 541.65 & 185.69 & $185.7 \mathrm{I}$ & 175.25 \\
\hline Mullica, ...... & 6 & 2 & 495 & 330 & $92.4 \mathrm{I}$ & 39.71 & 39.70 & 13.00 \\
\hline Pleasantville & 5 & $\begin{array}{r}6 \\
\ldots\end{array}$ & $\begin{array}{r}1250 \\
\ldots \ldots\end{array}$ & 560 & I 94.03 & 66.07 & 66.06 & 61.90 \\
\hline Port Repu & & $\cdots$ & & & $\ldots$ & $\begin{array}{l}\cdots \ldots \ldots \\
\cdots \ldots \ldots\end{array}$ & $\cdots \cdots \cdots$ & $\cdots \cdots \cdots$ \\
\hline Weymouth,... & 8 & I 3 & 6106 & 8313 & 348.26 & $43 \cdot 53$ & $43 \cdot 52$ & $26 \mathrm{I} .2 \mathrm{I}$ \\
\hline Total, . & 72 & 49 & 22450 & $\$ 21080$ & $\$ 1746.78$ & $1 \$ 538.77$ & $\$ 538.75$ & $\$ 700.26$ \\
\hline \multicolumn{9}{|l|}{$\begin{array}{l}\text { Bergen County- } \\
\text { Franklin, ...... }\end{array}$} \\
\hline Hohokus,...$\ldots$ & & I) & & & 6.00 & 3.00 & 3.00 & \\
\hline Oakland (Boro.) & 2 & 17 & I6 & .. & $5 \mathrm{I} .20$ & I 5.45 & I 5.45 & 20.30 \\
\hline Ridgefield (Boro.) & & $\cdots$ & $\cdots \cdots$ & & $\ldots \ldots \ldots$ & $\ldots \ldots \ldots$ & $\cdots \cdots \cdots$ & ......... \\
\hline Total; & 2 & 18 & I6 & & 57.20 & I 8.45 & 18.45 & $\$ .20 .30$ \\
\hline \multicolumn{9}{|l|}{ Burlington County- } \\
\hline Bass River, ..... & I & 2 & 1075 & 350 & 166.10 & 83.05 & 83.05 & \\
\hline Eve & 5 & & 595 & 460 & 39.75 & 14.38 & 14.37 & II.00 \\
\hline Medford, . ..... & 6 & 2 & I 37 & 310 & I80.10 & 90.07 & 90.03 & ...... \\
\hline New Hanover, .. & 2 & I & 45 & 45 & 31.00 & $15 \cdot 50$ & 15.50 & \\
\hline Pemberton, ....... & 3 & I & 300 & 595 & 66.65 & $27 \cdot 38$ & $27 \cdot 37$ & 21.90 \\
\hline Shamong, ....... & I I & 4 & 2660 & 5005 & 490.86 & 80.72 & 80.74 & 329.40 \\
\hline Southampton, .... & $\mathbf{I}$ & & 250 & 200 & 53.60 & 26.80 & 26.80 & $\ldots \ldots$ \\
\hline Tabernacle, ...... & 2 & 2 & I 450 & 2320 & 59.95 & 28.98 & 28.97 & 2.00 \\
\hline Washingt & 4. & $\cdots$ & 570 & 220 & 59.40 & 29.70 & 29.70 & $\cdots \cdots$ \\
\hline Woodland, ...... & 6 & 5 & 565 & I 345 & $204 \cdot 30$ & $97 \cdot 35$ & $97 \cdot 35$ & 9.60 \\
\hline Total, ......... & $4 \mathrm{I}$ & I7) & 7667 & $\$ 10850$ & $\$ 1350.7 \mathrm{I}$ & $\$ 493.93$ & $\$ 493.88$ & $\$ 373.90$ \\
\hline \multicolumn{9}{|l|}{ Camden County- } \\
\hline Berlin & 3 & $\begin{array}{l}3 \\
2\end{array}$ & $\begin{array}{c}238 \\
\ldots \ldots\end{array}$ & 256 & $\begin{array}{l}10.00 \\
16.90\end{array}$ & $\begin{array}{l}5.00 \\
8.45\end{array}$ & $\begin{array}{l}5.00 \\
8.45\end{array}$ & \\
\hline Clementon, ...... & 2 & 3 & 70 & 30 & 27.75 & $\begin{array}{l}0.45 \\
5.50\end{array}$ & $\begin{array}{l}0.43 \\
5.50\end{array}$ & 16.75 \\
\hline & & I & & & 9.00 & & & 49.00 \\
\hline Gloucester, . & 3 & 5 & 256 & I 35 & 53.00 & I 8.74 & 18.76 & I 5.50 \\
\hline Voorhees, .... & & $\mathrm{I}$ & $\cdots$ & $\cdots$ & & & & 5.00 \\
\hline Waterford, .. & 4 & ... & 205 & 200 & 40.60 & I6. I7 & 16.18 & 8.25 \\
\hline Winslow. & I 2 & $3 \mathrm{I}$ & 634 & 400 & 221.90 & $35 \cdot 42$ & $35 \cdot 43$ & 156.05 \\
\hline Total, & 24 & $46 !$ & 1403 & \$ 1021 & $\mid \$ 377.15$ & 89.35 & 89.39 & $\$ 250.55$ \\
\hline
\end{tabular}


TABLE VII.-FOREST FIRES BY COUNTIES AND TOWNSHIPS, I9I3-Continued.

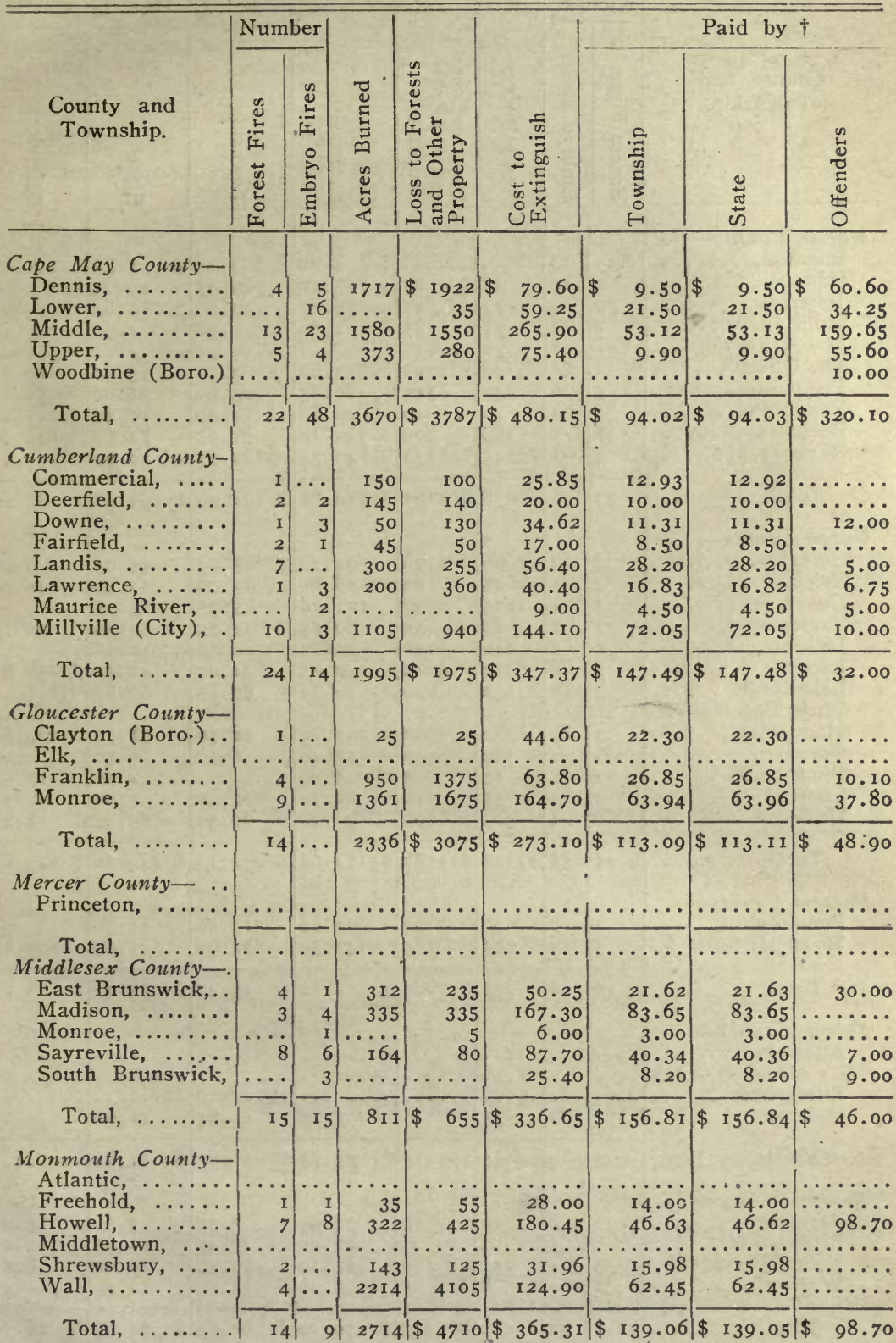


TABLE VII.-FOREST FIRES BY COUNTIES AND TOWNSHIPS, I9I3-Continued.

\begin{tabular}{|c|c|c|c|c|c|c|c|c|}
\hline \multirow[b]{2}{*}{$\begin{array}{l}\text { County and } \\
\text { Township. }\end{array}$} & \multicolumn{2}{|c|}{ Number } & \multirow[b]{2}{*}{ 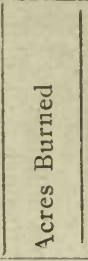 } & \multirow[b]{2}{*}{ 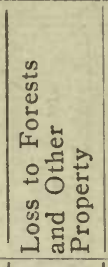 } & \multirow[b]{2}{*}{ 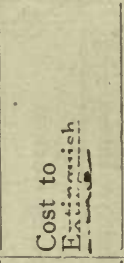 } & \multirow[b]{2}{*}{ 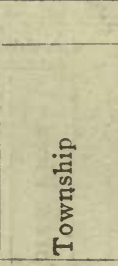 } & Paid by $\dagger$ & \multirow[b]{2}{*}{ 总 } \\
\hline & 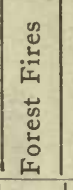 & 离 & & & & & 峁 & \\
\hline 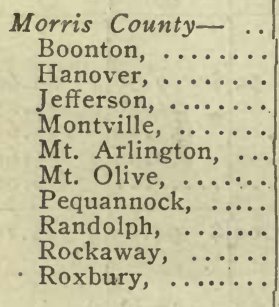 & $\mid \begin{array}{r}\cdots \\
2 \\
2 \\
2 \\
\cdots \\
1 \\
5 \\
1 \\
10 \\
4\end{array}$ & $\left.\mid \begin{array}{r}1 \\
10 \\
3 \\
1 \\
\hdashline \\
1 \\
6 \\
2 \\
6 \\
1\end{array}\right]$ & $\begin{array}{r}\cdots \\
47 \\
23 \\
75 \\
\cdots \\
40 \\
238 \\
20 \\
288 \\
145 \\
\end{array}$ & $\begin{array}{r}\$ \\
67 \\
5 \mathrm{I} \\
55 \\
\cdots \\
55 \\
505 \\
20 \\
273 \\
135\end{array}$ & $\mid \begin{array}{r}4.50 \\
105.10 \\
39.20 \\
1.80 \\
\cdots \quad 17.00 \\
106.15 \\
20.80 \\
143.30 \\
20.35 \\
\end{array}$ & $\begin{array}{r}2.25 \\
49.05 \\
19.60 \\
.90 \\
.7 .6 \\
3.50 \\
25.00 \\
10.40 \\
71.65 \\
10.62\end{array}$ & $\mid \begin{array}{r}2.25 \\
49.05 \\
19.60 \\
.90 \\
\cdots .2 . \\
3.50 \\
25.00 \\
10.40 \\
71.65 \\
10.63\end{array}$ & 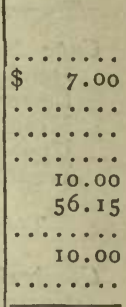 \\
\hline Total, ........ & 27 & $3 \mathrm{I}$ & 876 & $\$ 1161$ & $\$ 450.70$ & $\$ 192.97$ & $\$ 192.98$ & $\$ 83.15$ \\
\hline 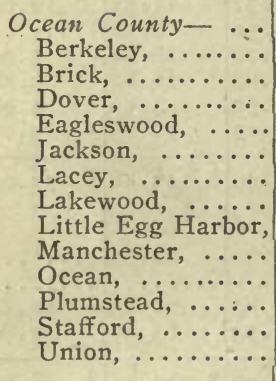 & \begin{tabular}{r|}
3 \\
3 \\
3 \\
1 \\
2 \\
5 \\
3 \\
. \\
3 \\
1 \\
1 \\
4 \\
6
\end{tabular} & $\begin{array}{r}2 \\
1 \\
1 \\
7 \\
1 \\
8 \\
2 \\
\cdots \\
27 \\
1 \\
\cdots . \\
\cdots \\
1\end{array}$ & \begin{tabular}{r}
1006 \\
75 \\
II 15 \\
25 \\
240 \\
8004 \\
532 \\
\hdashline$\ldots$. \\
1770 \\
150 \\
15 \\
59 \\
325
\end{tabular} & $\begin{array}{r}\mathrm{I} x 00 \\
90 \\
2327 \\
50 \\
140 \\
9215 \\
820 \\
\ldots \ldots . . \\
3020 \\
40 \\
5 \\
110 \\
670\end{array}$ & $\begin{array}{r}94.10 \\
26.60 \\
171.10 \\
50.75 \\
20.75 \\
140.85 \\
16.70 \\
\ldots \ldots \ldots \\
241.00 \\
17.40 \\
5.00 \\
60.50 \\
193.40\end{array}$ & $\begin{array}{r}45.05 \\
13.30 \\
85.55 \\
14.30 \\
10.37 \\
41.00 \\
80.85 \\
\ldots \ldots . . \\
58.70 \\
6.50 \\
\cdots \ldots . . \\
7.00 \\
69.52\end{array}$ & $\begin{array}{r}45.05 \\
13.30 \\
85.55 \\
14.30 \\
10.38 \\
41.00 \\
80.85 \\
\cdots \cdots \cdots \\
58.70 \\
6.50 \\
2.50 \\
7.00 \\
69.53\end{array}$ & 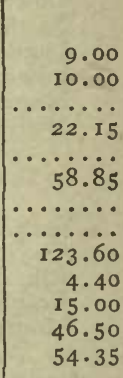 \\
\hline $\begin{array}{l}\text { Total, ......... } \\
\text { Passaic County- } \\
\text { Pompton, ....... } \\
\text { West Milford, ... }\end{array}$ & $\begin{array}{l}1 \\
5\end{array}$ & $\begin{array}{r}7 \\
13\end{array}$ & $\begin{array}{r}30 \\
195\end{array}$ & $\$ 17587$ & $\begin{array}{r}\$ 1182.65 \\
27.00 \\
147.50\end{array}$ & $\begin{array}{l}13.50 \\
21.92\end{array}$ & $\begin{array}{l}13.50 \\
21.93\end{array}$ & $\$ 343.85$ \\
\hline $\begin{array}{l}\text { Total, ........ } \\
\text { Salem County- } \\
\text { Alloway, ........ } \\
\text { L'r Alloways Creek } \\
\text { Pittsgrove, ........ } \\
\text { Quinton, ....... }\end{array}$ & $\begin{array}{c}\cdots \\
\cdots \cdots \\
\cdots \\
i\end{array}$ & $\begin{array}{r}\cdots \\
\cdots \\
\cdots \\
2\end{array}$ & $\mid \begin{array}{r}\cdots \\
\cdots \cdots \\
\cdots \cdots \\
35 \\
35\end{array}$ & 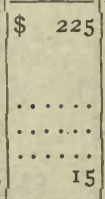 & $\begin{array}{r}\cdots \\
\cdots \cdots \\
\cdots \\
23.25\end{array}$ & $\begin{array}{l}\cdots \cdots \cdots \\
\cdots \cdots \cdots \\
\cdots \cdots \\
11.6_{3}\end{array}$ & 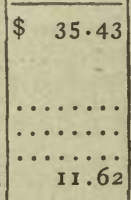 & $\$ 103.65$ \\
\hline $\begin{array}{l}\text { Total, ........ } \\
\text { Somerset County- } \\
\text { Bernard, ........ } \\
\text { Bridgewater, } 0 . . . \\
\text { North Plainfield, } \\
\text { Warren, ......... }\end{array}$ & $\begin{array}{r}1 \\
\cdots \\
5 \\
1\end{array}$ & $\begin{array}{l}2 \\
5 \\
4 \\
1\end{array}$ & $\begin{array}{r}10 \\
\ldots \ldots \\
271 \\
8\end{array}$ & $\begin{array}{r}10 \\
\ldots \ldots \\
130 \\
5\end{array}$ & $\begin{array}{l}30.00 \\
27.90 \\
67.30 \\
25.00\end{array}$ & $\begin{array}{r}7.50 \\
12.45 \\
29.40 \\
12.50\end{array}$ & $\begin{array}{r}7.50 \\
12.45 \\
29.40 \\
12.50\end{array}$ & $\begin{array}{r}15.00 \\
3.00 \\
8.50 \\
\ldots .6\end{array}$ \\
\hline Total, & 71 & 13 & 289 & 145 & $\$ 150.20$ & 61.85 & $\$ 61.85$ & $1 \$ \quad 26.50$ \\
\hline
\end{tabular}


TABLE VII.-FOREST FIRES BY COUNTIES AND TOWNSHIPS, 1913-Continued.

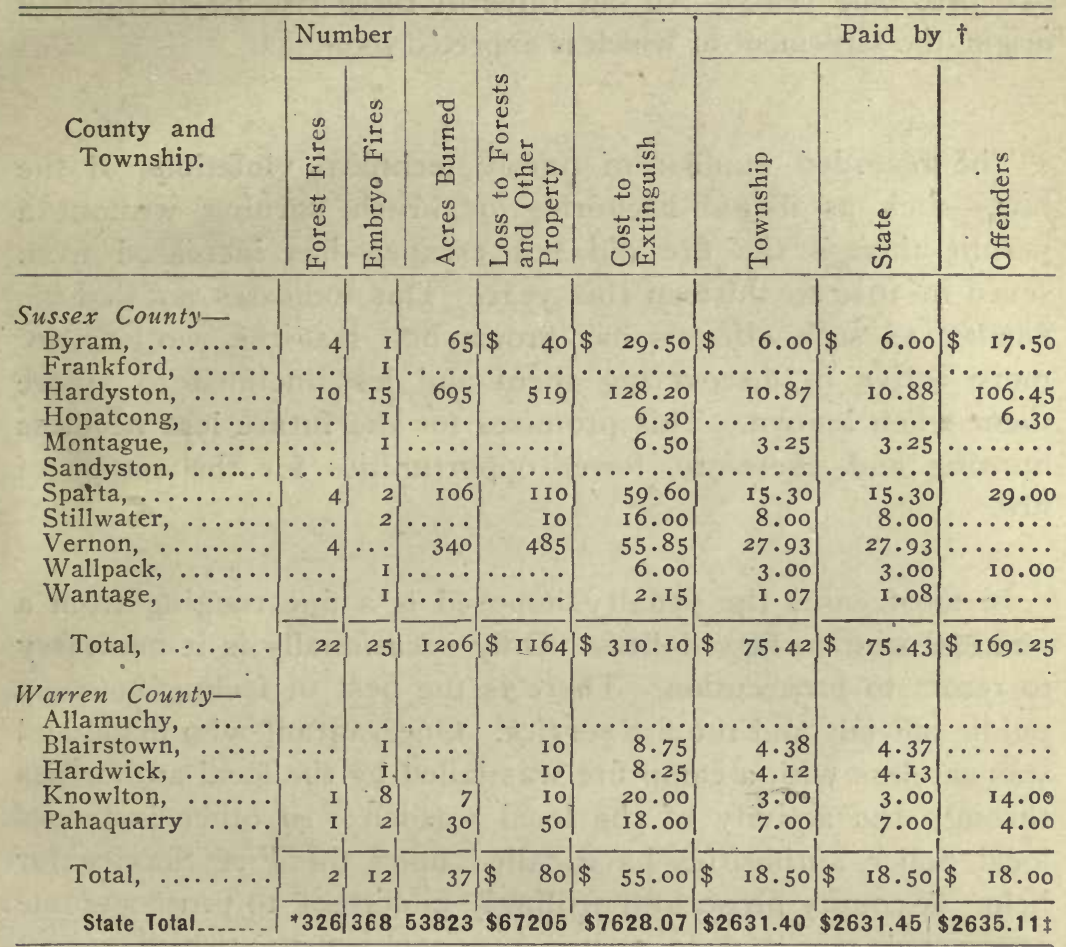

* This total is greater than the actual number ( $3 \mathrm{II}$ ) because ${ }_{5}$ fires burned in two or more townships at once.

† The sum of these columns often differs from the corresponding "Cost to Extinguish" item because a fine was larger than the bill, or a bill was withdrawn, etc.

$\$$ This total is greater than the year's collection $(\$ 1538.67)$ because all violation cases are not yet settled.

\section{VIOLATIONS OF LAW.}

Of all fires reported, 45 per cent have been fixed as violations of the law, a proportion, equal to that of last year, despite the increased number of the fires. The specific distribution and disposition of these cases is fully shown in Tables VIII, IX, X, XI and XII. Attention is directed particularly to the fact that 
65 per cent of all I9I 3 violations have been settled within the year, a larger percentage than has ever been shown heretofore, and to the fact that there remain so few unsettled cases from the two preceding years. All but three of these last are of railroad origin, the settlement of which is expected soon.

The recorded number of purely technical violations of the law,-such as illegal backfiring or brush burning without a permit though the fire did not escape,- - has increased from seven in 1912 to thirteen this year. This indicates, not that the number of such offenses has grown but, that the wardens are more active in discovering them and less inclined to ignore them when known. This promises for the future less needless

- burning and, therefore, fewer opportunities for the escape of fire.

In most cases the penalty imposed is a fine ranging from a nominal sum to fifty dollars. Only occasionally is it necessary to resort to prosecution. There is the best of feeling between public officials and the fire service. One vagrant who made and was careless with a camp fire was jailed by the local authorities through the activity of the local warden. In other instances local police authorities have called upon the Fire Service for help. A county prosecutor willingly undertook to prosecute one aggravated case and to secure a prison penalty, which cannot be done under the Forest Fire Law. These instances are cited, not because of their individual importance but because they are indicative of the public interest in forest fire control and of confidence in the work of the Fire Service.

A study of Tables X, XI and XII will indicate that the violators are leniently dealt with. That is in accord with the policy of the Forest Commission because most violations are unintentional and because the results sought are not punitive but corrective. The total amount of the penalties collected for the year was $\$ 1,538.67$. Of this $\$ 1,149.02$ was paid by railroads and $\$ 389.65$ by other agencies. See note, p. 8 . 

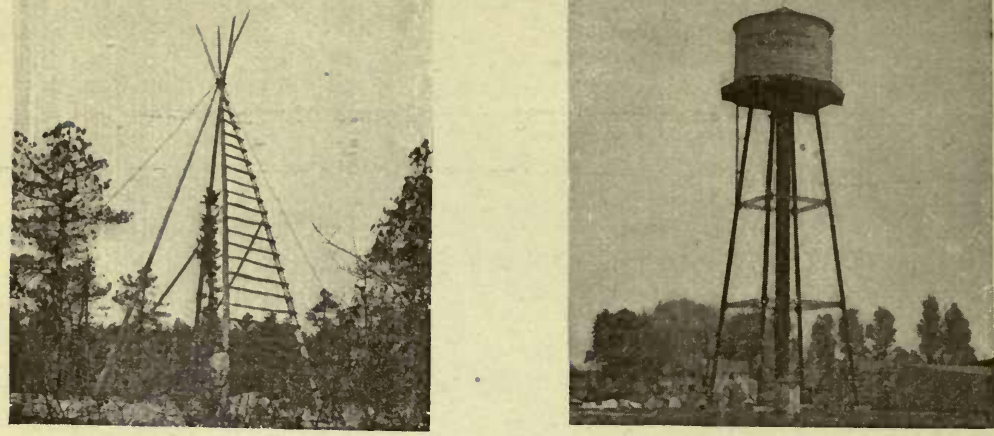

Fig. 38. Two Kinds of Lookouts. Fig 39.

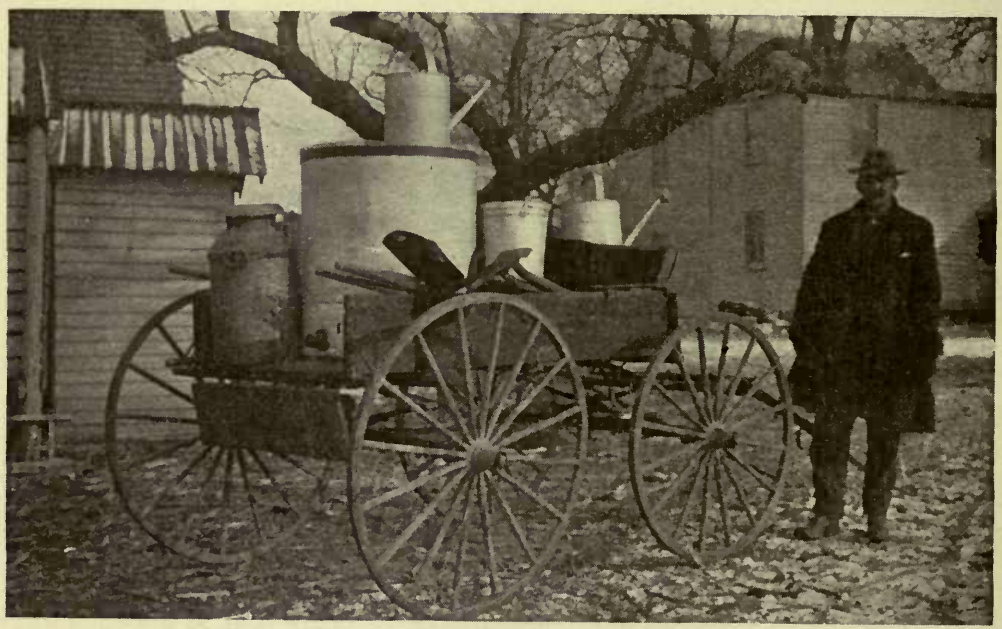

Fig. 40: Ready for a Fire Call.

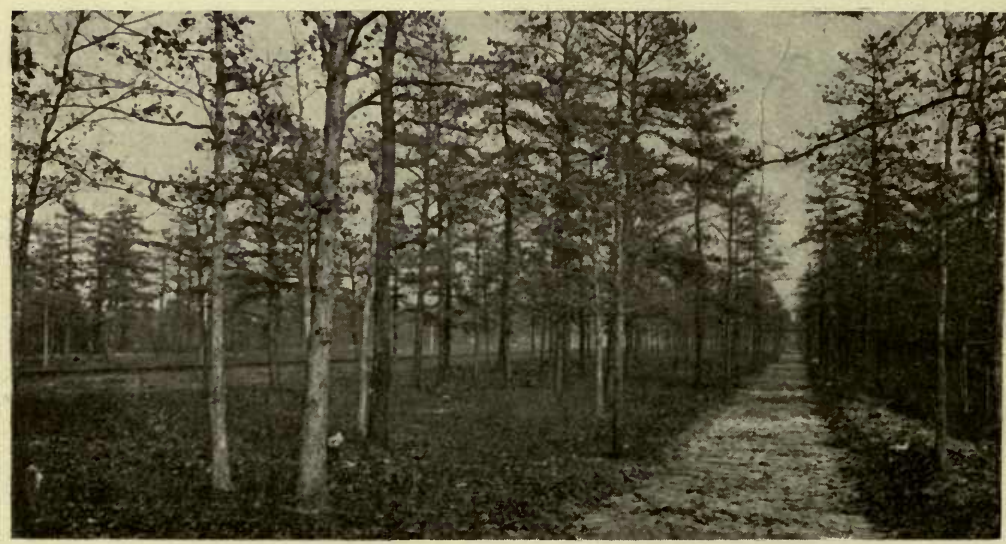

Fig. 4i: A Railroad Fire Line. When Kept Clear Like This, It Effectively Protects the Adjoining Forest.

MEANS TO CONTROL FOREST FIRES. 


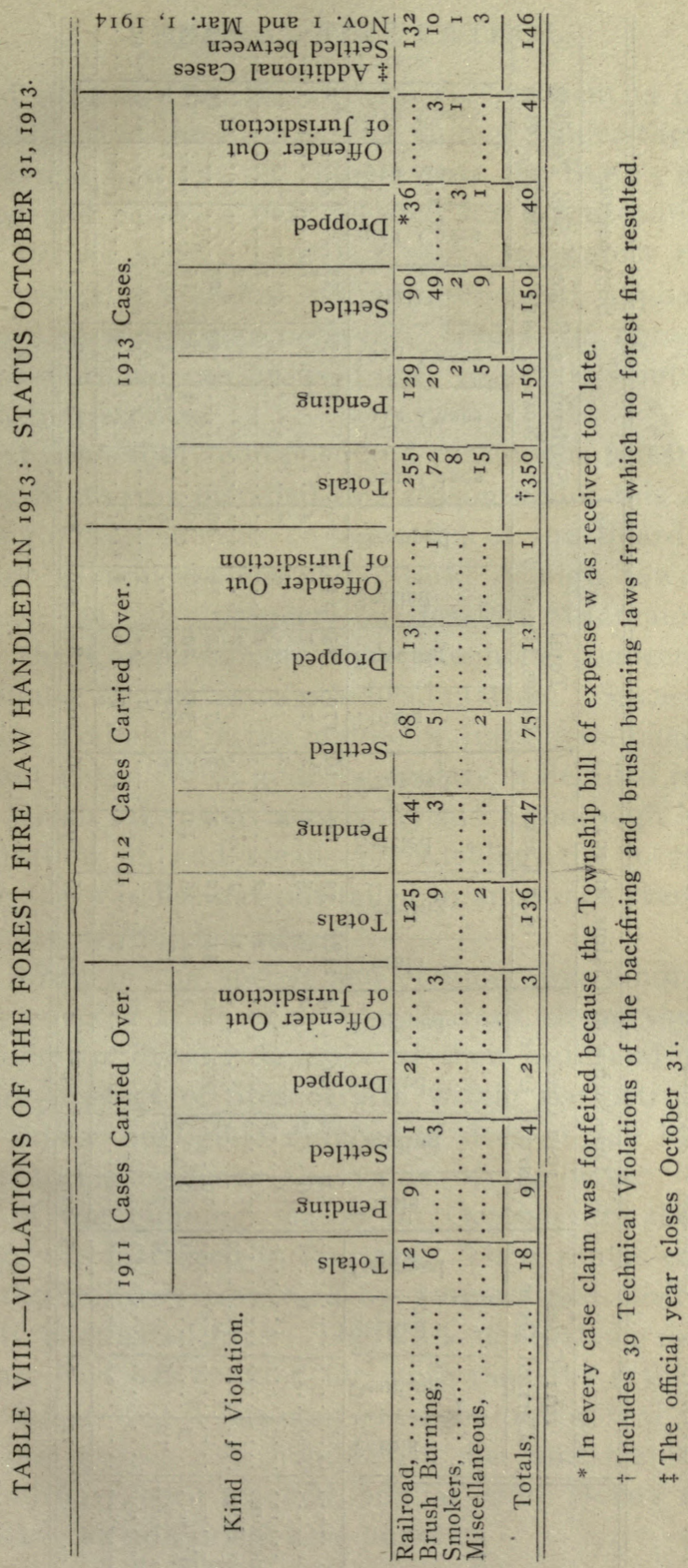




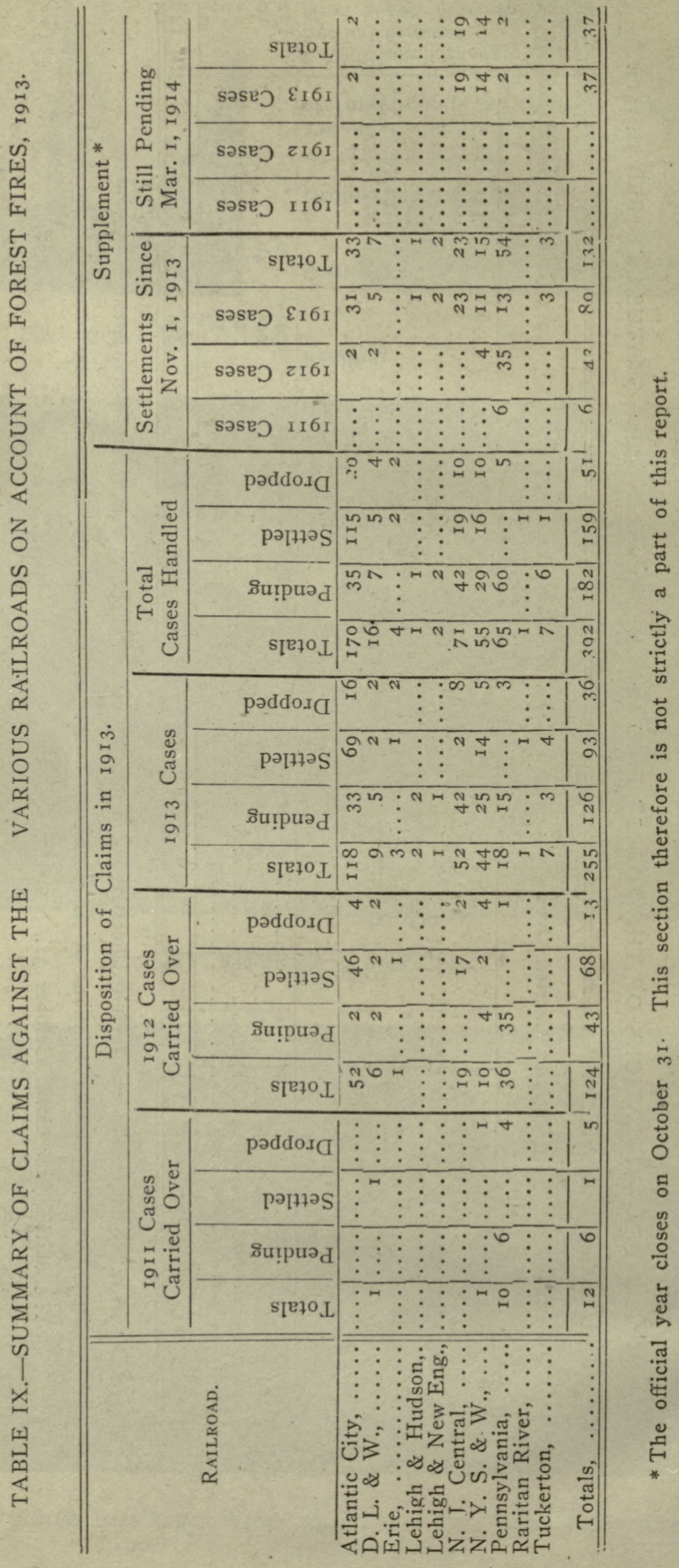




\section{FEDERAL FIRE PATROL.}

The aid furnished by the Federal Government is one of the most valuable that the Fire Service enjoys. Under the co-operative agreement first entered into in I9II the State's efforts are recognized and $\$ 2,000$ a year allotted for the execution of the so-called Weeks Law. That law seeks to protect the watersheds of navigable streams and, as interpreted, applies in New Jersey only to the northern rivers. Under the agreement the money appropriated can be used only to pay lookouts and patrolmen in that section.

The first thoroughly equipped and continuous forest fire lookout in the State was installed this season under this agreement and through the generous co-operation of the Board of Street and Water Commissioners of Newark. A high tower already standing on the city's property on Bearfort Mountain was provided by the Commissioners with telephone connection and a suitable house for the watcher's headquarters. Since the facilities became available, in the middle of June, a watcher has been on constant duty. With good binoculars, a detailed map of the territory which the tower commands and a thorough knowledge of the location of, and means of reaching, the local wardens promptly, the watcher has not failed to announce every fire that has occurred within his range.

Patrol work in the spring and summer was limited to two men who covered areas of peculiar hazard, doing the work by saddle horse or driving because of their extended territories. The entire absence of fires of size within the patrolled areas, and the almost negligible number of fires of any kind within these territories evidence the value of the work. With the opening of the gunning season on October ro, the force of patrolmen was increased to fourteen. Their routes covered the bulk of the territory traversed by gunners and their activities practically eliminated fires. The work done along this line for three years past has counted for more than the actual fire control afforded in that it has convinced the public that forest protection does protect. Without patrol the same result undoubtedly would have been reached, but far more slowly and at the cost of many an additional acre burned. 


\section{RAILROAD FIRE LINES.}

With the decision which nullified the fireline law, see p. 7 , all effort to continte fireline construction ceased. But since most of the firelines made or maintained during the past three years are the result of voluntary co-operation of a railroad with the property owners there is hope that firelines as an aid to fire control will not be given up. Hearty and willing co-operation is offered by the Fire Service to the extent of its powers.

\section{PUBLICITY.}

Recognizing the fact that the ultimate control of forest fires depends upon personal care in handling fire, a special effort has been made to reach the public upon whom the burden lies. In addition to the Fire Manual, List of Firewardens and Township fire notices, published annually, there have been issued five other publications of general or specific application, see p. 4I. These have been thoroughly distributed by both public and private agencies. Increased co-operation has been sought from the press and universal willingness to aid has been found. 


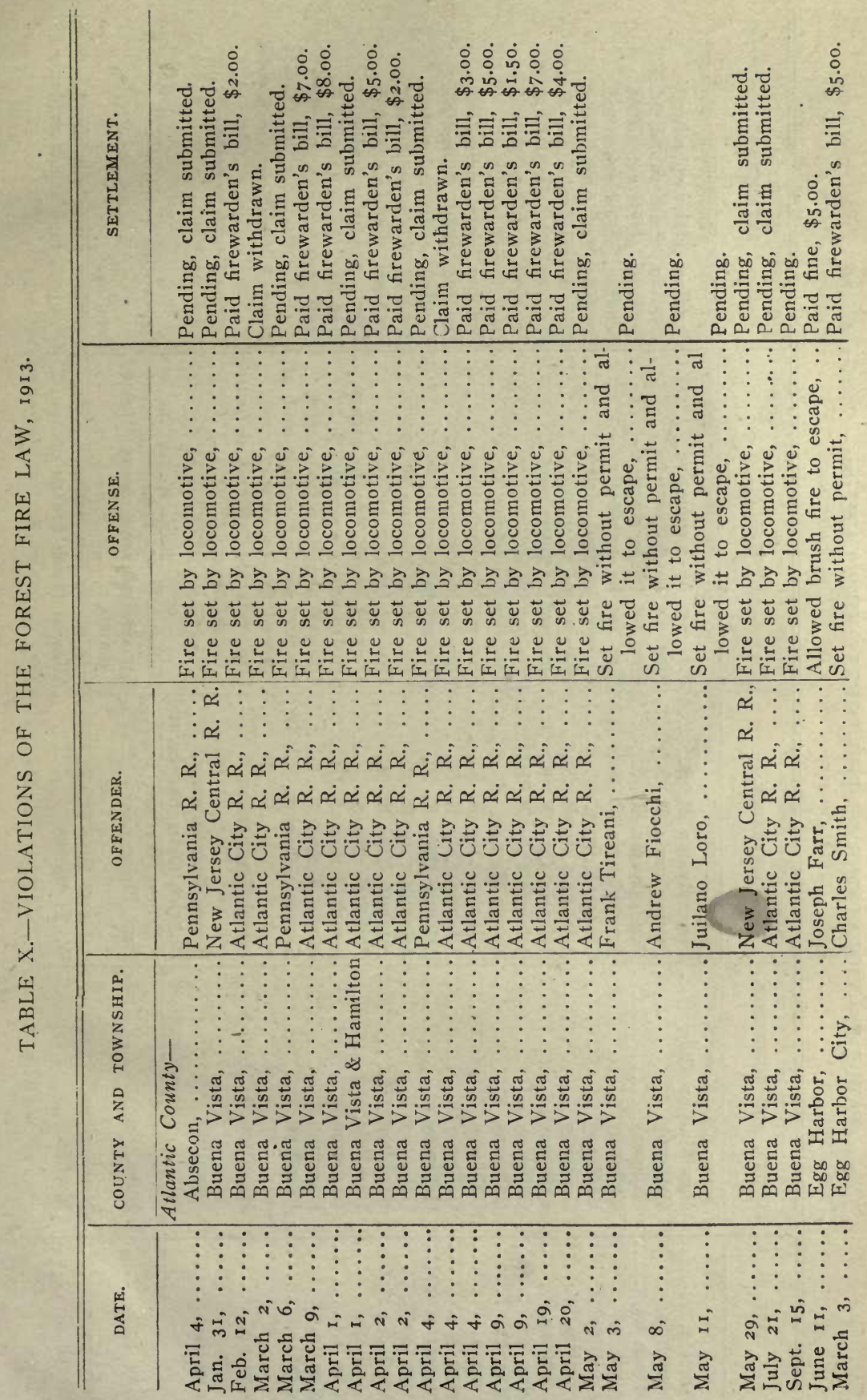




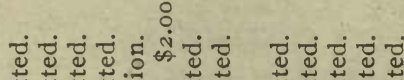

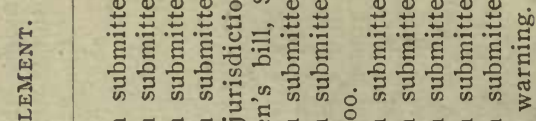

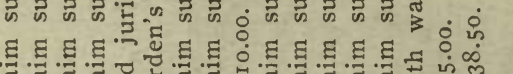
.

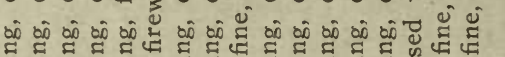

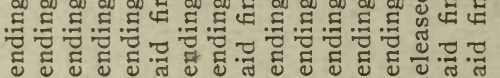

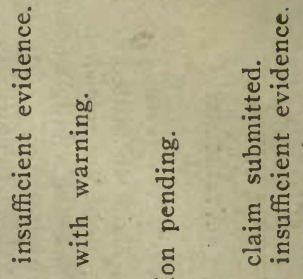

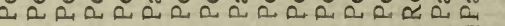

幽

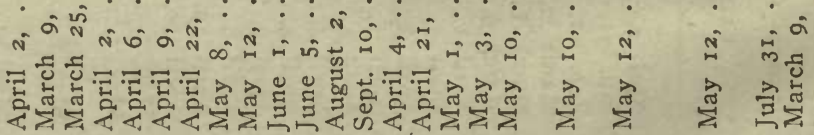




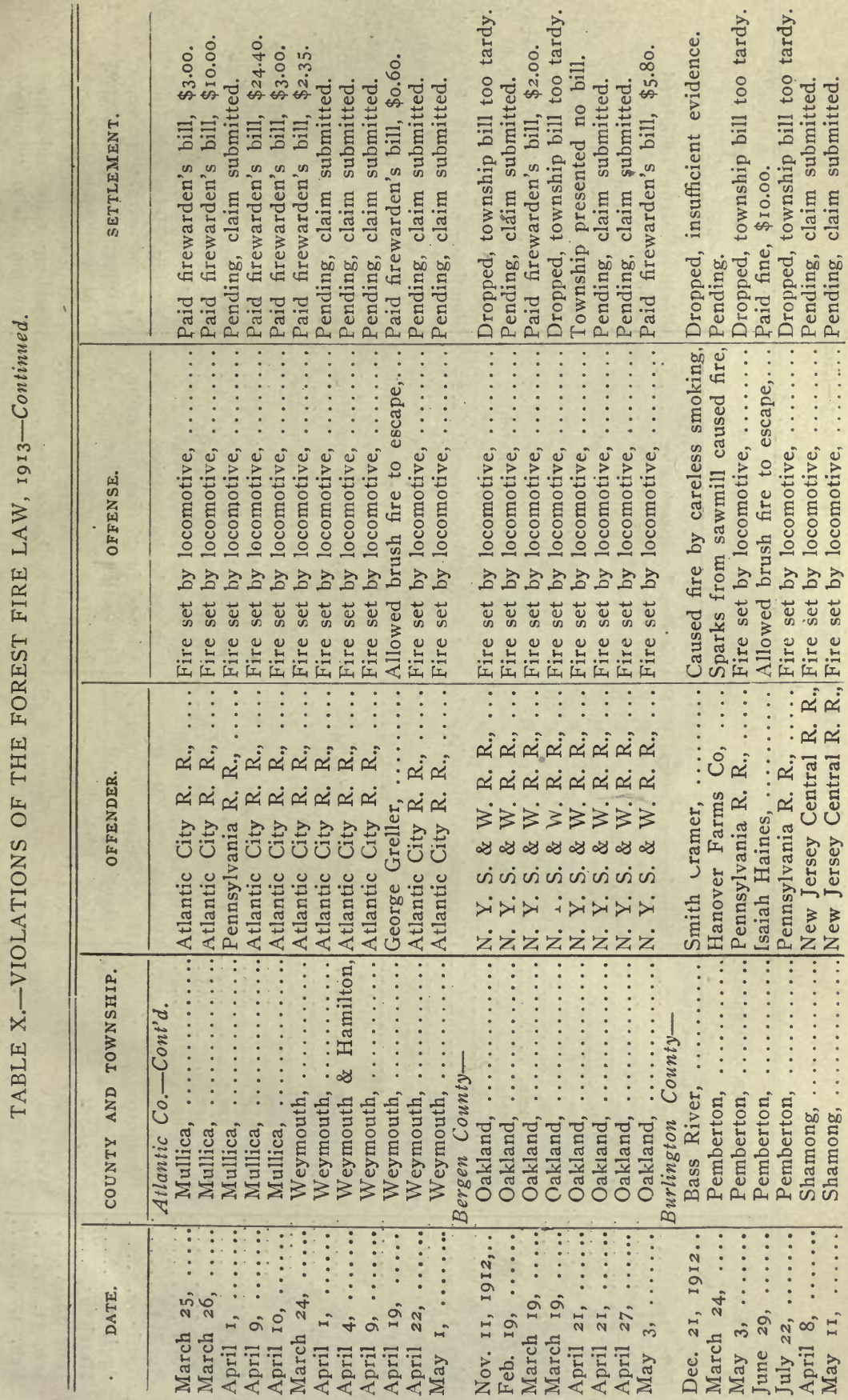




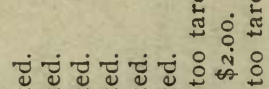

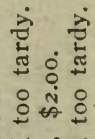

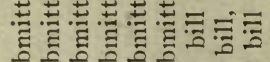

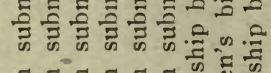

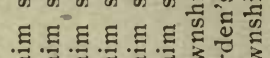

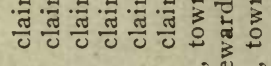

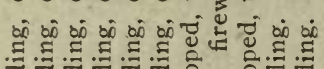

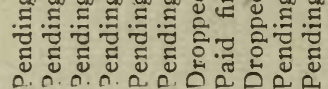

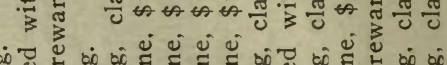
wis

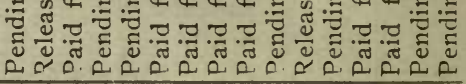

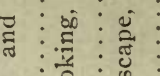

0
0

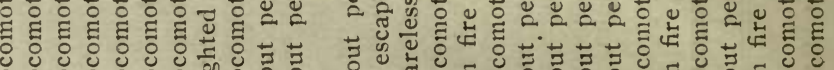

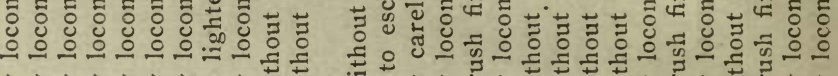

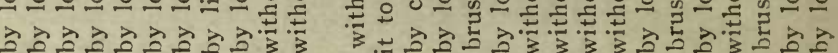

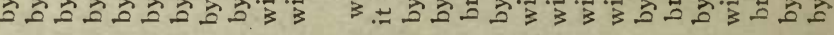

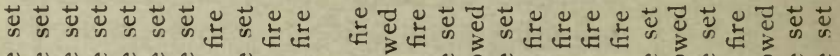

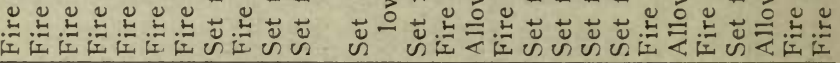

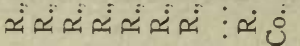

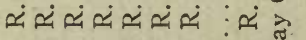

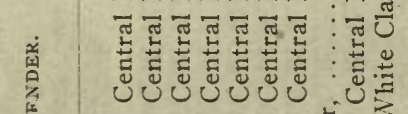

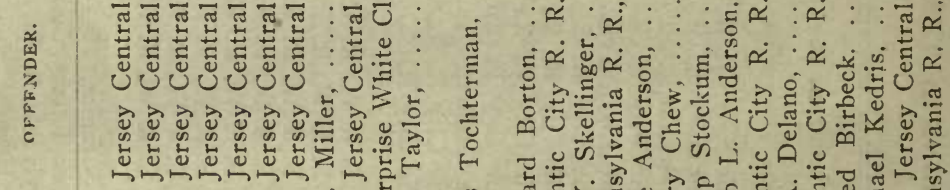

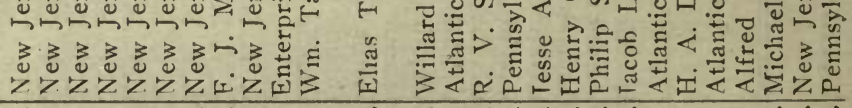

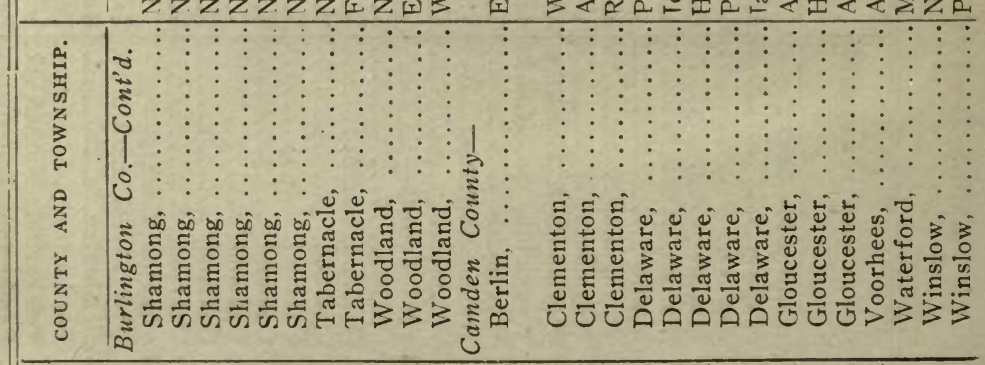

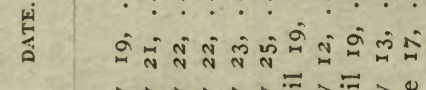
$\vdots \vdots \vdots \vdots \vdots \vdots \vdots: \vdots \vdots$

1

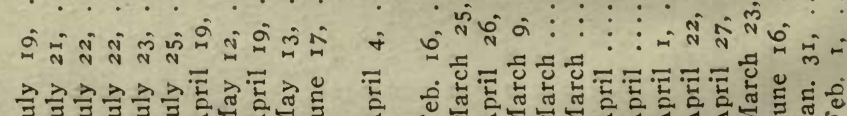

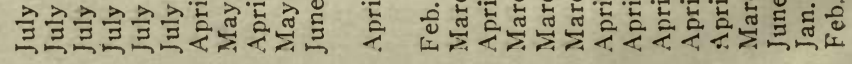


虫

ஸिं

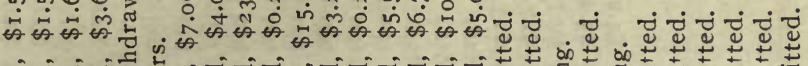

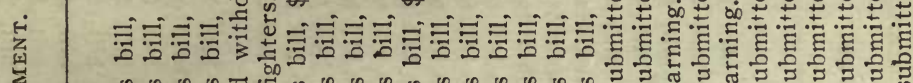

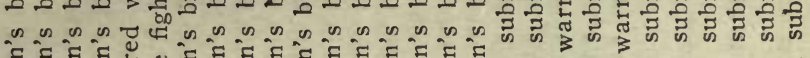
Е $\overline{0}$ 号

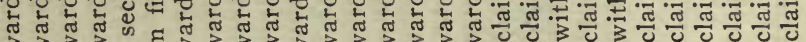

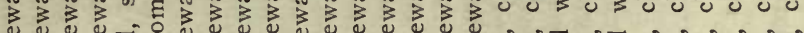

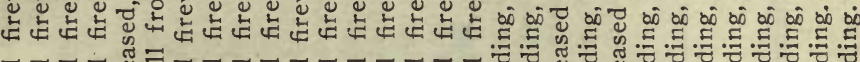

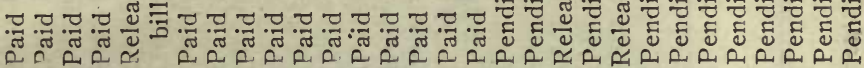

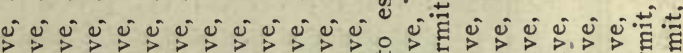
०००0 Eี हี छี U⿺辶寸 0. . O 0 0 0 O 0 O

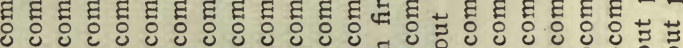

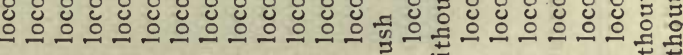

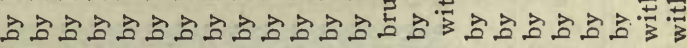
스르를

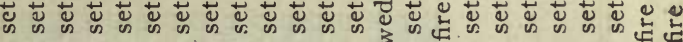
岕芯芯芯萝 논. ० $0000000000000000000+$

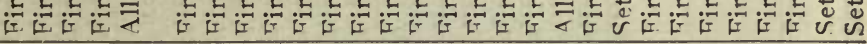

نَّهَ मिं

i

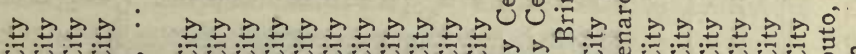

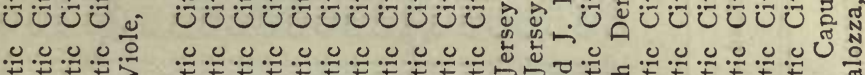
.

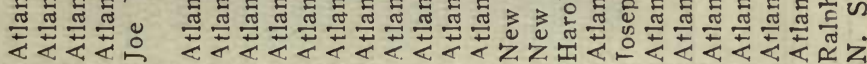

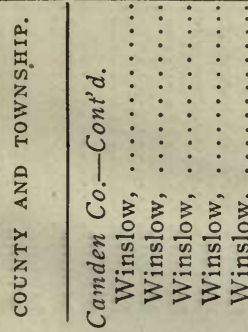

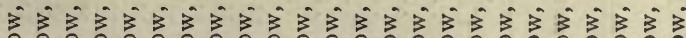

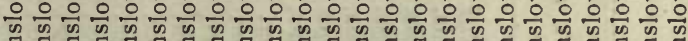

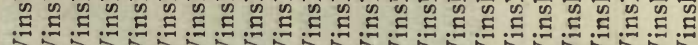

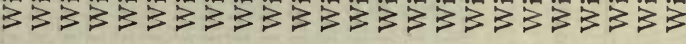




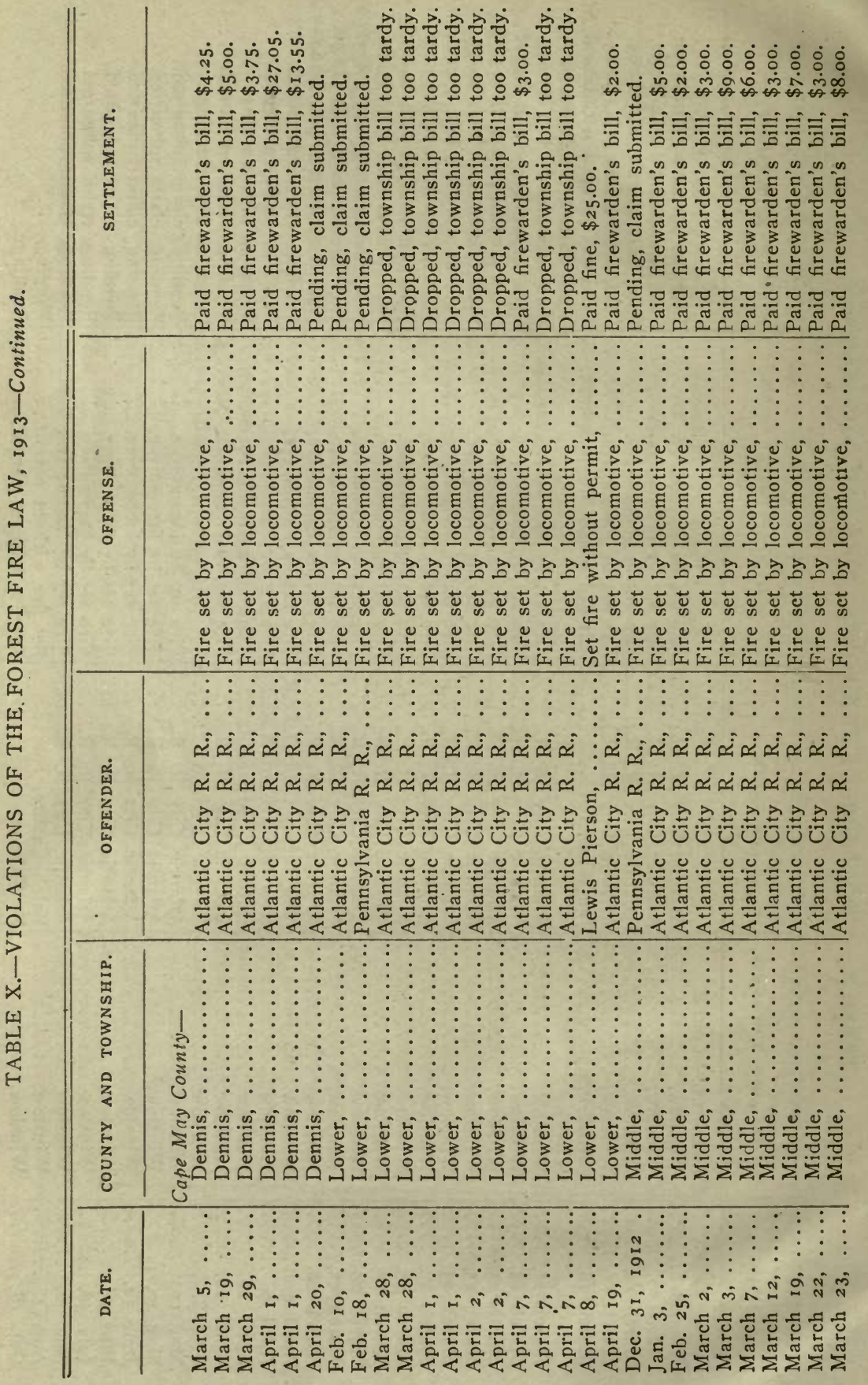




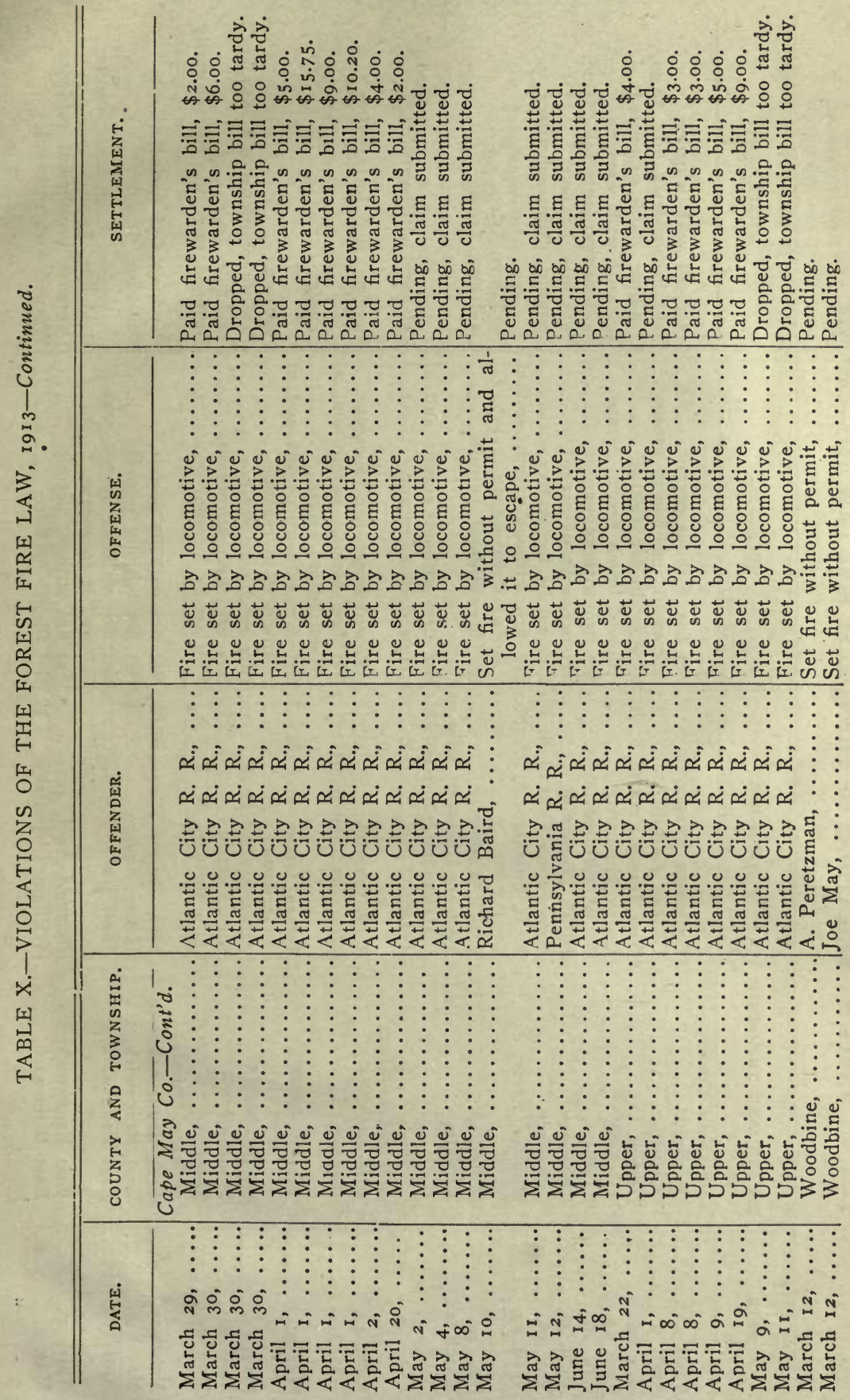




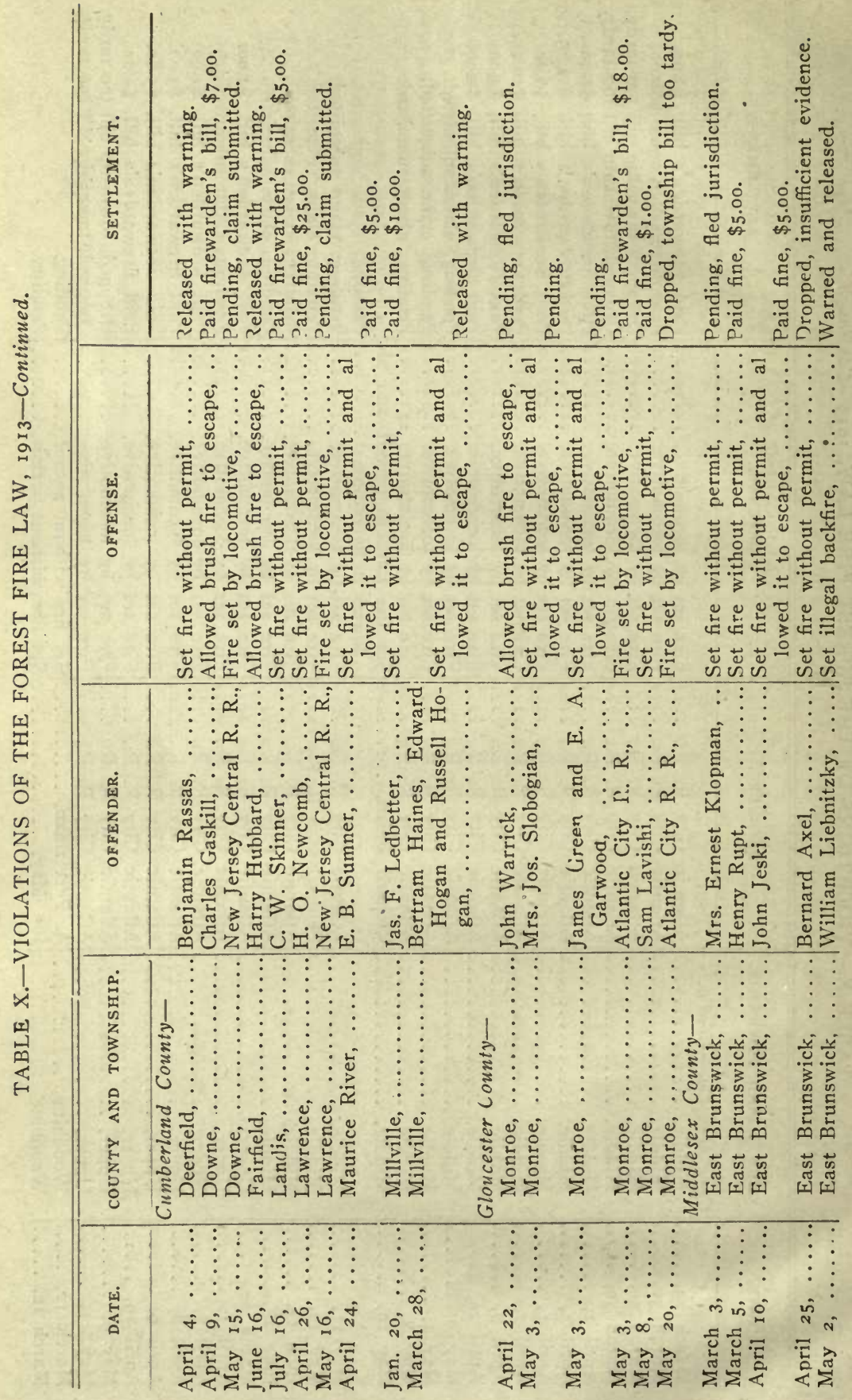




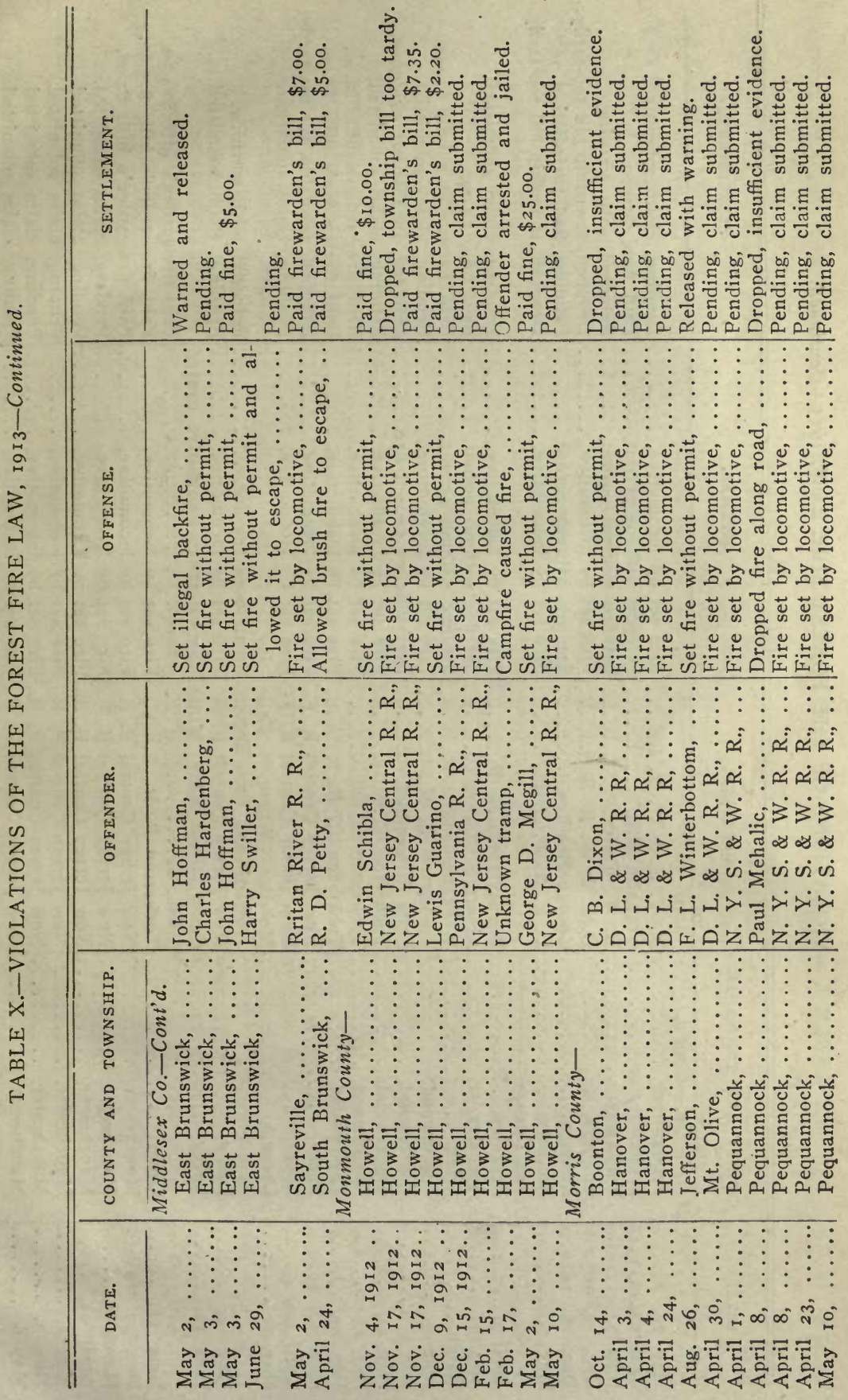




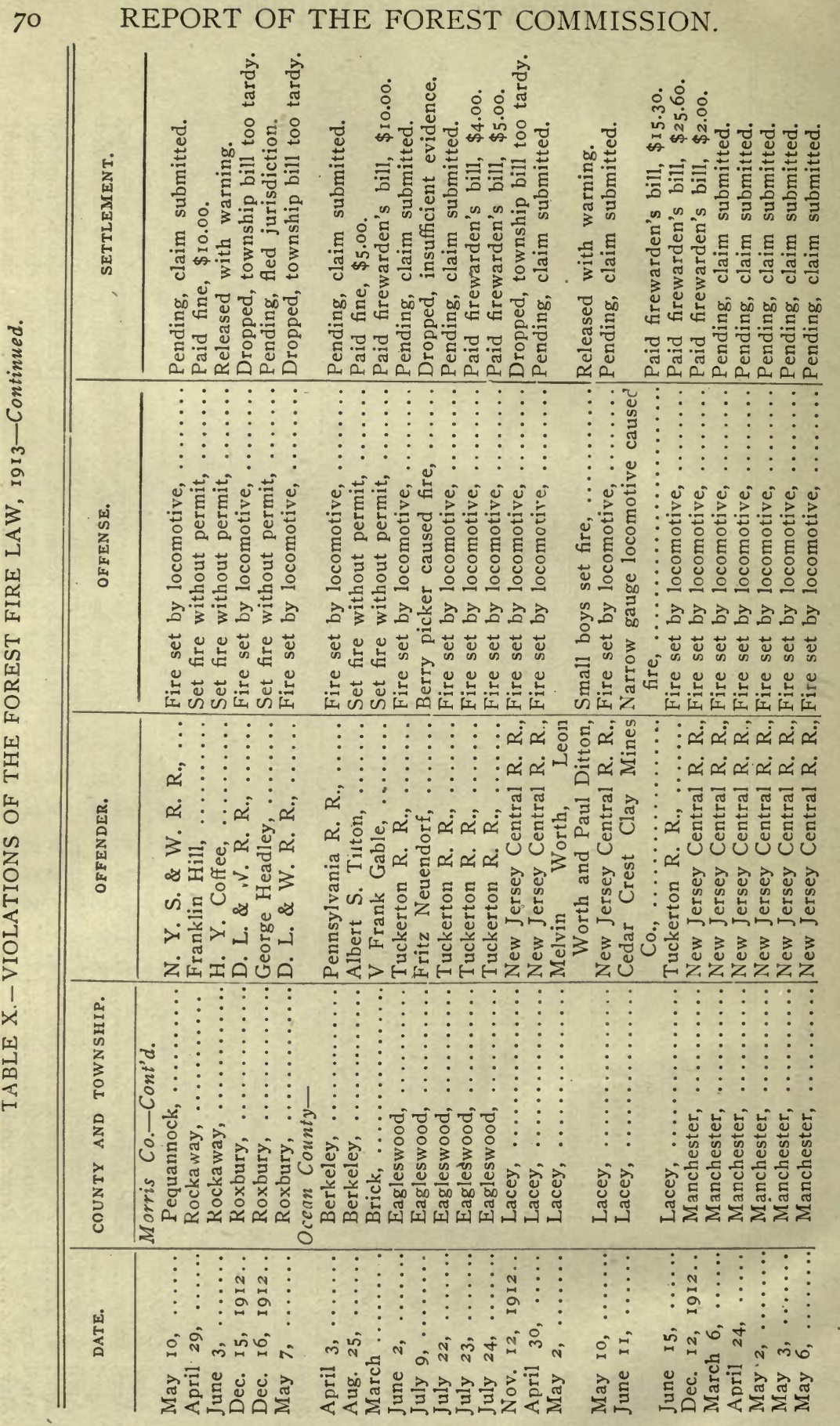




\begin{tabular}{|c|c|}
\hline & 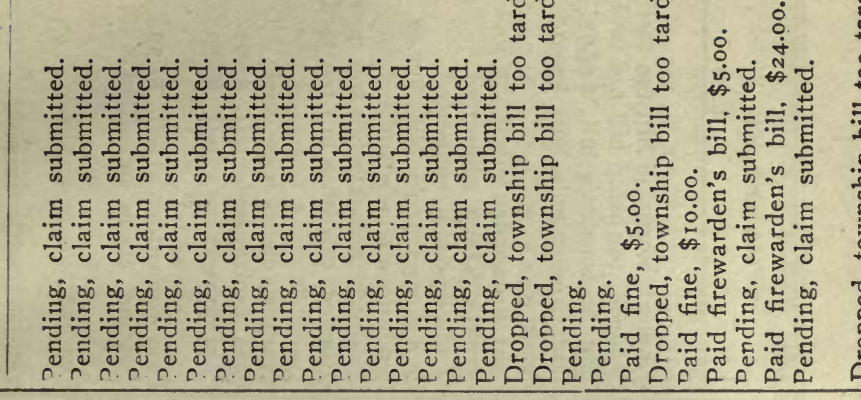 \\
\hline & $\begin{array}{l}\vdots \\
\vdots \\
\vdots\end{array}$ \\
\hline & 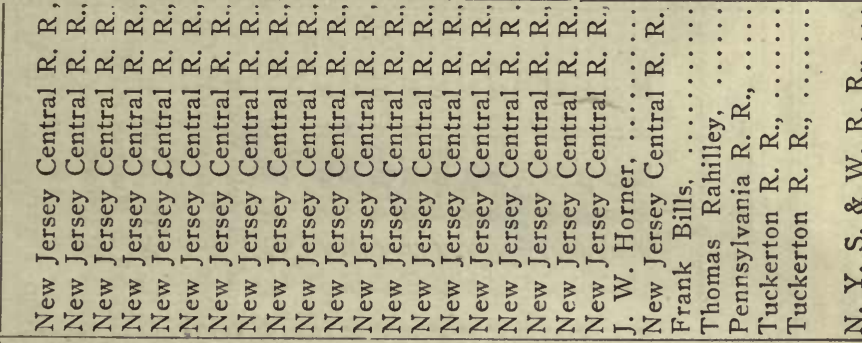 \\
\hline 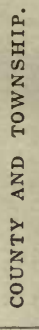 & 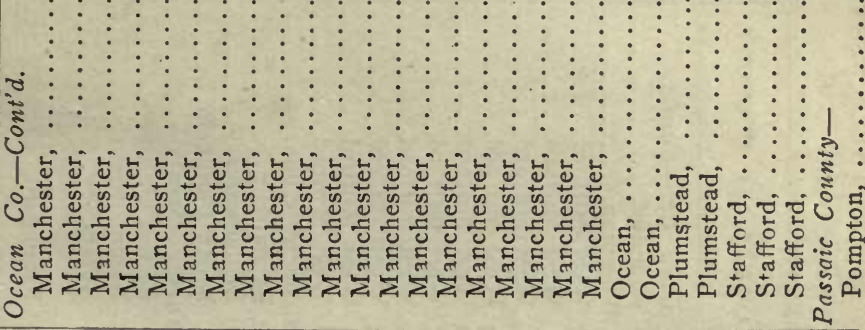 \\
\hline & 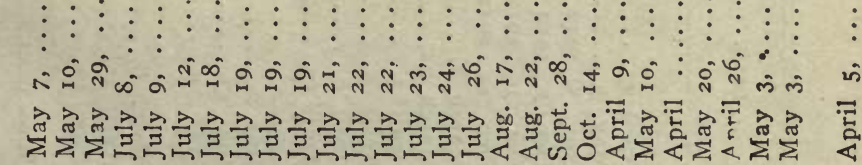 \\
\hline
\end{tabular}




\begin{tabular}{|c|c|c|c|c|c|}
\hline & 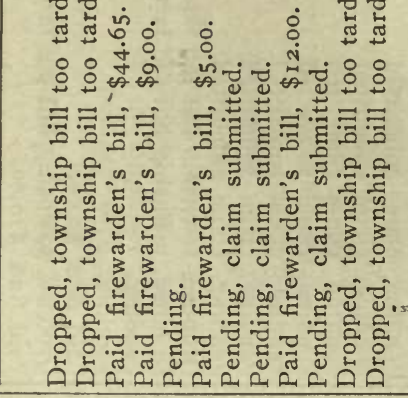 & 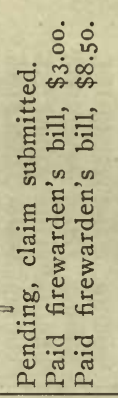 & 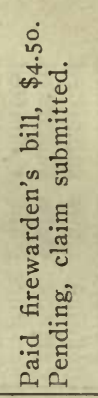 & : & 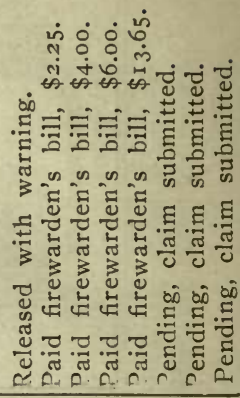 \\
\hline & 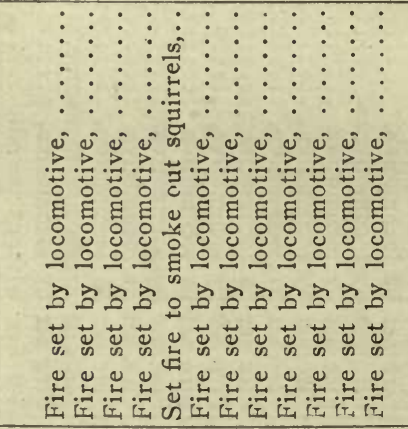 & 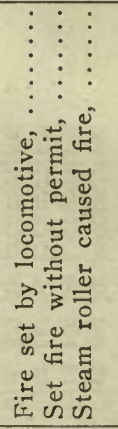 & 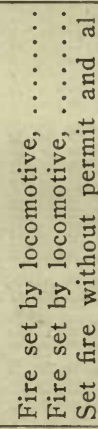 & 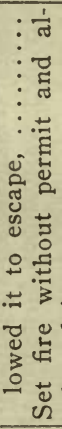 & 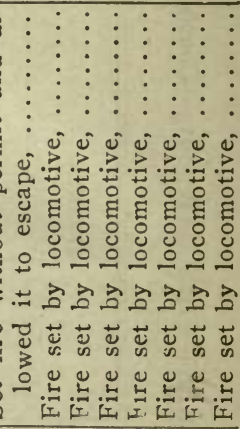 \\
\hline & 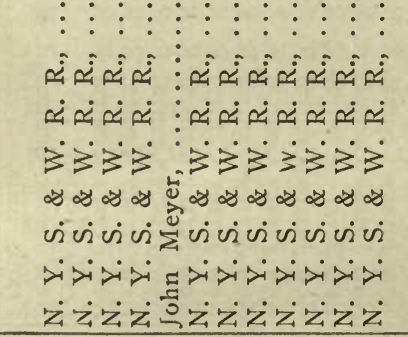 & 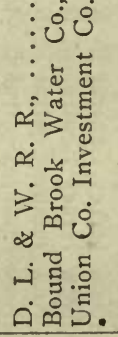 & 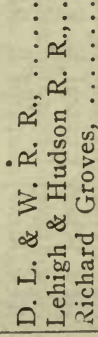 & 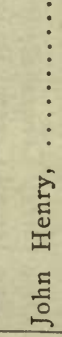 & 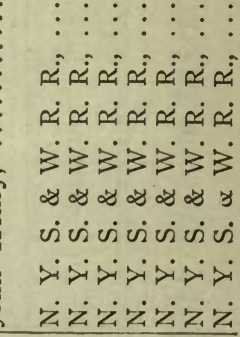 \\
\hline 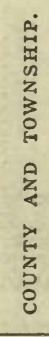 & 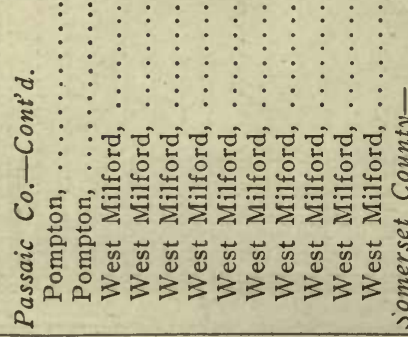 & 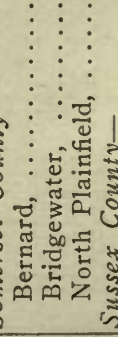 & 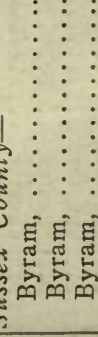 & 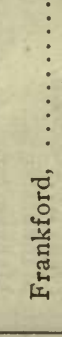 & 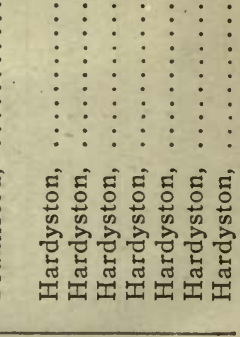 \\
\hline 晏 & 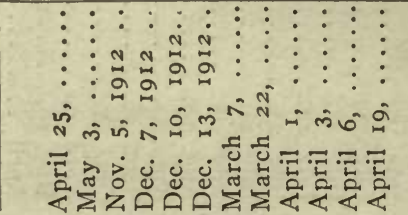 & 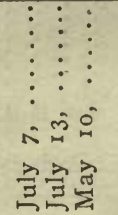 & 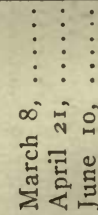 & $\begin{array}{l}\vdots \\
\vdots \\
\vdots \\
\text { m } \\
\sum_{i}^{2}\end{array}$ & 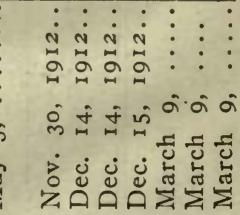 \\
\hline
\end{tabular}




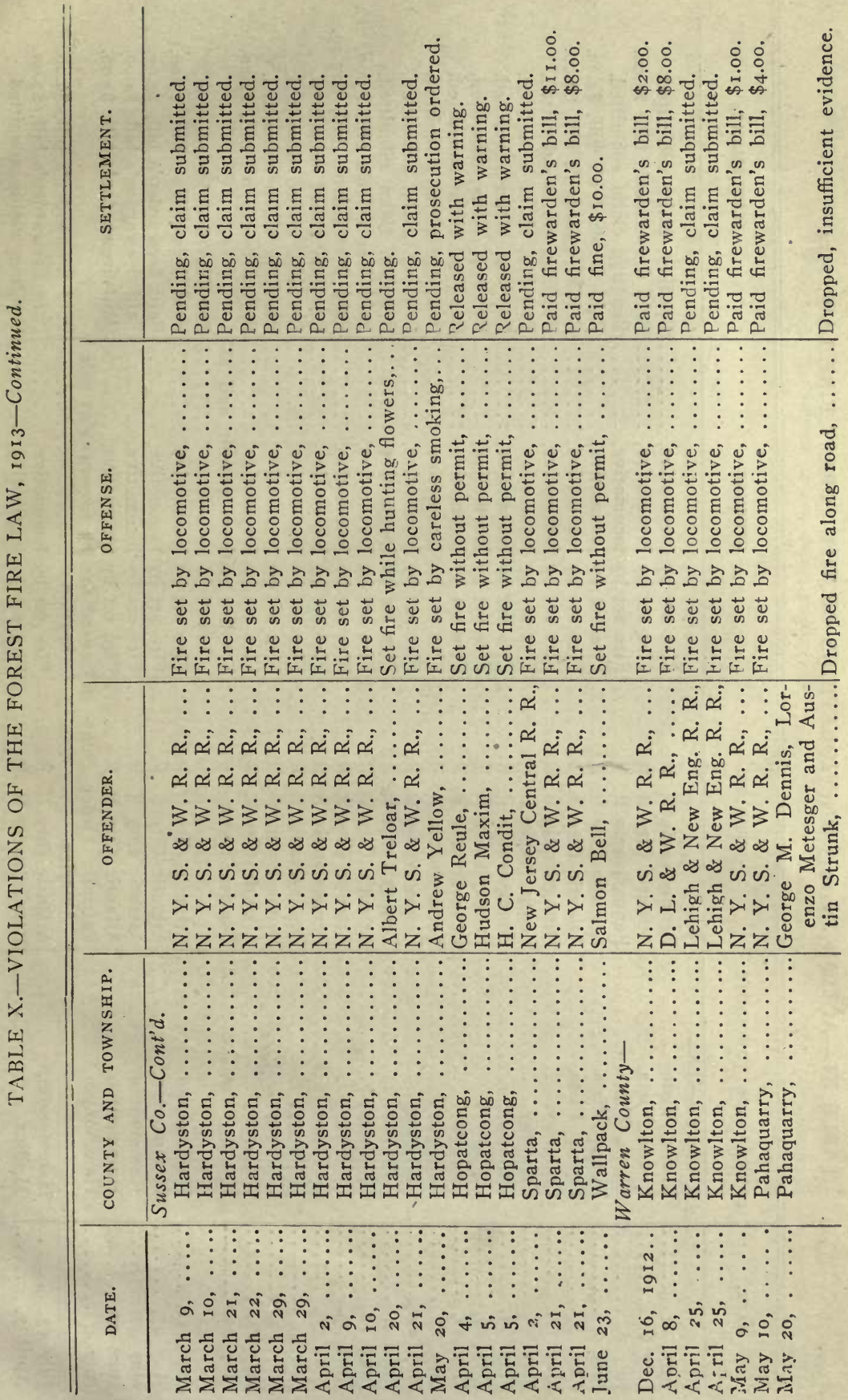




\section{REPORT OF THE FOREST COMMISSION.}

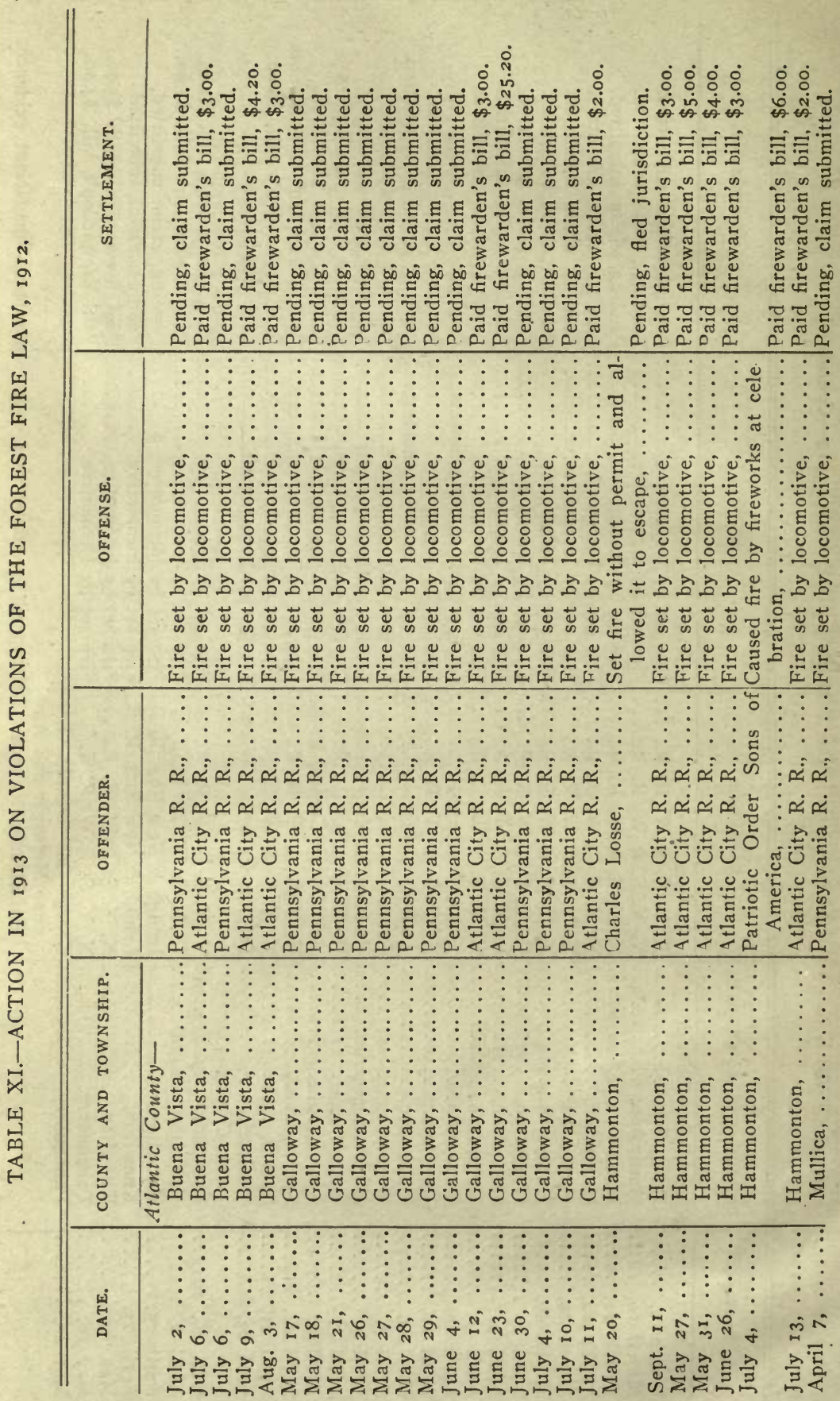




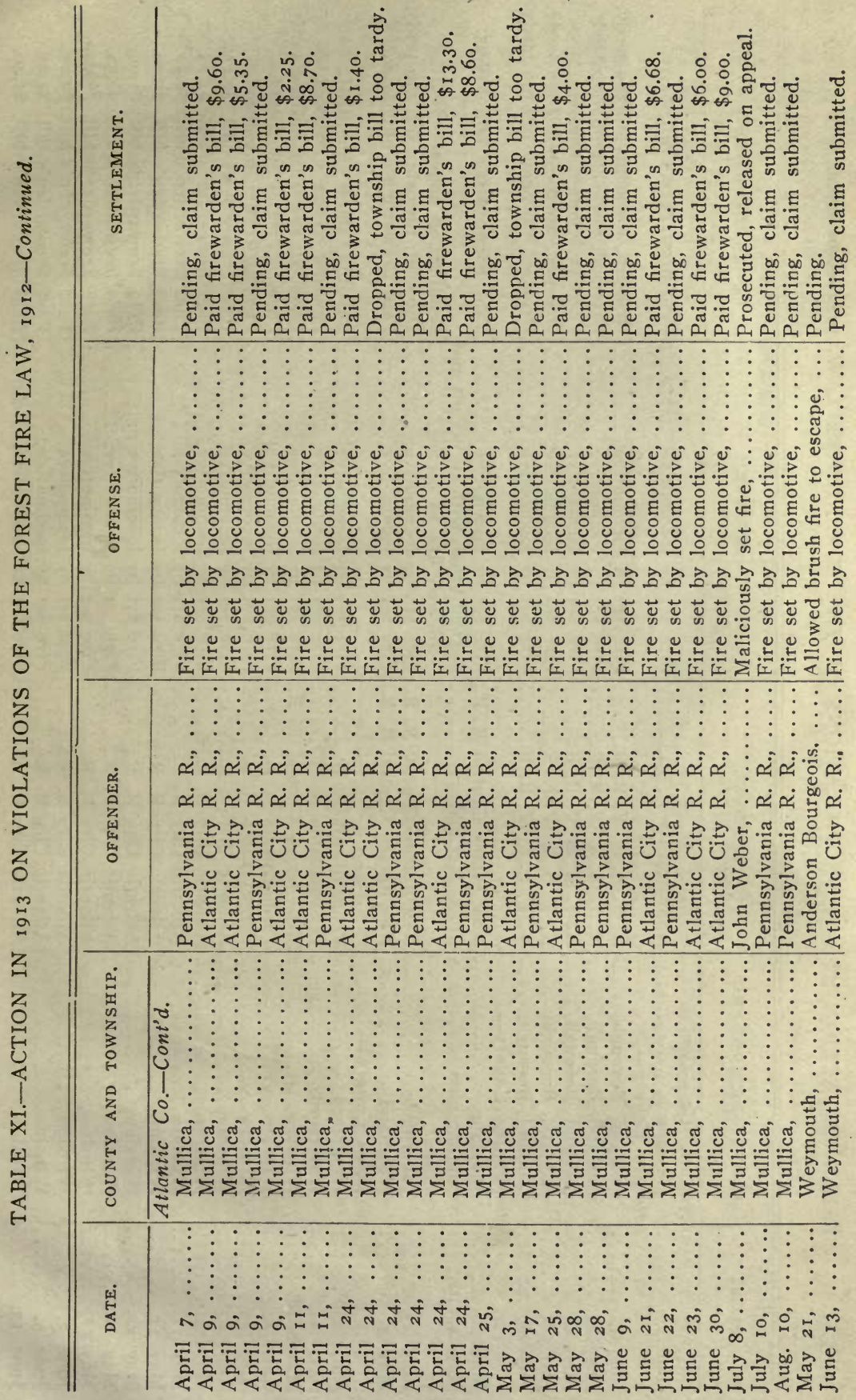




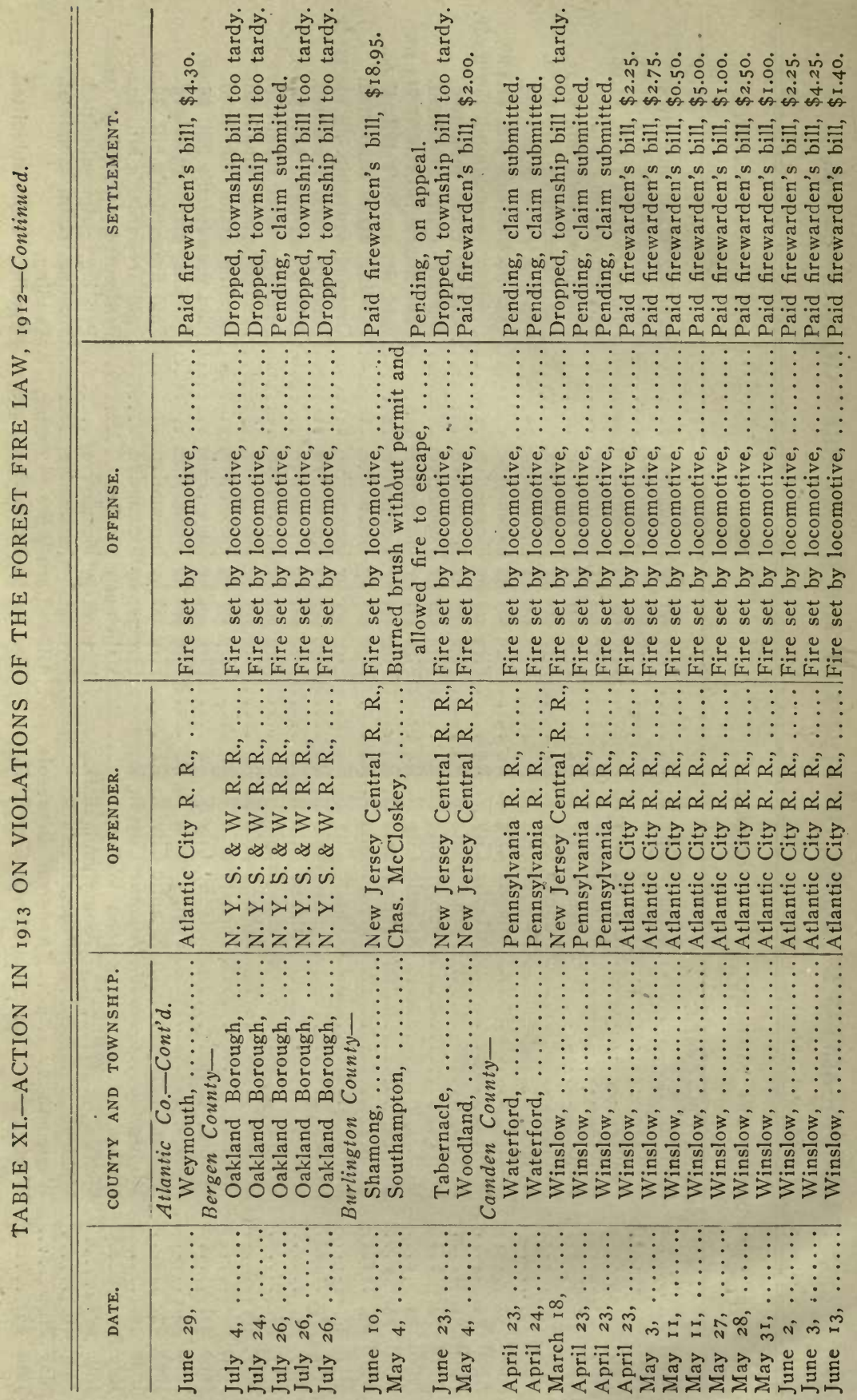




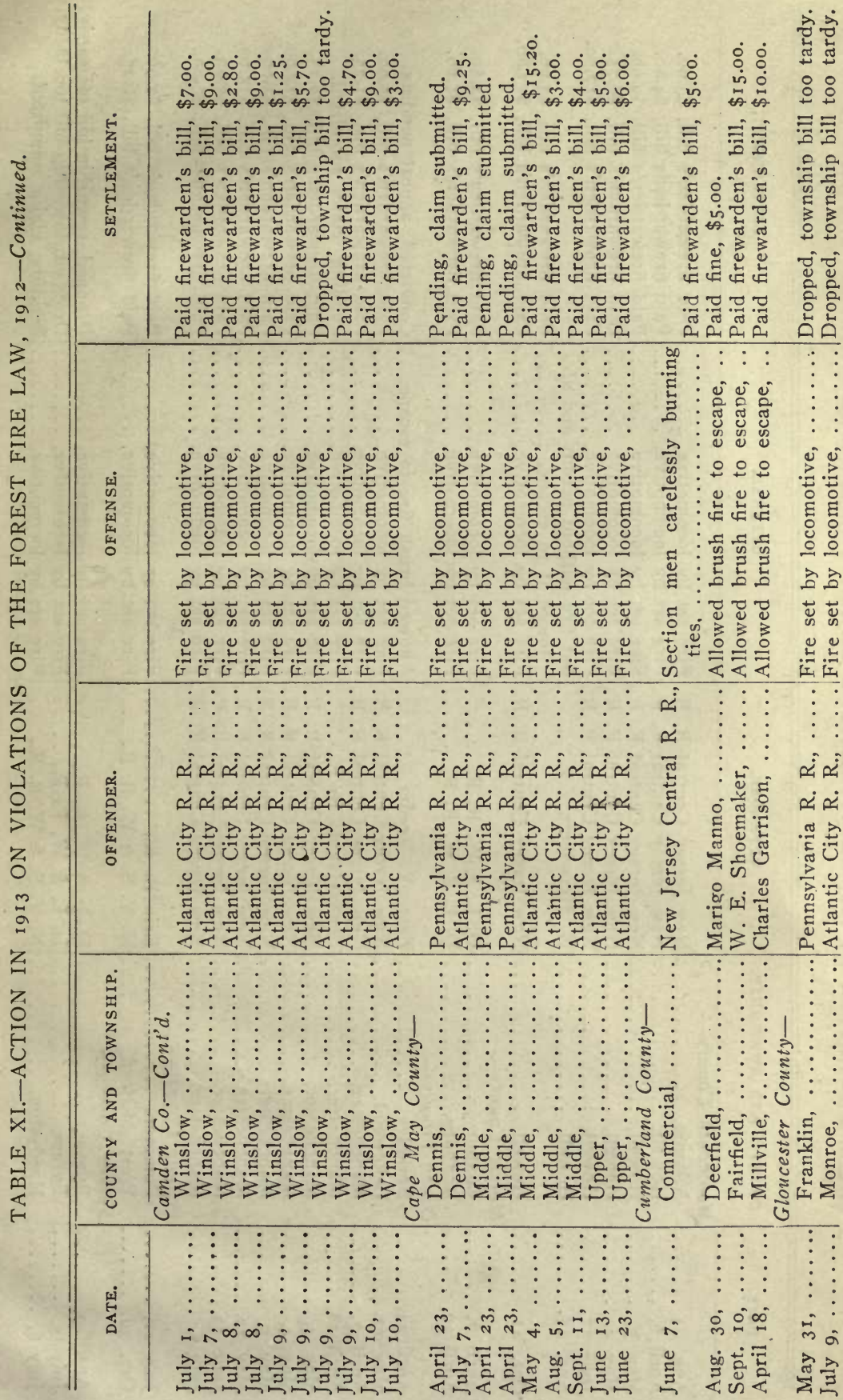




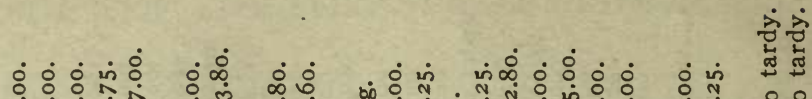

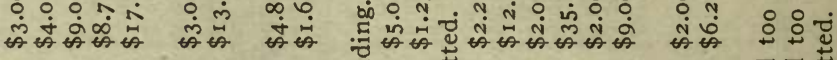

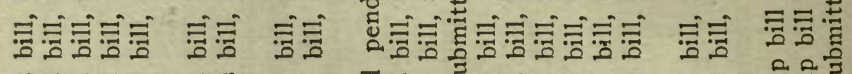

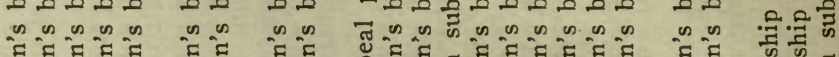
है Еี Еี

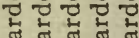
गู่

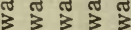
造造造造

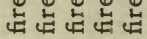
出它点

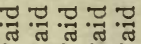
글

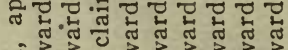

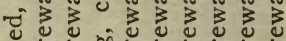

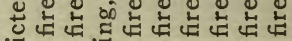

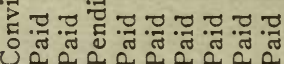
है हี जै जี

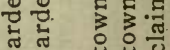

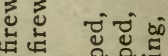
คคค คิ

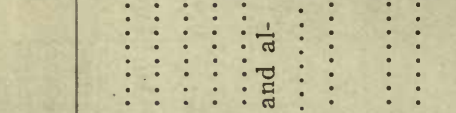

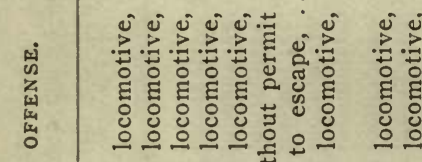

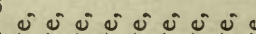
范

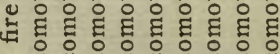

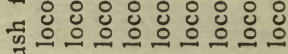

का का का के

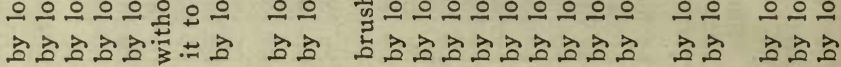

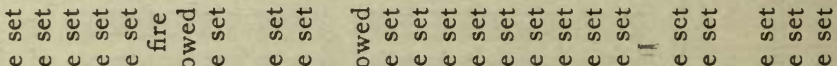

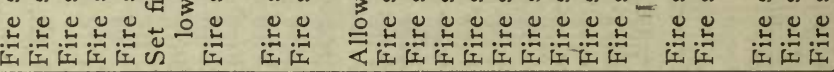

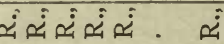

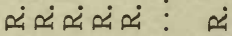

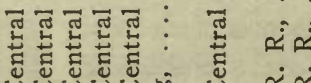

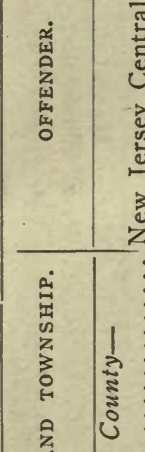

UUUUல்

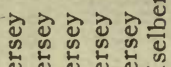

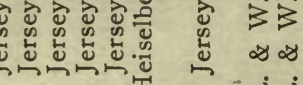

: نَّهَ

$\dot{\sim} \dot{\sim}:$ : نَّ

3 33 3 3 出

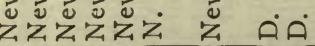

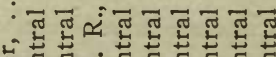

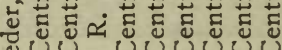

\&Uण

$>$ ते त्रुज्ञ

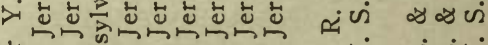

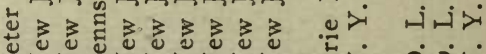
. $\cdots:$

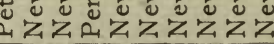

ż $\dot{A \dot{z}}$

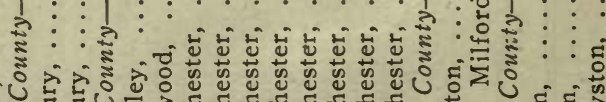

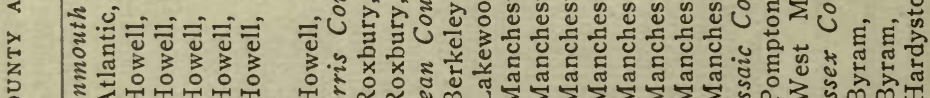
定

这

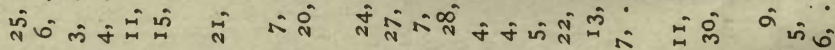

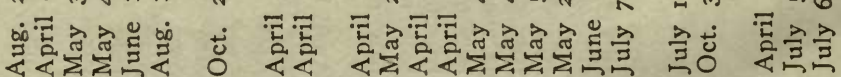




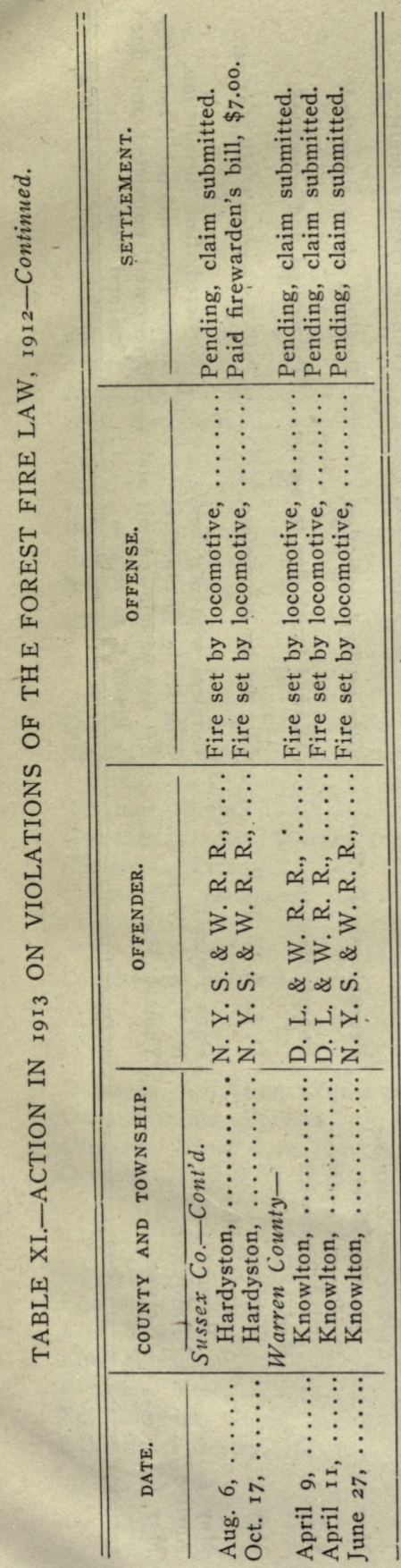




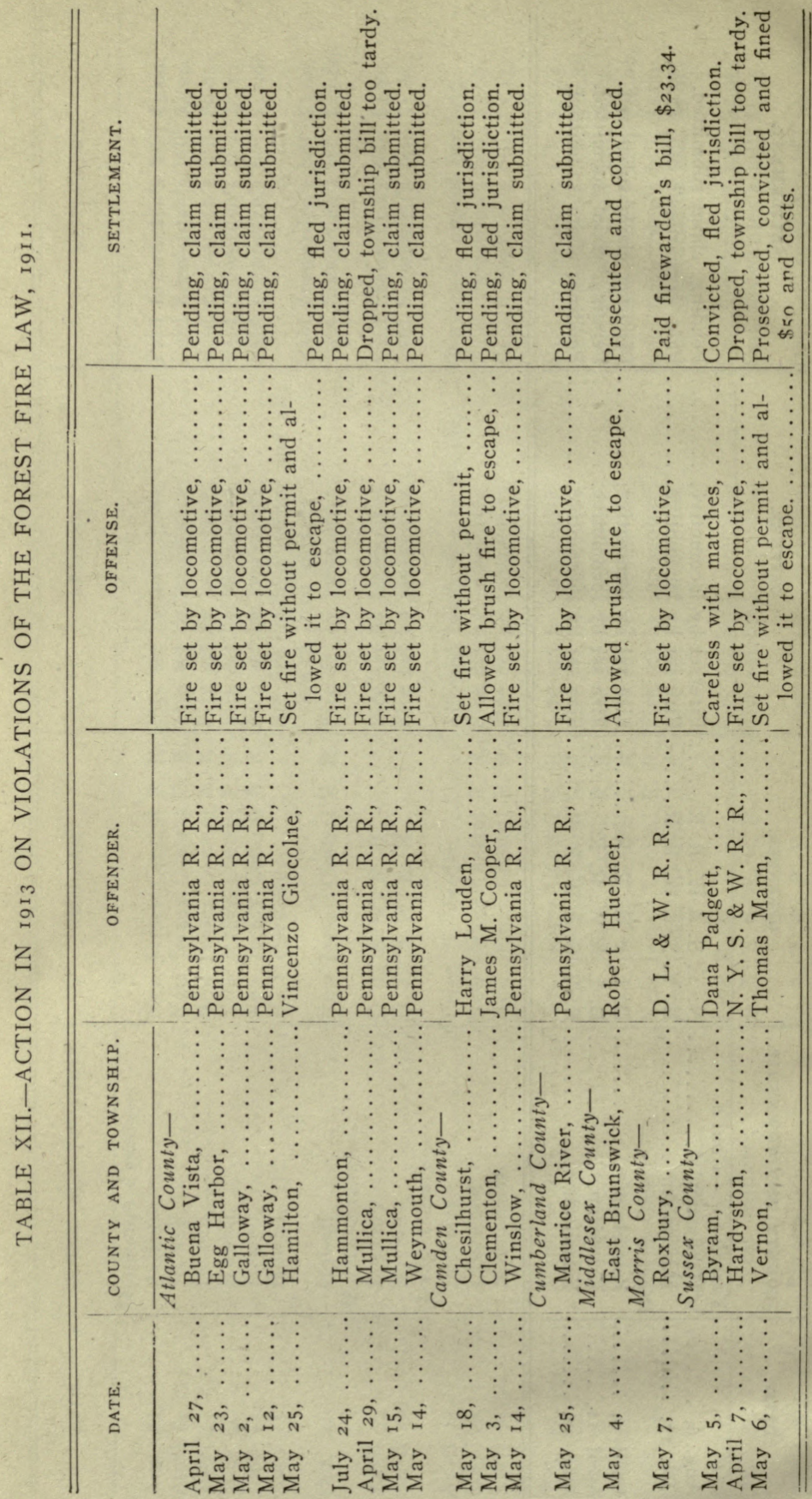




\section{INDEX.}

A.

PAGE.

Agricultural Opportunities, .... I0, I 8 Appropriations, ........... II Area of Forests, .......... 9, 16 Ash, European, ........... 27

\section{B.}

Beech, European, 27

Brown Tail Moth, ........... ${ }_{38} 8$

Brush Burning, ......... 7,46

Brush Fires, ........... 46

\section{C.}

Cabins, Shelter, ........... 26 Causes of Fires, (see Forest Fires)

Chestnut Blight, $\ldots \ldots \ldots \ldots \ldots 36,37$

Chestnut Timber, Market for, .. $30^{\circ}$

Christmas Trees, ........... 20

Claims for Damages, ........ 33

Co-operation,

$$
7-10,19,25,32-34,42,59,60
$$

Conferences, Firewardens',

\section{D.}

Damages, Adjusting Claims for,.. 33 Demonstration Forests, ....5, 9, I7, 23 Diseases, Tree, ............. 35, 36, 39 Drouth, . 34,43

\section{E.}

Education in Forestry, ........ $\mathrm{r}_{0} \mathrm{r}$

Elm Leaf Beetle, ........... 37

Elm Scale, .............. 35

Elm, White, .............. 34

Enemies, Tree, .............. 33

Entomologist, State, .......35, 37, 40

Exhibits, Forestry,

6

Farming, $\ldots \ldots \ldots \ldots \ldots \ldots \ldots$ ro, 18

Federal Co-operation, .......8 8, 59

Federal Fire Patrol, ........ 59

Financial Statement, .......... I4, I 5

Fire Control, .............. I2, I 7

Fire Lines, .............. 26

Fires, Forest, (see Forest Fires)

Firewardens' Conferences, ..... 5 I

Food, Tree, ............. 40

Forest, Area of, $\ldots \ldots \ldots \ldots$, 16

Forest Fires ........6, 17, 24,43

Area of, $\ldots \ldots \ldots \ldots \ldots \ldots \ldots 4,45$

Causes of, $\ldots \ldots \ldots \ldots \ldots 6,46-48$

Control of, $\ldots \ldots \ldots \ldots \ldots 5$, I 2,1 ;

Cost of, ........... I I I 4, 52-55

Loss by, ............. 6

Number of, ..........44, 45

Forest Fire Patrol, ......... 8

Forest Fire Service, .......43-80

Forest Fires, Responsibility for.. 7

Forest Planting, ......5, 9, 22, 25, 26

Forest Reserves, ........9, 17, 22-27

Area of, $\ldots \ldots \ldots \ldots \ldots . \ldots .22$

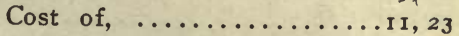

Policy for, ............ 23

Forests, Annual Yield, ........ 6

Area of, ............ I 6

Condition of $\ldots \ldots \ldots \ldots \ldots$ I 6

Protection of $\ldots \ldots \ldots \ldots \ldots \ldots$

Forestry Exhibits, ........... 19

Forestry, Private, ........5, 9, 19

G.

Gypsy Moth, ........... ${ }_{3} 8$

H.

Hickory Bark Beetle, ......... 37

Huckleberry Pickers, ......... 48

Hunters' Fires, ........... 7 
I.

PAGE.

Insects, $.35,37,3^{8}$

L.

Lakes, Appropriations for, ..... II

Land Schemes, ............. 10, 8

Legislation, ............... II

Leopard Moth, ............ ${ }_{38}^{8}$

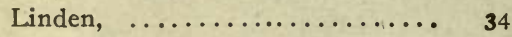

Locust, ................. 27

Locust Borer, ............ 27

Lookouts, ..............8, 9,59

Lumber Directory, ........... 40

M.

Maple Blight, ............. 39

Maple, Cottony Scale, ......... 35

Maple, Norway, ............ 34

Maple, Sugar, ............. 34

Mine Mount Forestry Association I9

Mount Laurel Reserve, .......23, 24

N.

Newark Street and Water Commissioners, Co-operation with, . Norway Maple, ............. 34

Norway Maple Blight, ........ 39

o.

Oak, Chestnut Blight, ........ 37

Oak, Red, ...............27, 34

Oak, Scarlet, .............. 34

Office Room, .............. I $_{2}$

Organization,..$\ldots \ldots \ldots \ldots \ldots$ r. $\mathrm{r}_{3}$

P.

Parks, $\ldots \ldots \ldots \ldots \ldots \ldots \ldots \ldots$. 27

Patrols, ............... 8, 59

Penalties, $\ldots \ldots \ldots \ldots \ldots \ldots .8,56$

Permits, Brush Burning, ...... 7,46

Pests, Tree, (see Tree Pests and

Tree Enemies).

Plantations, Forest, .........26, 27

Planting, (see Forest Planting).

Planting, Close, ............ 34

Plant Pathologist, State.......35, 40

Playgrounds, .............. 9

Population, Density of, ....... 9, r6

Private Forestry, .......... 9, 19

Products of Reserves, ........ 25

Prosecutions, ............... $5^{6}$

Protection, Forest, .......... 5

Publicity, ................ 1 , 60

Public Roads, ............ $: 2$
R.

PAGE.

Railroad Fire Lines, ......... 60

Railroad Fires, ........... $7,8,12,46$

Reserves, (see Forest Reserves). Use of by State Dependants, 25

Road Commissioner, State, Cooperation with, ............ 34

Roadside Trees, ............ 34

Road Surfacings, Injury by, ... 35

Roads, Tarred and Oiled, ...... 35

s.

Scale, Elm, ............... 35

Maple, ............... 35

Tulip, ................ 35

Shade Trees, ...... 10, 10, 12, 17, 27-33

Shade Tree Book, .......... 35

Shade Tree Commissions,:10, 17, 28-33

Shelter Cabins, ............ 26

Smokers' Fires, .......... 7, 8, 48

Sportsmen's Fires, .......... 7,48

Starvation, Tree, ........... 39

State Aid in Forestry, ....... 42

State Institutions, Co-operation with, $\ldots \ldots \ldots \ldots \ldots \ldots \ldots$. 10,25

Sugar Maple, .............. 34

Survey of Reserves, ......... $\quad 26$

Sycamore, $. . . \ldots \ldots \ldots \ldots \ldots . \quad 34$

T.

Telephones, $\ldots \ldots \ldots \ldots \ldots \ldots$. 24

Town Sites, ............... ro

Tree Cutting, Unlawful, ......20, 21

Tree Diseases, (see Diseases).

Tree Doctors, .............. 40

Tree Enemies, (see Enemies).

Tree Food, ................ 40

Tree Pests, .............. 35-40

Trespass on Reserves, ........ 25

Tulip Poplar, .............. 34

Tulip Soft Scale, ........... 35

Tussock Moth, ............. 38

V.

Violations of Law, ....... 8, 55-80

W.

Weeks Law, ............ 8, 59

Wharton Tract, ........... 23

White Pine Blister Rust, ...... 39

Wood Industries, ............11, 40

Wood Users, ............. II

Württemberg, Comparison with,.. 6 



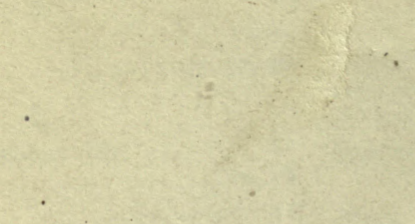




